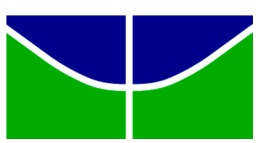

UNIVERSIDADE DE BRASÍLIA

CENTRO DE ESTUDOS AVANÇADOS MULTIDISCIPLINARES (CEAM)

PROGRAMA DE PÓS-GRADUAÇÃO EM DESENVOLVIMENTO, SOCIEDADE E COOPERAÇÃO INTERNACIONAL (PPGDSCI)

\title{
A RELAÇÃO ENTRE AS POLÍTICAS SETORIAIS DE HABITAÇÃO, SANEAMENTO E MOBILIDADE COM UMA POLÍTICA DE DESENVOLVIMENTO URBANO
}

\author{
Andréa Naritza S. M. de Araujo
}

TESE DE DOUTORADO EM DESENVOLVIMENTO E POLÍTICAS PÚBLICAS

BRASÍLIA / DF

Julho / 2017 
UNIVERSIDADE DE BRASÍLIA

CENTRO DE ESTUDOS AVANÇADOS MULTIDISCIPLINARES (CEAM)

PROGRAMA DE PÓS-GRADUAÇÃO EM DESENVOLVIMENTO, SOCIEDADE E COOPERAÇÃO INTERNACIONAL (PPGDSCI)

\section{A RELAÇÃO ENTRE AS POLÍTICAS SETORIAIS DE HABITAÇÃO, SANEAMENTO E MOBILIDADE COM UMA POLÍTICA DE \\ DESENVOLVIMENTO URBANO}

Andréa Naritza S. M. de Araujo

ORIENTADORA: MARÍLIA STEINBERGER

TESE DE DOUTORADO EM DESENVOLVIMENTO E POLÍTICAS PÚBLICAS

BRASÍLIA / DF

Julho / 2017 
UNIVERSIDADE DE BRASÍLIA

CENTRO DE ESTUDOS AVANÇADOS MULTIDISCIPLINARES (CEAM) PROGRAMA DE PÓS-GRADUAÇÃO EM DESENVOLVIMENTO, SOCIEDADE E COOPERAÇÃO INTERNACIONAL (PPGDSCI)

\section{A RELAÇÃO ENTRE AS POLÍTICAS SETORIAIS DE HABITAÇÃO, SANEAMENTO E MOBILIDADE COM UMA POLÍTICA DE DESENVOLVIMENTO URBANO}

Andréa Naritza S. M. de Araujo

TESE APRESENTADA AO PROGRAMA DE PÓSGRADUAÇÃO EM DESENVOLVIMENTO, SOCIEDADE E COOPERAÇÃO INTERNACIONAL DO CENTRO DE ESTUDOS AVANÇADOS MULTIDISCIPLINARES DA UNIVERSIDADE DE BRASÍlIA, PARA OBTENÇÃO DO TÍTULO DE DOUTORA.

APROVADA POR:

Prof ${ }^{a}$ MARÍLIA STEINBERGER, Dra. (UnB)

(ORIENTADORA)

Prof ${ }^{a}$ MAGDA DE LIMA LÚCIO, Dra. (UnB)

(EXAMINADOR INTERNO)

Prof BENNY SCHVARSBERG, Dr. (UnB)

(EXAMINADOR EXTERNO)

MARCO AURÉLIO COSTA, Dr. (IPEA)

(EXAMINADOR EXTERNO) 


\section{Agradecimentos}

Em 2004, iniciei os meus trabalhos na Administração Pública Federal na gestão de projetos de saneamento, tendo como público alvo as populações em zonas rurais, e, logo em 2005, no Ministério das Cidades, em um programa de assistência técnica para elaboração de projetos de saneamento integrado em favelas. Sem dúvida, essa experiência levou-me a um mundo até então desconhecido e complexo: o urbano.

Paralelamente à minha experiência pessoal com a problemática urbana, descobri, a partir das vivências prática e teóricas as quais foram elucidando meus pensamentos ao longo dos anos, que a minha formação em engenharia civil e o mestrado em tecnologia ambiental e recursos hídricos não me bastavam na minha jornada de atuação no âmbito da política urbana. Assim, posso dizer que o meu objeto de tese já me instigava há alguns anos, antes mesmo de ingressar no CEAM.

A experiência profissional adquira pela prática na política urbana também me mostrou a necessidade de tratar a complexidade da questão urbana de forma multidisciplinar e considerando os conhecimentos das ciências sociais, sendo esta a razão principal de ter procurado um programa de pós-graduação com a proposta do CEAM.

Ao ingressar no doutorado em 2013, aventurei-me em um mundo ainda não experimentado, o das ciências sociais. O desafio foi enorme e ao mesmo tempo enriquecedor, na medida em fui apresentada a autores e novos conteúdos que, com certeza, mudaram a minha forma de ver o mundo e de lidar com as temáticas políticas públicas e o urbano. Por outro lado, o fato de estar mais amadurecida e de estudar um tema com a qual estabeleci uma ligação quase emocional, tornou o progresso da pesquisa empolgante, tornando a organização das ideias mais natural e precisa.

Agora que concluí a pesquisa entendo a dimensão e a abrangência de uma tese de doutorado na vida de quem opta por seguir um caminho como este. Por isso, agradeço em tom emotivo, com um nó na garganta e sentindo um misto de satisfação pelo trabalho concluído, mas também uma alegria por ter conseguido me manter firme e focada em um projeto de longo prazo que demandou tantos sacrifícios meus e da minha amada família. 
Também percebi que é impossível se aventurar em uma experiência como essa sem dispor do apoio e da compreensão de muitas pessoas. Nesses anos, fui privilegiada por ter à minha disposição tudo que era necessário para a realização deste sonho. Por isso, serei eternamente grata por todo apoio e incentivo que recebi de tantas pessoas.

De imediato, agradeço pelo apoio incondicional da minha orientadora Marília Steinberger que, desde o início, compreendeu o meu objeto de trabalho e guiou-me de forma construtiva, instigando o meu pensamento sempre para "fora da caixinha". Agradeço imensamente pela disponibilidade, por compartilhar seu conhecimento, pela compreensão e acolhimento nos momentos difíceis e pelas longas conversas. Tenho certeza de que o nosso encontro foi providencial e indispensável para a concretização desta tese.

Agradeço aos professores do CEAM que me agregaram novos saberes em todas as disciplinas cursadas, bem como ao professor Benny Schvarsberg que enriqueceu as discussões da minha banca de qualificação, pela análise minuciosa que apontou alguns caminhos que eu ainda precisava trilhar para o aprofundamento do objeto de pesquisa.

Meu muito obrigada aos amigos e colegas de trabalho do Ministério das Cidades pelas discussões sobre a tese, pelos dados e pelo apoio de sempre. Em especial, agradeço ao meu ex-chefe Cláudio Erasmo Lira Dantas pelo apoio incondicional para o curso em todas as etapas. Sem a sua colaboração eu não teria vencido as burocracias para me dedicar aos estudos de maneira apropriada.

Ao meu companheiro Caio, não encontro palavras para expressar o meu amor e minha eterna gratidão. Jamais teria conseguido realizar este sonho sem ter compartilhado a vida com alguém que me apoia de forma incondicional. Agradeço pela sua compreensão, por ter compreendido minhas ausências, por ter cuidado tão bem da nossa família nas minhas faltas, pela paciência e por estar sempre ao meu lado na busca dos meus sonhos.

Aos meus amados filhos Carlos Rodrigo e Beatriz, que representam uma fonte permanente de força e renovação, agradeço pelo amor e pela compreensão durante todos os anos. Também deixo para vocês a inspiração para seguirem o coração e que não tenham medo de trilharem caminhos que demandam persistência e esforço. 
Um urbanismo genuinamente humano ainda está por surgir. Cabe à teoria revolucionária mudar o caminho de um urbanismo baseado na exploração para um urbanismo apropriado à espécie humana.

(HARVEY, 1980, p. 271) 


\section{LISTA DE FIGURAS}

Figura 1 - Considerações sobre os princípios de justiça social de Harvey para alocação de recursos.

Figura 2 - Elementos funcionais que favorecem a industrialização segundo Castells

Figura 3 - Concentração, estratificação social e segregação urbana segundo Castells

Figura 4 - Evolução média da Força de Trabalho do Ministério das Cidades

Figura 5 - Comparação entre Estruturas Gerenciais e Orçamento de 2014

Figura 6 - Evolução de Estruturas Gerenciais de Órgãos Gestores do PAC

Figura 7 - População no Brasil por região (1991 a 2010)

Figura 8 - Domicílios no Brasil por região (1991 a 2010)

Figura 9 - Déficit habitacional absoluto no Brasil e regiões (2004 a 2014)

Figura 10 - Composição do déficit habitacional no Brasil

Figura 11 - Composição do déficit habitacional na região Norte

Figura 12 - Composição do déficit habitacional na região Nordeste

Figura 13 - Composição do déficit habitacional na região Sudeste

Figura 14 - Composição do déficit habitacional na região Sul

Figura 15 - Composição do déficit habitacional na região Centro-Oeste

Figura 16 - Inadequação dos domicílios no Brasil

Figura 17 - Inadequação dos domicílios na região Norte

Figura 18 - Inadequação dos domicílios na região Nordeste

Figura 19 - Inadequação dos domicílios na região Sudeste

Figura 20 - Inadequação dos domicílios na região Sul

Figura 21 - Inadequação dos domicílios na região Centro-Oeste

Figura 22 - Déficit habitacional relativo no Brasil segundo situação do domicílio 
Figura 24 - Distribuição do déficit habitacional urbano no Brasil por faixa de renda

Figura 25 - Cobertura de abastecimento de água no Brasil por região

Figura 26 - Cobertura de esgotamento sanitário no Brasil por região

Figura 27 - Cobertura de coleta de resíduos sólidos no Brasil por região

Figura 28 - Déficit relativo na cobertura de abastecimento de água por região

Figura 29 - Déficit relativo na cobertura de esgotamento sanitário por região

Figura 30 - Déficit relativo na coleta de resíduos sólidos por região

Figura 31 - Frota de veículos automotores no Brasil por tipo de veículo

Figura 32 - Taxa de motorização no Brasil (2001 a 2012)

Figura 33 - Divisão modal em capitais do Brasil

Figura 34 - Extensão do metrô em cidades brasileiras

Figura 35 - Maiores sistemas de transportes do Brasil

Figura 36 - Estrutura cicloviária em cidades do Brasil

Figura 37 - Quatro sistemas de transportes com o mesmo custo

Figura 38 - Execução orçamentária do Ministério das Cidades 2007 a 2014

Figura 39 - Financiamentos contratados por fonte de recurso

Figura 40 - Financiamentos contratados por fonte de recurso

Figura 42 - Contratações e Entregas do PMCMV

Figura 43 - Evolução dos investimentos em habitação por faixa de renda

Figura 44 - Distribuição por região dos recursos de SBPE

Figura 45 -Valores acumulados do PAC Saneamento 2007 a 2015

Figura 46 - Valores desembolsados do PAC Saneamento 2007 a 2015

Figura 47 - Evolução dos valores contratados e desembolsados por região

Figura 48 - Execução orçamentária dos programas de mobilidade urbana e segurança e educação de trânsito 
Figura 49 - Execução dos recursos onerosos de mobilidade urbana

Figura 50 - Diagrama de representação dos componentes do Modelo de Coalizões de Defesa

Figura 51 - Representação dos sistemas de crenças

Figura 52 - Principais eventos externos e mudanças institucionais que impactaram a política urbana desde a criação do MCidades

\section{LISTA DE QUADROS}

Quadro 1- Propostas Estruturantes para a PNDU segundo os Cadernos MCidades

Quadro 2 - Temas das políticas urbanas e planos nacionais dos períodos estudados

Quadro 3 - Ações da Secretaria Nacional de Habitação

Quadro 4 - Ações da Secretaria Nacional de Transportes e da Mobilidade Urbana

Quadro 5- Ações da Secretaria Nacional de Acessibilidade e Programas Urbanos

Quadro 6 - Ações da Secretaria Nacional de Saneamento Ambiental

Quadro 7 - Categorias de análise para caracterizar as crenças das coalizões

Quadro 8 - Principais crenças compartilhadas pelos atores da Coalizão dos Movimentos Sociais Urbanos

Quadro 9 - Principais crenças compartilhadas pelos atores da Coalizão dos Especialistas

Quadro 10 - Principais crenças compartilhadas pelos atores da Coalizão dos Tecnocratas Desenvolvimentistas

Quadro 11 - Principais crenças compartilhadas pelos atores da Coalizão dos Políticos

Quadro 12 - Principais crenças compartilhadas pelos atores da Coalizão do Mercado 


\section{LISTA DE TABELAS}

Tabela 1 - Estrutura de cargos do Ministério das Cidades na sua criação

Tabela 2 - Evolução dos investimentos feitos pelo Ministério das Cidades

Tabela 3 - Montante de recursos monitorados e número de operações

Tabela 4 - Histórico dos ministros do Ministério das Cidades

Tabela 5 - Estrutura de cargos do Ministério das Cidades após a reforma

Tabela 6 - Estrutura de FCPEs do Ministério das Cidades após a reforma

Tabela 7 - Estrutura final de cargos e FCPEs após a reforma

Tabela 8 - População, domicílios e domicílios vagos no Brasil (1991-2010)

Tabela 9 - População e domicílios no Brasil por situação do domicílio (19912010)

Tabela 10 - Percentual de população e domicílios no Brasil por situação do domicílio (1991-2010)

Tabela 11 - Distribuição da população em aglomerados subnormais no Brasil

Tabela 12 - Produção de veículos no Brasil (1957 - 2014)

Tabela 13 - Tempo gasto no deslocamento casa/trabalho por localização da moradia

Tabela 14 - Tempo gasto no deslocamento casa/trabalho por região em 2010

Tabela 15 - Percentual de famílias das RMs com tempos de viagem nas faixas consideradas por renda per capita em 2012

Tabela 16 - Principais Indicadores sobre BRT no Brasil (corredores existentes)

Tabela 17 - Comparação entre tipos de modais de transportes

Tabela 18 - Investimentos do PAC 1 e 2 no período de 2007 a 2014

Tabela 19 - Planejamento dos recursos de FGTS para 2016

Tabela 20 - Investimentos selecionados no PAC 1 e 2 por modalidade 


\section{LISTA DE SIGLAS}

Advocacy Coalition Framework - ACF

Banco Nacional do Desenvolvimento - BNDES

Banco Nacional de Habitação - BNH

Bus Rapid Transit - BRT

Comissão Intersetorial de Saneamento e Meio Ambiente - CISAMA

Comitê Gestor do PAC - CGPAC

Conselho das Cidades - ConCidades

Conselho Monetário Nacional - CMN

Conselho Nacional de Saúde - CNS

Conselho Nacional de Recursos Hídricos - CNRH

Conselho Nacional de Meio Ambiente - CONAMA

Constituição Federal - CF

Empresa Brasileira de Transportes Urbanos - EBTU

Fundação da Casa Popular - FCP

Fundação Getúlio Vargas - FGV

Fundo de Amparo ao Trabalhador - FAT

Fundo de Garantia de Tempo de Serviço - FGTS

Grupo Executivo de Acompanhamento do PAC - GEPAC

Fundo Nacional de Habitação de Interesse Social - FNHIS

Institutos de Aposentadoria e Pensões - IAPs

Lei de Diretrizes Orçamentárias - LDO

Lei Orçamentária Anual - LOA

Ministério das Cidades - MCidades

Ministério do Interior - MINTER

Ministério do Planejamento - MINIPLAN

Movimento dos Trabalhadores Sem-Teto - MTST 
Orçamento Geral da União - OGU

Parcerias Público Privadas - PPPs

Partido da Social Democracia Brasileira - PSDB

Partido do Movimento Democrático Brasileiro - PMDB

Partido Progressista - PP

Partido Social Democrático - PSD

Partido dos Trabalhadores - PT

Plano Nacional de Desenvolvimento - PND

Plano Nacional de Desenvolvimento da Nova República - PND-NR

Plano Nacional de Saneamento Básico - PLANSAB

Política Nacional de Desenvolvimento Urbano - PNDU

Política Nacional de Habitação - PNH

Plano Plurianual - PPA

Programa de Aceleração do Crescimento - PAC

Programa Minha Casa, Minha Vida - PMCMV

Regiões Metropolitanas - RMs

Secretaria de Estado de Desenvolvimento Urbano - SEDU

Secretaria Nacional de Acessibilidade e Programas Urbanos - SNAPU

Secretaria Nacional de Habitação - SNH

Secretaria Nacional de Saneamento Ambiental - SNSA

Secretaria Nacional de Transportes e da Mobilidade Urbana - SEMOB

Sistema Brasileiro de Poupança e Empréstimo - SBPE

Sistema Financeiro Imobiliário - SFI

Sistema Nacional de Desenvolvimento Urbano - SNDU

Sistema Nacional de Habitação de Interesse Social - SNHIS

Sistema Nacional de Informações sobre Saneamento - SNIS

Sistema Nacional de Vigilância Ambiental em Saúde - SINVAS 
União dos Ciclistas do Brasil - UCB

Veículo Leve Sobre Trilho - VLT 


\section{Resumo}

No Brasil, mais de $85 \%$ das pessoas residem em áreas urbanas, indicando que os problemas que incidem nos grandes centros tendem a impactar parcela significativa da população. A segregação sócio-espacial, a pobreza e a desigualdade social podem ser consideradas herança de um modelo de desenvolvimento concentrador e excludente, que vem se impondo desde os primórdios do processo de urbanização brasileiro, devido à forma como o Estado percebe e atua sobre o processo de desenvolvimento urbano. A análise dos discursos institucionais propagados e da política urbana implementada na última década, aponta que os avanços obtidos na trajetória da política urbana brasileira, embora importantes, representam conquistas pouco significativas, não sendo capazes de superar a ótica setorialista de implementar as ações governamentais, tampouco de transformar o modo de produção das cidades. As evidências indicam que as estratégias adotadas para o enfrentamento da problemática urbana não tiveram o êxito esperado e continuam privilegiando a atuação fragmentada por setores (habitação, saneamento, mobilidade urbana), esquivando-se de confrontar os interesses do capital, em particular a propriedade privada da terra e seu uso de acordo com o interesse privado.

Palavras-chave: desenvolvimento urbano, política urbana, coalizões de interesses, setorialismo. 


\begin{abstract}
In Brazil, more than $85 \%$ of people live in urban areas, indicating that the problems that affect large centers tend to impact a significant portion of the population. Socio-spatial segregation, poverty and social inequality can be considered as inheritance of a concentrative and exclusionary development model, which has been imposed since the beginning of the brazilian urbanization process, due to the way the state perceives and acts on the urban process development. The analysis of the institutional discourses propagated, together with the practice implemented in the last decade, point out that the advances obtained in the trajectory of brazilian urban policy, although important, represent little significant achievements, not being able to overcome the sectorialist perspective of implementing governmental actions, nor to transform the mode of production of cities. The evidence indicates that the strategies adopted to confront urban problems have not been hoped for and continue to favor fragmented performance by sectors, avoiding to confront the interests of capital, in particular the private ownership of land and its use according to the private interest.
\end{abstract}

Keywords: urban development, urban politics, advocacy coalition, sectorialism. 


\section{SUMÁRIO}

INTRODUÇÃO ................................................................................................................1

Capítulo 1. A problemática urbana em perspectiva teórica: contribuições para

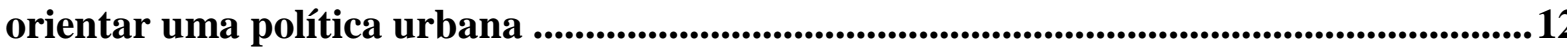

1.1 Formulações teóricas para estudar a problemática urbana: justificativa para

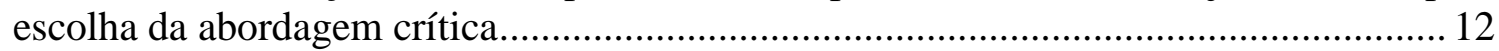

$1.2 \mathrm{O}$ espaço como conceito básico da problemática urbana .............................. 21

$1.3 \mathrm{O}$ método adotado para compreender a problemática urbana......................... 29

1.4 Aspectos políticos da problemática urbana................................................... 36

1.5 O Estado como principal interventor na problemática urbana......................... 49

1.6 Temas relevantes para entender a problemática urbana..................................53

1.7 Pressupostos para nortear uma política de desenvolvimento urbano............... 65

Capítulo 2. Os discursos das políticas nacionais de desenvolvimento urbano brasileiras em perspectiva histórica................................................................................................68

2.1 Antecedentes das políticas urbanas nacionais no Brasil ...............................6 69

2.2 As políticas urbanas nacionais no Brasil dos anos 70 e 80 ............................ 78

II Plano Nacional de Desenvolvimento (1975-1979).............................................80

III Plano Nacional de Desenvolvimento (1980-1985) ...........................................8 84

I Plano Nacional de Desenvolvimento da Nova República (1986-1989) ...............8 87

Considerações gerais sobre os planos................................................................. 96

2.3 As propostas de políticas urbanas em planos nacionais formulados entre $1987 \mathrm{e}$ 2003

Presidente da República José Sarney: Programa de Ação governamental (19871991) 102

Presidente da República Fernando Collor: Brasil: Um Projeto de Reconstrução Nacional (1990-1995) 105

Presidente da República Fernando Henrique Cardoso (1 ${ }^{o}$ governo): Mão à Obra Brasil (1994-1997)

Presidente da República Fernando Henrique Cardoso (2º governo): Avança Brasil (1998-2001) e Plano de Ação para o Desenvolvimento Urbano (1999-2003) ... 106 
Cadernos MCidades

Políticas setoriais de habitação, saneamento e mobilidade urbana..

Programa de Aceleração do Crescimento (PAC) e Programa Minha Casa, Minha Vida $(P M C M V)$

2.5 Pressupostos identificados nos discursos das políticas urbanas nacionais .... 131

\section{Capítulo 3. A política urbana do Ministério das Cidades: do discurso às ações...137}

3.1 Estrutura organizacional e competências do Ministério das Cidades

3.2 Panorama recente da qualidade urbana: habitação, saneamento e mobilidade 155

Panorama da habitação.

Panorama do saneamento básico

Panorama da mobilidade urbana

3.3 Panorama recente dos investimentos da política urbana: habitação, saneamento e mobilidade

Investimentos em habitação

Investimentos em saneamento

Investimentos em mobilidade urbana.

3.4 Desafios a serem enfrentados para se ter uma política de desenvolvimento urbano menos setorial 240

Capítulo 4. A coalizão de interesses na política de desenvolvimento urbano do Ministério das Cidades

4.1 O modelo de coalizões de defesa 253

Pressupostos e descrição do modelo. 258

Sistemas de crenças e hipóteses 262

4.2 Aplicação do modelo no subsistema da política urbana: atores, coalizões crenças e recursos para influenciar o processo decisório 267

Coalizão dos Movimentos Sociais Urbanos

Coalizão dos Especialistas. 282

Coalizão dos Tecnocratas Desenvolvimentistas 292

Coalizão dos Políticos 306 
4.3 Atuação das coalizões e influências dos eventos externos e mudanças institucionais.... 335

CONCLUSÕES 


\section{INTRODUÇÃO}

O processo de urbanização, vivenciado mais fortemente no século $\mathrm{XX}$, provocou mudanças significativas no modo de vida nas cidades. Entretanto, o universo urbano não superou algumas características dos períodos colonial e imperial, marcados pela concentração de terra, renda e poder; pelo exercício do coronelismo ou política do favor e pela aplicação arbitrária da lei. Essas concentrações permanecem e, atualmente, manifestam-se nas cidades de forma mais contundente, a partir da percepção de três aspectos: (1) segregação sócio-espacial, (2) pobreza e desigualdade social, (3) perpetuação de um modelo de desenvolvimento concentrador e excludente.

Nesse período de crescimento urbano acelerado, a população brasileira passou de predominantemente rural para majoritariamente urbana em menos de 40 anos (1940-1980). Já em 2014, o percentual observado da população urbana no Brasil foi de 85,1\%, segundo dados da PNAD, chegando a mais de $90 \%$ na região Sudeste. Esses dados revelam a dimensão que a problemática urbana vem assumindo ao longo do tempo, pela abrangência e por afetar direta ou indiretamente a vida da grande maioria das pessoas do país, por assumir a característica de ser prioritariamente urbana.

De acordo com a literatura, esse movimento foi impulsionado pela migração de um vasto contingente de pobres para as cidades, paralelamente enquanto se dava o processo de industrialização, por meio de um modelo de desenvolvimento urbano que privou as faixas de menor renda da população de acessar condições básicas de urbanidade e também da inserção efetiva na cidade. Assim, a presença de um grande contingente populacional, combinada com um processo de urbanização acelerado, orientado por um modelo de desenvolvimento concentrador de recursos, teve como resultado a intensificação da pobreza e da exclusão social. E isso favoreceu a formação de um número significativo de assentamentos precários que se inseriram na cidade de maneira ambígua.

A despeito de toda cultura da modernização que se associou ao modo de vida das cidades, juntamente com a ideia de desenvolvimento, a parcela da população que passou a habitar os assentamentos irregulares, desprovidos de serviços e de infraestrutura, tinha menos acesso às oportunidades econômicas e de desenvolvimento humano que estas 
passaram a oferecer. Por isso, já de partida, a vida nas cidades não se mostrava acolhedora às necessidades de todos.

A crescente pressão social que surgiu devido à configuração do quadro de degradação social que se consolidou nos grandes centros, juntamente com as reivindicações da classe dominante, provocou o Estado a implementar ações voltadas para a melhoria das condições de vida no meio urbano, sendo inicialmente concentradas em torno da crise habitacional, que foi a primeira temática relativa à problemática urbana a ganhar notoriedade. Porém, essas primeiras iniciativas eram embrionárias e ainda não assumiam o mesmo formato das políticas mais tradicionais já implementadas pelo Estado, como saúde e educação, tampouco alcançavam toda a complexidade da questão.

Inicia-se então, ainda na década de 1940, a trajetória da política brasileira de desenvolvimento urbano, voltada inicialmente para a construção de conjuntos habitacionais de baixa renda. Posteriormente, nas décadas subsequentes, as iniciativas governamentais foram ganhando corpo e demandando mais conhecimento técnico por parte da Administração Pública, sendo substituídas por um conjunto de ações mais diversificadas e estruturadas. Ainda nos primórdios da política urbana brasileira, foram incorporadas outras temáticas, além da habitação no rol de ações governamentais, que também tinham interface com essa problemática, destacando-se saneamento e transportes.

Na década de 1970, a política urbana visava garantir o crescimento econômico pelo controle da urbanização acelerada nos grandes centros. Tinha como estratégias a reestruturação do sistema urbano, visando uma maior eficácia nas funções exercidas pela cidade por meio de três linhas de atuação: (i) solucionar a expansão desenfreada e desordenada das metrópoles e as suas consequências negativas; (ii) responder à carência das cidades por infraestrutura adequada para o desenvolvimento das atividades econômicas e produtivas; (iii) diminuir a carência de equipamentos sociais nas regiões metropolitanas e nas cidades com potencial econômico.

Nos períodos seguintes, a partir de debates e do surgimento de novos questionamentos sobre a problemática urbana e sobre as alternativas estatais adotadas para lidar com esta questão, foi se consolidando um discurso mais abrangente em torno das políticas urbanas. Desse modo, ao mesmo tempo em que essas políticas sofriam 
significativas transformações, recebiam novos temas em seu escopo, tais como: infraestrutura, saneamento, transportes, equipamentos sociais, regularização fundiária, participação social, planejamento, meio ambiente, diferenças regionais, uso e ocupação do solo, prevenção e recuperação de áreas de risco, acessibilidade, patrimônio histórico e natural, além de outros.

Vale ressaltar, entretanto, que mesmo sendo reconhecida a interface da política urbana com outros temas, essa percepção se dava de forma fragmentada e segundo a ótica das políticas setoriais separadamente (habitação, saneamento, mobilidade urbana). Destaca-se ainda que essas mesmas políticas setoriais passaram a ser orientadas pelas prioridades políticas, pelos objetivos econômicos e pelos interesses que permeavam o aparelho estatal sem considerar o impacto destas na configuração do espaço, distanciandose, cada vez mais, das diretrizes preconizadas nos discursos institucionais das políticas urbanas.

Ao longo da história, mesmo que a problemática urbana tenha ascendido à agenda governamental, as estratégias estatais de intervenção nas cidades permaneciam alicerçadas por um modelo de desenvolvimento baseado na economia de mercado, que promovia cada vez mais a concentração dos recursos na sociedade, acentuando a pobreza e as desigualdades. Assim, a cada novo período de empreendedorismo do Estado, a partir da edição de planos de desenvolvimento e programas, buscava-se consolidar o processo de desenvolvimento do país lastreado pelo fortalecimento da industrialização e pelo crescimento econômico.

Desse modo, na medida em que o crescimento econômico se consolidava como a principal estratégia para alavancar o desenvolvimento do país, também se fortalecia a lógica setorial de pensar e implementar a política urbana. A ação governamental se dava de forma fragmentada e por setores, priorizando ações e investimentos em habitação, saneamento e transportes, sem contemplar todas as temáticas apontadas como relevantes para combater as causas da problemática urbana.

O que se percebe acerca das diversas iniciativas de políticas e planos governamentais estruturados até o final da década de 1990 para agir sobre essa problemática no Brasil é que todos eles atuavam como intervenções sobre as consequências dos problemas e não 
sobre suas verdadeiras causas. Assumiam o caráter "curativo" e tentavam minimizar os efeitos negativos do processo de desenvolvimento nas cidades sem promoverem uma transformação substancial no "modus operandi" do Estado, do mercado e da sociedade, tampouco sem romper o ciclo de perpetuação da segregação sócio-espacial e da pobreza.

Mesmo que no discurso difundido para legitimar essas políticas tenha sido reconhecido o processo de desenvolvimento concentrador de recursos como a principal razão para a consolidação e acentuação da crise urbana, em nenhum momento foi tomada a decisão de intervir sobre este aspecto. Pelo contrário, a cada nova tentativa era reforçada a crença na economia de mercado como a alternativa mais adequada e o principal caminho a ser adotado para se promover o desenvolvimento no país.

Em função desse contexto, onde as políticas urbanas vinham sucessivamente falhando na sua missão primordial de promover melhorias estruturais nas condições de vida das grandes cidades, diferentes movimentos sociais se organizaram, com destaque para o de Reforma Urbana. Esses movimentos se fortaleceram e caminharam na direção de uma agenda de reformas sociais, identificada como agenda da reforma urbana. Institucionalmente, os ganhos dessas reivindicações foram materializados na inserção da temática desenvolvimento urbano na Constituição Federal de 1988, em seus artigos 182 e 183, bem como na aprovação do Estatuto das Cidades (2001) e na criação do Ministério e do Conselho das Cidades (2003).

Além das importantes mudanças de ordem institucional apontadas, também se destaca a retomada do Estado como formulador de políticas a partir de 2003, e de diversas iniciativas para o fortalecimento da sua capacidade técnica e institucional para implementação de políticas públicas. Esse fato é relevante visto que o papel do Estado como principal promotor de políticas públicas para o desenvolvimento tinha sido fortemente enfraquecido desde o final da década de 1980, perdurando até o início da década de 2000, devido à forte difusão do neoliberalismo que se dispersava no mundo inteiro, em razão de uma crise fiscal do Estado.

O enraizamento desse ideário nos governos foi fortalecido devido a um movimento de alcance mundial, consolidando-se até como um modelo de Administração Pública, denominado de "Nova Gestão Pública". Portanto, essa foi uma das razões que 
influenciaram o Estado brasileiro a interromper a formulação de praticamente todas as políticas nacionais, incluindo as urbanas. A principal herança desse período foi um vazio institucional e a acentuação da problemática urbana e da pobreza devido à ausência do Estado na condução de uma estratégia nacional e que contasse com relevante taxa de investimentos.

A criação do Ministério das Cidades, juntamente com a consolidação do aparato institucional e normativo instituído na década de 2000, resultou, em parte, do processo de redemocratização do país que possibilitou a retomada das discussões sobre a problemática urbana e diversos outros temas sociais. Os principais eixos que orientaram o movimento pela reforma urbana surgiram fortalecidos nesse período, influenciando os debates e o pensamento sobre as políticas urbanas, sendo difundidos em torno de três temas chave: (i) o direito à cidade; (ii) a gestão democrática da cidade; e (iii) a função social da cidade. Essas reivindicações buscavam combater ou criar mecanismos que, de alguma forma, pudessem modificar o modelo de desenvolvimento excludente que vinha sendo reproduzido ao longo do tempo.

Dessa maneira, a política de desenvolvimento urbano preconizada pelo Ministério das Cidades, no momento de sua criação, foi concebida em torno de temas considerados estruturadores do espaço urbano e de maior impacto na vida da população. Nessa época, também foi elaborada uma estratégia que contemplava a discussão democrática e participativa da política urbana, com destaque para as Conferências Nacionais que passaram a ser realizadas no âmbito do Conselho das Cidades.

Além das grandes mudanças institucionais, a partir de 2003, foi sendo conferida prioridade aos investimentos estatais em infraestrutura, o que mais tarde deu origem a programas governamentais de grande porte. Esses programas possibilitaram a retomada significativa dos investimentos federais nas políticas setoriais eleitas como prioritárias, as quais também receberam prioridade política, tendo em vista superar os entraves para viabilizar sua concretização da forma mais efetiva possível.

Contudo, evidências mostram que essa estratégia de desenvolvimento abraçada pelo Estado brasileiro, com a criação do Programa de Aceleração do Crescimento (PAC) e do Programa Minha Casa, Minha Vida (PMCMV), mais uma vez estava alicerçada em 
prerrogativas econômicas, tendendo a conduzir as políticas urbanas mais no sentido da dinamização da economia do que da produção de cidades melhores.

Portanto, embora tenham sido observadas transformações significativas nas políticas urbanas, verifica-se que esta ainda não alcançou a integração à política global de desenvolvimento que seria necessária à sua efetiva implementação. $\mathrm{Na}$ verdade, o que se evidencia é o descompasso entre o discurso das políticas preconizadas e as práticas realizadas em virtude da prioridade conferida a ações setoriais voltadas para o crescimento econômico ou para o atendimento de outros objetivos governamentais.

Essa constatação nos faz atentar para o atual contexto político-institucional brasileiro, onde existem vários atores e interesses a serem coordenados e processados na execução de uma política pública: burocracias de diferentes poderes e níveis de governo; parlamentares de diversos partidos; o mercado, bem como diversas organizações da sociedade civil (sindicatos de trabalhadores, associações empresariais, movimentos sociais). Desse modo, para entender os rumos das políticas urbanas também se faz necessário compreender como esses atores interagem entre si na condução do processo decisório que concretiza as políticas públicas no espaço.

A influência de grupos de interesse no cenário político precisa ser analisada devido à intensa intervenção desses atores nas decisões políticas e suas consequências para a sociedade. Também se destaca a necessidade de compreensão da dinâmica desses grupos, de suas crenças e de seu processo de formação e mobilização, além de suas pactuações e alianças, que condicionam o processo decisório segundo seus próprios interesses.

O Estado se mostra como um desses atores, que, ao privilegiar determinadas políticas públicas, o faz em resposta à pressão de interesses específicos. A habitação, o saneamento básico, os transportes urbanos e, em pequena escala, até mesmo o planejamento urbano, suscitaram o interesse de grupos empresariais capazes de exercer pressão sobre o subsistema da política urbana. Além disso, outros aspectos do desenvolvimento urbano foram recorrentemente evitados, exatamente por se revelarem capazes de provocar conflitos, quer seja em nível do próprio aparelho estatal, quer seja com as classes dominantes interessadas na manutenção do "status quo". 
Em razão dessas reflexões construídas ao longo da minha vida profissional e da formação acadêmica, a pergunta de pesquisa foi sendo elaborada e aprimorada, principalmente, com o ganho de experiência e por meio da maturidade acadêmica e científica aprofundada durante o doutorado.

Inicialmente, minhas questões se concentravam em problemas ambientais, depois na gestão de recursos hídricos, no saneamento e, em seguida, no processo de planejamento e gestão pública no âmbito da política urbana. Foi quando me atentei ao fato de que todos esses temas estavam inseridos em um universo mais amplo e complexo: o urbano. Também percebi que a lógica de atuação do Estado brasileiro ocorre de forma fragmentada, setorial e departamentalizada, organizada segundo a sistemática orçamentária e financeira que orienta e materializa as ações e os programas estatais.

E foi por meio desse raciocínio e de minhas inquietações sobre a problemática urbana que nasceu a seguinte questão de pesquisa: por que hoje, em 2017, ainda há desafios na concepção e na implementação de uma política de desenvolvimento urbano menos setorialista, mesmo depois do avanço institucional com a criação do Ministério das Cidades, do cenário econômico favorável e da prioridade política conferida por mais de uma década?

Parte-se da premissa de que o somatório das políticas setoriais de habitação, saneamento e mobilidade não constitui, tampouco substitui de fato uma política de desenvolvimento urbano.

Para responder a essa questão, na forma em que esta tese se propõe, foi essencial o ingresso em um programa de pós-graduação com uma proposta multidisciplinar, por duas razões: primeiro, para possibilitar que a problemática urbana fosse abordada sob o enfoque de diferentes olhares, a partir da construção de uma sistemática metodológica capaz de abarcar sua complexidade; e, segundo, para superar as minhas fragilidades em termos de formação acadêmica, a partir do acesso a novos conhecimentos e da construção de uma nova forma de ver o mundo, que até então, vinha sendo alicerçada segundo o pragmatismo da engenharia.

A vivência das dinâmicas que ocorrem no interior da Administração Pública por mais de dez anos foi um dos fatores que me fizeram perceber que a análise de uma política 
pública, para ser mais consistente, não pode ser realizada apenas segundo a perspectiva técnica que embasa o tema. Também precisa abordar os processos políticos e sociais que incidem sobre ela e no espaço, tendo em vista explicar fenômenos e mecanismos implícitos que interferem no seu rumo, os quais normalmente requerem o uso de uma abordagem crítica para sua compreensão.

Desse modo, o caminho percorrido para se responder à questão de pesquisa foi ao mesmo tempo árduo e enriquecedor, na medida em que precisei abandonar a lógica racional e empirista que já estava consolidada na minha forma de pensar para construir uma nova epistemologia embasada nos saberes das ciências sociais.

Portanto, nesta tese será abordada a política de desenvolvimento urbano brasileira com o objetivo geral de identificar e compreender as mudanças ocorridas ao longo do tempo nos discursos oficiais, bem como as transformações institucionais e a atuação dos atores e agentes, para entender por que esta política permanece estruturada priorizando a lógica setorial centrada nas políticas setoriais de habitação, saneamento e mobilidade urbana, apesar de todo aprendizado e do processo de mudanças vivenciado em sua trajetória.

Para responder à pergunta de pesquisa foram realizadas etapas de trabalho de acordo com os seguintes objetivos específicos:

1. identificar as contribuições teórico-conceituais apontadas pela literatura, destacando-se os pressupostos e premissas essenciais que deveriam orientar a concepção e a implementação de uma política urbana;

2. identificar os pontos em comum e as especificidades dos discursos e das práticas relativos às políticas setoriais de saneamento, habitação e mobilidade e uma política de desenvolvimento urbano, a partir da análise dos discursos das políticas urbanas e dos planos governamentais já elaborados;

3. analisar a política de desenvolvimento urbano implementada pelo Ministério das Cidades, considerando sua estrutura, recursos e ações implementadas tendo em vista verificar se as práticas adotadas estavam em conformidade com os discursos preconizados e de acordo com os critérios de implementação; 
4. identificar e analisar o comportamento das principais coalizões que influenciam as políticas urbanas e quais são suas crenças, prioridades, interesses, os atores que as integram e sua forma de atuação no processo decisório.

Visando alcançar esses objetivos fez-se uso da combinação de uma análise qualitativa e quantitativa, tendo como principal referencial a abordagem crítica. A sistemática metodológica adotada envolveu quatro momentos distintos de análise, os quais estão expressos em cada capítulo da tese, como apresentado a seguir:

- inicialmente, buscou-se compreender os principais aspectos teóricos com relação à problemática urbana, visando compreender os pressupostos básicos a serem considerados numa política urbana;

- em seguida, realizou-se a análise dos discursos institucionais já disseminados tendo em vista analisar se as premissas apontadas no capítulo teórico foram incorporadas aos discursos, além de verificar quais as temáticas fizeram parte dos discursos propostos;

- o terceiro momento envolveu a análise qualitativa e quantitativa da política de desenvolvimento urbano implementada pelo Ministério das Cidades, onde foi apresentado o panorama recente da qualidade urbana e dos investimentos nos setores de habitação, saneamento e mobilidade;

- o último momento da tese envolveu a aplicação do modelo de Coalizões de defesa para identificar as coalizões e os interesses que nortearam a política urbana implementada pelo MCidades.

A etapa de levantamento documental e bibliográfico implicou a seleção de referências bibliográficas relevantes para a reflexão acerca da problemática urbana; o levantamento dos discursos oficiais já disseminados em nível de governo central (União); o levantamento de dados quantitativos primários e secundários relativos ao Ministério das Cidades e às ações implementadas pelo órgão; bem como o levantamento de fatos, falas e eventos capazes de caracterizar as crenças e os interesses dos atores integrantes das coalizões estudas.

Buscava-se com essas etapas de trabalho compreender a questão de pesquisa do ponto de vista teórico e conceitual, analisar a política urbana considerando aspectos 
teóricos e práticos, e, finalmente, entender a retratar a dinâmica dos atores que conduziram o processo decisório acerca da política urbana desde a criação do MCiddaes.

Desse modo, Para alcançar os objetivos propostos, no Capítulo 1 foram revisitados os principais autores marxistas que abordaram a problemática urbana, buscando identificar premissas e pressupostos essenciais para orientar uma política urbana, bem como para a compreensão do tema de forma crítica. A partir desses autores foi possível reconhecer os mecanismos inerentes ao processo de urbanização e industrialização, possibilitando o entendimento da raiz dos problemas enfrentados nos centros urbanos. Também foi possível verificar que, desde os primórdios da urbanização até a atualidade, em decorrência da ampla aceitação de um modelo de desenvolvimento perverso, se impôs um padrão de segregação e pobreza urbana nas cidades.

O passo seguinte se deu com a elaboração do Capítulo 2 onde o discurso das políticas urbanas já instituídas no Brasil foi revisto e analisado, desde seus antecedentes até a criação do Ministério das Cidades, que é atualmente o órgão competente por tratar do assunto no governo em âmbito federal. Além desses documentos foram analisados os sucessivos planos propostos para orientar as ações relativas ao urbano, mas que não chegaram a se constituir como uma política de fato. Buscou-se com isso identificar como o discurso oficial foi sendo construído e modificado ao longo do tempo, com atenção especial em relação aos temas que passaram integrar o escopo de uma política de desenvolvimento urbano. Também foi feita uma análise de como os pressupostos identificados no capítulo anterior foram contemplados nesses documentos.

Em seguida, detive-me a estudar o universo da política urbana no âmbito do Ministério das Cidades no Capítulo 3, observando as peculiaridades relativa à estrutura e às competências do órgão, as proposições contidas na Política Nacional de Desenvolvimento Urbano preconizadas nos Cadernos MCidades publicados logo após a sua criação, e nas políticas nacionais de habitação, saneamento e mobilidade publicadas nos anos 2000 . Também foram analisar as influências decorrentes do PAC e do PMCMV como principais programas de governo implementados a partir de 2007 nas condições de habitação, saneamento e mobilidade. Buscou-se verificar a aderência entre a política preconizada nos discursos e aquela praticada por meio da implementação das ações realizadas pelo Ministério no período de 2003 até 2014. 
Por se tratar de um estudo sobre uma política pública, no Capítulo 4, foi utilizado um modelo para analisar os processos políticos e de mudança institucional que incidem no subsistema da política urbana, em função da atuação dos atores que normalmente interferem no processo de tomada de decisão. Buscou-se ainda identificar as coalizões e os interesses que protagonizam as mudanças ou até a manutenção do "status quo", bem como o reconhecimento de suas crenças, interesses e interlocução com o Estado.

Nas conclusões foram apresentadas ponderações com o objetivo de sistematizar as evidências que tentam esclarecer o fato de a política de desenvolvimento urbano brasileira manter-se centrada nas políticas setoriais de habitação, saneamento e mobilidade, mesmo que diversas outras temáticas tenham sido apontadas como relevantes ao longo do tempo e também que pressupostos teóricos tenham sido apontados como essenciais por diversos autores especialistas no tema para nortear as políticas urbanas.

As evidências encontradas sugerem que embora as mudanças institucionais ocorridas, tanto na política urbana quanto no ambiente organizacional da Administração Pública tenham sido relevantes, não foram suficientes para transformar a forma como as cidades são pensadas e produzidas, dando continuidade à permanência de um modelo de desenvolvimento perverso e concentrador no que se refere ao urbano. 


\section{Capítulo 1. A problemática urbana em perspectiva teórica: contribuições para orientar uma política urbana}

\subsection{Formulações teóricas para estudar a problemática urbana: justificativa para escolha da abordagem crítica}

Para compreender a natureza da problemática urbana é essencial voltar-se aos primórdios de como esta temática se tornou um problema social, sendo formulado em termos teóricos e práticos, em âmbito acadêmico, na burocracia e também na sociedade. É preciso entender ainda de que forma essa problemática ascendeu à agenda governamental, imputando ao Estado a responsabilidade de apresentar estratégias para sua solução ou minimização dos seus efeitos negativos sobre as cidades e a sociedade.

Quais são os determinantes da problemática urbana? Que fatores impulsionaram o crescimento das cidades e contribuíram para o quadro de pobreza e desigualdade social nos grandes centros urbanos? Quais interesses e atores protagonizaram esse processo? Como o Estado é levado a intervir no meio urbano e de que forma ele atua? O que faz com que essa condição de precariedade social se perpetue e até se acentue ao longo do tempo?

Questionamentos como esses incitaram a elaboração de diferentes formulações teóricas, por diversos ramos do conhecimento, visando possibilitar uma compreensão mais aprofundada da problemática urbana. Sobre isso, Mendonza (2005, p. 440) destaca que a cidade é o objeto de pesquisa de estudos urbanos de vários campos científicos.

As teorias que tentaram explicar a transformação, o crescimento, o sentido e a função da cidade para informar seus melhoramentos e/ou planejamento, tiveram grande importância nas intervenções feitas, tanto pelo Estado quanto pela sociedade. Assim, diferentes campos do saber produziram análises sistemáticas e científicas sobre o urbano, destacando-se: (i) a teoria de polos de crescimento e desenvolvimento proposta por François Perroux e complementada por Jacques Boudeville; (ii), a Escola de Chicago liderada por John Rockfeller; e (iii) os estudos desenvolvidos pela abordagem marxista, que teve como expoentes Lefebvre, Castells, Harvey e Lojkine.

A produção teórica sobre a problemática urbana que se tinha como referência até meados dos anos 1960 estava concentrada na produção elaborada pela Escola de Chicago. 
De acordo com Monte-Mor (2006) a abordagem ecológica é reconhecida como o primeiro esforço teórico abrangente para uma abordagem social compreensiva da cidade, ganhando força nos Estados Unidos no período entre as grandes guerras. Esse reconhecimento ocorreu particularmente em Chicago, onde o intenso crescimento urbano-industrial produzia grande diferenciação de concentrações humanas e funcionais no território urbano.

A Escola de Chicago (décadas de 20 a 50) foi a primeira sistematização de uma teoria de cidades. Nessa abordagem, o urbano era visto como um ecossistema que possuía seres diversos, tomando como referência a ideia de um organismo vivo, fazendo uma analogia à biologia. Para essa escola, a cidade se expande de forma natural e os efeitos da organização econômica e dos processos competitivos seriam explicados por padrões agregados de comportamento social. Os autores vincularam o comportamento humano à competição econômica e a ordem social ao deslocamento espacial da divisão do trabalho sem considerar os valores culturais na interação social (PIROLA, 2009, p. 4)

De acordo com Monte-Mór (2006) o viés espacialista implícito nessa abordagem também foi abordado na economia e no planejamento urbano e regional, onde ações centradas na produção de formas espaciais e organização do espaço foram tomadas como determinantes dos processos sociais que deveriam se desenvolver. Assim, algumas teorias desenvolvidas no âmbito da economia urbana (e regional) resgataram estudos iniciados desde o século anterior.

Seguindo uma orientação diferente da escola de Chicago, os estudos urbanos e regionais buscaram propor padrões de organização de redes de cidades (tomadas como lugares centrais) e da localização de indústrias e das atividades primárias e terciárias em função dos custos de transportes, de mão de obra e de energia, entre outros fatores, como também da renda da terra e da centralidade dos bens e serviços, definindo tamanhos e vantagens da aglomeração de atividades (economias). É preciso ressaltar que em todos esses casos, a dimensão espacial foi reduzida e simplificada, assim como identificado nos modelos da ecologia urbana (Monte-Mor, 2006, p. 6).

No período iniciado após a Segunda Guerra Mundial, a problemática regional foi discutida por diversos teóricos influenciando fortemente o planejamento econômico regional nos países periféricos, especialmente na América Latina. Percebia-se que o 
processo de desenvolvimento econômico não ocorria de maneira igual e simultânea em toda a parte, tratando-se de um processo irregular e desigual no espaço, tendo como resultado o fortalecimento de áreas/regiões mais dinâmicas e que apresentavam maior potencial de crescimento.

O crescente interesse pelo estudo do regional deve-se ao crescimento explosivo das cidades, da concentração da atividade econômica, dos desequilíbrios regionais resultantes desta concentração, das migrações rurais, urbanas e intra-regionais, dentre outros fatores (PIROLA, 2009, p. 3). A partir do reconhecimento da existência de grandes desequilíbrios entre as regiões e os desdobramentos perversos dessa constatação, surgem as teorias do desequilíbrio regional, tendo como autor de maior destaque Perroux e, posteriormente, Boudeville.

Diversos teóricos se propuseram a estudar a dinâmica econômica regional com o intuito de esclarecer sua problemática, indicando, inclusive, as possíveis soluções para a superação do subdesenvolvimento. Entretanto, as análises produzidas por François Perroux ganharam destaque e estimularam uma série de estudos convergentes como os desenvolvidos por Jacques Boudeville (LIMA e SIMÕES, 2009, p. 6).

François Perroux foi um dos primeiros teóricos a contestar, em uma série de trabalhos desenvolvidos no decorrer da década de 50, a noção inexata de espaço utilizada nas análises econômicas realizadas até então que consideravam espaços econômicos e humanos coincidentes, resultando consequentemente, em recomendações imprecisas para políticas econômicas.

A teoria dos polos de crescimento foi desenvolvida por Perroux em 1955, ao observar a concentração industrial na França, em torno de Paris, e na Alemanha, ao longo do Vale da Ruhr, chegando à conclusão que os polos industriais de crescimento surgiam em torno de uma aglomeração urbana importante (Paris), ao longo das grandes fontes de matérias primas, assim como nos locais de passagem de fluxos comerciais significativos e em torno de uma grande área agrícola dependente (SOUZA, 2005a, p.88).

Para Perroux o polo de crescimento tem uma forte identificação geográfica, porque ele é produto das economias de aglomeração geradas pelos complexos industriais, que são liderados pelas indústrias motrizes. Um complexo industrial é um conjunto de atividades 
ligadas por relações de insumo-produto. Ele forma um polo de crescimento quando for liderado por uma ou mais indústrias motrizes; e ele se tornará um polo de desenvolvimento quando provocar transformações estruturais e expandir o produto e o emprego no meio em que está inserido (SOUZA, 1993, p. 33).

Segundo Lima e Simões (2009, p. 9) Perroux preconizava que uma economia nacional apresenta-se como uma combinação de conjuntos relativamente ativos (indústrias motrizes, polos de indústria e de atividades geograficamente concentradas) e de conjuntos relativamente passivos (indústrias movidas, regiões dependentes dos polos geograficamente concentrados), onde os primeiros induzem nos segundos fenômenos de crescimento. Isso gera duas consequências para a análise do crescimento: (i) a possibilidade de conflito entre espaços econômicos de grandes unidades econômicas e os espaços politicamente organizados dos Estados Nacionais (não são coincidentes); e (ii) políticas nacionais ultrapassadas podem gerar desperdícios que prejudicam o desenvolvimento.

Por outro lado, a implantação de um polo de desenvolvimento provoca desequilíbrios econômicos e sociais, em função de distribuir salários e rendimentos adicionais sem aumentar necessariamente a produção local de bens de consumo, assim como concentra o investimento e a inovação sem necessariamente alargar a vantagem de outros locais, nos quais o desenvolvimento pode ser retardado. Por isso, Perroux evidencia a necessidade de políticas econômicas, cujo objetivo deve ser o desenvolvimento técnico e humano e a cooperação entre regiões ricas e pobres, o que chamou de desenvolvimento recíproco (Lima e Simões, 2009, p. 9).

Embora diferentes áreas do conhecimento e diversos autores tenham elaborado uma produção teórica consistente sobre a problemática urbana, fez-se a escolha nesta tese de adotar a abordagem crítica / marxista para embasar as análises. Essa escolha se justifica por se acreditar que a Escola de Chicago e a abordagem regional, mesmo tendo sua importância, não dispõem de instrumentos adequados para lidar com a complexidade da problemática urbana, tratando os problemas urbanos a partir do olhar quantitativo e de maneira empirista. 
O estudo dessa temática requer a compreensão de aspectos implícitos, das crises, das tensões e contradições que existem no meio urbano, as origens e a perpetuação do processo de segregação sócio-espacial, conforme apontado por teóricos como Lefebvre, Castells, Harvey e Santos. Supõe-se que as abordagens convencionais apresentam limitações para responder a respeito desses aspectos devido à sua incapacidade de escapar do olhar que privilegia o crescimento econômico e por não abordarem o espaço de forma adequada, sem considerar as relações sociais juntamente com sua parte material.

O desenvolvimento de estudos críticos sobre a cidade foi estimulado devido ao aprofundamento de uma crise capitalista que ampliou as deficiências fiscais do Estado de forma generalizada. Isso ocorreu em meados dos anos 1970, provocando a acentuação de uma crise social e econômica (SILVA, et al., 2014, pp. 8-9).

Souza (2005, p. 60) aponta os estudos franceses produzidos na segunda metade do século XX como um movimento do pensamento sociológico de crítica à tradição empirista para o tratamento do espaço urbano, que era a abordagem central da Escola de Chicago. Para o autor, essa nova fundamentação teórica, também chamada de "Nova Sociologia Urbana", ganhou relevância nos meios acadêmicos a partir da década de 1960, tendo como objeto de estudo a compreensão de como se operam os processos de segregação sócioespaciais condicionados pela lógica interna do capital, seguindo uma abordagem crítica.

O debate central dessa formulação teórica tem sua origem na corrente marxista francesa, com maior destaque entre o período de 1972 a 1982, quando "A Questão Urbana" de Manuel Castells emergiu como principal eixo temático (SOUZA, 2005b, p. 62).

A abordagem crítica foi elaborada a partir da obra de Marx e teve como desafio desvendar a cidade e a urbanização, uma vez que a ampliação do capitalismo resultou no surgimento de novas condições de reprodução das sociedades capitalistas no século XX. Buscava-se encontrar uma resposta política apropriada a uma urbanização crescente da economia e da vida social e política em todos os aspectos e escalas (LIMONAD, 1999, p. 74).

Segundo Souza (2005b, p. 65) essa abordagem introduz uma análise crítica das condições socioeconômicas vividas pela classe trabalhadora na Inglaterra, propondo uma reflexão mais aprofundada sobre o fenômeno da cidade-industrial, considerando-a como 
uma das manifestações do capital, trazendo uma alternativa à explicação da descrição do crescimento demográfico e dos fluxos migratórios. Tenta relacionar esses fenômenos ao que acreditava estar subjacente ao crescimento exponencial da aglomeração urbana na Europa: o fundamento social oculto representado pela emergência do novo modo de produção capitalista.

Limonad (1999, p. 74) destaca que nesse período, o planejamento urbano foi examinado de forma crítica, sendo considerado como um instrumento de coerção e normatização do espaço pelo Estado. Além disso, a atenção inicial que se dava aos locais de trabalho (fábricas) foi transferida para o meio urbano, que era o local onde ocorriam os conflitos relativos à reprodução e sobrevivência da força de trabalho.

Essa mudança de foco também favoreceu a consolidação de diversos estudos sobre os movimentos sociais urbanos identificados como a nova forma de luta política, contribuindo para ampliar o campo de análise urbana em diversos segmentos, os quais estavam preocupados com a reprodução da força de trabalho e o consumo coletivo. Assim, a Escola Marxista Francesa deu início a um programa de estudos sobre o urbano, tendo suas formulações se tornado referência básica para as pesquisas latino-americanas, ganhando hegemonia no Brasil, especialmente após o período da redemocratização (SOUZA, 2005b, p. 71).

A proposta da Nova Sociologia Urbana apresenta uma ruptura teórica com a Escola de Chicago, que adotava uma abordagem empirista e buscava soluções concretas para uma cidade caótica, marcada por intenso processo de industrialização e de urbanização. Segundo essa nova abordagem, a cidade deveria ser compreendida como espaço socialmente produzido, assumindo diferentes configurações, de acordo com os vários modos de organização socioeconômica e de controle político.

Nesse período, vários teóricos, entre eles, Castells, Lojkine e Lefebvre, apresentaram novas formulações tendo em vista renovar a reflexão sobre a cidade, a partir de uma produção de inspiração marxista (SANT’ANNA, 2003, p. 94). Para a autora (p. 95), a cidade passa a ser pensada considerando a interação entre as relações de produção, consumo, troca e poder, por meio de um novo enfoque que politiza a questão urbana, dando origem a novas questões de investigação: movimentos sociais urbanos, os meios de 
consumo coletivo, a estruturação social do território na sociedade capitalista, bem como o papel do Estado na urbanização.

Para Harvey (1996, p. 48) a pesquisa do papel da urbanização na dinâmica social não é nenhuma novidade, visto que de tempos em tempos, essa temática aflora como foco dos principais debates. Contudo, na maioria das vezes, não são levadas em conta as circunstâncias histórico-geográficas específicas nas quais o papel da urbanização e das cidades aparece particularmente relevante.

Em função disso, o núcleo das preocupações acadêmicas do autor nas últimas décadas tem consistido no esclarecimento do papel da urbanização na transformação social, especialmente sob as condições das relações e acumulação capitalistas, dando seguimento às formulações elaboradas pela escola marxista francesa. Nesse sentido, o autor procura uma melhor compreensão do processo de criação da cidade, que é, ao mesmo tempo, produto e condição de processos sociais de transformação.

Para conhecer as principais contribuições propostas pela abordagem crítica foram estudadas as obras dos autores listados a seguir, de acordo com o ano de publicação do exemplar original:

- O direito à cidade (1968) e A revolução urbana (1971) de Henri Lefebvre;

- A questão urbana (1972) de Manuel Castells;

- A justiça social e a cidade (1973) de David Harvey;

- O Estado capitalista e a questão urbana (1977) de Jean Lojkine;

- Por uma geografia nova (1978) e A natureza do espaço (1996) de Milton Santos.

A escolha desses autores e das respectivas obras se justifica pelo fato de todos esses autores terem contribuído significativamente para descrever as causas implícitas e explícitas relacionadas à problemática urbana que decorrem do processo de urbanização e por se apresentarem como os principais autores que abordaram a problemática urbana seguindo a abordagem marxista.

Também foi preciso considerar que era necessário entender a problemática urbana em sua essência e de forma detalhada, visto que a minha formação em engenharia civil não havia suprido essa lacuna. A revisão bibliográfica precisava ser profunda sem ser muito 
extensa, então era preciso escolher obras que de certo modo contemplassem os principais assuntos inerentes a essa problemática.

Desse modo, a leitura de Lefebvre, a partir das obras selecionadas, é considerada ponto de partida para qualquer leitor que busca se aprofundar no tema por inaugurar uma nova perspectiva sobre a problemática urbana, destacando que esta apresenta um caráter político e ideológico.

“A Questão Urbana” de Castells também foi uma das obras escolhidas por ir além da tradição positivista que orientava os estudos sobre as cidades trazendo para o centro de suas análises o conflito de classes, as lutas e os problemas urbanos. O autor buscava estabelecer uma contribuição pioneira para uma teoria marxista e científica da urbanização.

A leitura de "A justiça social e a cidade" de Harvey foi essencial pela importância da obra, que traz contribuições em diferentes níveis de ideias. Assim como Castells, o autor tenta propor uma nova forma de teorizar os estudos urbanos e a ciência regional, combinando reflexões sociológicas e geográficas, assim como abre o espaço para discussão de questões que não eram contempladas no campo da ciência regional anglo-saxônica que era usual naquela época. Aborda o conceito de justiça social que se baseia em um conjunto de fatores que derivam da necessidade de cooperação na busca do desenvolvimento dos indivíduos, além de abordar aspectos que condicionam a distribuição de recursos no espaço.

Para compreender o debate a respeito do papel do Estado capitalista na produção do espaço urbano foi importante a leitura de "O Estado capitalista e a questão urbana" de Lojkine. Nessa obra, o autor procura compreender e explicar teoricamente o funcionamento do Estado na sociedade capitalista, destacando a análise do urbano como componente chave para o desvendamento do Estado.

Finalmente, a escolha de Milton Santos se explica pelo fato de o autor se destacar como um geógrafo preocupado com o entendimento pleno de seu objeto de estudo e por se destacar, ao expor de forma abrangente, importantes considerações sobre o espaço geográfico. Em sua obra "Por uma geografia nova", o autor aponta os problemas que impedem a construção de uma geografia orientada para uma problemática social mais ampla e construtiva. Além disso, é nesse livro que o autor apresenta bases iniciais de seu 
projeto teórico que, mais adiante, é apresentado na sua obra principal obra: "A natureza do espaço". A obra apresenta uma revisão crítica da evolução da Geografia como campo do conhecimento e propõe uma nova forma de pensar esta ciência em tempos mais atuais.

Alguns estudiosos do autor apontam "A natureza do espaço" como o livro chave para quem quer realmente compreender a totalidade da obra de Milton Santos e descobrir o que significa o seu método de análise geográfica. Em sua obra o autor apresenta as diferentes nuances do espaço geográfico, além de relacioná-lo intimamente com seus agentes formadores e influenciadores. Também foi feita a opção por este autor devido à adoção da categoria de análise "território usado" que é sinônimo de espaço geográfico e engloba o espaço material mais o espaço social.

Em seus estudos, os autores selecionados apontam a concentração de recursos em determinadas classes da sociedade, a dificuldade de acesso ao solo urbano, a segregação sócio-espacial e a questão habitacional como consequências de uma urbanização orientada para os ganhos do capital. Além disso, apresentam elementos que podem nortear a superação desses problemas por meio da transformação da própria sociedade.

Embora a produção teórica desses autores tenha se concentrado nas décadas de 1970 e 1980, suas reflexões continuam atuais, sendo leituras essenciais e ponto de partida para a compreensão dos problemas urbanos. Os autores ressaltam a complexidade do tema e a necessidade de adotar um método adequado e abrangente para analisar a problemática urbana sob diferentes perspectivas, inclusive destacando a abordagem crítica como aquela mais adequada para esse fim.

A partir da leitura dessas obras, foi possível identificar que na formulação teórica dos autores foram apresentadas discussões mais precisas em torno de cinco aspectos centrais: (i) o espaço como conceito básico da problemática urbana; (ii) o método adotado para compreender a problemática urbana; (iii) aspectos políticos da problemática urbana; (iv) o Estado como principal interventor na problemática urbana; (v) temas relevantes para entender a problemática urbana.

Essas discussões revelaram a existência de pressupostos e premissas básicas que possibilitam a compreensão das origens da problemática urbana, sua essência e natureza, atores e interesses relevantes e os principais temas discutidos. Entende-se que esses 
pressupostos e premissas deverão ser considerados no estudo da temática urbana e também na proposição de políticas públicas voltadas para a transformação dos desequilíbrios que incidem nas cidades.

\subsection{O espaço como conceito básico da problemática urbana}

Buscando melhor descrever as dimensões do fenômeno urbano, Lefebvre ([1971] 2004, p. 85) chamou a atenção para três aspectos que podem aprimorar o debate em torno da problemática urbana: (i) a projeção das relações sociais no solo; (ii) o fenômeno e o espaço urbano não são apenas projeção das relações sociais, mas lugar e terreno onde as estratégias se confrontam; (iii) há uma prática urbana que não se reduz às ideologias nem às instituições globais.

Ao iniciar essa discussão, o autor defende a ideia de que o espaço é o elemento central de estruturação da sociedade, além de apontá-lo como o elemento onde as relações conflitantes de poder são projetadas e materializadas. O espaço é considerado um produto social que revela as contradições da realidade social, mas também é o lugar onde as relações se reproduzem e se localizam, juntamente com a manifestação de todos os conflitos, lutas e contradições que lhe são inerentes. $\mathrm{O}$ autor defende que não é apenas toda a sociedade que se torna o lugar da reprodução, mas sim todo o espaço social, que não pode ser visto apenas como um produto, sendo necessário que também se dê atenção ao processo de produção social do espaço e a suas transformações.

De acordo com o Lefebvre ([1971] 2004, p. 33) cada modo de produção produziu um tipo de cidade, sendo influenciados pelos diferentes interesses inerentes a esses modos de produção. Em função disso, o autor considera o espaço urbano uma contradição concreta; um campo de tensões altamente complexo devido aos embates vivenciados pela contradição desses interesses muitas vezes contrários.

Portanto, o estudo da lógica do espaço e de suas propriedades conduz à análise dialética de suas contradições, sendo também necessário identificar a lógica existente por trás da sua formação. Para Lefebvre o urbano não se define apenas como lugar de passagens ou de trocas, tampouco a realidade urbana se restringe apenas ao consumo, visto que ela intervém na produção e nas suas respectivas relações. Para o autor ([1971] 2004, p. 79): 
"A divisão social do trabalho não parece funcionar espontaneamente, visto que invoca o controle de uma potência superior de organização: o Estado. Inversamente, essa potência, instituição suprema, tende a perpetuar suas próprias condições, a manter a separação do trabalho manual e do intelectual, como a dos governos e dos governantes e, talvez, a separação entre a cidade e o campo" (LEFEBVRE, [1971] 2004, p. 79).

Santos ([1978] 2012a, p. 252) amplia a discussão sobre o espaço ao trazer ao debate a noção de um "espaço quadrimensional" que se impõe como uma ideia promissora, porque ela reforça a noção de espaço relativo, ou seja, do espaço considerado como "um sistema de relações ou como um campo de forças, possibilitando a imposição do tempo como uma dimensão essencial". Mas isso supõe que o tempo seja definido em um contexto propriamente geográfico e não subjetivamente.

Cada variável é inteiramente desprovida de significação fora do sistema ao qual pertence, visto que as variáveis isoladas perdem sua especificidade quando passam por um processo de interação localizada. Portanto, a individualidade do espaço resultante provém de um tipo específico de combinação de variáveis e a continuidade desse espaço é assegurada pelo fato de que cada combinação também é função da combinação precedente (SANTOS, [1978] 2012a, pp. 254-255).

Em cada continente, país, região ou subespaço, cada lugar representa a soma de ações particulares inicialmente localizadas em períodos diferentes. A presença simultânea de variáveis com idades tão diversas tem como resultado uma combinação característica única para cada lugar. Levando em conta a defasagem entre as variáveis e os pedaços de tempo correspondentes, é possível explicar as diversidades de organização do espaço entre países, bem como o que se chama de desigualdades regionais (SANTOS, [1978] 2012a, p. 259).

Em seus estudos, Castells ([1972] 2014) também buscou ultrapassar o empirismo da descrição geográfica, e passou a defender que a cidade deve ser considerada como a projeção da sociedade no espaço. O autor considera que este é um ponto de partida essencial e, ao mesmo tempo, elementar para que não se corra o risco de imaginar o espaço como uma página em branco, na qual se inscreve a ação dos grupos e das instituições. É 
preciso compreender que o espaço é um produto material que se relaciona com outros elementos materiais, os quais conferem a ele forma, função e uma significação social.

Santos ([1978] 2012a) reforça esse aspecto ao explicar que o espaço que a geografia matemática pretende reproduzir não é o espaço das sociedades em movimento e sim a fotografia de alguns de seus momentos. Segundo o autor o problema disso é que essas fotografias permitem apenas a percepção descritiva, sendo que a simples descrição de um fenômeno não pode ser confundida com a sua explicação, que pode ser elevada ao nível do trabalho científico.

Nesse sentido, o espaço não pode ser visto como o simples desdobramento da estrutura social, mas como a expressão concreta de cada conjunto histórico a partir do qual uma sociedade se especifica. É preciso então, estabelecer as leis estruturais e conjunturais que comandam sua existência e sua transformação, além da sua articulação com outros elementos de uma realidade histórica (CASTELLS, [1972] 2014, p. 182). Portanto:

“Analisar o espaço enquanto expressão da estrutura social resulta, consequentemente, em estudar sua modelagem pelos elementos do sistema econômico, do sistema político e do sistema ideológico, bem como pelas combinações e práticas sociais que decorrem dele" (CASTELLS, [1972] 2014, p. 193).

Essa modelagem na qual o autor se refere pode ser percebida no âmbito dos processos que ocorrem na base de uma estrutura social e econômica, sendo resultantes da ação dos diferentes grupos sociais. Além disso, a representação desses sistemas varia e se sucede ao longo do tempo, produzindo diferentes realidades históricas que coexistes e se somam, interferindo na configuração do espaço segundo uma lógica dominante.

Desse modo, o espaço é produto de uma sociedade, constituindo meio e resultado das ações e das relações sociais, o que lhe confere um caráter dialético. Essa dialética também se expressa nas tensões entre atores que buscam objetivos diferentes e conflitantes, como pode ser percebido entre aqueles que desejam a manutenção do espaço social existente e aqueles que lutam por sua transformação.

Castells conclui sua obra "A questão urbana" destacando as seguintes considerações sobre o espaço: 
“A compreensão da estrutura espacial passa por sua caracterização, sua decomposição e sua articulação, nos termos próprios à teoria geral das formações sociais. Assim, é preciso analisar o espaço econômico, político-jurídico, ideológico, especificando de maneira precisa estas categorias com relação ao domínio em questão, e deduzir disso as formas (conjunturas espaciais) a partir dos elementos assim enunciados. (...) A ligação entre o espaço, o urbano, e um certo sistema de comportamentos, considerados como típicos da "cultura urbana", só tem como fundamento o ideológico: trata-se de uma ideologia da modernidade, visando mascarar e naturalizar as contradições sociais” (CASTELLS, [1972] 2014, pp. 539540).

Dentre os autores abordados neste capítulo, Santos foi o que mais se dedicou a estudar o espaço e tecer conclusões sobre sua formação e sua natureza. De acordo com o autor ([1978] 2012a) é preciso compreender quais aspectos são relevantes na formação espacial de uma realidade específica, sendo importante verificar a lógica embutida nas relações e nas contradições sociais, na medida em que:

“Uma geografia que deseja seguir essa linha deve ter como meta fundamental o fato de que conhecer uma realidade é conhecer a forma como ela se produz. O novo saber dos espaços deve ter a tarefa essencial de denunciar todas as mistificações que as ciências do espaço puderam criar e difundir” (SANTOS, [1978] 2012a, p. 263).

Em sua obra mais completa, “A Natureza do Espaço”, Santos ([1996] 2012b, p. 61) aprofunda essas discussões e propõe uma definição atual para a geografia, considerando que, a esta disciplina, cabe estudar "o conjunto indissociável de sistemas de objetos e sistemas de ações" que formam o espaço. Para o autor, "o espaço é formado por um conjunto indissociável, solidário e também contraditório de sistemas de objetos e sistemas de ações, não considerados isoladamente, mas como o quadro único no qual a história se dá”.

Esses sistemas de objetos e sistemas de ações interagem, sendo que os sistemas de objetos condicionam a forma como se dão as ações assim como, os sistemas de ações levam à criação de objetos novos ou se realizam sobre objetos preexistentes. $\mathrm{O}$ espaço 
encontra a sua dinâmica e se transforma ao longo do tempo em um movimento dialético, em que esses sistemas são, ao mesmo tempo, base e produto das interações.

Para o autor, as relações sociais variam no tempo e no espaço de acordo com as etapas do processo histórico e dos elementos que o compõem, podendo destacar o modo de produção, a formação social e a organização do espaço. Esses elementos interagem entre si, desenvolvem-se juntos e concretizam um arranjo espacial particular. Desse modo:

“(...) considerar o espaço como esse conjunto indissociável de sistemas de objetos e sistemas de ações, assim como estamos propondo, permite, a um só tempo, trabalhar o resultado conjunto dessa interação, como processo e como resultado, mas a partir de categorias suscetíveis de um tratamento analítico que, através de suas características próprias, dê conta da multiplicidade e da diversidade de situações e processos” ([1996] SANTOS, 2012b, p. 52).

Os sistemas de objetos compreendem a natureza dotada de valor, sendo a valorização da forma dada pela intensidade com a qual os sujeitos a utilizam, a partir de um conjunto de intenções sociais. Existem, portanto, sistemas de ações que também passam a ser objetos na medida em que são materializados. Assim, a composição do espaço pode ser baseada em dois fatores: o primeiro é a "configuração espacial", aquilo que Santos denominou de conjunto de fixos, e o segundo, as "relações sociais", que formam os fluxos. Os dois fatores juntos, fixos e fluxos, contêm em si a realidade geográfica, que é o espaço ([1996] SANTOS, 2012b, pp. 62-63).

Essa discussão aponta a necessidade de se considerar a interação entre as partes material e imaterial do espaço para que se alcance o devido entendimento da sua natureza complexa. A aplicação desses conhecimentos no nível do sistema urbano possibilita inferir que a própria natureza da problemática urbana é espacial, visto que esta, por se materializar no espaço geográfico, assume as mesmas características complexas e relacionais. Também não se pode deixar de considerar a relação dialética entre a configuração espacial e as relações sociais, já que elas interagem entre si e se complementam na formação do espaço.

Santos ([1996] 2012b, p. 96) também destaca as transformações verificadas no espaço geográfico devido às mudanças ocorridas nos processos de trabalho e nas 
respectivas relações sociais. Segundo o autor, "é assim que as épocas se distinguem umas das outras".

Ao se referir ao uso do território, Santos ([1996] 2012b) especifica que é o uso o principal aspecto a definir o território, visto que são os modos de produção e seus respectivos atores e agentes hegemônicos que visam garantir sua reprodução e seus interesses. É a partir dos usos do território que são reveladas as relações conflitantes e complementares que ocorrem no meio urbano, já que cada grupo de atores busca a satisfação de objetivos específicos, sendo na maioria das vezes contraditórios. Sendo assim, as ações realizadas por estes, seguindo a lógica do modo de produção dominante, produz o espaço. Sobre isso, o autor destaca que:

“O espaço, uno e múltiplo, por suas diversas parcelas, e através do seu uso, é um conjunto de mercadorias, cujo valor individual é função do valor que a sociedade, em um dado momento, atribui a cada pedaço de matéria, isto é, a cada fração da paisagem” (SANTOS, [1996] 2012b, p. 104).

Ao discorrer sobre a natureza do espaço o autor ([1996] 2012b, p. 106) especifica que este é formado pelo resultado material acumulado das ações humanas no decorrer do tempo, assim como é animado pelas ações atuais que hoje lhe atribuem um dinamismo e uma funcionalidade. $\mathrm{O}$ espaço, portanto, é formado pela interação entre as partes material e imaterial do contexto social, sendo a paisagem (aspecto descritivo) e a sociedade (aspecto imaterial) variáveis complementares, cuja síntese, sempre por refazer, é dada pelo espaço humano. Nesse sentido, o autor afirma que:

"É a sociedade, isto é, o homem que anima as formas espaciais, atribuindolhes um conteúdo, uma vida. Só a vida é passível desse processo infinito que vai do passado ao futuro, só ela tem o poder de tudo transformar amplamente. Tudo o que não retira sua significação com o homem é incapaz de um movimento próprio, não pode participar de nenhum movimento contraditório, de nenhuma dialética. (...) não existe dialética possível entre formas enquanto formas. Nem a rigor, entre paisagem e sociedade. A sociedade se geografiza através dessas formas, atribuindo-lhes uma função que, ao longo da história, vai mudando. O espaço é a síntese, sempre provisória, entre o conteúdo social e as formas espaciais. Mas a contradição principal é entre sociedade e espaço” (SANTOS, [1996] 2012b, p. 109). 
Outro aspecto destacado pelo autor ([1996] 2012b, p. 113) se refere à questão da totalidade, que a seu ver, tem sido enfrentada pela geografia de forma tímida. Para Santos, não se pode dizer que essa disciplina tenha abandonado completamente esse tema. Mas, também, não se pode afirmar que o tema tenha sido abordado por ela de modo sistemático. Defende que a noção de totalidade é uma das mais fecundas, constituindo em elemento fundamental para o conhecimento e a análise da realidade.

De acordo com Santos ([1996] 2012b, p. 117), o processo histórico constitui um processo de complexificação, onde a totalidade vai se fazendo mais densa e mais complexa. Além disso, o universo não é desordenado, sendo necessário buscar reconhecer a sua ordem interna, que se comporta segundo as leis que o regem. $\mathrm{O}$ autor chama isso de totalidade concreta, mas considera que a totalidade é uma realidade fugaz, que está sempre se desfazendo para voltar a se fazer. Por isso, o todo é algo que está sempre buscando renovar-se para se tornar, de novo, outro todo. Santos ([1996] 2012b) afirma que:

“A totalidade é, ao mesmo tempo, o real-abstrato e o real-concreto. Só se torna existência, só se realiza completamente, através das formas sociais, incluindo as geográficas. E a cada momento de sua evolução, a totalidade sofre uma nova metamorfose. Volta a ser real-abstrato. (...) Assim, podemos conceber a totalidade como um todo de "essências" e como um todo de "existências" simultaneamente" (SANTOS, [1996] 2012b, pp. 122-123).

O autor complementa sua formulação explicando que, a totalidade social é formada por mistos de realidade e ideologia, influenciando o curso da história nos diferentes momentos que se sucedem. Por isso, a cada nova divisão do trabalho, ocorre uma nova transformação social que promove, paralelamente, a renovação das ideologias e dos universos simbólicos (SANTOS, [1996] 2012b, p. 127).

Para Santos ([1996] 2012b, p. 129) a divisão do trabalho constitui o motor da vida social e da diferenciação espacial, sendo a divisão do trabalho o "processo pelo qual os recursos disponíveis se distribuem social e geograficamente no espaço". Mas chama atenção para o fato de que a divisão do trabalho supõe a existência de conflitos que devem ser levados em conta no momento de empreender uma análise do fenômeno. 
Assim, Santos ([1996] 2012b) entende que o espaço geográfico é produzido social e historicamente, sendo diariamente, reproduzido mediante o trabalho e as demais atividades do homem. E é a partir dessas práticas que as contradições e desigualdades sociais são reveladas. Em função disso, as mudanças ocorrem de maneira dialética, fruto de intencionalidades sociais e promovem a construção do espaço geográfico de acordo com a evolução histórica. O espaço é, portanto, um híbrido entre o meio natural e a técnica, com múltiplas relações que se caracterizam a partir dos objetos (formas) e ações (conteúdos) que transcorrem no tempo.

Tentando compreender a lógica espacial decorrente do crescimento urbano, Harvey (1980) observou que o processo de urbanização teve como resultado mudanças significativas na forma espacial das cidades. $\mathrm{O}$ autor também ressalta que durante esse processo ocorre a reorganização em termos de localização e distribuição de algumas atividades no sistema urbano, apontando que essas mudanças representam algo muito maior que simples manifestações de ajustamento desse sistema urbano por contribuem para produzir várias formas de redistribuição de renda na cidade.

Para Lojkine ([1977] 1981) cada vez mais, a cidade é lugar de atuação dos agentes de produção do espaço, refletindo na sua organização um padrão conferido pela representação das relações sociais. Essas relações imprimem um padrão característico que pode ser averiguado a partir da observação da materialização da segregação sócio-espacial no território, que é reforçada, principalmente, pela diferenciação nos níveis de renda da sociedade. Assim, a cidade é a expressão materializada da atuação da sociedade no espaço, como resultado da reprodução das relações sociais no interior de uma sociedade capitalista.

Em função disso, por perceber que a ação humana sobre o espaço interfere na forma das cidades e na distribuição dos recursos, Harvey ([1973] 1980, p. 71) se questiona sobre a existência de alguma estrutura ou série de estruturas espaciais que possam maximizar a equidade e a eficiência do sistema urbano ou, que pelo menos, possa maximizar a habilidade em se controlar os mecanismos ocultos que produzem essa distribuição.

O autor considera que, com essa resposta, seria possível explicar efeitos distributivos a partir de estruturas espaciais existentes, assim como imaginar estruturas espaciais para a obtenção de um objetivo distributivo específico. Assim, Harvey ([1973] 1980, p. 76) 
constrói argumentos a favor da organização territorial, considerando que uma organização "adequada" pode contribuir significativamente para minimizar o conflito e maximizar a eficiência do sistema urbano.

O urbanismo, na medida em que possui suas próprias leis de transformação também é construído de princípios básicos de organização espacial. E o papel específico que o espaço desempenha, tanto na organização da produção como na padronização das relações sociais está expresso na respectiva estrutura urbana. Mas o urbanismo não é apenas uma estrutura decorrente de uma lógica espacial por estar ligado a ideologias específicas, assumindo, por isso, certa capacidade de moldar o modo de vida de uma sociedade. Assim, uma vez criada a estrutura urbana, será afetado o desenvolvimento futuro das relações sociais e a organização da produção desse sistema (HARVEY, [1973] 1980, p. 265).

Portanto, qualquer tentativa de intervir na lógica de organização espacial dominante, tendo em vista minimizar os conflitos existentes e maximizar a distribuição de recursos em um sistema urbano, no combate da segregação urbana, por exemplo, não se pode prescindir da análise do espaço levando em conta toda a sua complexidade. Desse modo, a compreensão da natureza da problemática urbana e de suas peculiaridades requer a adoção de teorias e sistemáticas metodológicas que possibilitem reflexões precisas acerca do espaço urbano, tendo em vista abarcar toda sua complexidade.

\subsection{0 método adotado para compreender a problemática urbana}

Santos (2012a) inicia sua obra "Por uma geografia nova", destacando que a geografia oficial, foi "desde os seus começos" mais uma ideologia que uma filosofia. A ideologia engendrada pelo capitalismo, quando da sua implantação, tinha que ser adequada às suas necessidades de expansão nos países centrais e na periferia, uma vez que era necessário criar condições para expansão do comércio. Nesse período, era imperativo adaptar as estruturas espacial e econômica dos países pobres às novas tarefas que deviam assegurar sem descontinuidade (SANTOS, [1978] 2012a, p. 30).

Diante da expansão do imperialismo, os geógrafos dividiram seus pontos de vista. De um lado estavam aqueles que lutavam por um mundo mais justo, onde o espaço deveria ser organizado com o fim de oferecer ao homem mais igualdade e mais felicidade. De outro lado, estavam aqueles que preconizavam claramente o colonialismo e o império do capital. 
Segundo o autor, ([1978] 2012a, p. 31) a utilização da geografia como instrumento de conquista colonial não foi uma orientação isolada. Em todos os países colonizadores, houve geógrafos empenhados nessa tarefa, deixando evidente a relação entre expansão da geografia e a da colonização.

Nessa obra, Santos faz uma crítica à geografia, apontando que esta ciência se manifestou, sobretudo por meio da quantificação. Para o autor ([1978] 2012a, pp. 74-75), a principal falta da geografia quantitativa é que ela desconhece totalmente a existência do tempo e suas qualidades essenciais. A aplicação coerente da matemática à geografia permite trabalhar com estágios sucessivos da evolução espacial, mas é incapaz de dizer alguma coisa sobre o que se encontra entre um estágio e outro.

Assim, é destacado o papel do geógrafo como um profissional que pode contribuir para o conhecimento das causas dos conflitos e das contradições que emergem na sociedade, bem como tem o dever de apresentar os mecanismos ocultos que condicionam a produção do espaço. A geografia deve funcionar como uma ciência que dispõe de ferramentas e alternativas para reconhecer a realidade como ela se produz e desmistificar as possíveis incoerências já propostas por outras ciências e até mesmo por outras correntes da própria geografia.

Nesse debate, o autor também destaca a necessidade de se trabalhar com a noção de contexto, que se refere àquilo que está subliminar e não é diretamente perceptível pelos indivíduos. Ressalta que trabalhar com o que não se vê é ainda mais importante que o visível, indicando que o espaço é ordenado por leis e mecanismos que não são diretamente expressos, mas que detêm a força necessária para se imporem em uma sociedade e moldála de acordo com interesses específicos. Sobre isso, Santos ([1978] 2012a) afirma que:

"O que se chama invisível passa a ser o mais fundamental da explicação, porque nos leva além da forma e da aparência, para oferecer-nos o que está por detrás do fenômeno” (SANTOS, [1978] 2012a, p. 264).

O autor também levanta o debate acerca da necessidade de se formular um sistema de conceitos (jamais um só conceito) que possa abranger o todo e suas respectivas partes em interação. Coloca que existe uma questão de método, visto que é necessária a 
construção de um sistema intelectual que permita, analiticamente, abordar uma realidade a partir de um ponto de vista. Trata-se de reconhecer o valor social dos objetos, mediante um enfoque geográfico.

O processo de formação espacial é complexo e requer o desenvolvimento de ferramentas e sistemáticas científicas que sejam capazes de assimilar suas especificidades. Essa questão também foi apontada por Harvey ([1973] 1980), ao mostrar que a inexistência de um conjunto de formulações teóricas que possam explicar as relações complexas existentes no espaço ainda constitui um desafio a ser enfrentado e dificulta a proposição de intervenções mais coerentes para atuar sobre os conflitos e contradições existentes. Segundo o autor, para se alcançar o referido enfoque geográfico, deve-se considerar o material e o imaterial que convive simultaneamente na realidade de uma sociedade.

Na obra “A questão Urbana”, Castells ([1972] 2014, p. 11) destaca que o papel central do Estado no novo processo de urbanização exige uma teoria capaz de integrar a análise do espaço com a das lutas sociais e dos processos políticos, sendo a tradição marxista obrigatória como ponto de partida. $\mathrm{O}$ autor explicita a necessidade de se tratar a problemática urbana de maneira crítica, buscando inclusive compreender as contradições inerentes ao processo de urbanização, reconhecendo o próprio Estado como um dos agentes que influenciam o urbano numa relação contraditória e conflitante. $\mathrm{O}$ autor também enfatiza a necessidade de se entender a lógica que rege a urbanização ao explicar que:

“(...) o processo social que está na base da organização do espaço não se reduz a situar o fenômeno urbano no seu contexto. Uma problemática sociológica da urbanização deve considerá-la enquanto processo de organização e de desenvolvimento, e, por conseguinte, partir da relação entre forças produtivas, classes sociais e formas culturais (dentre as quais o espaço). Uma investigação deste tipo não pode processar-se unicamente no abstrato; deve, com a ajuda de seus instrumentos conceituais, explicar situações históricas específicas, bastante ricas para que apareçam as linhas de força do fenômeno estudado, a organização do espaço” (CASTELLS, [1972] 2014, p. 36). 
Dessa forma, é possível compreender que o urbano é algo complexo, que integra aspectos da economia, da sociedade, do espaço e do tempo, sendo permeado por relações dialéticas e contraditórias as quais podem ser manifestadas pelas disputas por espaços habitáveis por diferentes representações da sociedade. Posto isso, para compreender a lógica da urbanização é preciso entender como esses diferentes aspectos se integram e condicionam a organização do espaço, sua transformação, bem como os mecanismos e as forças ocultas que possibilitam sua concretização.

Na sua obra "A revolução urbana", Lefebvre ([1971] 2004, p. 9) defende que a problemática urbana não pode ser entendida enquanto for considerada como subproduto da industrialização. De acordo com o autor, o resultado dessa redução do urbano é o urbanismo, entendido como a tentativa de submeter a realidade à racionalidade industrial, às exigências do mundo supostamente lógico, sem contradições nem conflitos.

Nesse sentido, tentando vencer essa lógica reducionista de pensar o urbano, o autor busca considerar o tema de forma crítica, identificando o urbanismo como "parte fundamental das tentativas de estender ao conjunto das atividades sociais os pressupostos, intencionalidades e representações que governam a divisão manufatureira do trabalho, com suas ordens e coações". O autor defende que:

"Quanto ao urbano, esse olhar redutor não permite vê-lo enquanto campo de tensões e conflitos, como lugar dos enfrentamentos e confrontações, unidade das contradições" (LEFEBRVRE, [1971] 2004, p. 10).

Para Lefebvre ([1971] 2004) não analisar o processo de urbanização e industrialização de forma crítica não permite que se perceba qual é a lógica que de fato move o processo que transforma as cidades e satisfaz as necessidades da classe dominante que é a principal beneficiada de todas essas transações. Também não é possível se questionar acerca da realidade desigual das cidades, onde coexistem mundos paralelos de convivência entre riqueza e pobreza exorbitantes, e da existência de uma vida urbana precária, desigual e degradante no meio dos grandes centros. Sem a crítica, fica quase impossível questionar se há algo errado nesse padrão de exclusão e segregação social, 
sustentado por um modelo de vida que satisfaz a vontade de poucos em detrimento das necessidades básicas de muitos.

O autor ([1971] 2004, p. 57) também ressalta que a complexidade do fenômeno urbano requer uma análise multidisciplinar, em função de não pertencer a nenhuma ciência especializada. Para o Lefebvre:

“(...) quanto mais cada ciência particular aprofunda sua análise, mas ela põe em evidência um resíduo. Que lhe escapa. Que se revela essencial; que depende de outros métodos. Assim, o economista encontra-se diante de algumas coisas que lhe escapam; para ele, isso é o residual" (LEFEBVRE, [1971] 2004, p. 59).

A discussão sobre o método a ser adotado para compreender a problemática urbana também foi objeto de estudo de Harvey. O autor ([1973] 1980, p. 40) inicia sua obra "A justiça social e a cidade" concentrando atenção sobre os mecanismos que tendem a redistribuir a renda numa população urbana. Afirma que essa questão tem sido levantada por diversos autores em passado recente e busca avaliar os efeitos de certos "mecanismos ocultos" de redistribuição, os quais tendem a ser "obscurecidos" pela inabilidade em analisar um sistema que exibe interdependência entre variação social e espacial.

Assim como Santos e Lefebvre, Harvey parte do pressuposto de que não se dispõe de uma teoria ou sistemática adequada para se analisar a problemática urbana, abrangendo toda sua complexidade e as questões que ficam implícitas. Desse modo, sugere a construção de formulações que privilegiem a visão multidisciplinar e que seja adotada uma abordagem espacial, tendo em vista compreender os aspectos material e imaterial inerentes à vida nas cidades, para que assim seja possível entender seus conflitos e contradições.

O caminho de investigação seguido pelo autor conduz à análise das vantagens que são geradas no sistema urbano. Observa que existem vantagens marginais, as quais são geradas pelas trocas que ocorrem no sistema urbano, que são distribuídas desigualmente pela população urbana. O autor ([1973] 1980, p. 43) tenta examinar como essas vantagens operam em relação a ganhos, valores de propriedade e utilidade de recursos no contexto urbano e especifica que a distribuição diferencial de certos recursos, nos diferentes 
segmentos de uma população, pode ser uma das mais importantes "vantagens marginais" geradas num sistema urbano.

A partir dessas constatações, verifica-se que Harvey dedica atenção especial à ideia dos mecanismos que governam a redistribuição de renda, sugerindo que estes parecem estar conduzindo a sociedade a um estado de maior desigualdade e injustiça, que consequentemente deverá resultar em um período de intenso conflito.

De acordo com o autor, para que seja possível intervir nesse estado de desigualdade, é preciso que se tenha a compreensão dos processos que geram mudança, e que seja feita uma avaliação sobre a direção que aqueles processos estão conduzindo o sistema social como um todo. Por outro lado, Harvey destaca a nossa incapacidade em lidar com esses processos ao apontar que:

“Não temos, realmente, o tipo necessário de compreensão do sistema urbano global para sermos capazes de tomar decisões políticas sábias, mesmo quando motivados pelos mais altos objetivos sociais. A elaboração bem sucedida de políticas adequadas, e a prevenção de suas implicações, vai depender de alguma investida interdisciplinar ampla sobre o processo social e os aspectos da forma espacial do sistema urbano" (HARVEY, [1973] 1980, p. 79).

$\mathrm{O}$ autor chega à conclusão de que a complexidade da problemática urbana, em termos de desigualdades e distribuição de renda em um sistema urbano, implica a proposição de uma teoria normativa de alocação espacial ou territorial, baseada em princípios de justiça social. Nessa proposta, a justiça deve ser pensada, essencialmente, como um princípio (ou série de princípios) para resolver a distribuição de direitos que se mostram conflitivos em uma sociedade. Busca-se, portanto, um princípio que permita a avaliação das distribuições existentes, da maneira como elas se aplicam aos indivíduos, aos grupos, às organizações e aos territórios, assim como que possibilite a avaliação dos mecanismos que proporcionam essa distribuição no sistema urbano.

Nesse sentido, Harvey ([1973] 1980, p. 90) elenca três princípios de justiça social, tais como se aplicam a situações geográficas, como se mostra a seguir: 
- "a organização espacial e o padrão de investimento regional deveriam ser tais que satisfizessem as necessidades da população. Isto requer que primeiro estabeleçamos métodos socialmente justos para determinar e medir necessidades. A diferença entre necessidades e alocações atuais provê-nos de uma avaliação inicial do grau de injustiça territorial num sistema existente;

- uma organização espacial e um padrão de alocação de recurso territorial que provê benefícios extras na forma de satisfação de necessidades (primariamente) e resultado agregado (secundariamente) em outros territórios, através de efeitos de sobre oferta, efeitos multiplicadores e similares, é uma forma "melhor" de organização espacial e alocação;

- desvios no padrão de investimento territorial podem ser tolerados se estão destinados a superar dificuldades específicas do meio, que poderiam de outro modo prejudicar a evolução de um sistema que encontraria necessidade de contribuir para o bem comum".

Segundo o autor ([1973] 1980, p. 91), esses princípios podem ser usados para avaliar distribuições espaciais existentes por fornecerem os princípios de uma teoria normativa da organização espacial baseada na justiça distributiva territorial. Dessa maneira, uma boa tentativa de aplicação desses princípios pode ser observada a partir da análise dos investimentos públicos realizados em diferentes regiões, considerando suas diferenças em termos de precariedade no sistema urbano com relação às ações e programas de uma política de desenvolvimento urbano.

Embora Harvey demonstre como esses mecanismos de alocação desigual dos recursos interferem de forma negativa na configuração de um sistema urbano, assim como propõe a adoção de princípios de justiça social como uma alternativa à continuidade da condição de desigualdade, reconhece os obstáculos impostos a uma teoria do urbanismo que seja capaz de superar esses entraves. Assim, afirma que:

\footnotetext{
"Uma teoria geral do urbanismo é provavelmente impossível de ser construída. O urbanismo é um fenômeno bastante complicado para ser incluído facilmente em alguma teoria abrangente. As teorias, como as definições, têm suas raízes na especulação metafísica e na ideologia, e dependem, também, dos objetivos do pesquisador e das características do fenômeno que está sendo investigado. Há, parece, demasiadas posições ideológicas a serem defendidas, demasiadas
} 
especulações ocultas a serem seguidas, demasiados pesquisadores e demasiados contextos nos quais o fenômeno pode ser encontrado, para que uma teoria geral do urbanismo possa emergir facilmente. Essa falta de teoria geral não nos deve deter, contudo, na busca de indagações gerais” (Harvey, [1973] 1980, pp. 167-168).

De maneira geral, as tentativas de compreender a problemática urbana e de interferir na sua acentuação ou perpetuação têm influenciado decisivamente no formato das políticas urbanas, ou pelo menos nos discursos institucionais já propagados. Considerando que essas políticas constituem ou deveriam constituir formas concretas de intervir nas cidades para a melhoria dos problemas que nelas incidem, o método utilizado para compreender a problemática urbana constitui um dos elementos chave que podem contribuir para o sucesso ou o insucesso dessas ações.

\subsection{Aspectos políticos da problemática urbana}

Em “A questão urbana", Castells aponta quais são os problemas concretos que, há tanto tempo, exprimem a importância crescente do urbano: (i) a concentração urbana crescente, por meio da concentração de população em aglomerados cada vez maiores; (ii) a intervenção intensa do Estado na produção e na distribuição dos equipamentos coletivos e no arranjo urbano; (iii) o desenvolvimento das "lutas urbanas", as novas formas de conflitos sociais; (iv) o desenvolvimento crescente dos discursos sobre o urbano, da "tomada de consciência sobre estes problemas" e da sua colocação em primeiro plano pelos aparelhos institucionais oficiais.

Esses apontamentos mostram que a problemática urbana vem se acentuando ao longo do tempo em função da concentração populacional nos grandes centros urbanos, onde as contradições e tensões entre os diferentes atores e agentes que protagonizam as relações sociais também são potencializadas. Nesse contexto, a distribuição dos recursos na sociedade é um fator determinante na vida das pessoas e também na formação e organização do espaço, sendo controlada por um grupo seleto de atores que dispõem de influência política e acesso ao Estado.

As lutas e as novas formas de conflitos sociais indicados pelo autor, em sua maioria, estão relacionados à busca de uma maioria maciça de pessoas que habitam as cidades por 
condições mínimas de sobrevivência. E em nome dessas lutas, surgem diferentes discursos sobre o urbano, quer seja para a compreensão dos problemas, ou para empreender tentativas minimizá-los ou solucioná-los, bem como para disseminar uma ideologia relativa à vida urbana, como mostra Castells:

\begin{abstract}
"A questão urbana, tal como se formula na prática social e nas "teorias" sociológicas urbanísticas, é uma questão ideológica, no sentido preciso de que confunde num mesmo discurso a problemática das formas espaciais, a que se refere ao processo de reprodução da força de trabalho e a da especificidade cultural da "sociedade moderna". (...) A base social que permite o enraizamento da ideologia urbana é formada pelas contradições vividas cotidianamente pelos indivíduos e grupos sociais, no que diz respeito ao processo de reprodução simples e ampliado de sua subsistência e das relações sociais a ela vinculadas" (CASTELLS, [1972] 2014, p. 537).
\end{abstract}

Lefebvre ([1968] 1991, p. 14) busca conhecer o que está por trás da problemática urbana ao perceber que "o assalto da cidade pela industrialização não se trata de um processo natural, sem intenções, sem vontades". O autor ressalta que nesse processo, intervêm ativamente classes ou frações de classes dirigentes que possuem o capital (os meios de produção) e que geram, não apenas o emprego econômico do capital e os investimentos produtivos, como também a sociedade inteira, com o emprego de uma parte das riquezas produzidas na cultura, na arte, no conhecimento e na ideologia.

De outro lado, diante dos grupos sociais dominantes, existe a classe operária que se apresenta dividida em camadas, em grupos parciais, em tendências diversas, segundo os ramos da indústria, as tradições locais e nacionais. Esse contexto favorece a luta de classes entre grupos com características antagônicas, incitando inclusive o ódio entre elas, uma vez que essa classe operária não dispõe dos mesmos recursos acessados pela classe dominante.

$\mathrm{O}$ autor complementa afirmando que, enquanto o processo global de industrialização/urbanização segue seu curso, "a cidade explode, dando lugar a desequilíbrios: subúrbios, conjuntos residenciais ou complexos industriais, pequenos aglomerados satélites pouco diferentes de burgos urbanizados (transformação material das cidades)". Assim, é percebida uma aparente "desordem", onde os operários ameaçam os 
novos ricos, fazendo com que seja elaborada uma estratégia de classe que visa ao remanejamento da cidade. Mas é preciso ressaltar que a desordem é apenas aparente, visto que a situação se mantém em função de uma orientação superior que condiciona a formação e a organização das cidades.

Conforme explicado por Castells ([1972] 2014), existem mecanismos ocultos que propiciam a reprodução e a propagação da problemática urbana, tendo em seu cerne as contradições resultantes do modo de produção dominante (o capitalismo). Juntamente a esse processo, nasce uma ideologia por trás da estrutura embutida nessas contradições, sendo emanada pelas instituições produzidas no espaço econômico e político-jurídico que moldam a vida social. Assim, emerge sobre as cidades uma cultura específica (a cultura urbana) que condiciona os comportamentos no espaço urbano.

Em função dos desequilíbrios percebidos nos centros urbanos, aqueles que não conseguem se inserir de forma equilibrada na sociedade, rebelam-se e buscam meios de satisfazerem suas necessidades de sobrevivência e até buscam caminhos de subversão da ordem social dominante. Isso porque passa a existir uma diferença gritante entre o padrão e a forma de vida daqueles que possuem os recursos suficientes para a manutenção da vida na cidade e aqueles que não possuem. Assim, Lefebvre ([1968] 1991) destaca que:

\footnotetext{
"A vida urbana pressupõe encontros, confrontos das diferenças, conhecimentos e reconhecimentos recíprocos (inclusive no confronto ideológico e político) dos modos de viver, dos "padrões" que coexistem na Cidade" (LEFEBVRE [1968] 1991, p. 15).
}

Foi buscando reagir a essa situação de desequilíbrios entre as classes que, no decorrer do século XIX, a ideologia inerente à democracia de origem camponesa, chegou a influenciar as populações oriundas dos campos. Entretanto, não foi possível surgir uma democracia urbana, por esta ameaçar os privilégios da nova classe dominante, que usou como estratégia para conter esse movimento, a expulsão do proletariado da cidade.

Dessa maneira, foram criados subúrbios sob a pressão das circunstâncias. Buscava-se responder a um impulso da industrialização, devido à chegada maciça dos camponeses nos centros urbanos, que demandavam moradia. Mas também, houve a expulsão dessas pessoas 
das cidades por parte da classe dominante que se via "ameaçada" pelos males que supostamente acompanhavam as populações mais pobres.

Isso deu origem ao que Lefebvre ([1968] 1991) chamou de "urbanização desurbanizante e desurbanizada", que também contou com a participação do Estado. O autor aponta um movimento que promove uma mudança radical no formato das cidades, a partir da suburbanização materializada na descentralização, iniciada com o período dos "novos conjuntos" e das "novas cidades". Dessa maneira, a questão habitacional vem à tona e se torna o aspecto central na crise da problemática urbana, como destacado pelo autor:

“(...) o direito à moradia aflora na consciência social. Ele se faz reconhecer de fato na indignação provocada pelos casos dramáticos, no descontentamento engendrado pela crise. Entretanto, não é reconhecido formal e praticamente, a não ser como um apêndice dos "direitos do homem" (...) não é um pensamento urbanístico que dirige as iniciativas dos organismos públicos e semipúblicos, é simplesmente o projeto de fornecer moradias o mais rápido possível pelo menor custo possível. (..) Única lei deste crescimento ao mesmo tempo urbano e não urbano: a especulação sobre os terrenos" (LEFEBVRE [1968] 1991, p. 19).

Devido a suas peculiaridades, o urbano é apontado por Lojkine ([1972] 1981) como um dos lugares decisivos da luta de classes, na medida em que ele resume a principal contradição entre a exigência de desenvolvimento do trabalho e a lógica de acumulação, que tende a restringir ao máximo esse desenvolvimento em função de suas necessidades imediatas. Nisso, reside o problema da distribuição social e espacial desigual dos meios de consumo coletivos, bem como a correlação entre divisão social do trabalho e formas de urbanização.

O autor também aponta que, cada vez mais, os critérios de implantação espacial das grandes firmas capitalistas entram em contradição com as necessidades tecnológicas e sociais de um verdadeiro planejamento territorial, de uma cooperação desenvolvida em termos de território nacional. O fator prioritário para a escolha do lugar da instalação dessas firmas são as vantagens de localização conferidas pela existência de ligações fáceis 
com os outros países, de equipamentos e de serviços de todo tipo (portos, aeroportos, telecomunicações), o conjunto das infraestruturas e não as necessidades sociais.

Dessa maneira, é possível verificar como as contradições estão inerentes ao processo de produção do espaço, por gerarem conflitos e surgirem diante das diferentes necessidades de uma sociedade que é norteada pela acumulação privada de suas riquezas. Disso, resulta a reprodução de um espaço orientado pelos interesses do capital, que perpetua o ideário dominante e a desigualdade entre as classes.

Para Lojkine ([1972] 1981), as contradições emergentes na cidade são resultado de fenômenos sócio-espaciais, destacando que o crescimento anárquico das cidades e seu desenvolvimento desigual decorrem em boa parte das estratégias de implantação das firmas:

"Dois fenômenos espaciais contraditórios: o subdesenvolvimento crescente das regiões menos equipadas em infraestruturas urbanas (meios de circulação materiais e meios de consumo coletivos) $e$, por outro, o congestionamento urbano, a gigantesca aglomeração de metrópoles onde já estão concentrados os mais variados e densos meios de comunicação e de consumo coletivos" (LOJKINE, [1972] 1981 p. 163).

Embora a urbanização possa conferir às cidades um novo padrão de desenvolvimento em termos de acesso a novos tipos de recursos e serviços, é preciso registrar que isso ocorre de forma desigual, onde a cidade passa a ser dividida por fatores financeiros ou de renda, fazendo com que as desigualdades se concretizem no arranjo urbano. Quanto maiores forem as disparidades socioeconômicas entre as classes sociais, maiores serão as diferenças nas condições de moradia, na prestação e na oferta dos serviços públicos, bem como nos níveis de qualidade de vida da população ampliando os conflitos entre os diferentes atores de uma sociedade.

Santos ([1996] 2012b, p. 135) mostra que alguns desses conflitos são mais relevantes, destacando, inicialmente, a disputa entre o Estado e o mercado. $\mathrm{O}$ autor aponta que dentro do mercado, as diversas empresas induzem a uma divisão do trabalho que corresponde ao seu próprio interesse, proporcionalmente à sua força e de acordo com seus 
respectivos processos produtivos. Paralelamente, as diversas escalas do poder público também concorrem por uma organização do território adaptada às suas prerrogativas. Dessa forma, as modalidades de exercício da política do poder público e da política das empresas influenciam na divisão territorial do trabalho, buscando modificá-la à sua imagem.

Percebe-se então, que diferentes forças atuam de forma concorrente para alcançar os resultados segundo as intenções de interesses opostos. Desse modo, a divisão territorial do trabalho que muda a cada novo momento histórico, constitui uma lei geral que promove uma combinação específica em tempos diferentes e faz com que cada lugar seja distinto do outro. E é esse "equilíbrio de forças", que se forma em torno de uma específica divisão do trabalho que é o principal fator a nortear a formação do espaço e determina a distribuição dos recursos em um sistema urbano.

Segundo Harvey ([1973] 1980, p. 41) a maioria das políticas sociais é elaborada como tentativas de manter a distribuição de renda específica em um sistema social, assim como para promover a redistribuição dessa renda entre os vários grupos sociais que coexistem em uma sociedade. Contudo, o autor ressalta que, ao se tentar executar a distribuição de renda, é essencial que se tenha ideia dos mecanismos que geram desigualdades, porque é pelo controle e manipulação desses mecanismos que é possível alcançar esse objetivo.

O autor ([1973] 1980, pp. 41-42) constata que os "mecanismos ocultos" de distribuição de renda que estão presentes em um sistema urbano complexo, usualmente contribuem para a existência das desigualdades mais do que as reduzem, tendo implicações imediatas na política social. Harvey argumenta que para reverter esse quadro e conter a redistribuição oculta, é preciso que seja implantada uma política de "amparo" na redistribuição direta da renda. A partir dessas constatações, o autor se questiona sobre como as mudanças na forma espacial da cidade e nos processos sociais modificam a renda do indivíduo.

Assim, Harvey ([1973] 1980) busca relacionar as condições de rendas e os diversos tipos de ganhos que podem ser revertidos como recursos, com as vantagens dos indivíduos no contexto urbano. Nesse quadro, os grupos mais dotados de recursos financeiros e 
educacionais detêm condições de se adaptarem melhor e mais rápido às mudanças que ocorrem no sistema urbano. Essas condições são denominadas de disposições diferenciais e funcionam como uma fonte básica de desigualdade, mostrando que os indivíduos apresentam capacidades diferentes de reagir às mudanças que sempre ocorrem no espaço, já que todo sistema urbano está em permanente estado de desequilíbrio.

Outros aspectos que são discutidos pelo autor ([1973] 1980, p. 45) para ajudar a compreender a condição de desigualdade no sistema urbano são a acessibilidade e a proximidade. Harvey ([1973] 1980) entende que, da mesma forma que o formato espacial da cidade é modificado em função da relocação de residências, da implantação de vias de transporte, de oportunidades de emprego, fontes de poluição e de outros aspectos, também é alterado o preço de acessibilidade e o custo de proximidade de qualquer moradia. Assim, percebe-se que esses preços e custos são função de atitudes sociais da população e a consideração dessas mudanças tem o potencial de produzir substanciais redistribuições de renda.

Essa discussão permite entender que as diferentes intervenções que são realizadas no espaço têm o poder de influenciar nos níveis de desigualdades de recursos inerentes a um sistema urbano, assim como existe um custo a ser pago pelos os indivíduos, na medida em que essas mudanças acontecem. Daí é possível perceber que os grupos sociais detentores de menos recursos financeiros e educacionais dispõem de acesso limitado às condições de vida na cidade, o que constitui o cerne da segregação sócio-espacial.

Essa situação é acentuada pelo mecanismo de mercado, que é ineficiente para alocar recursos em um sistema econômico, e, analogamente, em um sistema urbano, o que abre espaço para, do ponto de vista político, existir a interferência pública para mediar essa questão. Entretanto, embora o Estado seja invocado a interferir na redistribuição de recursos no sistema urbano, acaba não cumprindo este papel por se aliar às forças que são as reais causadoras da condição de desigualdade.

Para Harvey ([1973] 1980, p. 49) a mudança de localização da atividade econômica na cidade significa uma mudança de localização de oportunidades de emprego, enquanto a mudança de localização da atividade residencial significa mudança de localização de oportunidades de moradia, estando as duas associadas a gastos de mudanças em transporte. 
Presume-se, portanto, que as mudanças em transporte afetam em grande escala o custo de acesso a oportunidades de emprego a partir da localização das moradias.

Em função disso, famílias de renda baixa têm poucas opções para morar no centro da cidade que é mais valorizado. De acordo com o autor ([1973] 1980), essas mudanças ocorrem em qualquer modelo de crescimento urbano, sendo que suas implicações para a redistribuição da renda não são sempre claramente percebidas. Essas distorções poderiam ser parcialmente modificadas por meio da implementação de políticas urbanas, porém, na realidade, essas políticas têm favorecido a situação existente mais do que alterado.

Assim, o Harvey ([1973] 1980, p. 51) conclui que o desequilíbrio diferencial na forma espacial da cidade pode redistribuir renda, na medida em que os detentores de maior riqueza podem se beneficiar, enquanto os mais pobres acabam se tornando imóveis, pelo fato de disporem apenas de oportunidades restritas. Sobre isso, Harvey conclui que:

"Parece que a distribuição usual da renda real em um sistema urbano deve ser vista como a “consequência previsível do processo político”. Qualquer intenção de entender os mecanismos geradores de desigualdades de renda deve, por isso, consistir em compreender o processo político que opera numa cidade" (HARVEY, [1973] 1980, p. 59).

O autor demonstra a relação existente entre a redistribuição da renda real e as decisões políticas. E é a partir dessa atividade política existente na cidade que os grupos sociais mais abastados lutam e barganham o uso e o controle dos "mecanismos ocultos" da redistribuição, que naturalmente tendem a beneficiar o rico e a enfraquecer o pobre.

Isso se comprova ao analisar a vida nas favelas, que estão inseridas em áreas precárias em termos de disponibilidade de equipamentos sociais, de infraestrutura e na prestação de serviços, tanto em termos de qualidade quanto em relação à oferta. As áreas precárias constituem espaços urbanos onde a população carece de recursos para competir de forma efetiva, requerendo que existam controles sobre os canais de distribuição desses recursos ou de sua manutenção.

Desse modo, é reconhecida a necessidade de redistribuição de poder, de acesso mais amplo a recursos e de ampliação da capacidade de escolha individual para as populações 
que constantemente ficam à margem da sociedade. Harvey chama essa necessidade de redistribuição de justiça social e destaca que:

“As perspectivas de equidade ou de justa distribuição de renda em um sistema urbano através de um processo político naturalmente emergente (particularmente aquele que está baseado numa filosofia do interesse individual) são certamente precárias. A possibilidade de que um sistema social possa reconhecer este fato e ajustar-se para combater essa tendência natural, está, creio eu, correlacionada ao grau de êxito do sistema social em evitar os problemas estruturais e as tensões sociais profundas, consequentes do processo da maciça urbanização” (HARVEY, [1973] 1980, p. 65).

O autor ([1973] 1980, p. 68) também supõe que os valores culturais são afetados pelas oportunidades criadas nas cidades, sendo possível prever a evolução cultural dentro do sistema urbano, de forma parcial. Isso ocorre por meio da reorganização dos estímulos físicos e sociais que existem dentro desse sistema, visto que as atitudes culturais do centro da cidade têm sido sempre diferentes das dos subúrbios. Desse modo, é possível perceber que a distribuição de recursos em um sistema urbano, além de ser um condicionante da forma como os indivíduos acessam o espaço urbano, também influenciam na maneira como as pessoas pensam e agem na sociedade.

Para Harvey ([1973] 1980, p. 71) a redistribuição da renda pode ocorrer em função de mudanças nos seguintes aspectos: (1) na locação de empregos e moradias; (2) no valor dos direitos de propriedade; e (3) no preço dos recursos para o consumidor. Essas mudanças são, por sua vez, afetadas pelas alocações de custos e benefícios externos, em diferentes regiões do sistema urbano, e por mudanças na acessibilidade e proximidade.

Por outro lado, em uma sociedade capitalista, a distribuição dos ganhos é feita visando à acumulação do capital, o que é incompatível com a proposta de alternativas que admitam a transferência de poder produtivo e a distribuição de excedente para setores e territórios onde as necessidades sociais são mais evidentes, sendo praticamente impossível a aplicação desses princípios de justiça social sem tensões nem conflitos de ordem política.

Em função disso, Lefebvre ([1968] 1991, p. 19) entende que a sociedade contemporânea precisa passar por um conjunto de transformações para que seja possível 
transcender e sair do período onde predominam as questões de crescimento e de industrialização. Busca-se com isso, a revolução urbana orientada por uma nova forma de pensar, onde a problemática urbana pode prevalecer decisivamente, e a "busca das soluções e das modalidades próprias à sociedade urbana passará ao primeiro plano”.

É em busca de soluções para essa situação que são trazidas à tona boas intenções humanísticas. Lefebvre ([1968] 1991, p. 95) enfatiza que é preciso tender à direção de um novo humanismo, imprimindo esforços para uma nova práxis e de outro homem para a sociedade urbana, embora a prática caminhe para a segregação social e política. Observa-se que no contexto da cidade, Estado e a empresa, apesar de suas diferenças e conflitos, atuam como aliados que promovem a segregação, destruindo morfologicamente a cidade e ameaçando a vida urbana.

Por isso, Lefebvre ([1968] 1991, p. 112) entende que a mudança desse cenário requer a transformação da própria estrutura social, onde cada projeto de reforma urbana põe em questão as estruturas da sociedade existente, sendo a estratégia de renovação urbana necessariamente revolucionária pela força contra as coisas estabelecidas. Assim, "o direito à cidade não pode ser concebido como um simples direito de visita ou de retorno às cidades tradicionais. Só pode ser formulado como direito à vida urbana transformada, renovada".

O autor aponta que é preciso reorientar o crescimento, substituindo a planificação econômica por outra que seja social, onde a produção de bens é orientada pelas necessidades sociais não devendo ser primordialmente movida pela maximização de lucros (LEFEBVRE, [1968] 1991, p. 125). Nesse caso, não se trata apenas dos índices de crescimento da produção e da renda, mas da divisão. Espera-se então, que a realidade urbana seja destinada aos usuários e não aos especuladores nem aos promotores capitalistas e aos planos técnicos. Para o autor:

"O direito à cidade se manifesta como forma superior dos direitos: direito à liberdade, à individualização na socialização, ao habitat e ao habitar. $O$ direito à obra (à atividade participante) e o direito a apropriação (bem distinto do direito à propriedade) estão implicados no direito à cidade” (LEFEBVRE, [1968] 1991, p. 135). 
A cidade, portanto, deve propiciar o encontro das pessoas, da vida. Não se trata apenas de democratizar o acesso aos diferentes lugares, mas acima de tudo, promover uma nova forma de vida em sociedade. E o modelo de urbanização que se estabelece juntamente com a industrialização, além de corromper as características urbanísticas da cidade, também impede que o modo de vida urbano se concretize em sua plenitude.

Para Lefebvre ([1968] 1991), o duplo processo de industrialização e de urbanização perde todo seu sentido se não se concebe a sociedade urbana como objetivo e finalidade da industrialização que subordina a vida urbana ao crescimento industrial. É aí que entra a revolução urbana proposta por ele, que dá lugar a uma estratégia que se opõe à estratégia da classe dominante, no sentido de se atender às necessidades da sociedade em primeiro plano.

É por meio da revolução urbana que o autor propõe estratégias para fazer a problemática urbana entrar não apenas no pensamento, mas, sobretudo na prática, pela formação consciente de uma práxis urbana. Lefebvre acredita que, para que a história exista como produto da ação concreta, as pessoas precisam deliberar e fazer escolhas.

Com essa proposta, Lefebvre ([1968] 1991) vai além da ideia de democratização dos espaços urbanos ao propor "o conceito de direito à cidade" e de toda a sua elaboração teórica em torno da ideia de "revolução urbana". O autor propõe uma elaboração mais complexa e sofisticada, que transcende a ideia de direito a equipamentos, bens, serviços e vai além do que preconiza a democratização do acesso à terra urbana urbanizada ou à habitação, tratando-se quase da proposição de um novo paradigma da forma de vida em sociedade.

Sendo influenciado pelos mesmos anseios de Lefebvre, Harvey ([1973] 1980, p. 98) afirma ser necessária a "definição de um novo padrão de organização, no qual o mercado seja substituído (provavelmente por um processo de planejamento descentralizado), a escassez e a privação sejam sistematicamente eliminadas, tanto quanto possível, e um sistema de competição degradante seja substitutivamente reduzido como incentivo ao trabalho, sem de qualquer modo diminuir o poder produtivo total útil para a sociedade". Inclusive, segundo os preceitos embutidos nos princípios de justiça social, os quais consideram as necessidades regionais e territoriais, a alocação desigual dos recursos seria 
permitida se (e somente se) os territórios favorecidos estivessem dispostos a contribuir para o bem comum de todos.

Na realidade, o que se observa no mecanismo de mercado é a obrigação em manter padrões de apropriação, privação e escassez, sendo institucionalmente incapaz de distribuir os ganhos de acordo com as necessidades de cada região. O sistema urbano que está imerso na lógica capitalista é antagônico aos princípios de justiça social, sem dar espaço para a busca do bem comum.

Nesse sentido, Harvey ([1973] 1980, p. 99) propôs e analisou princípios de justiça social, chegando ao conceito de justiça social territorial, partindo de três premissas básicas: "a distribuição de renda deveria ser tal que (a) as necessidades da população dentro de cada território fossem localizadas, (b) os recursos fossem então alocados para maximizar os efeitos multiplicadores inter-territoriais, e (c) os recursos extras fossem alocados para ajudar a resolver as dificuldades específicas emergentes do meio físico e social; os mecanismos institucional, organizacional, político e econômico deveriam ser tais que as perspectivas do território manos favorecido fossem tão grandes quanto possivelmente pudessem ser". Para o autor, se essas condições fossem satisfeitas haveria uma distribuição dos recursos alcançada com justiça.

O autor conclui sua obra defendendo a ideia de um urbanismo que seja norteado pelas necessidades humanas superando os males oriundos do processo de urbanização ocorrido no berço das sociedades capitalistas. E mesmo que soe utópico, profetiza a vinda de um novo padrão de urbanização ao afirmar que:

“Um urbanismo genuinamente humano ainda está por surgir. Cabe à teoria revolucionária mudar o caminho de um urbanismo baseado na exploração para um urbanismo apropriado à espécie humana. Cabe à prática revolucionária desempenhar tal transformação” (HARVEY, [1973] 1980, p. 271).

Na Figura 1 é possível verificar a síntese de Harvey em torno das disposições diferenciais de renda no sistema urbano, os princípios de justiça social para alocação de recursos no território, e sobre uma abordagem com justiça social. 

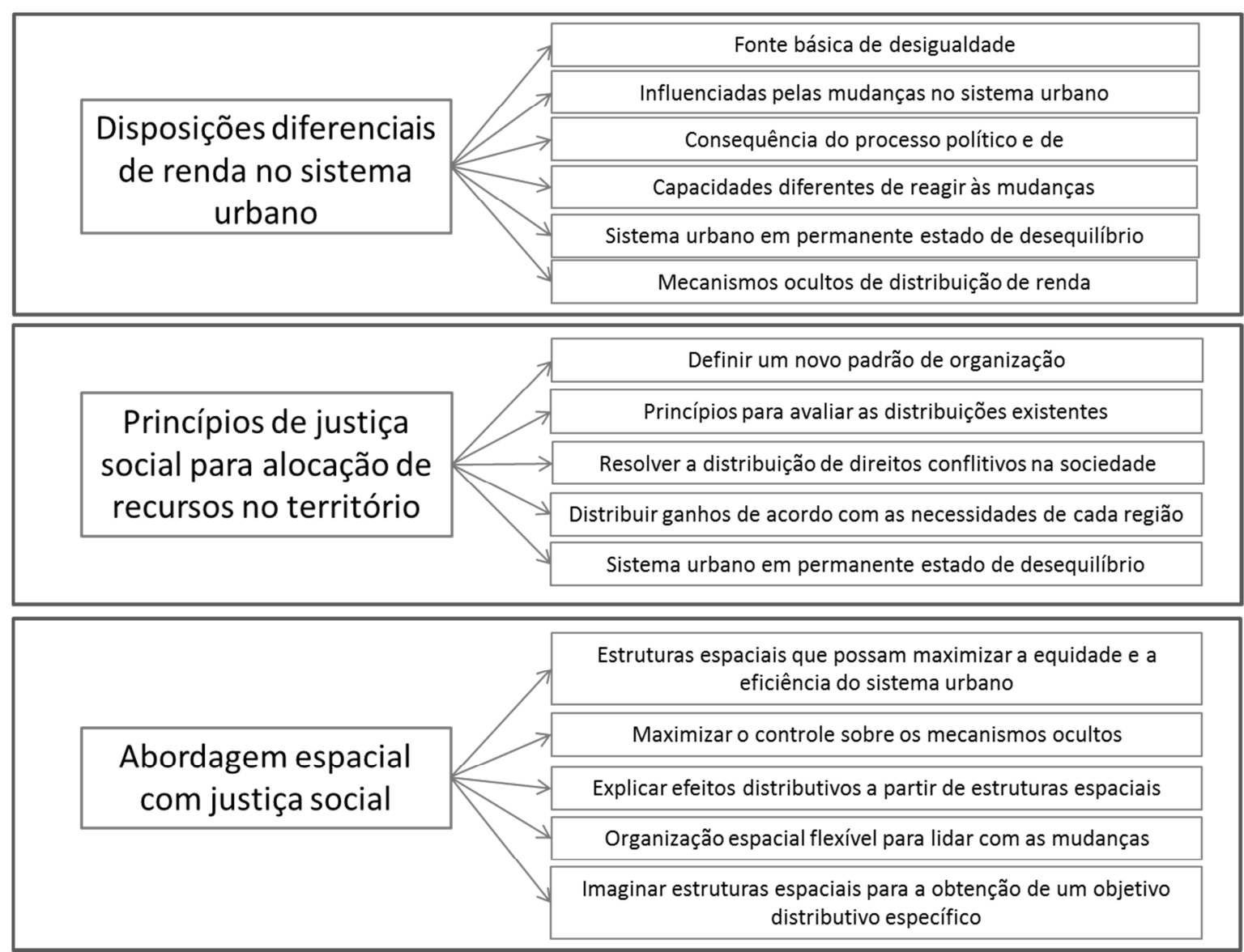

Figura 1 - Considerações sobre os princípios de justiça social de Harvey para alocação de recursos. Fonte: elaboração da autora.

Santos ([1978] 2012a p. 267) conclui sua obra "Por uma geografia nova" destacando que os geógrafos, ao lado de outros cientistas sociais, devem trazer para a discussão os fundamentos de um espaço verdadeiramente humano. É preciso defender um espaço que "una os homens por e para seu trabalho", sem os separar entre classes onde existem polaridades permitindo que os exploradores difiram dos explorados. Busca-se um espaço que considere a reprodução da vida como o aspecto central da sociedade.

Assim como Harvey ([1973] 1980) e Lefebvre ([1971] 2004), Santos ([1978] 2012a), desperta para a necessidade de enfatizar o componente humano nas discussões e nas intervenções que modifiquem o espaço de modo a privilegiar a vida em sociedade. Embora não destaque que esse caminho deva ser trilhado por meio de uma "revolução", só o fato de propor a inversão da lógica econômica e financeira a favor do humano, por si só, já constitui uma forma revolucionária de se pensar o espaço em função de estar propondo 
uma alternativa que seja capaz de subverter a lógica dominante que vem se perpetuando ao longo do tempo.

\subsection{O Estado como principal interventor na problemática urbana}

A quem o Estado deveria servir prioritariamente e a quem ele serve? Quem são os atores que buscam a manutenção de uma situação que tem como consequências a segregação social? Quais são os interesses e as forças contraditórias que estão no centro da problemática urbana? Essas são algumas questões que precisam ser respondidas para que se compreenda em detalhe os mecanismos ocultos e a questão ideológica inerente à problemática urbana.

No final de sua obra, “A justiça social e a cidade” Harvey ([1973] 1980, p. 236) chama a atenção para o papel crescente do Estado na sociedade urbanizada que deve ser entendido "tomando-se como referência a crescente acumulação de capital, a poderosa expansão da produção, a penetração crescente do mercado de troca e a urbanização do campo em escala global". Defende que o Estado, juntamente com organizações supranacionais, deve intervir em todas as crises geradas, principalmente, pela dinâmica interna do capitalismo.

O Estado é apontado pelos autores (Castells, Harvey e Lojkine) como um dos atores que acentuam os desequilíbrios que incidem nas cidades, atuando, principalmente, por meio da planificação. Essa estratégia adotada pelo Estado tem como principal função regular ou reprimir as contradições inerentes à problemática urbana, contribuindo para assegurar os interesses da classe dominante. Isso faz com que a política urbana seja considerada um campo de estudo que poderá dar respostas mais adequadas ao estudo desses problemas.

Assim como Castells (2014), Lefebvre ([1968] 1991) aponta que o Estado atua de forma a consolidar e perpetuar um urbanismo desigual e excludente, na medida em que é provocado a atuar sobre essa estrutura, mas se associa aos atores e agentes que orientam a organização industrial. O Estado, portanto, se vale do seu poder superior de planificação e controle da sociedade para fazer perpetuar a lógica dominante e atender os seus próprios anseios e interesses. De acordo com Castells ([1972] 2014): 
“No que diz respeito à problemática urbana, o campo teórico que corresponde à intervenção do Estado pode ser denominado "planificação urbana"; o relativo à sua articulação com a luta política de classe, de "movimentos sociais urbanos". Assim, o campo da "política urbana" é centro de toda análise do fenômeno urbano. Por planificação urbana, entendemos, mais precisamente, a intervenção do político sobre a articulação específica das diferentes instâncias de uma formação social no seio de uma unidade coletiva de reprodução da força de trabalho, com a finalidade de assegurar sua reprodução ampliada, de regular as contradições não antagônicas suscitadas e de reprimir as contradições antagônicas, assegurando assim os interesses de classe social dominante no conjunto da formação social e a reorganização do sistema urbano, de forma a garantir a reprodução estrutural do modo de produção dominante” (CASTELLS, [1972] 2014, p. 537-545).

Sabendo que a ação estatal para atuar frente à problemática urbana se dá prioritariamente por meio de políticas, em sua obra "O Estado capitalista e a questão urbana", Lojkine afirma que as contradições inerentes ao desenvolvimento urbano são acentuadas pela política estatal. Segundo o autor o movimento contraditório observado no sistema urbano acaba por se explicitar na organização do Estado enquanto representação do poder político institucional, que possibilita à classe que controla política e economicamente os aparelhos de Estado, a aplicação de políticas que atingem a sociedade como um todo. Dessa maneira, bem mais do que campo de aplicação da política estatal, o urbano é um componente-chave que não pode ser deixado de lado (LOJKINE, [1977] 1981, p. 19).

O Estado é apontado por Lojkine como uma figura central na acentuação da problemática urbana ao se aliar à classe dominante, e realizar suas intervenções priorizando as necessidades das empresas, que também controlam a política, em detrimento dos anseios das populações mais pobres, quanto à redistribuição de recursos no sistema urbano. O Estado deixa o aspecto econômico, alinhado aos interesses capitalistas, nortear as políticas que são concebidas e implementadas com o objetivo de "amenizar" ou “corrigir” os desvios promovidos pelo processo de industrialização. Lojkine assume que não existe autonomia do aspecto político, sendo este outro fator determinante na política urbana: 
"A dificuldade de nossa tarefa: toda tentativa de definição objetiva de política urbana esbarra, com efeito, na resistência - quase sempre inconsciente - que a ideologia dominante opõe a qualquer discussão da "autonomia" do aspecto político em relação à estrutura econômica" (LOJKINE [1977] 1981, p. 19-20).

Segundo o autor ([1977] 1981, p. 20), as determinações sociais ou econômicas da política estatal se restringem à "autonomia" do "sistema político" que são suas leis próprias de funcionamento, as quais diferem das leis econômicas. Assim sendo, o papel dos atores políticos não pode ser negado, indicando que essa autonomia política interfere nas decisões e nas ações realizadas pelo Estado, conforme apontado a seguir:

\footnotetext{
"Mesma pergunta quanto ao discurso "decisório": quem prova que houve decisão ou, melhor, que uma política é um conjunto de decisões? E, antes de mais nada, o que a noção de decisão postula? Indivíduos "livres" e "conscientes", uma sucessão lógica entre "vontades" racionais, "deliberações" e "atos" que “executam” o que foi decidido?” (LOJKINE, [1977] 1981, p. 20).
}

Lojkine ([1977] 1981, p. 21) conclui esse argumento desconstruindo a hipótese de que a política urbana é a resultante cega da luta de classes, por um lado, e, por outro, das formas e dos estágios de desenvolvimento do capitalismo. Para o autor ([1977] 1981, p. 84) a política estatal não é constituída por uma série de "decisões" ou de "estratégias" de atores autônomos. Ela segue segundo uma ordem dominante que opera pela interferência de mecanismos ocultos que condicionam a atuação de todos os atores envolvidos no processo.

Percebe-se que a política urbana se submete indiscriminadamente às condições que se impõem e regulam o espaço. Mesmo dispondo de um aparato político consistente, o Estado não domina o processo urbano, embora ofereça as condições fundamentais para que o capitalismo prevaleça. Diante disso, o Estado interfere decisivamente na organização do espaço urbano, funcionando como uma estrutura que age como elemento chave na difusão e na perpetuação da segregação social urbana. 
Lojkine ([1977] 1981, p. 169) também se refere à participação do Estado no processo de segregação sócio-espacial que emerge nas cidades e parte da tese de que a intervenção estatal é a forma mais elaborada e mais desenvolvida da resposta capitalista à necessidade de socialização das forças produtivas. Considerando isso, afirma ser possível dar uma primeira definição das políticas urbanas dos Estados capitalistas desenvolvidos, que são "contratendências produzidas para regular e atenuar os efeitos negativos - no nível do funcionamento global das formações sociais - da segregação e da mutilação capitalistas dos equipamentos urbanos".

O autor ([1977] 1981) reforça essa argumentação mostrando que, além da atuação estatal voltada ao crescimento econômico, o papel do Estado em relação à política urbana também acentuou essas contradições:

"Longe de suprimir a contradição entre os meios de reprodução do capital e meios de reprodução da força de trabalho, a política urbana vai exacerbá-la, tornando-se um instrumento de seleção e de dissociação sistemática dos diferentes tipos de equipamento urbano. O Estado monopolista vai, portanto, refletir ativamente as contradições e as lutas de classe geradas pela segregação social dos valores de uso urbanos" (LOJKINE, [1977] 1981, p. 171).

Sobre esse aspecto, é preciso destacar a capacidade que as intervenções estatais têm de interferir na formação e organização do espaço, bem como sua associação aos interesses capitalistas. É possível visualizar o papel do Estado a favor desses interesses por meio da seletividade do investimento público, quer seja pela realização dos investimentos em infraestrutura e equipamentos públicos, quer seja pela normatização ou pela fiscalização do uso do solo. Ao privilegiar investir em prol de políticas públicas específicas, o Estado atua em resposta às pressões de grupos de interesse específicos que fazem parte de uma classe dominante, que consequentemente, tem seus interesses alinhados e interligados com o capital.

Lojkine ([1977] 1981, p. 180) conclui sua obra afirmando que a política urbana é produto de contradições urbanas, oriundas de relações entre diversas forças sociais opostas, que estão relacionadas ao modo de ocupação ou ao tipo de produção do espaço urbano. Dito isso, é possível observar a existência de três dimensões dessa política: 
(i) a dimensão planificadora, que é a intervenção do Estado sobre as relações de produção e de circulação dos elementos urbanos, por meio da intervenção jurídica sobre as relações de produção e pela programação dos equipamentos públicos;

(ii) a dimensão operacional, que é o conjunto das práticas reais pelas quais o Estado central e os aparelhos estatais locais intervêm financeira e juridicamente na organização do espaço urbano;

(iii) a dimensão urbanística que condensa, materializa e mede os efeitos sociais - no espaço - do par planificação urbana / operações de urbanismo.

É a partir desses três níveis de dimensões que a política urbana implementada pelo Estado realiza o seu papel de intervir no espaço condicionando a ação, tendo como resultado a acentuação da condição de desigualdade e segregação sócio-espacial que resulta da materialização das relações de produção capitalista no espaço.

A partir dos aspectos apontados, talvez, este seja um dos grandes desafios que se apresentam à problemática urbana: o papel do Estado como principal interventor nessa problemática. Isso se deve ao se constatar que, historicamente o Estado, ao invés de assumir o papel de interventor para amenizar ou resolver as contradições do capitalismo nas cidades que se acentuaram com a urbanização, toma partido ao lado dos atores que defendem os interesses segundo a ordem dominante do capital.

\subsection{Temas relevantes para entender a problemática urbana}

A problemática urbana é abordada por Henri Lefebvre, em sua obra "O direito à cidade", considerando o processo de industrialização como um ponto de partida para expor a problemática da urbanização, destacando que esse processo é, há um século e meio, o motor das transformações na sociedade. $\mathrm{O}$ autor aponta que:

"Se distinguirmos o indutor e o induzido, pode-se dizer que o processo de industrialização é indutor e que se pode contar entre os induzidos os problemas relativos ao crescimento e à planificação, as questões referentes à cidade e ao desenvolvimento da realidade urbana, sem omitir a crescente importância dos lazeres e das questões relativas à cultura” (LEFEBVRE [1968] 1991, p. 3). 
De acordo Lefebvre ([1968] 1991, p. 9), a cidade desempenhou um papel importante na arrancada da indústria, uma vez que as concentrações urbanas acompanharam as concentrações de capitais, sendo possível perceber um processo com duplo aspecto: industrialização e urbanização, crescimento e desenvolvimento, produção econômica e vida social. Para o autor esses dois aspectos são inseparáveis e conflitantes, existindo um choque entre a realidade urbana e a realidade industrial. Urbanização e industrialização acontecem por meio de um processo dialético, com vontades ocultas, que está longe de ser elucidado e terminado.

Segundo o autor ([1968] 1991, p. 141) existem dois grupos de questões que ocultaram os problemas da cidade e da sociedade urbana: (i) as questões da moradia; e (ii) as questões da organização industrial e da planificação global. Esses dois grupos de problemas foram e são colocados pelo crescimento econômico e pela produção industrial. Sendo que o primeiro repercute diretamente na vida do indivíduo, enquanto o segundo interfere na orientação espacial das cidades.

Buscando compreender mais profundamente as origens da problemática urbana e as questões que se situam em torno desse tema, Lefebvre ([1968] 1991) analisa as influências do capitalismo na formação dos centros urbanos tentando entender como este sistema contribuiu para a situação onde prevalecem violentos contrastes entre a riqueza e pobreza, além dos conflitos entre os que são os detentores de poder e os que são oprimidos por estes.

De acordo com o autor, parte desse processo se iniciou quando as antigas estruturas agrárias se dissolveram fazendo com que camponeses sem posses ou arruinados se dirigissem às cidades em busca de trabalho e de subsistência. Sobre isso, o autor constata que:

“Atualmente, portanto, aprofunda-se um processo induzido que se pode chamar de a "implosão-explosão" da cidade. O fenômeno urbano se estende sobre uma grande parte do território, nos grandes países industriais” (LEFEBVRE [1968] 1991, p. 10). 
Para Lefebvre ([1968] 1991), no processo de urbanização, o interesse do "tecido urbano" não se limita à sua morfologia, por ser o suporte de um "modo de viver" que é materializado pela sociedade urbana. Na base econômica do tecido urbano aparecem fenômenos de outra ordem, além da vida social e cultural. Existe uma lógica que segue um interesse superior, onde a industrialização e a urbanização são apenas meios para que ela se concretize. Nesse caso, não é a formação e o desenvolvimento das cidades que são almejados, mas sim a consolidação e o fortalecimento do modo de produção que as permite existir.

O autor ([1968] 1991, pp. 74-75) também considera que a crise da cidade é mundial, indicando que as causas práticas e as razões ideológicas dessa crise variam segundo os regimes políticos, segundo as sociedades e de acordo com cada país. A sociedade moderna surge como sendo pouco capaz de fornecer soluções para a problemática urbana, agindo apenas por meio de pequenas medidas técnicas que prolongam o estado atual das coisas. Para Lefebvre:

“Nos países ditos em vias de desenvolvimento, a dissolução da estrutura agrária empurra para as cidades camponeses sem posses, arruinados, ávidos de mudança; a favela os acolhe e desempenha o papel de mediador (insuficiente) entre o campo e a cidade, entre a produção agrícola e a indústria; frequentemente a favela se consolida e oferece um sucedâneo à vida urbana, miserável e, no entanto, intensa, àqueles que ela abriga. (...) Em resumo, uma crise mundial da agricultura e da vida camponesa tradicional acompanha, subentende, agrava uma crise mundial da cidade tradicional” (LEFEBVRE, [1968] 1991, p. 75).

As reflexões de Harvey ([1973] 1980, p. 168) complementam as colocações de Lefebvre ao mostrarem que o urbanismo pode ser encarado como uma "forma particular ou padronizada do processo social" que se desenvolve num meio espacial estruturado, criado pelo homem. A cidade pode ser vista como um ambiente construído possível, sendo resultado de um produto social. Por isso, não se pode deixar de considerar que o modelo de produção da vida material condiciona o processo geral da vida social, tendo como resultado a formação de relações sociais. Assim, fica estabelecida uma estrutura social que é mantida por meio da atuação de forças conflitantes. 
O autor ([1973] 1980) explica que o urbanismo é uma forma social, um modo de vida associado a uma divisão específica do trabalho e a uma ordem hierárquica da atividade, que está em conformidade com o modo de produção dominante. Harvey ([1973] 1980, pp. 174-175) acredita que a cidade e o urbanismo podem, por isso, funcionar para estabilizar um modo de produção particular, visto que um modo de produção dominante se caracteriza por uma forma dominante de urbanismo. O autor observa um padrão de homogeneidade na forma construída da cidade, sugerindo que exista alguma relação entre a forma e o funcionamento do urbanismo e o modo de produção dominante.

Ao concordar com Harvey, Lojkine se refere às formas de urbanização como maneiras de divisão social e territorial do trabalho. Segundo o autor ([1977] 1981, p. 121) estas estão no centro da contradição entre as novas exigências do processo técnico, essencialmente em matéria de formação ampliada das forças produtivas humanas e as leis de acumulação do capital.

Lojkine ([1977] 1981) também aponta que o processo de urbanização não é natural e autônomo, mas sim ocorre segundo os interesses de acumulação do capital. Afirma que a urbanização capitalista atual poderia ser definida como a forma mais desenvolvida da divisão do trabalho material e intelectual, como pode ser visto a seguir:

"Sendo assim, a aglomeração da população, dos instrumentos de produção, do capital, dos prazeres e das necessidades - em outras palavras a cidade - não é de modo algum um fenômeno autônomo sujeito a leis de desenvolvimento totalmente distintas das leis de acumulação capitalista: não se pode dissociá-la da tendência que o capital tem a aumentar a produtividade do trabalho pela socialização das condições gerais de produção - das quais a urbanização, já vimos, é componente essencial” (LOJKINE, [1977] 1981, p. 137).

Já Castells ([1972] 2014, p. 40) aborda a urbanização de acordo com parâmetros quantitativos e qualitativos ao especificar que o termo urbanização pode se distinguir de duas formas: (i) relacionado à concentração populacional delimitada por dimensão e densidade; (ii) buscando diferenciar o sistema de valores, as atitudes e os comportamentos da sociedade, a cultura urbana. $\mathrm{O}$ autor aponta que a urbanização pode ser tratada tanto do ponto de vista da parte material e concreta da vida urbana, representada pelas estruturas 
físicas e pelas pessoas que habitam as cidades, bem como em relação a uma parte imaterial, que se relaciona à cultura urbana e à forma de como as pessoas pensam e se comportam nas cidades.

O autor vai mais adiante reconhecer a existência de dicotomias associadas ao duplo processo de industrialização e urbanização, bem como a uma cultura específica que estabelece um sistema de valores associados ao urbano, como mostrado a seguir:

\begin{abstract}
“(...) assimilamos urbanização e industrialização, fazendo equivaler os dois processos, ao nível de escolha dos referenciais utilizados, para construir as dicotomias correspondentes rural/urbana e emprego agrícola/emprego industrial. De fato, a tendência culturalista da análise da urbanização fundamenta-se numa premissa: a correspondência entre um certo tipo técnico de produção (essencialmente definido por uma atividade industrial, um sistema de valores o "modernismo") e uma forma específica de organização do espaço, a cidade, cujos traços distintivos são uma certa forma e uma certa densidade" (Castells, [1972] 2014, pp. 39-40).
\end{abstract}

Desde os primórdios do processo de urbanização surge a contradição entre rural e urbano, onde um era visto como o oposto do outro, sendo este associado à necessidade de transformação das cidades em busca de um futuro moderno e supostamente melhor. E assim, a cultura urbana se estabelecia e ia sendo alicerçada por um conjunto de valores que propagava a crença no progresso como uma consequência da revolução industrial que se materializava nas cidades.

Para Castells ([1972] 2014, p. 40) é clara a relação entre urbanização e industrialização, que além de crescerem em conjunto, criam as novas dicotomias discutíveis: rural/urbano e emprego agrícola/emprego industrial. Campo e cidade são espaços produzidos em função de diferentes relações sociais, as quais formam realidades distintas. Contudo, ambas constituem realidades que são impulsionadas pela mesma lógica produtiva, o modo de produção capitalista.

Segundo o autor ([1972] 2014, pp. 45-46), a urbanização ligada à primeira revolução industrial e inserida no desenvolvimento do tipo de produção capitalista, constitui um processo de organização do espaço, devido a dois conjuntos de fatos fundamentais: (i) a decomposição das estruturas sociais agrárias e a emigração da população para os centros 
urbanos, fornecendo a força de trabalho essencial à industrialização; (ii) a passagem de uma economia doméstica para uma economia manufatureira, e depois para uma economia de fábrica, promovendo concomitantemente a concentração de mão-de-obra, a criação de um mercado e a constituição de um meio industrial.

Dessa forma, é possível perceber a que relação urbanização e industrialização estão vinculadas, visto que a concentração populacional nos centros urbanos atende à demanda dos processos produtivos por mão-de-obra, no mesmo tempo que promove a consolidação do modo de produção capitalista, viabilizando, inclusive, sua evolução ao longo do tempo. Em função disso, Castells ([1972] p. 45) considera que as cidades atraem a indústria devido a dois fatores essenciais: mão-de-obra e mercado.

$\mathrm{Na}$ indústria são criadas novas possibilidades de empregos, além de serem demandados novos serviços. O processo inverso também é relevante, visto que onde existem elementos funcionais, tais como matérias-primas e meios de transporte, a indústria coloniza e promove a urbanização. Assim, nos dois casos, o elemento dominante é a indústria, sendo capaz de influenciar e de organizar toda a paisagem urbana, seguindo a expressão da lógica capitalista que está na base da industrialização (CASTTELS, [1972] 2014, p. 45).

Portanto, ao assumir que a lógica capitalista é a base desse processo, entende-se que não existe desordem urbana de fato, uma vez que a organização espacial segue aos preceitos do mercado, não existindo outro tipo de força que resista à supremacia da atividade industrial. Assim, o autor, além de mencionar a existência de uma lógica implícita que orienta a formação do espaço, destaca a autonomia inerente à atividade industrial, que não sofre controle por parte da sociedade, representada pela força de trabalho.

Mas é preciso pontuar que nos tempos atuais, a supremacia da indústria vem sendo quebrada pela hegemonia do capital financeiro, que vem dando espaço à era da financeirização.

Os elementos funcionais que favorecem a industrialização, segundo Castells, podem ser compreendidos como apresentado na Figura 2. 


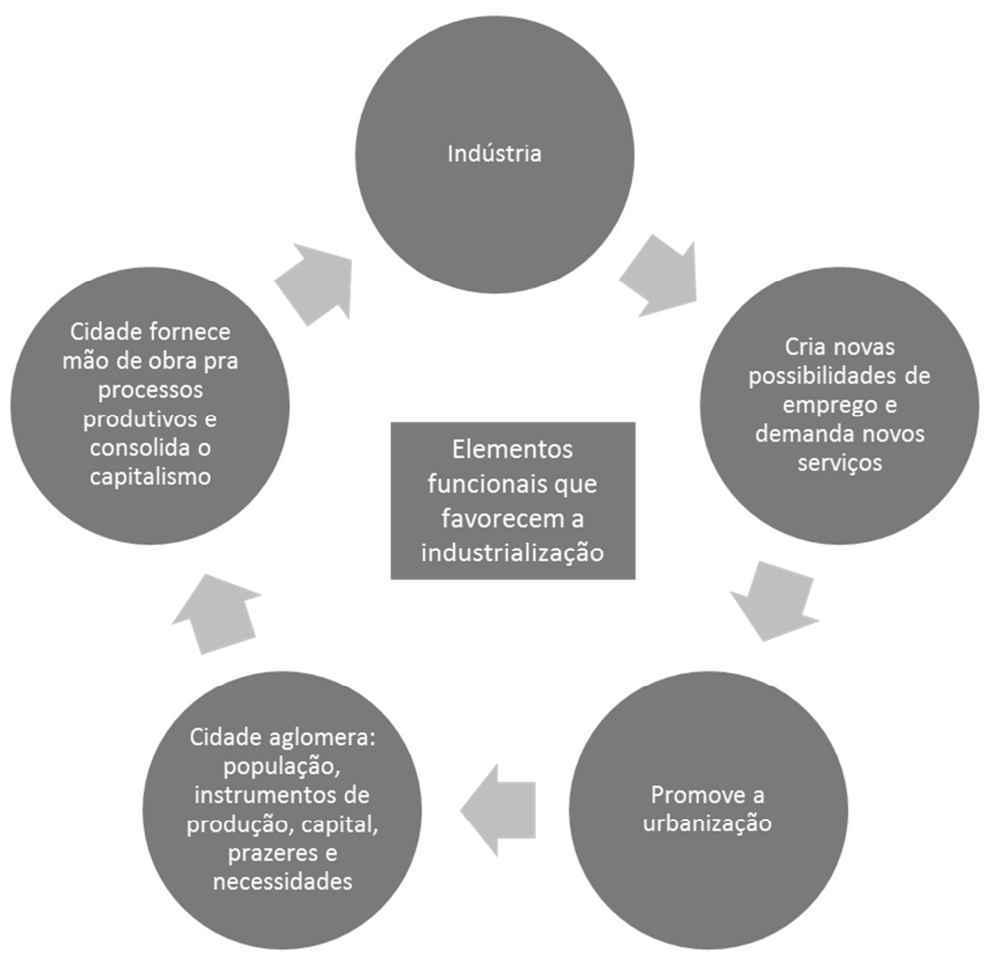

Figura 2 - Elementos funcionais que favorecem a industrialização segundo Castells. Fonte: Elaboração da autora.

Em contraponto, Lojkine ([1977] 1981, p. 153) ressalta que mesmo que exista um consenso de que o processo de industrialização exerce um papel determinante no crescimento das cidades, imaginar que o desenvolvimento urbano é assegurado exclusivamente pela necessidade constante que tem o capitalismo de aumentar a produtividade do trabalho social é equivocado.

O autor argumenta, inicialmente, que todo desenvolvimento da produtividade, ao elevar a composição do capital social, reforça, a prazo, a tendência à baixa da taxa de lucro e provoca uma reação de freagem e de seleção do desenvolvimento das forças produtivas. E, segundo, porque a necessidade de cooperação dos diferentes agentes de produção no espaço urbano é contrariada: (i) pelas leis da concorrência capitalista; (ii) pela fragmentação do espaço urbano em porções independentes umas das outras que são a propriedade privada dos proprietários fundiários (limite da renda fundiária).

Assim, as relações de produção capitalistas provocam, juntamente com a indústria moderna, uma tendência crescente à aglomeração urbana e imprimem um limite a qualquer organização racional do planejamento urbano. Para Lojkine ([1977] 1981, p. 162), na 
medida em que o desenvolvimento da aglomeração urbana depende estreitamente de sua articulação com o centro de empregos, os modos de implantação das indústrias e dos empregos de escritório vão pesar muito no desenvolvimento das cidades.

Outro aspecto discutido pelo autor diz respeito a um terceiro valor de uso do solo, com crescente importância: sua capacidade de aglomerar e de combinar socialmente meios de reprodução de uma formação social. A fragmentação desse valor de uso é consequência da apropriação privada do solo, que vai tornar-se um obstáculo, no interior do modo de produção capitalista, para o desenvolvimento das forças produtivas sociais.

A partir dessa constatação é possível analisar fenômenos como a hierarquização dos usos do solo, o papel do setor imobiliário para a acumulação do capital e para a reprodução das relações de produção capitalistas, além de ser importante para o entendimento do processo de segregação sócio-espacial e fragmentação do espaço no urbano. Para entender a atual importância da renda fundiária é indispensável identificar quem são os atuais proprietários fundiários urbanos, visto que uma das principais consequências dessa fragmentação é a segregação espacial.

Para Lojkine ([1977] 1981, p. 167) é possível distinguir três tipos de segregação urbana:

(i) a oposição entre o centro e a periferia, onde o preço do solo é o mais alto, no primeiro caso. O papel-chave dos efeitos de aglomeração explica a importância dessa renda de acordo com a localização;

(ii) a separação crescente entre as zonas de moradias reservadas às camadas sociais mais privilegiadas e as zonas de moradia popular;

(iii) o esfacelamento generalizado das funções urbanas, disseminadas em zonas geograficamente distintas e cada vez mais especializadas: zonas de escritórios, zona industrial, zona de moradia, além de outras. É o que a política urbana sistematizou e racionalizou sob o nome de zoneamento.

O autor complementa esse assunto defendendo que não basta justapor esses três tipos de segregação urbana, devendo-se concluir que há uma hierarquização dessas três formas de segregação em função de seu vínculo mais ou menos direto com a contradição social, entre o uso monopolista e o uso não monopolista do solo. Lojkine ([1977] 1981, pp. 222 - 
223) especifica que, a partir dessas considerações, é possível realizar a análise de três níveis de segregação social e espacial: (i) no nível da habitação; (ii) no nível dos equipamentos coletivos; (iii) no nível do transporte domicílio-trabalho. Conclui que talvez, o nível mais forte de segregação social seja a localização da habitação, visto que esta acaba influenciando nos demais.

As diferenças existentes entre os grupos sociais também são projetadas no espaço urbano, como pode ser exemplificado pela forma como as diferentes classes acessam o solo com o intuito da moradia. Nesse contexto, as classes dominantes têm o poder de escolha sobre que parte da cidade irão habitar, enquanto as demais classes não dispõem de acesso à terra urbana e nem à habitação de qualidade, passando a realizar ocupações irregulares da terra onde as condições de vida são extremamente precárias.

A segregação no nível da habitação confere ao indivíduo uma condição limitada de vida, daí sua sobreposição aos demais níveis de segregação apontados pelo autor. $\mathrm{Na}$ medida em que o indivíduo vivencia as limitações da segregação residencial, indiscutivelmente já está à mercê dos efeitos da segregação em termos de acessos a equipamentos e transportes públicos, visto que os locais onde essas populações podem habitar, em função de sua renda, também são precários com relação à oferta e à prestação de serviços e de infraestrutura urbana. Nessas condições, são consideradas inclusive, as limitações em termos de oportunidades e suscetibilidade a riscos e violência.

Para Castells ([1972] 2014, p. 249), a questão da moradia se coloca como o centro da dialética conflitual do meio urbano, com relação à apropriação social do produto do trabalho. $\mathrm{O}$ autor aponta a incapacidade da economia privada em garantir as necessidades mínimas de moradia, já que não há praticamente produção privada de moradia "social", por não ser lucrativa. Em função disso, o que se percebe é a estratificação social mensurada pelo poder de aquisição da moradia, ou até pela não-satisfação dessa demanda.

Devido a isso, emerge uma situação de escassez de um bem de uso indispensável em desequilíbrio permanente, sendo mantido pela concentração urbana. Fica configurada então, a estratificação social, chegando ao nível da segregação urbana, devido às disparidades entre as regiões urbanas, manifestas nas diferenças qualitativas e pela hierarquia entre as áreas. 
Lefebvre ([1968] 1991) também aponta a crise habitacional como um problema relevante, que inclusive precisa ser enfrentado pelo Estado. Contudo, ressalta que nos primórdios da urbanização, o assunto ainda não era percebido em toda sua complexidade, nem entendido como uma das principais faces da problemática urbana. Buscava-se apenas resolver uma situação considerada provisória, tentando dar um encaminhamento ao contingente populacional que se amontoava nas cidades e que era imprescindível à continuidade da industrialização. Naquela época, não se tinha a devida noção dos impactos espaciais que o processo de ampliação dos subúrbios causava, tampouco na própria estrutura da sociedade.

A distribuição das residências no espaço produz sua diferenciação e especifica a paisagem urbana, na medida em que as características das moradias e de sua população estão na base do tipo e do nível das instalações e das funções que se ligam a elas. Castells (2014) explica que:

“A distribuição dos locais residenciais segue as leis gerais da distribuição dos produtos e, por conseguinte, opera os reagrupamentos em função da capacidade social dos indivíduos, isto é, no sistema capitalista, em função de suas rendas, de seus status profissionais, de nível de instrução, de filiação étnica, da fase do ciclo de vida, etc. Falaremos, por conseguinte, de uma estratificação social (ou sistema de distribuição dos produtos entre os indivíduos e os grupos) e, nos casos em que a distância social tem uma expressão espacial forte, de segregação urbana. Num primeiro sentido, entendemos por segregação urbana a tendência à organização do espaço em zonas de forte homogeneidade social interna e com intensa disparidade social entre elas, sendo esta disparidade compreendida não só em termos de diferença, como também de hierarquia” (CASTELLS, [1972] 2014, p. 249-250).

A partir da ordem geral mantida pelas leis de distribuição dos produtos, é percebida a materialização espacial das consequências do modo de produção que regula a vida social, tendo como uma de suas externalidades a concentração de recursos. A distribuição assimétrica dos produtos faz com que grupos de indivíduos, os quais são mais numerosos, não disponham de recursos nem da capacidade necessária de se instalarem adequadamente na cidade, satisfazendo a necessidade de moradia de forma precária. Esses aspectos podem ser melhor compreendidos a partir da Figura 3. 


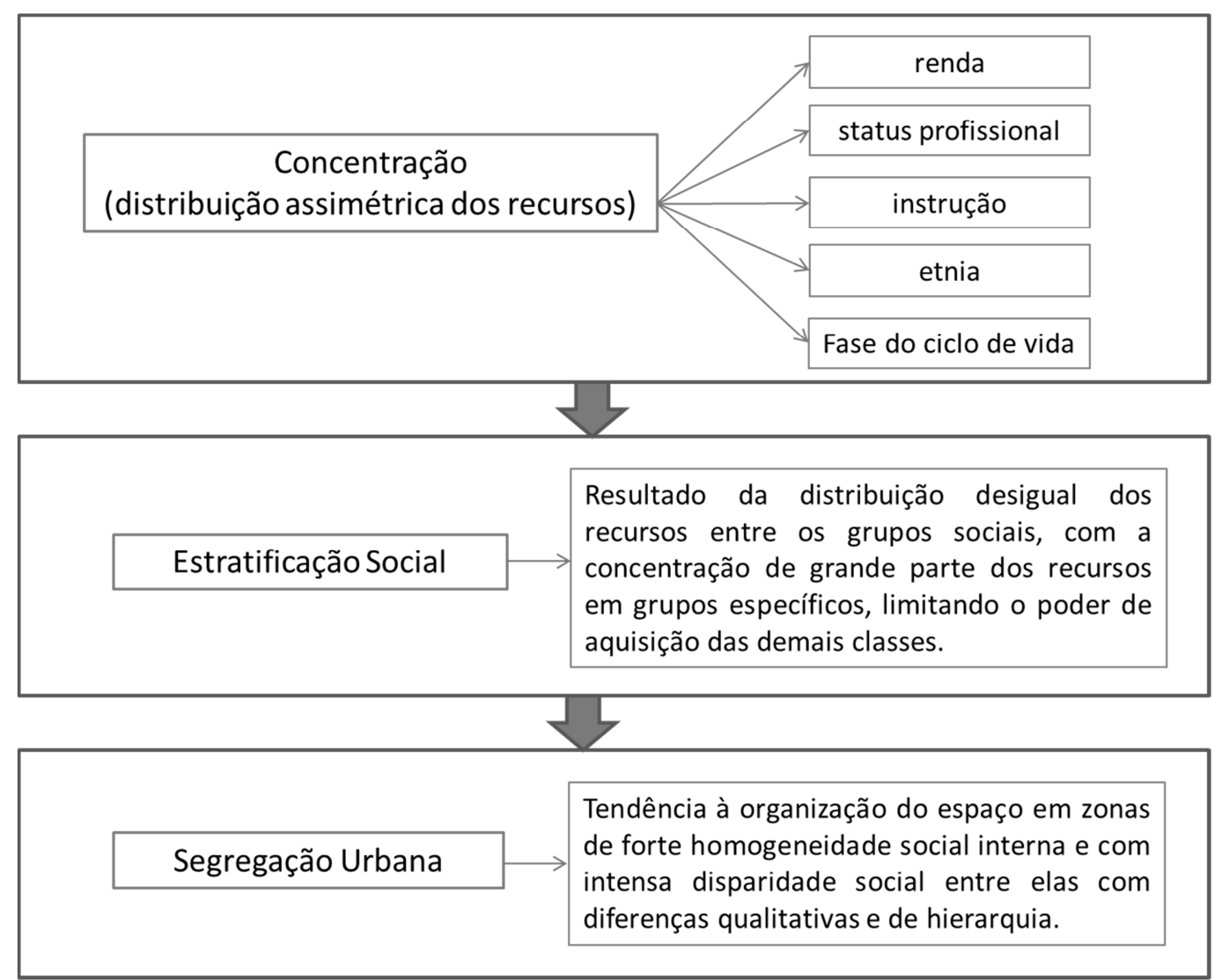

Figura 3 - Concentração, estratificação social e segregação urbana segundo Castells. Fonte: Elaboração da autora.

Mas essa satisfação insuficiente da moradia ou até a não satisfação dessa necessidade, não se restringe apenas à precariedade nas condições de vida em termos de qualidade das instalações da moradia. Vai muito além, ao configurar uma condição permanente de estratificação e de segregação social, visto que as localidades onde estão instaladas as moradias em condição de precariedade também prescindem de qualidade em vários outros aspectos da vida urbana: prestação de serviços, infraestrutura, renda, além de outros aspectos, os quais limitam e restringem o modo de vida de quem habita esses locais.

Ainda naquela época, nos primórdios da ascensão da problemática urbana a um nível crítico, Lefebvre ([1968] 1991, p. 21) cultivava um olhar otimista sobre a questão ao acreditar que a revolução urbana seria o ponto final do processo de urbanização. $\mathrm{O}$ autor aponta a sucessão de três períodos:

1. Primeiro período: a indústria e o processo de industrialização assaltam e saqueiam a realidade urbana preexistente, conduzida segundo uma estratégia de classe; 
2. Segundo período: a urbanização se amplia e a sociedade urbana se generaliza, fazendo com que a cidade seja reconhecida como realidade sócio-econômica;

3. Terceiro período: reencontra-se ou reinverta-se a realidade urbana, tentando restituir a centralidade.

Infelizmente, o que se percebe na sucessão dos tempos, é a acentuação da problemática urbana nos centros urbanos em escala global. Devido à lógica que vem norteando o processo de desenvolvimento urbano no mundo, o terceiro período destacado por Lefebvre parece ser algo difícil de ser conquistado, ou até mesmo se apresenta como uma proposta romântica e utópica.

É paradoxal esperar que uma estrutura social fundada no sistema capitalista tome, de forma unilateral, a decisão de inverter a ordem dominante que continua a se perpetuar no tempo. Já existiam ali muitos interesses em jogo, além de atores que estavam sendo beneficiados com a situação, indicando que reverter essa ordem implicaria romper com esses interesses. Daí surge a importância da mobilização social de grupos que se rebelam e buscam a transformação da ordem vigente.

Já na década de 1980, Castells ([1972] 2014, p. 46) aponta que o estágio atual da problemática urbana ocorre em torno da constatação de quatro problemas: (i) a aceleração do ritmo da urbanização no contexto mundial; (ii) a concentração desse crescimento urbano nas regiões ditas "subdesenvolvidas", sem correspondência com o crescimento urbano que acompanhou a primeira urbanização nos países capitalistas industrializados; (iii) o aparecimento de novas formas urbanas e, em particular, de grandes metrópoles; (iv) a relação do fenômeno urbano com novas formas de articulação social provenientes do modo de produção capitalista e que tendem a ultrapassá-lo

Esses argumentos continuam atuais, ressaltando-se apenas o fato de os países subdesenvolvidos terem sofrido os efeitos da urbanização de forma mais exacerbada devido ao complicador de não terem alcançado os mesmos padrões de crescimento urbano dos países desenvolvidos. Isso mostra que embora os países desenvolvidos também sejam impactados pela lógica perversa imputada ao modo de produção capitalista, puderam contar com um padrão mais elevado em termos de prestação de serviços e da rede de infraestrutura urbana, por exemplo. 


\subsection{Pressupostos para nortear uma política de desenvolvimento urbano}

A formulação teórica produzida no âmbito da escola marxista viabilizou a construção de novos saberes sobre os problemas da cidade, possibilitando a compreensão de aspectos implícitos e mais profundos, que estão inerentes às contradições existentes nos sistemas urbanos. Discutiu-se sobre a influência da lógica capitalista na formação, organização e estruturação dos espaços urbanos; destacou-se o fato de diferentes atores atuarem segundo interesses próprios; identificou-se o Estado como um protagonista nesse processo de interação; assim como se apontou a crise habitacional como a mais forte representação da segregação sócio-espacial.

Além disso, fez-se referência aos questionamentos de parte da sociedade, que foi se organizando ao longo do tempo, como uma reação às contradições vivenciadas no meio urbano. Esses anseios da população que vive à margem da cidade bem estruturada estão associados, principalmente, à concretização de direitos, à democratização e ao acesso mais justo à cidade. Também fazem parte dessas reivindicações, o atendimento às demandas por serviços, infraestrutura, equipamentos e bens de uso coletivo, tendo em vista alcançar uma condição digna de vida nos centros urbanos.

As políticas urbanas constituem algumas das ações desempenhadas pelo Estado, sendo concebidas para amenizar ou corrigir os desvios resultantes do processo de industrialização/urbanização. Entretanto, acabam acentuando as contradições inerentes ao desenvolvimento urbano por estarem associadas aos interesses que promovem as desigualdades. A produção dessas políticas requer um amplo processo de interlocução com atores e agentes que estão movidos por interesses difusos e contraditórios, os quais condicionam tanto a produção do espaço, quanto a concepção e implementação das ações estatais. Devido a isso, também se apresentam como produtos das contradições urbanas.

Por outro lado, existe um problema conceitual com relação às políticas produzidas pelo Estado, já que predomina a incompreensão do sistema urbano global, fazendo com que o Estado seja incapaz de tomar decisões politicamente sábias.

O Estado também é apontado como um ator preponderante para acentuação da problemática urbana por ser a representação do poder político institucional que se alia à classe dominante para o alcance de seus objetivos. Age como um elemento chave na 
difusão da segregação urbana por ter a capacidade de interferir significativamente na organização do espaço, principalmente por meio da planificação e das práticas urbanísticas.

Desse modo, oferece as condições necessárias para a consolidação do sistema de produção capitalista que está assentado no mecanismo de mercado. Por sua vez, esse sistema é ineficiente em alocar recursos no sistema urbano, fazendo com que essa problemática se torne cada vez mais acentuada.

Os autores apresentaram discussões em torno de quatro temas interligados que fazem parte das discussões sobre a problemática urbana: industrialização, urbanização, habitação e uso do solo. Sobre esses temas, Castells e Lefebvre explicam que industrialização e urbanização são processos equivalentes, sendo a industrialização o principal motor das transformações na sociedade.

Castells, Lefebvre, Lojkine e Harvey destacam que o processo de industrialização e urbanização é repleto de tensões e contradições que resulta em muitas situações problemáticas nas cidades, sendo manifestas pelas disputas por espaço. Castells e Lefebvre complementam esse argumento especificando que trata-se de um processo dialético.

Os quatro autores também apontam o fato de a industrialização, segundo a ótica capitalista, deter o poder de imprimir mudanças significativas na forma espacial das cidades, mostrando as influências do capitalismo na formação dos centros urbanos. $\mathrm{O}$ fato de esse processo contribuir para a aglomeração urbana compromete a capacidade de organização racional do planejamento urbano nas cidades, conforme ressaltado por Lojkine.

Castells e Harvey mostram que o urbano está ligado a uma forma específica de produção e de divisão do trabalho associada a valores e a uma cultura. As cidades atraem a indústria por possuírem os fatores essenciais para perpetuação da lógica produtiva dominante: mercado e mão de obra, como mostra Castells. Sobre a prevalência de uma lógica dominante, Castells, Lefebvre, Lojkine e Harvey destacam que o processo de industrialização e urbanização ocorre segundo mecanismos e forças ocultas que representam os interesses da acumulação do capital. 
Quanto aos temas habitação e uso do solo, Castells, Lefebvre e Lojkine destacam a habitação como o aspecto central da crise da problemática urbana. Os quatro autores também se referem à dificuldade das populações mais pobres quanto ao acesso ao solo urbano. A questão do acesso ao solo é priorizada por Castells e Lojkine que desenvolvem reflexões sobre diferentes níveis de segregação urbana, considerando que esta está relacionada à organização do espaço em zonas de forte homogeneidade social e com a concentração de recursos em determinadas classes sociais.

Também é levanta por Castells a incapacidade da economia privada em garantir as necessidades mínimas de moradia por não ser uma atividade lucrativa para o mercado. Desse modo, a questão habitacional das populações mais pobres é acentuada tanto pela dificuldade de acesso ao solo (custo da terra) quanto por não existir oferta de habitações no padrão que essas populações podem adquirir.

A partir dessas análises, percebe-se que é unanimidade entre os autores a influência da industrialização na urbanização e, consequentemente, na meterialização da problemática urbana nas cidades. A indústria consiste no elemento dominante desse processo, sendo o principal responsável pelas transformações na sociedade e na organização da paisagem urbana. Trata-se de um duplo processo, autônomo e repleto de intenções que compõe uma teia de interesses.

De acordo com esses argumentos, as contradições começam a surgir na medida em que o mecanismo que rege esse processo (mercado) passa a revelar sua incapacidade em distribuir os ganhos de produção de maneira eficiente e equilibrada entre os diferentes atores participantes, bem como quando o atendimento a um dos interesses específicos passa a comprometer os demais.

A questão habitacional tem sido apontada, por unanimidade entre os autores, como o centro da dialética conflitual da problemática urbana, configurando o nível mais forte de segregação social. O problema se inicia a partir da distribuição desigual dos recursos entre os grupos sociais existentes em um sistema urbano, onde aqueles detentores de menos renda têm a sua capacidade de acesso à moradia tolhida e comprometida. Paralelamente, ocorre um efeito sobre a paisagem urbana, por meio da coexistência de diferentes padrões de qualidade urbana que se associam às condições sociais desiguais das populações. 
A criação de subúrbios e a formação de assentamentos precários são resultado da dificuldade de reprodução da força de trabalho nas cidades capitalistas, sendo a produção de moradias social apontada como uma solução paliativa. Como esse tipo de produção não é rentável, o Estado é chamado a mediar os conflitos e apresentar soluções a partir da implementação de uma política urbana ou de ações regulatórias.

As construções teóricas elaboradas pelos autores estudados não estão em sua maioria voltadas para o apontamento de temas que devem integrar uma política de desenvolvimento urbano, porém, constituem pressupostos e premissas básicas que esclarecem sobre os mecanismos ocultos e as contradições que estão no cerne da problemática urbana. Desse modo, esses apontamentos são essenciais para a compreensão do assunto e imprescindíveis para a realização das análises sobre as políticas urbanas que serão estudadas nos próximos capítulos da tese.

Após a discussão dos aspectos teóricos relativos à problemática urbana, buscou-se conhecer os discursos oficiais orientadores da política urbana no Brasil, visando compreender como esta foi sendo moldada em torno das políticas setoriais de habitação, saneamento e mobilidade urbana. Assim, no Capítulo 2 serão estudados os discursos das políticas urbanas nacionais esboçadas desde a década de 1940 até a política urbana implementada pelo Ministério das Cidades, que desde 2003 é o órgão competente para conduzir a política brasileira de desenvolvimento urbano. Nessa etapa da pesquisa serão tomados como referência os pressupostos e as premissas teóricas levantadas pelos autores estudados neste capítulo.

\section{Capítulo 2. Os discursos das políticas nacionais de desenvolvimento urbano brasileiras em perspectiva histórica}

Neste capítulo, busca-se discutir sobre os discursos oficiais, legalmente aprovados ou não, produzidos para nortear a política urbana no Brasil, considerando a formação institucional de cada momento, bem como as temáticas abordadas. Busca-se com isso, compreender como os governos e a sociedade foram gradativamente amadurecendo e elaborando concepções sobre a problemática urbana até chegar ao desenho atual da política urbana, que é basicamente representado pela junção das políticas setoriais de habitação, saneamento e mobilidade urbana. 


\subsection{Antecedentes das políticas urbanas nacionais no Brasil}

A definição da problemática urbana como um conjunto complexo de demandas políticas e sociais de caráter urbano, requer um exame atento das características assumidas recentemente pelo processo de urbanização no Brasil, destacando-se: o fato de a urbanização brasileira ter ocorrido em ritmo mais acelerado do que o observado na maioria das sociedades capitalistas ocidentais; e por esse processo ter sido caracterizado por uma concentração cada vez maior da população nas áreas metropolitanas (SCHMIDT e FARRET, 1986, p. 27).

Para Bernardes (1986), a agudização dos problemas urbanos e das desigualdades regionais pode ser vista como resultado da aceleração da urbanização nas últimas décadas, e devido à implementação de políticas setoriais que estavam voltadas para a promoção do desenvolvimento econômico.

Essa forma de urbanização deu origem a um mercado formal de urbanização que produz, privadamente, "cidade", o que de fato ocorreu para as classes médias e altas. Por outro lado, para os demais brasileiros, restou uma inserção precária e ambígua no território sem condições básicas de urbanidade, estando essas populações vulneráveis a expulsões e a remoções. Nas cidades, o resultado desse processo culminou numa urbanização sem infraestrutura básica, tanto pela omissão do poder local da tarefa de fiscalizar o mercado formal, que frequentemente deixava os loteamentos sem infraestrutura, quanto por sua incapacidade de ofertar moradia e loteamentos adequados aos grupos de menor renda, impulsionando um mercado privado paralelo de baixíssima qualidade urbanística e habitacional (ROLNIK e KLINK, 2011).

Para os autores essa lógica impôs um padrão predatório que condenou as cidades a um modelo insustentável do ponto de vista ambiental e econômico por ter imposto perdas ambientais e externalidades negativas difíceis de serem recuperadas. $\mathrm{O}$ cenário observado nas grandes cidades após a urbanização segundo esta lógica financeira é representado pela espacialização da concentração das oportunidades em um fragmento do espaço urbano, juntamente com a ocupação extensiva de suas periferias densas, precárias e cada vez mais distantes. 
Em função de diversas consequências negativas sobre as cidades, devido ao processo de urbanização descrito anteriormente, a sociedade passou a demandar a interferência do Estado para a implementação de ações específicas, tendo em vista solucionar os problemas oriundos da situação crítica no meio urbano. Nesse sentido, foram realizadas iniciativas governamentais com esse propósito, as quais passaram a integrar o rol das políticas de desenvolvimento urbano já produzidas.

Nesse contexto, a trajetória da política de desenvolvimento urbano se confunde, na sua origem, com a concepção da própria política habitacional, uma vez que a questão urbana passou a fazer parte da agenda governamental a partir do momento em que os problemas decorrentes da falta de habitação tinham se tornado um ponto crítico e central nos debates acerca dos problemas urbanos.

Nos primeiros anos do século XX, o problema da habitação popular ganhou grandes proporções, decorrente da necessidade de adequação do espaço urbano e das transformações ocorridas no padrão das relações de produção. As referências às habitações populares eram comuns no discurso político oficial da época, expressando um conjunto de elementos que proporcionavam uma valorização ideológica que traduzia o pensamento dos segmentos dominantes da sociedade (DUARTE, 2013).

O processo de "descoberta" das favelas na década de trinta constitui um dado essencial para o entendimento da política de habitação e, por extensão, da política social adotada na década de quarenta. A crise de habitação colocou a questão na agenda política e foi um tema abordado na campanha presidencial de 1945 pelos candidatos. O vencedor afirmou que o problema era grave e que precisava ser resolvido com toda a urgência, preconizando a criação de uma Caixa Nacional de Habitação, visando à construção de cem mil casas populares (MELLO, 1991).

Azevedo (1988) relata que até 1930, a parca legislação e as medidas governamentais concernentes à habitação popular não consideravam a melhoria das condições de residência das classes de baixa renda como seu principal objetivo. A preocupação básica das autoridades era com o perigo que as favelas, cortiços e bairros populares poderiam representar no futuro, em termos de "contaminação", para a parte "sã" da cidade. Tratavase, na ótica dominante, de isolar ao máximo e de se evitar o crescimento destes focos de 
enfermidades e doenças sociais (prostituição, marginalidade, criminalidade, além de outros aspectos).

Mello (1991) destaca que os principais fatores que estavam associados à politização da questão habitacional e à sua incorporação à agenda estatal foram: (i) a existência de uma forte crise de habitação, afetando, sobretudo as camadas médias urbanas; (ii) a dinâmica interna do aparelho de Estado onde a questão era objeto de análise; (iii) (re) descoberta e politização da questão urbana, expressa num novo discurso sobre favelas e habitações insalubres.

O autor aponta que o auge da crise da habitação, nesse primeiro momento, ocorreu no período de 1942 a 1946, estando fortemente associado aos movimentos especulativos que se instalaram na economia brasileira durante a Segunda Guerra Mundial, à queda na importação de materiais de construção e a canalização de uma grande massa de capitais excedentes para o mercado imobiliário (cumpria o papel do mercado financeiro), além da ocorrência de um forte "boom" imobiliário. Com a crise, o problema da habitação passou a ter grande visibilidade política e adquiriu potencial para articular um consenso, visto que incorporava demandas populares e empresariais (habitação e emprego). Dessa forma, a crise politizou a questão da habitação e deflagrou uma mobilização pioneira.

É no Estado populista de Getúlio Vargas que a habitação ganha novo sentido, o de instrumento de poder, a fim de servir à população como ideário da casa própria, objeto de consumo perseguido a todo e qualquer custo pelas famílias, tendo em vista a inserção no espaço urbano e, pelo governo, para manutenção do sistema político vigente (DUARTE, 2013). Por outro lado, nesse período, a posição do Estado brasileiro na área da habitação social se limitava a incentivar a produção privada de moradias para operários e classes pobres, geralmente voltadas para a locação, além de reprimir situações de insalubridade, por meio de legislação sanitária e ação policial (BONDUKI, 1994, p. 724).

Segundo o autor, as primeiras intervenções públicas na área de habitação popular tinham como objetivo mostrar às populações urbanas de baixa renda a preocupação do governo com seus problemas. Apesar de a retórica dos discursos ser repleta de boas intenções, as realizações concretas se mostravam bastante modestas e de discutível impacto sobre as precárias condições de moradia das classes de baixa renda. Para as autoridades 
públicas, o mais importante era reafirmar sua determinação de enfrentar o desafio da questão habitacional e manter acesa a esperança da possibilidade de cada um, individualmente, poder resolver seu problema habitacional por meio da ajuda governamental.

Na década de 1940, o poder público passa a atuar na produção direta de Conjuntos Habitacionais e no financiamento de moradias populares, sendo os órgãos pioneiros no Brasil para esse fim, os Institutos de Aposentadoria e Pensão (IAPs), em 1937, e a Fundação Casa Popular (FCP), em 1946, quando o Estado finalmente assumiu a responsabilidade do problema habitacional no país (DUARTE, 2013). Foi somente com a criação da Fundação da Casa Popular (FCP), em 1946 que foi institucionaliza a primeira agência em nível nacional, voltada exclusivamente para a construção de casas populares para as classes de baixa renda (BONDUKI, 1994, p. 724).

Conforme Bonduki (1994, p. 717), nem o governo Vargas, nem os posteriores, chegaram a formular uma política habitacional articulada e coerente, visto que não houve a estruturação de uma estratégia para o enfrentamento do problema, tampouco a efetiva delegação de poder a um órgão responsável de coordenar a implementação de uma política habitacional em todos seus aspectos (regulamentação do mercado de locação, financiamento habitacional, gestão dos empreendimentos e política fundiária). Para o autor, seria necessária uma ação articulada entre os vários órgãos e ministérios que interferiram na questão, o que não aconteceu no caso da FCP. Bonduki explica que:

“A proposta da Fundação da Casa Popular revelava objetivos surpreendentemente amplos, demonstrando até mesmo certa megalomania (ela se propunha financiar, além de moradia, infraestrutura, saneamento, indústria de material de construção, pesquisa habitacional e até mesmo a formação de pessoal técnico dos municípios); no entanto, sua fragilidade, carência de recursos, desarticulação com os outros órgãos que, de alguma maneira, tratavam da questão e, principalmente, a ausência de ação coordenada para enfrentar de modo global o problema habitacional mostram que a intervenção dos governos do período foi pulverizada e atomizada, longe, portanto, de constituir efetivamente uma política" (BONDUKI, 1994, p. 718).

A criação da Fundação da Casa Popular (FCP) se constituiu numa resposta do Estado à forte crise nacional de habitação, que atingiu, sobretudo, o antigo Distrito Federal (Rio de Janeiro), bem como à descoberta e politização da questão urbana expressa num discurso novo sobre as favelas e os mocambos. Quanto ao processo institucional interno ao 
Ministério do Trabalho, culminou na unificação dos diversos Institutos de Aposentadoria e Pensões (IAPs) e, consequentemente, das suas carteiras prediais, abrindo a possibilidade de uma política nacional de habitação (MELLO, 1991).

Teoricamente, a FCP preconizava várias medidas operacionais, objetivando o barateamento das casas populares e, por consequência, a ampliação do acesso ao programa para uma parte considerável dos setores de baixa renda. Entre essas medidas, incluíram-se diversos subsídios indiretos, como construir somente em terrenos doados pelas prefeituras, garantir baixas taxas de juros e um longo prazo de financiamento para o comprador final do imóvel. Entretanto, a inexistência de mecanismos de receita constante e a perda de parte importante do capital investido - em função da ausência de indexação das prestações, num contexto inflacionário - acarretaram um desempenho medíocre da instituição, referente à quantidade de casas populares produzidas (AZEVEDO, 1988).

Para Bernardes (1986), a questão habitacional era amplamente reconhecida, mas, na maioria dos casos, apenas quanto ao déficit de moradias e não quanto às suas demais implicações. A consideração do urbano, em grande parte da década de 1960, era muito restrita e estava fundamentada em uma visão de urbanistas que acreditavam encontrar no planejamento urbano uma possibilidade concreta de ordenar o espaço por meio de técnicas próprias de controle do seu uso. Esse urbanismo progressista/racionalista influenciou os especialistas em administração e direito municipal que viam na modernização da gestão urbana o caminho para o ordenamento de espaço nas cidades brasileiras. Nasceriam desses grupos as primeiras preocupações com os planos integrados "compreensivos", que viriam mobilizar profissionais das várias áreas envolvidas com o urbano (início do planejamento integrado).

De acordo com a autora, na segunda metade da década de 60, não se estruturou uma proposta explícita de política urbana nacional, mas, pela primeira vez, em nível do discurso oficial, foi reconhecida a necessidade de o governo central atuar diretamente nas cidades, não apenas na oferta da habitação. Por outro lado, a natureza complexa dos problemas institucionais a serem enfrentados para a implantação de uma política urbana deve ter contribuído para que não fosse conferida prioridade à formulação e implementação de uma política com essa abrangência. 
O modelo de política habitacional implementado a partir de 1964, pelo Banco Nacional de Habitação (BNH), baseava-se em um conjunto de características que deixaram marcas importantes na estrutura institucional e na concepção dominante de política habitacional nos anos que se seguiram. Essas características podem ser identificadas a partir dos seguintes elementos fundamentais: primeiro, a criação de um sistema de financiamento que permitiu a captação de recursos específicos e subsidiados, o Fundo de Garantia de Tempo de Serviço (FGTS) e o Sistema Brasileiro de Poupança e Empréstimo (SBPE), que chegaram a atingir um montante bastante significativo para o investimento habitacional. $\mathrm{O}$ segundo elemento foi a criação e a operacionalização de um conjunto de programas que estabeleceram, em nível central, as diretrizes gerais a serem seguidas, de forma descentralizada, pelos órgãos executivos. Terceiro, a criação de uma agenda de redistribuição dos recursos, que funcionou principalmente em nível regional, a partir de critérios definidos no nível central. E, por último, a criação de uma rede de agências, nos estados da federação, responsáveis pela operação direta das políticas e fortemente dependentes das diretrizes e dos recursos estabelecidos pelo órgão central (MCIDADES, 2004b).

A criação do Sistema Financeiro de Habitação (SFH) juntamente com o BNH, de fato representa um marco institucional relevante para consolidação da política de desenvolvimento urbano no Brasil visto que tinham como missão estimular a construção de habitações de interesse social e o financiamento da aquisição da casa própria, especialmente pelas classes da população de menor renda. Nesse período, a habitação popular ingressou na agenda governamental e passou a contar com uma fonte de financiamento específica (BOTEGA, 2008, pp. 5-6).

Para Schmidt e Farret (1986, p. 34), a atuação do BNH se desenvolveu rapidamente entre 1964 e 1973. Inicialmente, em 1964, tinha como foco a questão habitacional, sendo inserida a temática saneamento em 1968, com a criação do Planasa. Continuou a crescer e se diferenciar até 1973, quando foram criadas as regiões metropolitanas, tendo seu arcabouço terminado com a inserção da temática transportes em 1976, quando nasceu a Empresa Brasileira de Transportes Urbanos (EBTU).

Inicialmente, a política de desenvolvimento urbano brasileira foi se constituindo em torno dos setores habitação, saneamento, e transportes devido à prioridade e à ordem com 
que esses temas foram ascendendo à agenda governamental. Entretanto, posteriormente, esse formato foi sendo mantido devido aos interesses econômicos e políticos.

Naquela época já havia sido consolidado o modelo de política de desenvolvimento urbano que predomina no Brasil, priorizando a atuação em habitação, saneamento e transportes. Esse fato pode ser comprovado na medida em que os autores apontam que embora o BNH tenha investido 51,41\% de seus recursos em habitação, o perfil dos anos seguintes indicou a diminuição dos investimentos em habitação em detrimento à crescente participação de outros programas setoriais.

Observou-se que no período de 1972 a 1975, o BNH investiu cerca de 29,7\% em habitação, $43,8 \%$ em saneamento, $12,3 \%$ em transportes e 14,2\% em desenvolvimento urbano, termo adotado para todas as outras ações (SCHMIDT e FARRET, 1986, p. 40). Desde então, o modelo setorialista passou a ser a lógica predominante no planejamento e na implementação dos investimentos relativos ao desenvolvimento urbano por setores, com destaque às temáticas tradicionais. Mesmo que outras temáticas fossem discutidas e identificadas como relevantes, não chegavam a contemplar $15 \%$ da priorização na aplicação de recursos.

De acordo com os autores (p. 6) o SFH teve sua importância aumentada em 1967 devido ao fato de o BNH receber a gestão dos depósitos do Fundo de Garantia por Tempo de Serviço (FGTS), bem como com a implementação do Sistema Brasileiro de Poupança e Empréstimos (SBPE), ampliando de forma relevante o capital do banco. Esse fato transformou o $\mathrm{BNH}$ em uma das principais instituições financeiras do país e a maior instituição mundial voltada especificamente para o problema da habitação.

Tendo em vista a materialização dessa política foi implementada uma rede de agências públicas e privadas que funcionava sob a gerência do BNH. Porém, paulatinamente, o Banco limitou seu papel ao de um órgão normativo e de supervisão, deixando a seus diferentes agentes especializados a aplicação de sua política. Paralelamente a isso, o mercado imobiliário foi estratificado segundo os diferentes níveis de renda dos mutuários (popular, econômico e médio), ficando cada um deles, sob a responsabilidade de um agente promotor e regido de acordo com uma legislação específica (AZEVEDO, 1988). Nesse momento, já se percebia a tentativa de fragmentação 
institucional na gestão da problemática da habitação, o que posteriormente, irá favorecer à setorialização das ações.

Em pouco tempo, o BNH se transformou em um órgão de natureza essencialmente setorial, com papel de indutor da produção de habitações, deixando prevalecer o enfoque setorial do problema habitacional sem ser dada a devida atenção às outras questões que integravam a problemática urbana. Ao estruturar os mecanismos de instrumentalização da sua ação, o BNH, consolidou-se como um banco e teve sua atuação voltada para uma programação setorial. Ao assumir essa condição de banco, o BNH passou a diversificar suas aplicações e não mais concentrou seus investimentos na habitação de interesses social. Com o passar do tempo, o Sistema Financeiro da Habitação (SFH) se agigantou e o BNH passou a abarcar, já na década de 70, as mais diversas formas de construção imobiliária, além de incorporar novos programas, de saneamento básico, transportes urbanos, além de outros tipos de intervenções (BERNARDES,1986). Para a autora, a incorporação desses programas poderia fazer do $\mathrm{BNH}$ um banco de desenvolvimento urbano, todavia, sua condição de órgão financeiro gestor de programas setoriais sempre prevaleceu no comando das suas ações.

No BNH, desde a sua criação, prevaleceu a lógica de instituição financeira, sendo todas as suas operações transferidas para a iniciativa privada. O Banco arrecadava os recursos financeiros e em seguida os transferia para os agentes privados intermediários. Algumas medidas demonstravam que existia uma preocupação com o planejamento das ações de urbanização aliada aos interesses do capital imobiliário. Assim, o SFH/BNH funcionava como um eficaz agente de dinamização da economia nacional que desempenhava um importante papel junto ao capital imobiliário nacional, cada vez mais se afastando do seu objetivo principal, apresentado no discurso, de ser o indutor das políticas habitacionais para superação do déficit de moradia. Nesse período, o BNH reorientou seus investimentos para as camadas sociais com maior poder aquisitivo, deixando de lado a construção de habitações populares (BOTEGA, 2008, p. 7).

Bernardes (1986) destaca que, na segunda metade da década de 60, não foi estruturada uma proposta explícita de política urbana nacional, contudo, pela primeira vez, o discurso oficial passou a reconhecer a necessidade de o governo central atuar diretamente nas cidades, não apenas na oferta da habitação. Por outro lado, a natureza complexa dos 
problemas institucionais que deveriam ser enfrentados para a implantação de uma política urbana pode ter contribuído para que não tivesse sido conferida a devida prioridade à formulação e implementação de uma política com esse formato, uma vez que o discurso dos planejadores e as diretrizes oficiais explicitadas eram diferentes das ações desenvolvidas pelo Estado como agente promotor do desenvolvimento urbano.

Para Rolnik e Klink (2011) a política nacional de desenvolvimento urbano foi concebida nos anos de 1960/1970 por meio da estruturação de um sistema de financiamento de habitação e saneamento, onde o governo federal realizava a arrecadação dos recursos e os distribuía, mediante empréstimos, tendo como principal fonte de financiamento das ações o FGTS. Na habitação, o modelo se baseava no financiamento da produção privada e de companhias públicas, incorporando posteriormente a oferta de crédito bancário para o consumidor final. Na política de saneamento, o financiamento foi canalizado para companhias estaduais, tendo os sistemas expandidos nas regiões de maior renda, onde o retorno financeiro dos investimentos era garantido, devido ao valor pago pelos beneficiários finais por meio de tarifas dos serviços de saneamento e das prestações da casa própria.

No início da década de 70 os problemas urbanos passaram a ter maior atenção, juntamente com a problemática dos desequilíbrios macrorregionais. Esses dois tipos de problemas foram agravados em decorrência das políticas setoriais implementadas, juntamente com a macropolítica econômica que vigorava e estavam estreitamente relacionados em função de decorrem de um mesmo processo espacial (BERNARDES, 1986). Segundo a autora, a incorporação do desenvolvimento urbano ao desenvolvimento regional e à diretriz de integração nacional ocorreu no I PND, mostrando que o Estado já considerava o problema urbano, contudo, não o considerava em toda sua complexidade e amplitude. A autora destaca que:

"Somente em 1973-1974 o desenvolvimento urbano iria ser efetivamente situado no modelo de desenvolvimento brasileiro. A incorporação do desenvolvimento urbano ao desenvolvimento regional e à diretriz de integração nacional - como figura no $1^{\circ}$ PND - já abria o aparelho estatal à consideração do problema, mas não bastara para que a questão fosse considerada em toda sua complexidade e amplitude. A concorrência do MINTER e do MINIPLAN quanto à gestão dos assuntos urbanos revela o reconhecimento da importância que poderiam adquirir os instrumentos a serem criados. Isso porque a implementação de uma política urbana implicaria a estruturação de mecanismos de coordenação em nível da União e o desdobramento e coordenação de suas intervenções no nível dos estados e município, em particular nos 
grandes polos metropolitanos. A instituição das regiões metropolitanas não só poderia ser considerada como mais um instrumento da penetração do poder da União, mas também representaria a criação de instrumentos financeiros que viriam reforçá-lo” (BERNARDES, 1986, p. 97).

\subsection{As políticas urbanas nacionais no Brasil dos anos 70 e 80}

Desde o final dos anos 60 existiam diversas recomendações em nível técnico favoráveis à definição de uma política de desenvolvimento urbano. Contudo, só em meados de 1973, com a edição da Lei Complementar $n^{\circ} 14$, que instituiu as regiões metropolitanas, a necessidade de uma política urbana mais abrangente ficou evidente para os níveis de decisão superiores, em função dos efeitos perversos das políticas públicas da década anterior, sobre a configuração espacial do país. Naquela época, ganhou destaque a constatação da tendência à crescente concentração de renda e a verificação de que, mesmo nas áreas nas quais se pretendia "consolidar o desenvolvimento", bolsões de pobreza absoluta estavam sendo gerados e/ou ampliados no interior nordestino e na periferia dos grandes centros urbanos.

Steinberger (1998, pp. 3-4) aponta que a política urbana recebeu heranças importantes dos seis Planos Nacionais que antecederam o II PND, como apresentado a seguir:

- Plano Trienal (1963-1965): neste documento, o espaço urbano não aparecia como objeto de planejamento, porém, foram lançadas ideias que posteriormente foram apropriadas pelos discursos de política urbana, tais como: urbanização resultante da industrialização; pobreza e precárias condições de vida; e elevação da renda e sua mais equitativa distribuição;

- Plano de Ação Econômica do Governo-PAEG (1964-1966): abordou o espaço urbano mais diretamente, contudo, este tema foi tratado em conjunto com as denominadas "políticas de produtividade social" (emprego e habitação). Fez-se menção à necessidade de incluir a política habitacional no escopo de uma "política de planejamento urbanístico e de desenvolvimento regional", mas esta não foi formulada. Também foi prevista a iniciativa de realizar assistência a estados e municípios na elaboração de planos urbanísticos; 
- Plano Decenal (1967-1976): contou com um capítulo específico para tratar a temática urbana, onde foram apresentadas as bases de uma política nacional de desenvolvimento urbano, bem como foi proposta uma metodologia para sua formulação. Também foi editado um volume específico para o desenvolvimento social, onde o tema habitação foi abordado, esclarecendo que a política urbana não deveria ser confundida com a política setorial de habitação;

- Programa Estratégico de Desenvolvimento-PED (1968-1970): neste documento o tema espaço urbano foi incluído nas "Políticas de Emprego e População", considerando sua distribuição espacial como uma das linhas de ação. Mesmo que de forma restrita, fez-se menção do tema em conjunto com o espaço regional e sugeriu uma política de desenvolvimento urbano integrado;

- Metas e Bases para a Ação de Governo (1970): mais uma vez foram feitas referências esparsas ao espaço urbano sem fazer referência a uma política urbana. Contudo, existia no documento um capítulo sobre desenvolvimento regional e urbano, que abordava as ideias de equidade e redistribuição;

- I Plano Nacional de Desenvolvimento (1972-1974): neste Plano, havia breves referências ao espaço urbano de forma conjunta com a temática regional e a estratégia de integração nacional.

A seguir, serão apresentados os discursos das políticas nacionais de desenvolvimento urbano contidos nos Planos Nacionais de Desenvolvimento do período de 1974 a 1989: (i) II Plano Nacional de Desenvolvimento (1975-1979), (ii) III Plano Nacional de Desenvolvimento (1980-1985); e (iii) I Plano Nacional de Desenvolvimento da Nova República, os quais foram legalmente instituídos e adotados como discursos oficiais.

Além dos discursos, optou-se por também apresentar a contextualização geral desses planos e o conteúdo específico da política urbana, a partir de seus objetivos gerais e principais diretrizes, tendo em vista esclarecer o que de fato estava norteando a ação estatal nesses diferentes momentos onde foram formalmente aprovadas por lei ou por normativo legal equivalente, iniciativas para o desenvolvimento do país. 


\section{Plano Nacional de Desenvolvimento (1975-1979)}

A primeira e única Política Nacional de Desenvolvimento Urbano efetivamente formalizada no Brasil foi instituída pelo II Plano Nacional de Desenvolvimento (II PND), que foi aprovado pela Lei $\mathrm{n}^{\circ}$ 6.151, de 04 de dezembro de 1974 para vigorar no período de 1975 a 1979. O referido Plano tinha como objetivo realizar conquistas econômicas e sociais, destacando-se a tentativa de consolidar, até o fim da década em curso, uma sociedade industrial moderna e um modelo de economia competitiva, tendo como núcleo básico o Centro-Sul.

O II PND buscava promover o pleno desenvolvimento econômico do país, a partir do fortalecimento da economia interna com o objetivo de minimizar os impactos da crise mundial do petróleo. De acordo com o documento, a viabilização da meta de crescimento econômico estaria estreitamente vinculada à importância de consolidar um modelo brasileiro de capitalismo industrial, tendo em vista viabilizar o desenvolvimento da indústria por meio do setor privado, bem como assegurar à empresa nacional papel importante na estrutura industrial moderna que se desejava consolidar (p. 19-20). Embora o viés econômico tivesse sido o principal orientador desse PND, apresentou-se um capítulo específico para uma estratégia de integração nacional e outra voltada ao desenvolvimento social, reconhecendo que o desenvolvimento do país não deveria estar atrelado exclusivamente ao aspecto econômico.

A política nacional de desenvolvimento urbano proposta foi inserida no II PND juntamente com a estratégia de controle da poluição e preservação do meio ambiente, indicando a percepção de integração entre a problemática urbana e a temática ambiental, requerendo uma estratégia de preservação do meio ambiente em função da poluição industrial, causada pelo processo intenso de industrialização incentivado pelo Estado. Também foi apontada a preocupação acerca dos efeitos deletérios associados à excessiva concentração urbana em determinadas regiões, acarretando sérios problemas de congestionamento, superlotação e poluição em detrimento da qualidade de vida e do equilíbrio social.

Nesse sentido, o Plano preconizava definir, de forma geral, a estrutura urbana que se desejava estabelecer nacionalmente, concebida em função dos objetivos e programas de desenvolvimentos nacional e regionais. Buscava-se com isso, promover uma melhor 
estruturação do sistema urbano, com vistas à maior eficiência das funções exercidas pelas cidades e à elevação dos padrões de urbanização e qualidade de vida. Propagava o discurso com foco na redução das desigualdades regionais e priorizava a atuação nas regiões menos desenvolvidas (p. 67-68).

No documento, foram propostas diretrizes para o controle da urbanização acelerada, tendo como prioridade três linhas de atuação: (i) solucionar a expansão desenfreada e desordenada das metrópoles e as suas consequências negativas; (ii) responder à carência das cidades por infraestrutura adequada para o desenvolvimento das atividades econômicas e produtivas; (iii) diminuir a carência de equipamentos sociais nas regiões metropolitanas e nas cidades com potencial econômico.

Além das estratégias preconizadas para cada região do país, a Política Nacional de Desenvolvimento Urbano proposta considerava prioridades para o planejamento integrado das regiões metropolitanas, destacando-se: (i) prioridades gerais, direcionadas para todas as regiões, com foco em transportes coletivos, uso do solo, zoneamento urbano, saneamento e outros equipamentos sociais; (ii) prioridades específicas para o Rio de Janeiro, São Paulo e em favelas, visando ao uso coordenado de fundos de desenvolvimento urbano e a realização de programa de investimentos em desenvolvimento social urbano, além dos programas de abastecimento de água, esgotos e habitação.

No mesmo capítulo, o II PND especificou estratégias relativas à poluição industrial e à preservação do meio ambiente, especificando que o combate à poluição já é importante no Brasil, devido à concentração industrial em certas áreas metropolitanas, sem zoneamento adequado, assim como em função da proliferação de veículos nos aglomerados urbanos. Também é destacado no documento o nível de devastação de recursos naturais, que assumiu proporções inadmissíveis, como consequência da construção a infraestrutura, da execução de programas industriais e agrícolas, e principalmente, devido à ação predatória de interesses imediatistas.

No documento, faz-se um apelo à defesa sistemática e pragmática do patrimônio de recursos naturais e do patrimônio cultural representado pelas cidades históricas, que também fazem parte do desenvolvimento. Ao mesmo tempo, é reconhecida a carência de requisitos básicos de saneamento e controle biológico, indispensáveis à saúde das 
populações de baixa renda. Em função desses aspectos, buscava-se conciliar o desenvolvimento que ocorria em alta velocidade com o mínimo de efeitos danosos sobre o meio ambiente, garantindo inclusive, o uso racional dos recursos naturais do país.

Dessa maneira, foram pensadas ações específicas para o controle da poluição industrial destacando-se a importância de disciplinar a ocupação industrial segundo a intensidade da ação poluidora das indústrias, bem como estabelecer padrões de emissão para diferentes tipos de resíduos. Foram sugeridas como atividades relevantes para esta ação o sensoriamento das águas e do ar para o conhecimento da situação ambiental e verificação do comportamento e da quantidade de agentes poluentes presentes nas comunidades.

Para a execução das diretrizes preconizadas no II PND foi elaborado um programa de investimentos, onde os recursos de saneamento, integração social e de desenvolvimento social urbano estavam alocados no eixo de orçamento social, sendo o BNH a organização responsável pelas ações de habitação e infraestrutura urbana.

A partir da análise do Plano, percebe-se que, do ponto de vista do discurso, buscouse abordar a política de desenvolvimento urbano em âmbito nacional e considerando sua interface com outras temáticas, além das tradicionalmente abordadas até então (habitação, saneamento, transportes, urbanização) tais como as diferenças regionais e a problemática ambiental. Isso indicou que existe, por parte do Estado, o entendimento da natureza complexa da problemática urbana e da política de desenvolvimento urbano, mesmo que a ação governamental não contemple todas as ações necessárias para o enfrentamento da questão.

Por outro lado, o formato adotado para conceber a Política Nacional de Desenvolvimento Urbano constante no II PND seguiu o modelo vigente à época, tecnocrático e centralizador. Esse modelo era condizente com o período da ditadura e atuava de forma a corrigir os efeitos deletérios do modelo de desenvolvimento, conforme reforçado por Steinberger (1998, p. 5).

Também se destaca o fato de coexistir em um mesmo plano de desenvolvimento que preconiza uma estratégia de intervenção nacional a difícil tarefa de compatibilizar a consolidação do modelo brasileiro de capitalismo industrial, tendo em vista viabilizar o 
desenvolvimento da indústria por meio do setor privado, com uma proposta de desenvolvimento que não enfoque exclusivamente o viés econômico. No entanto, fica evidente a prevalência de um discurso fortemente voltado à iniciativa privada, por ter como foco promover a estrutura industrial visando à modernidade.

Em função de se conceber uma política urbana pautada por um discurso alicerçado na economia, como seria possível dar prioridade às questões oriundas da problemática urbana, que requerem um olhar diferenciado a populações de baixa renda, já que o objetivo primordial do Estado divulgado no seu discurso oficial visa privilegiar o mercado?

Mesmo assim, o conjunto de proposições apresentado no II PND para uma PNDU foi o que apresentou maior detalhamento no nível das ações em conformidade com as diferentes necessidades de cada região do país. Outro ponto relevante deste documento se refere à amplitude de temas abordados no Plano, indicando a relação entre a temática urbana com a regional e a ambiental, e de forma menos explícita, com a rural. Isso se mostrou como uma tentativa de pensar a problemática urbana além da visão setorial tradicionalmente adotada.

Embora tenha sido um ganho significativo do ponto de vista institucional a existência de uma política nacional de desenvolvimento urbano no II PND, verifica-se que, das proposições gerais contidas nela, pouco foi alcançado por não haver ocorrido a coalizão necessária à adoção de medidas coercitivas e à priorização coerente da alocação dos recursos, conforme as ações preconizadas. O grupo de técnicos que atuavam na esfera governamental, sem respaldo político e sem apoio dos grupos econômicos, não teve meios de influir decisivamente no aparelho estatal e fazer com que a política de desenvolvimento urbano alcançasse melhores resultados (BERNARDES, 1986).

Souza (2015, p. 114) reconhece que existiam duas concepções no II PND, sendo uma globalista e outra setorialista. Enquanto a primeira procurava lidar com o espaço brasileiro como uma totalidade materializada no território, a segunda trazia uma visão segmentada do urbano, entendida como a soma de habitação, saneamento básico, transportes, gestão administrativa e das finanças. Apesar disso, a visão setorial mostrou-se vencedora por propiciar de imediato uma ação sobre a política urbana dos diferentes grupos de interesse que influenciavam em cada um desses aspectos. 
A autora (p. 115) também destaca que na época de concepção do II PND ainda predominavam "deficiências teóricas sobre o conhecimento da urbanização brasileira", sendo mais evidente a visão mecanicista e funcionalista sobre a sociedade e o espaço. A dificuldade da época consistia em estruturar uma política de desenvolvimento urbano que pudesse incorporar o espaço como social, além da compreensão de que a concentração de renda era diretamente afetadas pelas concentrações urbanas.

\section{Plano Nacional de Desenvolvimento (1980-1985)}

Dando continuidade às estratégias nacionais para o desenvolvimento, em $05 \mathrm{de}$ dezembro de 1979 foi aprovada, pelo Congresso Nacional, a Resolução $n^{\circ} 1$ que instituía o III Plano Nacional de Desenvolvimento (III PND), destinado ao período de 1980 a 1985, explicitando objetivos e linhas de atuação governamental, bem como orientações para os setores privados.

O III PND também especificou que o desenvolvimento do país não deveria estar atrelado exclusivamente ao aspecto econômico, demonstrando a preocupação quanto à necessidade de concentrar esforços governamentais na promoção da distribuição mais justa dos frutos do desenvolvimento econômico, dirigindo-se prioritariamente para a melhoria das condições de vida dos segmentos menos favorecidos da população brasileira. Entretanto, reconhecia a opção brasileira pela economia de mercado, onde o planejamento do desenvolvimento e toda sua atuação governamental deveriam voltar-se para orientação, apoio e estímulo aos setores privados, escancarando a natureza paradoxal dessa proposição (p. 22). Fica claro, desde as diretrizes iniciais do referido documento, que o Plano estava prioritariamente orientado para o viés econômico, mesmo possuindo em seu escopo temáticas relacionadas às questões sociais, ao desenvolvimento urbano e às desigualdades regionais.

Na Seção 2 do III PND são tratas as políticas regional e urbana, onde se faz referência à prevalência de fortes desequilíbrios regionais no Brasil, intra-regionais de renda, de atividades econômicas e de qualidade de vida. No documento é apontado que o vertiginoso processo de urbanização que acompanhou o desenvolvimento industrial das últimas décadas redefiniu e tornou complexo o quadro urbano nacional. Além disso, ficou reconhecido que a acelerada expansão econômica da última década beneficiou de forma 
desigual as diferentes classes sociais do país, visto que a renda média das populações de menor poder aquisitivo foi a que cresceu com menor rapidez (p. 23).

Tem-se, portanto, o entendimento de que o modelo de desenvolvimento baseado na economia de mercado, o qual vem sendo implementado desde as décadas anteriores, favorece a remuneração do capital e daqueles que são detentores dos meios de produção, tendo como resultado a concentração desses ganhos e a acentuação das desigualdades sociais. Com isso, o Estado vem atuando como um dos atores que contribuem para que este quadro se torne ainda mais crítico.

Em função disso, é possível supor que o objetivo de melhoria da distribuição de renda, com redução dos níveis de pobreza absoluta e elevação dos padrões de bem-estar das classes de menor poder aquisitivo ficaria comprometido. Contudo, estava explícito no III PND (p. 24) que o rápido crescimento da economia poderia e deveria ser conjugado com o objetivo de melhor distribuir a renda gerada.

Assim, mais uma vez se repete a estratégia paradoxal que visa compatibilizar interesses do mercado, que são sustentados por operações rentáveis, com interesses de populações de baixa renda, que não dão a rentabilidade esperada para quem está conduzindo as ações governamentais e a tomada de decisão. Isso já vem se repetindo historicamente, desde o momento de implantação da FCP e do BNH, onde os interesses de empreiteiros e de imobiliárias se sobrepunham às necessidades das populações de baixa renda.

O discurso de defesa das populações mais pobres e da defesa de ações específicas para esse público-alvo vem sendo utilizado para justificar a proposição de alternativas governamentais e a concepção de uma nova ordem institucional. Porém, a implementação das ações sempre esteve orientada para os ganhos financeiros, favorecendo o ganho de capital e os interesses de um grupo de atores que sempre priorizou os interesses dos empresários e de outros atores em detrimento das populações menos favorecidas e que sempre estiveram reféns da problemática urbana.

A respeito disso, Bernardes (1986, p. 117) constata que a política urbana brasileira, desde seus primórdios, não alcançou a adequada interação à política global de desenvolvimento necessária à sua efetiva implementação. Observa-se que as diretrizes 
dessa política não foram perseguidas com a mesma prioridade que foi conferida às ações setoriais, que estavam voltadas ao crescimento econômico. Isso pode ser comprovado na medida em que se observa o descolamento entre o discurso oficial, a prática e os resultados das ações.

As temáticas relativas à política de desenvolvimento urbano foram tratadas em duas partes do Plano, primeiro, no Capítulo V, direcionado para as políticas setoriais, onde se tratou a política de transportes. Segundo, na Seção 2 do documento, onde foram abordadas as políticas regional e urbana.

Com relação ao setor urbano, as prioridades deveriam estar voltadas para o fortalecimento das cidades de pequeno e médio portes, buscando voltar todos os esforços para o crescimento de suas áreas metropolitanas e das cidades de maior porte, inclusive para prevenir problemas e prejuízos à qualidade de vida, como já se percebia em diferentes áreas do país.

Também se tornaram prioritários o disciplinamento da expansão e o fortalecimento da infraestrutura relacionado ao crescimento de cidades específicas e às regiões menos desenvolvidas no país. Mais uma vez, o discurso em torno da política de desenvolvimento urbano estava propondo uma estratégia específica para cada região do país, tendo em vista produzir ações diferenciadas para cada tipo de problema diagnosticado. Contudo, por diferentes razões, o que se viu na prática, foi a ampliação do quadro crítico nos grandes centros urbanos e nas regiões menos desenvolvidas do país.

É importante salientar que no III PND, as políticas regional e urbana são tratadas de forma conjunta, apontando o reconhecimento no discurso oficial de que essas duas temáticas são interligadas e que ambas sofreram consequências negativas em função do modelo de desenvolvimento que vem sendo adotado recorrentemente.

Também fica evidente o entendimento de que o modelo/estratégia de desenvolvimento que vem sendo praticada ao longo do tempo, com foco no viés econômico e amparado no desenvolvimento do mercado, é responsável pela prevalência de fortes desequilíbrios regionais no Brasil, intra-regionais de renda, de atividades econômicas e de qualidade de vida, além de acentuar os problemas já existentes. Tudo isso 
como herança do processo de urbanização que acompanhou o desenvolvimento industrial das últimas décadas, redefinindo e tornando mais complexo o quadro urbano nacional.

Em relação ao meio ambiente e aos recursos naturais, o texto do Plano buscou dar ênfase na preservação do patrimônio histórico artístico e cultural e dos recursos naturais, assim como na prevenção, controle e combate da poluição em todas as suas formas, estando todos esses aspectos presentes nos desdobramentos da política nacional de desenvolvimento e na sua execução. Também foram listados como prioridades a expansão de áreas de equipamentos, especialmente as de localização próxima às concentrações urbanas; a adaptação de áreas urbanizadas à prática do lazer e a instalação de equipamentos nos programas habitacionais, tendo em vista melhorar as condições de recreação e lazer.

Embora a temática ambiental não tenha tido neste plano a mesma relevância conferida no II PND, pôde contar com diretrizes relativas ao saneamento básico e ambiental, no sentido de erradicar doenças endêmicas. Isso aponta o reconhecimento de que a temática ambiental está relacionada à problemática urbana e requer uma solução que, de alguma forma, englobe os dois temas. Ressalta-se mais uma vez que o tratamento da questão envolve outros temas que vão além da precariedade observada na oferta de habitações e na prestação dos serviços de saneamento e transportes, como enfatiza o recorte setorial.

Por outro lado, a forma tradicionalmente adotada para analisar a problemática urbana e conceber políticas e alternativas de ação estatal para sua resolução ou até minimização dos seus efeitos, tem conduzido ao processo de planejamento fragmentado e setorializado. O documento passa a impressão de que as temáticas regional, urbano e ambiental comungam de uma relação implícita devido à percepção existente sobre a manifestação das problemáticas atreladas a esses temas. Contudo, não são propostas intervenções que possam contemplar sua complexidade de forma satisfatória, que dirá em sua plenitude. Além disso, as contribuições do III PND voltadas para a política de desenvolvimento urbano foram tímidas e se limitaram em torno de diretrizes e proposições superficiais.

\section{Plano Nacional de Desenvolvimento da Nova República (1986-1989)}

Seguindo a sequência temporal, o próximo Plano oficial analisado foi o Primeiro Plano Nacional de Desenvolvimento da Nova República (I PND-NR), aprovado pela Lei ${ }^{\circ}$ 
7.486, de 06 de junho de 1986, destinado a vigorar durante o período de 1986 a 1989. O documento foi apresentado em IX partes onde cada uma delas, antes de apresentar o conteúdo da política em questão, foi divulgado um diagnóstico acerca da problemática que seria abordada, apontando os fatores que orientaram a proposição das ações. No plano, fezse menção à temática urbana em três partes do texto: (i) Parte II - Desenvolvimento Social, onde foi feita referência a Saneamento Básico e Habitação; (ii) Parte III Desenvolvimento Econômico, onde se tratou do tema transportes no item de Transporte Urbano; (iii) Parte VII - Desenvolvimento Regional e Urbano.

$\mathrm{Na}$ apresentação do Plano consta que a Nova República se instalou com o compromisso de mudar a vida política, econômica e social do país, visando alcançar três metas estratégicas: realizar reformas, promover o crescimento econômico e combater a pobreza. Explica que o Plano se difere dos anteriores em vários aspectos, destacando o fato de trazer uma forte orientação social. Reforça isso partindo da tese de que nenhum modelo de crescimento é capaz, por si só, de erradicar a pobreza que atinge grande parte da população em níveis intoleráveis em um contexto de resseção e alto nível de inflação (p. 9).

O governo também considerou como ponto essencial, o fato de que a erradicação da pobreza exige investimentos voltados a esse fim específico, implicando a melhoria da distribuição da renda e a concentração de esforços e recursos em programas para reduzir os problemas sociais. Contudo, isso se apresenta de forma paradoxal na medida em que a concepção de desenvolvimento adotada pelo I PND-NR parte da tese de que cabe ao setor privado o papel de destaque na retomada do crescimento.

Sabe-se que a economia de mercado tem suas regras e interesses próprios, os quais, na maioria das vezes, são incompatíveis com a proposição de uma agenda de cunho social e de equidade. Isso pode ser constatado na própria trajetória da ação estatal voltada para a resolução da problemática urbana, visto que sucessivamente, o modelo de desenvolvimento que vem sendo adotado no Brasil, tem acentuado as disparidades sociais e a condição de extrema pobreza nos grandes centros urbanos, como destacado no texto do III PND.

Neste Plano, também foi reconhecido o contexto de desequilíbrios que caracterizam a sociedade brasileira, sendo o crescimento a condição necessária à transição democrática e 
à estabilidade social do país. Na estratégia de combate à pobreza fica especificada a redefinição do modelo de desenvolvimento nacional, que deveria se basear no condicionamento das opções macroeconômicas às prioridades sociais inadiáveis, dando destaque aos padrões dignos de habitação. Para tanto, o gasto público deveria ser orientado para o resgate da dívida social acumulada, repondo para as populações mais carentes, as perdas resultantes da recessão e da falta de orientação social na política econômica do passado.

Também fazia parte da política do setor público sua reorganização interna, implicando a transferência de atividades do âmbito federal para os governos estaduais e municipais, promovendo a ampla descentralização de recursos e de atribuições, assim como a implementação de um amplo programa de privatização e democratização do capital das empresas estatais.

Vale salientar que a crise do Sistema Financeiro de Habitação e a extinção do BNH criaram um hiato em relação à política habitacional e as demais políticas urbanas, com a desarticulação progressiva da instância federal, a fragmentação institucional, a perda de capacidade decisória e a redução significativa dos recursos disponibilizados para investimento na área. Extinto em agosto de 1986, as atribuições do BNH foram transferidas para a Caixa Econômica Federal, permanecendo a área de habitação vinculada ao Ministério do Desenvolvimento Urbano e Meio Ambiente (MDU), cuja competência abrangia as políticas habitacional, de saneamento básico, de desenvolvimento urbano e do meio ambiente, enquanto a Caixa estava vinculada ao Ministério da Fazenda.

Ao se analisarem as propostas do Plano, percebe-se que a primeira temática discutida em relação à problemática urbana, tinha como objeto a infraestrutura, ao se expressar a necessidade de melhoria dos serviços proporcionados pelo sistema de transportes. Nesse campo, as diretrizes para os transportes urbanos previam a tentativa de tornar compatíveis os preços dos transportes coletivos com o poder aquisitivo dos usuários e descentralizar a política e a programação setorial, atribuindo poderes aos órgãos e instituições locais.

No item de prioridades sociais, ficou estabelecido que o setor saneamento básico é decisivo no esforço da redução da mortalidade infantil, sendo prioritário ampliar o acesso a esses serviços com prioridade ao grupo da população de menor renda. Já no setor 
habitacional, tinha-se como objetivo atender às populações de baixa renda, especialmente aquelas localizadas na periferia das cidades, em favelas e cortiços, com a construção de milhões de novas habitações.

Assim, observa-se que as temáticas tradicionalmente abordadas na política de desenvolvimento urbano, mais especificamente habitação, saneamento e transportes, já eram tratadas separadamente, considerando a existência de interfaces entre as duas primeiras com a questão social, e a última, entendida como um problema relacionado à infraestrutura ou com relação à prestação de um serviço.

Destaca-se ainda o fato de que saneamento e habitação, mesmo inseridos na estratégia de prioridades sociais do PND-NR, já eram entendidos como setores, os quais deveriam ser trabalhados em âmbito governamental, de forma dissociada e independente. Apenas era enfatizado o entendimento de que ambos os setores deveriam priorizar o atendimento às populações de baixa renda como uma das formas de combate à pobreza.

A temática do desenvolvimento regional foi tratada no documento de forma relacionada à política de desenvolvimento social, na sua justificativa, considerando que o fato de estar destina às populações mais pobres, é em essência, uma política de desenvolvimento regional. Ficou reconhecido no Plano que as disparidades de renda entre as regiões são tão agudas que exigem implantação de projetos específicos, com prioridade absoluta no combate à pobreza no Nordeste.

Fica evidente no documento que existe o entendimento por parte dos formuladores da estratégia de desenvolvimento nacional a relação entre as fragilidades na oferta de habitação e saneamento com os níveis de pobreza e de desigualdades inter e intraregionais, causados pelo modelo de desenvolvimento que vem sendo conduzido em nível nacional recorrentemente. É reconhecida, inclusive, a condição de maior vulnerabilidade da região Nordeste e dos bolsões de pobreza que se formaram nos grandes centros das regiões mais desenvolvidas.

Os temas saneamento e habitação foram abordados de forma mais detalhada na Parte II - Desenvolvimento Social, nos itens V e VI. A sequência metodológica do documento para tratar dos assuntos envolveu a seguinte sequência: 1. Diagnóstico; 2. Diretrizes Básicas; 3. Estratégia Setorial; 4. Programas e Projetos Prioritários. 
Com isso, percebeu-se a tentativa do formulador do Plano de mostrar o devido encadeamento entre o conhecimento do problema, a definição de diretrizes para nortear sua solução, a definição de uma estratégia factível e a especificação de ações para atuar em causas e efeitos dos problemas.

Nesse momento, já existia por parte do Estado a compreensão das causas, dos efeitos e de algumas interfaces entre a problemática urbana com outras temáticas, tais como: efeitos deletérios do modelo de desenvolvimento adotado, a urbanização acelerada e desordenada, as condições de desigualdades inter e intra-regionais, interfaces com as temáticas ambiental e rural, associação com as condições críticas de urbanidade e os níveis de pobreza. Mesmo assim, embora exista a compreensão de que a problemática urbana é complexa e requer um olhar multidisciplinar, saneamento e habitação foram abordados como dois setores separados.

No diagnóstico do plano foi enfatizado que a extrema diferença nas condições socioeconômicas das regiões do país se reflete no acesso diferenciado aos serviços de saneamento básico. Isso mostra que domicílios excluídos dos sistemas públicos correspondem aos estratos de menor renda, por estarem condicionados à sua capacidade de pagar tarifas, sendo essa situação agravada nas áreas rurais.

Constatou-se ainda que os problemas relativos ao saneamento não se restringem apenas à cobertura dos serviços, uma vez que foi apontada a fragilidade das instituições do setor. Foi observado que estas atuam de forma quase sempre desarticulada, sem claras definições de prioridades e orientadas por objetivos e métodos diferentes, apontando a necessidade de reformulação político-institucional. Tudo isso, somado à prevalência de interesses que regem as regras do setor. As diretrizes básicas para o setor saneamento estavam voltadas para sua reorganização visando assegurar maior descentralização e articulação inter e intra-setorial, além de outros direcionamentos específicos. Seguindo essa forma de pensar, os programas prioritários para o setor saneamento foram agrupados em: (i) Saneamento Básico em Áreas Urbanas; (ii) Saneamento Básico em Áreas Rurais; e (iii) Saneamento geral.

Essa forma de dividir os programas mostra a existência de mais um nível de fragmentação no planejamento da ação estatal na tentativa de promoção do 
desenvolvimento urbano. Além de os setores serem divididos por temas, passaram a existir categorias para classificar a situação das áreas urbanas, das áreas rurais e para o que foi denominado de geral (gestão de recursos hídricos, drenagem e controle da poluição).

Embora essa iniciativa visasse contemplar as peculiaridades dos diferentes públicosalvo identificados, é uma tentativa frágil e insuficiente para se tentar abarcar a complexidade que o saneamento envolve. Partir e enquadrar o problema em caixinhas separadas apenas reforça a forma de pensar de maneira compartimentada, o que fragiliza o alcance da ação pública que, cada vez mais, se consolida como fragmentada e setorializada.

A temática habitação foi abordada no item VI do documento, onde foi apontado no diagnóstico que o déficit habitacional está concentrado na faixa da população com renda inferior a três salários mínimos, representando cerca de $20 \%$ da população dos grandes centros urbanos que vivem em favelas e cortiços. Mesmo diante desse quadro, também é mostrado que o Sistema Financeiro de Habitação (SFH) tem atendido principalmente aos segmentos de renda média e alta (superior a cinco salários mínimos), representando cerca de $66 \%$ do total de financiamentos e $33 \%$ da população urbana.

Também é ressaltada a crescente redução dos investimentos do SFH em função da diminuição drástica dos depósitos de FGTS, devido ao contexto de inflação, recessão e desemprego. Isso contribuiu para a reorientação dos recursos para programas de natureza social, sob pena de comprometer seu equilíbrio financeiro, reforçando a lógica financeira que já vinha orientando o setor de habitação desde os períodos anteriores. Ou seja, em períodos de crise e em situação de restrições financeiras e orçamentárias, são suspensas ou reduzidas ao mínimo, as ações voltadas para as populações de baixa renda, sendo revertidos os investimentos aos setores da sociedade que podem dar algum tipo de retorno financeiro às aplicações.

Outro aspecto levantado no Plano se refere à ausência de mecanismos de participação da sociedade na concepção e na implantação das políticas, programas e projetos habitacionais, sendo uma das causas da proliferação de empreendimentos com má localização, ausência de serviços urbanos e má qualidade das construções. Assim, já se percebe nesse momento, o reconhecimento por parte das próprias instâncias 
governamentais de que o modelo tecnocrata e centralizador, vigente nas décadas anteriores, não tem sustentação e contribui para o mau desempenho da ação pública no que tange à problemática urbana.

Sobre esse assunto, vale salientar que a CF/88 foi instituída durante o horizonte de implementação do I PND-NR, juntamente com a proposição de um regime democrático, preconizando a criação de diferentes instâncias de participação popular, bem como propondo a descentralização do poder central, a partir do estabelecimento de instâncias locais, visando fortalecer o papel do município na gestão das políticas públicas. Com isso, buscava-se instituir espaços para a ampliação do debate acerca das demandas da sociedade em relação ao Estado, além de favorecer a participação de representantes da sociedade civil organizada.

O pacto federativo decorrente desta nova ordem institucional representou um grande avanço na consolidação de uma nova estrutura para a condução das políticas, tanto por estabelecer a divisão de competências entre os diferentes entes federados (União, estados, municípios e Distrito Federal) e promover a descentralização, quanto por buscar tornar o processo mais participativo e representativo.

Contudo, essa mudança não seria fácil, na medida em que implicava novas estratégias para promover a coordenação entre os diferentes atores que passaram a integrar o processo de implementação das ações. Outro ponto destacado é o fato de o município ter sido sobrecarregado de novos encargos sem estar devidamente dotado de estrutura administrativa e financeira para a assunção de suas novas responsabilidades legais.

No Item VI do documento, tratou-se sobre a temática habitação e no texto relativo ao diagnóstico, fez-se menção sobre as estimativas de déficit habitacional. Essa estimativa apontou a existência um elevado número de moradias que apresentam deficiências diversas, bem como há um grande contingente de casas que não possuem o mínimo necessário de condições sanitárias. Deu-se destaque ao fato de essas carências estarem concentradas na faixa da população com renda inferior a três salários mínimos, representando cerca de $20 \%$ da população dos grandes centros urbanos que vivem em favelas e cortiços. 
Dessa maneira, as diretrizes básicas preconizadas no PND-NR, para os setores de habitação e saneamento deveriam ser implementadas com o objetivo de ampliar significativamente o atendimento às populações de baixa renda que viviam em condições precárias, sendo consideradas as metas estabelecidas para o atendimento dos diferentes públicos-alvo especificados.

A temática de transportes foi discutida no item VI do Plano, sendo abordado no diagnóstico o problema enfrentado pela sociedade no setor de transportes urbanos devido ao desequilíbrio entre a capacidade de pagamento dos usuários e o preço dos serviços. Também foi destacada a desarticulação entre o sistema de transporte e o planejamento do uso do solo urbano, além do desempenho ineficaz do poder concedente na gestão do sistema de transporte público por ônibus. Esses problemas provocam o adensamento nos corredores de transportes e a expansão inadequada do sistema com a elevação dos custos das tarifas, penalizando as populações de renda mais baixa.

Tomando como referência os problemas diagnosticados, os principais objetivos e diretrizes para o setor de transportes foram: garantir ao cidadão meios de transporte coletivo adequados ao exercício do seu direito à mobilidade, a preços compatíveis com seus rendimentos; proporcionar às populações urbanas de menor renda transporte eficiente e de baixo custo; caracterizar o transporte urbano como uma questão de política local, atuando o governo federal em caráter complementar às ações empreendidas pelas municipalidades; reduzir o custo dos transportes de massa; capacitar órgãos; estimular a pesquisa; estimular a utilização de veículos de melhor desempenho.

Destaca-se aqui o enfoque dado à atuação do município, como o titular dos serviços de transportes, sendo o responsável por sanar as fragilidades que o setor vem acumulando juntamente com a acentuação da urbanização desordenada dos grandes centros. Entretanto, essa situação nos faz questionar sobre como o município, por si só, seguindo a determinação de novas competências constitucionais, poderia solucionar os pontos críticos relativos a uma temática complexa, que já vem se acentuando há décadas? Assim, é possível constatar que a sistemática da ação estatal não contempla, mais uma vez, o comprometimento necessário para o alcance das grandes proporções dessa problemática. 
Também fica incoerente a proposta de garantir os meios de transporte coletivo para o direito à mobilidade quando uma das principais estratégias de desenvolvimento do governo é o incentivo à indústria automobilística.

O Desenvolvimento Regional e Urbano foi discutido na Parte VII do documento, sendo separados em dois itens. A questão regional foi atribuída ao cenário caracterizado por profundas desigualdades de renda em níveis intra e inter-regional e por alarmantes índices de pobreza nas regiões menos desenvolvidas e nas periferias urbanas.

Os fatores que contribuíram para a diferenciação regional identificada foram: (i) a grande concentração de atividades econômicas na região Sudeste; (ii) a debilidade estrutural dos sistemas produtivos das regiões periféricas, incapazes de prover emprego e sustento para toda a população, especialmente a do Nordeste; (iii) os vazios demográficos no Centro-Oeste e na Amazônia, com substituição ou aproveitamento inadequado de suas potencialidades; (iv) os bolsões de miséria nas regiões mais desenvolvidas; (v) Intensas migrações inter-regionais e rurais-urbanas, acelerando o processo de urbanização e acentuando as deficiências da oferta de empregos e serviços básicos.

Dessa forma, foi construído um discurso onde os objetivos do desenvolvimento regional deveriam estar vinculados aos objetivos da política de desenvolvimento nacional, que, supostamente, deveria priorizar as regiões menos desenvolvidas e as periferias, além da indução de novos padrões de ocupação espacial, considerando os espaços urbanos e rurais. No discurso, existia clareza com relação às causas dos desequilíbrios regionais, bem como quanto aos gargalos que precisavam ser superados. Porém as estratégias pensadas para a resolução dessa problemática, além de não contemplarem toda sua complexidade, não era seguida no momento de sua implementação.

O desenvolvimento urbano foi abordado no I PND-NR considerando que a problemática urbana no Brasil resultou do processo acelerado de urbanização ocorrido nas últimas décadas, o qual foi acompanhado da deterioração das condições de vida da sociedade, em função do aumento dos índices de pobreza. Segundo o Plano, essa situação foi acentuada devido à fragilização na prestação de serviços e da redução da amplitude dos programas sociais. 
Nessa parte do documento, deu-se enfoque ao contexto de crise fiscal que acentuava a incapacidade estatal em atender às necessidades da população com relação às ações de promoção do desenvolvimento urbano. Por outro lado, é preciso destacar que mesmo em outros momentos, onde o Estado concebeu e implementou ações com esse propósito e em melhores condições para realizar investimentos, a problemática urbana não foi atenuada, pelo contrário, tornou-se mais crítica. Por isso, é preciso identificar que fatores são preponderantes na ação governamental, fazendo com que o discurso que legitima a política de desenvolvimento urbano não seja colocado em prática ao longo dos anos, recorrentemente.

No discurso do Plano também foi apontado que a situação crítica das cidades exige uma solução de alcance global, evitando as intervenções tópicas e setoriais que vinham sendo realizadas nos últimos anos. Sugere a necessidade de uma atuação governamental integrada e de orientação espacial, devendo ser parte integrante da política de desenvolvimento econômico do país. Entretanto, percebe-se que a problemática urbana, na pratica, vem sendo prioritariamente trabalhada de forma fragmentada, sob o enfoque da ótica setorialista, resultando em alternativas de intervenção que atuam nos problemas de forma parcial e muitas vezes desconectada. O máximo de avanço já percebido, no sentido de modificar a forma setorial de pensar, é pensar o setorial de forma separada para depois integrar, como se vê a seguir.

Assim, os objetivos específicos da política de desenvolvimento urbano elencados no documento mostram desarticulação entre o discurso e a prática já que propõem ações que não são atendidas (estabelecer mecanismos de controle de valorização fundiária urbana; fortalecer a participação das populações na organização do espaço) ou ações que são trabalhadas em parte (melhorar a qualidade de vida dos habitantes das cidades, por meio ampliação de oferta de serviços básicos; impedir o agravamento das condições urbanas do país, mediante tratamento integrado de ações setoriais; reduzir desequilíbrios na rede urbana, por meio da promoção de investimentos públicos em cidades médias e pequenas).

\section{Considerações gerais sobre os planos}

A partir da análise dos planos e dos antecedentes das políticas urbanas nacionais praticadas até o final dos anos 1980, percebe-se que, ao longo do tempo, segundo os diferentes momentos históricos, foi-se construindo um discurso em torno da problemática 
urbana e das respectivas estratégias de ação governamental para combatê-la ou minimizar seus efeitos negativos sobre as cidades e na sociedade. Verificou-se que a cada novo governo e a cada novo contexto institucional e de proposição de uma ação estatal, novos fatores eram somados à retórica política e aos discursos oficiais, conferindo maior complexidade ao texto. Com isso, muitas temáticas foram introduzidas nos debates além da problemática habitacional, contudo, esses mesmos discursos não eram seguidos em sua plenitude.

Na proposta de criação da FCP e no momento de instituição do BNH e do SFH, a questão da habitação era o aspecto primordial que norteava a ação pública, sendo logo em seguida inseridos outros temas nas prioridades governamentais, tais como saneamento básico e transportes públicos. Já nos anos finais de atuação do $\mathrm{BNH}$, era adotado o termo desenvolvimento urbano por já existir diferentes tipos de modalidades de investimentos (habitação, saneamento básico, transportes, urbanização de favelas, construção de equipamentos públicos e sociais, pavimentação de vias, além de outros).

Os planos de desenvolvimento estudados (PNDs) inovaram ao propor uma estratégia nacional de desenvolvimento urbano, inserindo no escopo da estratégia governamental as temáticas ambiental, regional e rural, além de reconhecerem a problemática como uma questão social, que se origina a partir do modelo de desenvolvimento pautado no viés econômico que vinha sendo reproduzido ao longo de décadas.

Por outro lado, mesmo reconhecendo a amplitude da complexidade da problemática urbana, a forma de intervenção governamental para o tratamento da questão foi reforçando e cristalizando ao longo do tempo a prática da fragmentação e da setorialização das ações. Ficou evidente o reconhecimento de que as ações devem ser planejadas e executadas segundo a organização dos setores de habitação e saneamento, considerados como problemas sociais, e do setor de transportes, relacionado às questões de infraestrutura, separadamente. Mesmo que outros temas tenham sido mencionados nas orientações gerais ou nos textos de diagnósticos dos documentos, apenas foram propostas medidas mais concretas para os temas habitação, saneamento e transportes.

Outro aspecto identificado em todos os Planos foi o fato de proporem uma estratégia paradoxal de desenvolvimento ao priorizar a economia de mercado como a principal 
estratégia de desenvolvimento nacional, buscando compatibilizá-la com ações de orientação social com foco no combate à pobreza e na diminuição das desigualdades. Essa abordagem se mostra paradoxal, uma vez que se tem constatado que foi esse próprio modelo de desenvolvimento, assentado na economia de mercado, que originou e acentuou o contexto de desequilíbrios e concentração de renda no país. É reconhecido que os interesses e as regras que regem o modelo capitalista de desenvolvimento, em muitos momentos, são contraditórios e incompatíveis com ações necessárias ao tratamento da problemática urbana.

Pereira (2012, p. 380) se refere a esse assunto destacando que a dinâmica da acumulação do capital não é constituída por processo linear, assim como não é contratualmente pactuado como se tenta aparentar no liberalismo. Tomando como referência as desigualdades que estruturam essa dinâmica, tem-se a crise como um elemento endógeno a seu funcionamento. Considerando a materialização desse modelo nas cidades, entende-se que a propriedade privada fundiária, base da escassez habitacional, tem se constituído em um fator chave do processo de acumulação no modo de produção capitalista. Segundo a autora, a cidade industrial capitalista promove o acirramento das contradições entre as classes sociais, onde a urbanização assume o papel que favorece as condições necessárias à consolidação dessa ordem, bem como para a expansão do capital.

Pinto (2005, p. 98) se refere a esse aspecto apontando que o papel do Estado é visualizado na seletividade do investimento público em infraestrutura, equipamento coletivo, normatização e fiscalização do solo, o qual encobre o "segredo" da valorização da terra. A intervenção estatal tende a estruturar e ordenar a cidade a favor dos lucros e da iniciativa privada.

Guimarães (2013, p. 181) complementa esse debate mostrando que o desenvolvimento das forças produtivas que sustenta o modo de produção capitalista, apresenta como características principais a exploração, a apropriação de espaços e a destruição de recursos naturais e da força humana de trabalho, visando assegurar a crescente taxa de lucro. O autor destaca que:

"O espaço como produto da atividade humana e da relação homem-natureza faz parte do processo de reprodução geral da sociedade e, tendo sua produção assentada nas necessidades impostas pelo desenvolvimento da acumulação capitalista, e também mercadorizado, tal como a cidade e a própria moradia que 
passam a ser concebidas como mercadorias necessárias à viabilização da produção, circulação, distribuição e troca, condição para a realização do ciclo de acumulação de capital. Afinal, sendo o espaço urbano moldado essencialmente para potencializar a acumulação do capital, sua formatação articula as diferentes esferas do modo capitalista de produzir.” (GUIMARÃES, 2013, p. 181).

Tendo em vista compreender como a ação humana interfere nesse processo, no Capítulo 4 da tese serão abordados os atores e os interesses que de fato condicionam a forma tradicional de conduzir as políticas urbanas no Brasil.

A prática associada às políticas urbanas também precisa ser estudada em função de se observar o descolamento entre o discurso institucional adotado pelo Estado para justificar sua atuação no enfrentamento da problemática urbana e as estratégias realizadas na prática para este fim. Observa-se, a partir da análise dos planos, que em cada momento histórico estudado foram identificados aspectos críticos e, reconhecidas pelo Estado, relações de causa e efeito que agravam a precariedade das condições de vida nas cidades.

Todas as propostas estudas buscaram especificar objetivos, diretrizes, estratégias e ações para sistematizar como o Estado deveria intervir, tomando como base estudos e diagnósticos que descrevem a gravidade do problema. Contudo, o que se observa nos relatos desses mesmos documentos é a deterioração das condições de vida nas cidades, principalmente nas regiões menos desenvolvidas e nas periferias dos grandes centros, devido a uma estratégia governamental que preconiza a economia de mercado e difere do discurso institucional de combate à pobreza e diminuição das desigualdades.

Tem-se como evidência disso o fato de sempre se reconhecer a necessidade de priorizar as populações de baixa renda nos discursos, sendo, entretanto, a prática voltada às classes média e de renda superior a cinco salários mínimos. O reconhecimento da necessidade de priorização das populações de baixa renda nos discursos oficiais é uma evidência de que não há dúvidas com relação ao público alvo que deveria ser contemplado com maior atenção por parte da ação estatal. Entretanto, a prática vivenciada nas ações e programas estatais está prioritariamente voltada às classes média e de renda superior a cinco salários mínimos que produzem maiores retornos financeiros ao mercado.

Isso mostra que a sistemática da ação estatal está inapropriada, pelo menos sob três aspectos: (i) por atuar de forma fragmentada e setorializada sem considerar o espaço como 
unidade básica de análise; (ii) menosprezo da população que mais requer apoio; (iii) proposição de práticas desalinhadas do discurso institucional.

A necessidade de rompimento com um modelo centralizador e autoritário na condução das políticas urbanas também tem sido apresentada como uma questão central para o aprimoramento da ação estatal com relação à política urbana. A democratização e a descentralização do processo de concepção e de implementação dessas políticas constituem uma mudança essencial no sentido de se pensar em alternativas mais condizentes com as necessidades das populações e para dar abertura e amplitude às lutas encabeçadas pelos movimentos sociais. Acredita-se que assim seria possível fortalecer o combate aos interesses das minorias que historicamente condicionam o processo de tomada de decisão no âmbito das políticas urbanas por conferir representação a diversos segmentos da sociedade que questionam a estrutura vigente.

A partir das reflexões desenvolvidas é possível perceber que, embora no período observado não tenha sido formalizada uma lei para instituir uma política de desenvolvimento urbano no formato mais tradicional que se observa em outros temas, foi construído, ao longo do tempo, um discurso em torno da problemática urbana que condicionou a ação estatal.

Nesse contexto, surgiram conflitos entre forças opostas, onde se situa, de um lado, o discurso institucional, que defende a "estratégia adequada" de combate à problemática urbana, priorizando o público-alvo que se encontra nas condições mais precárias; e, de outro, uma estratégia de desenvolvimento nacional pautada na economia de mercado, que se orienta pelos interesses privados dos diferentes setores e dos atores relacionados. Com isso, a tendência histórica observada é a subordinação do discurso institucional aos interesses privados e econômicos, sucessivamente.

\subsection{As propostas de políticas urbanas em planos nacionais formulados entre} 1987 e 2003

A seguir, serão discutidos outros planos nacionais que foram apresentados para vigorar no período de 1987 a 2001, com exceção do Plano de Ação para o Desenvolvimento Urbano que foi uma iniciativa da Secretaria de Estado de Desenvolvimento Urbano (SEDU) para vigorar no período de 1999 a 2003. Esses Planos 
Nacionais coincidem com as propostas de governo dos respectivos Presidentes da República e tratam do desenvolvimento urbano de forma simplista e superficial:

- Presidente da República José Sarney: Programa de Ação governamental (19871991);

- Presidente da República Fernando Collor: Brasil: Um Projeto de Reconstrução Nacional (1990-1995);

- Presidente da República Fernando Henrique Cardoso ( $1^{\circ}$ governo): Mãos à Obra Brasil (1994-1997);

- Presidente da República Fernando Henrique Cardoso ( $2^{\circ}$ governo): Avança Brasil (1998-2001);

- Plano de Ação para o Desenvolvimento Urbano (1999-2003), no segundo governo de FHC.

Antes de abordar o conteúdo desses documentos, é preciso ressaltar que no final dos anos 80 percebeu-se um movimento de difusão do neoliberalismo que se dispersou no mundo. Esse acontecimento colocou em cheque o modelo de Estado que vinha sendo difundido, dando lugar ao Estado Regulador, influenciando o Estado brasileiro a interromper a formulação de praticamente todas as políticas nacionais, inclusive as urbanas. Por outro lado, em função das discussões promovidas pelos estudiosos do tema, e devido à pressão exercida pelos movimentos sociais, a temática urbana foi inserida na Constituição Federal de 1988 nos Artigos 182 e 183.

Guimarães (2013, p. 192) reconhece que a inserção da temática urbana na $C F / 88$ representou um grande avanço, mas esclarece que os desdobramentos que se apresentam no plano econômico e político se tornaram obstáculos à concretização das ações governamentais no tratamento dessa problemática. Isso explicitou a existência de uma tensão entre o marco legal e a luta política em prol do direito à cidade contra as condições do ideário neoliberal postas à política pública.

Devido à situação de crise físcal do Estado, mesmo a $\mathrm{CF} / 88$ tendo previsto direitos sociais, imputando ao Estado a responsabilidade de um conjunto de ações para resolução de problemas críticos da sociedade, incluindo-se nesse rol a temática urbana, a década de 1990 foi marcada por um vazio institucional e por poucos investimentos estatais. Para 
minimizar os efeitos da situação de precariedade que continuava a se acentuar e a persistir nos grandes centros urbanos nesse período, os governos, em todas as instâncias, investiram em políticas de urbanização de assentamentos precários sem contar com o respaldo de uma política nacional.

Em função disso, os documentos analisados a seguir, não contaram com a mesma ênfase política conferida aos Planos Nacionais de Desenvolvimento elaborados na década de 1970 e o I PND da Nova República. Destaca-se que as propostas contidas nesses documentos tinham como pano de fundo a ideia de um Estado regulador em contraposição ao Estado desenvolvimentista que vigorava nos períodos de amplo desenvolvimento industrial das décadas anteriores.

\section{Presidente da República José Sarney: Programa de Ação governamental (1987-} 1991)

O Programa de Ação Governamental instituído no governo de José Sarney e estava dividido em dez partes focando em uma estratégia de desenvolvimento econômico autosustentado, preocupando-se com as grandes desigualdades sociais existentes e com as profundas disparidades intra-regionais que perduravam até o momento. Tinha um discurso semelhante ao apresentado no I PND-NR, tanto no que diz respeito ao formato do documento em relação às temáticas abordadas, quanto em relação à estruturação (diagnóstico, objetivos e estratégias, metas e programas prioritários).

As políticas regional e de desenvolvimento urbano foram tratadas em partes diferentes do documento, sendo o desenvolvimento urbano abordado, separadamente em três itens: nas diretrizes sociais; no desenvolvimento urbano e no desenvolvimento urbano integrado. Já a proposta de política regional previu ações diferenciadas para cada região do país, buscando ouvir a sociedade em todos os seus segmentos, respeitando diferentes formas de representatividade política. Assim, o Programa deveria privilegiar a regionalização das políticas setoriais e de gasto público, tendo em vista corrigir as desigualdades regionais.

Apontou-se no documento que os programas de desenvolvimento, mesmo os que contemplaram especificamente a questão regional, foram concebidos segundo a ótica setorial. Aspecto que já vinha sendo pontuado no diagnóstico dos planos estudados 
anteriormente, indicando que as realidades regionais e a desarticulação das ações requereu mudança na metodologia proposta até o momento. Sugeriu-se então, no Plano, a adoção de uma abordagem que viabilizasse a integração das ações governamentais, considerando que o desenvolvimento só é possível se conciliar eficiência econômica com a justiça e a equidade social.

Aqui, mais uma vez se repete o padrão de planejar e implementar políticas públicas segundo a ótica setorial e individual de cada uma delas. A única novidade se dá em torno da sugestão de integração das ações governamentais e da ampla participação dos entes federados no planejamento nacional. Também se coloca a necessidade de conciliar economia com justiça social para a promoção do desenvolvimento.

Ora, se o desafio da conciliação entre o crescimento econômico e a justiça social para que de fato o desenvolvimento seja alcançado pela sociedade brasileira já vem sendo mencionado há décadas, inclusive sendo constatado como um dos fracassos do modelo de desenvolvimento praticado desde os primórdios da industrialização no Brasil é de se esperar que sejam feitos questionamentos acerca das causas da perpetuação desse fato.

Sabe-se que o modelo capitalista e a economia de mercado se impõem em praticamente todas as economias do mundo. Contudo, mesmo considerando as diferenças entre o Brasil e os países desenvolvidos, é preciso refletir sobre quais seriam os verdadeiros entraves ao desenvolvimento urbano, pelo menos em relação à consolidação da urbanização em termos de infraestrutura, que outros países alcançaram e o Brasil não. Causa estranhamento perceber o registro desses aspectos nos sucessivos documentos oficiais, os quais constatam causa, efeitos e caminhos para soluções à problemática urbana, e mesmo assim desviarem do foco na sua execução.

Em função disso, supõe-se que as falhas ou dificuldades observadas na elaboração dos planos relativos às diretrizes para as políticas urbanas já praticados até o momento não sejam os principais gargalos a serem superados na efetiva promoção do desenvolvimento urbano. É possível que os maiores desafios estejam associados ao processo decisório, com relação à forma como as ações são implementadas. Também é preciso conhecer o resultado final do equilíbrio de forças e interesses entre os atores que conduzem ou interferem significativamente na etapa de implementação das ações a partir das decisões tomadas. 
É possível que essas interferências associadas aos interesses sejam tão representativas ao ponto de supor que elas sejam as principais "instituições" norteadoras de uma política de desenvolvimento urbano. Supõem-se ainda que essa orientação segundo interesses é o que materializa de fato a política de desenvolvimento urbano que vem sendo conduzida ao longo dos anos. Uma prática diferente dos discursos oficiais, mas que se mantém ao longo do tempo mesmo sem existir uma política formal de desenvolvimento urbano legalmente aprovada.

Nas diretrizes sociais apresentadas no plano, explicitou-se o entendimento de que o estímulo à criação de empregos seria a única forma de consolidar o desenvolvimento econômico e distribuir a riqueza nacional de forma crescente, para um número cada vez maior de brasileiros. Assim, percebe-se que a estratégia governamental para equidade e justiça estava baseada primordialmente no aumento de renda da população, sendo esta uma estratégia fadada ao insucesso por se saber que renda não é o único aspecto que condiciona o nível de desenvolvimento de uma sociedade.

O desenvolvimento urbano é tratado no documento a partir da apresentação de diretrizes para a política de desenvolvimento urbano, além da especificação de orientações para os setores de habitação e saneamento básico em um item específico. As especificações voltadas para o setor de transporte urbano foram apresentadas em item específico da parte que trata da programação e metas dos setores produtivos, sendo abordada de forma mais superficial.

As propostas relativas ao desenvolvimento urbano do Programa seguiram uma apresentação similar ao que foi apresentado no I PND-NR, com exceção da inclusão de um item sobre desenvolvimento urbano integrado. Neste capítulo, afirmou-se que o processo de urbanização exige uma solução global por parte dos diferentes níveis de governo, devendo ser evitadas soluções meramente tópicas e setoriais. O que se apresenta como mais uma contradição do documento, uma vez que já foi visto anteriormente que esse mesmo Programa trata as ações de forma setorial.

Além disso, as propostas de desenvolvimento urbano integrado mencionadas priorizavam o fortalecimento e o desenvolvimento institucional, visando à promoção do 
gerenciamento local das ações setoriais, a articulação entre as diferentes esferas de governo, e a capacitação dos governos locais.

Presidente da República Fernando Collor: Brasil: Um Projeto de Reconstrução Nacional (1990-1995)

O plano seguinte a ser discutido foi apresentado no governo do Presidente Fernando Collor, intitulado "Brasil: um projeto de reconstrução nacional". As orientações relativas aos temas habitação, saneamento básico e transportes, bem como a questão regional, foram tratadas no capítulo III do documento, relativo às prioridades para a reconstrução nacional, sendo os setores de habitação, saneamento e transportes considerados no item de combate à pobreza.

Ressalta-se que o documento tratou dessas temáticas de forma superficial, sem propor intervenções para os setores. Por outro lado, o documento reflete a prevalência da ótica neoliberal que predominava à época, bem como da tendência da União a transferir responsabilidades aos municípios, esquivando-se da responsabilidade de preconizar políticas públicas nacionais. O ideário neoliberal justificou o vazio institucional percebido no período.

Presidente da República Fernando Henrique Cardoso (1 ${ }^{\circ}$ governo): Mão à Obra Brasil (1994-1997)

O Plano "Mãos à Obra Brasil” foi do primeiro governo do Presidente da República Fernando Henrique Cardoso, visava redefinir um projeto de desenvolvimento que pudesse abrir para o Brasil a perspectiva de um futuro melhor e propiciasse uma qualidade de vida decente para o conjunto da sociedade, baseado em um modelo economicamente sustentado (p. 3).

Nesse plano os setores de transportes, habitação e saneamento foram tratados separadamente, sendo o primeiro tema abordado no capítulo relativo à construção de um novo país, no Programa Setorial de Investimentos, enquanto os outros dois foram discutidos no capítulo relativo aos setores complementares. $\mathrm{O}$ setor de transportes recebeu maior deferência que os setores de habitação e saneamento, indicando a principal orientação para concepção do plano. Esse tema contou com a apresentação da problemática 
da época, com as diretrizes do Programa Nacional de Transportes, e com os Principais Projetos para o Programa, de acordo com as peculiaridades de cada região do país.

O mesmo não foi percebido na discussão sobre habitação e saneamento que contaram apenas com algumas diretrizes gerais e com a indicação de possíveis soluções para possibilitar o saneamento do SFH, no caso da ampliação dos investimentos em habitação popular. Foi apresentada uma meta de investimentos em habitação priorizando as populações de baixa renda, contudo, não se fez nenhuma menção aos investimentos para ampliação da cobertura de abastecimento de água e esgotamento sanitário, limitando a discussão do saneamento a diretrizes para melhorar a gestão integrada dos recursos hídricos.

A única explicitação acerca do desenvolvimento urbano foi relativa à estratégia do governo que deveria tratar a habitação no âmbito de uma política de desenvolvimento urbano, mediante a ação conjunta da União, dos estados e dos municípios. Essa estratégia deveria garantir o uso e a ocupação adequada do solo urbano e a função social das cidades. Também se mencionou que os programas habitacionais deveriam integrar-se aos programas de saneamento ambiental, de infraestrutura social e de transportes urbanos.

Presidente da República Fernando Henrique Cardoso (2ºverno): Avança Brasil (1998-2001) e Plano de Ação para o Desenvolvimento Urbano (1999-2003)

Em função de fazerem parte do mesmo governo, os planos "Avança Brasil", do segundo governo de Fernando Henrique Cardoso proposto para o período de 1998 a 2001 e o "Plano de Ação para o Desenvolvimento Urbano" proposto para vigorar durante o período de 1999 a 2003, serão discutidos de forma conjunta.

De todos os planos propostos no período de 1987 a 2003, o Avança Brasil foi o que de fato abordou de forma mais profunda a questão do desenvolvimento urbano. Contudo, por se tratar de um plano de governo, no momento de ser colocado em prática, não mostrou conformidade com o discurso apresentado na proposta. Isso fica evidenciado a partir da análise do texto da proposta de Política de Desenvolvimento Urbano inscrita no Plano de Ação para o Desenvolvimento Urbano.

O discurso do documento Avança Brasil abordava que uma política para as cidades não é uma opção, mas um imperativo para qualquer política social e de combate à miséria, 
indicando que, no Brasil, esse desafio é ainda maior. Aponta que é preciso deixar para trás a carga de atraso e injustiça que onera a história brasileira, limitando suas possibilidades. Para isso, propõe-se que, ao lado da articulação das políticas setoriais de corte tradicional e de primária responsabilidade dos governos (habitação, saneamento e transporte coletivo) a gestão das grandes cidades deverá estar apta a incorporar um conjunto de novos instrumentos de intervenção e mudança baseados na parceria Estado-sociedade (p. 115).

Destaca-se aqui o fato de já estar consolidado em nível governamental o entendimento de que uma política de desenvolvimento urbano, mesmo que aborde outras temáticas, deva estar prioritariamente focada na articulação / integração das políticas setoriais de habitação, saneamento e transportes. Por outro lado, essa abordagem de pensar separado por setores para depois integrar, além de ser um grave erro conceitual, no sentido de limitar a percepção da complexidade inerente à natureza da problemática urbana e, consequentemente, às políticas direcionadas para seu tratamento, possibilita que os interesses setoriais prevaleçam na tomada de decisões no momento de implementação das ações. Acredita-se que essas sejam duas das principais razões de insucesso na condução das políticas urbanas no Brasil nas últimas décadas.

No Plano, faz-se menção a uma proposta de política urbana buscando mostrar caminhos para o alcance dessa dupla tarefa: enfrentar as carências de infraestrutura nas metrópoles, articular o conjunto de políticas públicas mais relevantes e incentivar a arrancada de revitalização da vida econômica, social e cultural das grandes cidades (p. 117). Nesse caso, o ponto de partida seria a integração das políticas nacionais de habitação, saneamento e transporte urbano.

Contudo, em 1999, no segundo governo de Fernando Henrique Cardoso, foi publicado o Plano de Ação para o Desenvolvimento Urbano para vigorar durante o período de 1999 a 2003. O documento foi formulado por uma equipe técnica de especialistas de diferentes segmentos governamentais atuantes na área de desenvolvimento urbano, a partir da análise do diagnóstico das carências urbanas e das estruturas institucional, legal e de financiamento do setor.

A justificativa apontada para a execução desse documento se assentava na necessidade de reverter o tradicional quadro de segmentação institucional do setor, que não 
conseguiu êxito na execução e na implementação de forma integrada de programas, projetos e ações com a qualidade e a eficiência esperados pela sociedade.

O plano abordou a evolução do quadro urbano e da atuação pública nos últimos anos, onde foi apontada a incapacidade econômica e financeira do Estado em arcar com as responsabilidades que lhe foram imputadas. Nesse documento também prevaleceu a ideia de Estado mínimo, indicando que seria necessário estabelecer uma nova matriz institucional e um novo marco regulatório que ampliasse o conjunto de agentes e de instrumentos que pudessem favorecer a superação dos dilemas urbanos contemporâneos (p. 8). Ou seja, estava sendo proposto um aparato institucional para viabilizar a transferência das responsabilidades anteriormente conferidas ao Estado para outros agentes, principalmente aqueles capazes de fazer aporte de recursos financeiros.

No item II do plano foi proposta uma política de desenvolvimento urbano que defendia a doção de ações integradas de planejamento e gestão do uso do solo e relativas aos setores de habitação saneamento e transporte urbano. Também foi apresentado o discurso em torno do Estado contemporâneo, que iria adotar um novo modelo de atuação, baseado na ampliação de parcerias e das fontes de financiamento para a solução das questões urbanas, mediante maior sinergia entre Estado, setor privado e sociedade civil.

Para a aplicação dos recursos foram elencados critérios de focalização das ações, considerando os municípios pertencentes às aglomerações urbanas e aqueles que detinham os menores índices de cobertura dos serviços e a menor renda. Para o alcance do sucesso da política foram propostos três macro-objetivos, além da proposição de uma agenda de ações, que tratava basicamente da consolidação do aparato institucional e normativo; fortalecimento do Estado como agente normativo da ação pública e a busca de melhoria da gestão.

Assim, o documento assumiu muito mais um formato de normativo para disciplinar a participação de outros agentes e atores nos processos de implementação das ações relativas aos setores tradicionais do desenvolvimento urbano (habitação, saneamento e transportes) do que o papel de uma política nacional de desenvolvimento urbano.

Tinha como foco a devida implementação dos preceitos da Nova Gestão Pública, onde o Estado passa a atuar como um gerente, que monitora as ações desenvolvidas pelas 
parcerias público-privadas, seguindo as orientações preconizadas em um acordo de gestão previamente estabelecido. Portanto, embora o documento fizesse menção a uma política de desenvolvimento urbano, esta não se concretizou nem no discurso, corroborando as impressões sobre a década de 1990, onde acaba prevalecendo um vazio institucional e a ausência de políticas nacionais.

Dessa forma, os planos governamentais com orientações sobre as políticas e as temáticas relativas à problemática urbana, produzidos para o período de 1987 a 2003, refletiram o momento histórico da época, onde prevalecia a ideário neoliberal, que preconizava o Estado mínimo e a transferência da prestação de serviços não essenciais para a iniciativa privada. Esse momento foi marcado pela ausência de políticas públicas nacionais e pela predominância de políticas fiscais e monetárias focadas no reequilíbrio financeiro das contas nacionais.

Assim, os planos discutidos nessa parte da tese não tiveram muito a contribuir quanto aos temas que fazem parte do debate da problemática urbana ou que devam integrar o escopo de uma política nacional de desenvolvimento urbano.

\subsection{A política de desenvolvimento urbano do Ministério das Cidades}

A criação do Ministério das Cidades foi fortemente influenciada pelo processo de redemocratização do país, ainda na década de 1980, quando se pressionava o Estado por uma resposta, principalmente por parte dos governos locais, às demandas da população relativas aos problemas urbanos. Naquela época, a urbanização ganhou um espaço importante na agenda política e como nos processos político-eleitorais em nível local e em outras instâncias de poder. Com isso a "agenda de reforma urbana" foi sendo formulada e institucionalizada mediante reformas no ordenamento legal do país e a partir da constituição de espaços de participação popular, como conferências e conselhos como previstos na $\mathrm{CF} / 88$.

Ferreira (2011, p. 45) mostra que na década de 1980, o processo de redemocratização do país possibilitou a retomada do debate sobre a reforma urbana, iniciado em períodos anteriores, quando a problemática urbana passa a ser entendida como resultado do rápido processo de industrialização e urbanização que produziu desigualdades e a segregação sócio-espacial, degradação ambiental e um crescente déficit habitacional. Para a autora, 
esse quadro se mantém ao longo do tempo na medida em que é resultado de um modelo de desenvolvimento fundado na produção das desigualdades. Dessa forma, a luta histórica pela reforma urbana teve como eixos principais:

1. o direito à cidade, compreendendo a garantia dos direitos básicos a toda a população: o direito à moradia digna, ao saneamento ambiental, ao transporte, à mobilidade, ao trabalho, ao lazer e à cultura;

2. a gestão democrática da cidade, entendida como a forma de planejar, produzir, operar e governar as cidades submetidas ao controle social e à participação da sociedade civil organizada;

3. a função social da cidade e da propriedade, entendida como a prevalência do interesse comum sobre o direito individual de propriedade.

De acordo com Santos Júnior (2009) um olhar sobre as políticas urbanas no Brasil envolvendo as políticas de habitação, regularização fundiária, saneamento ambiental, transporte e mobilidade - não deixa dúvidas a respeito das significativas transformações que estas vem passando nos últimos anos. Tais mudanças parecem caminhar em duas direções: primeiro, na direção do aprofundamento do processo de descentralização, iniciado com a reforma constitucional de 1988; segundo, na adoção de uma agenda de reformas sociais, identificada como agenda da reforma urbana.

Para o autor essas mudanças, sob a perspectiva histórica, são conquistas do movimento brasileiro pela reforma urbana que, desde os anos 1980 vem propondo uma agenda centrada: (a) na institucionalização da gestão democrática das cidades; (b) na municipalização da política urbana; (c) na regulação pública do solo urbano com base no princípio da função social da propriedade imobiliária e (d) na inversão de propriedade no tocante à política de investimentos urbanos.

Percebe-se então, que a pauta das reivindicações do movimento de reforma urbana buscava exatamente combater ou criar mecanismo que, de alguma forma, pudessem modificar o modelo de desenvolvimento excludente e desigual que vinha sendo produzido ao longo do tempo. Buscava-se encontrar uma maneira de limitar a sobreposição dos interesses privados relativos aos setores produtivos e de serviços que tinham interface com 
a temática urbana, tendo em vista priorizar as necessidades das populações que viviam em situação de precariedade e vulnerabilidade social.

Assim, as principais conquistas institucionais que nasceram das lutas do movimento de reforma urbana foram: a aprovação do Estatuto das Cidades (Lei $\left.n^{\circ} 10.257\right)$ a partir de uma iniciativa popular em 2001; a criação do Ministério das Cidades em 2003 (estruturado em quatro Secretarias Nacionais: Programas Urbanos, Habitação, Saneamento e Mobilidade Urbana); e a implantação do Conselho das Cidades em 2003. Esses marcos legais, juntamente com as Conferências Nacionais das Cidades passaram a orientar as ações relativas à política urbana desenvolvida pelo Ministério das Cidades.

A seguir, serão discutidas as políticas urbanas que foram preconizadas para orientar a ação do Ministério das Cidades visando melhores condições de vida no meio urbano. Para tanto, é preciso reconhecer a transição entre três períodos, em função da sucessão dos normativos e programas governamentais que vigoraram entre 2003 e 2015 :

- Cadernos MCidades;

- Políticas setoriais de Habitação, Saneamento e Mobilidade Urbana;

- Programa de Aceleração do Crescimento (PAC) e Programa Minha Casa, Minha Vida (PMCMV).

\section{Cadernos MCidades}

Para fins didáticos também será considerado como um marco institucional da política urbana brasileira, na época de criação do Ministério, a publicação do conjunto dos oito volumes de Cadernos MCidades publicados em 2004. Nessas publicações foram apresentados os princípios, as diretrizes e as propostas estruturantes para uma política nacional de desenvolvimento urbano, que seria implementada, provisoriamente, pelo órgão, enquanto uma PNDU era produzida no âmbito do Conselho das Cidades, a partir de um processo democrático e participativo.

Naquela época, buscava-se conceber e implementar a política de desenvolvimento urbano se contrapondo ao formato tecnocrático e centralizador experimentado nas décadas de 1970 e 1980. E enquanto essa pretensa PNDU não se concretizava, a atuação do órgão 
deveria estar norteada segundo as propostas estruturantes especificadas na referida publicação dos Cadernos MCidades.

Nesse documento, o desenvolvimento urbano é entendido como:

“(...) a melhoria das condições materiais e subjetivas da vida nas cidades, com diminuição da desigualdade e garantia de sustentabilidade ambiental, social $e$ econômica. Ao lado da dimensão quantitativa da infraestrutura, dos serviços e dos equipamentos urbanos, o desenvolvimento urbano envolve também uma ampliação da expressão social, cultural e política do indivíduo e da coletividade, em contraponto aos preconceitos, à segregação, a discriminação, ao clientelismo e à cooptação. $O$ objetivo de uma política de desenvolvimento urbano é o espaço socialmente construído " (MCIDADES, 2004a, p. 8).

O entendimento de desenvolvimento urbano apresentado nessa publicação insere no discurso a garantia da sustentabilidade ambiental e social mesmo que se busque o crescimento econômico, o qual vem sendo a base de sustentação do modelo de desenvolvimento praticado no Brasil há muitas décadas. Também se destaca que, ao lado da dimensão quantitativa, que é representada pela execução de obras, o desenvolvimento urbano também traz uma dimensão social e intangível que determina o modo de vida das cidades. Por fim, ao especificar que o objetivo de uma política de desenvolvimento urbano é o espaço socialmente construído, dá ênfase à participação da sociedade na construção dos espaços urbano, buscando superar a lógica da sobreposição dos interesses de uma pequena minoria sobre as reais necessidades da sociedade.

A série de publicações, denominada Cadernos MCidades foi apresentada como mais uma etapa da construção da política de desenvolvimento, visando promover o debate das políticas e das propostas formuladas. Para tanto, no documento (p. 8) foi adotado o recorte em torno de temas considerados estruturadores do espaço urbano e de maior impacto na vida da população, sendo eles: habitação; saneamento ambiental; mobilidade urbana; trânsito; e mais dois temas estratégicos, política fundiária / imobiliária e política de capacitação / informação.

Além dessas publicações, também são considerados como marcos orientadores da ação do Ministério das Cidades, as políticas nacionais de habitação (2004), saneamento (2007) e mobilidade urbana (2012), que foram publicadas posteriormente e passaram a orientar os programas e ações de cada setor. 
Na Apresentação do Volume 1 dos Cadernos MCidades, Política Nacional de Desenvolvimento Urbano, ficou estabelecido um grande pacto de construção da Política Nacional de Desenvolvimento Urbano - PNDU, pautado na ação democrática, descentralizada e com participação popular, visando à coordenação e a integração dos investimentos e ações, por meio da discussão ocorrida nas Conferências das Cidades.

No Volume 1 (BRASIL, 2004a, p. 55) foram estabelecidas as Propostas Estruturantes da PNDU que deveria ser implementada provisoriamente, destacando que o Ministério das Cidades atuaria segundo a organização por setores (programas urbanos, habitação, saneamento, mobilidade urbana), em função de cada um deles ter suas peculiaridades. Também foi evidenciado no documento que as políticas setoriais de competência do MCidades são indispensáveis e podem ser estruturantes do desenvolvimento urbano, principalmente quando estiverem integradas a uma Política Nacional de Desenvolvimento Urbano.

Quanto a isso, Caldas (2015) analisa que:

"É inegável que políticas como habitação, saneamento ambiental, mobilidade urbana, política fundiária/imobiliária sejam estruturantes do ambiente urbano, pois, de um modo geral, são profundamente determinantes das condições de vida no seu sentido mais elementar, interferindo diretamente na saúde, salubridade e segurança dos cidadãos. No entanto, ao limitar-se a temas setoriais, a PNDU mostra-se contraditória com o seu próprio pressuposto, que reconhece que o direito à cidade extrapola as condições materiais da infraestrutura para incorporar a visão de que o cidadão tem direito a usufruir plenamente de sua condição de cidadania, ampliando sua expressão cultural e exercendo sua expressão política no sentido mais amplo" (CALDAS, 2015, p. 65).

Assim, a despeito de todos os avanços alcançados com a democratização e com a criação de instâncias de participação social no processe de discussão da política de desenvolvimento urbano, o viés setorial continua a ser um desafio a ser enfrentado.

As cinco frentes de atuação que constam nas Propostas Estruturantes para a PNDU segundo os Cadernos MCidades preconizavam os seguintes objetivos:

1. Implementação dos Instrumentos Fundiários do Estatuto da Cidade: estimular municípios a novas práticas democráticas e participativas de gestão e planejamento territorial; enfrentar o tema da irregularidade urbana por meio da construção de 
marco jurídico; operar política inovadora na prevenção e remoção do risco de escorregamento em encostas em assentamentos precários; contrapor o modelo de expansão permanente de fronteiras e periferização dos mais pobres e subutilização de áreas consolidadas;

2. Política Nacional de Habitação (PNH): garantir à população, especialmente a de baixa renda, o acesso à habitação digna; construção de uma política e de programas com foco na integração urbana dos assentamentos precários; Ampliar o estoque de moradias, gerando uma redução no déficit e atendimento da demanda demográfica; Estimular os municípios e apoiá-los para desenvolverem ações relativas ao: planejamento urbano, à regulação do uso do solo, e a gestão urbana participativa;

3. Promoção da Mobilidade Urbana Sustentável e Cidadania no Trânsito: promover a mobilidade urbana sustentável, de forma universal à população urbana brasileira, promovendo ações articuladas entre a União, estados, o Distrito Federal e os municípios, com a participação da sociedade; estabelecer diretrizes de transporte para os serviços públicos de transporte coletivo e para mobilidade urbana em geral; estabelecer novos paradigmas regulatórios, organizacionais e institucionais; apoio à elaboração de projetos; financiamento para projetos e obras de transporte; fomentar a execução de Plano de Transporte nas Regiões Metropolitanas; propor medidas com vistas à redução dos insumos que compõem a tarifa do transporte coletivo; criação da Câmara Interministerial de Trânsito, do Fórum Consultivo do Sistema Nacional de Trânsito e atribuição ao Ministério das Cidades para coordenação do Sistema Nacional de Trânsito;

4. Novo Marco Legal para Saneamento Ambiental: instituir a Política Nacional de Saneamento Ambiental por lei; melhorar e expandir os serviços de abastecimento de água e esgoto para moradores de baixa renda nas cidades que têm entre 15 mil e 75 mil habitantes; implantar sistemas integrados de saneamento em sedes municipais e distritais, vilas e povoados em municípios com até 20 mil habitantes, localizados no semiárido brasileiro; ampliar a cobertura e melhorar a qualidade dos serviços de saneamento ambiental no território brasileiro; treinamento e capacitação de profissionais; apoiar ações de infraestrutura urbana em municípios de portes diferenciados; conjugar ações estruturantes de gestão integrada de resíduos sólidos; promover, em articulação com as demais políticas de 
desenvolvimento urbano, de uso e ocupação do solo e de recursos hídricos, uma gestão sustentável de drenagem urbana; promover o uso racional e a conservação da água de abastecimento público; fomento à racionalização do uso da água e energia elétrica em saneamento; aprimoramento do Sistema Nacional de Informações sobre Saneamento - SNIS;

5. Capacitar e Informar as Cidades: promover, coordenar a apoiar programas e ações voltados para a capacitação de agentes públicos e sociais visando apoiar o desenvolvimento institucional do setor público municipal e estadual; garantir acesso a informações organizadas e confiáveis referentes às áreas de atuação do Ministério das Cidades para o público interno e externo.

Quadro 1- Propostas Estruturantes para a PNDU segundo os Cadernos MCidades

\begin{tabular}{|c|c|}
\hline Temas & Programas \\
\hline \multirow{4}{*}{$\begin{array}{l}\text { 1. Implementação dos Instrumentos } \\
\text { Fundiários do Estatuto da Cidade }\end{array}$} & Política de Apoio à Elaboração e revisão dos Planos Diretores \\
\hline & $\begin{array}{l}\text { Política Nacional de Apoio à Regularização Fundiária } \\
\text { Sustentável }\end{array}$ \\
\hline & $\begin{array}{l}\text { Política Nacional de Prevenção de Risco em Assentamentos } \\
\text { Precários }\end{array}$ \\
\hline & Política Nacional de Apoio à Reabilitação de Centros Urbanos \\
\hline \multirow{4}{*}{$\begin{array}{l}\text { 2. Política Nacional de Habitação } \\
\text { (PNH) }\end{array}$} & Política Nacional de Habitação (PNH) \\
\hline & Integração Urbana de Assentamentos Precários \\
\hline & Provisão da Habitação \\
\hline & $\begin{array}{lllllll}\text { Integração da Política de } & \text { Habitação à Política de } \\
\text { Desenvolvimento Urbano } & & & & & \\
\end{array}$ \\
\hline \multirow{7}{*}{$\begin{array}{l}\text { 3. Promoção da Mobilidade Urbana } \\
\text { Sustentável e Cidadania no Trânsito }\end{array}$} & Política Nacional de Mobilidade Urbana \\
\hline & Lei de Diretrizes para Transportes Urbanos \\
\hline & Reforma regulatória no Transporte público Urbano \\
\hline & Financiamento de Infraestrutura para a Mobilidade e Transporte \\
\hline & Financiamento de Infraestrutura para a Mobilidade e Transporte \\
\hline & $\begin{array}{l}\text { Grupo de Trabalho para Barateamento de Tarifas de Transporte } \\
\text { Público }\end{array}$ \\
\hline & Reestruturação do Sistema Nacional de Trânsito \\
\hline \multirow{3}{*}{$\begin{array}{l}\text { 4. Novo Marco Legal para } \\
\text { Saneamento Ambiental }\end{array}$} & Política Nacional de Saneamento Ambiental \\
\hline & $\begin{array}{l}\text { Programas de Financiamento para Implantação do Saneamento } \\
\text { Ambiental }\end{array}$ \\
\hline & $\begin{array}{l}\text { Apoio aos Entes Federados para Estudos, Projetos, Planos e } \\
\text { Infraestrutura }\end{array}$ \\
\hline 5. Capacitar e Informar as Cidades & Apoio aos Entes Federados \\
\hline
\end{tabular}

Fonte: Cadernos MCidades, (2004a). 
Como apresentado no Quadro 1, as Propostas Estruturantes para a condução da PNDU provisória pelo MCidades (2004a), podem ser agrupadas segundo os seguintes temas: (1) Implementação dos Instrumentos Fundiários; (2) Política Nacional de Habitação; (3) Mobilidade Sustentável e Cidadania no Trânsito; (4) Novo Marco Legal para o Saneamento Ambiental; e (5) Capacitação e Informação para as Cidades.

Enquanto as diretrizes preconizadas nos Cadernos orientavam a condução das ações no âmbito das Secretarias Nacionais do Ministério, o Conselho das Cidades deu início às suas atividades, visando à concepção da PNDU. Até o momento já foram realizadas cinco

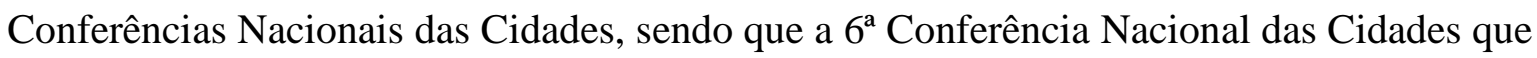
estava prevista para acontecer no período de 5 a 9 de junho de 2017, com o tema Função Social da Cidade e da Propriedade, não ocorreu.

A $1^{\text {a }}$ Conferência Nacional das Cidades foi realizada em 2003 e teve como resultado a estipulação de parâmetros para uma Política de Desenvolvimento Urbano com propostas de integração das políticas setoriais, dos princípios para a construção do Direito à Cidade, do cumprimento da função social da cidade e da propriedade, combate à segregação sócioespacial, acesso universal à moradia digna, ao saneamento básico, ao transporte público e acessibilidade, gestão descentralizada e democrática, acesso à informação, participação social na formulação, decisão, implementação e avaliação da Política Nacional de Desenvolvimento urbano.

$\mathrm{Na} 2^{\mathrm{a}}$ Conferência Nacional das Cidades realizada em 2005 foi aprovado o princípio da gestão democrática, da participação e do controle social como uma das diretrizes da política de planejamento urbano. Ainda foi aprovada a estruturação e os instrumentos da política regional e metropolitana.

Já na $3^{\text {a }}$ Conferência Nacional das Cidades realizada em 2007, os temas considerados fundamentais foram os de avançar na construção da Política Nacional de Desenvolvimento Urbano, construir o Sistema Nacional de Desenvolvimento Urbano e a criação de uma Política de Regularização Fundiária e de uma Política de Prevenção e Mediação de Conflitos Fundiários Urbanos.

$\mathrm{Na} 4^{\mathrm{a}}$ Conferência realizada em 2010, foi realizado um balanço das conquistas e dos desafios ocorridos ao longo do processo de construção da Política Nacional de 
Desenvolvimento Urbano, enquanto na $5^{\text {a }}$ Conferência das Cidades realizada em 2013, buscou-se discutir estratégias para transformar o Sistema Nacional de Desenvolvimento Urbano (SNDU) em Lei e colocá-lo em funcionamento.

No texto base da $5^{\text {a }}$ Conferência das Cidades, realizada em 2013, destacou-se que, para a reversão do quadro de privações observado nas cidades, era preciso que a coordenação das ações governamentais assumisse a política urbana como uma política estratégica para o país. Isso requer que se promova a universalização do acesso às políticas urbanas e se supere a cultura de fragmentação da gestão, que separa a política de habitação da política de saneamento ambiental e da política de mobilidade urbana, gerando ineficiência e a reprodução das desigualdades sócio-espaciais. Nesse evento, apontou-se o Sistema de Desenvolvimento Urbano (SNDU) como o principal instrumento para a reversão desse quadro, visto que a sua criação parte da necessidade de se coordenar as ações governamentais relacionadas às políticas urbanas de forma a universalizar o direito à cidade.

Embora tenham ocorrido cinco Conferências Nacionais das Cidades com o intuito de elaborar uma Política Nacional de Desenvolvimento Urbano e instituir um Sistema Nacional de Desenvolvimento Urbano para fortalecer a participação social e democratizar o processo de execução da PNDU, são observadas limitações a esse processo participativo, visto que o Conselho das Cidades não é uma instância deliberativa com relação à definição do formato das ações implementadas por cada Secretaria Nacional, nem acerca da aplicação dos investimentos realizados pelo Ministério.

Também se percebe que o trabalho desenvolvido no âmbito do Conselho das Cidades não interfere nos rumos que a PNDU vem tomando, indicando que houve um desvirtuamento da estratégia inicial do momento de criação do MCidades. A proposta inicial de ter uma PNDU provisória para orientar as ações enquanto a PNDU definitiva era discutida e aprimorada no âmbito do Conselho das Cidades não se concretizou ao longo do tempo.

É verdade que na $5^{\text {a }}$ Conferência tentou-se discutir maneiras de legalizar e institucionalizar o SNDU como a alternativa oficial do Ministério na condução da política urbana. Contudo, não foram alcançados resultados concretos em relação a isso. Existem 
interesses implícitos que impedem que um instrumento no formato do SNDU seja efetivado e modifique a lógica habitual de condução das políticas setoriais. Além disso, não se pode afirmar que a proposta de um SNDU nos moldes do que foi proposto no Conselho seja a solução mais adequada para todos os problemas relacionados à política urbana brasileira.

O que se percebe ao analisar a trajetória do MCidades é que, ao longo do tempo, foi sendo conferida prioridade aos investimentos em infraestrutura urbana, que se transformaram, posteriormente, em programas de grande porte. Esses programas retomaram, de forma significativa, os investimentos federais nas políticas setoriais consideradas prioritárias, sendo conferida prioridade política. Dessa forma, as políticas setoriais desenvolvidas pelo MCidades passaram a ser orientadas segundo as diretrizes e os objetivos do Programa de Aceleração do Crescimento (PAC) e do Programa Minha Casa, Minha Vida (PMCMV), contrapondo, inclusive as propostas contidas para cada setor nas suas respectivas políticas nacionais já publicadas.

Assim, cada um dos setores coordenados pelo Ministério das Cidades, os quais deveriam ser orientados provisoriamente pela PNDU estruturada em 2004 nos Cadernos MCidades, foram amadurecendo e se consolidando, cada um segundo sua lógica e interesses internos, distanciando-se, cada vez mais, da proposta inicial de criação do órgão. A despeito disso, foi mantida a histórica hierarquização que sempre houve entre os setores, em termos de estruturação do aparato institucional e da disponibilidade de recursos. As melhores condições sempre foram atribuídas à Secretaria de Habitação, depois à Secretaria de Saneamento, seguida pela Secretaria de Mobilidade Urbana e, por último, à Secretaria de Programas Urbanos, seguindo os mesmos moldes do que já se apresentava no BNH.

\section{Políticas setoriais de habitação, saneamento e mobilidade urbana}

No setor habitacional, um novo aparato institucional surge com a Política Nacional de Habitação (PNH), Lei no 11.124, instituída pelo Ministério das Cidades em 2004, que apresentava vários instrumentos criados para viabilizar sua implantação e efetividade. Dentre esses instrumentos têm destaque o Sistema Nacional de Habitação (SNH), o Desenvolvimento Institucional, o Sistema de Informação, Avaliação e Monitoramento da Habitação e o Plano Nacional de Habitação, todos conduzidos pela Secretaria Nacional de Habitação. 
No SNH foram previstos dois segmentos para viabilizar a implementação da Política Nacional de Habitação. O primeiro deles foi o Subsistema de Habitação de Interesse Social (SHIS), composto por fundos públicos, para atender à demanda da população de baixa renda. O segundo foi o Subsistema de Habitação de Mercado (SHM), composto por recursos do Sistema Brasileiro de Poupança e Empréstimo (SBPE) e pelo Sistema Financeiro Imobiliário (SFI), com ênfase na ampliação do fomento à habitação para a iniciativa privada, destinado a atender a demanda da população de classe média.

Em 2007, o setor saneamento, já sob a gestão da Secretaria Nacional de Saneamento Ambiental, vivenciou uma sucessão de grandes mudanças iniciadas com a promulgação da Lei $\mathrm{n}^{\circ} 11.445$, que dispõe sobre as diretrizes nacionais e a política federal de saneamento básico. Com isso, o setor passou a ser regulamentado em nível nacional, equacionando a ausência de um quadro normativo e criando as condições para um novo ambiente políticoinstitucional.

Dessa forma, foi possível contar com um arcabouço jurídico-legal que possibilitaria a sustentação de investimentos de forma permanente para propiciar a universalização do acesso e a melhoria da qualidade dos serviços de saneamento básico, além de algumas medidas voltadas para a qualificação do gasto público. Tinha-se como destaque a adoção de processo de seleção pública de propostas e o atendimento a requisitos técnicos e institucionais como condição aos proponentes para o acesso aos recursos geridos pela União.

Conforme a Lei $\mathrm{n}^{\mathrm{o}}$ 11.445/2007, o Plano Nacional de Saneamento Básico deve abranger o abastecimento de água, o esgotamento sanitário, o manejo de resíduos sólidos e o manejo de águas pluviais e outras ações de saneamento básico de interesse para a melhoria da salubridade ambiental, incluindo o provimento de banheiros e unidades hidrossanitárias para populações de baixa renda.

Com essa Lei, institui-se também o Sistema Nacional de Informações em Saneamento Básico - SINISA, que incorporou o Sistema Nacional de Informações em Saneamento (SNIS). As informações do SINISA são públicas e acessíveis a todos, devendo ser publicadas na internet. Dentre seus objetivos, destacam-se: 
(i) coletar e sistematizar dados relativos às condições da prestação dos serviços públicos de saneamento básico;

(ii) disponibilizar estatísticas, indicadores e outras informações relevantes para a caracterização da demanda e da oferta de serviços públicos de saneamento básico;

(iii) permitir e facilitar o monitoramento e avaliação da eficiência e da eficácia da prestação dos serviços de saneamento básico.

O Plano Nacional de Saneamento Básico (PNSB), denominado PLANSAB é um dos instrumentos definidos na Lei 11.445 e foi publicado em 6 de dezembro de 2013, por meio da Portaria Interministerial $\mathrm{n}^{\circ} 571$ visando estabelecer diretrizes, metas e ações de saneamento básico no país para o período de 2014 a 2033.

O Plansab também destaca o conceito de intersetorialidade, partindo de dois pressupostos: i) a concepção do setor de saneamento básico como campo político, estruturado pelos agentes que nele atuam e os interesses que defendem nas arenas de deliberação e de gestão; ii) a afirmação da política pública de saneamento básico como estruturadora da cidade, que revela a sua corresponsabilidade na dinâmica de valorização do solo urbano e sua incidência na dinâmica de segregação urbana e social, implicando, portanto, sobre a mais valia urbana e como o saneamento (não) captura parte dessa valorização (MCIDADES, 2013).

Segundo o MCidades, nessa perspectiva, a intersetorialidade requisita uma articulação estrutural do saneamento básico com as demais políticas públicas de interfaces mais evidentes, como a gestão de recursos hídricos, o meio ambiente, a política urbana e a de saúde. Isso significa analisar os desafios e as potencialidades da intersetorialidade sob três dimensões: a normativa, a institucional e a territorial.

A dimensão normativa diz respeito às normas que regem cada política pública e que podem dificultar ou impedir o exercício da intersetorialidade. A dimensão institucional diz respeito à própria composição política do campo, ou seja, como os agentes que se movem e se organizam em torno de cada área, e os interesses que defendem, cristalizam a política praticada no setor. 
A análise dessas duas dimensões deixa claro que a promoção da intersetorialidade implica o enfrentamento dessa disputa política, inclusive quanto ao financiamento. Para isso, faz-se necessária a criação de mecanismos institucionais capazes de reduzir o poder de veto dos agentes que atuam no sentido de manter o status quo da setorialização. Na dimensão territorial, a questão central é como se define a escala de intervenção. E para isso não se tem resposta pronta.

Na visão do Plansab, não se devem adotar definições rígidas e dogmáticas nessa escolha, como apenas a bacia ou apenas o município, entre outros recortes. Trabalha-se com a hipótese de que a escala pode ser construída a partir do problema e do tipo de ação que reivindica. Essa concepção abarca, além da referência territorial, a percepção social dos agentes sobre o problema e a própria organização dos demais serviços que o tangenciam. Assim, identificam-se desafios e potencialidades referentes à construção da intersetorialidade:

- necessidade de fortalecer o MCidades, como instância formuladora de políticas públicas no nível federal, e efetivamente como coordenador da política de saneamento básico, de modo a superar e minimizar a pulverização e o conflito de competências entre diversas instituições governamentais e o repasse de recursos sem aderência à política do setor;

- capacidade de enfrentar a baixa articulação ainda existente entre os quatro componentes do saneamento básico, inclusive explorando, no processo de planejamento, a integração estimulada pela legislação referente aos resíduos sólidos, bem como entre o setor e a política de desenvolvimento urbano;

- $\quad$ administrar a multiplicação de instâncias de participação específicas a cada setor que não interagem e que demandam grande esforço dos movimentos sociais no sentido de ocupar esses espaços de forma autônoma e qualificada;

- $\quad$ superar a cisão de linguagem, a visão setorial e a resiliência das organizações e processos que dificultam o diálogo entre os saberes e a aplicação de um conjunto vasto de instrumentos legais e jurídicos que estão à disposição para serem incorporados ao cotidiano da gestão das cidades;

- $\quad$ enquanto se constrói algo mais sistêmico e institucionalizado no nível federal, aproveitar o Plansab como uma oportunidade para revitalizar os espaços 
existentes como o ConCidades, as Conferências das Cidades, a Comissão Intersetorial de Saneamento e Meio Ambiente (Cisama) e os conselhos nacionais como o CNS, o CNRH e o Conama como instâncias institucionalizadas para o exercício da intersetorialidade.

A partir da publicação da Lei $\mathrm{n}^{\circ} 12.587$ de 2012, apresentou-se a proposta de um novo conceito de mobilidade urbana, e, embora a lei tenha sido aprovada apenas em 2012, as discussões que orientavam um novo discurso já vinham norteando as ações setoriais juntamente com habitação e saneamento. Esse marco institucional foi considerado um avanço por modificar a maneira tradicional de tratar, isoladamente, o trânsito, o planejamento e a regulação do transporte coletivo, a logística de distribuição das mercadorias, a construção da infraestrutura.

A orientação atual proposta na Política Nacional de Mobilidade Urbana consiste em adotar uma visão sistêmica sobre a movimentação de bens e de pessoas, envolvendo todos os modos e todos os elementos que produzem as necessidades desses deslocamentos. Desse modo, para a elaboração dos Planos de Mobilidade, que são o principal instrumento de planejamento instituído pela Política Nacional, foram definidos dez princípios para o planejamento da mobilidade, considerando sua relação com o planejamento urbano:

1. diminuir a necessidade de viagens motorizadas, posicionando melhor os equipamentos sociais, descentralizando os serviços públicos, ocupando os vazios urbanos, favorecendo a multi-centralidade, como formas de aproximar as oportunidades de trabalho e a oferta de serviços dos locais de moradia;

2. repensar o desenho urbano, planejando o sistema viário como suporte da política de mobilidade, com prioridade para a segurança e a qualidade de vida dos moradores em detrimento da fluidez do tráfego de veículos;

3. repensar a circulação de veículos, priorizando os meios não motorizados e de transporte coletivo nos planos e projetos, considerando que a maioria das pessoas utiliza estes modos para seus deslocamentos e não o transporte individual;

4. desenvolver os meios não motorizados de transporte, passando a valorizar a bicicleta como um meio de transporte importante, integrado-a com os modos de transporte coletivo; 
5. reconhecer a importância do deslocamento dos pedestres, valorizando o caminhar como um modo de transporte para a realização de viagens curtas e incorporando definitivamente a calçada como parte da via pública, com tratamento específico;

6. reduzir os impactos ambientais da mobilidade urbana, uma vez que toda viagem motorizada que usa combustível, produz poluição sonora, atmosférica e resíduos;

7. propiciar mobilidade às pessoas com deficiência e restrição de mobilidade, permitindo o acesso dessas pessoas à cidade e aos serviços urbanos;

8. priorizar o transporte público coletivo no sistema viário, racionalizando os sistemas, ampliando sua participação na distribuição das viagens e reduzindo seus custos, bem como desestimular o uso do transporte individual;

9. promover a integração dos diversos modos de transporte, considerando a demanda, as características da cidade e a redução das externalidades negativas do sistema de mobilidade;

10. estruturar a gestão local, fortalecendo o papel regulador dos órgãos públicos gestores dos serviços de transporte público e de trânsito.

\section{Programa de Aceleração do Crescimento (PAC) e Programa Minha Casa, Minha Vida (PMCMV)}

As orientações para os setores de habitação e de saneamento passaram a divergir das diretrizes preconizadas nas suas respectivas políticas nacionais a partir da instituição do Programa de Aceleração do Crescimento (PAC), que foi criado em 28 de janeiro de 2007, visando estimular o crescimento da economia brasileira, focado no investimento em obras de infraestrutura até o ano de 2010.

Buscava-se com esse Programa superar os gargalos de infraestrutura do país, mediante planejamento estratégico de médio e longo prazos, o fortalecimento da regulação e da competitividade, a adequação dos instrumentos financeiros às perspectivas de longo prazo, parcerias entre o setor público e o investidor privado e articulação entre os entes federativos (BRASIL, 2007).

O Programa foi pensado com uma previsão de investimento de $\mathrm{R} \$ 503$ bilhões, para o período 2007-2010, nas áreas de transporte, energia, saneamento, habitação e recursos 
hídricos. No final do ano de 2008, foi anunciado o aumento do montante de recursos destinado ao PAC que passou a ser de R $\$ 656,5$ bilhões (BRASIL, 2007).

Com o investimento em infraestrutura, o objetivo do governo era eliminar os principais gargalos que impediam o crescimento econômico, viabilizando o aumento da produtividade das empresas, além do estímulo ao investimento privado e à redução das desigualdades regionais. O PAC, além de prever obras de infraestrutura, também envolveu a proposição de medidas de caráter econômico, visando manter a estabilidade econômica e o cumprimento dos acordos internacionais assinados ainda na década anterior.

As ações e metas do PAC foram organizadas em um amplo conjunto de investimentos em infraestrutura associado a um grupo de medidas de incentivo e facilitação do investimento privado. Uma de suas estratégias foi a realização de parcerias entre o setor público e o investidor privado, somadas a uma articulação constante entre os entes federativos. Assim o Programa buscava alcançar o desenvolvimento com enfoque em três eixos:

- Infraestrutura Logística: envolvendo a construção e ampliação de rodovias, ferrovias, portos, aeroportos e hidrovias;

- Infraestrutura Energética: correspondendo a geração e transmissão de energia elétrica; produção, exploração e transporte de petróleo; gás natural e combustíveis renováveis;

- Infraestrutura Social Urbana: englobando saneamento, a universalização do programa Luz Para Todos, habitação, metrôs, trens urbanos e infraestrutura hídrica.

Os objetivos do programa, declarados em seu lançamento, foram o incentivo ao investimento privado, o aumento do investimento público em infraestrutura e a remoção de obstáculos (burocráticos, administrativos, normativos, jurídicos e legislativos) ao crescimento (BRASIL, 2007). Assim, tinha como principal objetivo a promoção do crescimento de maneira mais célere e sustentada, com distribuição de renda, tanto no âmbito social como no regional. Para tanto, além de incentivar o investimento privado, propunha um conjunto de projetos de investimento público e diversas formas de Parcerias Público-Privadas (PPPs). 
Verifica-se aqui a repetição no padrão de estratégia de desenvolvimento, percebendose similaridades com as propostas apresentadas nos PNDs produzidos nos anos 1970 e 1980. Mais uma vez é dado o enfoque no viés econômico em detrimento das diretrizes e dos objetivos das políticas nacionais de habitação e saneamento que já estavam publicadas, as quais contituíram uma base institucional para nortear as ações relativas a esses temas.

Essa situação se acentuou ainda mais com a criação do Programa Minha Casa Minha Vida (PMCMV), anunciado no dia 25 de março de 2009 com foco específico no financiamento do setor de habitação. Para isso, foi previsto o investimento de R $\$ 34$ bilhões para a construção de 1 milhão de moradias. O PMCMV foi instituído pela Lei $\mathrm{n}^{\circ}$ 11.977, de 7 de Julho de 2009, sendo estruturado por dois programas: (i) Programa Nacional de Habitação Urbana (PNHU) e (ii) Programa Nacional de Habitação Rural (PNHR).

A segunda fase do PMCMV foi formalizada pela Medida Provisória $\mathrm{n}^{\circ}$ 514/2010, convertida na Lei $\mathrm{n}^{\mathrm{o}}$ 12.424, de 16 de junho de 2011, que estabeleceu novas diretrizes e metas para o programa habitacional. Estabeleceu como principal meta o financiamento da construção de dois milhões de residências no país até o ano de 2014, sendo $60 \%$ delas direcionadas a famílias com renda mensal de até $\mathrm{R} \$ 1.600,00$, com um investimento de $\mathrm{R} \$$ 71,7 bilhões. Como diretrizes, destacam-se a redução do déficit habitacional, a distribuição de renda e inclusão social; e a dinamização do setor da construção civil, além da geração de trabalho e renda.

Em 2011 foi lançada a segunda fase do Programa de Aceleração do Crescimento, o PAC 2, com os mesmos objetivos do anterior. Teve novo aporte de recursos, aumentando a parceria com estados e municípios, durante o período entre os anos de 2011 e 2014. Esses investimentos têm sido de fundamental importância para aumentar o nível de emprego no país, melhorar a oferta de infraestrutura e garantir o desenvolvimento econômico em todas as regiões do Brasil.

Esses Programas foram concebidos como instrumentos anticíclicos para reagir à crise econômica mundial de 2008, sendo concebidos como programas de governo e desfrutando de forte influência política. Além da ampliação dos recursos para investimentos nos setores de habitação, saneamento e mobilidade urbana, a criação do PAC e do PMCMV também 
contou com profundas mudanças na gestão e na operacionalização das ações. Um exemplo disso é que o Decreto $n^{\circ}$ 6.025/2007, que institui o PAC delega ao seu Comitê Gestor, o CGPAC, amplos poderes para "discriminar as medidas integrantes do PAC". Também delega para o Grupo Executivo de Acompanhamento do PAC (GEPAC), a competência de consolidar as ações, estabelecer as metas e acompanhar os resultados de implementação e execução do programa. O Comitê de Acompanhamento do PMCMV tem a competência de acompanhar e avaliar as atividades do Programa.

A instituição desses mecanismos de gestão de políticas públicas, de forma colegiada, trouxe benefícios à implementação das ações, visto que possibilitou a articulação das instâncias decisórias no governo federal e o monitoramento da ação de agentes políticos. Contudo, os Ministérios da Fazenda e Planejamento, juntamente com a Casa Civil, compunham a estrutura do governo que tinha mais peso nas decisões acerca das ações, fazendo prevalecer suas expectativas em relação à execução e aos resultados do PAC e PMCMV e impondo sua vontade às necessidades específicas das políticas implementadas pelo Ministério das Cidades.

Nesse contexto, prevaleciam as decisões que privilegiavam os aspectos macroeconômicos, orçamentários e políticos, que estavam associados às questões mais estratégicas desses Programas, as quais estavam alinhadas ao projeto maior de desenvolvimento do país. Também se destaca o fato de que o processo de participação social vivenciado no âmbito do Conselho das Cidades estava cada vez mais longe da condição de interferir nas decisões tomadas na cúpula do governo.

Essa nova configuração institucional provocou mudanças significativas na tomada de decisão em relação às políticas nacionais de habitação, saneamento e mobilidade, além de se fazer prevalecer a visão setorial. Anteriormente, as principais decisões relacionadas a esses Programas, estavam sendo tomadas no âmbito do Ministério das Cidades. Entretanto, após a criação dessas instâncias decisórias e de gestão, foram ampliados os atores que influenciam as decisões, assim como foi dado foco às diretrizes econômicas priorizadas no arcabouço do PAC e do PMCMV.

Acerca da trajetória das políticas urbanas implementadas pelo Ministério das Cidades desde a sua criação, Caldas (2015, p. 120) analisa que, dentre todas as políticas setoriais, a 
Política de Habitação reuniu, até o momento, as condições capazes de gerar expressivos impactos nas cidades, tanto em relação à urbanização de áreas precárias, quanto à indução da expansão urbana gerada por suas intervenções. A autora também aponta a Politica Habitacional, como aquela que mais se destaca nas interações com os instrumentos fundiários e de planejamento das cidades.

Segundo a autora (p. 121) é incontestável reconhecer que as áreas de saneamento e mobilidade urbana tenham ampliado significativamente o aporte de recursos para a realização dos investimentos no âmbito do PAC, continuando uma trajetória de crescimento incremental. Contudo, os investimentos em saneamento foram direcionados para enfrentar o déficit existente nas áreas precárias já existentes, não se relacionando diretamente com o crescimento das cidades. Além disso, segundo a autora, a área de mobilidade urbana foi inicialmente incluída no PAC de forma bastante restrita. A temática ocupou maior centralidade somente depois das manifestações de 2013, representando uma carteira de projetos ainda muito recente. Dessa forma, a política de habitação continuou a se sobrepor em relação às demais políticas sob a competência do MCidades, assumindo grande destaque político e institucional.

A criação do Ministério das Cidades promoveu uma nova configuração institucional para o enfrentamento das problemáticas inerentes à temática transportes urbanos, sendo a Secretaria Nacional de Transportes e da Mobilidade Urbana (SEMOB) a unidade que passou a receber, de forma concentrada as demandas do setor. Buscou-se inclusive, uma nova compreensão sobre os transportes públicos para a superação dos desafios relacionados à mobilidade urbana.

O entendimento atual de mobilidade urbana como as condições de deslocamento das pessoas e bens nas cidades, independentemente do modo de transporte utilizado (coletivo ou individual, motorizado ou não motorizado) e serviu como base para a formulação do projeto de lei, pelo Poder Executivo, entre 2004-2006 (PL n.1.687/2007) que culminou com a promulgação da Lei de Diretrizes da Política Nacional de Mobilidade Urbana (Lei $\left.\mathrm{n}^{\mathrm{o}} 12.587 / 2012\right)$.

Com relação à habitação, Bonduki (2009a) destaca que a proposta contida no PMCMV teve origem no contexto da crise econômica internacional iniciada no final de 
2008, sendo uma das medidas anticíclicas adotadas pelo governo federal com vistas a combater os efeitos da crise sobre a economia brasileira. A despeito dos avanços ocorridos quanto ao financiamento e aos subsídios, o PMCMV traz consigo retrocessos em relação à política habitacional que já vinha sendo estruturada no âmbito do Ministério das Cidades. Estava sendo construído um discurso que visava ao planejamento do setor, à ampliação da participação popular por meio do SNHIS e à criação de estratégias específicas para a população de baixa renda.

Ao assumir esse formato, o programa inverte a lógica buscada na base do SNHIS, de fortalecimento da atuação do setor público na promoção de moradias, ao privilegiar a promoção privada. Um dos motivos se refere ao repasse de recursos por canais diferentes do FNHIS, sem precisar se submeter aos mecanismos de controle social criados. Como consequência, houve o enfraquecimento do SNHIS, como já observado em momentos anteriores da trajetória da política habitacional. O autor defende que, na prática, o PMCMV acaba se materializando na própria política de habitação praticada pelo governo federal, distanciando o setor, cada vez mais, dos princípios estabelecidos na Política Nacional de Habitação de 2004, voltando-se à dinamização do setor da construção civil e a outros objetivos econômicos.

Por outro lado, Shimbo (2010, p. 92) reconhece que a proposição do PMCMV apenas formalizou o "espírito" que já vinha se instituindo desde meados dos anos 1990, de incentivo à provisão privada de habitação. Para a autora o Programa não pode ser visto como uma "surpresa", já que a própria política de habitação formulada em 2004 já vinha tendo sua estrutura alterada na medida em que a atuação privada vinha ganhando destaque, tanto no Subsistema de Habitação de Interesse Social, quanto no Subsistema de Habitação de Mercado.

A autora (2010, p. 93) também lembra que o PMCMV foi apresentado como uma das principais ações do governo em reação à crise econômica internacional, como uma política setorial de grande escala, mobilizando um conjunto de medidas de estímulo à produção habitacional, mantendo o desenvolvimento dos setores imobiliário e da construção civil.

Em função desses aspectos, Shimbo (2010, p. 96) supõe que é preciso se questionar sobre qual é o pressuposto da própria política urbana, uma vez que ele pode ser contrário 
ao "conteúdo universalizante de uma concepção normativa de política pública, além de corresponder à lógica seletiva dos mercados". Para a autora, esse é o contexto mais amplo, nacional e internacional, que privilegia a ótica privada e financeira da economia e da política.

Embora tenham sido realizados muitos esforços estatais na tentativa de reduzir as desigualdades sociais no espaço urbano, a partir de várias iniciativas materializadas na forma de planos e programas, a trajetória da política urbana brasileira aponta que existem limites à tentativa da $\mathrm{CF} / 88$ de assegurar as condições de cidadania para todos. No caso das políticas urbanas, Guimarães (2013, p. 192) destaca o expressivo poder das empreiteiras como orientadoras dos investimentos públicos urbanos, privilegiando o capital e o mercado.

O autor aponta que um dos critérios de decisões sobre os investimentos públicos e privados é a visibilidade das obras, assim como continua a prevalecer a lógica do uso dos fundos públicos como subsídio para a produção de novas localizações que possam contribuir e atender à expansão do mercado imobiliário. Desse modo, esse modelo de execução dos investimentos constitui um impasse à política de desenvolvimento urbano, indicando que a dinâmica de produção e de reprodução do espaço não pode ser pensada sem ser considerada a sua relação com os processos de acumulação capitalista.

Outro aspecto relevante sobre a política de desenvolvimento urbano que deve ser observado se refere ao papel que ela deve ter, como destacado por Francisconi e Souza (1976, p. 7). Os autores mostram que a política urbana deve compatibilizar aspectos físicos, econômicos, políticos e sociais do desenvolvimento urbano, indo além de uma abordagem setorial (habitação, saneamento, transportes). Para os autores (1976, p. 17), uma política de desenvolvimento urbano concretiza-se por meio da organização territorial da rede urbana, que é representada espacialmente pela estratégia nacional de desenvolvimento, sendo diretamente materializada pelos programas setoriais, fiscais e tributários e pelas definições institucionais que são instituídas pelo poder público.

Isso nos faz pensar no quanto a perpetuação da estratégia de desenvolvimento tradicionalmente adotada no Brasil, fortemente orientada para o crescimento econômico, para o setorialismo e para a fragmentação da ação governamental vem interferindo de 
forma significativa na configuração espacial brasileira. São consequências marcantes que se manifestam na acentuação das diferenças regionais e intra-regionais, na concentração de renda e nas desigualdades sociais. Essas diferenças são supostamente "combatidas" por meio de ações de ordem "curativa", que apenas atuam sobre as consequências desse modelo, sem imprimir esforços representativos sobre as verdadeiras causas da problemática urbana.

Em função disso, Cintra (1978, pp. 181-182) sugere que a forma fragmentada de atuar sobre o território seja abandonada e que a dimensão espacial seja incorporada ao planejamento em nível nacional, visando voltar o olhar e a tomada de decisão tanto para rede urbana nacional, vista em sua totalidade, a qual será alvo das políticas de ocupação territorial, quanto para as cidades, local onde as atividades setoriais tornam-se interdependentes. $\mathrm{O}$ autor (p. 224) complementa argumentando que a "organização espacial de pessoas e atividades deve ser considerada no prisma dos interesses envolvidos".

Acerca disso, Brito (2012, p. 154) conclui que o PAC e PMCMV tendem a conduzir as políticas urbanas mais no sentido da dinamização da economia do que da produção de cidades melhores, como pode ser comprovado pelo "boom" imobiliário dos últimos anos e pela a sobrecarga de veículos nas grandes cidades. A autora reconhece que a execução de uma política pública com as características da política urbana envolve muito mais do que a transferência de recursos, estando apoiada num amplo conjunto de variáveis. A autora indica que:

“(...) antes de ser um evento espontâneo e alheio à capacidade de intervenção governamental, a configuração da rede urbana brasileira é consequência também de ações deliberadas promovidas pelo poder público ao longo de décadas, de forma articulada ou não. $O$ Estado possui plenas condições de interferir na configuração da rede urbana e o faz sistematicamente, embora raramente avalie os "efeitos colaterais" das diversas políticas públicas, uma vez que a dimensão espacial é frequentemente ignorada e a política de desenvolvimento urbano, por si mesma, tem tido escasso poder de influência sobre este processo (BRITO, 2012, p. 156).

Desse modo, embora a criação do Ministério das Cidades tenha consolidado um aparato institucional mais estruturado, além de ter ampliado a aplicação de investimentos para o fortalecimento da política urbana no Brasil, continua a reproduzir o modelo de 
desenvolvimento desigual e concentrador, amparado pelo mercado, que vem sendo praticado há décadas, mesmo que em menor gradação.

Um dos caminhos que se apresenta como uma saída para que seja possível um novo olhar sobre a problemática urbana e a respectiva política de desenvolvimento, capaz de superar a visão fragmentada e setorial da ação pública, é a tentativa de pensar de que forma essas ações devem se materializar no território. Deve-se, inclusive, considerar sua interface com as demais políticas, tendo em vista a configuração espacial que se precisa ter para a real superação das disparidades regionais e promoção do desenvolvimento a todas as camadas da população.

\subsection{Pressupostos identificados nos discursos das políticas urbanas nacionais}

A seguir, serão apresentados os temas que fizeram parte do debate sobre a problemática urbana e que constaram nas diferentes propostas de políticas urbanas apresentadas em momentos distintos da história brasileira. Busca-se com isso, mostrar que, além das temáticas setoriais tradicionalmente apontadas (habitação, saneamento e transportes) existem outras de suma importância para o enfrentamento desses problemas e para a melhoria da efetividade na ação governamental.

Nesse sentido, no Quadro 2 são apresentadas as temáticas encontradas nos textos relativos aos seguintes períodos analisados: antecedentes das políticas urbanas; políticas urbanas nacionais dos anos 1970 e 1980; propostas de políticas nos planos nacionais formuladas entre 1987 e 2003; política de desenvolvimento urbano do Ministério das Cidades. Todos os planos foram legalmente aprovados, com exceção do III PND, que foi aprovado por Resolução da Câmara dos Deputados e dos Cadernos MCidades, os quais foram publicados no momento de criação do Ministério. Esses documentos foram apresentados como discursos oficiais que deveriam nortear as políticas urbanas nos respectivos períodos de vigência.

O primeiro aspecto importante a ser destacado acerca da seleção desses temas referese à temática de diferenças regionais, que, embora seja considerada como relevante na Proposta dos Cadernos MCidades, não faz mais parte da discussão conjunta como foi abordado nos PNDs das décadas anteriores. Esses documentos apresentaram propostas 
diferentes para o desenvolvimento urbano e o regional, porém, as temáticas eram consideradas de forma relacionada, sendo abordadas conjuntamente nas análises críticas.

Por outro lado, foram apontados como pontos críticos da época da ditadura a centralização e a ausência da participação social no processo de tomada de decisão da política urbana. Tinha-se como resultado disso, uma política urbana desconectada dos reais anseios da população. Com a criação do MCidades houve um avanço quanto à questão da participação social, visto que o Conselho das Cidades passou a ser o local institucional de discussão da política urbana, bem como os movimentos sociais passaram a ser recebidos pelos gestores para negociar alguns aspectos da política.

Outra questão a ser ressaltada tem a ver com a política urbana do MCidades, onde o discurso preconizava uma PNDU integrada com outras políticas setoriais. Com isso, as setoriais se sobrepuseram à PNDU estabelecida nos Cadernos MCidades, favorecendo a cristalização do modelo de política urbana em torno das temáticas setoriais de habitação, saneamento e transportes (agora chamada de mobilidade urbana). A proposta inicial de seguir as diretrizes de uma PNDU provisória enquanto uma PNDU definitiva seria elaborada no âmbito do Conselho das Cidades, a partir de uma abordagem democrática e participativa não se concretizou. Essas diretrizes deram espaço às políticas nacionais setoriais que foram publicadas ao longo da década de 2000 que, posteriormente, foram superadas pela supremacia dos programas de governo de maior relevância, PAC e PMCMVC.

Assim, percebe-se o descolamento entre o discurso institucional e a política urbana implementada, indicando que desde os primórdios da ação estatal voltada para a problemática urbana, não é o discurso que de fato orienta a execução das ações, dos planos e dos programas. Ao longo do tempo foi construído um discurso consistente, mesmo que com algumas ressalvas, mas que não era contemplado pelas práticas da ação estatal, que estavam prioritariamente orientadas pela ótica econômica. 
Quadro 2 - Temas das políticas urbanas e planos nacionais dos períodos

estudados

\begin{tabular}{|c|c|c|}
\hline Períodos & Temas Setoriais & Outros temas \\
\hline 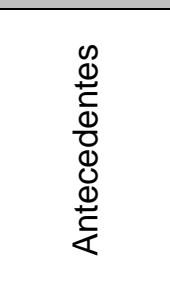 & $\begin{array}{l}\text { - Habitação } \\
\text { - Habitação popular } \\
\text { - Melhorias habitacionais } \\
\text { - Saneamento } \\
\text { - Transportes } \\
\text { - Transporte coletivo } \\
\text { - Infraestrutura (outras obras) }\end{array}$ & $\begin{array}{l}\text { - Desenvolvimento urbano } \\
\text { - Desenvolvimento regional } \\
\text { - Planejamento urbano } \\
\text { - Planejamento integrado } \\
\text { - Ordenamento e controle do uso do } \\
\text { solo } \\
\text { - Estrutura institucional }\end{array}$ \\
\hline $\begin{array}{l}0 \\
0 \\
0 \\
\\
0 \\
0 \\
0 \\
0 \\
\\
0 \\
0 \\
0 \\
0 \\
0 \\
\end{array}$ & $\begin{array}{l}\text { - Habitação } \\
\text { - Habitação popular } \\
\text { - Saneamento básico e ambiental } \\
\text { - Abastecimento de água } \\
\text { - Esgotamento sanitário } \\
\text { - Drenagem urbana } \\
\text { - Destinação final de resíduos sólidos } \\
\text { - Saneamento rural } \\
\text { - Transportes } \\
\text { - Infraestrutura (outras obras) }\end{array}$ & $\begin{array}{l}\text { - Desenvolvimento urbano } \\
\text { - Desenvolvimento regional } \\
\text { - Planejamento urbano } \\
\text { - Planejamento integrado } \\
\text { - Ordenamento e controle do uso do } \\
\text { solo } \\
\text { - Estrutura institucional } \\
\text { - Equipamentos sociais } \\
\text { - Patrimônio histórico e natural } \\
\text { - Regiões Metropolitanas } \\
\text { - Controle e combate da poluição } \\
\text { - Preservação dos recursos naturais } \\
\text { - Zoneamento do solo / urbano } \\
\text { - Integração nacional } \\
\text { - Obras de prevenção de enchentes } \\
\text { - Regularização fundiária } \\
\text { - Modernização da gestão } \\
\text { - Descentralização do planejamento } \\
\text { territorial } \\
\text { - Estudos e pesquisas } \\
\text { - Participacão social }\end{array}$ \\
\hline 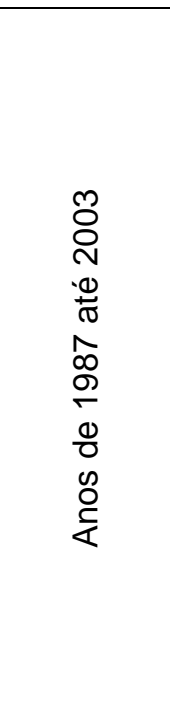 & $\begin{array}{l}\text { - Habitação } \\
\text { - Habitação popular } \\
\text { - Saneamento Básico e Ambiental } \\
\text { - Abastecimento de água } \\
\text { - Esgotamento sanitário } \\
\text { - Drenagem urbana } \\
\text { - Destinação final de resíduos sólidos } \\
\text { - Transportes } \\
\text { - Transporte coletivo } \\
\text { - Infraestrutura (outras obras) }\end{array}$ & $\begin{array}{l}\text { - Desenvolvimento urbano } \\
\text { - Desenvolvimento regional } \\
\text { - Planejamento urbano } \\
\text { - Planejamento integrado } \\
\text { - Integração das ações setoriais } \\
\text { - Estrutura institucional } \\
\text { - Parcerias público-privadas } \\
\text { - Participação Social } \\
\text { - Cooperação entre os entes } \\
\text { federados } \\
\text { - Revitalização das cidades } \\
\text { - Renovação de áreas degradadas } \\
\text { (áreas portuárias, centros históricos) } \\
\text { - Recuperação do patrimônio } \\
\text { histórico } \\
\text { - Legislação urbanística } \\
\text { - Urbanização de áreas de risco } \\
\text { - Regularização fundiária }\end{array}$ \\
\hline
\end{tabular}

Fonte: elaboração da autora. 
Quadro 2 - Temas das políticas urbanas e planos nacionais dos períodos estudados (continuação)

\begin{tabular}{|c|c|c|}
\hline Períodos & Temas Setoriais & Outros temas \\
\hline 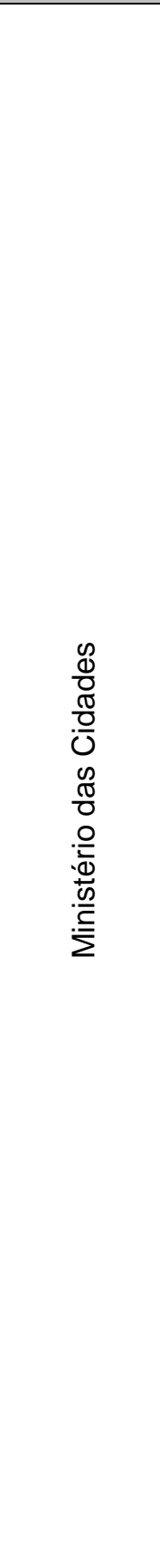 & $\begin{array}{l}\text { - Habitação } \\
\text { - Habitação popular } \\
\text { - Habitação de interesse social } \\
\text { - Saneamento básico e ambiental } \\
\text { - Abastecimento de água } \\
\text { - Esgotamento sanitário } \\
\text { - Drenagem urbana } \\
\text { - Destinação final de resíduos sólidos } \\
\text { - Coleta de lixo } \\
\text { - Saneamento rural } \\
\text { - Mobilidade urbana } \\
\text { - Transportes públicos coletivos } \\
\text { - Transportes não motorizados } \\
\text { (ciclovias) } \\
\text { - Acidentes de trânsito } \\
\text { - Infraestrutura (outras obras) }\end{array}$ & $\begin{array}{l}\text { - Desenvolvimento urbano } \\
\text { - Desenvolvimento regional } \\
\text { - Planejamento urbano } \\
\text { - Planejamento integrado } \\
\text { - Integração das ações setoriais } \\
\text { - Cooperação entre os entes federados } \\
\text { - Revitalização das cidades } \\
\text { - Renovação de áreas degradadas (áreas } \\
\text { portuárias, centros históricos) } \\
\text { - Recuperação do patrimônio histórico } \\
\text { - Urbanização de áreas de risco } \\
\text { - Metrópoles } \\
\text { - Acessibilidade } \\
\text { - Regularização fundiária } \\
\text { - Regularização de assentamentos } \\
\text { precários } \\
\text { - Ordenamento territorial } \\
\text { - Uso e ocupação do solo } \\
\text { - Macrozoneamento } \\
\text { - Áreas de proteção ambiental } \\
\text { - Áreas socialmente vulneráveis } \\
\text { - Planejamento e gestão territorial } \\
\text { - Prevenção de riscos em áreas de } \\
\text { encostas } \\
\text { - Educação ambiental } \\
\text { - Cooperação federativa } \\
\text { - Consórcios entre municípios } \\
\text { - Gestão associada de serviços } \\
\text { - Parcerias publico-privadas } \\
\text { - Cooperação Técnica } \\
\text { - Capacitação de agentes públicos e } \\
\text { sociais } \\
\text { - Assistência técnica para proponentes } \\
\text { - Modernização administrativa dos } \\
\text { municípios } \\
\text { - Inclusão social } \\
\text { - Direito à cidade } \\
\text { - Função social da cidade e da propriedade } \\
\text { - Qualidade ambiental urbana } \\
\text { - Participação social } \\
\text { - Controle social } \\
\text { - Gestão participativa } \\
\text { - Desenvolvimento institucional } \\
\text { - }\end{array}$ \\
\hline
\end{tabular}

Fonte: elaboração da autora. 
A partir das reflexões apresentadas, verifica-se que a lógica da fragmentação e do setorialismo, amparada em uma estratégia de orientada por fatores econômicos e financeiros, vem se mostrando como unanimidade no Governo Federal. Os setores são separados por órgãos / Ministérios que fragmentam sua atuação por temas que são geridos por diferentes secretarias e departamentos, em conformidade com a sistemática de planejamento e execução orçamentária do setor público. Essa mesma lógica também é adotada por estados e municípios, tendo como consequência a consolidação de uma forma equivocada de se pensar as cidades e as intervenções técnicas, que não contempla o todo, que é a unidade do espaço.

A análise dos discursos dos planos e da política urbana do MCidades mostra que embora se faça o apontamento de diversos temas associados à problemática e à política urbana, prevalece a visão setorial e fragmentada sobre o assunto. Supõe-se que isso ocorra devido ao fato de, historicamente, a percepção sobre os problemas urbanos ter sido formada em torno de temas isolados, na medida em que iam se manifestando e ascendendo à agenda pública (habitação, saneamento, transportes, uso do solo, ambiental, regional, regularização fundiária). Também é possível que essa tendência ocorra em função do pensamento compartimentado e fragmentado ser o padrão na sistemática de planejamento e execução da ação pública. Outra hipótese para a prevalência da visão setorial na política urbana se ampara nas peculiaridades e nos interesses aos setores que estão relacionados ao tema.

Com relação aos demais pressupostos considerados relevantes para orientar uma política urbana, verifica-se que nenhum dos discursos das políticas já preconizadas, tampouco os planos, consideraram o espaço como conceito básico da problemática urbana. Em todos os documentos analisados prevaleceu a ótica setorial que prioriza as ações em torno das políticas setoriais de habitação, saneamento e transportes, que posteriormente passou a ser chamada de mobilidade.

Isso reforça o entendimento de que as políticas urbanas já concebidas padeceram de um equívoco conceitual já de ponto de partida, sendo este um dos obstáculos a serem superados para que de fato seja possível promover o desenvolvimento urbano no Brasil. De fato, no momento de criação do Ministério das Cidades, em função das influências inerentes ao Movimento de Reforma Urbana, buscou-se inspiração no direito à cidade para 
a consolidação do discurso. Entretanto, a tentativa de materializar as ações e até na própria estruturação organizacional do órgão reforçou a lógica fragmentada que já vinha se propagando desde períodos anteriores.

Desse modo, o método adotado para compreender a problemática urbana também fica comprometido. Ao invés de se adotar uma abordagem espacial, predomina no período recente a lógica orçamentária de planejamento governamental, considerando o rateamento de recursos orçamentários especificados nos planos plurianuais de investimentos e nas leis orçamentárias anuais.

Segundo essa lógica de orientação do setor público, considera-se apenas o território como receptáculo das ações sem que sejam elaboradas as análises críticas acerca dos processos políticos e sociais que também interferem na implementação das ações. Percebese que o discurso tem evoluído, no sentido de abarcar outros temas que anteriormente não eram considerados, seguindo inclusive orientações de ordem técnica e operacional que visam melhores práticas de gestão. Contudo, não se busca pensar o espaço em sua completude para diminuir ou minimizar os efeitos deletérios que as ações inapropriadas podem causar na organização espacial das cidades.

As discussões sobre redemocratização, bem como as lutas focadas no direito à cidade introduziram os aspectos políticos nos discursos institucionais, como visto no Estatuto da Cidade, nas discussões produzidas nas Conferências Nacionais das Cidades e até em alguns dispositivos contidos nas políticas setoriais de habitação, saneamento e mobilidade.

Por outro lado, a adoção de programas governamentais com o formato do PAC e do PMCMV, que privilegiam o raciocínio econômico, acabam por favorecer ao abandono do ideário social que havia se fortalecido, deixando de lado preceitos como a função social da cidade e da propriedade, fragilizando as discussões e deliberações no âmbito das Conferências das Cidades.

Esses programas passaram a ter seus investimentos pautados segundo a lógica do mercado, sendo voltados primordialmente para os ganhos econômicos e financeiros, com total apoio do Estado. Embora a retomada dos investimentos tenha trazido um novo vigor às políticas setoriais de habitação, saneamento e mobilidade, tem prevalecido o protagonismo do Estado em apoiar o desenvolvimento e o fortalecimento do capital 
financeiro e empresarial, como observado desde os primórdios das políticas urbanas. Em todos os momentos estudados, o Estado continua a ser o principal interventor na problemática urbana, porém, sempre capturado pelos interesses econômicos, políticos e inerentes à sua própria estrutura.

A partir das análises realizadas é possível compreender que a política urbana apresenta dois tipos de problemas: o primeiro é uma questão conceitual, onde prevalece a visão fragmentada; e o segundo, tem relação com a atuação dos atores que se beneficiam com a ação setorializada.

Nesse sentido, no Capítulo 3 serão estudadas as práticas das políticas urbanas implementadas pelo MCidades, visando esclarecer de forma mais precisa os ganhos e as perdas devido à adoção do PAC e do PMCMV, além de buscar a compreensão das razões que fazem com que as ações realizadas pelo Estado não estejam em conformidade com os discursos oficiais.

\section{Capítulo 3. A política urbana do Ministério das Cidades: do discurso} às ações

\subsection{Estrutura organizacional e competências do Ministério das Cidades}

As discussões que envolvem a problemática urbana, suas características e implicações, morfologias e desdobramentos, tanto do ponto de vista social, econômico, quanto político ou demográfico, apontam para as características que configuram uma situação de caos e desordem em grandes centros urbanos. Fazem parte desse contexto o acesso desigual a bens e serviços, o tipo de ocupação e uso do solo em determinadas áreas, as possibilidades e restrições relativas à mobilidade urbana, além de outras questões, que envolvem um cenário complexo com desafios que estão presentes no cotidiano das grandes cidades, local de residência de $84,4 \%$ da população brasileira de acordo com o Censo Demográfico de 2010 (MARQUES e FREY, 2015, p. 255-256).

Nesse sentido, o processo sócio-político vivenciado no período de redemocratização do país possibilitou o debate acerca de políticas de acesso ao solo urbano tendo em vista assegurar o direito à cidade. Também era entendido que, em função das frustrações vivenciadas em períodos anteriores, o desafio de equacionamento da problemática urbana 
não se limitava a aspectos institucionais e financeiros, mas também deveria envolver uma nova abordagem técnica.

O Movimento pela Reforma Urbana, que tinha como objeto de luta o "direito à cidade", teve como uma das suas vitórias a inserção da temática desenvolvimento urbano na Constituição Federal de 1988 em seus artigos 182 e 183. No texto constitucional consta que essa política deve ser executada pelo poder público municipal, segundo diretrizes gerais fixadas em lei, tendo por objetivo ordenar o pleno desenvolvimento das funções sociais da cidade e garantir o bem-estar de seus habitantes. Vale salientar que o artigo $6^{\circ}$ da $\mathrm{CF} / 88$ assegura a moradia digna como um direito fundamental, cabendo ao Estado a promoção das condições necessárias para sua efetivação.

Em relação às competências dos entes federados, de acordo com o artigo 21, inciso XIX da Constituição, é competência privativa da União instituir diretrizes para o desenvolvimento urbano, incluindo habitação, saneamento básico e transportes urbanos, além de estabelecer as normas gerais de direito urbanístico, no âmbito da competência legislativa concorrente com os estados (artigo 24, I).

O Estatuto da Cidade constitui a lei que tanto regulamenta o capítulo de política urbana (artigos 182 e 183) da CF/88, quanto atende aos requisitos de competência privativa da União, ao instituir diretrizes gerais para o desenvolvimento urbano. Essa norma apresenta quatro grupos de propósitos para o alcance do objetivo da política urbana: (i) promover a gestão democrática das cidades; (ii) oferecer mecanismos para a regularização fundiária; (iii) combater a especulação imobiliária; e (iv) assegurar a sustentabilidade ambiental, social e econômica dos núcleos urbanos.

No Estatuto foram preconizados instrumentos que o município, deve utilizar para enfrentar os problemas de desigualdade social e territorial nas cidades, a partir da aplicação das diretrizes e instrumentos a seguir:

- diretrizes gerais da política urbana, destacando a garantia do direito às cidades sustentáveis, à gestão democrática da cidade, à ordenação e controle do uso do solo, tendo em vista evitar a retenção especulativa de imóvel urbano, à regularização fundiária e à urbanização de áreas ocupadas por população de baixa renda; 
- instrumentos voltados para assegurar o princípio de função social da propriedade, incluindo o Plano Diretor, o parcelamento e edificação compulsória de áreas e imóveis urbanos, imposto sobre a propriedade urbana (IPTU) progressivo no tempo, desapropriação para fins de reforma urbana, o direito de preempção, a outorga onerosa do direito de construir;

- instrumentos de regularização fundiária, tais como o usucapião urbano, a concessão de direito real de uso, as zonas especiais de interesse social;

- instrumentos de gestão democrática da cidade, incluindo conselhos de política urbana, conferências da cidade, orçamento participativo, audiências públicas, iniciativa popular de projetos de lei, e estudo de impacto de vizinhança.

De acordo com Saule Júnior e Rolnik (2001, p. 11), o resultado deste processo foi significativo, dando destaque ao fato de as diretrizes e os instrumentos de política urbana terem sido regulamentados com base nas experiências de política urbana, habitacional, de regularização fundiária e de participação popular vivenciadas em diversas cidades brasileiras na década de 90. Para os autores, o Estatuto da Cidade inova ao viabilizar o desenvolvimento de uma política urbana com a aplicação de instrumentos de reforma urbana voltados à promoção da inclusão social e territorial nas cidades brasileiras, considerando aspectos urbanos, sociais e políticos.

Para Trindade (2012, pp. 155-156), do ponto de vista jurídico, o direito à cidade deve ser interpretado enquanto uma obrigação positiva do Estado, tornando-o um direito social, cuja finalidade reside na garantia da segurança material e do bem-estar coletivo aos cidadãos diante dos mecanismos excludentes que constituem o fundamento da economia de mercado. Em se tratando da cidade, esses mecanismos se manifestam na maneira como o espaço urbano é produzido e apropriado pelos interesses capitalistas, principalmente a partir da especulação imobiliária, que acentua a condição de segregação urbana.

O autor explica que a garantia do direito à cidade aos segmentos sociais excluídos exige, uma ação positiva do Estado, que necessariamente implica restrições do direito individual dos grandes proprietários de terras e imóveis, ao estabelecer normas públicas de controle e regulação da propriedade urbana. Dessa forma, a luta pela instauração do direito à cidade reproduz o conflito entre direitos sociais (obrigações positivas), de um lado, e 
direitos civis (obrigações negativas), do outro. Assim, a garantia dos direitos sociais, depende essencialmente da mobilização e da luta social, uma vez que a materialização concreta desses direitos afronta de forma significativa os interesses das classes detentoras do poder econômico.

Desse modo, a efetiva implementação do Estatuto da Cidade e, consequentemente, do direito à cidade, implica a restrição significa das possibilidades de ganhos e apropriação da renda fundiária urbana por parte dos atores que compõem o mercado imobiliário. Naturalmente, essa condição suscita fortes reações negativas desses atores a qualquer tentativa de efetivação dessa lei, principalmente no que diz respeito aos instrumentos jurídico-urbanísticos de coibição da especulação imobiliária.

Existem questionamentos em relação às razões que teriam levado o empresariado urbano, que num primeiro momento reagia de forma negativa às propostas da reforma urbana desde seus primórdios, a aprovar e apoiar, por unanimidade, instrumentos legais destinados a confrontar seus interesses. Segundo Bassul (2010, p. 87), a aprovação do Estatuto da cidade por unanimidade pode ser atribuída aos efeitos do longo tempo que passou da sua formulação até a aprovação (12 anos).

O autor acredita que isso se deve ao fato de que alguns dos instrumentos da norma já vinham sendo praticados pelos municípios, mesmo antes da sua aprovação, com resultados considerados estimulantes pelo capital imobiliário, sendo este um importante fator de diminuição do grau de restrições que esse segmento fazia ao projeto. Assim, o que parecia uma ameaça passou a ser gradativamente percebido como uma oportunidade.

Outro ganho atribuído ao "Movimento Pela Reforma Urbana" foi a criação do Ministério das Cidades, instituído em $1^{\circ}$ de janeiro de 2003, por meio da Medida Provisória $\mathrm{n}^{\mathrm{o}} 103$, que depois convertida na Lei $\mathrm{n}^{\mathrm{o}} 10.683$, de 28 de maio do mesmo ano, especificando que a atuação do órgão se daria a partir da atuação de quatro Secretarias Nacionais: Habitação, Saneamento Ambiental, Mobilidade Urbana e Programas Urbanos e do Departamento Nacional de Trânsito.

O Decreto $\mathrm{n}^{\circ} 4.665$, de 3 de abril de 2003, aprovou a estrutura regimental e o quadro demonstrativo dos cargos em comissão do Ministério, incluindo as competências e as atribuições para atuar nas seguintes áreas: 
1. política de desenvolvimento urbano;

2. políticas setoriais de habitação, saneamento ambiental, transporte urbano e trânsito;

3. promoção, em articulação com as diversas esferas de governo, com o setor privado e organizações não-governamentais, de ações e programas de urbanização, de habitação, de saneamento básico e ambiental, transporte urbano, trânsito e desenvolvimento urbano;

4. política de subsídio à habitação popular, saneamento e transporte urbano;

5. planejamento, regulação, normatização e gestão da aplicação de recursos em políticas de desenvolvimento urbano, urbanização, habitação, saneamento básico e ambiental, transporte urbano e trânsito;

6. participação na formulação das diretrizes gerais para conservação dos sistemas urbanos de água, bem assim para adoção de bacias hidrográficas como unidades básicas do planejamento e gestão do saneamento.

Em 2011, com a publicação do Decreto $\mathrm{n}^{\mathrm{o}}$ 7.618, foi introduzida uma nova competência na estrutura do Ministério das Cidades, sendo delegada à Secretaria Nacional de Programas Urbanos. Após a inserção dessa competência, promoção da acessibilidade arquitetônica e urbanística, com ênfase na pessoa com deficiência ou com mobilidade reduzida, a Secretaria mudou de nome e passou a ser chamada de Secretaria Nacional de Acessibilidade e Programas Urbanos (SNAPU).

O conjunto de instrumentos propostos na $\mathrm{CF}$ e no Estatuto da Cidade, bem como a criação do Ministério das Cidades, estabeleceu um novo arcabouço institucional, fortalecendo a articulação das ações, o aporte de recursos e a interação dos agentes comprometidos em enfrentar a problemática urbana no Brasil.

Para Bonduki (2009b, p. 78) isso se torna ainda mais relevante, visto que entre a extinção do BNH em 1986 e a criação do Ministério das Cidades em 2003, a gestão da política de habitação, por exemplo, esteve subordinada a sete ministérios ou estruturas administrativas diferentes, provocando descontinuidade administrativa e fragmentação de uma possível estratégia para o enfrentamento do problema. Soma-se a isso o vazio institucional deixado pela ausência de políticas nacionais para o enfrentamento da problemática urbana desde o final da década de 80 até o início dos anos 2000. 
A estrutura de cargos do MCidades no momento de sua criação está apresentada na Tabela 1, sendo agrupada de acordo com as principais unidades do órgão.

A distribuição de cargos entre as unidades do Ministério na sua criação mostra a concentração na área meio, visto que $40 \%$ deles são destinados para a Secretaria-Executiva e Gabinete do Ministro, enquanto os $60 \%$ restantes estão destinados a quatro Secretarias Nacionais (Habitação, Saneamento, Mobilidade Urbana e Acessibilidade e Programas Urbanos) e ao Departamento Nacional de Trânsito, que são as unidades finalísticas do órgão. Isso indica que, já de partida, as áreas finalísticas do órgão já estavam deficitárias em termos de estrutura, com relação às áreas administrativas e de assessoria à alta gestão.

Também se destaca a importância dada às Secretarias de Habitação e Saneamento que receberam maior quantitativo de cargos em comparação com a Secretaria de Mobilidade e com a de Programas Urbanos, que teve o menor número. Isso é reflexo da priorização histórica que sempre foi dada às políticas de habitação e, posteriormente, a saneamento e transportes, segundo uma ótica setorialista e compartimentada.

Tabela 1 - Estrutura de cargos do Ministério das Cidades na sua criação

\begin{tabular}{|c|c|c|c|c|c|c|c|c|}
\hline Tipo de Cargo & GAB & SE & SNH & SNSA & SEMOB & SNAPU & Denatran & $\begin{array}{c}\text { Total de } \\
\text { Cargos }\end{array}$ \\
\hline DAS 1 & 2 & 0 & 0 & 0 & 8 & 0 & 3 & 13 \\
\hline DAS 2 & 2 & 26 & 4 & 4 & 0 & 4 & 2 & 42 \\
\hline DAS 3 & 7 & 15 & 11 & 11 & 1 & 7 & 4 & 56 \\
\hline DAS 4 & 9 & 10 & 9 & 9 & 11 & 9 & 9 & 66 \\
\hline DAS 5 & 7 & 3 & 3 & 3 & 3 & 3 & 1 & 23 \\
\hline DAS 6 & 0 & 0 & 1 & 1 & 1 & 1 & 0 & 4 \\
\hline N.E & 0 & 1 & 0 & 0 & 0 & 0 & 0 & 1 \\
\hline Total & $\mathbf{2 7}$ & $\mathbf{5 5}$ & $\mathbf{2 8}$ & $\mathbf{2 8}$ & $\mathbf{2 4}$ & $\mathbf{2 4}$ & $\mathbf{1 9}$ & $\mathbf{2 0 5}$ \\
\hline Valor unitário & 85,18 & 110,68 & 76,09 & 76,09 & 74,69 & 70,97 & 51,38 & $\mathbf{5 4 5 , 0 8}$ \\
\hline
\end{tabular}

Fonte: Decreto n ${ }^{\circ} 4.665$ de 2003.

De todo modo, o Ministério das Cidades surgiu como uma resposta aos pleitos de um movimento social que se organizou e buscou criar meios para garantir o "direito à cidade" a partir de uma atuação mais precisa do Estado. Para isso, acreditava-se ser necessária a criação de um órgão que tivesse como competência promover o desenvolvimento urbano. Contudo, há uma incompatibilidade entre a idealização e a 
prática, já que foi criado um ministério setorializado, onde as temáticas essenciais do desenvolvimento urbano ficaram limitadas aos temas habitação, saneamento, transportes, trânsito e programas urbanos.

Isso pode ser visto logo no Art. $1^{\circ}$ do Anexo I do decreto de criação do órgão, onde as políticas setoriais de habitação, saneamento, transporte e trânsito são citadas de forma desvinculada da política de desenvolvimento urbano, visto que são listadas em incisos separados. A contradição do discurso é percebida até na forma de organizar a redação das competências do Ministério.

Também se tinha a expectativa de "integrar" a atuação das secretarias visando alcançar um objetivo comum, mas não foram percebidas iniciativas que concretas que viabilizassem essa integração. Ressalta-se ainda que a SNAPU, apontada como a unidade essencial para promover essa integração, voltada prioritariamente para o planejamento territorial e para a regularização fundiária, já nasceu fragilizada em comparação com as demais, tanto em termos de cargos, quanto em relação a suas competências. Isso foi sendo acentuado ao longo do tempo, na medida em que o orçamento da SNAPU passou a ser significativamente inferior às demais secretarias, como será detalhado mais adiante.

Ao longo dos anos, a lógica setorial foi se fortalecendo e se consolidando no órgão, tendo como resultado a estruturação das políticas setoriais segundo lógicas e dinâmicas independentes. Em função da estruturação dessas políticas, bem como pela opção do governo federal em ampliar os investimentos no setor de infraestrutura por meio de um planejamento de médio prazo, foram sendo imputadas novas responsabilidades e ações ao órgão, tais como:

- o Programa de Aceleração do Crescimento (PAC 1) em 2007 (Decreto no 6.025 de 22 de janeiro de 2007, que instituiu o PAC e o seu comitê gestor);

- o Programa Minha Casa Minha Vida (PMCMV) em 2009 (Lei n 11.977, de 7 de julho de 2009, que dispõe sobre o Programa Minha Casa, Minha Vida (PMCMV) e a regularização fundiária de assentamentos em áreas urbanas); e

- o Programa de Aceleração do Crescimento fase 2 (PAC 2) em 2011 (lançamento da segunda fase do Programa em 29 de março de 2010 com os mesmos objetivos do PAC 1 e novo aporte de recursos); 
- o Programa Minha Casa Minha Vida (PMCMV) fase 2 em 2011.

A inserção desses programas nas atribuições do Ministério repercutiu significativamente no aumento dos investimentos gerenciados pelas Secretarias Nacionais, como pode ser visto na Tabela 2 e na Figura 4. Da mesma forma, houve impacto negativo na capacidade gerencial do órgão, que não dispunha dos recursos operacionais necessários para a gestão efetiva dessas ações.

A análise da evolução histórica dos investimentos realizados pelo Ministério nas áreas de sua competência mostra que o PAC, juntamente com o PMCMV, foram os principais responsáveis por alavancar os investimentos realizados pelo MCidades, de forma mais contundente, a partir de 2009. Considerando os investimentos realizados em 2005 e 2014, o montante de recursos gerenciados pelo Ministério aumentou cerca de 5,8 vezes.

Tabela 2 - Evolução dos investimentos feitos pelo Ministério das Cidades

\begin{tabular}{|c|c|c|c|c|}
\hline Ano & FGTS (R\$) & OGU & Total & Programa \\
\hline 2005 & $11.200 .000 .000,00$ & $3.242 .855 .605,66$ & $14.442 .855 .605,66$ & - \\
\hline 2006 & $11.830 .000 .000,00$ & 3.834.261.912,01 & 15.664.261.912,01 & - \\
\hline 2007 & $12.450 .000 .000,00$ & 7.405.369.443,04 & $19.855 .369 .443,04$ & \multirow{2}{*}{ PAC 1} \\
\hline 2008 & $21.950 .000 .000,00$ & 7.078.309.858,85 & $29.028 .309 .858,85$ & \\
\hline 2009 & $28.600 .000 .000,00$ & 4.912.636.466,48 & $33.512 .636 .466,48$ & \multirow{2}{*}{$\begin{array}{l}\text { PAC } 1+ \\
\text { PMCMV }\end{array}$} \\
\hline 2010 & $42.600 .000 .000,00$ & $2.625 .215 .517,70$ & $45.225 .215 .517,70$ & \\
\hline 2011 & $50.900 .000 .000,00$ & 2.395.009.638,96 & 53.295.009.638,96 & \multirow{4}{*}{$\begin{array}{l}\text { PAC } 2+ \\
\text { PMCMV }\end{array}$} \\
\hline 2012 & $53.550 .000 .000,00$ & $4.698 .873 .149,95$ & $58.248 .873 .149,95$ & \\
\hline 2013 & $71.100 .000 .000,00$ & 8.445.537.797,51 & 79.545.537.797,51 & \\
\hline 2014 & $71.100 .000 .000,00$ & $13.308 .493 .532,46$ & $84.408 .493 .532,46$ & \\
\hline
\end{tabular}

Fonte: MCidades, Secretaria-Executiva, empenho liquidado - Dezembro/2014 / Nota Técnica EGP/MCIDADES/2016. Os investimentos envolvem os repasses realizados pelo MCidades mais as contrapartidas dos proponentes. Valores Correntes.

Mas é preciso destacar que os investimentos do órgão foram prioritariamente realizados por meio dos recursos relativos ao FGTS, numa média de $83 \%$, enquanto os recursos de OGU estavam sempre oscilando numa média de $13 \%$ do total executado. É importante dar destaque à natureza do recurso visto que o FGTS é um recurso oneroso e 
afeta a capacidade de gasto dos proponentes, tornando-se, por si só, uma barreira àqueles que possuem menos recursos e capacidade gerencial limitada.

Em função do aumento progressivo no aporte de investimentos, a execução do PAC e do PMCMV pelo MCidades, nas fases 1 e 2, passou a demandar o aprimoramento da sua estrutura gerencial e da força de trabalho, em termos quantitativos e qualitativos, principalmente em função dos seguintes aspectos:

1. elevação significativa do aporte dos recursos gerenciados pelo Ministério;

2. ampliação e diversificação dos programas e das ações;

3. aumento do número de operações realizadas com os proponentes (estados, municípios, empresas de saneamento) que requerem o monitoramento constante e a resolução de pendências legais e técnicas;

4. incapacidade técnica e operacional para acompanhar a execução física e financeira de todas as obras, além de dar respostas a órgãos de controle e atender suas recomendações;

5. necessidade de elevação da capacidade técnica para lidar com situações críticas que demandam a execução de obras de grande porte e de soluções de projeto de maior complexidade técnica;

6. inclusão de novos perfis de profissionais e especialistas para o desenvolvimento de atividades técnicas especializadas;

7. necessidade de realizar capacitação e assistência técnica para os proponentes.

Em função disso, percebe-se que, além das dificuldades relativas à adoção de uma abordagem setorial e fragmentada, a implementação da política urbana do Ministério sofreu impactos negativos devido às carências gerenciais do órgão. Salienta-se que o aumento significativo dos investimentos destinados ao Ministério das Cidades foi importante para alavancar a política urbana que vinha sendo negligenciada desde o final da década de 1980, quando se iniciou o período de crise financeira que justificou o discurso do neoliberalismo. A retomada dessas políticas, de forma mais incisiva, em meados da década de 2000, também acentuou as dificuldades de gestão em todos os níveis da Administração Pública, porque os diferentes entes federados, bem como o próprio Ministério, não estavam organizados e aparelhados em termos de estrutura técnica e operacional para gerir muitos empreendimentos ao mesmo tempo. 
Portanto, passou a existir um hiato entre a capacidade técnica dos entes federados para elaborar projetos, contratar e fiscalizar obras de médio e grande porte; solucionar problemas relativos à regularização fundiária e de ordem ambiental; além de outros, e a ampla oferta de recursos disponibilizados pelo governo federal para a concretização desses objetivos. A busca de soluções para esses problemas de ordem prática e operacional também dificultou a percepção das deficiências conceituais que pairavam sobre a política urbana concebida: pensar o urbano de forma setorial e fragmentada sem considerar a totalidade e a complexidade do espaço.

Os encargos cresciam e demandavam respostas da estrutura do órgão, entretanto, verifica-se que a força de trabalho do Ministério foi crescendo de forma mais significativa durante o período de 2005 a 2011, apresentando queda e se mantendo constante a partir de 2012, como mostrado na Figura 4.

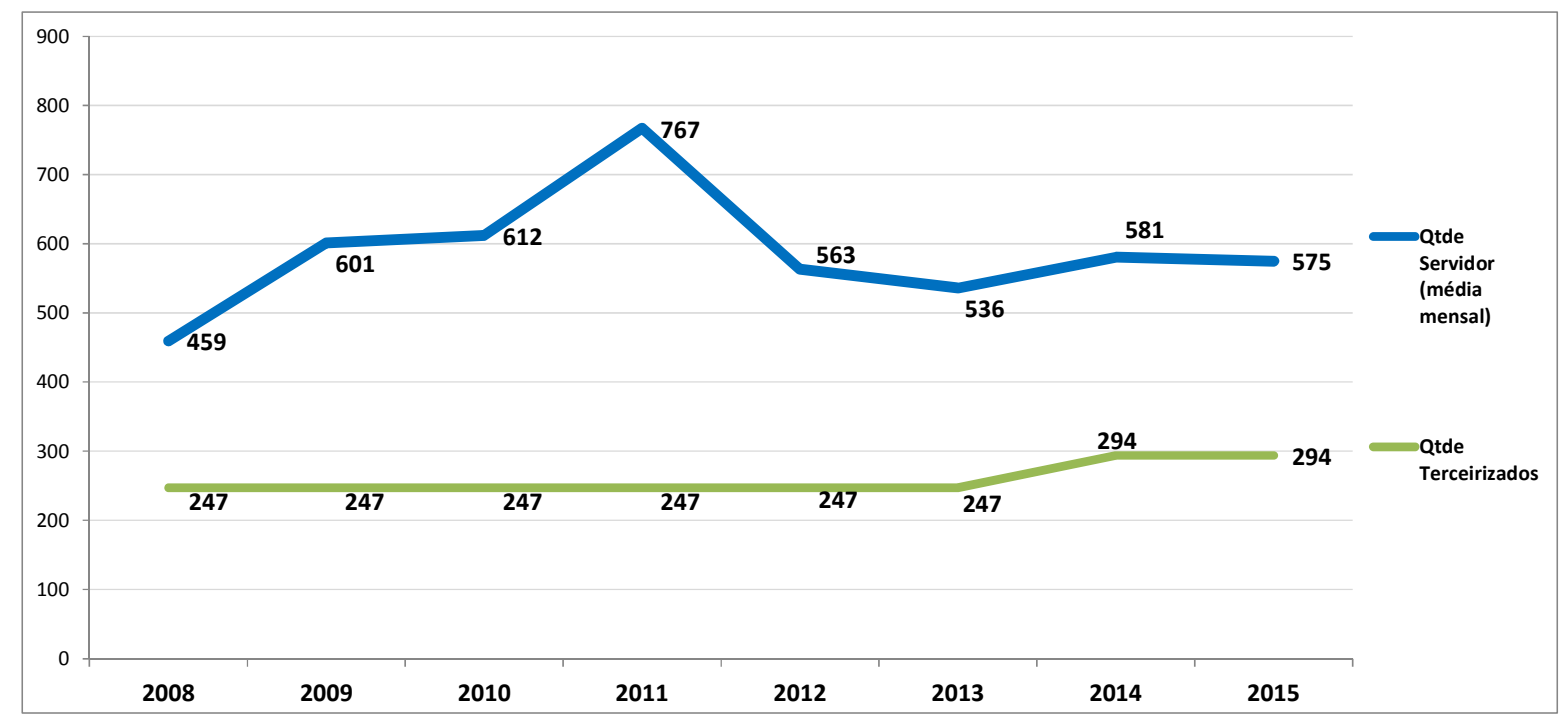

Figura 4 - Evolução média da Força de Trabalho do Ministério das Cidades Fonte: Nota Técnica EGP/MCIDADES/2016; SIAPE, média de 2008 a 2014 e CGRH para outubro/2015.

A análise comparativa entre o crescimento do montante de recursos gerenciados pelo órgão e da sua respectiva força de trabalho, mostra que, no período de 2005 a 2015, houve um incremento de $434 \%$ nos recursos financeiros, não ocorrendo o mesmo em relação à força de trabalho, que apresentou crescimento de $23 \%$ no período de 2008 a 2015. Assim, o crescimento dos recursos gerenciados pelo MCidades se deu cerca de 18,8 vezes mais que o do quadro de pessoal, tendo como resultado direto o comprometimento da sua capacidade gerencial em função da insuficiência de cargos e de pessoal. 
Esse comprometimento também pode ser observado na Tabela 3, onde se verifica que a força de trabalho atual do Ministério, que efetivamente gerencia os recursos relativos ao PAC, ao PMCMV e a emendas parlamentares, está deficitária. Dessa forma, fica evidente a deficiência do governo federal de oferecer o devido suporte aos estados, municípios e demais proponentes que contratam recursos do MCidades.

Essa questão acentua a fraqueza institucional do órgão e amplia sua vulnerabilidade em relação à Caixa Econômica Federal que é o agente operador e principal agente financeiro dos recursos do FGTS. Bonduki (2009, p. 97) destaca o fato de que mesmo que o Ministério seja o responsável pela gestão das políticas urbanas, na prática, a Caixa, devido à grande capilaridade e ao seu poder como entidade subordinada ao Ministério da Fazenda e por estar presente em todos os municípios do país, assume a responsabilidade de decisão sobre aprovação dos pedidos de financiamentos e acompanhamento dos empreendimentos apoiados pelo MCidades.

Tabela 3 - Montante de recursos monitorados e número de operações

\begin{tabular}{|l|c|c|c|}
\hline \multicolumn{1}{|c|}{ Informação } & PAC & PMCMV & $\begin{array}{c}\text { Emendas } \\
\text { Parlamentares }\end{array}$ \\
\hline Número de Operações Vigentes & 10.602 & 849.503 & 13.466 \\
\hline Número de Monitores & 85 & 28 & 8 \\
\hline Total de Recursos Monitorados & 208,143 bilhões & 205,500 bilhões & 8,838 bilhões \\
\hline Média de Operações por Monitor & $\mathbf{1 2 4 , 7 3}$ & $\mathbf{3 0 . 3 3 9 , 3 9}$ & $\mathbf{1 . 6 8 3 , 2 5}$ \\
\hline Média de Recurso por Monitor $(\mathbf{R} \mathbf{\text { ) }}$ & $\mathbf{2 , 4 4 9}$ bilhões & $\mathbf{7 , 3 3 9}$ bilhões & $\mathbf{1 , 1 0 5}$ bilhões \\
\hline
\end{tabular}

Fonte: Banco de Dados Corporativos do MCidades - Saci, março/2014

Nota Técnica EGP/MCIDADES/2016.

*Total de operações do PMCMV considerando PJ e PF.

Essa condição se torna ainda mais extrema na medida em que o órgão tem sua capacidade gerencial comprometida devido à insuficiência de estrutura burocrática. Somase a isso a visão financeira e econômica que prevalece em uma instituição financeira como a Caixa, que historicamente tem deixado esses interesses se sobreporem às prioridades das políticas urbanas, como observado no período do $\mathrm{BNH}$.

Uma das principais inferências que se pode ter a respeito dos aspectos apresentados sobre a evolução dos investimentos, da força de trabalho e da estrutura de cargos do Ministério das Cidades é que o órgão, apesar de apresentar destaque nos investimentos do 
PAC e do PMCMV, não teve sua estrutura considerada como uma prioridade quando comparado a outros Ministérios.

A própria origem do órgão pode revelar parte dessa falta de interesse por ter relação com as conquistas do movimento de reforma urbana, que teve origem na esfera popular, diferentemente do que acontece com outras pastas prioritárias para o governo federal, tal como agricultura, transportes e minas e energia, que são mais tradicionais e lidam com grupos de interesses mais estruturados e organizados.

Isso pode ser observado ao se comparar o MCidades com outros ministérios, como pode ser visto na Figura 5, onde se apresenta a comparação entre estruturas gerenciais e orçamento de outros órgãos que executam o PAC, no ano de 2014.

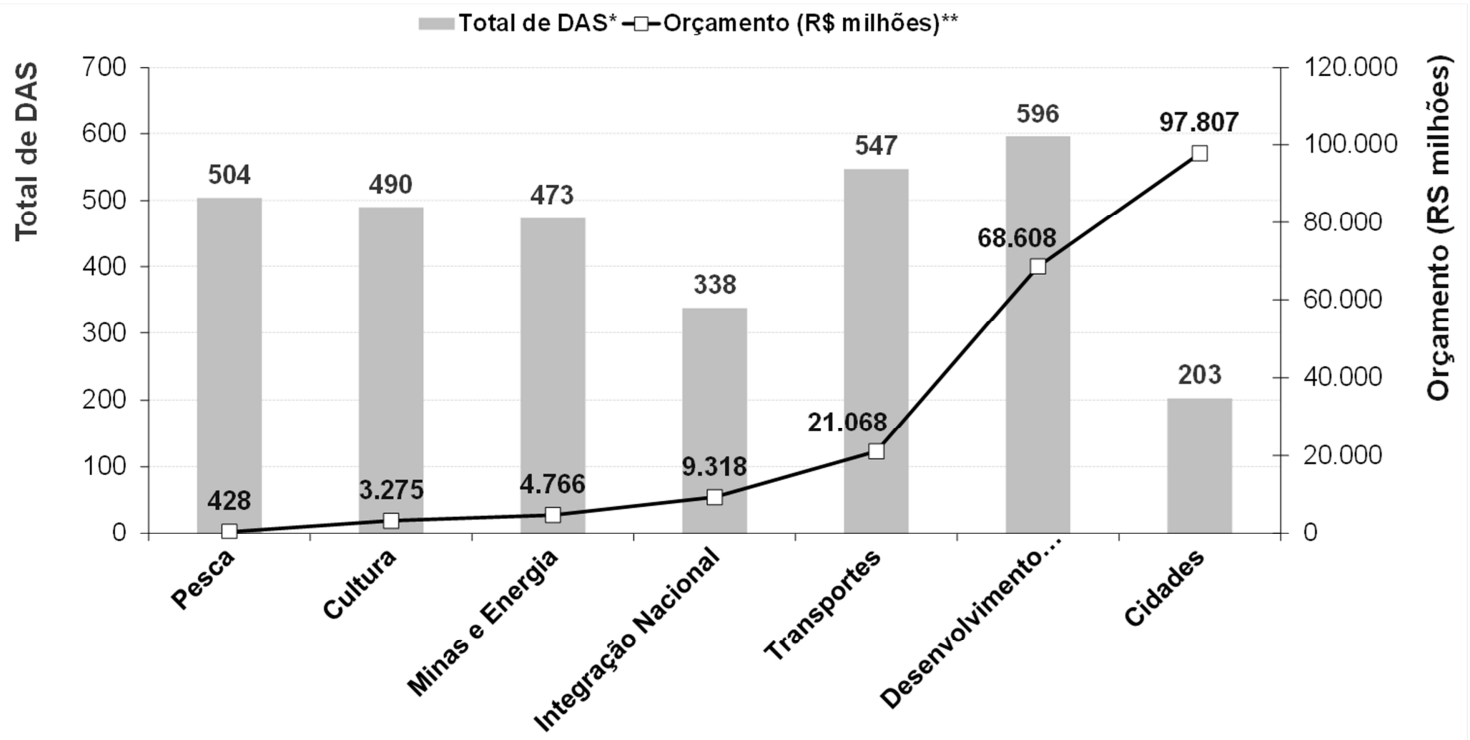

Figura 5 - Comparação entre Estruturas Gerenciais e Orçamento de 2014

Fonte: Nota Técnica EGP/MCIDADES/2016.

*Sistema SIORG, Ministério do Planejamento, Orçamento e Gestão.

** Sistema SIGA, Senado Federal e Conselho Curador do FGTS, orçamento 2014.

Então, mesmo que o MCidades apresente um quantitativo maior que outros ministérios, em termos de investimentos do PAC, dispõe da pior estrutura de cargos. A situação fica ainda mais evidente ao se observar a Figura 6, que mostra o atendimento desses órgãos quanto ao aumento de cargos ao longo dos anos, enquanto o Ministério das Cidades permaneceu constante. 
Esses outros órgãos tiveram seus orçamentos ampliados da mesma forma que o MCidades, comprometendo sua capacidade gerencial, contudo, tiveram seus pleitos de incremento na estrutura de cargos atendidos.

A permanência, desde sua criação, com a mesma estrutura gerencial somada à diminuição de força de trabalho provocou sério comprometimento da capacidade gerencial do Ministério das Cidades, mostrando que a estrutura existente não é capaz de entregar efetivamente os resultados preconizados nas suas competências.

Essa constatação também foi apontada pela Fundação Getúlio Vargas (FGV) que foi contratada em novembro de 2013 para prestar consultoria ao órgão na elaboração do planejamento estratégico, tendo como um de seus produtos a revisão da estrutura organizacional.

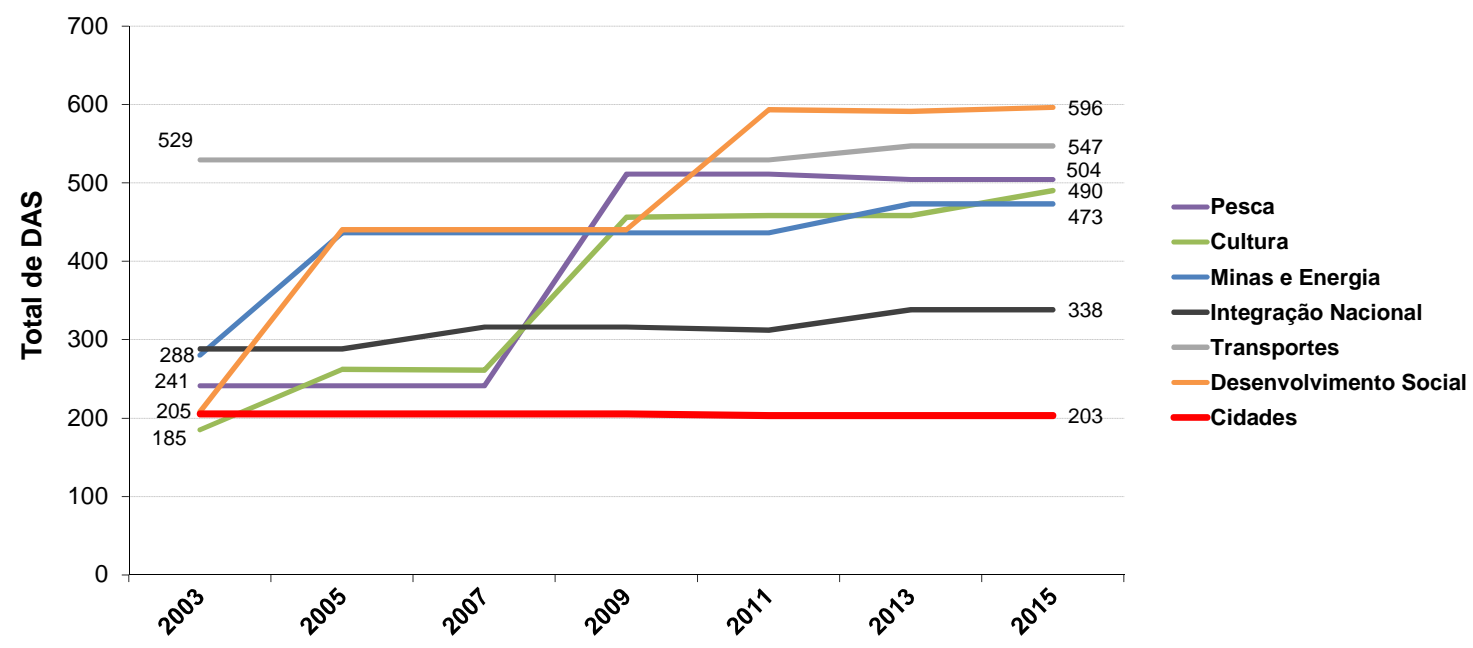

Figura 6 - Evolução de Estruturas Gerenciais de Órgãos Gestores do PAC

Fonte: *Sistema SIORG, Ministério do Planejamento, Orçamento e Gestão.

Decreto 6.972/2009 Ministério da Pesca

Decreto 8.470/2015 Ministério da Cultura

Decreto 7.798/2012 Ministério das Minas e Energia

Decreto 8.161/2013 Ministério da Integração Nacional

Decreto 7.717/2012 Ministério dos Transportes

Decreto 8.218/2014 Ministério do Desenvolvimento Social

Decreto 4.665/2003 Ministério das Cidades

A revisão da estrutura do órgão já era entendida como necessária em função das discrepâncias entre as responsabilidades atuais desempenhadas pelo órgão e a estrutura prevista no decreto de criação, bem como pela formação de arranjos informais ao longo do tempo e por recomendações de órgãos de controle. O produto entregue pela FGV apontou 
fragilidades graves na capacidade gerencial do Ministério das Cidades, devido ao longo período sem atualização da estrutura gerencial frente aos desafios operacionais assumidos.

A proposta de revisão da estrutura apresentada pela FGV também contou com a sugestão de reorganização das unidades e reorientação das competências. Embora a empresa de consultoria tenha identificado fragilidades do ponto de vista da estrutura organizacional, de cargos e de pessoal, propôs a exclusão da Secretaria Nacional de Acessibilidade e Programas Urbanos (SNAPU), sugerindo que suas atribuições deveriam ser redistribuídas entre as demais secretarias finalísticas e a Secretaria-Executiva. Essa proposta foi rejeitada em unanimidade pela Secretaria-Executiva, unidade gestora do contrato, devido ao entendimento acerca da importância das ações de planejamento urbano e territorial para a promoção da missão do MCidades e, consequentemente, para o desenvolvimento urbano.

As discussões decorrentes dessa proposta consideraram o fato de a Secretaria não estar desenvolvendo plenamente suas funções para a promoção da política de desenvolvimento urbano, em função de prevalecer a ótica setorial na concepção e implementação das ações desenvolvidas pelo Ministério. Mas, entendeu-se que isso não justifica a iniciativa de suprimir essa unidade nem a relocação de suas competências em outras unidades do órgão.

Mesmo sabendo que a supressão da SNAPU da estrutura do MCidades não seja uma proposta recente, a equipe técnica da Secretaria-Executiva compreende que essa visão também prevalece em função da relevância que as demais secretarias apresentam, por tratarem prioritariamente da execução de obras, que constituem as principais evidencias de sucesso e eficácia das políticas geridas pelo órgão.

Além das questões associadas às fragilidades na estrutura gerencial, o Ministério das Cidades vem sofrendo com a descontinuidade administrativa devido à alternância de ministros desde a sua criação. A primeira perda se atribui à substituição de um ministro do mesmo partido que o presidente Lula, o PT, para um partido de orientação conservadora, o $\mathrm{PP}$, e que não comungava do mesmo compromisso acordado com a luta pela reforma urbana. No período de gestão do ministro Olívio Dutra, foi aprovada a PNDU, a Política 
Nacional de Habitação com a estruturação de um Sistema de Habitação de Interesse Social, Plano Nacional de Habitação e demais instrumentos (2004).

$\mathrm{Na}$ gestão dos dois ministros seguintes ligados ao PP, foram aprovadas as políticas Nacionais de Saneamento Básico (2007) e de Mobilidade Urbana (2012), o lançamento do PAC (2007) e do PMCMV (2009). Esses marcos legais são evidências da importância dada ao viés setorial pelo $\mathrm{PP}$.

Desse modo, os impactos mais evidentes resultantes da troca de ministros passaram a representar um gargalo ao bom andamento do órgão a partir de 2015. Tudo isso devido a uma crise política que requereu negociações para o estabelecimento de um novo equilíbrio na coalisão dos partidos aliados, quando assumiu um ministro do PSD. O rompimento com a cultura gerencial e institucional que vinha se desenvolvendo no Ministério das Cidades, devido à permanência do PP durante quase onze anos, abalou significativamente o órgão com a entrada do PSD (2015), sendo ainda mais impactante devido à entrada do PSDB em 2016. Na tabela 4, apresenta-se a sucessão dos ministros do órgão desde a criação até o período atual.

Tabela 4 - Histórico dos ministros do Ministério das Cidades

\begin{tabular}{|c|c|c|c|c|c|c|}
\hline Item & Ministro & Início & Fim & $\begin{array}{c}\text { Tempo } \\
\text { Total }\end{array}$ & $\begin{array}{c}\text { Partido do } \\
\text { Ministro }\end{array}$ & Presidente \\
\hline 1 & Olívio Dutra & $\begin{array}{l}1 \text { de janeiro } \\
\text { de } 2003\end{array}$ & $\begin{array}{l}20 \text { de julho } \\
\text { de } 2005\end{array}$ & $\begin{array}{c}2 \text { anos, seis } \\
\text { meses e } 19 \\
\text { dias }\end{array}$ & PT & \multirow{2}{*}{$\begin{array}{l}\text { Luiz Inácio } \\
\text { Lula da Silva } \\
\text { (PT) }\end{array}$} \\
\hline 2 & $\begin{array}{c}\text { Márcio Fortes de } \\
\text { Almeida }\end{array}$ & $\begin{array}{l}21 \text { de julho } \\
\text { de } 2005\end{array}$ & $\begin{array}{c}31 \text { de } \\
\text { dezembro } \\
\text { de } 2010\end{array}$ & $\begin{array}{c}5 \text { anos, cinco } \\
\text { meses e } 10 \\
\text { dias }\end{array}$ & PP & \\
\hline 3 & Mário Negromonte & $\begin{array}{l}1 \text { de janeiro } \\
\text { de } 2011\end{array}$ & $\begin{array}{c}2 \text { de } \\
\text { fevereiro de } \\
2012\end{array}$ & $\begin{array}{c}1 \text { ano, } 1 \text { mês } \\
\text { e } 1 \text { dia }\end{array}$ & PP & \multirow{5}{*}{$\begin{array}{l}\text { Dilma } \\
\text { Rousseff } \\
\text { (PT) }\end{array}$} \\
\hline 4 & Aguinaldo Ribeiro & $\begin{array}{c}7 \mathrm{de} \\
\text { fevereiro de } \\
2012\end{array}$ & $\begin{array}{c}17 \mathrm{de} \\
\text { março de } \\
2014\end{array}$ & $\begin{array}{l}2 \text { anos, um } \\
\text { mês e dez } \\
\text { dias }\end{array}$ & PP & \\
\hline 5 & Gilberto Occhi & $\begin{array}{c}17 \text { de março } \\
\text { de } 2014\end{array}$ & $\begin{array}{l}1^{\circ} \mathrm{de} \\
\text { janeiro de } \\
2015\end{array}$ & $\begin{array}{l}10 \text { meses e } \\
16 \text { dias }\end{array}$ & PP & \\
\hline 6 & Gilberto Kassab & $\begin{array}{c}1^{\text {o }} \text { de janeiro } \\
\text { de } 2015\end{array}$ & $\begin{array}{l}15 \text { de abril } \\
\text { de } 2016\end{array}$ & $\begin{array}{c}1 \text { ano, } 3 \\
\text { meses e } 14 \\
\text { dias }\end{array}$ & PSD & \\
\hline 7 & $\begin{array}{l}\text { Inês da Silva } \\
\text { Magalhães }\end{array}$ & $\begin{array}{l}15 \text { de abril } \\
\text { de } 2016\end{array}$ & $\begin{array}{l}12 \text { de maio } \\
\text { de } 2016\end{array}$ & 23 dias & PT & \\
\hline 8 & Bruno Araújo & $\begin{array}{l}12 \text { de maio } \\
\text { de } 2016\end{array}$ & atual & $\begin{array}{c}1 \text { ano e } 1 \\
\text { mês } \\
\text { (junho/2017) }\end{array}$ & PSDB & $\begin{array}{l}\text { Michel } \\
\text { Temer } \\
(\mathrm{PMDB})\end{array}$ \\
\hline
\end{tabular}

Fonte: Elaboração da própria. 
Em função das últimas trocas de ministro, o processo de revisão da estrutura organizacional do Ministério das Cidades contou com novas orientações a partir de outubro de 2015, quando, em função de um cenário de recessão, o governo federal anunciou uma reforma ministerial, propondo o enxugamento da máquina. Inicialmente, a reforma anunciou a eliminação de 8 das 39 pastas, por meio da fusão e da eliminação de alguns ministérios, a extinção de 3 mil cargos comissionados, a eliminação de 30 secretarias, o corte de gastos de custeios, além de outros aspectos.

Esse cenário restritivo fez com que a metodologia participativa e de consulta às áreas para a elaboração de uma minuta de decreto e de regimento interno para a nova estrutura organizacional do órgão, que já estava em andamento, tendo sido substituída por uma estratégia sigilosa e decidida exclusivamente pela alta gestão. A orientação encaminhada ao MCidades pela Secretaria-Executiva do então Ministério do Planejamento, Orçamento e Gestão, estabeleceu a redução de 205 para 173 cargos.

Paralelamente ao processo de elaboração da proposta para a nova estrutura do MCidades foi iniciado o processo de impeachment da Presidente Dilma Rousseff em 02/12/2015, pela aceitação da Câmara dos Deputados, sendo concluído em 31/08/2016 pela votação do Senado que foi favorável à sua destituição do cargo. As retóricas políticas apontavam o desrespeito à lei orçamentária e à lei de improbidade administrativa por parte da presidente, além de suspeitas de envolvimento em atos de corrupção na Petrobrás, que eram objeto de investigação pela Polícia Federal, no âmbito da Operação Lava Jato. Por outro lado, o que se viu foi a reorganização política de uma macro coalizão que fez da presidente eleita um bode expiatório. Esses que estão à frente do poder no momento atual também faziam parte da coalizão juntamente com o PT, constituindo a base aliada do governo.

Em função desses acontecimentos, a elaboração da nova estrutura do órgão foi suspensa até a publicação do Decreto $\mathrm{n}^{\mathrm{o}} 8.785$ e da Medida Provisória $\mathrm{n}^{\mathrm{o}} 731$, ambos publicados em 10 de junho de 2016, que tratavam do remanejamento de cargos ao Ministério do Planejamento, bem como da transformação de cargos em comissão de livre nomeação em funções comissionadas do poder executivo, que apenas poderão ser ocupadas por servidores públicos de carreira. Esses normativos foram publicados especificando o quantitativo de cargos que deveriam ser cortados por todos os Ministérios, 
sendo a meta do Ministério das Cidades o corte de quarenta e seis (46) cargos, equivalentes a um valor unitário de 83,4.

A versão final da minuta de decreto com nova estrutura de cargos e de funções comissionadas do Ministério das Cidades foi elaborada pelo Gabinete do Ministro, com participação da Secretaria-Executiva, sendo encaminhada para apreciação do Ministério do Planejamento, Desenvolvimento e Gestão e publicação pela Casa Civil em setembro de 2016.

Em função desses cortes, verifica-se que os problemas relacionados à capacidade gerencial do órgão foram acentuados, tanto em relação à diminuição dos cargos comissionados, bem como com relação à formalização de estruturas gerenciais. O único ganho com esse processo foi a atualização das competências das Secretarias e demais unidades, as quais estavam deficitárias.

Nas Tabelas 5 a 7 apresenta-se a nova estrutura de cargos do Ministério das Cidades, segundo Decreto $\mathrm{n}^{\circ}$ 8.927, publicado em 8 de dezembro de 2016.

Tabela 5 - Estrutura de cargos do Ministério das Cidades após a reforma

\begin{tabular}{|l|c|c|c|c|c|c|c|c|}
\hline $\begin{array}{c}\text { Tipo de } \\
\text { Cargo }\end{array}$ & GAB & SE & SNH & SNSA & SEMOB & SNDU & Denatran & Cargos \\
\hline DAS 1 & 1 & 0 & 0 & 0 & 0 & 0 & 2 & 3 \\
\hline DAS 2 & 1 & 6 & 0 & 0 & 0 & 2 & 1 & 10 \\
\hline DAS 3 & 6 & 8 & 0 & 0 & 1 & 2 & 2 & 19 \\
\hline DAS 4 & 10 & 11 & 8 & 8 & 8 & 5 & 9 & 59 \\
\hline DAS 5 & 7 & 2 & 3 & 3 & 3 & 3 & 1 & 22 \\
\hline DAS 6 & 0 & 0 & 1 & 1 & 1 & 1 & 0 & 4 \\
\hline N.E & 0 & 1 & 0 & 0 & 0 & 0 & 0 & 1 \\
\hline Total & $\mathbf{2 5}$ & $\mathbf{2 8}$ & $\mathbf{1 2}$ & $\mathbf{1 2}$ & $\mathbf{1 3}$ & $\mathbf{1 3}$ & $\mathbf{1 5}$ & $\mathbf{1 1 8}$ \\
\hline $\begin{array}{l}\text { Valor } \\
\text { unitário }\end{array}$ & 88,55 & 77,74 & 53,47 & 53,47 & 54,75 & 46,37 & 46,68 & $\mathbf{4 2 4 , 5 3}$ \\
\hline
\end{tabular}

Fonte: Decreto $\mathrm{n}^{\circ} 8.927$ de 8 de dezembro de 2016. 
Tabela 6 - Estrutura de FCPEs do Ministério das Cidades após a reforma

\begin{tabular}{|l|c|c|c|c|c|c|c|c|}
\hline $\begin{array}{c}\text { Tipo de } \\
\text { Cargo }\end{array}$ & GAB & SE & SNH & SNSA & SEMOB & SNDU & Denatran & Cargos \\
\hline FCPE 1 & 0 & 0 & 0 & 0 & 1 & 0 & 0 & 1 \\
\hline FCPE2 & 0 & 10 & 2 & 2 & 0 & 2 & 0 & 16 \\
\hline FCPE3 & 0 & 4 & 9 & 7 & 0 & 2 & 0 & 22 \\
\hline FCPE4 & 0 & 0 & 0 & 0 & 0 & 0 & 0 & 0 \\
\hline $\begin{array}{l}\text { Total } \\
\text { Valor } \\
\text { unitário }\end{array}$ & $\mathbf{0}$ & $\mathbf{1 4}$ & $\mathbf{1 1}$ & $\mathbf{9}$ & $\mathbf{1}$ & $\mathbf{4}$ & $\mathbf{0}$ & $\mathbf{3 9}$ \\
\cline { 2 - 10 } & 0 & 12,64 & 12,86 & 10,34 & 0,6 & 4,04 & 0 & $\mathbf{4 0 , 4 8}$ \\
\hline
\end{tabular}

Fonte: Decreto $\mathrm{n}^{\circ} 8.927$ de 8 de dezembro de 2016.

Tabela 7 - Estrutura final de cargos e FCPEs após a reforma

\begin{tabular}{|c|c|c|c|c|c|c|c|}
\hline GAB & SE & SNH & SNSA & SEMOB & SNDU & Denatran & Cargos \\
\hline 25 & 42 & 23 & 21 & 14 & 17 & 15 & $\mathbf{1 5 7}$ \\
\hline 88,55 & 90,38 & 66,33 & 63,81 & 55,35 & 50,41 & 46,68 & $\mathbf{4 6 5 , 0 1}$ \\
\hline
\end{tabular}

Fonte: Decreto ${ }^{\circ} 8.927$ de 8 de dezembro de 2016.

A partir da análise da nova estrutura organizacional do Ministério das Cidades conferida pelo decreto $\mathrm{n}^{\circ} 8.927$, de 8 de dezembro de 2016, verifica-se que a SNAPU mudou de nome para Secretaria Nacional de Desenvolvimento Urbano (SNDU), mantendo-se as mesmas atribuições temáticas: planejamento e gestão urbana, áreas de risco, reabilitação urbana e regularização fundiária. A mudança ficou apenas no nome da secretaria que continuou desfalcada em termos de quantitativo de cargos por apresentar o menor valor unitário de cargos ao ser comparada com as demais. Assim, permaneceu a superioridade institucional e organizacional da SNH e da SNSA.

A perpetuação da condição de desequilíbrio entre as prioridades conferidas às temáticas relacionadas problemática urbana, também materializada na estrutura desigual das Secretarias Nacionais formalizadas no Ministério das Cidades, será discutida de forma mais aprofundada nas seções seguintes deste capítulo, quando será abordada a execução das ações relativas à política urbana implementada pelo órgão. 


\subsection{Panorama recente da qualidade urbana: habitação, saneamento e}

mobilidade

Nesta seção, busca-se apresentar e discutir as condições de precariedade urbana no Brasil para em seguida, verificar se as ações realizadas pelo Ministério das Cidades estão sendo direcionadas para as reais necessidades da sociedade. Para tanto, buscou-se identificar as fontes de dados e as temáticas que usualmente são adotadas pelo poder público e pela academia quando se procura caracterizar as condições de vida nas cidades.

Num primeiro momento, verificou-se que os dados coletados e os indicadores produzidos para compor o retrato das cidades já nascem de forma fragmentada e setorializada. Tradicionalmente, os dados são levantados e agrupados de acordo com os setores: habitação, saneamento e transportes, bem como são produzidos e divulgados por diferentes fontes. Ressalta-se que além de os dados e os indicadores sobre a qualidade urbana serem levantados e concebidos de forma separada, não contemplam a totalidade dos temas relacionados à problemática e à política urbana.

Assim, a partir da análise dos dados e dos indicadores amplamente difundidos e adotados pelo Ministério das Cidades e por outros órgãos centrais da Administração Pública brasileira, percebe-se a priorização na quantificação e na qualificação das condições de habitação, saneamento e mobilidade urbana, não se dando a mesma importância a outros aspectos e temáticas também relevantes para a compreensão e análise da problemática urbana.

Nesse sentido, será apresentada, na medida do possível, de acordo com os dados e os indicadores disponíveis e usualmente adotados pelo Ministério, as condições urbanas das cidades por meio da análise da evolução dos indicadores relativos à precariedade urbana ao longo dos últimos anos no Brasil e nas grandes regiões. É preciso destacar que os indicadores serão apresentados exatamente como são divulgados na sua fonte, tendo em vista registrar aqui a forma como os dados e as informações são trabalhados e organizados.

\section{Panorama da habitação}

A publicação "Déficit Habitacional" foi consolidada ao longo dos anos como a principal referência para o conhecimento das necessidades habitacionais no Brasil. Trata-se de um documento técnico elaborado pela Fundação João Pinheiro em parceria com o 
Programa das Nações Unidas para o Desenvolvimento (PNUD), o Banco Interamericano de Desenvolvimento (BID) e o Ministério das Cidades, apresentando referências para formuladores de políticas públicas, pesquisadores e interessados na dimensão dos problemas urbanos no território nacional.

Nessa publicação, os dados sobre a questão da moradia no Brasil são apresentados de forma desagregada, possibilitando o conhecimento aprofundado sobre essa problemática, as necessidades relativas à construção de novas moradias, bem como com relação à inadequação dos domicílios. O primeiro estudo foi publicado em 1995, retratando a situação habitacional em 1991, sendo incrementado metodologicamente na segunda versão, que trouxe informações para o ano 2000.

A metodologia desenvolvida para o cálculo do déficit habitacional e das inadequações de domicílios exige um nível de detalhamento de dados secundários que, para o caso de municípios, só poderia ser obtido com a divulgação e liberação, pelo IBGE, dos microdados do Censo Demográfico 2000, o que ocorreu no final de 2002. Assim, com o objetivo geral de calcular o déficit e a inadequação habitacional para os municípios brasileiros selecionados, as microrregiões geográficas e a totalidade das regiões metropolitanas em 2000, contratou-se o terceiro estudo da série, sendo divulgado em 2004 (JOÃO PINHEIRO, 2005, p. 9).

Ao longo dos anos, a metodologia desenvolvida pela Fundação João Pinheiro para o cálculo do déficit habitacional foi aprimorada, sendo incorporada em 2007 a variável coabitação familiar. Esse estudo se consolidou como uma referência relevante para o processo de planejamento da política habitacional brasileira, visto que a metodologia utilizada pela entidade é considerada um importante marco para a discussão do déficit habitacional, levando em conta a abordagem adotada e a ampla divulgação dos resultados.

Para o Ministério das Cidades, o principal mérito dessa publicação foi rearticular inúmeras contribuições realizadas anteriormente de forma inovadora. Por outro lado, em função das exigências e dos requisitos técnicos associados à sua elaboração, apresenta algumas dificuldades do ponto de vista de sua função como indicador, visto que requer uma "contratação" para ser efetivada. A impossibilidade de contratação da fundação 
poderá inviabilizar a apuração do indicador resultando na descontinuidade da série histórica.

O processo de urbanização brasileiro foi consolidado durante o período de intensa industrialização, tendo como resultados a transformação no perfil das cidades, com sua população passando de predominantemente rural para majoritariamente urbana em menos de 40 anos (1940-1980). Essas transformações tiveram como pano de fundo a migração de um vasto contingente de pobres, ocorrendo sob a orientação de um modelo de desenvolvimento urbano que basicamente privou as faixas de menor renda da população de condições básicas de urbanidade, ou de inserção efetiva na cidade.

Embora as transformações populacionais no período de 1991 a 2010 tenham ocorrido de forma menos impactante que a observada nos períodos anteriores, verifica-se que as condições de vida urbana tornaram-se ainda mais críticas, já que a concentração populacional nas áreas urbanas continuou a aumentar, passando de 75,5\% em 1991 para $81,2 \%$ em 2000 e 84,4\% em 2010. Também é destaque a concentração de 42,13\% da população na região Sudeste.

Nas figuras 7 e 8 e nas Tabelas 8 a 10, apresentam-se dados sobre o crescimento populacional e de domicílios no Brasil e por regiões, no período de 1991 a 2010. Assim, são destacados os percentuais de populações e domicílios em área urbana e na área rural. 


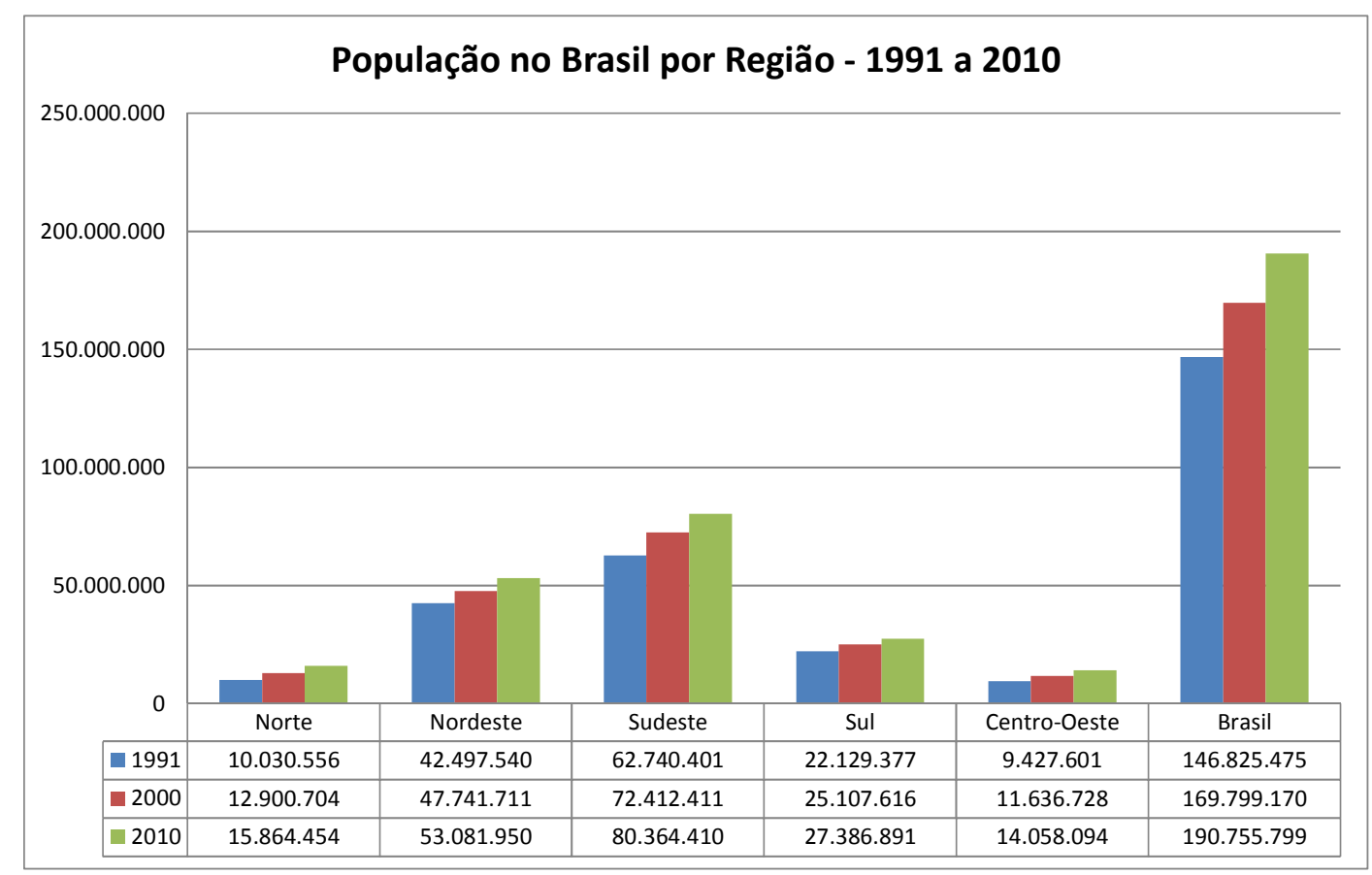

Figura 7 - População no Brasil por região (1991 a 2010) Fonte: Censos Demográficos/IBGE.

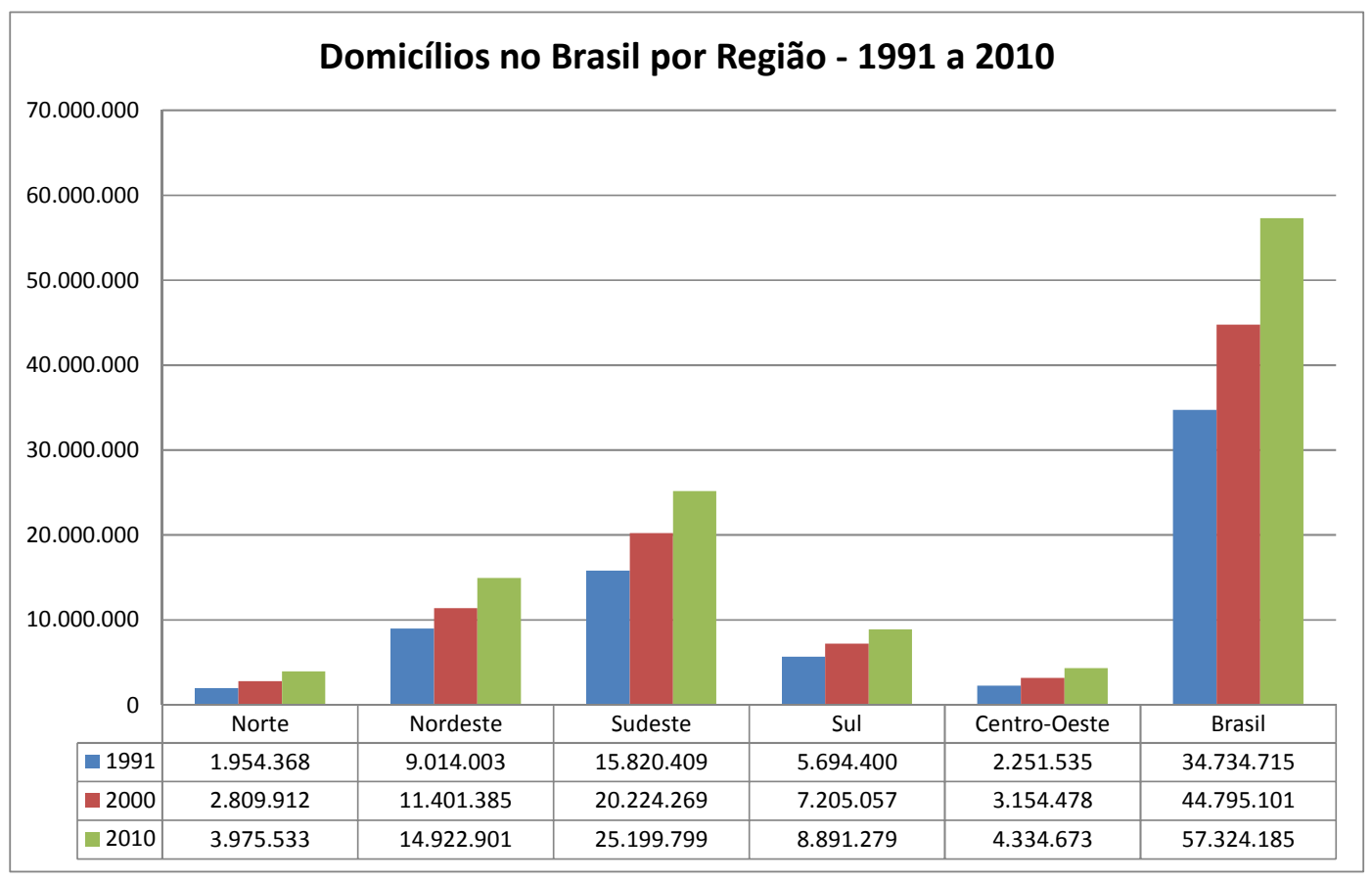

Figura 8 - Domicílios no Brasil por região (1991 a 2010)

Fonte: Censos Demográficos/IBGE. 
Tabela 8 - População, domicílios e domicílios vagos no Brasil (1991-2010)

\begin{tabular}{|c|c|c|c|c|c|c|c|c|c|c|c|c|}
\hline \multirow{2}{*}{ Região } & \multicolumn{3}{|c|}{ População } & \multicolumn{3}{|c|}{ Total de Domocílios } & \multicolumn{3}{|c|}{ Domicílios Vagos } & \multicolumn{3}{|c|}{ Déficit Total Absoluto } \\
\hline & 1991 & 2000 & 2010 & 1991 & 2000 & 2010 & 1991 & 2000 & 2010 & 1991 & 2000 & 2010 \\
\hline Norte & 10.030 .556 & 12.900 .704 & 15.864 .454 & 1.954 .368 & 2.809 .912 & 3.975 .533 & 271.657 & 313.431 & 405.630 & - & 848.696 & 823.442 \\
\hline \begin{tabular}{|l|} 
Nordeste \\
\end{tabular} & 42.497 .540 & 47.741 .711 & 53.081 .950 & 9.014 .003 & 11.401 .385 & 14.922 .901 & 1.334 .072 & 1.765 .220 & 1.932 .971 & 2.314 .933 & 2.851 .197 & 2.111 .517 \\
\hline \begin{tabular}{|l} 
Sudeste \\
\end{tabular} & 62.740 .401 & 72.412 .411 & 80.364 .410 & 15.820 .409 & 20.224 .269 & 25.199 .799 & 2.341 .421 & 2.794 .954 & 2.448 .165 & 1.889 .899 & 2.341 .698 & 2.674 .428 \\
\hline Sul & 22.129 .377 & 25.107 .616 & 27.386 .891 & 5.694 .400 & 7.205 .057 & 8.891 .279 & 711.800 & 735.362 & 811.495 & 548.107 & 678.879 & $770.750,00$ \\
\hline Centro-Oeste & 9.427 .601 & 11.636 .728 & 14.058 .094 & 2.251 .535 & 3.154 .478 & 4.334 .673 & 329.421 & 420.789 & 453.900 & 392.672 & 502.175 & $560.554,00$ \\
\hline Brasil & 146.825 .475 & 169.799 .170 & 190.755.799 & 34.734.715 & 44.795 .101 & 57.324 .185 & 4988371 & 6.029 .756 & 6.052 .161 & 5.145 .611 & 7.222 .645 & 6.940 .691 \\
\hline
\end{tabular}

Fonte: Censos Demográficos/IBGE.

Tabela 9 - População e domicílios no Brasil por situação do domicílio (1991-2010)

\begin{tabular}{|c|c|c|c|c|c|c|c|c|c|c|c|c|}
\hline \multirow{3}{*}{ Região } & \multicolumn{4}{|c|}{1991} & \multicolumn{4}{|c|}{2000} & \multicolumn{4}{|c|}{2010} \\
\hline & \multicolumn{2}{|c|}{ População } & \multicolumn{2}{|c|}{ Domicílios } & \multicolumn{2}{|c|}{ População } & \multicolumn{2}{|c|}{ Domicílios } & \multicolumn{2}{|c|}{ População } & \multicolumn{2}{|c|}{ Domicílios } \\
\hline & Rural & Urbana & Rural & Urbana & Rural & Urbana & Rural & Urbana & Rural & Urbana & Rural & Urbana \\
\hline Norte & 4.098 .989 & 5.931 .567 & 763.602 & 1.190 .766 & 3.886 .339 & 9.014 .365 & 768.427 & 2.041 .485 & 4.199 .945 & 11.664 .509 & 963.156 & 3.012 .377 \\
\hline Nordeste & 16.744 .185 & 25.753 .355 & 3.355 .308 & 5.658 .695 & 14.766 .286 & 32.975 .425 & 3.240 .489 & 8.160 .896 & 14.260 .692 & 38.821 .258 & 3.722 .808 & 11.199 .667 \\
\hline \begin{tabular}{|l|} 
Sudeste \\
\end{tabular} & 7.590 .964 & 55.149 .437 & 1.689 .405 & 14.131 .004 & 6.863 .217 & 65.549 .194 & 1.733 .809 & 18.490 .460 & 5.668 .232 & 74.696 .178 & 1.671 .813 & 23.533 .529 \\
\hline Sul & 5.736 .667 & 16.392 .710 & 1.357 .886 & 4.336 .514 & 4.785 .617 & 20.321 .999 & 1.277 .302 & 5.927 .755 & 4.125 .995 & 23.260 .896 & 1.275 .002 & 7.615 .578 \\
\hline Centro-Oeste & 1.778 .844 & 7.648 .757 & 411.246 & 1.840 .289 & 1.543 .752 & 10.092 .976 & 405.122 & 2.749 .356 & 1.575 .131 & 12.482 .963 & 459.524 & 3.867 .102 \\
\hline Brasil & 35.949 .649 & 110.875 .826 & 7.577.447 & 27.157 .268 & 31.845 .211 & 137.953 .959 & 7.425.149 & 37369952 & 29.829 .995 & 160.925 .804 & 8.092 .302 & 49.228.253 \\
\hline
\end{tabular}

Fonte: Censos Demográficos/IBGE.

Tabela 10 - Percentual de população e domicílios no Brasil por situação do domicílio (1991-2010)

\begin{tabular}{|c|c|c|c|c|c|c|c|c|c|c|c|c|}
\hline \multirow{3}{*}{ Região } & \multicolumn{4}{|c|}{1991} & \multicolumn{4}{|c|}{2000} & \multicolumn{4}{|c|}{2010} \\
\hline & \multicolumn{2}{|c|}{ População } & \multicolumn{2}{|c|}{ Domicílios } & \multicolumn{2}{|c|}{ População } & \multicolumn{2}{|c|}{ Domicílios } & \multicolumn{2}{|c|}{ População } & \multicolumn{2}{|c|}{ Domicílios } \\
\hline & Rural \% & Urbana \% & Rural \% & Urbana \% & \begin{tabular}{l|l} 
Rural \% \\
\end{tabular} & Urbana \% & Rural \% & Urbana \% & Rural \% & Urbana \% & Rural \% & Urbana \% \\
\hline Norte & 40,9 & 59,1 & 39,1 & 60,9 & 30,1 & 69,9 & 27,3 & 72,7 & 26,5 & 73,5 & 24,2 & 75,8 \\
\hline Nordeste & 39,4 & 60,6 & 37,2 & 62,8 & 30,9 & 69,1 & 28,4 & 71,6 & 26,9 & 73,1 & 24,9 & 75,1 \\
\hline Sudeste & 12,1 & 87,9 & 10,7 & 89,3 & 9,5 & 90,5 & 8,6 & 91,4 & 7,1 & 92,9 & 6,6 & 93,4 \\
\hline Sul & 25,9 & 74,1 & 23,8 & 76,2 & 19,1 & 80,9 & 17,7 & 82,3 & 15,1 & 84,9 & 14,3 & 85,7 \\
\hline Centro-Oeste & 18,9 & 81,1 & 18,3 & 81,7 & 13,3 & 86,7 & 12,8 & 87,2 & 11,2 & 88,8 & 10,6 & 89,4 \\
\hline Brasil & 24,5 & 75,5 & 21,8 & 78,2 & 18,8 & 81,2 & 16,6 & 83,4 & 15,6 & 84,4 & 14,1 & 85,9 \\
\hline
\end{tabular}

Fonte: Censos Demográficos/IBGE. 
Como apontado no capítulo anterior, as características relacionadas ao modelo de desenvolvimento praticado ao longo dos anos foram se perpetuando no tempo e acentuaram ainda mais as condições críticas relacionadas à questão habitacional

A situação é intrigante e requer uma análise aprofundada e sistematizada, tomando como base um método que seja capaz de fornecer informações que apontem os aspectos implícitos que promovem a perpetuação desse processo. A partir da análise dos dados, verifica-se que o quantitativo de domicílios, em todos os momentos, cresceu mais do que o contingente populacional, sendo também importante destacar que, em 2010, a quantidade de domicílios vagos quase se igualava ao déficit habitacional absoluto. Em função disso, cabe a pergunta: se existe um estoque de domicílios capaz de absorver a demanda por novos domicílios, por que a situação se perpetua ao longo dos anos?

Marques e Frey (2015) questionam a necessidade da construção de novas unidades para todos os demandantes, uma vez que esta é vista como a principal solução para o déficit habitacional. Segundo os autores, grande parte desse número constitui o estoque de mercado destinado a uma camada da população com perfil diferente daquele que demanda as moradias.

Vale ressaltar que a decisão pela construção de novas unidades habitacionais não está relacionada apenas à superação de um gargalo ou de uma face da problemática urbana nas grandes cidades. Também deve ser considerada a decisão governamental em empreender uma política que promova a construção de casas, mas que também movimente a economia, gere empregos e satisfaça interesses associados ao setor da construção civil e do mercado imobiliário.

Brandão (1984, p. 103) destaca que o problema da moradia, entendido dentro de uma perspectiva sociológica, reflete o dinamismo e a complexidade de uma determinada realidade socioeconômica. Em função disso, o autor considera que as necessidades do habitat não se reduzem exclusivamente a um instrumento material por dependerem da vontade coletiva e se articularem às condições culturais e a outros aspectos da dimensão individual e familiar. Nesse sentido, as demandas habitacionais para os diversos setores sociais são diferentes e se transformam de acordo com a dinâmica da sociedade.

Para o Ministério das Cidades (2005) a discussão do tema habitação possui fortes interfaces com outras questões que se apresentam de forma recorrente e complementar, sendo inadequado adotar uma abordagem setorial, onde a questão é considerada reduzindo a 
complexidade do habitat a um déficit habitacional "stricto sensu". É preciso, portanto, que a questão habitacional seja analisada levando em conta suas interfaces com outras políticas urbanas, devido à interdependência da moradia com outras esferas.

Em relação a isso, Azevedo (1996) aponta que nem sempre, um simples incremento dos programas de habitação se mostra como a solução mais indicada para melhorar as condições habitacionais da população mais pobre. Para o autor, esses programas podem ser inviabilizados caso não sejam integradas a eles outras políticas urbanas, tais como a de transportes, energia elétrica e saneamento básico.

Nesse sentido, uma questão relevante para ser discutida diz respeito à própria nomenclatura de déficit habitacional. No sentido tradicional, ela induz equivocadamente a expectativas de enfrentar o problema da moradia de forma setorial, além de camuflar uma realidade complexa por meio de uma quantificação padronizada, atemporal e neutra (MCIDADES, 2005, p. 13).

O conceito de déficit habitacional utilizado pela Fundação João Pinheiro está ligado diretamente às deficiências do estoque de moradias, envolvendo aquelas sem condições de serem habitadas em razão da precariedade das construções ou do desgaste da estrutura física. Além disso, inclui no cálculo da variável a necessidade de incremento do estoque em função da coabitação familiar forçada (famílias que pretendem constituir um domicilio unifamiliar), dos moradores de baixa renda com dificuldades de pagar aluguel e dos que vivem em casas e apartamentos alugados com grande densidade.

Nesse sentido, o déficit habitacional pode ser entendido como déficit por reposição de estoque (enfoque qualitativo) e déficit por incremento de estoque (enfoque quantitativo). $\mathrm{Na}$ metodologia adotada o déficit por incremento de estoque contempla os domicílios improvisados, parte da coabitação familiar e dois tipos de domicílios alugados: os fortemente adensados e aqueles em que famílias pobres (renda familiar até três salários-mínimos) pagam $30 \%$ ou mais da sua renda para o locador. E para se chegar ao valor final do déficit, a metodologia envolve quatro componentes: (i) habitação precária; (ii) coabitação familiar; (iii) ônus excessivo com aluguel; (iv) adensamento excessivo.

O conceito de habitações precárias considera os domicílios rústicos e os domicílios improvisados no seu cálculo, por fazer sentido refletir sobre esses componentes de maneira conjunta. Já o conceito de domicílios improvisados engloba todos os locais e imóveis sem fins 
residenciais e lugares que servem como moradia alternativa (imóveis comerciais, embaixo de pontes e viadutos, carcaças de carros abandonados e barcos e cavernas, entre outros), sendo uma indicação clara da carência de novas unidades domiciliares.

O segundo componente do déficit é a coabitação familiar, que tradicionalmente, compreendia a soma das famílias conviventes secundárias que viviam junto a outra família no mesmo domicílio. Na nova fase da metodologia, desde 2007, a principal proposta de ajuste do modelo se refere à fórmula de apreensão desse componente.

O terceiro componente do indicador é o ônus excessivo com aluguel urbano, que corresponde ao número de famílias urbanas com renda familiar de até três salários-mínimos que moram em casa ou em apartamento (domicílios urbanos duráveis) e que despendem 30\% ou mais de sua renda com aluguel.

O quarto componente do déficit é o adensamento excessivo de moradores em domicílios alugados, que em 2007 sofreu um ajuste metodológico. Essa variável constitui o número médio de moradores superior a três pessoas por dormitório. Até 2007, constituía apenas um componente da inadequação de domicílios e não do déficit habitacional. Contudo, a partir de 2007, passou-se a considerar o déficit habitacional como um percentual dos domicílios com adensamento excessivo, envolvendo os apartamentos e as casas alugados.

A partir da análise da Figura 9, que se refere ao período de 2004 a 2014, percebe-se a diminuição do déficit habitacional, existindo uma tendência a estabilização entre 2011 e 2012, seguida da retomada do crescimento da variável a partir de 2014. Em todos os anos observados o déficit se apresenta concentrado na região Sudeste, seguida da região Nordeste. A primeira, devido à concentração populacional e a segunda, em função dos níveis de pobreza.

A partir de 2005, verifica-se a diminuição relativa entre essas duas regiões até 2009, indicando que os esforços na produção de unidades habitacionais podem ter contribuído para a diminuição do déficit de forma mais significativa no Sudeste. Contudo, em 2010 verifica-se novamente maior distância dos índices computados no Nordeste e no Sudeste. 


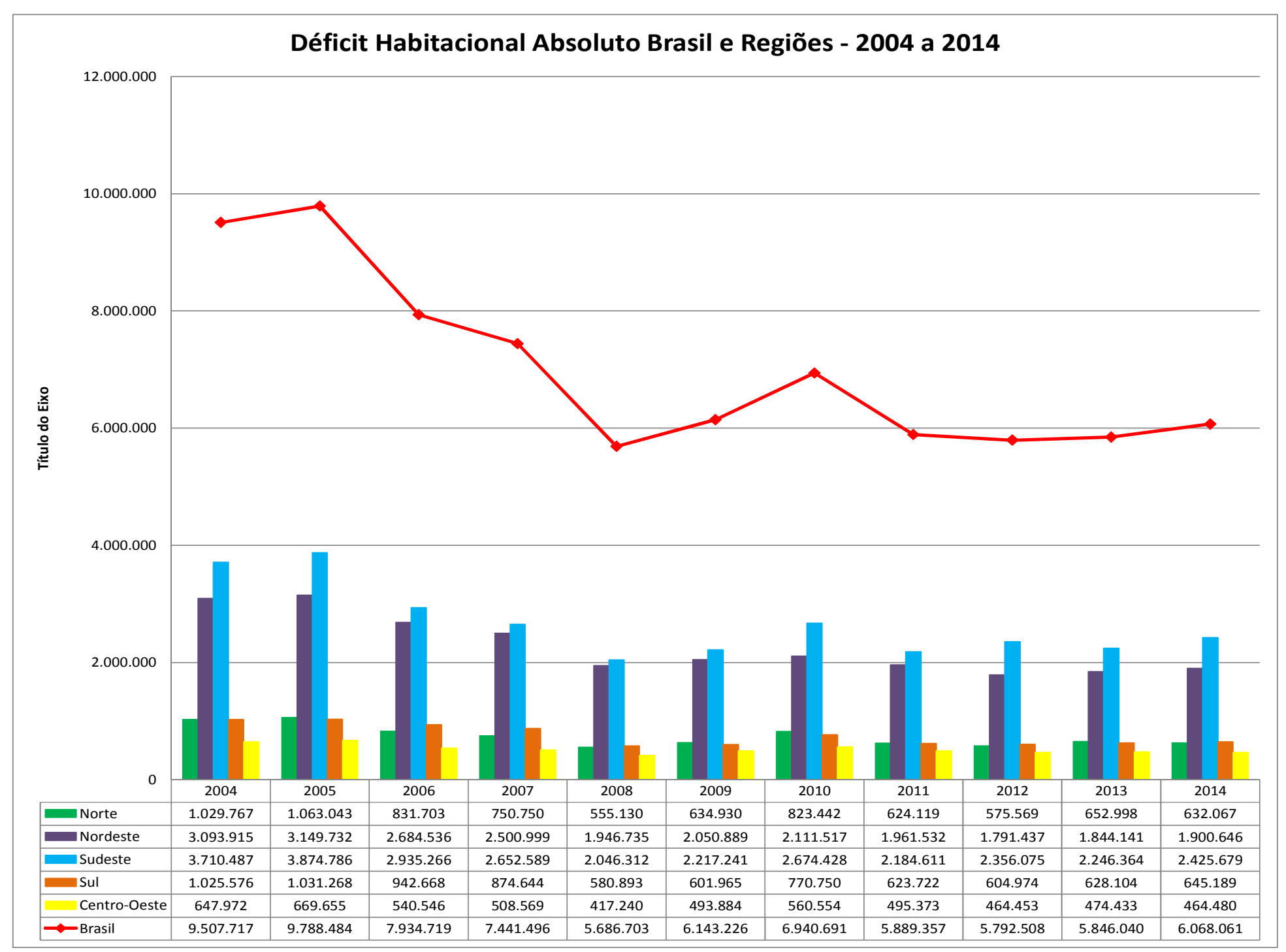

Figura 9 - Déficit habitacional absoluto no Brasil e regiões (2004 a 2014) Fonte: Fundação João Pinheiro, 2005, 2009, 2013, 2015, 2016. 
De acordo com as informações disponibilizadas pela Fundação João Pinheiro (2005), a análise por situação do domicílio revela comportamento distinto entre as regiões. De acordo com os autores, o crescimento em números absolutos do déficit habitacional na região Sudeste ocorreu em função de acréscimo significativo do déficit em áreas urbanas. Entre 1991 e 2000 houve o acréscimo de 490 mil domicílios para 563 mil, no período de 2000 a 2005. O contrário foi observado na região Nordeste, onde a demanda por moradias nas áreas rurais se mantém muito elevada, com pequena elevação em números absolutos do problema nas áreas urbanas.

Nessas duas regiões, responsáveis por mais de $70 \%$ das carências habitacionais do país, persiste a diferença na composição do déficit. Enquanto na Sudeste as áreas urbanas concentram mais de $90 \%$ das deficiências do setor, na região Nordeste representam 63,5\%, em 2000, e 67,2\%, em 2005. Esse padrão diferenciado de distribuição interna das carências habitacionais pode ser compreendido em função da observação das variáveis que compõem o déficit.

Nas Figuras 10 a 15 é possível conhecer de forma mais aprofundada as variáveis que compõem o cálculo de déficit habitacional no Brasil e por região. Observa-se que no ano de 2014, de maneira geral, o déficit habitacional no Brasil é principalmente composto pelo ônus excessivo com aluguel e coabitação familiar, correspondendo a $31,5 \%$ e a $48,23 \%$ do indicador, respectivamente.

A literatura aponta que existem distinções no comportamento desses componentes, dependendo da situação do domicílio e de sua localização regional. Entretanto, a coabitação familiar é a grande responsável pelas estimativas do déficit, não importa a região considerada. É um componente com características eminentemente urbanas, não tendo presença significativa nas áreas rurais. O contrário acontece com a habitação precária, que sobressai na zona rural e principalmente nas regiões Nordeste e Norte do país. Já o componente do ônus excessivo com aluguel é analisado apenas nas áreas urbanas e tem presença marcante principalmente nas regiões Sudeste e Centro-Oeste.

Nas regiões Norte e Nordeste, as menos desenvolvidas e com maior parcela de população rural, ainda é relevante o número das habitações precárias, com elevados 
percentuais também nas áreas urbanas. O ônus excessivo com aluguel, por outro lado, é menos significativo do que o observado nas regiões mais ao Sul do país.

A análise desses gráficos possibilita verificar que, no Brasil, outras variáveis de destaque na composição do déficit habitacional são o adensamento excessivo e a habitação precária que inverteram sua influência na composição do indicador. Em 2004, o adensamento excessivo era de $17,91 \%$ e passou para $6,05 \%$ em 2014 , enquanto a habitação precária aumentou de 10,00\% em 2004 para 14,22\% em 2014. Por outro lado, ao se analisar a condição das variáveis por regiões, verificam-se particularidades com relação às regiões Norte e Nordeste, visto que as regiões Sudeste, Sul e Centro-Oeste seguem o mesmo padrão de concentração no déficit com ônus excessivo com aluguel e coabitação familiar.

Entre 2004 e 2007 a componente adensamento excessivo era mais representativa na composição do déficit habitacional tanto com relação ao Brasil quanto em relação às grandes regiões. Em 2004, no país, existiam 1.703 .098 domicílios contabilizando o adensamento excessivo, enquanto em 2008 esse valor passou para 388.390 e 366.890 em 2014.

A partir dos dados apresentados, verifica-se que a componente ônus excessivo com aluguel é mais significativa na região Sudeste. Contudo, percebe-se seu aumento de forma mais contundente no Brasil e nas demais regiões partir de 2011, mesmo que em 2005 tenha apresentado decréscimo. Em 2005, o Norte apresentava 71.474 domicílios nessa condição, enquanto o Nordeste, o Sul e o Centro-Oeste apresentavam 377.549, 218.624, 174.309, respectivamente. Em 2014 esses valores estavam mais altos passando para 155.399 no Norte, 671.431 no Nordeste, 346.996 no Sul e 277.053 no Centro-Oeste.

Na região Norte, a coabitação familiar passa a ser mais representativa que o ônus excessivo com aluguel com percentuais de $44,35 \%$ e $24,58 \%$, respectivamente com aumento da variável habitação precária que passa para 24,07\%, enquanto a média no Brasil fica em torno de $14,22 \%$. Mas é no Nordeste que a variável habitação precária tem sua maior incidência chegando a $26,38 \%$ e quase igualando os percentuais entre ônus excessivo com aluguel e coabitação familiar de $35,33 \%$ e $34,28 \%$. 
Na região Sudeste, a habitação precária é menos relevante, com os menores percentuais do país. Por outro lado, é nessa região que o ônus excessivo com aluguel assume maior relevância, devido ao reflexo da presença das aglomerações urbanas nas regiões metropolitanas.

Também foi destacada na publicação a importância relativa das habitações precárias no Sul, provavelmente em função do padrão de construção característico dessa região, onde é comum a presença de casas de madeira aparelhada. Isso pode ter incorrido em problemas de interpretação por parte de entrevistadores do IBGE, superestimando o número de habitações consideradas rústicas.

A partir das análises da evolução das componentes do déficit habitacional, bem como sua representação de forma regionalizada, verifica-se que é preciso adotar especificidades na própria política de habitação, tendo em vista modificar a condição crítica identificada em cada região do Brasil.

A consideração dessas particularidades poderá orientar as alternativas técnicas visando ao tratamento adequado do problema, considerando as peculiaridades de cada componente. Como exemplo, é possível discutir se a construção de novas unidades habitacionais, inserida na cultura de aquisição da casa própria, é de fato a melhor alternativa para "combater" a componente ônus excessivo com aluguel que é mais concentrado no Sudeste. Analogamente, é possível se questionar quanto à alternativa de construção de novas moradias nas regiões Norte e Nordeste onde a componente habitação precária se mostra mais impactante. 


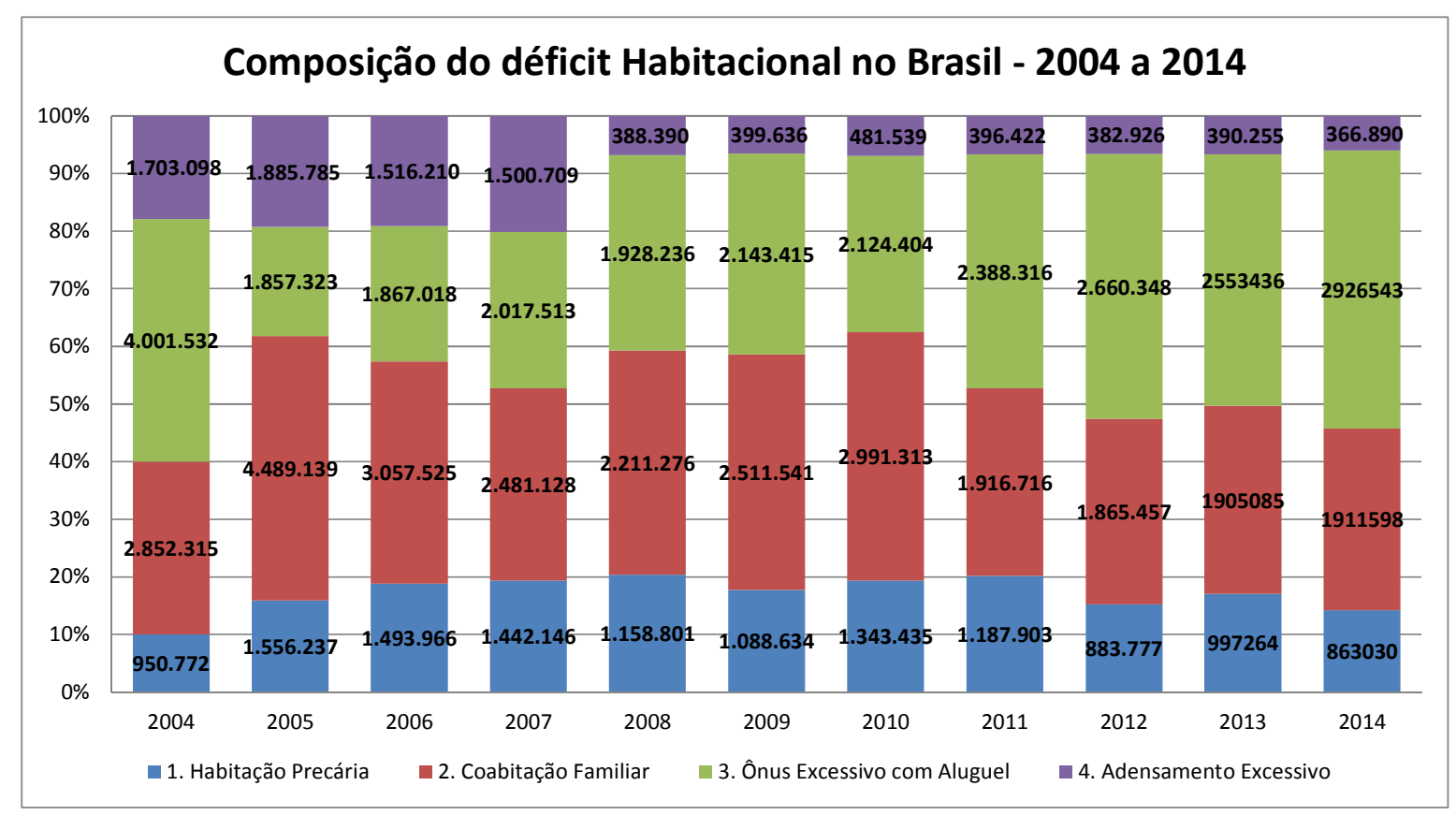

Figura 10 - Composição do déficit habitacional no Brasil Fonte: Fundação João Pinheiro, 2005, 2009, 2013, 2015, 2016.

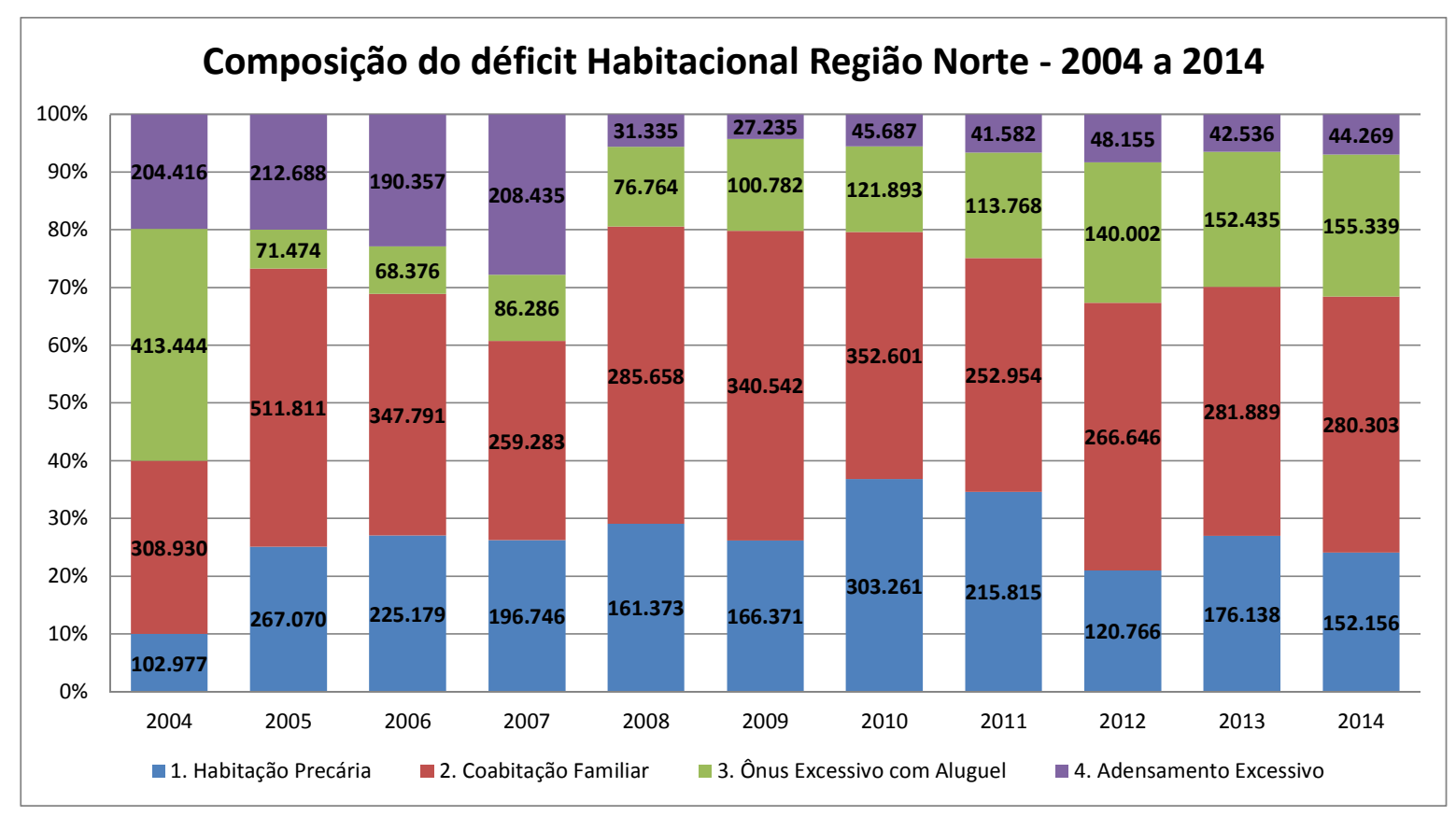

Figura 11 - Composição do déficit habitacional na região Norte Fonte: Fundação João Pinheiro, 2005, 2009, 2013, 2015, 2016. 


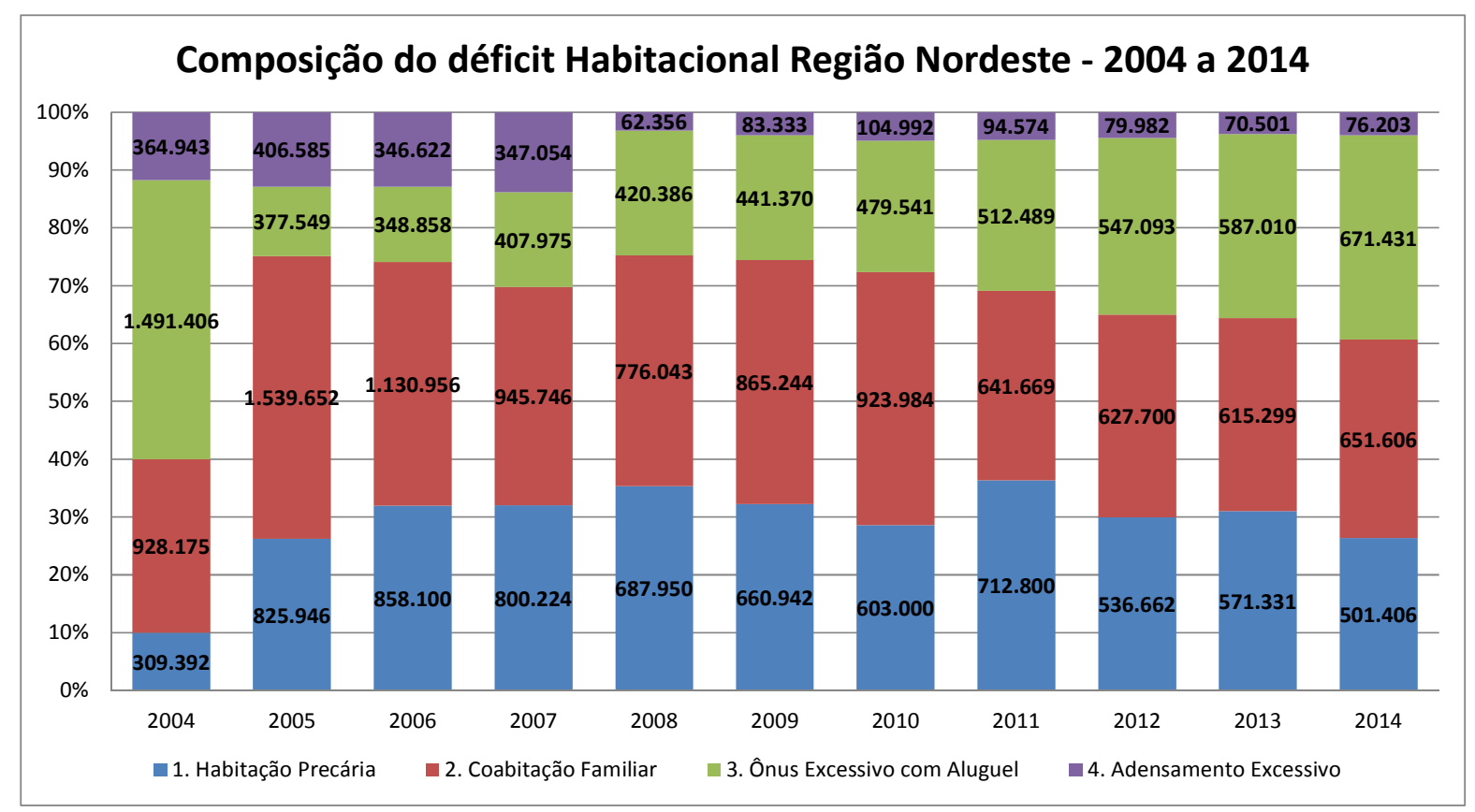

Figura 12 - Composição do déficit habitacional na região Nordeste Fonte: Fundação João Pinheiro, 2005, 2009, 2013, 2015, 2016.

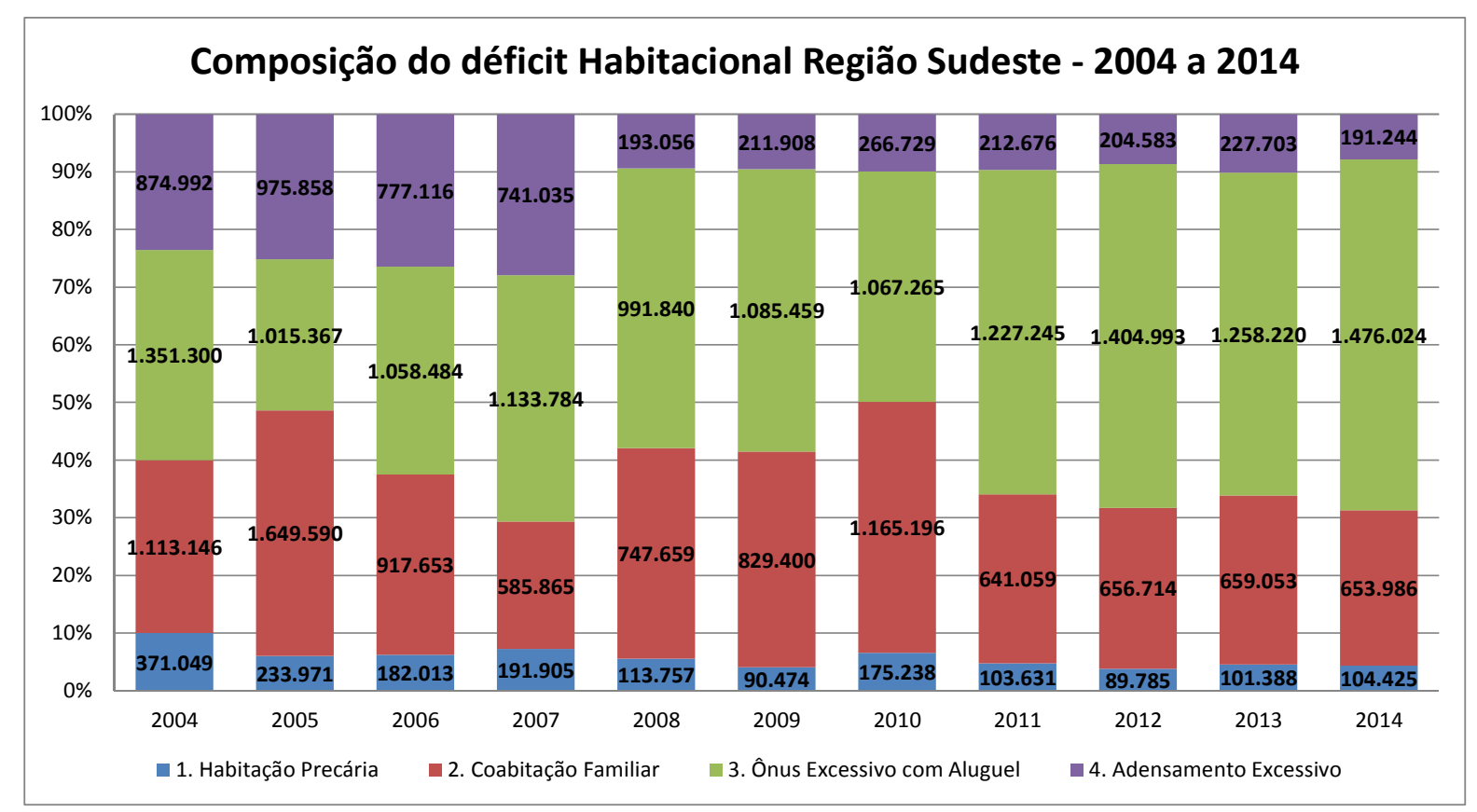

Figura 13 - Composição do déficit habitacional na região Sudeste Fonte: Fundação João Pinheiro, 2005, 2009, 2013, 2015, 2016. 


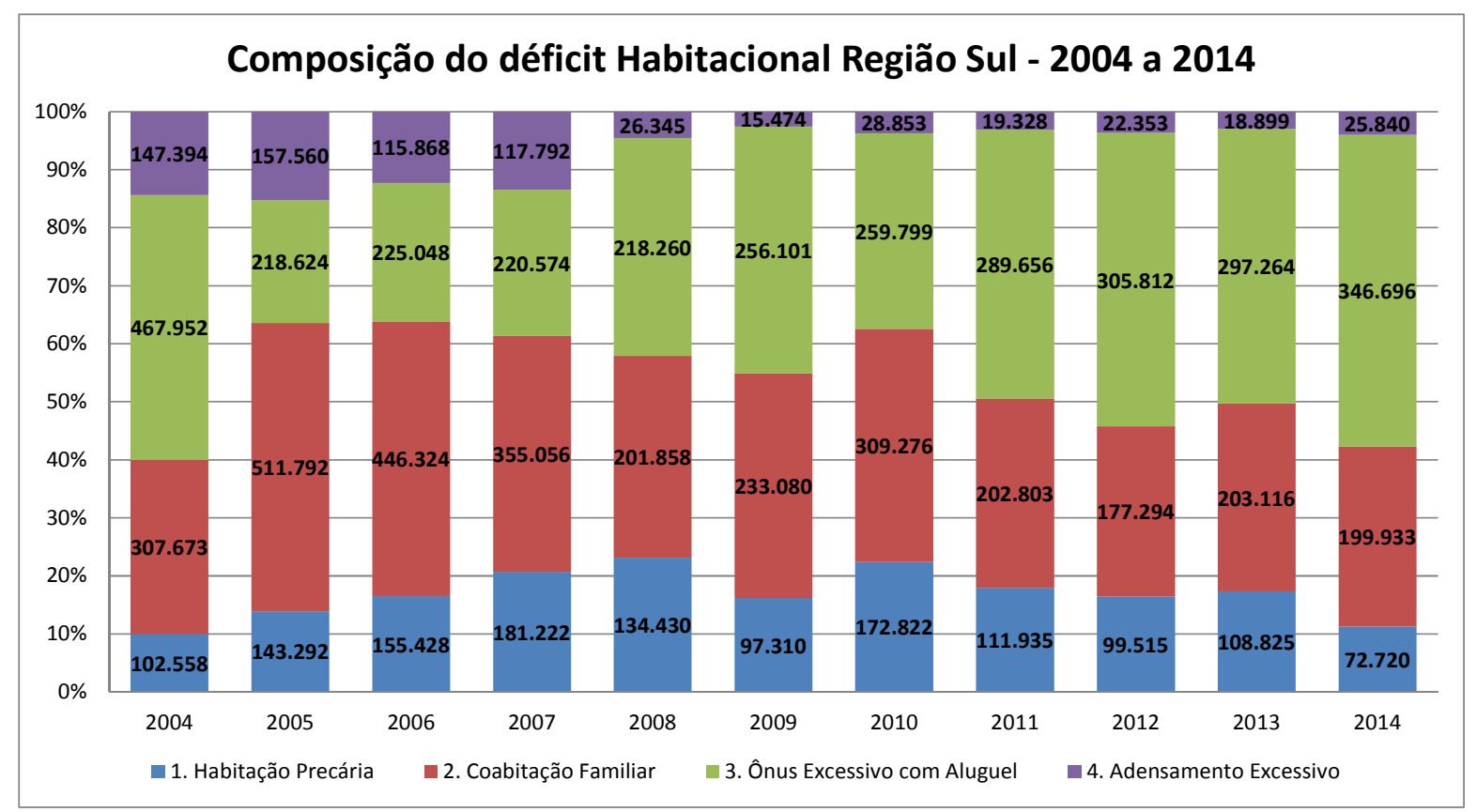

Figura 14 - Composição do déficit habitacional na região Sul Fonte: Fundação João Pinheiro, 2005, 2009, 2013, 2015, 2016.

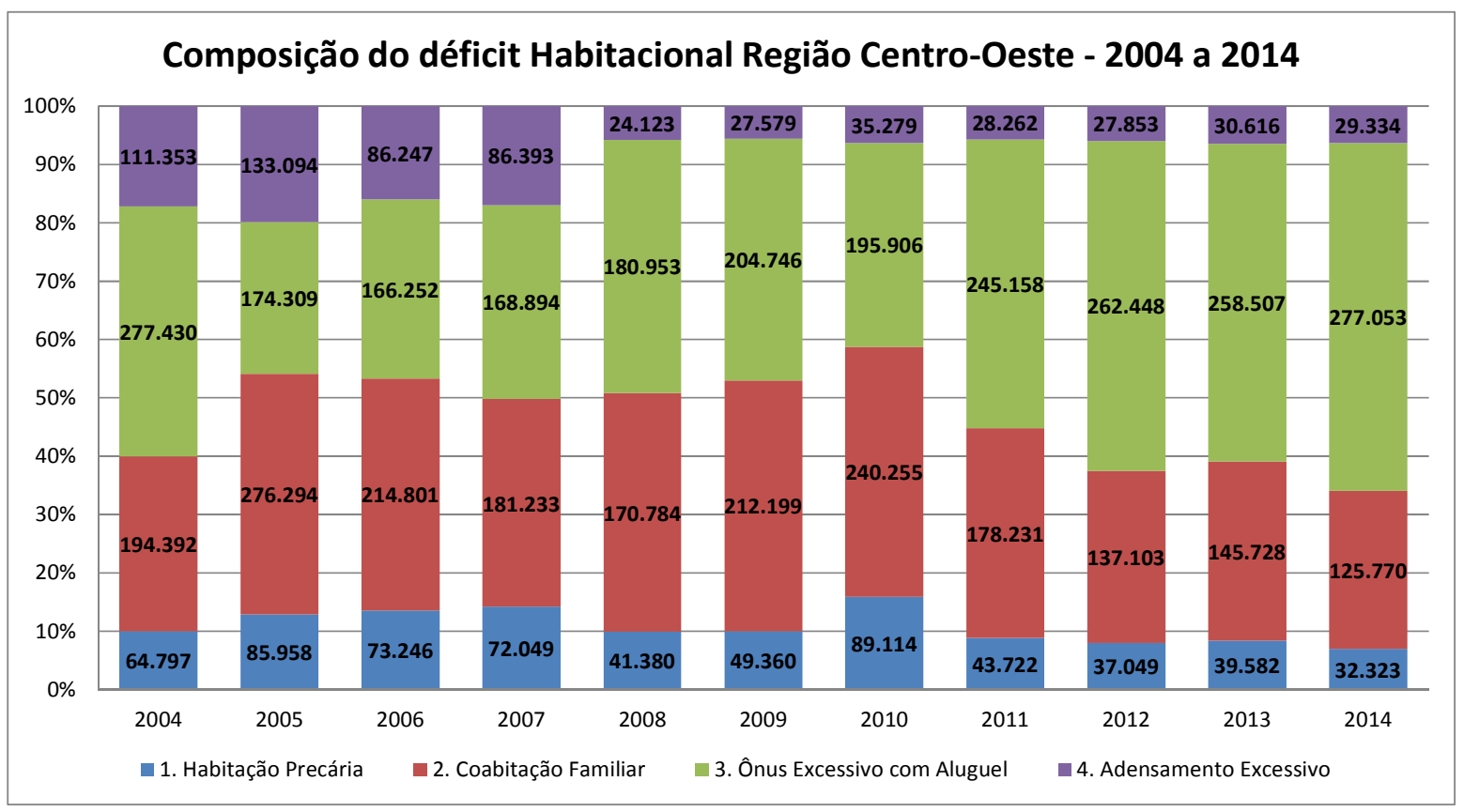

Figura 15 - Composição do déficit habitacional na região Centro-Oeste Fonte: Fundação João Pinheiro, 2005, 2009, 2013, 2015, 2016.

Outra forma de analisar o déficit habitacional envolve o estudo das variáveis que compõem a inadequação dos domicílios, conforme os dados apresentados nas Figuras 16 a 21. Uma das estratégias para diminuir o déficit habitacional poderia concentrar esforços 
em sanar as deficiências nos domicílios que apresentassem as condições legais, técnicas e fundiárias de receber as devidas melhorias. Para esses casos, não deveria ser indicada a construção de novas moradias, mas sim a realização de reparos e adequações.

Segundo a metodologia da Fundação João Pinheiro, as habitações inadequadas não proporcionam condições desejáveis de habitação, o que não implica necessidade de construção de novas unidades. Pelo conceito adotado, são identificadas apenas as inadequações localizadas em áreas urbanas. As áreas rurais não são contempladas no cálculo, pois apresentam formas diferenciadas de adequação, não captadas pelos dados utilizados. São também excluídos do estoque a ser analisado os domicílios inseridos em alguma das categorias do déficit habitacional.

Ao contrário do déficit, os critérios adotados para a inadequação habitacional não são mutuamente exclusivos, por isso, os resultados não podem ser somados, sob risco de múltipla contagem, visto que a mesma moradia pode ser simultaneamente inadequada segundo vários critérios. Além disso, eles são apresentados de forma segmentada para possibilitar a elaboração de políticas públicas específicas, bem como para fornecer informações particulares que permitam ao poder público estabelecer diferentes prioridades par atuar segundo cada tipo de inadequação.

A classificação de domicílios inadequados envolve a carência de infraestrutura, o adensamento excessivo de moradores em domicílios próprios, problemas de natureza fundiária, cobertura inadequada e ausência de unidade sanitária domiciliar exclusiva ou em alto grau de depreciação. Para a composição dos gráficos deste estudo descartou-se a variável cobertura inadequada por falta de dados para compor a série histórica de 2004 a 2014, embora esta seja citada pela Fundação João Pinheiro.

São considerados domicílios carentes de infraestrutura todos aqueles que não dispõem de ao menos um dos seguintes serviços básicos: iluminação elétrica, rede geral de abastecimento de água com canalização interna, rede geral de esgotamento sanitário ou fossa séptica e coleta de lixo.

Para o cálculo do adensamento excessivo são considerados apenas os domicílios (casas e apartamentos) próprios, visto que os alugados são incorporados aos cálculos do 
déficit habitacional. Essa variável caracteriza situação em que o número médio de moradores no domicílio é superior a três por dormitório.

A condição de inadequação fundiária diz respeito aos casos em que pelo menos um dos moradores do domicílio tem a propriedade da moradia, mas não, total ou parcialmente, a do terreno ou da fração ideal de terreno (no caso de apartamento) onde ela está localizada. É importante salientar que a incidência dessa inadequação está longe de se restringir aos aglomerados subnormais por atingir muitos bairros populares, especialmente aqueles localizados nos subúrbios e nas periferias das grandes metrópoles.

A inexistência de unidade sanitária domiciliar exclusiva é o termo adotado para definir o domicílio que não dispõe de banheiro ou sanitário de uso exclusivo. Esse fato ocorre nos cortiços tradicionais (em trajetória de extinção ou de transformação) bem como em terrenos com dois ou mais domicílios.

Além desses componentes, foi apontada pela Fundação João Pinheiro a necessidade de ser considerada uma parcela de domicílios levando em conta a depreciação dos imóveis. Essa parcela é definida como o complemento dos domicílios com mais de 50 anos de construção que requerem reposição e, por isso, são incluídos no déficit habitacional.

Assim, os imóveis com mais de 50 anos que não devem ser repostos, não entram no cálculo do déficit, precisando apenas de manutenção ou de reparação. Por outro lado, a componente depreciação de domicílios não é calculada em razão da inexistência de informações, tanto no nível nacional como no regional. 


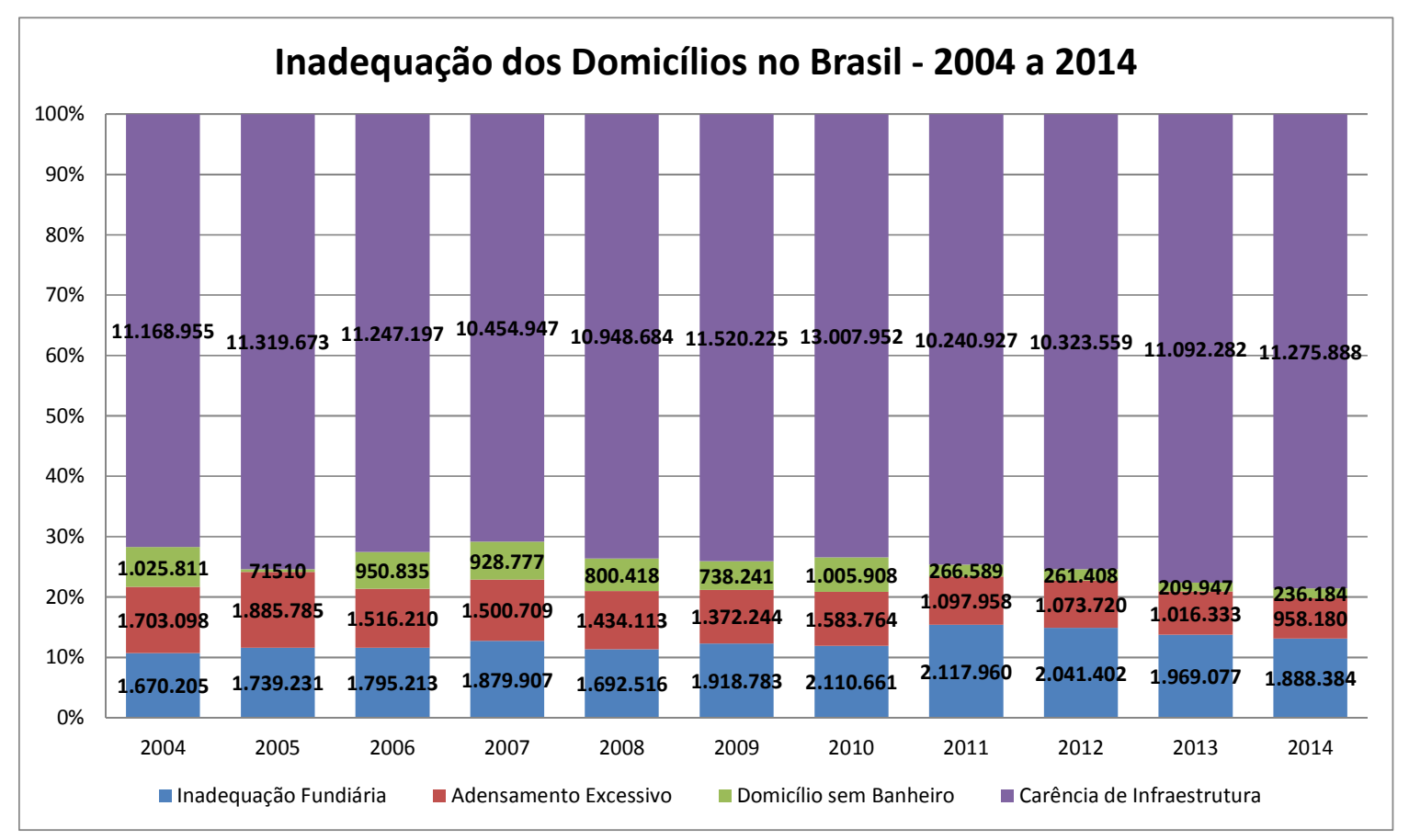

Figura 16 - Inadequação dos domicílios no Brasil

Fonte: Fundação João Pinheiro, 2005, 2009, 2013, 2015, 2016.

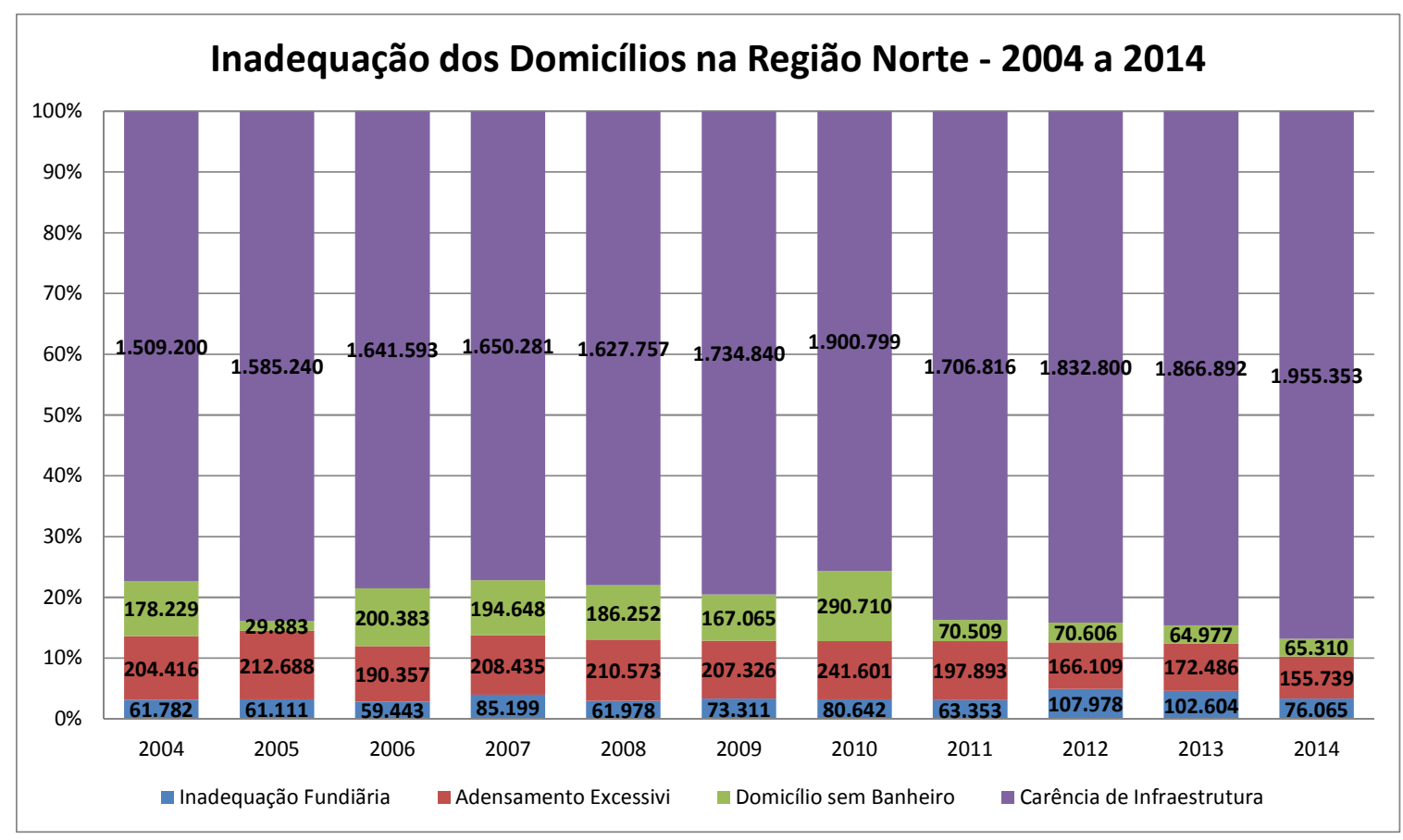

Figura 17 - Inadequação dos domicílios na região Norte

Fonte: Fundação João Pinheiro, 2005, 2009, 2013, 2015, 2016. 


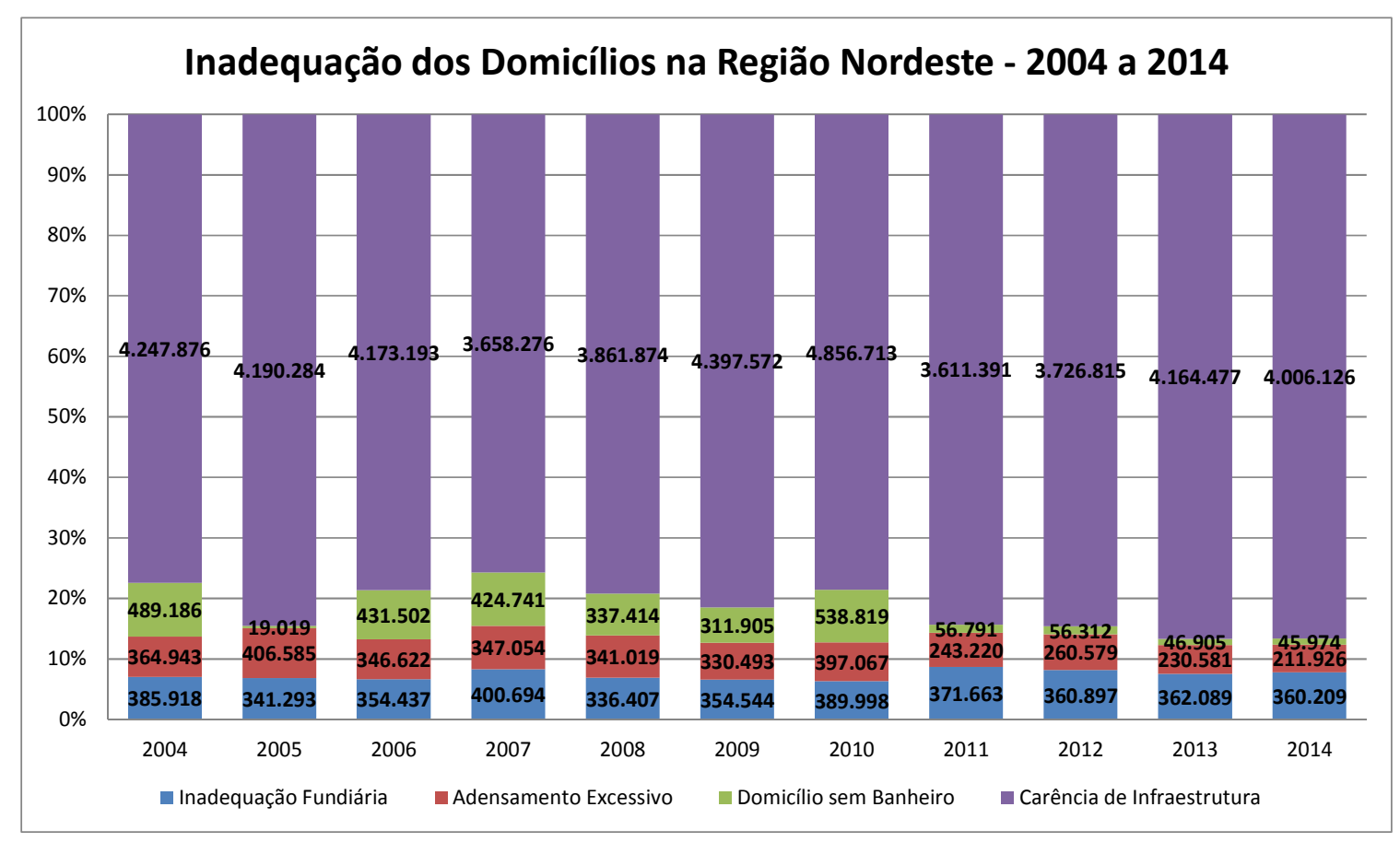

Figura 18 - Inadequação dos domicílios na região Nordeste

Fonte: Fundação João Pinheiro, 2005, 2009, 2013, 2015, 2016.

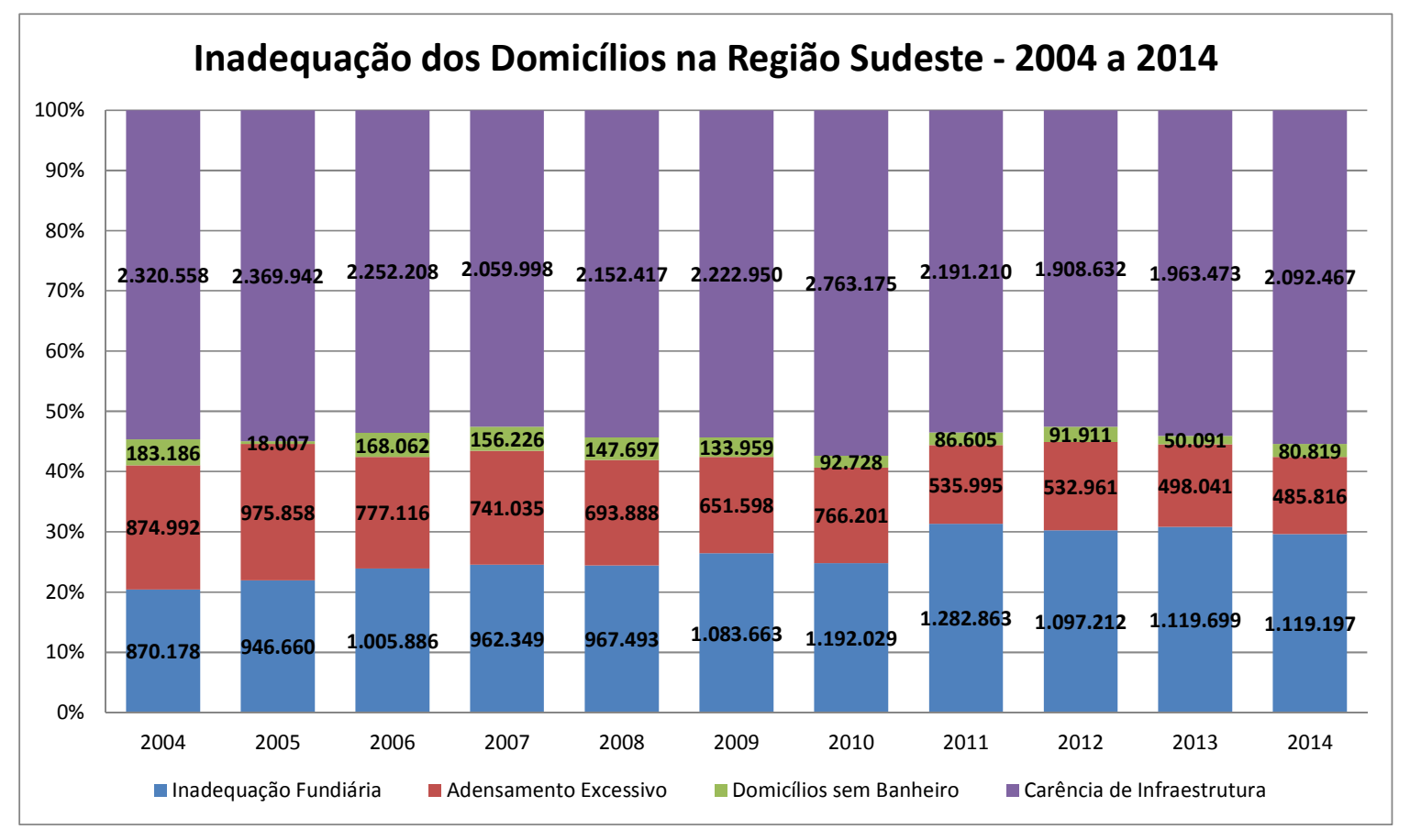

Figura 19 - Inadequação dos domicílios na região Sudeste Fonte: Fundação João Pinheiro, 2005, 2009, 2013, 2015, 2016. 


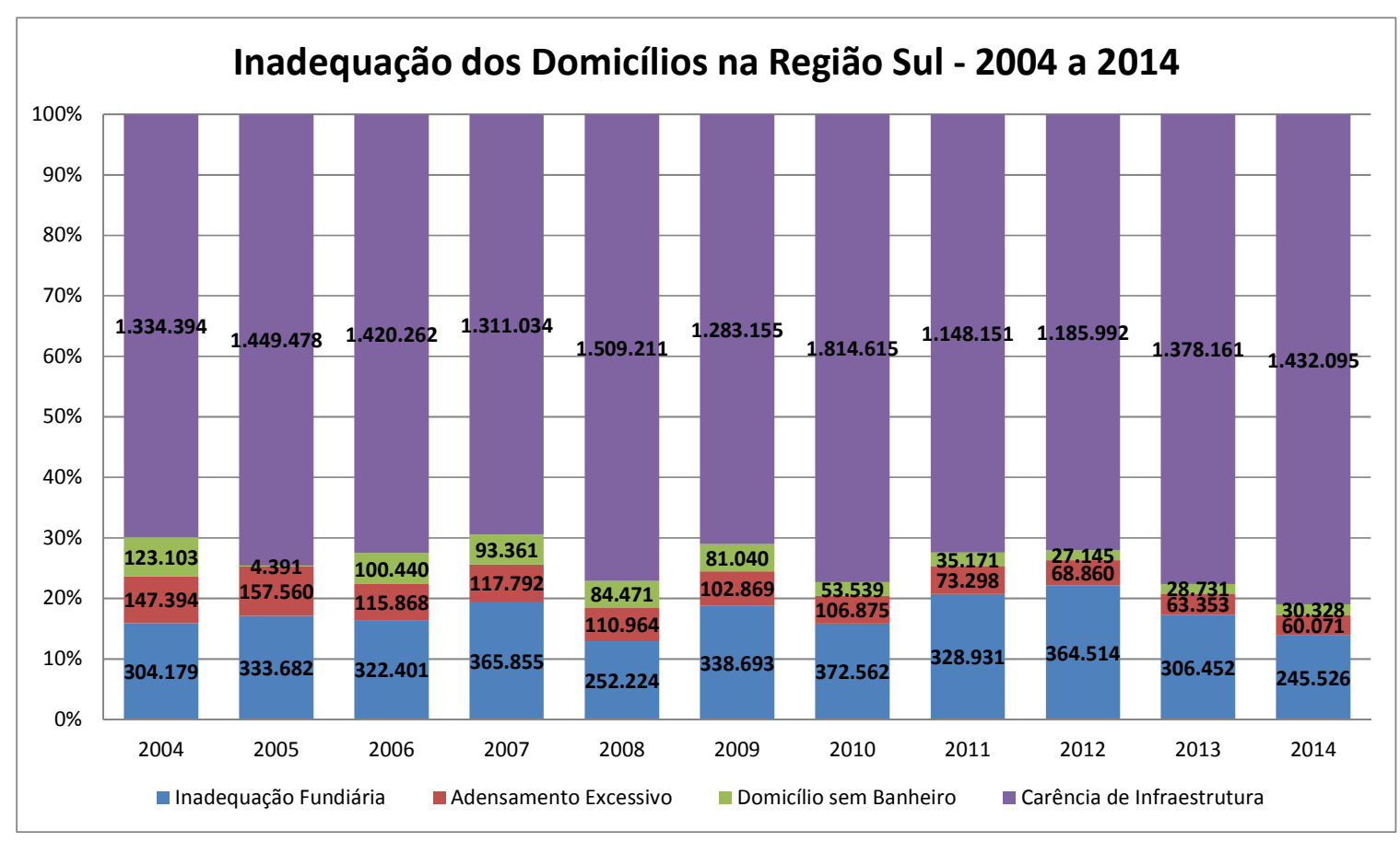

Figura 20 - Inadequação dos domicílios na região Sul

Fonte: Fundação João Pinheiro, 2005, 2009, 2013, 2015, 2016.

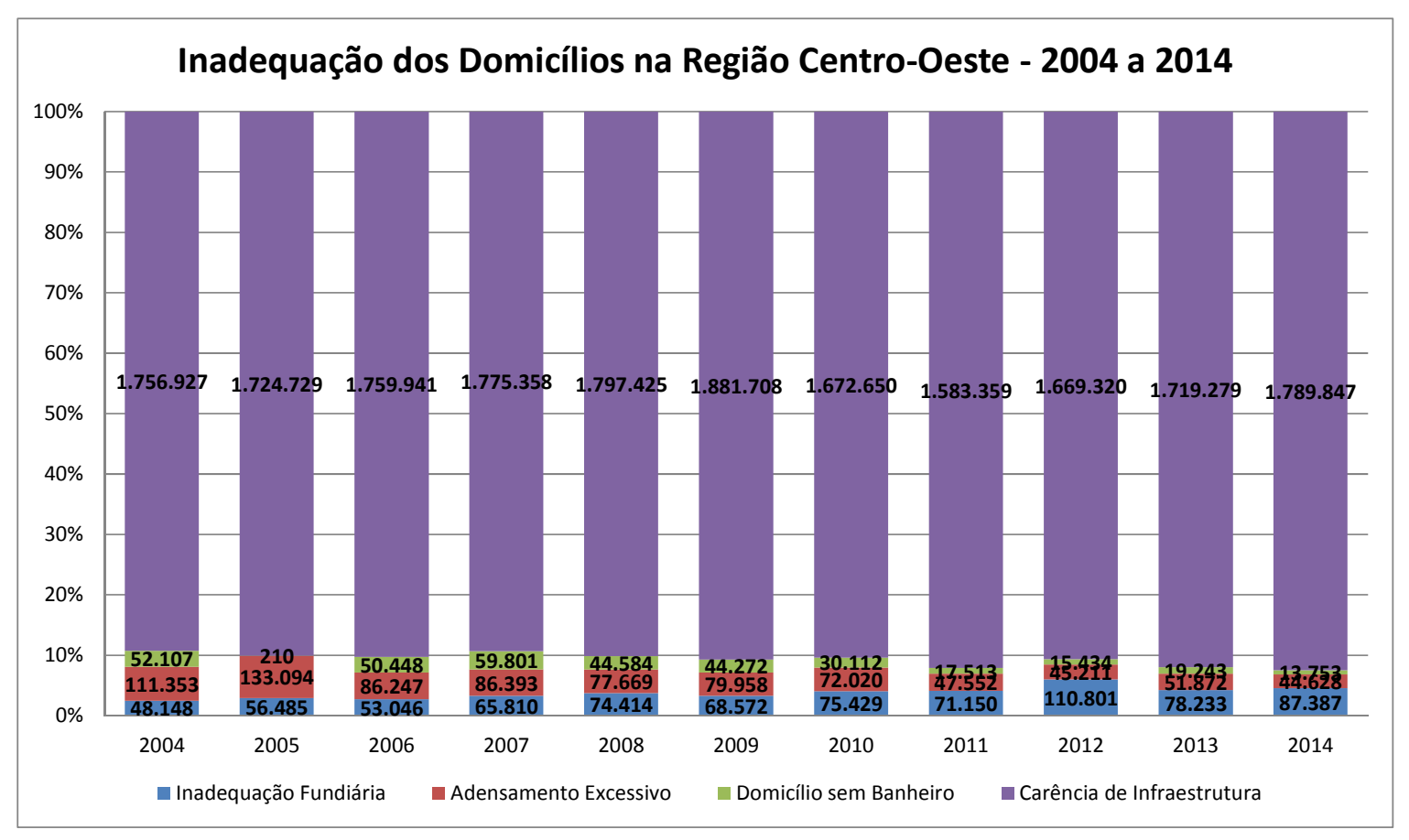

Figura 21 - Inadequação dos domicílios na região Centro-Oeste Fonte: Fundação João Pinheiro, 2005, 2009, 2013, 2015, 2016. 
A qualidade dos serviços básicos de infraestrutura está diretamente relacionada ao problema de inadequação dos domicílios, visto que as deficiências em qualquer um desses serviços afetam significativamente as condições de vida da população, além de resultarem em sérios problemas sociais, ambientais e de saúde. A identificação dos domicílios carentes em infraestrutura é realizada com o objetivo de dimensionar essas deficiências. É preciso destacar que apenas são passíveis de avaliação os domicílios que não são considerados em situação de déficit habitacional. Dessa forma, os números retratam a situação de uma parcela dos domicílios urbanos, e não com relação à totalidade deles.

A carência de infraestrutura é definida como ausência de atendimento adequado em um ou mais dos serviços básicos considerados (iluminação elétrica, rede geral de abastecimento de água, rede geral de esgotamento sanitário ou fossa séptica e coleta de lixo) e constitui o fator que mais contribui para que o domicílio seja classificado como inadequado. Isso ocorre quando se observam os dados relativos ao Brasil e às grandes regiões.

A partir da Figura 16, verifica-se que, no Brasil, em 2014, existiam mais de 11 milhões de moradias apresentando deficiência nos serviços de infraestrutura, representando $25,1 \%$ do estoque de domicílios urbanos que estão inadequados. Desse modo, os demais critérios apresentam menor relevância, não chegando a impactar 5\% dos domicílios. Contudo, é preciso destacar que, embora façam parte das componentes de menor peso, a inadequação fundiária e o adensamento excessivo constituem critérios com características ligadas mais diretamente às grandes aglomerações urbanas localizadas nas regiões metropolitanas.

As deficiências nos serviços de infraestrutura estão principalmente relacionadas às condições socioeconômicas da população, sendo, independentemente da região, o maior fator de inadequação dos domicílios, a carência de infraestrutura. Essa variável está concentrada na região Nordeste e, em 2014, existiam 4.190.284 domicílios, 42,6\% do estoque de moradias urbanas com esse tipo de carência, enquanto nas regiões Norte e Centro-Oeste, a situação se apresentou de forma mais contundente, estando presente em $1.955 .353(56,9 \%)$ e $1.789 .847(52,0 \%)$ dos domicílios, respectivamente. Nas regiões Norte e Centro-Oeste, mais de $50 \%$ dos domicílios não são atendidos por serviços adequados. 
Esses dados podem reforçar a ideia sobre a adoção de novas possibilidades para a diminuição do déficit habitacional, restando descobrir o quanto dessas deficiências com infraestrutura pode ser resolvido com a melhoria na prestação de serviços, e em outras carências com infraestrutura.

A análise das variáveis adensamento excessivo e inadequação fundiária mostra que apenas na região Sudeste são observados números absolutos mais significativos, chegando a mais de um milhão de domicílios em 2014. Acredita-se que grande parte disso ocorra devido às características predominantes nas regiões metropolitanas. Devido ao seu volume populacional, a região Sudeste sempre tem maior relevância, independente do problema considerado. Essas questões se tornam ainda mais acentuadas quando são considerados os problemas mais característicos das grandes aglomerações urbanas.

Por outro lado, em se tratando dos domicílios com deficiências diretamente relacionadas às condições socioeconômicas da população, tais como as carências de infraestrutura e de domicílios sem banheiro, verifica-se que a Região Nordeste concentra as ocorrências, sendo seguida pela região Norte. No caso das deficiências dos serviços básicos, tem destaque a região Centro-Oeste.

A componente inadequação fundiária é utilizada para classificar os domicílios em que os moradores declaram ter a posse do imóvel, mas não a do terreno. Em função disso, esse indicador está sujeito a grandes problemas de apreensão, com tendência à subestimação. Contudo, isso não invalida a tentativa de quantificação do problema. Embora a inadequação fundiária esteja, em grande parte, vinculada às populações de renda mais baixa, a análise por faixas de renda, detecta uma proporção que não deve ser desconsiderada entre as famílias de renda mais elevada.

A região Sudeste apresenta a maior concentração de domicílios em situação de inadequação fundiária, totalizando 1.119.197 domicílios em 2014. Comparando esse dado com o ano de 2004, observa-se um aumento de 128,6\%, visto que nesse ano existiam 870.178 domicílios nessa situação. Isso se justifica por ser mais acentuada em regiões metropolitanas e mais populosas e também por possivelmente estar associada à incidência de assentamentos subnormais. 
Embora essa variável apresente menor incidência nas demais regiões, apresentou crescimento no período de 2004 a 2014, com exceção da região sul que teve uma leve redução, passando de 304.179 para 245.526 domicílios. As regiões Norte, Nordeste e Centro-Oeste aumentaram a incidência da variável, passando em 2004 de 61.782, 385.918, 48.148 para $76.065,360.209$ e 87.387 em 2014, respectivamente.

A próxima componente a ser analisada é o adensamento excessivo que classifica os domicílios urbanos com mais de três moradores por dormitório. Considerando a orientação das alternativas das políticas habitacionais, esses dados são disponibilizados separadamente para casas e apartamentos por possibilitar soluções diferenciadas para ambas as situações. Em se tratando de casa, podem ser determinadas linhas de financiamento voltadas para a ampliação ou reforma das moradias, enquanto para os apartamentos poderiam ser definidas políticas que facilitassem a aquisição de casa própria ou a adequação do mercado de imóveis e do setor de aluguéis.

A partir da figura 16, verifica-se que o adensamento excessivo no Brasil vem se mantendo constante no período de 2004 a 2014, apresentando uma redução sensível apenas no último ano da série, passando de 1.703 .098 para 958.180 domicílios.

A região Sudeste concentra em torno de $52 \%$ dos domicílios do país nessa situação, totalizando 485.816 em 2014. Entretanto, o problema é mais relevante na Região Norte, sendo esta a segunda componente mais relevante no cálculo da inadequação dos domicílios, totalizando 155.739 unidades. Ressalta-se que essa situação é mais agravada nas grandes aglomerações urbanas.

Como domicílio sem banheiro foram classificados aqueles que não dispunham de instalações exclusivas dos moradores. A ausência dessas instalações está diretamente relacionada às condições socioeconômicas da população e tem uma ligação direta com a incidência de doenças de veiculação e origem hídrica. Também se acredita que grande parcela desses domicílios também esteja inserida no universo de domicílios carentes de infraestrutura e localizados nas regiões menos desenvolvidas.

Na Figura 16, verifica-se que a incidência de domicílios sem banheiro vem diminuindo drasticamente no universo de domicílios inadequados, passando de 1.025.811 em 2004 para 236.184 domicílios em 2014, no Brasil. Esse comportamento também se 
repete em todas as demais regiões, tendo o menor valor na região Centro-Oeste de 13.753 em 2014. Vale destacar a mudança do comportamento dessa variável nas regiões Norte e Nordeste que, até 2010, apresentavam números alarmantes, tendo assumido a tendência do Brasil e das demais regiões, apontando redução a partir de 2011. Em 2004, a região Norte apresentava 178.229 domicílios sem banheiros, enquanto a região nordeste apresentava 489.186 domicílios. Em 2014 a variável havia reduzido para 65.310 e 45.974 domicílios sem banheiro para Norte e Nordeste, respectivamente. Destaca-se que quase todos esses domicílios também são carentes de infraestrutura.

Para se fazer uma análise mais aprofundada desse dado é preciso proceder algumas relativizações, visto que características ambientais e culturais levam a população a adotar soluções diferentes das convencionalmente aceitas e indicadas. Nas regiões Sudeste, Sul e Centro-Oeste, apesar da presença pouco significativa, há uma diferença considerável em relação aos domicílios carentes também de infraestrutura, principalmente nas duas primeiras. Esse fato indica que, apesar da pequena quantidade, nessas regiões, parcela razoável das moradias informa não ter problemas quanto aos serviços básicos, mas utilizam banheiro comum a mais de um domicílio.

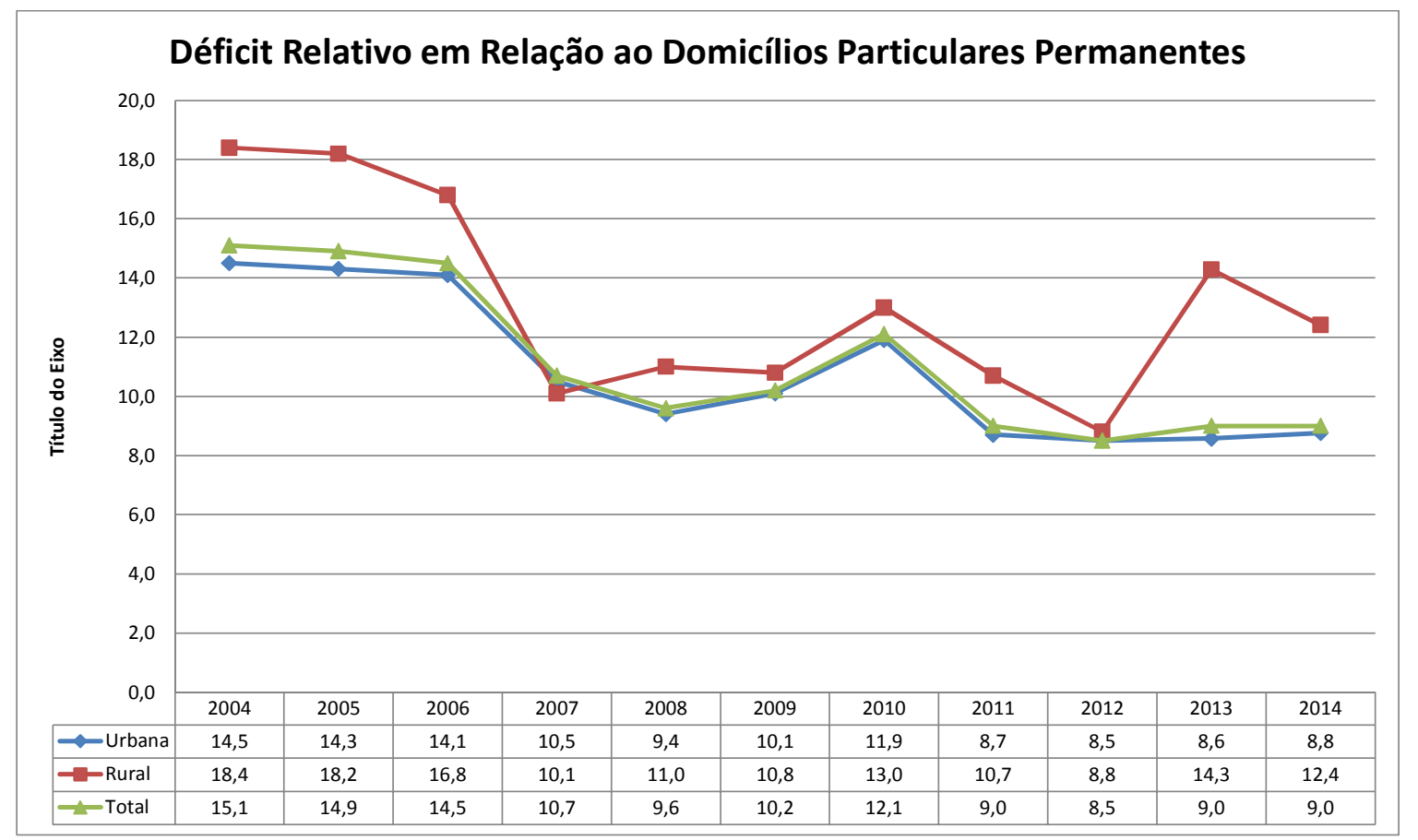

Figura 22 - Déficit habitacional relativo no Brasil segundo situação do domicílio Fonte: Fundação João Pinheiro, 2005, 2009, 2013, 2015, 2016. 
De acordo com a Figura 22, o déficit habitacional relativo no Brasil segundo a situação do domicílio (rural ou urbano) vem apresentando queda desde 2004, voltando a assumir valores mais elevados em 2013 e 2014. Verifica-se que a partir de 2006, o comportamento relativo do déficit total, cada vez mais, vem ocorrendo de forma similar ao comportamento da curva relativa às áreas urbanas desde 2006.

Também se destaca que o déficit relativo nas áreas rurais ainda é muito superior do que o observado nas áreas urbanas. A partir de 2013 esse dado voltou a crescer de forma significativa, indicando que os esforços das políticas habitacionais para a diminuição do déficit habitacional devem estar priorizando as áreas urbanas. Em 2014, 88,36\% dos municípios brasileiros apresentaram população de até 50 mil habitantes, sendo relevante estabelecer ações específicas com foco nos municípios desse menor porte.

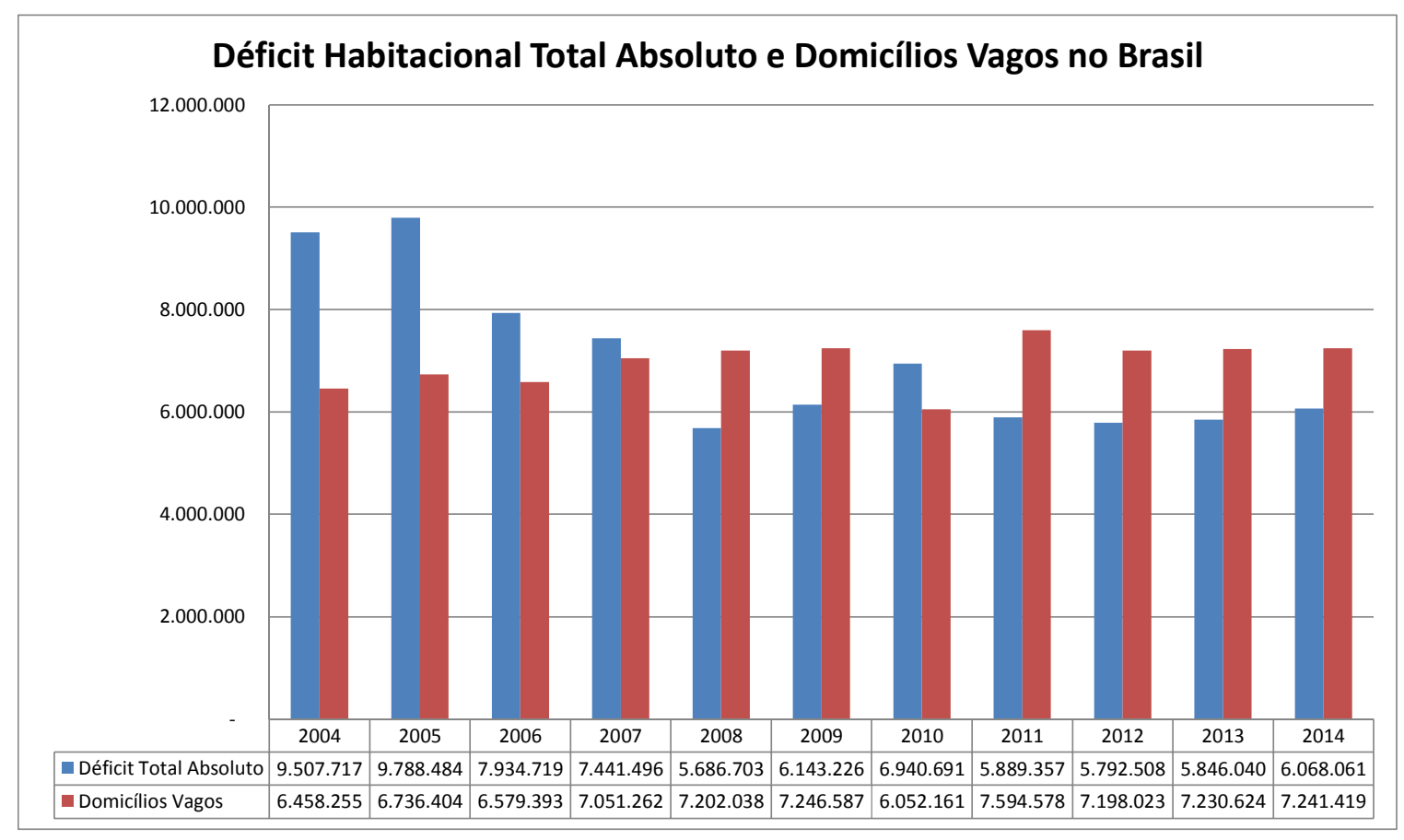

Figura 23 - Déficit habitacional absoluto no Brasil e domicílios vagos Fonte: Fundação João Pinheiro, 2005, 2009, 2013, 2015, 2016 e IBGE.

Segundo a Fundação João Pinheiro, em comparação ao estoque de domicílios particulares permanentes, em 2014, os domicílios vagos representavam 12,7\% do total, sendo a taxa um pouco mais baixa nas áreas urbanas, 11,3\%. Esses percentuais não sofrem alterações relevantes entre as regiões, observando-se pontualmente, em algumas unidades da Federação, valores mais ou menos acentuados. Em números absolutos, existiam 
6.736.404 domicílios vagos no Brasil em 2014, sendo 5.084.284 nas áreas urbanas. Nas regiões metropolitanas havia 1.899.184 domicílios vagos, representando $11,4 \%$ do total.

De acordo com a Figura 23, observa-se a diminuição do déficit habitacional absoluto no Brasil a partir de 2006, tendo o comportamento praticamente se estabilizado a partir de 2008, com um pico em 2010. Embora exista uma tendência à estabilização desse déficit, percebe-se uma leve tendência de crescimento a partir de 2014.

Uma inferência importante que se pode fazer a partir do cruzamento entre os dados relativos ao déficit absoluto e o número de domicílios vagos no Brasil, é que o segundo vem se mantendo praticamente constante no período de 2004 a 2014. Além disso, a partir de 2008, essa variável ultrapassa a necessidade de novos domicílios. Isso indica que os esforços referentes à política habitacional recente, devem estar, prioritariamente, aumentando o estoque de domicílios que não podem ser adquiridos pelo público alvo que compõe o maior quantitativo de população que faz parte do déficit habitacional.

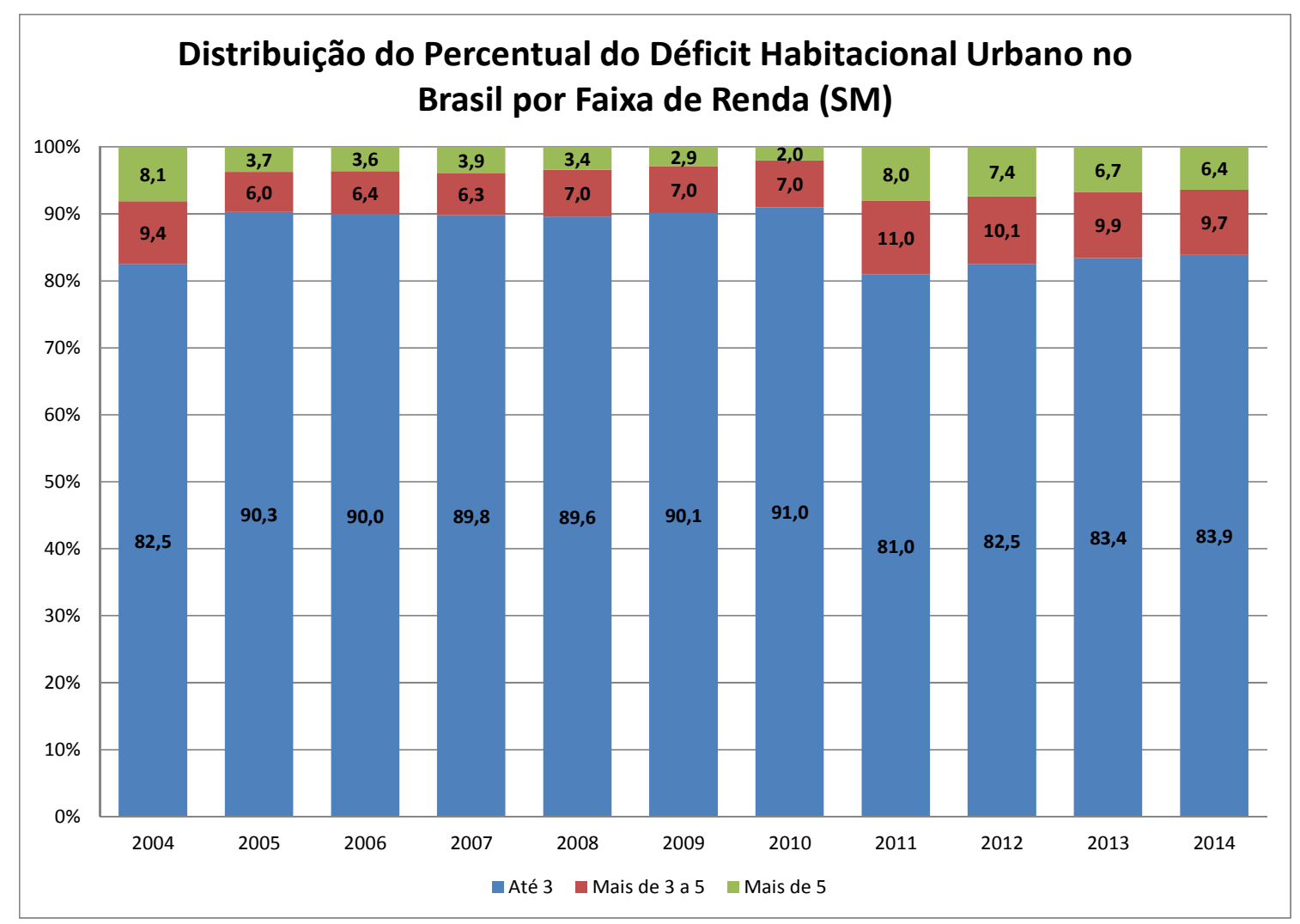

Figura 24 - Distribuição do déficit habitacional urbano no Brasil por faixa de renda Fonte: Fundação João Pinheiro, 2005, 2009, 2013, 2015, 2016 e IBGE. 
A análise da Figura 24 complementa os aspectos discutidos quanto à relação existente entre o déficit habitacional absoluto no Brasil e o quantitativo de domicílios vagos no período de 2004 a 2014, considerando apenas o segmento urbano da população. Assim, verifica-se que entre 2005 e 2010, o déficit habitacional urbano por faixa de renda apresentou a incidência em torno de $90 \%$ na população de menor renda com até 3 salários mínimos.

Apesar de ser observada uma diminuição para a faixa dos $80 \%$, o déficit continua tendo maior concentração na população de menor renda. Também se destaca o fato de se observar um leve crescimento dessa variável a partir de 2011 e se perpetuando até 2014, indicando que os esforços da política habitacional praticada no período não estão sendo suficientes para inverter essa situação.

Normalmente, as políticas públicas sociais concebidas e implementadas visando à melhoria das condições de vida da população, têm como foco a parcela populacional mais carente e que dispõe de menos recursos. No caso da problemática habitacional, grande parte das ações governamentais está direcionada às famílias que recebem até três salários mínimos, segmento em que a falta de moradias assume sua dimensão mais drástica.

Percebe-se então, que quase a totalidade das famílias que necessitam de uma nova moradia faz parte da população que ganha até cinco salários mínimos ou menos por mês, totalizando 93,6\% no Brasil em 2014. A concentração das carências ocorre na faixa mais baixa de renda de até três salários mínimos, correspondendo a 83,9\% do déficit.

Segundo a Fundação João Pinheiro, esse padrão se repete em todas as regiões, sendo mais acentuado no Nordeste, onde cerca de $94,7 \%$ do déficit é relativo a domicílios cujas famílias têm renda de até três salários mínimos. Por outro lado, na região Sul encontram-se os menores percentuais nessa faixa de renda, $84 \%$, e o déficit na faixa de renda familiar entre três e cinco salários mínimos é relativamente mais representativo, em 10,8\%.

Entretanto, na região Nordeste, onde reside o segundo maior contingente da população, 25,2\% dos domicílios que compõem a variável, encontram-se os maiores percentuais de famílias com baixa renda, chegando a 70,6\% de famílias que recebem menos de três salários mínimos. Entre as demais regiões, a Norte tende a se aproximar dos 
padrões da Nordeste, assim como a Centro-Oeste apresenta distribuição mais parecida com a situação da Sudeste.

Para Nadalin e colaboradores (2014) o fenômeno dos aglomerados subnormais se apresenta heterogêneo nas diversas tipologias observadas na rede urbana e nas grandes regiões, tornando necessária sua análise territorial. Para os autores esse é o melhor caminho para ser possível refinar o entendimento sobre a questão, bem como fortalecer o tratamento a ser realizado pela política pública às diversas situações de precariedade associadas à sua ocorrência. Ressalta-se ainda que esses assentamentos proporcionam condições de vida inadmissíveis para os níveis esperados de desenvolvimento social e econômico desejados para o país.

De acordo com o IBGE (2011), aglomerado subnormal consiste em "um conjunto constituído de, no mínimo, 51 unidades habitacionais carentes, em sua maioria de serviços públicos essenciais, ocupando ou tendo ocupado, até período recente, terreno de propriedade alheia (pública ou particular) e estando dispostas, em geral, de forma desordenada e densa. A identificação dos aglomerados subnormais deve ser feita com base nos seguintes critérios:

- ocupação ilegal da terra, ou seja, construção em terrenos de propriedade alheia (pública ou particular) no momento atual ou em período recente (obtenção de título de propriedade do terreno há 10 anos ou menos); e

- possuírem pelo menos uma das seguintes características: urbanização fora dos padrões vigentes, refletido por vias de circulação estreitas e de alinhamento irregular, lotes de tamanhos e formas desiguais e construções não regularizadas por órgãos públicos; ou precariedade de serviços públicos essenciais".

Essa situação de precariedade se aproxima do conceito de favelas, sendo o número divulgado pelo IBGE pouco representativo da real situação dessas áreas no Brasil. As dificuldades de se obterem informações detalhadas para as favelas em geral são conhecidas e isso legitima a consideração dos dados do IBGE, mesmo sabendo que estes estão subestimados. 
Parte-se da premissa de que nessas áreas encontram-se grandes problemas de infraestrutura e uma vasta população de renda mais baixa. Então, a tentativa de dimensionar as carências habitacionais na área se justifica ao se considerar a preocupação dos formuladores de políticas públicas em atender às demandas da população que vive em situação mais precária.

Na Tabela 11, apresenta-se a distribuição da população em aglomerados subnormais segundo diferentes categorias para o período de 2000 e 2010.

A partir da Tabela 11, verifica-se que, em 2010, 11,4 milhões de pessoas viviam em assentamentos subnormais, sendo que em torno de 6 milhões habitavam municípios classificados como metrópoles. Em função desse fenômeno ocorrer em uma área de pelos menos três quartos das áreas de metrópoles e abrangência, verifica-se que se trata de um fenômeno primordialmente metropolitano. Além disso, na Tabela 11 também é possível observar que as metrópoles e sua área de abrangência concentram 74,83\% das populações em assentamentos precários.

Tabela 11 - Distribuição da população em aglomerados subnormais no Brasil

\begin{tabular}{|l|c|c|c|c|c|c|c|}
\hline \multirow{2}{*}{ Tipologia } & \multicolumn{2}{|c|}{ Municípios com assentamentos precários } & \multicolumn{2}{c|}{ Todos os municípios } \\
\cline { 2 - 8 } & $\begin{array}{c}\text { População } \\
\text { em AS em } \\
\mathbf{2 0 0 0}\end{array}$ & $\begin{array}{c}\text { Total } \\
\text { \% }\end{array}$ & $\begin{array}{c}\text { População } \\
\text { em AS em } \\
\mathbf{2 0 1 0}\end{array}$ & $\begin{array}{c}\text { Total } \\
\text { \% }\end{array}$ & $\begin{array}{c}\text { Proporção da } \\
\text { população } \\
\text { em AS em } \\
\mathbf{2 0 1 0}\end{array}$ & $\begin{array}{c}\text { População } \\
\text { em 2010 }\end{array}$ & $\begin{array}{c}\text { Total } \\
\%\end{array}$ \\
\hline Metrópole & 3.929 .269 & 61,03 & 6.158 .778 & 53,87 & 16,86 & 36.534 .266 & 22,68 \\
\hline $\begin{array}{l}\text { Metrópole - } \\
\text { abrangência }\end{array}$ & 1.358 .547 & 21,10 & 2.396 .649 & 20,96 & 11,32 & 25.482 .212 & 15,82 \\
\hline $\begin{array}{l}\text { Capitais } \\
\text { regionais }\end{array}$ & 722.780 & 11,23 & 1.627 .380 & 14,24 & 8,49 & 26.162 .382 & 16,24 \\
\hline $\begin{array}{l}\text { Capital } \\
\text { regional } \\
\text { abrangência }\end{array}$ & 247.720 & 3,85 & 624.952 & 5,47 & 11,22 & 8.831 .124 & 5,48 \\
\hline $\begin{array}{l}\text { Centros sub- } \\
\text { regionais }\end{array}$ & 89.328 & 1,39 & 340.842 & 2,98 & 10,61 & 14.300 .704 & 8,88 \\
\hline $\begin{array}{l}\text { Centros de } \\
\text { zona }\end{array}$ & 35.116 & 0,55 & 106.508 & 0,93 & 5,58 & 16.638 .878 & 10,33 \\
\hline $\begin{array}{l}\text { Centros } \\
\text { locais }\end{array}$ & 55.149 & 0,86 & 177.054 & 1,55 & 11,10 & 33.163 .102 & 20,58 \\
\hline Total & $\mathbf{6 . 4 3 9 . 9 0 9}$ & $\mathbf{1 0 0 , 0}$ & $\mathbf{1 1 . 4 3 2 . 1 6 3}$ & $\mathbf{1 0 0 , 0}$ & $\mathbf{1 2 , 8 2}$ & $\mathbf{1 6 1 . 1 1 2 . 7 6 8}$ & $\mathbf{1 0 0 , 0}$ \\
\hline
\end{tabular}

Fonte: Nadalin et al. 2014, Censo demográfico 2010.

Embora a incidência de população em aglomerados subnormais tenha diminuído entre 2000 e 2010, passando de 61,03\% para 53,87\%, respectivamente, nas metrópoles, ainda existia um elevado percentual de pessoas vivendo nessa situação em 2010, em torno 
de 16,86\%. Também é preciso destacar que embora o fenômeno ainda seja prioritariamente observado em metrópoles, as capitais regionais passaram a aumentar a incidência dessa variável, passando de 11,23\% para 14,24\% de 2000 para 2010, indicando que esse fenômeno poderá tender a aumentar ainda mais nessa categoria de análise.

\section{Panorama do saneamento básico}

Analogamente ao que foi discutido com relação aos indicadores geralmente adotados para direcionar a tomada de decisão na política de habitação, apresentam-se os indicadores utilizados com relação à política de saneamento.

O déficit de serviços de saneamento ambiental adequados e a situação de exclusão social associados ao padrão de desenvolvimento econômico e de urbanização alcançado pelo país contribuem para diferentes combinações e sobreposições de exposições, riscos e efeitos sobre a saúde humana (Franco Netto, et al. 2009). Dessa forma, as questões relacionadas às condições de precariedade no fornecimento dos serviços de saneamento básico constituem fatores que condicionam os níveis de qualidade urbana de uma cidade, os quais influenciam diretamente as condições de saúde da população.

De acordo com Freitas e Porto (2006), quando se considera, na perspectiva da saúde pública, que as sociedades devem promover a saúde e prevenir as doenças, ao invés de somente responder aos problemas, isso exige uma abordagem que, ao mesmo tempo, considere os problemas de saúde ambiental situados nos níveis locais e próximos, bem como inclua os níveis relacionados aos determinantes sociais e ambientais. Essa abordagem exige, contudo, opções de ações e de práticas de gestão que vão além da vigilância em saúde ambiental, apontando para a ampliação de uma abordagem intrasetorial.

Essa forma de atuar vai além do setor saúde e requer uma atuação simultânea sobre os determinantes sociais e ambientais para ser possível uma mudança de rumo, onde a sustentabilidade ambiental e de saúde estejam entre os meios e os objetivos do desenvolvimento, reduzindo e eliminando vulnerabilidades ambientais e exclusões sociais.

Contudo, percebe-se um crônico distanciamento entre as políticas de saneamento e de saúde no Brasil. A prática e os planejamentos do setor não valorizam a relação com a saúde, havendo inclusive deficiências na formação dos profissionais. Além disso, Heller 
(1998,) ressalta que as políticas de saúde do país permanecem privilegiando a ótica curativa, dificultando o reconhecimento do papel preventivo das ações de saneamento.

Atualmente, o déficit do setor de saneamento básico no Brasil é elevado, principalmente quanto aos serviços de coleta e tratamento de esgotos sanitários, verificando-se uma maior carência nas áreas periféricas dos centros urbanos e nas zonas rurais. Diversos são os fatores que explicam o déficit dos serviços de água e esgotamento sanitário no país, destacando-se a fragmentação das políticas públicas e a carência de instrumentos de regulação efetivos.

No estudo desenvolvido por Galvão Junior (2009), mostrou-se que seriam necessários, para universalizar até o ano de 2020 as cinco regiões geográficas do país, cerca de 178 bilhões de Reais em investimentos de expansão e reposição da infraestrutura. No Brasil, o déficit dos serviços de água e esgoto é mais acentuado nas regiões onde estão assentadas as populações de baixa renda, que apresentam maiores problemas de saúde pública. Esse déficit evidencia características de desigualdades sob os aspectos interregionais, renda familiar e localização do domicílio.

Com relação ao uso da informação para subsidiar o ciclo de políticas públicas no setor saneamento é possível contar com o Sistema Nacional de Informação sobre Saneamento (SNIS), bem como com o Sistema Nacional de Vigilância Ambiental em Saúde (SINVAS) que está sendo estruturado no Brasil desde o ano de 2000.

Entre as atividades principais da vigilância ambiental em saúde estão os processos de produção, integração, processamento e interpretação de informações visando ao conhecimento dos problemas de saúde existentes, relacionados aos fatores ambientais. Nesse sentido, os Sistemas de Informações em Saúde podem ser uma ferramenta importante no estudo das Doenças Relacionadas a um Saneamento Ambiental Inadequado (DRSAI), fornecendo informações importantes sobre magnitude e distribuição desses agravos (COSTA, et al. 2002).

Para os autores, a vigilância ambiental, além de monitorar situações de risco, pode contribuir para a avaliação das políticas públicas de saneamento básico, bem como para a definição de critérios epidemiológicos para sua formulação. Ao propor a classificação Doenças Relacionadas a um Saneamento Ambiental Inadequado, tem-se em vista as 
possíveis contribuições para os programas de proteção e promoção da saúde, bem como na avaliação e formulação de políticas públicas de saneamento ambiental e de saúde.

Os mecanismos de implantação de políticas públicas redistributivas, tais como fundos, subsídios e recursos a fundo perdido, são essenciais para a universalização na maioria dos municípios brasileiros e, ao longo das últimas décadas, foram responsáveis pelo incremento da cobertura da infraestrutura (GALVÃO JÚNIOR, 2009). Em função da ampliação dessas fontes de recursos e de outros avanços institucionais, a política de saneamento no Brasil atravessa um momento de ricas possibilidades para novas formulações teórico-conceituais e metodológicas, após a promulgação da Lei 11.445/2007. Esse instrumento legal implicou a construção de um novo quadro institucional para a área, tendo em vista tornar as ações mais efetivas no atendimento dos interesses da população, em função de se ter mais clareza teórica acerca do alcance dos efeitos das várias opções político-institucionais disponíveis (HELLER e CASTRO, 2007).

Apesar de todos os avanços institucionais, ainda se observa uma realidade em que o saneamento básico inadequado reflete um quadro de exclusão social combinado com novos problemas de saúde. Um dos desafios que a saúde ambiental vem enfrentando nos últimos anos é definir e construir um conjunto de indicadores que propiciem subsídios para os processos de tomada de decisão e o planejamento de políticas públicas não só centradas nos efeitos sobre a saúde, mas que incorporem a compreensão do quadro socioeconômico e das mudanças ambientais e possibilite avançar em ações intersetoriais (FRANCO NETTO, et al. 2009).

Para os autores, ainda que a fração ambiental da carga das doenças possa variar de $5 \%$ a mais de $90 \%$ e que grande parte dos mecanismos causais ainda não sejam bem compreendidos, é certo que os determinantes ambientais, de diferentes modos, afetam o perfil de morbidade e mortalidade da população. Considerando que, em países como o Brasil, essa fração pode variar significativamente para muitas doenças, compreender a combinação dos determinantes sociais (forças motrizes e pressões sobre o ambiente) e ambientais (situação ambiental e exposições ambientais) a partir da construção de indicadores de saúde ambiental, vem se mostrando como um passo importante para permitir ao setor saúde desenvolver opções intersetoriais de gestão em saúde ambiental que possam impactar positivamente a saúde da população. 
Além dos clássicos fatores relacionados ao financiamento das ações, são apontados como necessários para a superação das deficiências, esforços adicionais, tais como o planejamento adequado dos serviços, além da criação de modelos institucionais efetivos e eficientes. É preciso adaptar as abordagens de ação a cada público-alvo das políticas, bem como desenvolver uma abordagem particular e distinta da convencional. Destaca-se a necessidade de ações específicas para viabilizar a atuação do poder público em assentamentos informais, combinando diretrizes e princípios inerentes aos setores saúde, saneamento, meio ambiente, regularização fundiária, urbanização de favelas e uso e ocupação do solo.

Nas Figuras 25 a 27, apresenta-se a evolução da cobertura de abastecimento de água, esgotamento sanitário e coleta de resíduos sólidos no Brasil e nas grandes regiões, no período de 2000 a 2014.

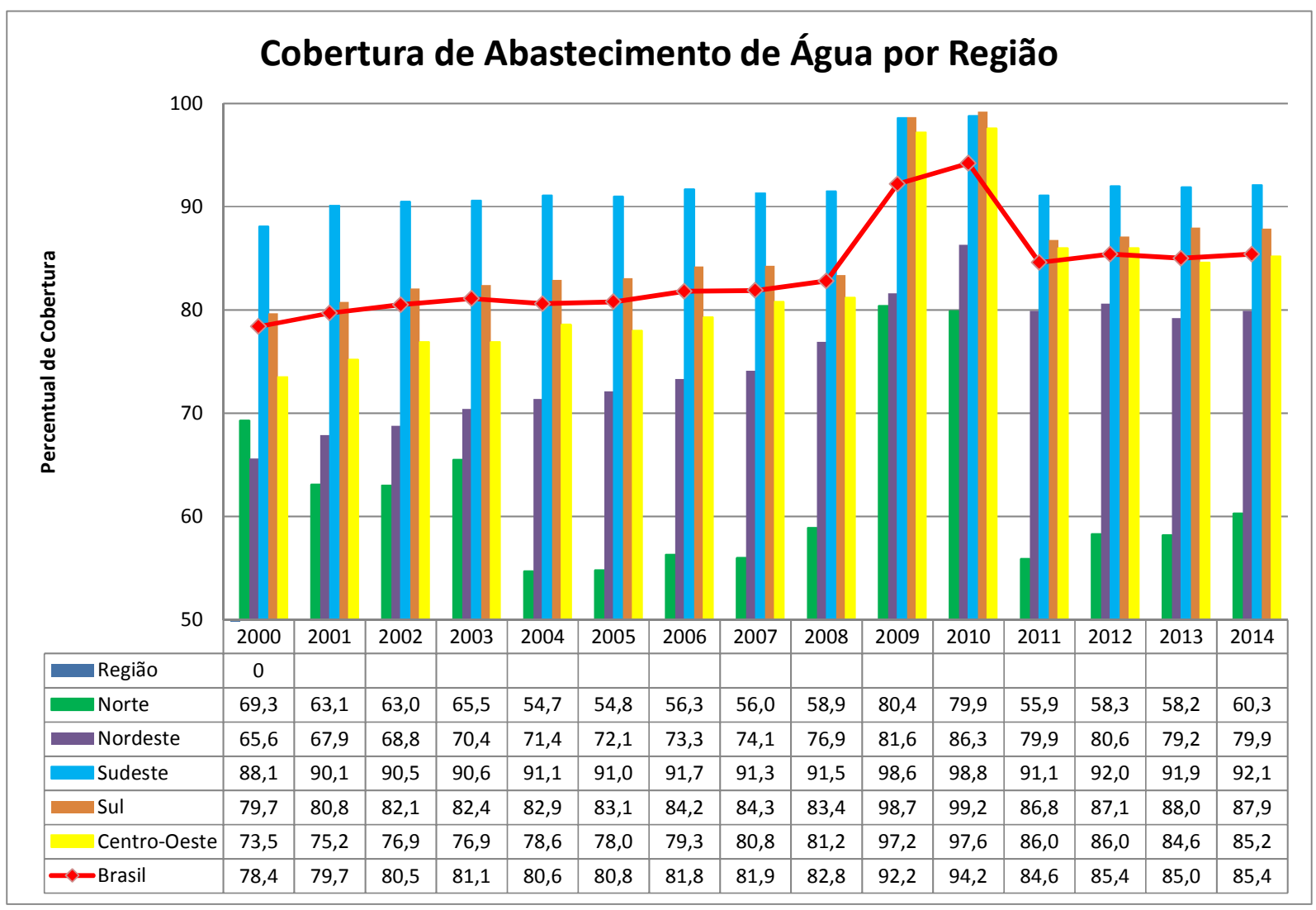

Figura 25 - Cobertura de abastecimento de água no Brasil por região Fonte: PNADs / IBGE.

A partir dos dados apresentados, verifica-se que a taxa de abastecimento de água no Brasil subiu sete pontos percentuais, mostrando que os esforços governamentais 
empreendidos estão contribuindo para avanços significativos na cobertura do serviço. Contudo, ao se analisar a variável por região, observa-se que muitos esforços e recursos ainda deverão ser concentrados nas regiões Norte e Nordeste. Vale salientar que todas as regiões aumentaram a cobertura de abastecimento de água, sendo identificado o maior aumento no Nordeste, que envolveu $14,3 \%$ de incremento.

A região Norte, devido a inconsistências na disponibilização de dados no SNIS, apresentou a pior situação por ter piorado nove pontos percentuais, passando de 69,3\% em 2000 na cobertura de abastecimento de água para 60,3\% em 2014. Isso indica que além de estar mais precário em termos de cobertura nos serviços, o Norte do país requer melhorias institucionais para o aprimoramento das ações. Não foi dada a devida importância ao crescimento das demandas ao longo do tempo.

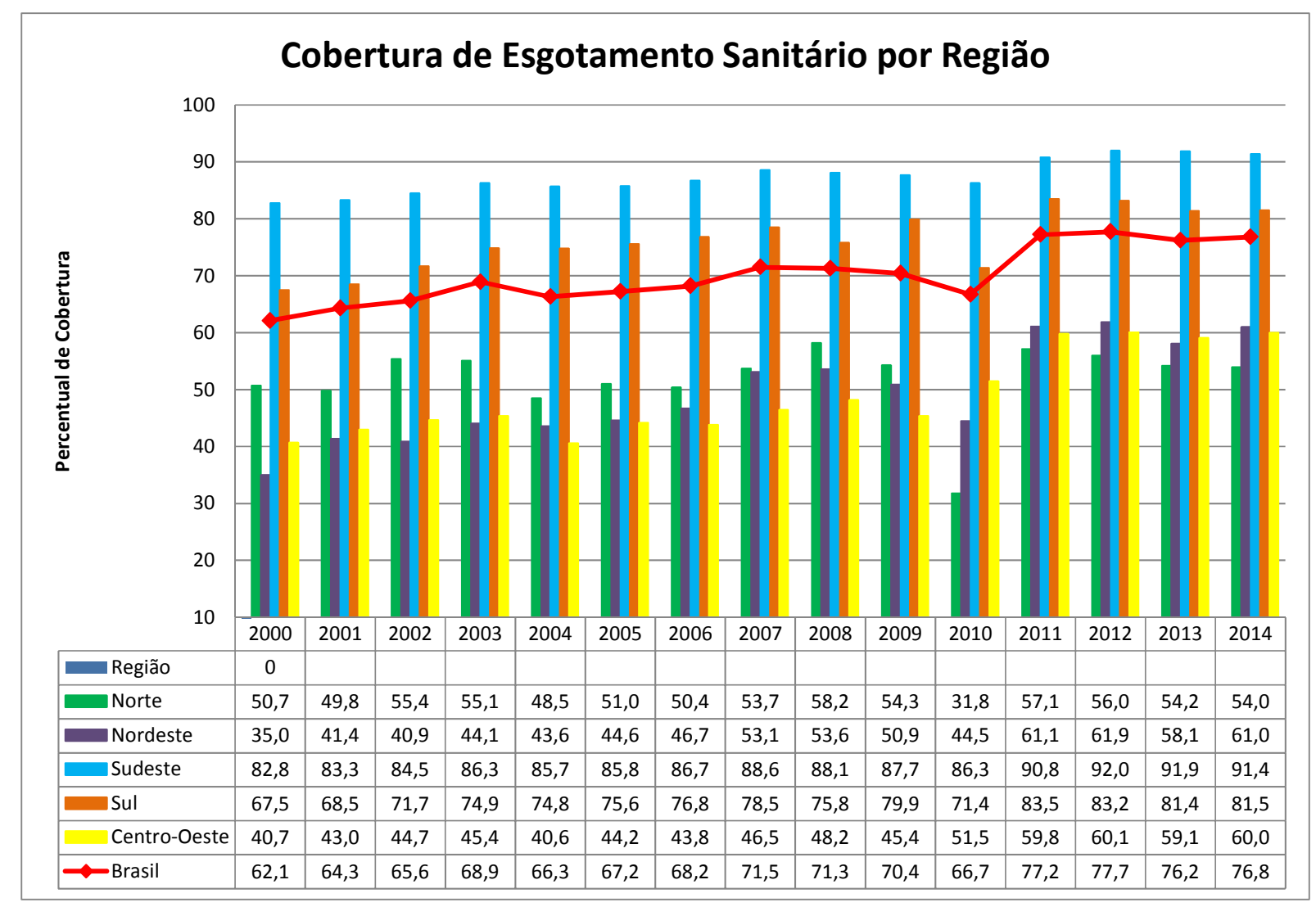

Figura 26 - Cobertura de esgotamento sanitário no Brasil por região Fonte: PNADs / IBGE.

O mesmo comportamento se repete ao se analisar os dados referentes à cobertura de esgotamento sanitário no Brasil e nas regiões. É importante destacar que, historicamente, 
em função da cultura herdada pelo principal programa governamental empreendido no âmbito da política de saneamento, o Planasa, existiu a tendência de se priorizar o atendimento às demandas de abastecimento de água em detrimento das demais modalidades de saneamento básico: esgotamento sanitário, gestão de resíduos sólidos e drenagem urbana. Desse modo, é verificado um grande passivo com relação a esse indicador.

A evolução da cobertura de esgotamento sanitário no período mostra que os esforços para a correção dessa tendência estão surtindo efeitos, visto que a taxa aumentou 14,7 pontos percentuais no Brasil, com destaque para a região Nordeste, onde o aumento foi de 26 pontos percentuais na cobertura dos serviços durante o período observado. Mais uma vez, a região Norte obteve o menor desempenho aumentando apenas 3,3 pontos percentuais na cobertura dos serviços.

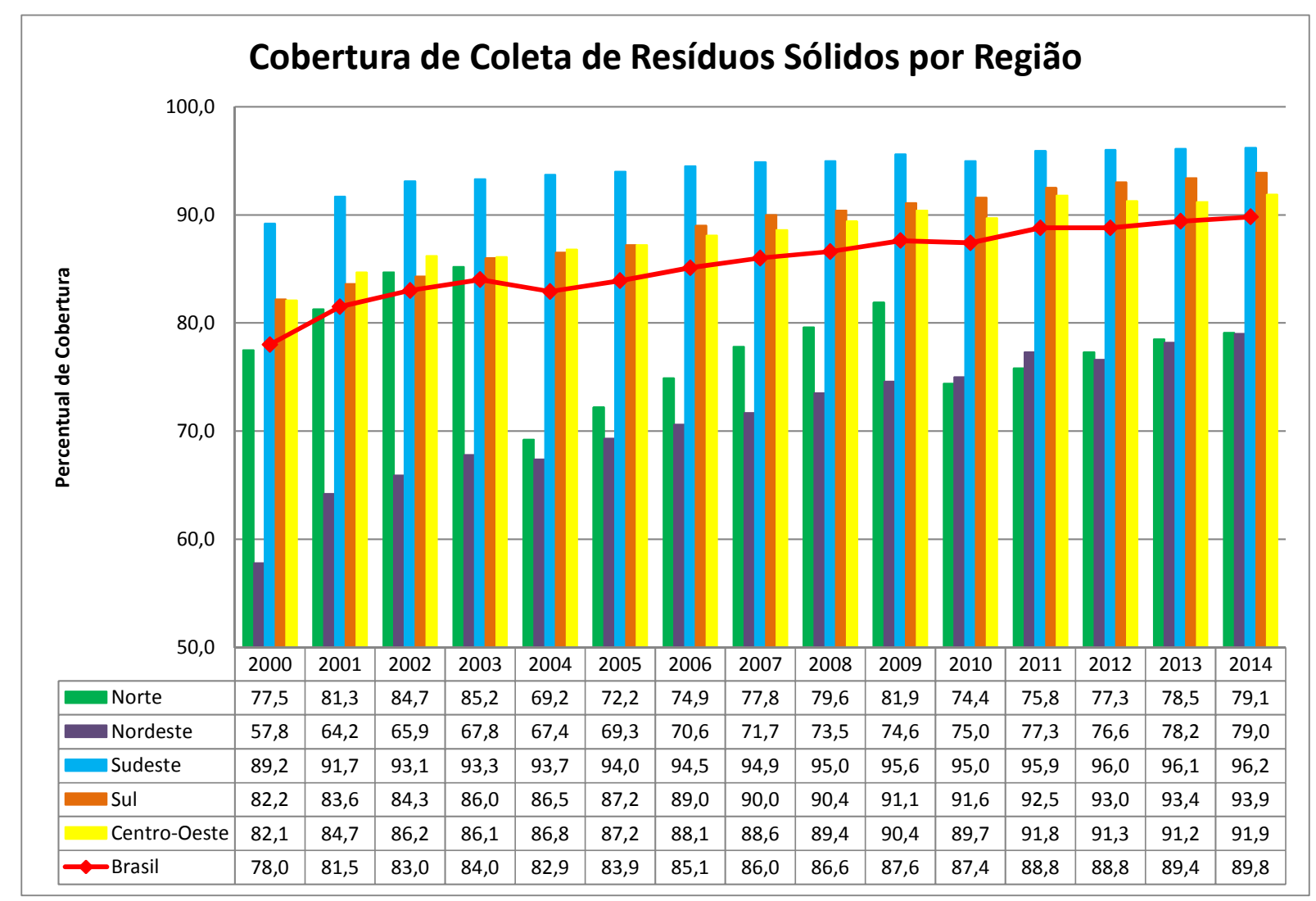

Figura 27 - Cobertura de coleta de resíduos sólidos no Brasil por região Fonte: PNADs / IBGE.

Com relação à cobertura da coleta de resíduos sólidos no Brasil, percebe-se que houve o aumento de 11,8 pontos percentuais no atendimento dos serviços, tendo os 
esforços concentrados na região Nordeste que aumentou 21, 2 pontos percentuais na cobertura. A região Norte apresentou o pior resultado, crescendo apenas 1,6 pontos percentuais.

Mesmo o Nordeste apresentando uma melhoria significativa na cobertura de coleta de resíduos sólidos é preciso salientar que ainda, grande parte da população ainda não conta com esses serviços, representando mais de $20 \%$ de déficit. Enquanto o Sudeste, o Sul e o Centro-Oeste apresentam um patamar superior no atendimento desse serviço, acima dos $90 \%$, o Norte e o Nordeste apresentam cobertura inferior a $80 \%$.

Nas Figuras 28 a 30 são apresentados os déficits na prestação dos serviços de abastecimento de água, esgotamento sanitário e coleta de resíduos sólidos para o Brasil e grandes regiões.

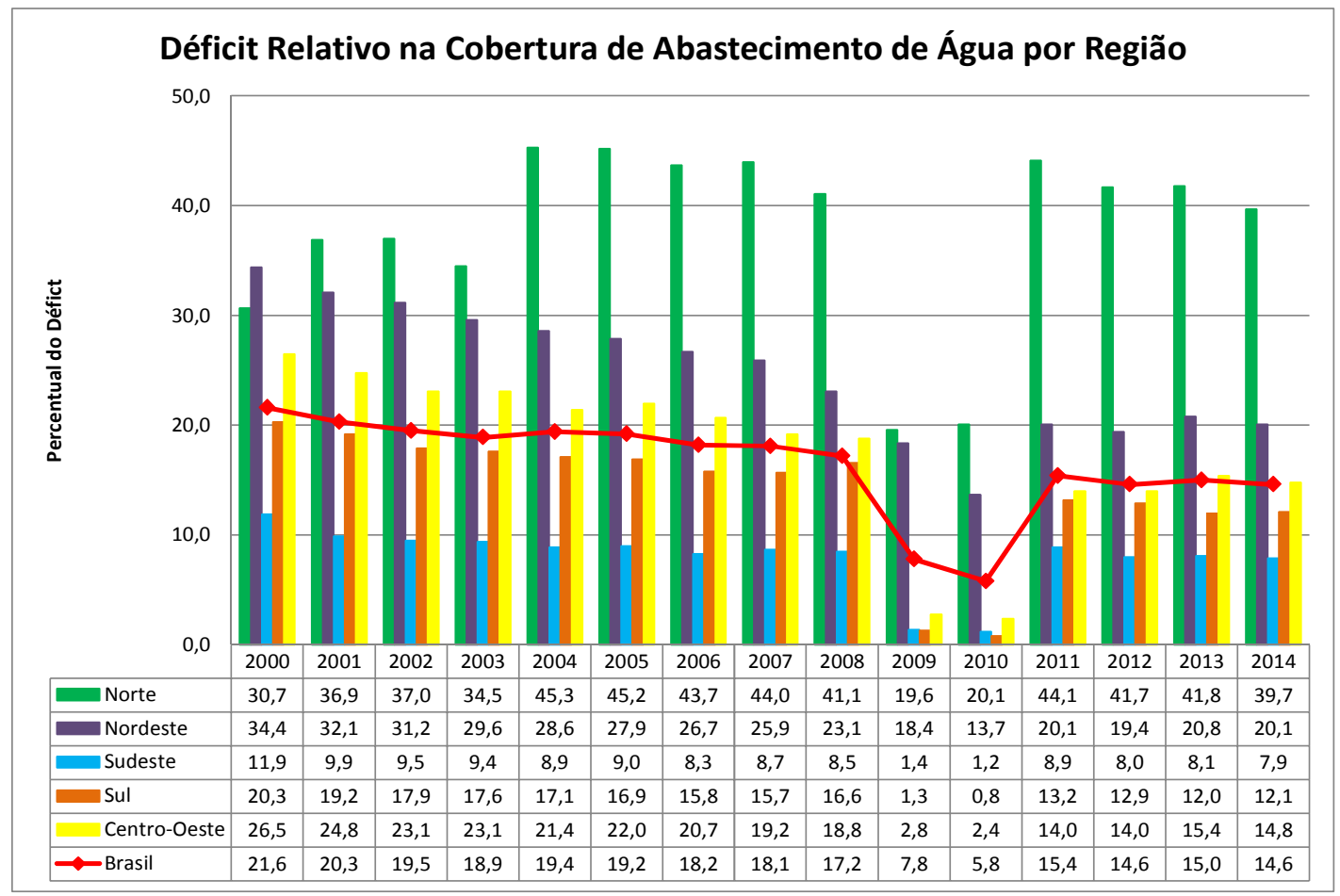

Figura 28 - Déficit relativo na cobertura de abastecimento de água por região Fonte: Elaboração própria (cálculo baseado na cobertura do serviço). 


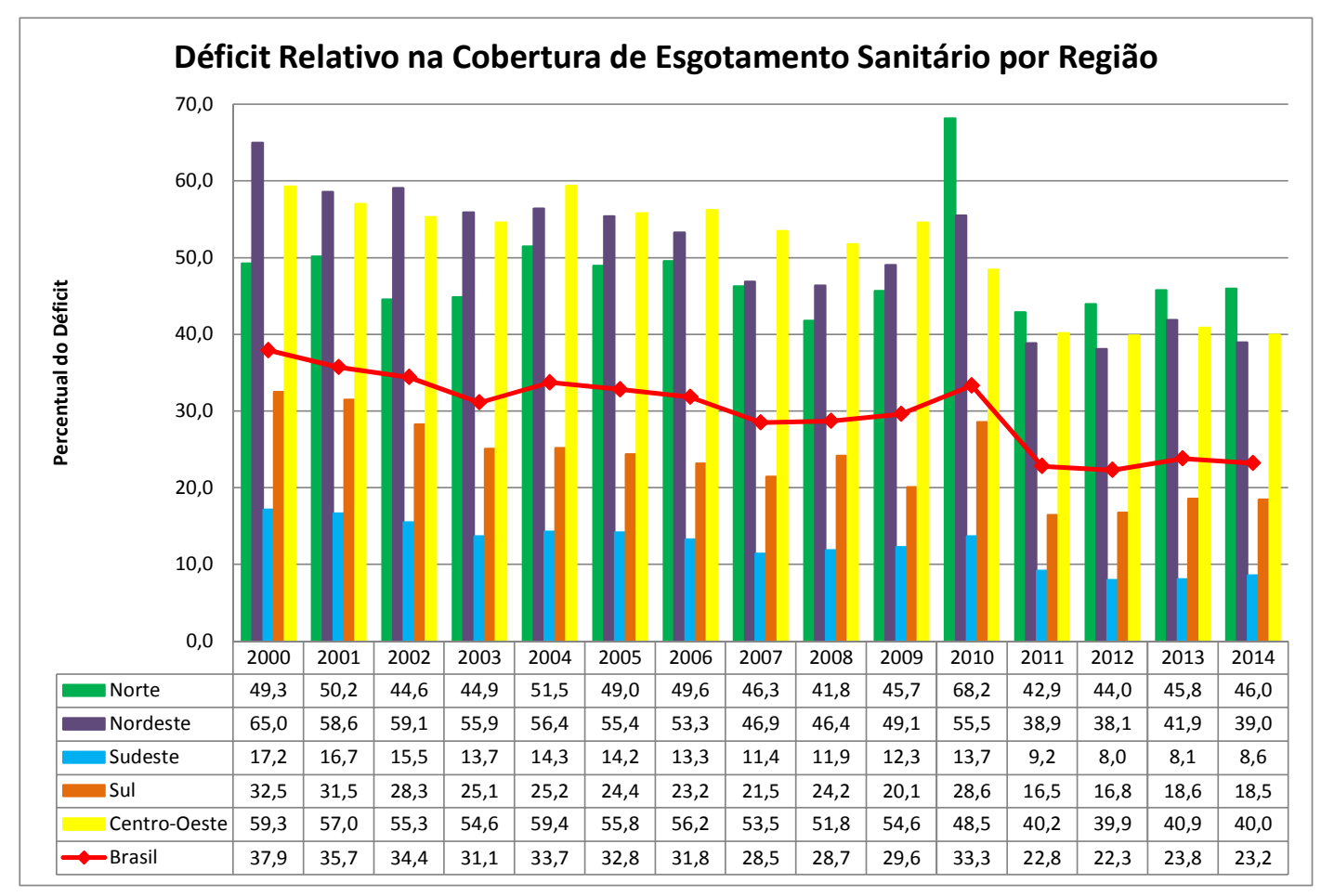

Figura 29 - Déficit relativo na cobertura de esgotamento sanitário por região Fonte: Elaboração própria (cálculo baseado na cobertura do serviço).

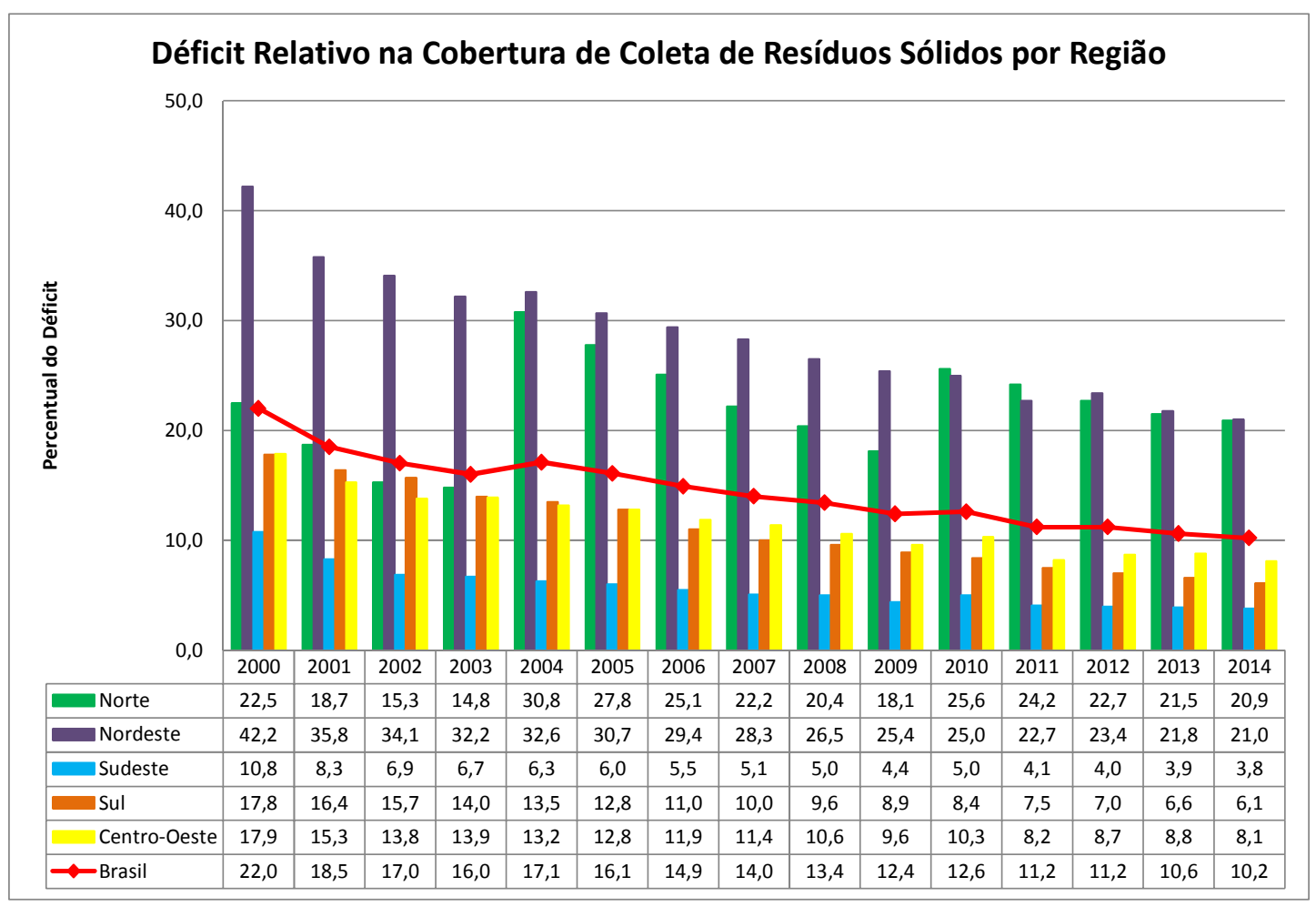

Figura 30 - Déficit relativo na coleta de resíduos sólidos por região Fonte: Elaboração própria (cálculo baseado na cobertura do serviço). 


\section{Panorama da mobilidade urbana}

O acelerado processo de urbanização brasileiro, acentuado a partir da década de 1970 refletiu-se nos problemas de transporte urbano, elevando a mobilidade ao patamar dos principais problemas enfrentados pelos habitantes dos grandes centros urbanos. Trata-se de uma questão complexa, que envolve a ênfase na utilização do automóvel como principal meio de locomoção, a precariedade e os altos preços dos transportes coletivos, bem como a falta de investimentos satisfatórios em infraestrutura de trânsito e transportes, o que insere a problemática da mobilidade urbana no grupo de temáticas essenciais para a melhoria da qualidade de vida nas grandes cidades.

Os trabalhos e levantamentos que divulgam os indicadores relativos à mobilidade urbana no Brasil, na maioria das vezes, vêm acompanhados de explicações acerca dos seguintes temas: acentuação dos problemas de transporte público em função da urbanização acelerada; incentivos à política automotiva e a ênfase no automóvel como principal meio de locomoção; tarifas e custos dos transportes públicos; necessidade de investimentos em infraestrutura e em formas alternativas de transportes. Mostra-se ainda, de forma enfática, como a frota de automóveis tem crescido e ampliado os congestionamentos nas cidades, ao mesmo tempo em que se ressalta a precariedade dos transportes públicos coletivos.

Essa temática tem se tornado um desafio cada vez maior com o passar do tempo, visto que, em 10 anos, a frota de automóveis e motocicletas (transporte individual) cresceu significativamente no Brasil, passando de 24,9\% em 2004 para 47,9\% em 2014 para carros e de 6,0\% em 2004, para 19,3\% 2014 no caso das motos, como apresentado na Figura 31. Assim, em 2014, 67,2\% da frota de veículos automotores no Brasil era composta por alternativas individuais de transportes.

Na Tabela 12, apresenta-se a evolução da produção de veículos automotores no Brasil, no período de 1957 a 2014. A partir desses dados, verifica-se que houve um aumento de $23.865 \%$ na produção de carros para o período, enquanto a produção de ônibus cresceu $1.557 \%$, o que representou uma diferença de mais de 15 vezes para a taxa de crescimento de automóveis. 


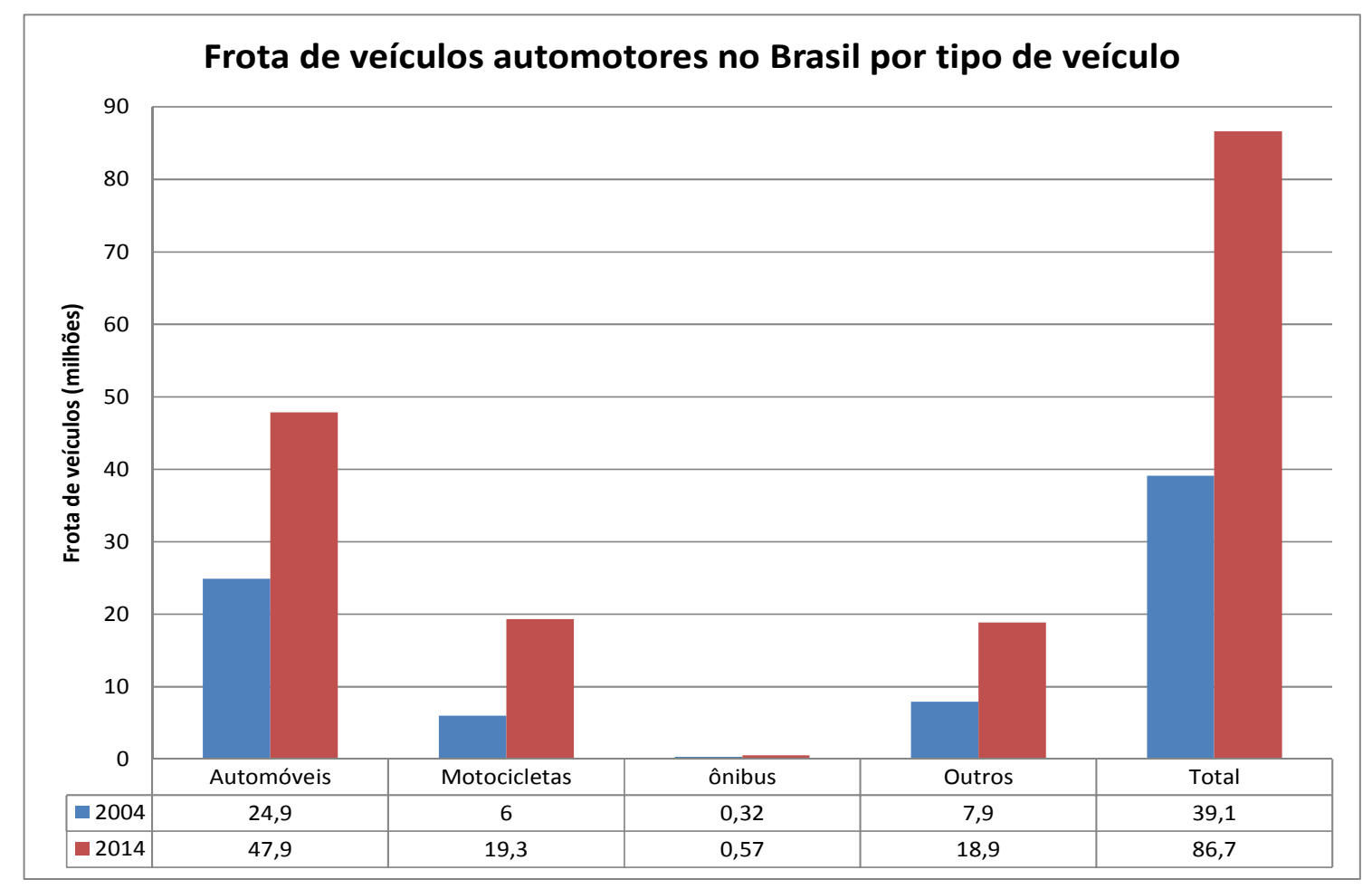

Figura 31 - Frota de veículos automotores no Brasil por tipo de veículo Fonte: Denatran.

Tabela 12 - Produção de veículos no Brasil (1957 - 2014)

\begin{tabular}{|c|c|c|c|c|}
\hline \multirow{2}{*}{ Ano } & \multicolumn{4}{|c|}{ Produção (veículos) } \\
\cline { 2 - 5 } & \multirow{2}{*}{ Autos } & Comerciais Leves & Caminhões & Ônibus \\
\hline 1957 & 10.449 & 1.588 & 16.259 & 2.246 \\
\hline 1960 & 70.479 & 20.875 & 37.810 & 3.877 \\
\hline 1970 & 319.574 & 54.069 & 38.388 & 4.058 \\
\hline 1980 & 939.278 & 109.414 & 102.017 & 14.465 \\
\hline 1990 & 665.051 & 182.787 & 51.597 & 15.031 \\
\hline 2000 & 1.375 .382 & 221.498 & 71.686 & 22.674 \\
\hline 2010 & 2.924 .208 & 484.839 & 191.621 & 45.880 \\
\hline 2014 & 2.504 .117 & 487.751 & 143.660 & 37.222 \\
\hline
\end{tabular}

Fonte: Brasil, Câmara dos Deputados, 2016.

Embora a alternativa de transporte individual tenha parecido uma grande solução para o problema no século XX, teve desdobramentos negativos nas condições atuais dos grandes centros, devido aos problemas com a paralisação do trânsito, com o desperdício de tempo e combustível, além das externalidades associadas a problemas ambientais. Vale salientar que a adoção dos automóveis como uma alternativa para solução ou minimização 
dos problemas relacionados à mobilidade urbana também encoberta os interesses inerentes à indústria automotiva no Brasil.

De maneira geral, a indústria automotiva ocupa lugar importante na estrutura produtiva de vários países desenvolvidos, onde está presente uma economia industrial avançada. Em alguns desses países, o setor automobilístico acabou se tornando um verdadeiro símbolo da maturidade e do vigor econômico (CALANDRO, 2000, p.116).

$\mathrm{O}$ aspecto determinante para o desenvolvimento da indústria automobilística brasileira foi a decisão estatal de se instituir a complementaridade produtiva com a Argentina, o que levou à assinatura de diversos acordos de integração comercial e produtiva. A integração dessas indústrias automobilísticas se deve às iniciativas dos dois governos, bem como à atuação das montadoras, que procuraram aumentar a escala de produção de alguns modelos de veículos por meio de um processo de especialização produtiva.

Esse processo de expansão da indústria automobilística no Brasil foi fortemente influenciado por discussões teóricas sobre o caminho que o país deveria seguir em busca de seu desenvolvimento econômico, tendo a Confederação Nacional da Indústria (CNI), como um dos principais atores. Nesse período, a necessidade da industrialização foi identificada como uma via de acesso para superar o atraso no país, a partir da adoção de um ideário desenvolvimentista seguido pelo Estado. As discussões no campo teórico, quanto ao padrão a ser adotado pelo Brasil na busca de seu desenvolvimento econômico, tomaram forma decisiva na década de 1950 e fizeram com que o desenvolvimentismo se tornasse o modelo dominante (ROEHE, 2011, p. 11).

Segundo a autora, o Grupo Executivo da Indústria Automobilística (GEIA), criado pelo decreto de Kubistchek, em 1956, desempenhou um papel importante na industrialização, por determinar índices de nacionalização na produção de veículos, concedendo benefícios fiscais e estímulos cambiais para a importação de máquinas pelas indústrias estrangeiras, nacionais e mistas, além de proporcionar os investimentos necessários para o crescimento do setor de autopeças no país.

Essa estratégia pautada no desenvolvimentismo buscava a transformação da sociedade brasileira com forte aderência ao projeto de industrialização. O discurso 
propagado para justificar esse modo de ação alegava que a industrialização integral era a maneira mais eficaz de combater a pobreza e o subdesenvolvimento no Brasil. Posteriormente, observou-se que as forças do livre mercado não se mostravam capazes de dar suporte à industrialização do país de forma racional e eficaz, sendo imperativo o planejamento formal do Estado.

Segundo Souza e Aguiar (2015, p. 283) a indústria automobilística brasileira desenvolveu-se em um ambiente caracterizado pela forte intervenção governamental e por mudanças nas condições de mercado. Esses fatores, conjuntamente, afetaram a estrutura de mercado e o grau de concorrência do setor. Durante a década de 1990 deu-se início à abertura de mercado, quando o governo chegou a reduzir as tarifas de importação de $80 \%$, em 1990, para 35\%, em 1994. Em 1995, o governo federal instituiu o Regime Automotivo Brasileiro, estabelecendo medidas de incentivo à modernização industrial e ao investimento no setor automotivo, com o objetivo de direcionar os investimentos especificamente para as regiões Norte, Nordeste e Centro-Oeste, por meio de benefícios fiscais para empresas que se localizassem nessas áreas.

Os autores complementam mostrando que, recentemente, houve mais duas medidas políticas de grande importância: a isenção do Imposto sobre Produtos Industrializados (IPI) para a comercialização de automóveis, feita para contrabalançar os efeitos da crise financeira internacional de 2008, que perdurou até 2014, e o aumento da tributação sobre carros importados, no final de 2011, visando proteger a indústria doméstica.

Assim, conforme mostrado na Figura 32, o Brasil, apresenta no período de 2001 a 2012, a elevação da taxa de motorização, medida pela relação entre a quantidade de automóveis para cada 100 habitantes, passando de 14,4 para 20,4 (incremento de 11,5 pontos percentuais). Esse dado se apresenta ainda maior ao se analisar a taxa para as regiões Metropolitanas, passando de 25,9 em 2001 para 33,8 em 2019, representando um aumento de 13,4 pontos percentuais.

Fica evidente, a partir dessas considerações, a preocupação primordial com o desenvolvimento econômico do país, focando no período da década de 1950 na implantação de uma estratégia desenvolvimentista para o Brasil, assim como, na década de 2008 em diante, com a movimentação da economia em um contexto de crise econômica. 
Dessa forma, os problemas associados à mobilidade urbana ficaram sempre em segundo plano, entendidos como uma consequência negativa do processo de desenvolvimento e da urbanização acelerada.

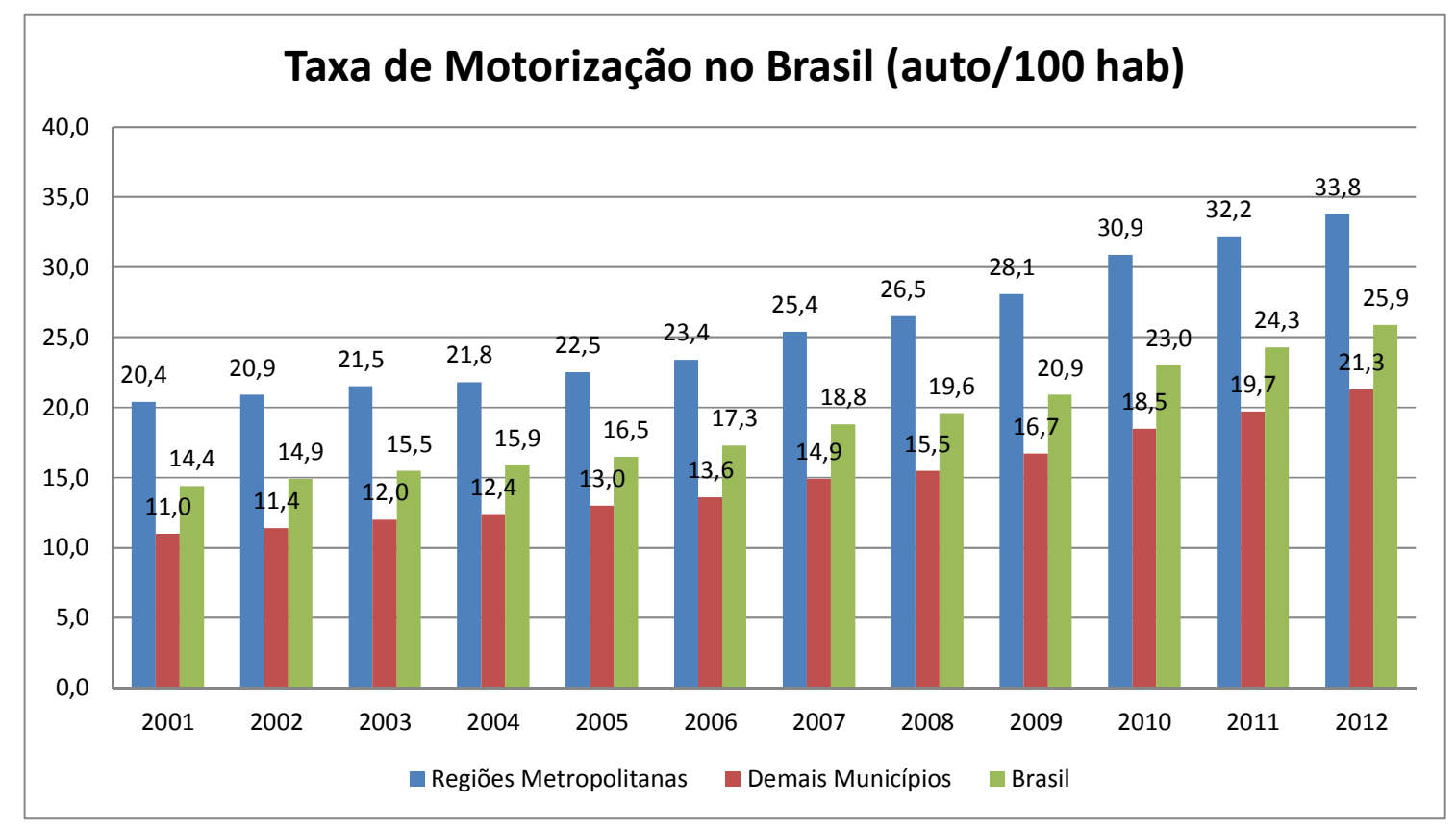

Figura 32 - Taxa de motorização no Brasil (2001 a 2012)

Fonte: Brasil, Câmara dos Deputados, 2015.

Tem-se como desdobramentos da condição de saturação populacional dos grandes centros urbanos, juntamente com os incentivos crescentes à indústria automobilística, grandes congestionamentos e o aumento progressivo da emissão de gases de efeito estufa, aumentando os níveis de poluição nas cidades. Por outro lado, a essência do debate sobre a problemática da mobilidade urbana está muito além das externalidades do crescimento na produção de automóveis, e das questões associadas ao uso dos meios de transporte com suas respectivas normatizações. Os aspectos centrais desse debate estão diretamente associados ao direito à cidade e ao direito do cidadão de se deslocar por ela e de acessar os diversos serviços oferecidos.

Portanto, ao relacionar o tema da mobilidade urbana ao direito à cidade, entende-se que a problemática está ligada à possibilidade que os diversos grupos sociais têm de acessarem os centros urbanos. Os serviços públicos essenciais são direitos constitucionais e o acesso aos locais de trabalho constitui uma necessidade fundamental à sobrevivência dos trabalhadores. 
Desse modo, a utilização desses serviços está ligada à possibilidade que as pessoas têm de chegar aos locais onde são desenvolvidas suas atividades cotidianas e de sobrevivência, tais como o deslocamento à escola, ao centro de saúde, ao cinema, ao teatro, ao local de trabalho, além de outros. O debate sobre a mobilidade urbana versa sobre a garantia de condições necessárias à utilização dos serviços prestados e sobre os obstáculos que dificultam ou impedem essa utilização.

Considerando esses aspectos, o indicador tempo gasto no deslocamento casa/trabalho reflete a precariedade no deslocamento dos trabalhadores na cidade para efetuarem uma atividade essencial à sua sobrevivência.

Na Tabela 13, apresenta-se o tempo gasto no deslocamento casa/trabalho por localização da moradia para os períodos de 1992 e 2012. A partir dos dados, verifica-se o tempo de deslocamento relativo às Regiões Metropolitanas, que é de 12,1\%. O dado fica mais alarmante ao se verificar que em 2012 , quase $19 \%$ da população gastava mais de 1 hora no trajeto de casa para o trabalho.

Tabela 13 - Tempo gasto no deslocamento casa/trabalho por localização da moradia

\begin{tabular}{|l|c|c|c|c|c|}
\hline \multirow{2}{*}{\begin{tabular}{c}
\multirow{2}{*}{ Local de Domicílio } \\
\cline { 2 - 5 }
\end{tabular}} & \multicolumn{2}{|c|}{ Minutos de casa ao trabalho } & \multicolumn{2}{c|}{$\begin{array}{c}\text { Gasta mais de 1 hora até o } \\
\text { trabalho }\end{array}$} \\
\cline { 2 - 5 } & $\mathbf{1 9 9 2}$ & $\mathbf{2 0 1 2}$ & Variação (\%) & $\mathbf{1 9 9 2}$ & $\mathbf{2 0 1 2}$ \\
\hline Brasil & 28,4 & 30,2 & $6,4 \%$ & $8,2 \%$ & $10,4 \%$ \\
\hline Áreas não-metropolitanas & 22,7 & 23,6 & $4,2 \%$ & $3,6 \%$ & $4,6 \%$ \\
\hline Áreas metropolitanas & 36,4 & 40,8 & $12,1 \%$ & $14,6 \%$ & $18,6 \%$ \\
\hline
\end{tabular}

Fonte: PNAD / IBGE, 1992 e 2012.

Tabela 14 - Tempo gasto no deslocamento casa/trabalho por região em 2010

\begin{tabular}{|l|c|c|}
\hline \multirow{2}{*}{\multicolumn{1}{|c|}{ Região }} & \multicolumn{2}{c|}{ Minutos de casa ao trabalho } \\
\cline { 2 - 3 } & Regiões Metropolitanas & Geral \\
\hline Norte & 72,26 & 55,17 \\
\hline Nordeste & 70,60 & 56,12 \\
\hline Sudeste & 92,52 & 73,18 \\
\hline Sul & 58,63 & 50,24 \\
\hline Centro-Oeste & 66,09 & 59,67 \\
\hline
\end{tabular}

Fonte: PNAD / IBGE, 2010.

Os dados apresentados na Tabela 14 dizem respeito ao tempo gasto no deslocamento casa/trabalho por região, no ano de 2010. Assim, verifica-se que a as RMs localizadas na região Sudeste apresentavam a situação mais precária, com a média de 92,52 minutos, seguida da Norte e da Nordeste, com as respectivas médias de 72,26 e 70,60 minutos. 
Na Tabela 15, apresentam-se os tempos de viagem casa/trabalho segundo faixas de renda em 2012, indicando que 34,3\% da população gastava entre 30 minutos e 1 hora para realizar esse trajeto, enquanto $15,7 \%$ da população gastava entre 1 e 2 horas. Verifica-se que é a população de menor renda que gasta o maior tempo de deslocamento para o trabalho, visto que 35,6\%, na faixa de 1 a 2 salários mínimos, gastam entre 30' e 1 hora para chegar ao trabalho e $16,8 \%$, na faixa de mais de $1 / 2$ até 1 salário mínimo, levam entre 1 e 2 horas para realizar o trajeto.

Tabela 15 - Percentual de famílias das RMs com tempos de viagem nas faixas consideradas por renda per capita em 2012

\begin{tabular}{|c|c|c|c|c|}
\hline \multirow[t]{2}{*}{ Faixas de renda per capita } & \multicolumn{4}{|c|}{$\begin{array}{c}\text { Percentual de famílias c/ tempo de viagem } \\
\text { casa/trabalho }\end{array}$} \\
\hline & $<30$ & 30' a 1h & 1h a $2 \mathrm{~h}$ & $>2 h$ \\
\hline Até $1 / 4$ salário mínimo & 57,9 & 26,6 & 10,5 & 4,9 \\
\hline Mais de $1 / 4$ até $1 / 2$ salário mínimo & 47,5 & 32,4 & 16,2 & 3,9 \\
\hline Mais de $1 / 2$ até 1 salário mínimo & 44,9 & 34,4 & 16,8 & 3,8 \\
\hline Mais de 1 até 2 salários mínimos & 43,8 & 35,6 & 16,6 & 4,0 \\
\hline Mais de 2 até 3 salários mínimos & 46,6 & 33,7 & 16,5 & 3,1 \\
\hline Mais de 3 até 5 salários mínimos & 48,6 & 35,4 & 13,6 & 2,5 \\
\hline Mais de 5 salários mínimos & 56,4 & 30,8 & 10,8 & 1,9 \\
\hline Total & 46,4 & 34,3 & 15,7 & 3,6 \\
\hline
\end{tabular}

Fonte: PNAD / IBGE, 1992 e 2012.

O pagamento da tarifa do transporte público, a necessidade de possuir um automóvel e a inexistência de condições aos modais alternativos, como as ciclovias, são considerados obstáculos à utilização dos serviços que promovem a mobilidade urbana. Destacam-se também como problemas a localização das edificações que oferecem os serviços estando concentradas nas áreas centrais, prejudicando o deslocamento das populações que habitam as periferias das cidades, as quais normalmente são obrigadas a se deslocarem por grandes distâncias.

O debate acerca das possíveis soluções para o problema da mobilidade urbana também tem como proposta o incentivo à utilização de modais de transporte alternativo, tais como a bicicleta e as ações restritivas de utilização do automóvel, como a criação de pedágios urbanos e o estabelecimento de rodízios de automóveis, além da ampliação dos investimentos com relação aos modais que se inserem nos sistemas de transporte coletivo.

Contudo, as medidas entendidas como fundamentais para a superação desses problemas esbarram nos interesses econômicos dos grupos sociais que controlam o 
desenvolvimento dos centros urbanos. Da mesma forma que as alterações urbanísticas esbarram nos planos que as grandes empreiteiras e construtoras estabelecem para seu crescimento, o aumento constante nas tarifas do transporte coletivo visa garantir o lucro das empresas de transporte. Destaca-se também o estímulo ao uso do automóvel que está em conformidade com os interesses da indústria automobilística e com foco no crescimento econômico.

As soluções discutidas e apontadas como estratégias de minimização da condição crítica atual, envolve a adoção de medidas de restrição do uso do automóvel, que são constantemente levantadas como meios para diminuir congestionamentos e o caos do trânsito; a realização de rodízio de veículos; a implantação de pedágios em áreas específicas. Também são apontadas como medidas essenciais à formação de uma cidade sustentável a criação de ciclovias e de corredores exclusivos de ônibus; a busca pela indústria de automóvel em desenvolver veículos menores que ocupem espaços reduzidos nas ruas das cidades; o estímulo ao uso de veículos que não emitam gases, como as bicicletas; ou o incentivo ao uso do transporte coletivo, que em virtude da quantidade de pessoas que transporta, tem menor potencial de poluição, se comparado com os automóveis.

Destaca-se que, a despeito do elevado contingente de automóveis nas ruas, o transporte coletivo ainda é a principal opção de muitos brasileiros. Desse modo, a maior eficiência dos transportes coletivos poderia diminuir o fluxo de veículos nas ruas, visto que ônibus e metrô possibilitam o transporte de maior número de passageiros por hora e por faixa. Dentre outras alternativas sugeridas para o transporte coletivo, tem-se o BRT (Bus Rapid Transit), ou seja, veículos articulados ou biarticulados, para um fluxo maior; VLT (veículo leve sobre trilhos ou metrô leve) e o metrô pesado, que tem um custo muito caro por quilômetro, sendo indicado apenas no caso do transporte de milhões de passageiros por dia.

Na Figura 33, apresenta-se a divisão modal em capitais do Brasil para o ano de 2011. A partir dos dados apresentados, verifica-se, em todas as capitais apontadas, a maior incidência dos modais coletivos, tendo maior destaque em Salvador, onde essa modalidade de transporte coletivo ultrapassa $56 \%$. 
As tendências de aumento do transporte individual no país ainda são muito fortes e isso traz grandes desafios para os gestores públicos que atuam no setor do transporte. Isso interfere no planejamento de políticas mitigadoras das externalidades negativas produzidas, bem como com relação ao planejamento de sistemas mais eficientes e sustentáveis.

Assim, na esfera federal, destaca-se a necessidade de se programar políticas perenes de financiamento e investimento direto com recursos do OGU de grandes obras de mobilidade urbana com foco na priorização do transporte coletivo e do transporte não motorizado. 

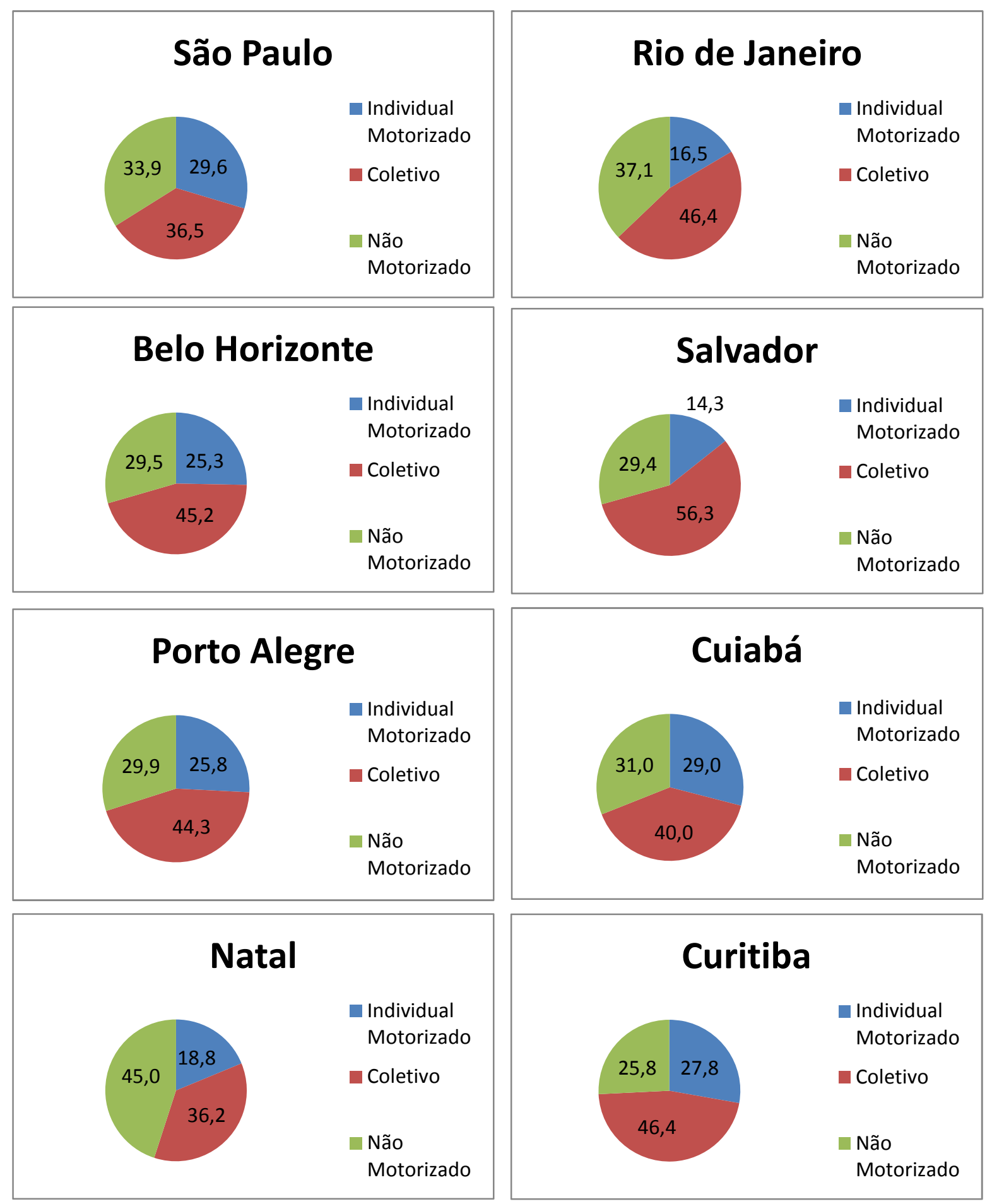

Figura 33 - Divisão modal em capitais do Brasil Fonte: Mobilize, 2011.

Na Tabela 16, apresentam-se os principais indicadores sobre BRT por Cidades no Brasil. 
Tabela 16 - Principais Indicadores sobre BRT no Brasil (corredores existentes)

\begin{tabular}{|c|c|c|c|c|c|c|}
\hline Cidade & $\begin{array}{c}\text { Passageiros / } \\
\text { dia }\end{array}$ & $\%$ & $\begin{array}{c}\mathbf{N}^{\mathbf{o}} \\
\text { Corredores }\end{array}$ & $\%$ & Km & $\%$ \\
\hline Belo Horizonte & 1.005 .000 & 8,38 & 7 & 5,83 & 39 & 4,7 \\
\hline Belém & 100.000 & 0,83 & 1 & 0,83 & 6 & 0,7 \\
\hline Blumenal & 82.000 & 0,68 & 8 & 6,66 & 11 & 1,3 \\
\hline Brasília & 301.000 & 2,51 & 6 & 5 & 91 & 10,9 \\
\hline Campinas & 200.000 & 1,7 & 3 & 2,5 & 13 & 1,6 \\
\hline Campo Grande & 73.000 & 0,6 & 4 & 3,33 & 7 & 0,87 \\
\hline Caxias do Sul & 0 & 0 & 7 & 5,83 & 10 & 1,15 \\
\hline Criciúma & 10.470 & 0,08 & 1 & 0,83 & 8 & 0,96 \\
\hline Curitiba & 561.000 & 4,7 & 7 & 5,83 & 84 & 10,07 \\
\hline Feira de Santana & 0 & 0 & 1 & 0,83 & 1 & 0,14 \\
\hline Fortaleza & 286.777 & 2,4 & 2 & 1,7 & 9 & 1 \\
\hline Goiânia & 378.300 & 3,15 & 3 & 2,5 & 27 & 3,2 \\
\hline Guarulhos & 30.000 & 0,25 & 1 & 0,83 & 4 & 0,44 \\
\hline Jaboatão dos Guararapes & 0 & 0 & 1 & 0,83 & 2 & 0,18 \\
\hline Joinville & 0 & 0 & 5 & 4,16 & 9 & 1,1 \\
\hline João Pessoa & 276.213 & 2,3 & 1 & 0,83 & 7 & 0,87 \\
\hline Juiz de Fora & 0 & 0 & 1 & 0,82 & 3 & 0,37 \\
\hline Londrina & 37.000 & 0,3 & 3 & 2,5 & 7 & 0,8 \\
\hline Maceió & 0 & 0 & 1 & 0,83 & 15 & 1,8 \\
\hline Natal & 0 & 0 & 1 & 0,83 & 4 & 0,4 \\
\hline Niterói & 250.000 & 2,1 & 1 & 0,83 & 6 & 0,7 \\
\hline Olinda & 447.695 & 3,72 & 1 & 0,83 & 14 & 1,62 \\
\hline Porto Alegre & 491.600 & 4,1 & 14 & 11,7 & 62 & 7,44 \\
\hline Recife & 701.259 & 5,84 & 4 & 3,33 & 25 & 3 \\
\hline Rio de Janeiro & 3.122 .600 & 26,04 & 16 & 13,33 & 140 & 16,4 \\
\hline Salvador & 0 & 0 & 3 & 2,5 & 8 & 0,93 \\
\hline Santos & 1.705 & 0,01 & 1 & 0,83 & 3 & 0,31 \\
\hline Sorocaba & 0 & 0 & 2 & 1,7 & 3 & 0,33 \\
\hline Sumaré & 75.000 & 0,62 & 1 & 0,83 & 33 & 3,92 \\
\hline São Paulo & 3.164 .000 & 26,4 & 10 & 8,33 & 130 & 15,6 \\
\hline $\begin{array}{lrr}\text { São Paulo } & - & \text { Área } \\
\text { Metropolitana } & & \end{array}$ & 360.000 & 3 & 1 & 0,83 & 45 & 5,4 \\
\hline Teresina & 0 & 0 & 1 & 0,83 & 2 & 0,9 \\
\hline Uberlândia & 35.100 & 0,29 & 1 & 0,83 & 8 & 0,9 \\
\hline Total & 11.989.719 & 100 & 120 & 100 & 836 & 100 \\
\hline
\end{tabular}

Fonte: Brasil, Câmara dos Deputados, 2015. 
Na Figura 34, apresenta-se a extensão do metrô em 2013 para diferentes cidades brasileiras (capitais), indicando a superioridade de São Paulo em relação às demais, enquanto na Figura 35 são apresentados os maiores sistemas de transportes do Brasil.

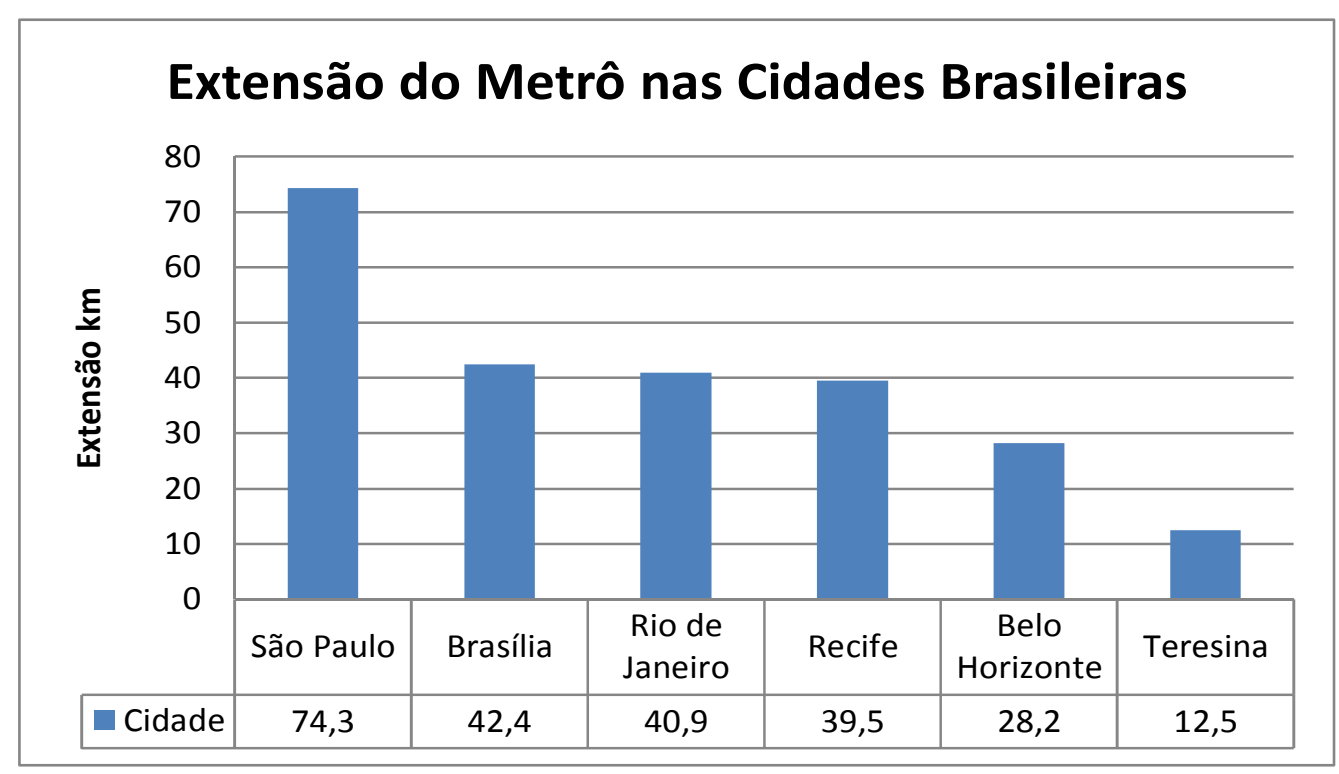

Figura 34 - Extensão do metrô em cidades brasileiras Fonte: Mobilize, 2013.

A inexistência de uma estrutura de transportes suficiente para o real atendimento das demandas da população não é o único problema enfrentado nos grandes centros brasileiros. Segundo a Câmara dos Deputados (2016, p. 36) a falta de qualidade e a ineficiência perpassam a prestação de todos os serviços urbanos, pressionados pela demanda crescente, diante de uma situação orçamentária deficitária.

Para os autores, o serviço de transporte coletivo não ficaria à revelia desse quadro, que, devido à forte presença da iniciativa privada, motivada pela maximização do lucro, a oferta e a gestão do transporte coletivo sempre estiveram aquém das necessidades da população.

Além disso, a omissão do poder público quanto à regulação e, sobretudo, à fiscalização, deu espaço para a prestação de serviços de baixa qualidade, com tarifa elevada e em horários irregulares. Desse modo, os serviços são prestados em veículos velhos, sem a manutenção adequada e estão sempre lotados.

A partir da análise da Figura 35, verifica-se que, em 2015, São Paulo e Rio de Janeiro são as capitais brasileiras que conseguem apresentar uma estrutura de transporte 
público de maior porte, principalmente com relação à tipologia de trilho, que apresenta o maior custo. Isso mostra o tamanho do déficit dos serviços de transportes, que requer o aprimoramento do contex to institucional e a realização de investimentos de longo prazo em diferentes tipos de modais.

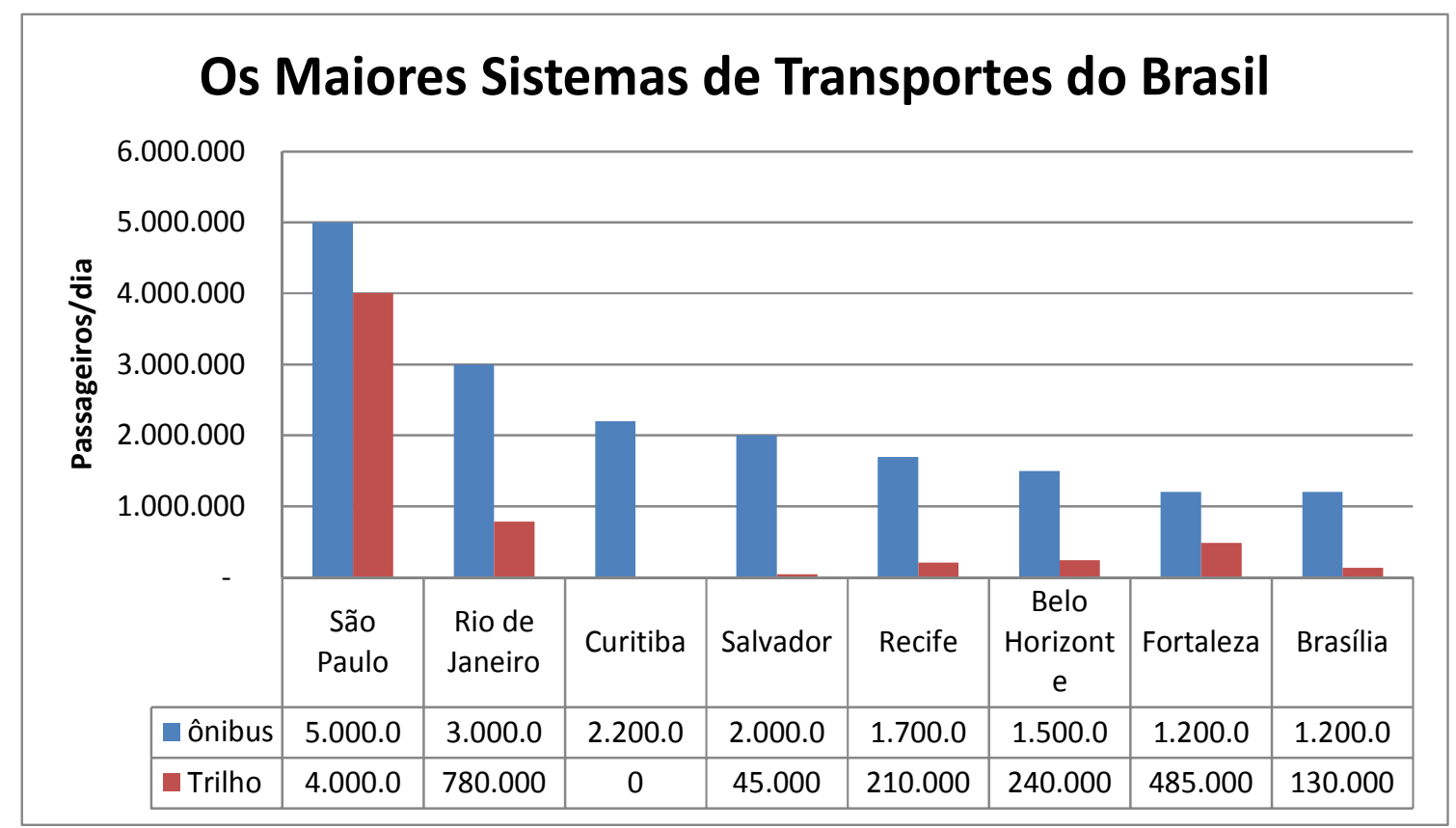

Figura 35 - Maiores sistemas de transportes do Brasil Fonte: Mobilize, março / 2015.

Para o IPEA (2016 p. 20), esses aspectos tornam-se ainda mais relevantes com relação às periferias dos aglomerados urbanos brasileiros, onde há a necessidade da definição de alternativas adequadas para o atendimento dentro de padrões aceitáveis de qualidade dos deslocamentos dessa população, principalmente no caso dos deslocamentos casa-trabalho.

Deslocamentos distantes, com baixo nível de conforto em função da acomodação em pé dos passageiros e alto nível de fragmentação dos destinos, requerem que as viagens ocorram no menor tempo possível e haja a oferta de múltiplos destinos pelo sistema público. Tudo a um preço compatível com o nível baixo de renda da população. Para isso, os corredores de transporte rodoviários têm que apresentar pistas exclusivas para o transporte coletivo, reduzindo o seu tempo de viagem, com áreas de transbordo adequadas e que permitam ultrapassagem entre os veículos nestes pontos. Além disso, o sistema tem de operar dentro do conceito de uma rede integrada para que todos possam ter condições de acesso a qualquer ponto da cidade. 
No caso de aglomerados urbanos que apresentam extensas regiões com alta densidade populacional, como ocorre principalmente no Rio de Janeiro e em São Paulo, a tecnologia metroferroviária passa a ter melhores condições de viabilidade. Atualmente, essas duas metrópoles e outras metrópoles nacionais com sistemas sobre trilhos apresentam malhas bastante reduzidas em relação às observadas nas metrópoles asiáticas, europeias e até mesmo em cidades da América Latina. A cidade do México, apresenta uma razão de 10 km de linha de metrô para cada 1 milhão de habitantes, enquanto no Rio de Janeiro e em São Paulo essa relação é superior a 2 milhões de habitantes para cada $10 \mathrm{~km}$ (CARVALHO, 2016 p. 11).

Por outro lado, os autores apontam que o grande problema dos investimentos em sistemas metroferroviários estão relacionados aos altos custos envolvidos. Uma linha de metrô pode custar a partir de $\mathrm{R} \$ 200$ milhões o quilômetro e chegar, em alguns casos, a um custo próximo de $\mathrm{R} \$ 500$ milhões/km (linha 4 do metrô de São Paulo). No caso dos BRTs, a experiência recente brasileira mostrou valores que variaram entre 10 milhões e 30 milhões de reais por quilômetro. Por isso, tem-se feito a opção de implantar essa tecnologia na maioria das grandes cidades.

Por outro lado, tendo em vista a adoção de outras formas de transportes, bem como para fazer frente aos novos tempos, muitas cidades estão investindo em infraestrutura cicloviária, além de incluir o transporte por bicicleta nos debates acerca de planos e programas de mobilidade urbana.

A partir da Figura 36, verifica-se um ranking das cidades brasileiras no que concerne à infraestrutura cicloviária, a partir de informações coletadas junto aos governos locais no início de 2015, realizada pela União dos Ciclistas do Brasil (UCB). Segundo esses dados, nas primeiras colocações, estão Brasília, Rio de Janeiro e São Paulo. De acordo com a UCB, a Capital Federal e São Paulo foram as cidades que mais ampliaram a infraestrutura para bicicletas nos dois anos anteriores à pesquisa, embora, ambas apresentem falhas de projeto e problemas com a baixa qualidade das vias implantadas.

Os debates atuais com relação à melhoria dos sistemas de transporte urbano também estão centrados com relação aos benefícios diretos e os impactos multiplicadores que as melhorias nos transportes públicos trazem para as cidades, como apontado pelo Ministério 
das Cidades no Manual de BRT (2008, p. 51). Para os autores, os benefícios de economia de tempo aos usuários de transporte público estão diretamente associados à produtividade do trabalho e à qualidade de vida. Também é apontada pelos autores a melhoria na qualidade do ar pela redução na emissão de gases de efeito estufa, além da contribuição para o desenvolvimento urbano.

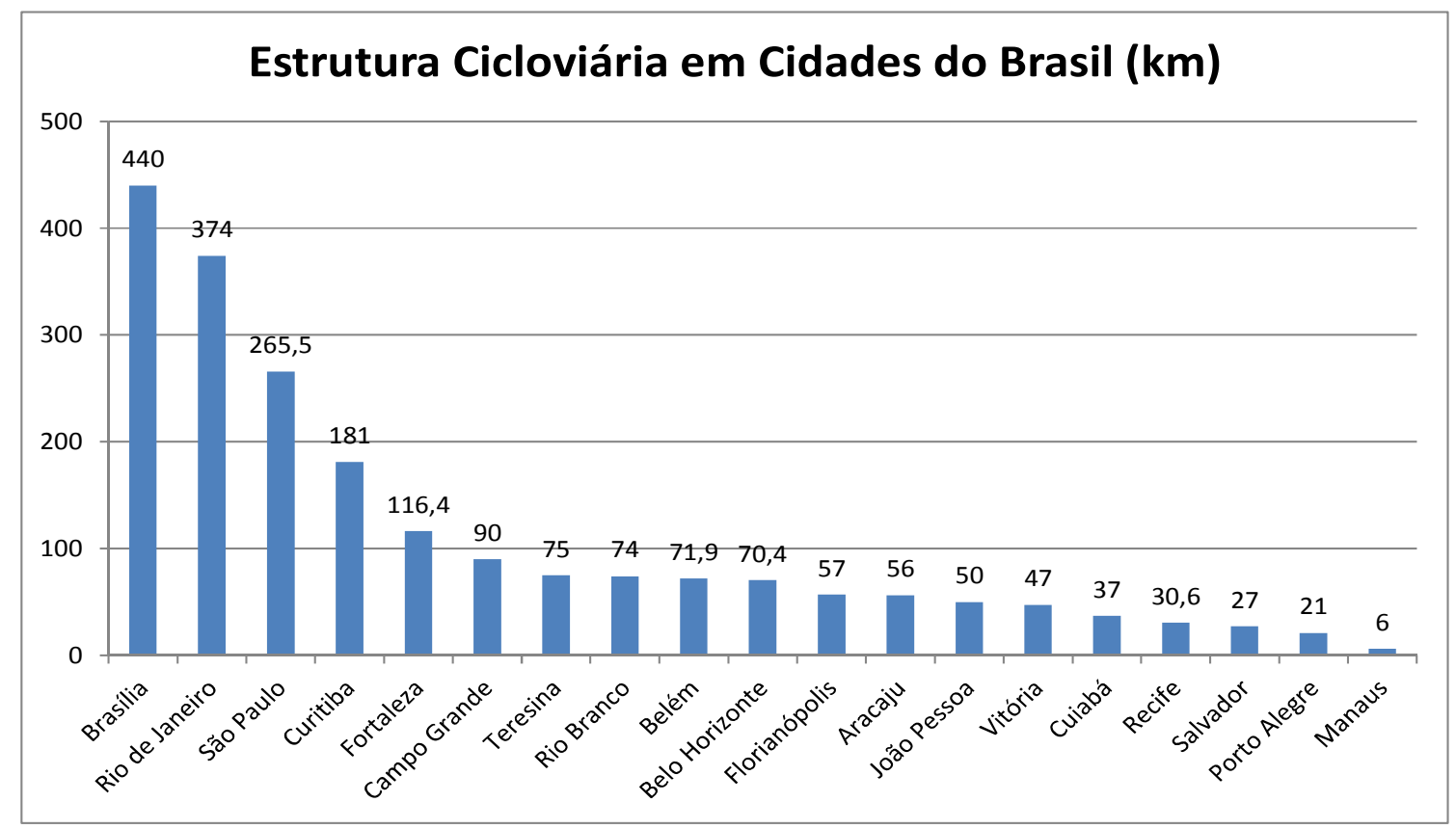

Figura 36 - Estrutura cicloviária em cidades do Brasil Fonte: Mobilize, 2015.

Embora existam diferentes opções de alternativas técnicas para a implantação de um sistema coletivo de transporte público, a escolha da tipologia a ser adotada poderá envolver um processo polêmico. De acordo com o Ministério das Cidades, no Manual de BRT (2008, p. 52), em função dos vários interesses dos grupos envolvidos e devido à quantidade substancial de contratos em jogo com o setor privado, o processo pode ficar bastante politizado. Entretanto, os autores asseguram que é preciso tomar uma decisão considerando uma sistemática racional para assegurar que o usuário seja verdadeiramente atendido.

Os principais aspectos que condicionam a escolha da tecnologia de transporte público são: o tempo de viagem, as despesas pessoais com condução e o conforto e a segurança do passageiro. Essa escolha afeta significativamente as finanças municipais e a eficiência da economia da cidade, podendo inclusive definir a forma urbana da cidade e imprimir um estilo próprio de vida aos seus habitantes. 
$\mathrm{Na}$ Tabela 17, apresentam-se informações técnicas que auxiliam no processo de escolha de diferentes tipologias de modais de transportes.

Tabela 17 - Comparação entre tipos de modais de transportes

\begin{tabular}{|c|c|c|c|c|}
\hline Característica & BRT & VLT & Monotrilho & Metrô \\
\hline $\begin{array}{l}\text { Custo médio de implantação (US\$ } \\
\text { milhões } / \mathrm{km} \text { ) }\end{array}$ & $15-40$ & $20-50$ & $40-70$ & $80-120$ \\
\hline $\begin{array}{l}\text { Capacidade máxima típica de } \\
\text { transporte (mil passageiros / hora) }\end{array}$ & $10-30$ & $10-40$ & $15-50$ & $25-80$ \\
\hline $\begin{array}{l}\text { Capacidade mínima típica de } \\
\text { transporte (passageiros / hora) }\end{array}$ & 2.000 & 2.000 & 3.000 & 10.000 \\
\hline Velocidade média $(\mathrm{km} / \mathrm{h})$ & $25-60$ & $25-40$ & $40-60$ & $40-90$ \\
\hline Ruído (dB) & 70 a 90 (elevado) & 60 a 80 & 60 a 80 & 75 a 100 \\
\hline Conforto & $\begin{array}{l}\text { Menor conforto } \\
\text { (interferências de } \\
\text { freadas e } \\
\text { semáforos) }\end{array}$ & $\begin{array}{c}\text { Conforto } \\
\text { médio } \\
\text { (interferências } \\
\text { de semáforos e } \\
\text { trânsito) }\end{array}$ & $\begin{array}{l}\text { Maior conforto (para } \\
\text { somente nas estações, } \\
\text { menor tempo de } \\
\text { trajeto, pode-se } \\
\text { apreciar a paisagem }\end{array}$ & $\begin{array}{l}\text { Maior conforto } \\
\text { (para somente } \\
\text { nas estações, } \\
\text { menor tempo de } \\
\text { trajeto) }\end{array}$ \\
\hline Interferência no trânsito & Alta & Alta & Mínima & $\begin{array}{l}\text { Mínima (se } \\
\text { subterrâneo) }\end{array}$ \\
\hline Custo previsto em desapropriação & Elevado & Elevado & Baixo & Médio \\
\hline Interferência durante a construção & Elevada & Elevada & Média & Baixa \\
\hline $\begin{array}{l}\text { Capacidade de atrair usuários do } \\
\text { transporte individual }\end{array}$ & Baixa & Média & Alta & Alta \\
\hline
\end{tabular}

Fonte: Brasil, Câmara dos Deputados, 2015.

A partir dessas informações, verifica-se que o metrô apresenta os maiores custos por $\mathrm{km}$, contudo, possibilita a maior capacidade de transporte, inclusive em maior velocidade. Por outro lado, o BRT apresenta os menores custos, a menor capacidade de transporte e a menor velocidade.

Embora o BRT apresente os menores custos, poderá ter um projeto inviabilizado em função de sua característica de elevado custo previsto com desapropriação. Esse aspecto se torna ainda mais relevante com relação aos grandes centros urbanos onde o problema se apresenta de forma mais concentrada.

$\mathrm{Na}$ Figura 37, apresenta-se a disposição de diferentes tipologias de sistema de transporte público que pode ser elaborada a partir do mesmo custo. 


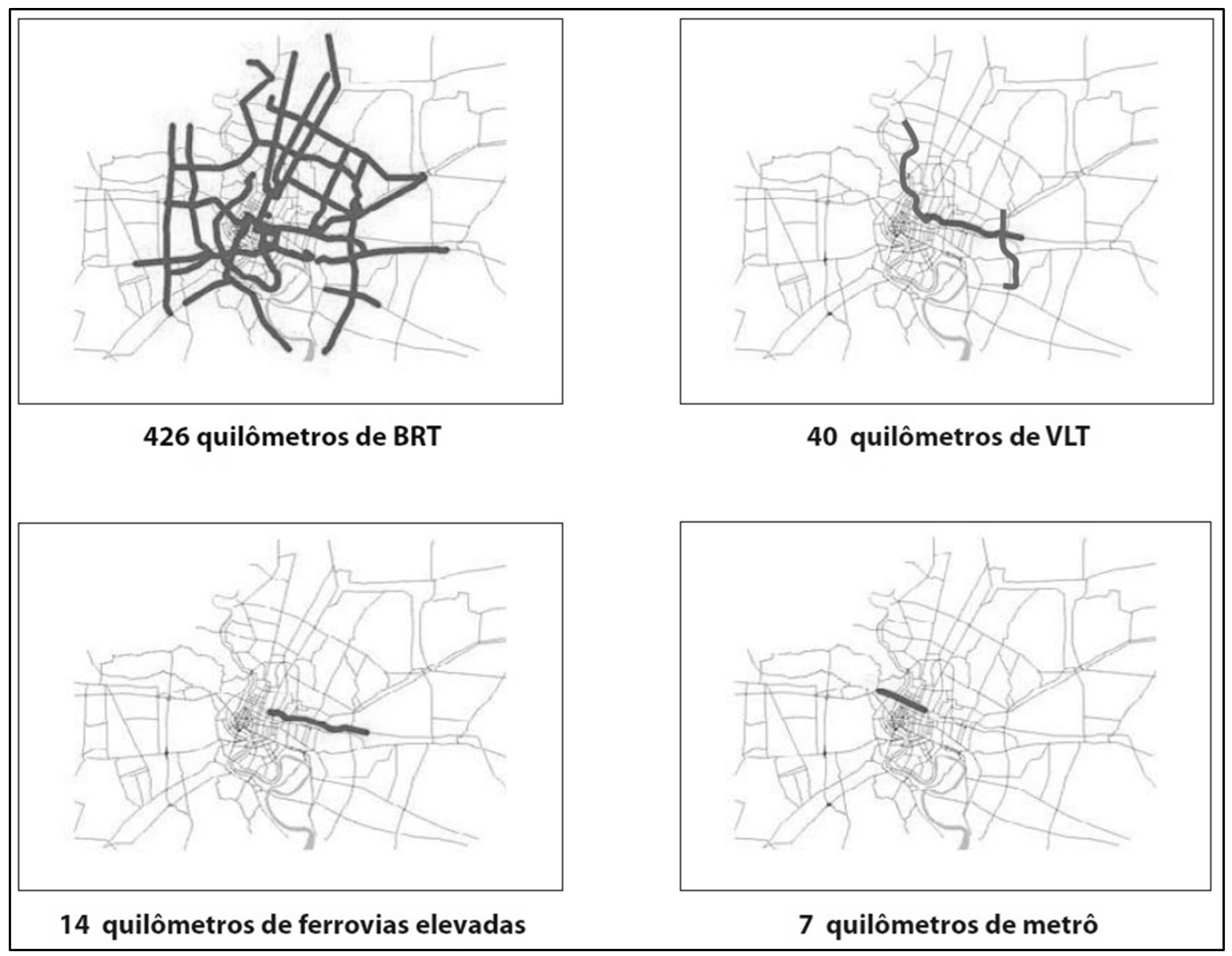

Figura 37 - Quatro sistemas de transportes com o mesmo custo Fonte: MCidades, Manual de BRT, 2008.

A opção por uma tecnologia específica deverá considerar custos, desempenho, condições locais e preferências pessoais. Em função disso, o Ministério das Cidades, por meio do Manual de BRT (2008, p. 57), sugere a adoção de um processo de tomada de decisão baseado na comparação entre diferentes tipologias de transportes públicos, a partir da elaboração de um quadro de trabalho para ser possível avaliar objetivamente cada critério.

Os autores advertem que uma abordagem de cima para baixo, que comece com o foco em uma tecnologia já determinada, talvez não seja a ideal. Defendem que é melhor definir as características desejadas para o transporte público antes de selecionar uma tecnologia em particular, visto que, ao entender as necessidades dos usuários a respeito das tarifas, itinerários e localização, tempos de viagem, conforto, proteção, segurança, frequência de serviços, qualidade da infraestrutura e facilidade de acesso, os 
desenvolvedores do sistema poderão definir o tipo preferido de serviço sem inclinações por uma tecnologia em particular.

Embora sejam definidos os critérios acima para orientar a tomada de decisão quanto à tecnologia a ser adotada, a escolha da tipologia de transporte a ser implantada fica restrita, majoritariamente, ao desempenho e ao custo. Supõe-se que isso ocorra no Brasil, principalmente, em função da grande demanda pelos serviços em contraposição à baixa disponibilidade de recursos orçamentários.

A experiência recente do Brasil diante de eventos internacionais, tais como a Copa e as Olimpíadas, representaram marcos na trajetória atual da política de transporte urbano em andamento. Porém, vale ressaltar que as condições atuais identificadas com relação à prestação desse serviço nas cidades brasileiras ainda são muito precárias e requerem investimentos públicos assegurados em linhas constantes de financiamento e em longo prazo para que seja possível a transformação efetiva do quadro atual.

A partir da discussão apresentada, percebe-se que, dos três aspectos observados com relação ao panorama das políticas setoriais de habitação, saneamento e mobilidade, o terceiro, apresenta um longo caminho a ser percorrido quanto à maturidade da política pública. Embora a política de transportes seja antiga, a estratégia tradicional para lidar com as demandas da sociedade priorizou o uso de automóveis, transferindo a resolução do problema ao particular, em detrimento das soluções de uso coletivo.

Com isso, os esforços empreendidos, a disponibilidade de recursos orçamentários e a organização institucional dessa política ainda não dispõem do mesmo nível de "maturidade" já observado com relação às políticas de habitação e saneamento. O mesmo também se repete quanto aos dados e indicadores disponíveis para monitorar os níveis de precariedade do contexto urbano em relação aos transportes e à qualidade na prestação dos serviços. Ressalta-se que habitação e saneamento dispõem de um maior número de variáveis monitoradas que são divulgadas por fontes de amplo acesso, possibilitando a construção de séries históricas.

Algo evidente após a discussão desses indicadores se refere à fragmentação entre eles. Cada um dos três setores tem sua lógica própria de planejamento e não considera essas problemáticas de forma conjunta. 


\subsection{Panorama recente dos investimentos da política urbana: habitação,}

saneamento e mobilidade

Diferentemente do setor privado, a Administração Pública requerer uma sistemática específica para a execução de ações que envolvem recursos orçamentários e financeiros, sendo o conjunto que envolve o Plano Plurianual (PPA), Lei de Diretrizes Orçamentárias (LDO) e a Lei Orçamentária Anual (LOA) a principal referência que normatiza essa prática. Desse modo, desde a sua criação em 2003, o Ministério das Cidades teve suas ações inscritas em três PPAs inteiros: 2004/2007, 2008/2011 e 2012/2015.

A primeira etapa de análise da política urbana executada pelo MCidades diz respeito à verificação das temáticas inseridas nos programas e ações conduzidos pelo órgão. Buscase com isso verificar se a prática contempla o discurso, contemplando a diversidade de temas considerados essenciais ao desenvolvimento urbano.

Logo de partida, percebe-se que a análise das ações realizadas pelo Ministério no PPA de 2012/2015 aponta a existência de um abismo entre o quantitativo de aspectos e temáticas destacadas nas teorias (Capítulo 1) e nos discursos das políticas já propostas (Capítulo 2) com relação às ações de fato realizadas. E isso também se estende ao conjunto de variáveis e indicadores adotados para monitorar os aspectos que caracterizam a qualidade urbana nas cidades (Capítulo 3).

De uma forma geral, isso mostra a dificuldade existente em se conseguir colocar em prática, em termos de políticas públicas, os aspectos discutidos quanto aos problemas e às alternativas técnicas para a solução da problemática urbana. Também confirma a suposição já discutida nesta tese de que a política urbana preconizada nos discursos não contempla a real complexidade da problemática urbana, sendo este aspecto ainda mais relevante com relação às ações praticadas, que representam a materialidade da política pública.

Ou seja, durante o caminho percorrido desde as discussões teóricas e conceituais sobre a problemática urbana, a construção do discurso da política pública e a definição das ações práticas para concretizar a resolução dos problemas mostra a simplificação grosseira do conteúdo. Sabe-se que uma situação que envolve um nível de complexidade alto, como é o caso da problemática urbana, requer uma sistemática de planejamento da ação pública 
mais requintada para que possa atender essa demanda bem como minimizar as perdas conceituais. Para esses casos, é indispensável, inclusive, a ação coordenada.

Em função dessas dificuldades e de outras peculiaridades da ação governamental para identificar causa e efeito dos problemas, bem como propor programas para combater ou minimizar um contexto social problemático, apenas sobrevivem alternativas que se mostram viáveis. Também são escolhidas as que são financeiramente rentáveis e aquelas que também favoreçam de alguma forma aos interesses dos atores que participam ou influenciam o processo de tomada de decisão.

Nos Quadros 3 a 6 são apresentadas as ações realizadas pelo Ministério das Cidades, que fizeram parte do PPA de 2012 a 2015. A partir das informações apresentadas, percebese a concentração das ações na SNH e na SNSA reforçando o desequilíbrio entre as secretarias, além de as ações orçamentárias não contemplarem a totalidade de temas e aspectos associados à problemática urbana.

Quadro 3 - Ações da Secretaria Nacional de Habitação

\begin{tabular}{|c|c|c|}
\hline \multirow{2}{*}{ Programa } & \multicolumn{2}{|r|}{ Ação } \\
\hline & Item & Nome \\
\hline \multirow{16}{*}{2049 Moradia Digna } & 00AF & Integralização de Cotas ao Fundo de Arrendamento Residencial - FAR \\
\hline & $00 \mathrm{CW}$ & $\begin{array}{l}\text { Subvenção Econômica Destinada a Implementação de Projetos de } \\
\text { Interesse Social em Áreas Urbanas (Lei no } 11.977 \text {, de 2009) }\end{array}$ \\
\hline & OOCX & $\begin{array}{l}\text { Subvenção Econômica Destinada a Implementação de Projetos de } \\
\text { Interesse Social em Áreas Rurais (Lei n }{ }^{\circ} 11.977 \text {, de } 2009 \text { ) }\end{array}$ \\
\hline & $00 \mathrm{CY}$ & Transferências ao Fundo de Desenvolvimento Social - FDS \\
\hline & 0E64 & $\begin{array}{l}\text { Subvenção Econômica Destinada à Habitação de Interesse Social em } \\
\text { Cidades com menos de } 50.000 \text { Habitantes (Lei n } 11.977 \text {, de 2009) }\end{array}$ \\
\hline & $10 \mathrm{~S} 3$ & Apoio à Urbanização de Assentamentos Precários \\
\hline & 10S6 & $\begin{array}{l}\text { Apoio à Melhoria das Condições de Habitabilidade de Assentamentos } \\
\text { Precários }\end{array}$ \\
\hline & $10 \mathrm{SJ}$ & Apoio à Provisão Habitacional de Interesse Social \\
\hline & $1 \mathrm{~B} 25$ & Apoio ao Fortalecimento da Política Nacional de Habitação \\
\hline & $20 \mathrm{NX}$ & $\begin{array}{l}\text { Apoio à sustentabilidade dos empreendimentos de habitação de interesse } \\
\text { social }\end{array}$ \\
\hline & $20 Z 0$ & Apoio ao Fortalecimento da Política Nacional de Habitação \\
\hline & $20 Z 9$ & Apoio à Melhoria e à Modernização do Setor da Construção Civil \\
\hline & 8098 & $\begin{array}{l}\text { Cooperação para Capacitação Profissional e Assistência Técnica à } \\
\text { Construção Civil }\end{array}$ \\
\hline & 8100 & $\begin{array}{l}\text { Fomento aos Sistemas de Qualidade e Inovação Tecnológica do Setor da } \\
\text { Construção Civil }\end{array}$ \\
\hline & 8873 & $\begin{array}{l}\text { Apoio ao Desenvolvimento Institucional dos Agentes Integrantes do } \\
\text { SNHIS }\end{array}$ \\
\hline & 8875 & $\begin{array}{l}\text { Apoio à Elaboração de Planos e Prestação de Serviços de Assistência } \\
\text { Técnica para Habitação de Interesse Social }\end{array}$ \\
\hline
\end{tabular}

Fonte: SIAFI. 
Quadro 4 - Ações da Secretaria Nacional de Transportes e da Mobilidade Urbana

\begin{tabular}{|l|l|l|}
\hline \multirow{2}{*}{ Programa } & \multicolumn{2}{c|}{ Ação } \\
\cline { 2 - 3 } & Item & \multicolumn{1}{c|}{ Nome } \\
\hline \multirow{4}{*}{$\begin{array}{l}\text { Urbana e Trânsito } \\
\text { UrosR }\end{array}$} & $\begin{array}{l}\text { Apoio à Elaboração de Planos e Projetos de Sistemas de Transporte } \\
\text { Público Coletivo Urbano }\end{array}$ \\
\cline { 2 - 3 } & 10SS & Apoio a Sistemas de Transporte Público Coletivo Urbano \\
\cline { 2 - 3 } & 10ST & Apoio a Projetos de Sistemas de Circulação Não-Motorizados \\
\cline { 2 - 3 } & 2D47 & Apoio a Medidas de Moderação de Tráfego \\
\cline { 2 - 3 } & 2D49 & $\begin{array}{l}\text { Apoio ao Desenvolvimento Institucional para a Gestão dos Sistemas de } \\
\text { Mobilidade Urbana }\end{array}$ \\
\cline { 2 - 3 } & N31F & $\begin{array}{l}\text { Desenvolvimento e Gestão de Sistemas de Mobilidade urbana e de } \\
\text { Transporte Coletivo Urbano }\end{array}$ \\
\hline
\end{tabular}

Fonte: SIAFI.

Quadro 5 - Ações da Secretaria Nacional de Acessibilidade e Programas Urbanos

\begin{tabular}{|c|c|c|}
\hline \multirow{2}{*}{ Programa } & \multicolumn{2}{|r|}{ Ação } \\
\hline & Item & Nome \\
\hline \multirow{2}{*}{$\begin{array}{l}2040 \text { Gestão de Riscos } \\
\text { e Resposta a Desastres }\end{array}$} & $20 \mathrm{NN}$ & $\begin{array}{l}\text { Planejamento e Monitoramento da Ocupação Urbana em Áreas } \\
\text { Suscetíveis a Inundações, Enxurradas e Deslizamentos }\end{array}$ \\
\hline & 8865 & $\begin{array}{l}\text { Apoio ao Planejamento e Execução de Obras de Contenção de Encostas } \\
\text { em Áreas Urbanas (Prevenção de Riscos) }\end{array}$ \\
\hline $\begin{array}{l}2048 \quad \text { Mobilidade } \\
\text { Urbana e Trânsito }\end{array}$ & $10 \mathrm{~T} 2$ & $\begin{array}{l}\text { Apoio a Projetos de Acessibilidade para Pessoas com Restrição de } \\
\text { Mobilidade e Deficiência }\end{array}$ \\
\hline \multirow{4}{*}{$\begin{array}{l}2054 \\
\text { Urbano }\end{array}$} & $20 \mathrm{NR}$ & $\begin{array}{l}\text { Apoio à Elaboração e Implementação de Planos e Projetos Urbanos } \\
\text { Integrados de Reabilitação e Requalificação de Áreas Urbanas }\end{array}$ \\
\hline & $7 \mathrm{~S} 30$ & $\begin{array}{l}\text { Construção de Pontes Urbanas em Municípios do Litoral do Estado da } \\
\text { Bahia }\end{array}$ \\
\hline & 8866 & Apoio à Regularização Fundiária em Áreas Urbanas (Papel Passado) \\
\hline & 8874 & $\begin{array}{l}\text { Apoio ao Planejamento Territorial e Gestão Urbana Municipal e } \\
\text { Interfederativa }\end{array}$ \\
\hline $\begin{array}{l}2064 \text { Promoção e } \\
\text { Defesa dos Direitos } \\
\text { Humanos }\end{array}$ & $20 \mathrm{NU}$ & $\begin{array}{l}\text { Apoio à Prevenção da Violação dos Direitos Humanos em Ações de } \\
\text { Desenvolvimento Urbano }\end{array}$ \\
\hline
\end{tabular}

Fonte: SIAFI. 
Quadro 6 - Ações da Secretaria Nacional de Saneamento Ambiental

\begin{tabular}{|c|c|c|}
\hline \multirow{2}{*}{ Programa } & \multicolumn{2}{|r|}{ Ação } \\
\hline & Item & Nome \\
\hline $\begin{array}{l}2040 \text { Gestão de Riscos } \\
\text { e Resposta a Desastres }\end{array}$ & $10 \mathrm{SG}$ & $\begin{array}{l}\text { Apoio a Sistemas de Drenagem Urbana Sustentável e de Manejo de } \\
\text { Águas Pluviais em Municípios com População Superior a } 50 \text { mil } \\
\text { Habitantes ou Integrantes de Regióes Metropolitanas ou de Regiôes } \\
\text { Integradas de Desenvolvimento Econômico }\end{array}$ \\
\hline $\begin{array}{ll}2054 & \text { Planejamento } \\
\text { Urbano }\end{array}$ & $1 \mathrm{D} 73$ & Apoio à Política Nacional de Desenvolvimento Urbano \\
\hline \multirow{13}{*}{$\begin{array}{l}2068 \\
\text { Básico }\end{array}$} & $10 \mathrm{~S} 5$ & $\begin{array}{l}\text { Apoio a Empreendimentos de Saneamento Integrado em Municípios com } \\
\text { População Superior a } 50 \text { mil Habitantes ou Municípios Integrantes de } \\
\text { Regiões Metropolitanas ou de Regiões Integradas de Desenvolvimento }\end{array}$ \\
\hline & $10 \mathrm{SC}$ & $\begin{array}{l}\text { Apoio à Implantação, Ampliação ou Melhorias em Sistemas de } \\
\text { Abastecimento de Âgua em Municípios com População Superior a } 50 \\
\text { mil Habitantes ou Municípios Integrantes de Regiões Metropolitanas ou } \\
\text { de Regiões Integradas de Desenvolvimento }\end{array}$ \\
\hline & $116 \mathrm{I}$ & $\begin{array}{l}\text { Apoio a Sistemas Públicos de Manejo de Resíduos Sólidos em } \\
\text { Municípios com População Superior a } 50 \text { mil Habitantes ou Municípios } \\
\text { Integrantes de Regiões Metropolitanas ou de Regiões Integradas de } \\
\text { Desenvolvimento }\end{array}$ \\
\hline & $12 \mathrm{MH}$ & $\begin{array}{l}\text { Apoio à Redução e Controle de Perdas de Água em Sistemas de } \\
\text { Abastecimento em Regiões Metropolitanas, Regiões Integradas de } \\
\text { Desenvolvimento Econômico, Municípios com mais de } 50 \text { mil } \\
\text { Habitantes ou Integrantes de Consórcios Públicos com mais de } 150 \text { mil } \\
\text { Hab }\end{array}$ \\
\hline & $142 \mathrm{H}$ & $\begin{array}{l}\text { Apoio a Sistemas de Manejo de Águas Pluviais e Drenagem Urbana } \\
\text { Sustentável em Municípios com População Inferior a } 50 \text { mil Habitantes, } \\
\text { exceto Municípios Integrantes de Regiões Metropolitanas ou de Regiões } \\
\text { Integradas de Desenvolvimento Econômico }\end{array}$ \\
\hline & $1 \mathrm{~N} 08$ & $\begin{array}{l}\text { Apoio à Implantação, Ampliação ou Melhorias de Sistemas de } \\
\text { Esgotamento Sanitário em Municípios com População Superior a } 50 \text { mil } \\
\text { Habitantes ou Municípios Integrantes de Regiões Metropolitanas ou de } \\
\text { Regiões Integradas de Desenvolvimento }\end{array}$ \\
\hline & 1P95 & $\begin{array}{l}\text { Apoio à Elaboração de Planos e Projetos de Saneamento em Municípios } \\
\text { com População Superior a } 50 \text { mil Habitantes ou Integrantes de Regiôes } \\
\text { Metropolitanas ou de Regiões Integradas de Desenvolvimento }\end{array}$ \\
\hline & $20 \mathrm{NV}$ & $\begin{array}{l}\text { Apoio à Implementação de Ações de Desenvolvimento do Setor Águas - } \\
\text { INTERÁGUAS }\end{array}$ \\
\hline & $20 \mathrm{NW}$ & $\begin{array}{l}\text { Apoio a Estruturação e Implementação do Sistema Nacional de } \\
\text { Informações em Saneamento Básico - SINISA }\end{array}$ \\
\hline & $20 \mathrm{Z5}$ & $\begin{array}{l}\text { Desenvolvimento de Atividades de Capacitação, Assistência Técnica e } \\
\text { Desenvolvimento Científico e Tecnológico voltados ao Setor de } \\
\text { Saneamento }\end{array}$ \\
\hline & 3955 & $\begin{array}{l}\text { Desenvolvimento de Atividades de Capacitação, Assistência Técnica e } \\
\text { Desenvolvimento Científico e Tecnológico }\end{array}$ \\
\hline & 8871 & $\begin{array}{l}\text { Apoio à Elaboração e Monitoramento de Planos de Saneamento } \\
\text { Regionais e Nacional }\end{array}$ \\
\hline & N34E & $\begin{array}{l}\text { Aperfeiçoamento da Gestão e Prestação de Serviços de Saneamento } \\
\text { Básico }\end{array}$ \\
\hline
\end{tabular}

Fonte: SIAFI. 
Na Tabela 18, são apresentados os investimentos realizados pelo Ministério das Cidades no período do PAC 1 e 2, segundo as Secretarias Nacionais. Vale ressaltar que o total de investimentos realizados também envolve a soma dos recursos de contrapartida dos proponentes (municípios, estados, concessionárias, e outros que recebem aporte de recursos do Ministério) que variam entre $5 \%$ e $15 \%$ a depender do tipo de ação.

Tabela 18 - Investimentos do PAC 1 e 2 no período de 2007 a 2014

\begin{tabular}{|l|c|}
\hline \multicolumn{1}{|c|}{ Setor } & $\begin{array}{c}\text { Investimentos contratado ou em contratação } \\
\text { (R\$ bilhão) }\end{array}$ \\
\hline HABITAÇãO & $\mathbf{2 8 3 , 3}$ \\
\hline Urbanização PAC & 28,8 \\
\hline PMCMV & 254,5 \\
\hline SANEAMENTO BÁSICO & $\mathbf{8 5 , 9}$ \\
\hline MOBILIDADE URBANA & $\mathbf{1 0 6 , 2}$ \\
\hline Pacto da Mobilidade & 50,0 \\
\hline PAC Copa & 12,6 \\
\hline PAC pavimentação & 10,6 \\
\hline PAC Grandes/médias cidades & 33,0 \\
\hline PROGRAMS URBANOS & $\mathbf{2 , 1}$ \\
\hline PAC Risco & 2,1 \\
\hline TOTAL & $\mathbf{4 7 7 , 5}$ \\
\hline
\end{tabular}

Fonte: MCidades, 2015.

Os dados referentes à habitação mostram que esse setor foi o que mais recebeu recursos durante todos os anos do PAC, representando 59,34\% do total dos investimentos realizados. Mesmo assim, ao analisar a distribuição dos recursos entre urbanização e o PCMCMV que realiza a construção de novas unidades habitacionais, verifica-se que os investimentos em urbanização representaram pouco mais de $10 \%$ do total dos recursos para o setor. Destaca-se que as ações de urbanização têm como objeto as favelas, que estão inseridas no universo da população em situação mais precária.

Os investimentos em saneamento representaram $18 \%$ do total de recursos investidos, sendo que os de mobilidade totalizam $22,2 \%$ e os de programas urbanos com foco em situações de áreas de risco, 0,4\%. Quase 50\% dos investimentos em mobilidade cresceram com o pacto da mobilidade realizado em 2013 e as áreas de risco representaram a principal preocupação das ações de programas urbanos durante o PAC. 


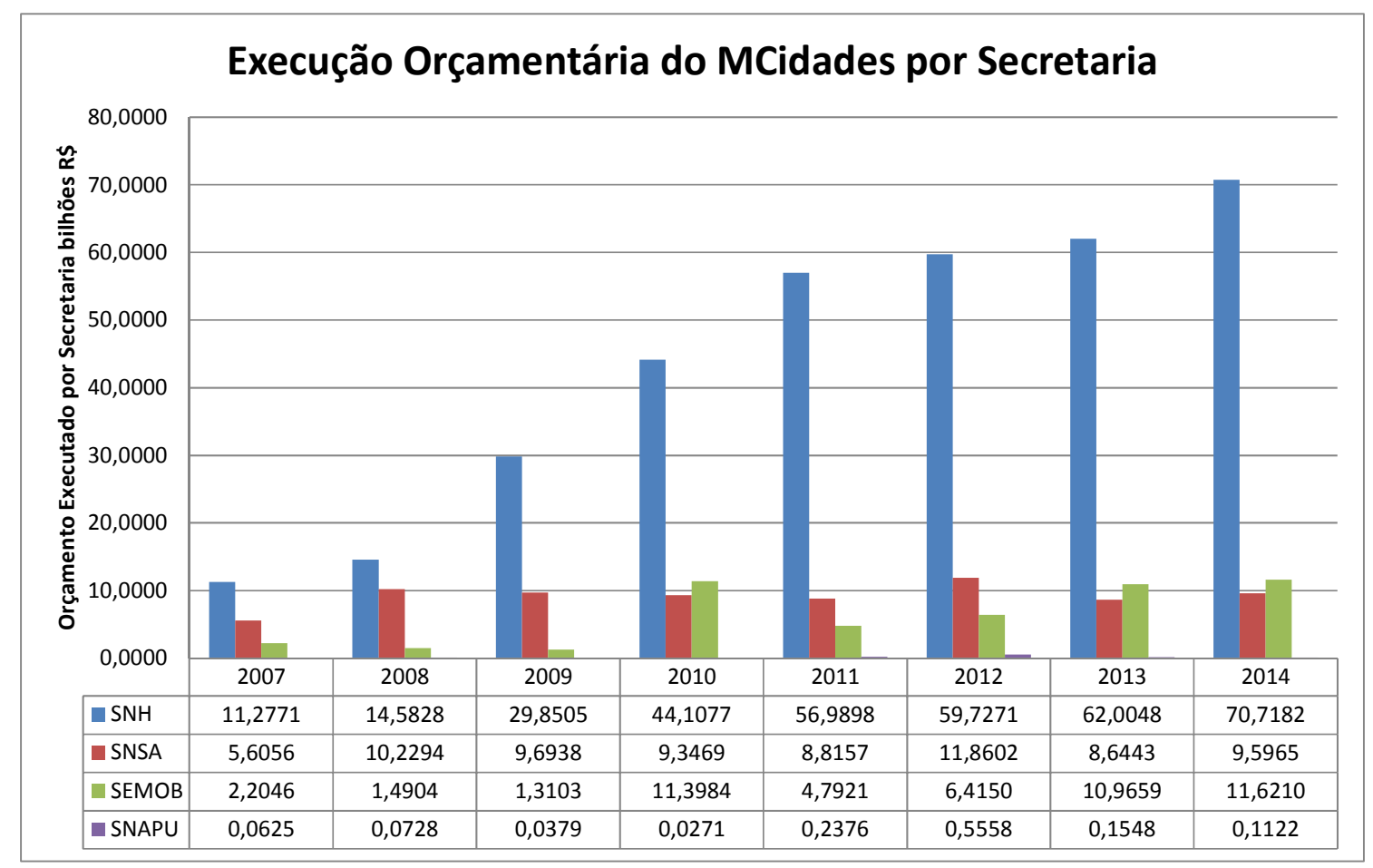

Figura 38 - Execução orçamentária do Ministério das Cidades 2007 a 2014 Fonte: Siga Brasil.

A inserção da Figura 38 no texto foi proposital, no sentido de mostrar graficamente o tamanho da distância existente entre a SNH e as demais secretarias do Ministério, principalmente com relação à SNAPU que nem aparece no gráfico. É possível visualizar graficamente a importância histórica que é conferida à habitação, bem como a forma desconectada e setorializada de como as demandas são atendidas. Mesmo que esse aspecto do problema possa ter preponderância em relação aos demais, como suposto por alguns autores, é possível se questionar se essa é a forma mais adequada de se tratar a questão.

Vale destacar que a partir de 2013 a SEMOB passou a contar com mais recursos que a SNSA em função da retomada da política de transportes de forma mais contundente pelo governo federal, devido ao pacto da mobilidade, após as manifestações de 2013. Também é preciso reconhecer que o nível de complexidade e a dimensão quanto ao montante de investimentos, requerem investimentos mais elevados que as demais tipologias de obras realizadas pelo Ministério.

Essa primeira análise da aplicação dos recursos mostra que a habitação, em 2014, dispôs de mais de 630 vezes dos recursos voltados para programas urbanos, mais de 7 vezes dos recursos de saneamento e mais de 6 vezes dos recursos de mobilidade. Mesmo 
que não deva existir uma relação diretamente proporcional entre as diferentes modalidades de investimentos, é possível se questionar se as necessidades de saneamento e transportes dessas populações realmente estão sendo atendidas, conforme a cidade cresce em função da expansão habitacional, tampouco se as demandas existentes estão sendo atendidas adequadamente.

Será que essas novas habitações estão recebendo as devidas instalações de saneamento básico? Dispõem de serviços de transportes adequados ou a prestação desse serviço ficará como uma pendência para ser resolvida em um futuro posterior? O processo de planejamento da implantação dessas habitações buscou conformidade com o planejamento urbano municipal, ou até existiam planos diretores nos municípios? Qual a proximidade dos conjuntos habitacionais construídos dos equipamentos sociais? Também abre espaço para se questionar com relação a outras temáticas apontadas como importantes para o enfrentamento da problemática urbana e que não são contempladas nas ações. As áreas estão devidamente regularizadas? As condicionantes ambientais para a autorização do início das obras foram atendidas? Os problemas associados à condição de risco e de acessibilidade foram devidamente contemplados nos projetos de engenharia?

Além da preocupação quanto ao atendimento na prestação de serviços urbanos, percebe-se que praticamente não existe preocupação com relação ao planejamento das cidades ou até com aquelas temáticas que não necessariamente envolvam a realização de obras, mas que são essenciais para a expansão "saudável" de uma cidade, tais como a regularização fundiária, os usos do solo, a questão ambiental e de acessibilidade. Desse modo, ficam em último plano as ações que deveriam contemplar os instrumentos especificados no Estatuto da Cidade as quais foram asseguradas em lei e que deveriam orientar o processo de "desenvolvimento urbano".

Tem-se aqui o receio de que a sistemática de aplicação desses recursos pelo Ministério das Cidades esteja replicando o processo de expansão das cidades ocorrido em períodos anteriores. Um dos resultados dessa época foi a perpetuação e acentuação da condição de desigualdade que se observa nos grandes centros urbanos. Embora seja importante concentrar esforços na diminuição do déficit habitacional que persiste nos grandes centros, é extremamente preocupante a forma como essas novas unidades habitacionais são inseridas no meio urbano. 
Esses aspectos serão analisados nos itens seguintes, que irão tratar dos investimentos realizados no âmbito da política de habitação, saneamento e mobilidade, separadamente.

\section{Investimentos em habitação}

Historicamente, o Brasil dispõe de duas fontes oficiais de financiamento para a política habitacional, as quais são fortemente subsidiadas e reguladas: (i) os depósitos de poupança relativos ao Sistema Brasileiro de Poupança e Empréstimo (SBPE); e (ii) os depósitos do Fundo de Garantia por Tempo de Serviço (FGTS).

A primeira fonte é alimentada principalmente pela poupança voluntária, proveniente dos depósitos de poupança do SBPE, constituído pelas instituições que captam essa modalidade de aplicação financeira. Esses depósitos são provenientes de recursos privados com subsídios implícitos para os poupadores, uma vez que esses rendimentos possuem isenção tributária.

As normas do Conselho Monetário Nacional (CMN) estabelecem que, no mínimo, $65 \%$, desses recursos devem ser aplicados em operações de financiamentos imobiliários, devendo $80 \%$ do montante anterior ser destinado para operações no âmbito do Sistema Financeiro de Habitação (SFH) e o restante em operações a taxas de mercado (Resoluções $\mathrm{n}^{\mathrm{o}} 1.980$, de 30.04.1993 e $\mathrm{n}^{\mathrm{o}} 3.005$, de 30.07.2002).

A segunda fonte de financiamento tem origem na poupança compulsória proveniente dos recursos do Fundo de garantia por Tempo de Serviço (FGTS), regidos segundo normas e diretrizes estabelecidas por um Conselho Curador, onde a Caixa Econômica Federal desempenha o papel de agente operador. Esses recursos, a partir de 2003, passaram a ser utilizados priorizando o atendimento a famílias de baixa renda, com ampliação de dotação orçamentária destinada a financiamento da habitação popular, viabilizando o subsídio a famílias nas faixas de renda abaixo de três salários mínimos.

De acordo com a Política Nacional de Habitação, fazem parte do Sistema Nacional de Habitação dois subsistemas: o Subsistema Nacional de Habitação de Mercado (SNHM) e o Subsistema Nacional de Habitação de Interesse Social (SNHIS). É a partir dessa divisão que fica estabelecido o atendimento à classe média por meio do mercado privado e à população de baixa renda pela produção de moradias pelo setor público. O setor público deve ter como alvo a população de baixa renda onde está concentrado o déficit 
habitacional. Nas Figuras 39 e 40, respectivamente, apresenta-se a evolução dos financiamentos imobiliários por fonte de recursos e a evolução do quantitativo das unidades financiadas.

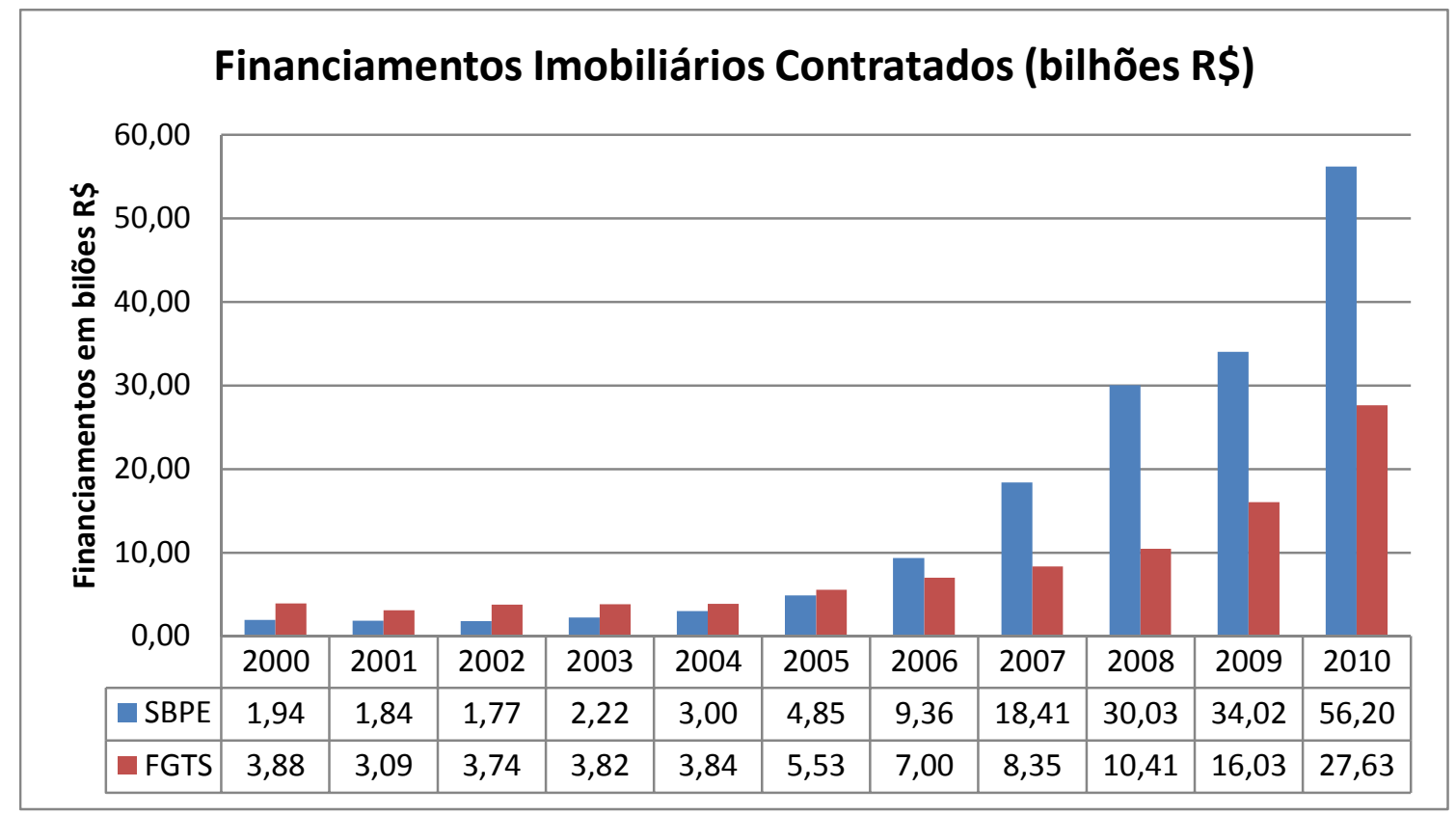

Figura 39 - Financiamentos contratados por fonte de recurso Fonte: Banco Central do Brasil, 2011.

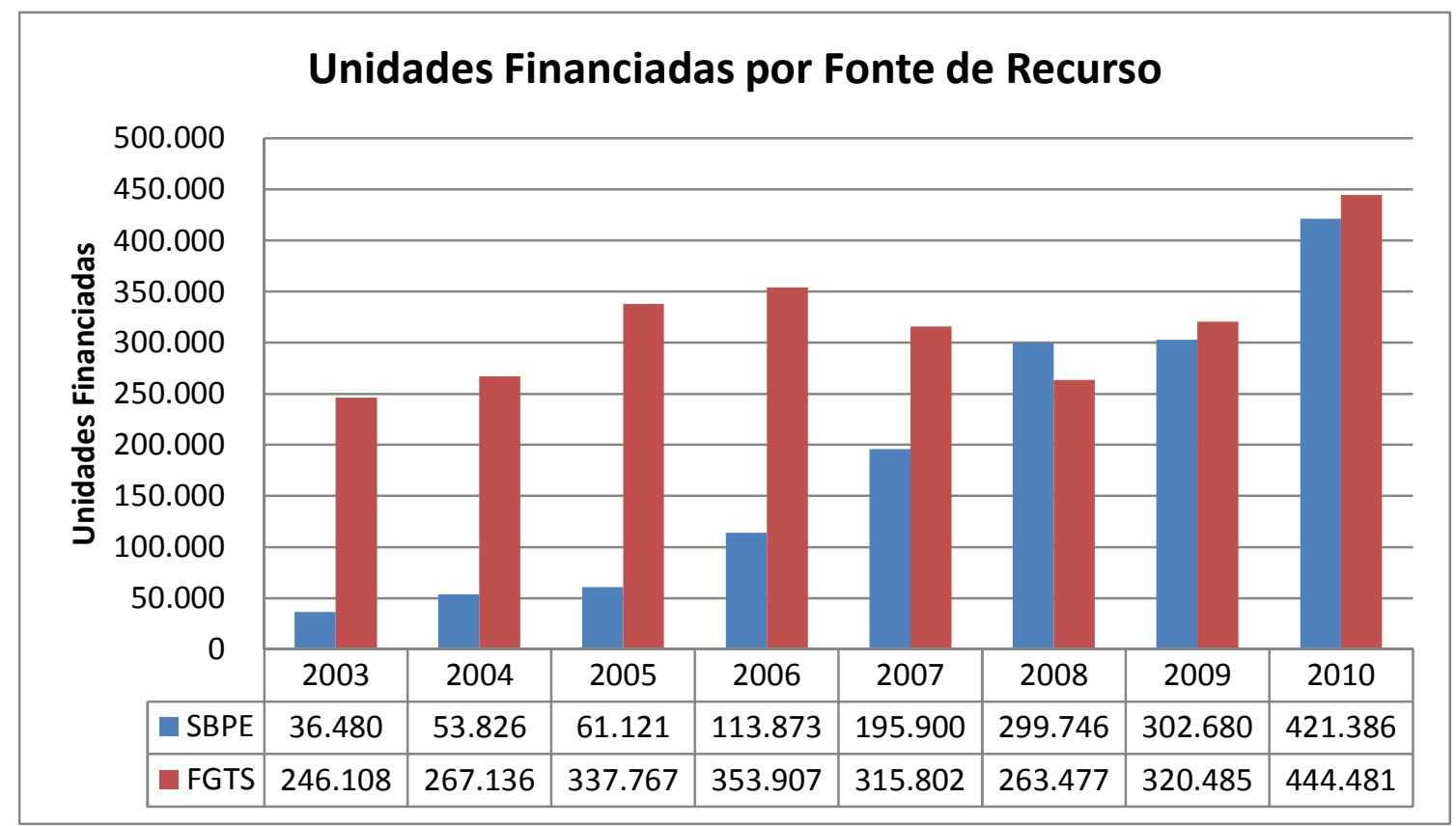

Figura 40 - Financiamentos contratados por fonte de recurso Fonte: IBGE, 2010. 
A partir dos dados apresentados na Figura 39, verifica-se que o crédito imobiliário no país, tanto pelo SBPE quanto pelo FGTS vem vivenciando um período de expansão acelerada. Entre os anos de 2000 a 2010 realizou-se o investimento de R \$ 56,2 bilhões pelo SBPE e de R\$27,63 bilhões do FGTS. Nessa figura, também é mostrado que os investimentos do SBPE tiveram um aumento mais significativo a partir de 2007 e os do FGTS a partir de 2009.

Durante o período observado, tem-se um aumento de quase 27 vezes dos recursos de SBPE e de sete vezes do FGTS. Entretanto, embora as duas fontes de financiamento tenham aumentado de forma relevante, os recursos do SBPE ainda são duas vezes maiores que os do FGTS. Essa constatação é importante visto que o aumento de recursos se deu exatamente com relação à fonte de recurso voltada para a construção de habitações do mercado. Em 2010, a soma dos financiamentos com recursos do FGTS e do SBPE totalizou R $\$ 83,83$ bilhões.

Na Figura 40, verifica-se que, até 2007, o número de unidades financiadas pelo FGTS era superior, contudo, a partir de 2008, o número de unidades financiadas pelo SBPE passou a ser maior. Assim, é possível constatar que as fontes de financiamento imobiliário no Brasil estão prioritariamente voltadas para o mercado, tanto em valores financiados, quanto em relação ao número de unidades habitacionais construídas. A análise das duas figuras conjuntamente aponta que a maioria dos imóveis financiados estão destinados principalmente para a população de renda acima das faixas do PMCMV.

No período de 2009, quando foi iniciado o PMCMV até 2015, foram contratadas 4.157.273 unidades habitacionais, das quais, 2.512.838 já tinham sido entregues, como pode ser constatado na Figura 41.

A partir da análise da evolução dos recursos das principais fontes de financiamento da política habitacional no Brasil, é inquestionável a constatação de que o PMCMV representou a retomada significativa dos investimentos no setor. Por outro lado, é preciso que esse investimento seja qualificado e direcionado às reais demandas da sociedade para que se promova a redução do déficit habitacional priorizando as populações de baixa renda onde a situação é mais crítica. 


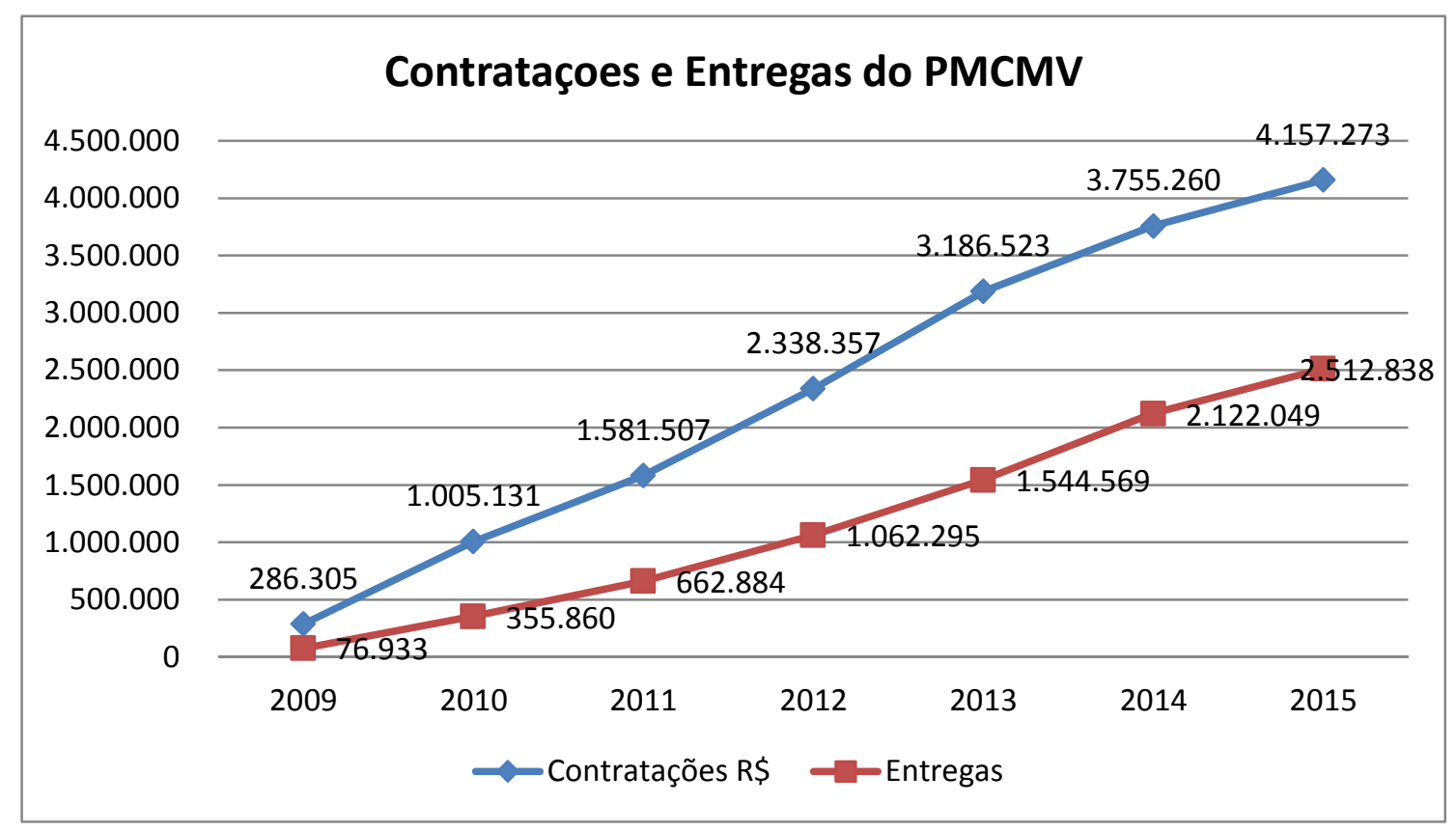

Figura 41 - Contratações e Entregas do PMCMV Fonte: MCidades, SNH, Relatório de Gestão 2015.

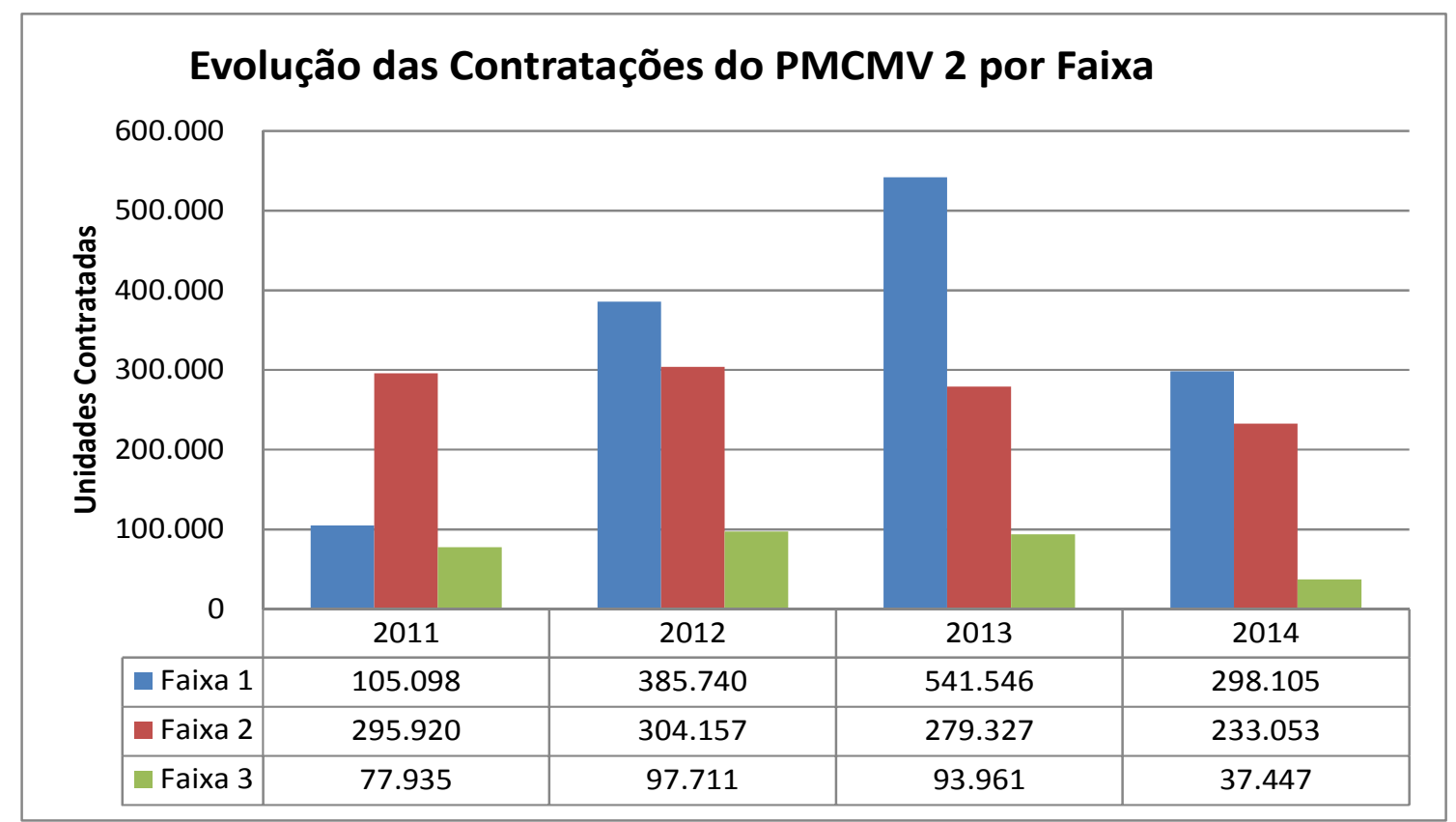

Figura 42 - Contratações e Entregas do PMCMV

Fonte: MCidades, SNH, Relatório de Gestão 2015.

*Faixas 1: renda bruta até $\mathrm{R} \$ 1.800 ; 2$ : entre $\mathrm{R} \$ 2.351$ e $\mathrm{R} \$ 3.600 ; 3$ : acima de $\mathrm{R} \$ 3.600$ e $<\mathrm{R} \$ \mathrm{R} \$ 6.500$.

Na Figura 42, apresenta-se a evolução do número de unidades habitacionais contratadas pelo PMCMV no período de 2011 a 2014. A análise dos dados aponta que a partir de 2012, as contratações do programa passaram a ser maiores na faixa 1, onde está 
concentrado o déficit habitacional (90\%), indicando os esforços para atendimento da população de baixa renda.

Na Figura 43, apresenta-se a evolução dos investimentos do FGTS por faixa de renda no período de 2002 a 2009. Esses dados mostram que já em 2006 houve uma inversão na lógica da aplicação dos recursos, apontando que os recursos passaram a priorizar o atendimento das populações de baixa renda com renda de até 3 salários-mínimos. Acreditase que esse fato tenha relação direta com a criação do Ministério das Cidades em 2003, que originariamente estava alinhado com as lutas sociais pelo "direito à cidade".

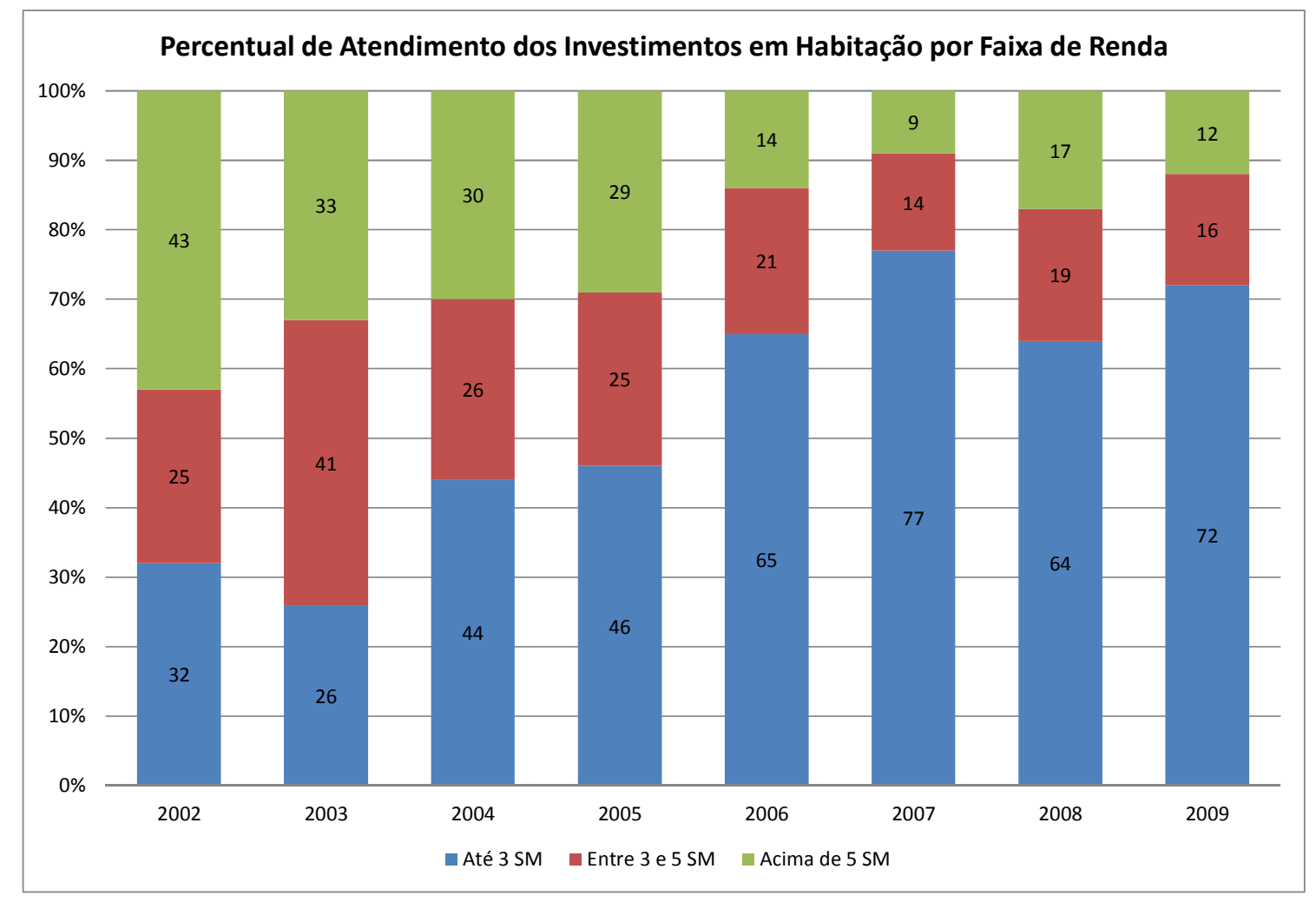

Figura 43 - Evolução dos investimentos em habitação por faixa de renda Fonte: Ministério das Cidades e Relatório da Caixa 2009.

*Valores referentes ao FGTS.

A distribuição geográfica dos recursos também se apresenta como um indicador importante para analisar o comportamento da política habitacional. Sabe-se que o déficit está concentrado na região Sudeste, em função das grandes metrópoles e na região Nordeste, que envolve o maior número de municípios pobres do Brasil.

Na Figura 44, apresenta-se a distribuição geográfica dos recursos do SBPE até 2011. Percebe-se que a região Sudeste concentra mais de $60 \%$ dos recursos aplicados durante o 
período observado, indicando que o mercado está voltado para a população de maior renda, já que esta região também concentra as maiores rendas do país.

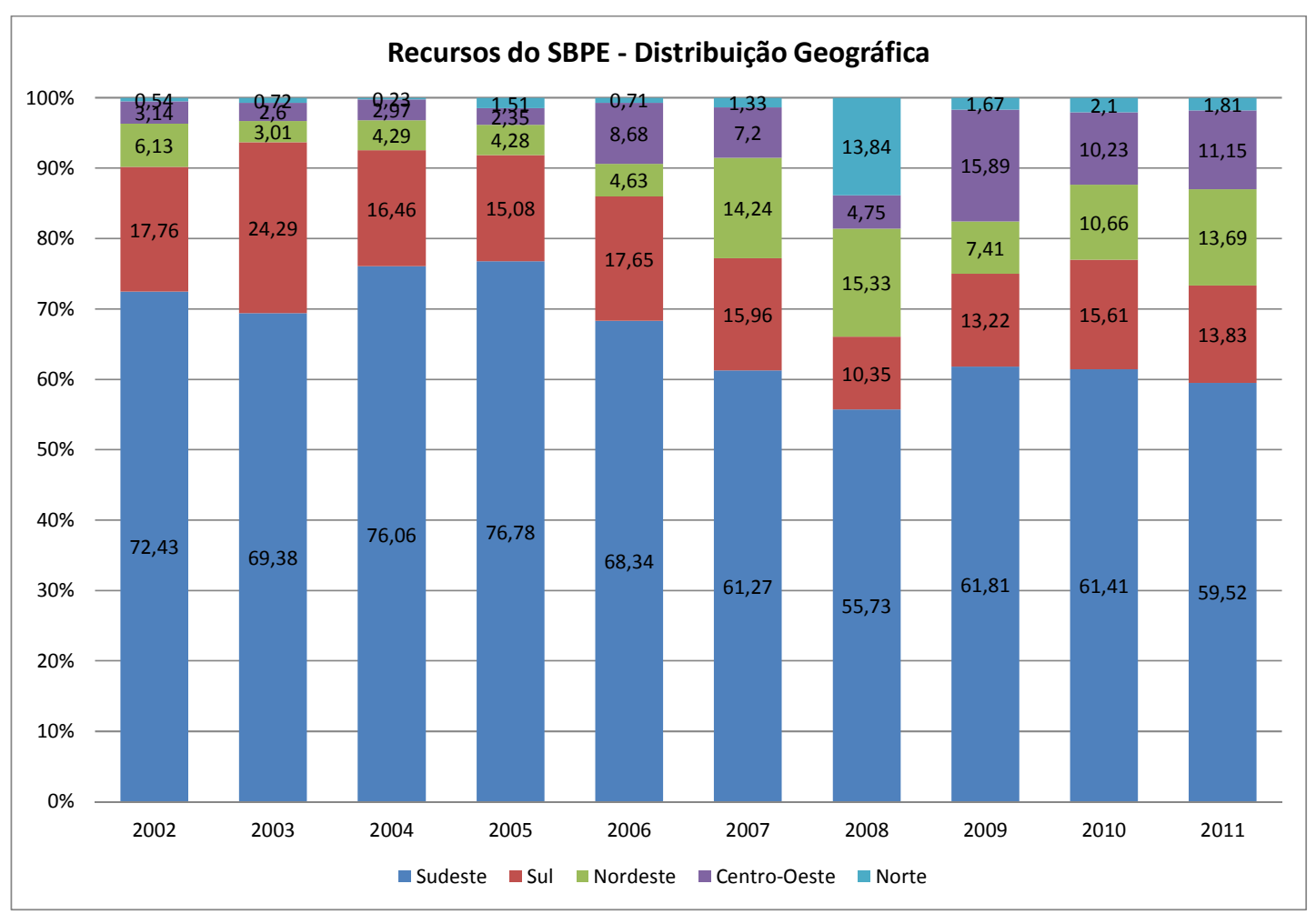

Figura 44 - Distribuição por região dos recursos de SBPE Fonte: Banco Central do Brasil, 2011.

Tabela 19 - Planejamento dos recursos de FGTS para 2016

\begin{tabular}{|l|c|c|}
\hline \multirow{2}{*}{\multicolumn{2}{c|}{ Região }} & \multicolumn{2}{c|}{ Recursos Planejados 2016 em R\$ mil } \\
\cline { 2 - 3 } & $\mathbf{R}$ & $\mathbf{\%}$ \\
\hline Norte & 6.319 .028 & 13,43 \\
\hline Nordeste & 14.820 .381 & 31,49 \\
\hline Sudeste & 13.904 .212 & 29,55 \\
\hline Sul & 3.965 .027 & 8,43 \\
\hline Centro-Oeste & 8.051 .352 & 17,11 \\
\hline Total Fonte: Conselho Curador do FGTS, 2016. & $\mathbf{4 7 . 0 6 0 . 0 0 0}$ & $\mathbf{1 0 0 , 0 0}$ \\
\hline \multicolumn{2}{|c}{} \\
\hline
\end{tabular}

Na Tabela 19, apresenta-se o planejamento das metas de investimentos dos recursos de FGTS por região, para o ano de 2016. Os dados mostram a intenção em cumprir com os critérios do PMCMV, destinando os recursos do FGTS para a população de baixa renda e onde está concentrada a maior parcela do déficit habitacional. Do total de recursos 
alocados, 31,49\% deveriam ser destinados à região Nordeste, seguidos de 29,55\% para a região Sudeste.

A partir de toda discussão apresentada é preciso dar destaque a dois aspectos que se apresentam relacionados: (i) confirmação da superioridade da $\mathrm{SNH}$ em termos financeiros e institucionais devido à histórica priorização da questão habitacional no tratamento da problemática urbana; (ii) a priorização da aplicação dos recursos do SBPE para a população de maior renda que representa a menor parcela na composição do déficit habitacional.

A superioridade da Secretaria Nacional de Habitação em termos institucionais já existia desde o momento de criação do Ministério, sendo possível constatar pela distribuição de cargos, importância das ações e montante de recursos. Essa diferenciação se justifica segundo os aspectos apontados pelos autores apresentados no Capítulo 1 da tese (Castells e Lojkine), onde a questão habitacional figura como o centro da problemática urbana.

Para outros autores, como Bonduki (2009, p. 95) o entendimento predominante era de que a moradia não poderia estar desvinculada de sua inserção urbana, definindo que essa questão significava garantia do direito à cidade, envolvendo o acesso a infraestrutura e a serviços urbanos. Essa premissa se baseava na ideia de que a habitação fixa o indivíduo ao solo e, para que a moradia pudesse ser considerada digna, não poderia estar desvinculada do acesso aos serviços urbanos, equipamentos públicos nem à infraestrutura.

Esse argumento está alinhado ao pensamento de Castells (2014) que enxergava o centro da dialética conflitual do meio urbano e estratificação social mensurado pelo poder de aquisição da moradia; e de Lojkine (1981) que considerava a localização da habitação como o nível mais forte de segregação social, visto que esta acaba influenciando nos demais níveis (nível dos equipamentos coletivos e nível do transporte domicílio-trabalho).

É em função desse potencial associado à questão da moradia que Marques e Frey (2015, p. 253) destacam que o dualismo da habitação enquanto mercado e direito humano caracteriza uma situação peculiar. Para os autores, da mesma forma que os financiamentos habitacionais da contemporaneidade se configuram como um tema essencial nas possibilidades de obtenção de moradia digna é necessário relacionar os padrões de 
financiamento da política habitacional às transformações dos padrões de acumulação capitalista.

No século XX, o Estado passou a ser a fonte central no financiamento habitacional, tendo como base o modelo do Estado de Bem-Estar Social. Contudo, a sustentação desse modelo foi esvaziada em função da expansão financeira mundial, da crise fiscal e da insuficiência dos fundos geridos pelo Estado, atribuindo ao mercado novas funções. Assim, o mercado imobiliário passou a imperar sob as relações econômicas do solo urbano, restringindo o acesso de grande parcela da população e fazendo surgir a periferia nas grandes cidades (MARQUES e FREY, 2015, p. 253).

É considerando esses argumentos que Moreira e Pina (2012, p. 87) apontam que o Ministério das Cidades precisa ser criterioso com relação ao formato da política habitacional em andamento, tendo em vista assegurar que a habitação enquanto direito humano se sobreponha à ideia de habitação como mercado como foi observado na experiência do BNH. Nesse período, houve o predomínio da visão econômica e quantitativa, sendo construídas as habitações sociais distantes de tudo, resultando no aumento da segregação sócio-espacial e das demandas por equipamentos, infraestrutura e serviços urbanos. Os autores ressaltam que caso essa lógica permaneça, a política habitacional brasileira irá continuar sem grandes rupturas, tratando o solo urbano sem considerar os efeitos da especulação imobiliária e das desigualdades sócio-territoriais.

Como resultado da dinamização do mercado imobiliário apartado de uma estratégia urbanística e fundiária consistente, tem-se o aumento do preço da terra e tornando cada vez mais caro o acesso à terra urbanizada. Bonduki (2008, p. 85) já afirmava que a dimensão desse problema mostra que a questão habitacional não pode ser equacionada apenas com a oferta de novas unidades, requerendo uma ação articulada com as políticas urbana, fundiária e de saneamento.

Assim, o debate acerca das razões que justificam a priorização da aplicação dos recursos do SBPE para a população de maior renda não pode prescindir das reflexões sobre o PMCMV. Embora a prioridade dada à produção habitacional a partir do aumento nos investimentos e subsídios realizados pelas linhas de financiamento do setor seja relevante para combater o déficit habitacional acumulado, torna-se preocupante a forma de como 
essa estratégia está sendo implementada. Percebe-se que já foi delegado ao mercado imobiliário o papel de protagonista dessas operações.

O resultado concreto disso consiste na imposição da "lógica privada do fazer" também observada no "modus operandi" do PMCMV que tem em sua essência uma política anticíclica em detrimento de uma estratégia estrutural para atacar um problema crônico e que requer um olhar que transcenda a ótica setorial. Na prática, além de o programa estar sendo implantado segundo a lógica privada, seus normativos não exigem que as operações sejam submetidas aos instrumentos de planejamento dos municípios, nem tampouco ao SNHIS, privilegiando a agilidade e o alcance de metas de unidades habitacionais em detrimento da qualidade urbanística e arquitetônica dos projetos.

Os normativos que condicionam as exigências ambientais também são amplamente criticados pelos empreendedores por serem considerados por estes entraves à execução de obras e, por conseguinte, ao processo de desenvolvimento.

Essa lógica de atuação não interfere apenas no desempenho da política habitacional, uma vez que a materialização das obras no território consolida, mais uma vez, um modelo de desenvolvimento urbano perverso que perpetua a segregação sócio-espacial. Dessa forma, é possível inferir que o formato a ser adotado pela política de habitação poderá influenciar de forma negativa nos resultados das demais políticas setoriais implementadas pelo MCidades, bem como, está comprometendo os objetivos inicialmente preconizados na PNDU estabelecida em 2004.

Quando as moradias são implementadas em locais distantes, devido à ausência de terrenos em locais mais próximos e também em função da alta no preço dos terrenos provocada pela especulação imobiliária, tem-se como resultado o aumento das periferias e a ampliação dos déficits de serviços, infraestrutura e equipamentos sociais, visto que essas áreas já são fragilizadas em relação a esses aspectos. A situação fica ainda mais crítica na medida em que as ações governamentais convivem constantemente com a insuficiência de recursos orçamentários para o devido atendimento das demandas sociais.

Sobre esse problema também se destaca a perpetuação da ótica setorial que produz um espaço urbano fragmentado e cada vez mais longe da busca pelo direito à cidade. Temse com isso a consolidação dos setores econômicos atrelados à cadeia produtiva das 
políticas públicas, fazendo com que a prática das ações estatais esteja cada vez mais distante do discurso institucional e mais perto dos interesses setoriais.

\section{Investimentos em saneamento}

Para qualquer país, a eficiência, a qualidade e a universalidade dos serviços de saneamento básico são fundamentais para a qualidade de vida da população, visto que esse setor tem impactos diretos sobre a saúde pública, o meio ambiente e o desenvolvimento econômico de um país. Levando em conta a essencialidade e as externalidades dos serviços de água e esgoto, pode-se afirmar que estes são serviços de utilidade pública e que as questões da universalidade, qualidade e equidade na sua prestação é fundamental (MADEIRA, 2010).

Para o entendimento da ação pública quanto à prestação dos serviços de saneamento é preciso considerar, inicialmente, a repartição de competências entre os entes federativos: município, estado, Distrito Federal e União, estabelecida pela Constituição Federal de 88. A validação desse pacto foi antecedida pelo processo de democratização que vem se difundindo no mundo. A Constituição Federal de 1988 internalizou essas questões na forma de direitos e garantias fundamentais e, em relação aos serviços de saneamento básico, estabelece que o município é o ente responsável por essas ações, o que posteriormente foi referendado na Política Nacional de Saneamento Básico, Lei no 11.445 de 05 de janeiro de 2007.

Entretanto, embora a competência dos serviços de saneamento seja dos municípios, a relação direta e imediata entre saneamento básico e direitos fundamentais, impossibilita a restrição exclusiva a um dos entes federados a titularidade da competência para promover direitos fundamentais. Deve prevalecer a interpretação de que todos os entes federados são titulares de competências relativas ao saneamento básico, mesmo que o ente local seja o detentor da organização e da prestação dos serviços. A responsabilidade pela satisfação das necessidades coletivas e individuais não é exclusiva de cada município, devendo ser compartilhada entre todos os entes federados, cabendo à União e aos estados assumirem uma parcela relevante de encargos, ainda que não seja de sua competência prover diretamente serviços em favor dos usuários. 
Portanto, o grande desafio da agenda federativa no Brasil tem sido a construção de mecanismos institucionais de coordenação que incluam estados e municípios não apenas na operação das políticas sociais, incluindo, na medida do possível, o financiamento compartilhado. O país é extremamente heterogêneo, o que exige muita sensibilidade para se compreender e contemplar as diferentes necessidades e capacidades dos atores sociais, exigindo estruturas institucionais mais complexas, flexíveis e com maior capacidade de coordenação horizontal, entre municípios e estados, e vertical, envolvendo a União.

Nesse contexto, também é visto como desafio o fato de o Brasil ser caracterizado pela existência de múltiplos centros de poder; por um sistema complexo de dependência política e financeira entre as esferas governamentais, não governamentais e multilaterais; pela existência de vários caminhos para a prestação de políticas públicas e por grandes disparidades inter e intra-regionais (maioria dos municípios brasileiros tem baixa capacidade financeira e administrativa). Essas diferenças geram contradições e tensões, promovendo resultados de políticas públicas e padrões de negociação de conflito que ainda são pouco conhecidos e que extrapolam as estruturas e os processos constitucionais, legais e institucionais.

Assim, embora sejam conhecidos e amplamente difundidos os ganhos diretos na implementação das políticas sociais, com a democratização e a descentralização de competências, algumas contradições, limites, ou mesmo efeitos perversos são percebidos. Como resultados desse processo surgem as diferenças profundas quanto à capacidade que os municípios têm de responder às necessidades e demandas da população. A parcela de municípios que dispõe efetivamente de condições financeiras, institucionais, políticas e técnico-administrativas e gerenciais para assumir esse papel, inovando, ampliando a eficácia, a participação e a democratização das políticas públicas, é relativamente pequena.

Na maioria dos casos, e, notadamente nas regiões e áreas menos desenvolvidas, o que predomina são municípios de reduzido porte, com economias de base agrícola pouco diversificada, estagnadas ou em crise, sendo por isso mesmo, desprovidos de condições mínimas de sustentação, necessitando da solidariedade dos governos estaduais e federal.

Além disso, a adoção de estratégias governamentais para a resolução de problemas sociais apresenta uma combinação única de fatores, atores, sinergia, informação, 
conhecimento, decisão, além de outros aspectos. Cada arena de políticas públicas tem suas características peculiares, sendo formada pelas partes que resultam em um todo único no espaço e no tempo, revelando inclusive, propriedades que não aparecem nas partes quando elas se encontram separadas.

Uma importante dimensão conceitual que deve ser considerada com relação à realidade brasileira se refere ao processo histórico de desenvolvimento e às mudanças históricas do Estado brasileiro, que podem dar pistas acerca do setor de saneamento básico no Brasil, quanto ao aparato institucional, aos marcos legais, aos agentes sociais, ao nível de acesso aos serviços e a todas as características que o fizeram ter assumido a configuração atual.

Assim, o entendimento dos determinantes políticos, econômicos e socioculturais do cenário brasileiro com relação ao acesso a saneamento básico passa por um esforço de compreensão das relações entre Estado, sociedade e capital e suas influências na definição de políticas públicas. Por outro lado, esse entendimento também envolve uma reflexão sobre os fluxos e nexos entre formulação de políticas, a tomada de decisão, a implementação, a execução, os resultados e os impactos produzidos (MCIDADES, 2013).

Após a apresentação dos debates conceituais em torno da política de saneamento básico, faz-se a discussão sobre a execução orçamentária das ações. Assim, os recursos governamentais em âmbito federal disponíveis para viabilizar as ações previstas no PLANSAB são: (i) recursos do Orçamento Geral da União (OGU) que são a fundo perdido; (ii) recursos onerosos do Fundo de Garantia por Tempo de Serviço (FGTS) e do Fundo de Amparo ao Trabalhador (FAT), que são onerosos (financiamentos). Nas Figuras 45 e 46 apresenta-se a evolução do PAC 1 e 2 referente às ações de saneamento realizadas pelo Ministério das Cidades, no período de 2007 a 2015. 


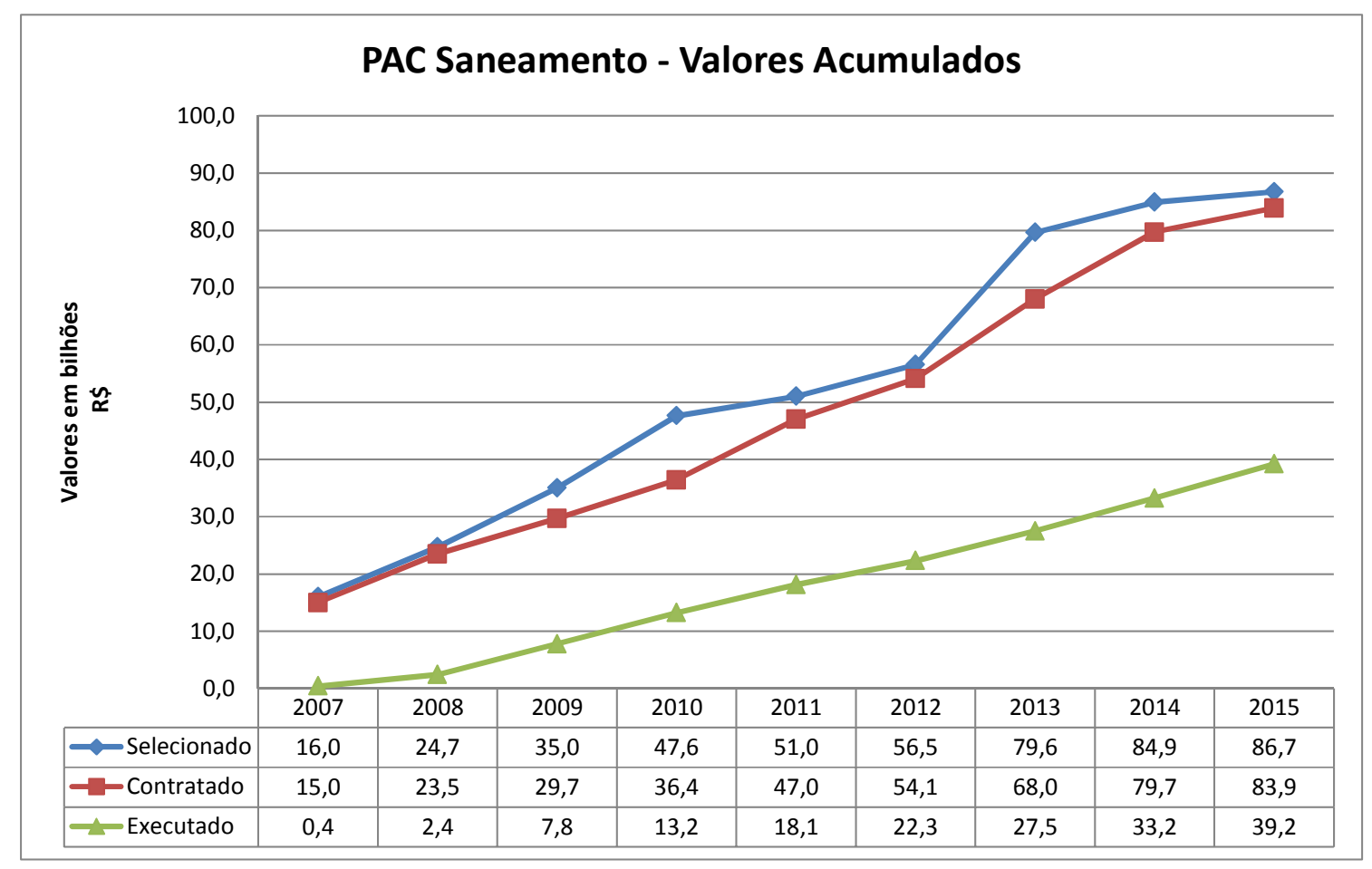

Figura 45 -Valores acumulados do PAC Saneamento 2007 a 2015 Fonte: MCidades, SNSA, 2016.

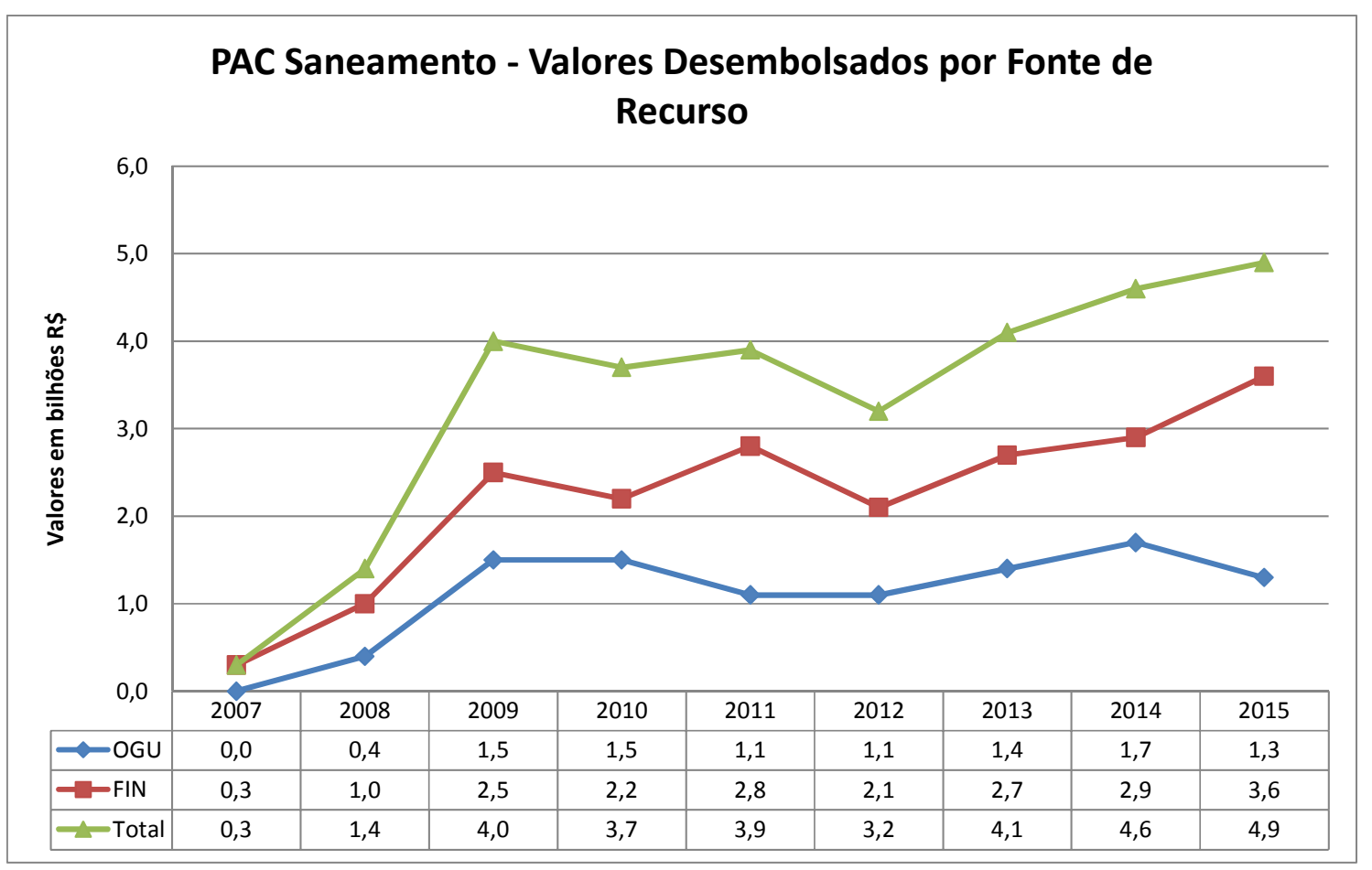

Figura 46 - Valores desembolsados do PAC Saneamento 2007 a 2015 Fonte: MCidades, SNSA, 2016. 
Os valores apresentados confirmam que o aumento de cobertura dos serviços de saneamento em quase todas as regiões do Brasil, é devido, em grande parte, pela continuidade das fontes de recursos que foram asseguradas durante o período analisado e pela prioridade conferida ao PAC. Embora esse programa tenha sido lançado com o propósito de uma política anticíclica e, com objetivos econômicos bem específicos, não se pode negar a importância dessa estratégia para reforçar os investimentos em saneamento.

Por outro lado, as dificuldades operacionais dos entes e proponentes privados que receberam aporte de recursos do Ministério das Cidades se refletem, em parte, na capacidade de conclusão das obras. Embora em 2015 já tivessem sido contratados R\$ 83,9 bilhões, desse total, apenas $\mathrm{R} \$ 39,2$ bilhões já tinham sido executados, representando $46,73 \%$ do total. O fato de menos de $50 \%$ dos recursos contratados terem sido executados mostra que outros problemas de natureza técnica e operacional continuam a conferir morosidade à política de saneamento, indicando que o arranjo institucional existente não está conseguindo funcionar a contento.

Outro aspecto relevante que deve ser discutido é o formato tradicional da política de saneamento que é amplamente conhecida como "política de balcão". Nesse tipo de política, os proponentes elegíveis para receber os recursos federais apresentam seus projetos, os quais, se não estiverem em conformidade com os critérios técnicos previamente definidos perdem os recursos que serão destinados a outro projeto que esteja mais qualificado e se mostre mais promissor para se concretizar em obra. Com isso, aqueles proponentes em situação mais precária, por serem menos capacitados e menos estruturados, ficam sempre atrás dos que, tradicionalmente, se mostram mais preparados. Normalmente, os entes em melhores condições técnicas e operacionais também são aqueles com maior cobertura dos serviços.

Desse modo, tem-se o comprometimento do próprio princípio da universalidade da cobertura dos serviços e do PLANSAB que visam à superação da precariedade em todas as regiões do país. Quando questionados quanto a esse problema e quanto à necessidade de imprimir esforços para apoiar os entes mais problemáticos, alguns dirigentes do Ministério das Cidades já justificaram essa ausência argumentando que a titularidade dos serviços é do município. Esse é um debate antigo que nasce junto com a própria política de 
saneamento e parece estar longe de ser superado. Assim, o Ministério assume um papel de instituição financeira que concentra seu papel no repasse de recursos.

Com relação às fontes de recursos que financiam a política de saneamento, destacase a importância do FGTS como a principal fonte de recursos que viabiliza as ações. Em 2015, verifica-se que essa fonte de recursos foi responsável por 73,5\% do total dos investimentos realizados. Salienta-se que, a depender da situação econômica que o país atravesse, esse aspecto pode se tornar um problema por dois fatores: tratam-se de recursos onerosos, que devem ser devolvidos pelos proponentes; em momentos de recessão, os depósitos de FGTS diminuem drasticamente, limitando a quantidade de recursos disponíveis para os financiamentos.

Na Tabela 20 apresenta-se a distribuição dos investimentos do PAC pelo tipo de modalidade. Esses dados mostram que, finalmente houve uma inversão da lógica tradicional de priorização dos investimentos em abastecimento de água, sem considerar a mesma importância a esgotamento sanitário. Pela primeira vez, na história da política de saneamento, houve priorização nos investimentos em esgotamento sanitário, chegando ao percentual de 40,4\% do total. Por outro lado, os recursos destinados às ações de resíduos sólidos representam apenas $1 \%$ do total do orçamento aplicado, sendo o baixo percentual de investimentos também observado para as ações de desenvolvimento institucional.

Tabela 20 - Investimentos selecionados no PAC 1 e 2 por modalidade

\begin{tabular}{|c|c|c|c|c|}
\hline \multirow{2}{*}{ Modalidade } & \multicolumn{2}{|c|}{ Operações } & \multicolumn{2}{|c|}{ Investimento } \\
\hline & Quantidade & $\%$ & $\mathrm{R} \$$ bilhões & $\%$ \\
\hline Abastecimento de Água & 803 & 27,6 & 22,9 & 26,5 \\
\hline Desenvolvimento Institucional & 47 & 1,6 & 1,5 & 1,7 \\
\hline Esgotamento Sanitário & 941 & 32,3 & 35,0 & 40,4 \\
\hline Estudos e Projetos & 525 & 18,0 & 0,7 & 0,8 \\
\hline Manejo de águas Pluviais & 325 & 11,2 & 15,2 & 17,5 \\
\hline Resíduos Sólidos Urbanos & 83 & 2,8 & 0,9 & 1,0 \\
\hline Saneamento Integrado & 190 & 6,5 & 10,5 & 12,1 \\
\hline Total & 2.914 & 100 & 86,7 & 100 \\
\hline
\end{tabular}

Fonte: MCidades, SNSA, 2016.

Quanto à regionalização dos investimentos, percebe-se, por meio da análise da Figura 47, que mesmo que a região Nordeste tenha aumentado significativamente a 
cobertura dos serviços de saneamento (discussão inicial do capítulo), nem sempre a distribuição dos recursos obedece aos critérios de precariedade das regiões para ser aplicado.

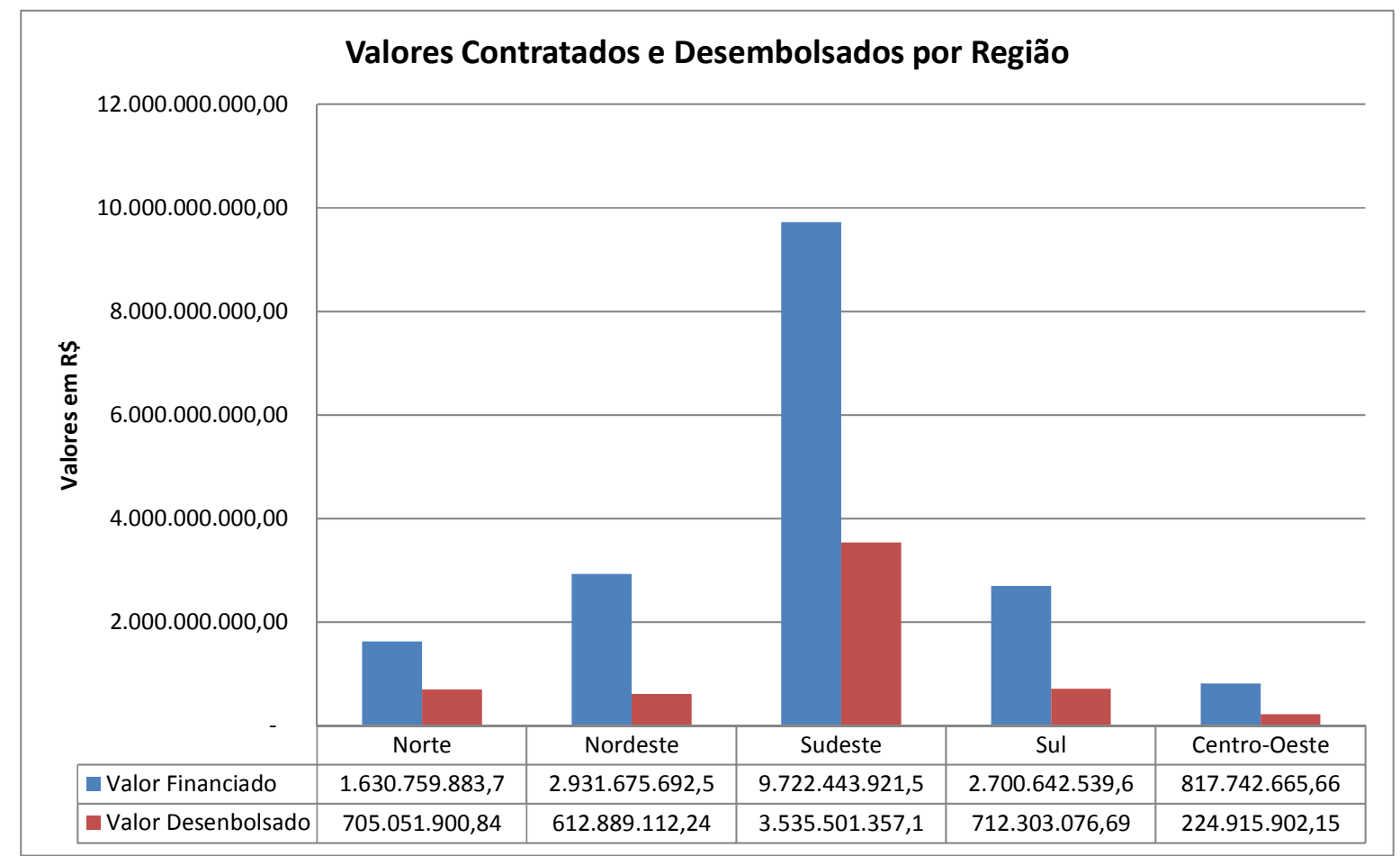

Figura 47 - Evolução dos valores contratados e desembolsados por região Fonte: MCidades, SNSA, Relatório de Gestão 2010.

No ano de 2010, a região Sudeste, que tem a maior cobertura do Brasil, sendo superior a $90 \%$, recebeu $54,61 \%$ dos recursos contratados. Nesse mesmo ano, o Nordeste contou com apenas 16,47\% dos recursos contratados, enquanto o Sul, que proporcionalmente tem uma população inferior ao Nordeste e a cobertura superior, recebeu $15,17 \%$ dos recursos contratados. A região Norte que tem a pior cobertura do país, contou com menos de $10 \%$ dos recursos contratados e a Centro-Oeste com 15,17\%. A partir desses dados, fica evidente a prática da política de balcão e o descompasso entre o discurso da política, a priorização dos planos e sua prática.

Apesar dos problemas ainda existentes na política de saneamento, não é possível ignorar ou minimizar os avanços observados no setor a partir da criação do Ministério das Cidades. Além da definição de um arcabouço jurídico-legal que possibilitou a sustentação de investimentos de forma mais perene, visando ampliar o acesso e a melhoria da 
qualidade dos serviços prestados, houve o aumento significativo dos recursos direcionados para o setor por meio do PAC.

Outros avanços que podem ser destacados são as medidas adotadas nesse período voltadas para a qualificação do gasto público, tais como a adoção de processo de seleção pública de propostas e o atendimento a requisitos técnicos e institucionais como condição aos proponentes para o acesso aos recursos geridos pela União. Assim, a "política de balcão" se perpetuou, mas buscou-se aprimorar a sistemática e os critérios de alocação de recursos.

Mesmo que o setor saneamento tenha evoluído do ponto de vista institucional e normativo e que tenha tido a ampliação dos investimentos, a estrutura governamental em âmbito federal responsável pela implantação das ações, ainda envolve diferentes atores e órgãos que atuam de forma conjunta. Sabe-se que além do Ministério das Cidades, pelo menos quatro outros órgãos desenvolvem ações do setor (Ministério da Integração Nacional, Ministério da Saúde, Ministério do Meio Ambiente, Ministério do Desenvolvimento Agrário).

Embora essa combinação de Ministérios e órgãos governamentais, juntamente com os entes federativos municipais e estaduais, seja imprescindível para o tratamento da questão de forma horizontalizada e com caráter multidisciplinar, o fato de existirem múltiplos agentes com responsabilidades sobrepostas e desarticuladas foi considerado um fator que contribuiu para o insucesso das ações implantadas e favorece a fragmentação da ação pública.

Quanto à cobertura dos serviços, mesmo com o aumento significativo dos índices e da garantia das fontes de financiamento das ações, percebe-se que a lógica do setor ainda é bastante perversa e continua a favorecer interesses diversos aos das necessidades sociais. As regiões Norte e Nordeste ainda apresentam as piores condições de cobertura nos serviços de saneamento, fortalecendo a ideia de que as localidades que apresentam maior precariedade não são as contempladas com investimentos mais robustos para diminuir os déficits relativos, não sendo conferida a devida importância com relação às reais necessidades diferenciais de cada região. Com isso, da mesma forma que se observa com relação à política de habitação, o setor saneamento apresenta práticas que não estão em 
conformidade com os discursos políticos e institucionais. Entretanto, a realidade da política de saneamento básico apresenta uma lógica menos perversa do que se observa no âmbito da política habitacional.

Tradicionalmente, o processo de tomada de decisão no subsistema da política de saneamento básico é incremental, sem acrescentar mudanças drásticas às ações que se sucedem no tempo. Verifica-se ainda que os interesses privados prevalecem em relação ao interesse público, mesmo após o fortalecimento das instâncias de participação social instituídas pela política nacional, da modernização do setor e da pressão exercida por órgãos de controle. Isso indica que os grupos de pressão dos empresários que visam à privatização do setor ainda dispõem de maior influência para atuar no processo decisório.

O setor saneamento passa por um momento de transformação quanto aos seguintes aspectos: (i) a natureza de serviço público de caráter social deverá assumir características de uma atividade econômica; (ii) a gestão tende a passar da esfera pública para o mercado como a melhor alternativa para resolução dos entraves; (iii) a relação com as pessoas está sendo afetada, uma vez que os usuárias de um serviço tenderão a ser vistos como consumidoras de um produto; (iv) o valor de uso, que passará de social para valor de troca mercantil; (v) condição de direito social e coletivo para ser tratado como mercadoria, que se adquire segundo a lógica do mercado.

\section{Investimentos em mobilidade urbana}

Segundo a Constituição de 1988 é competência municipal a organização e prestação do transporte coletivo, recaindo no mesmo problema de competência discutido com relação à política de saneamento básico. Como desdobramento dessa orientação, atualmente, mais de $90 \%$ da demanda total de transporte coletivo no Brasil está destinada à prestação dos serviços de ônibus urbanos, que ocorre por meio da delegação à iniciativa privada, com o planejamento e gestão de órgãos municipais. Já os metrôs e os trens urbanos estão presentes em aglomerações urbanas específicas e são prestados por empresas estatais, federais e estaduais, com exceção do estado do Rio de Janeiro, onde a operação dos serviços de trens e metrôs foi privatizada.

A mobilidade urbana, enquanto instrumento de acesso a outros bens e serviços é desigual e não serve adequadamente às populações que naturalmente já sofrem com os 
efeitos da desigualdade social por habitarem áreas precárias. Com isso, os indivíduos mais pobres dispõem de inserção urbana mais reduzida. $\mathrm{O}$ transporte inadequado contribui para a permanência e acentuação do quadro de exclusão social, especialmente daqueles que se encontram em situação de vulnerabilidade social.

A análise do panorama da mobilidade urbana realizada na seção anterior deste capítulo apontou várias deficiências do setor, bem como destacou a limitação orçamentária como o principal fator de orientação e escolha na definição de alternativas de transporte público coletivo. Além disso, a gestão das ações também apresenta seus gargalos por ocorrer de forma desarticulada, sendo realizada por órgãos que, na maioria das vezes, administram as questões do trânsito separadas dos problemas de transporte público coletivo, das demandas de infraestrutura e do deslocamento de pedestres e ciclistas.

Quanto ao financiamento das ações de transporte público coletivo, não existem fontes específicas ou um modelo considerado ideal. Usualmente, os municípios, por meio de orçamento próprio, financiam a infraestrutura viária, cujo uso é compartilhado entre ônibus, automóveis e veículos de carga, e a operação é custeada pelas receitas tarifárias, excetuando-se os metrôs e trens, cuja operação é subsidiada.

Historicamente, a ampliação do sistema viário para viabilizar o tráfego de automóveis, cuja frota vem crescendo acentuadamente a cada ano, acaba consumindo a maior parte dos recursos destinados aos transportes urbanos em detrimento das alternativas de transporte coletivo. Além disso, as ações destinadas a essa modalidade de transporte público convive com crises cíclicas relacionadas à incompatibilidade entre custos, tarifas e receitas; com as deficiências no planejamento e na gestão dos serviços; bem como com as dificuldades em se obter prioridade no uso das vias, como no caso de BRT, por exemplo.

Tem-se como principal resultado desse processo, a priorização das melhores condições de deslocamentos nas cidades para uma minoria que usa os meios individuais de transporte, em detrimento de uma maioria que depende do transporte público coletivo e que se encontra sem alternativas, diante da prestação um transporte público caro e de baixa qualidade.

Assim, as cidades cresceram e se desenvolveram baseadas em um modelo insustentável de mobilidade, no qual a prioridade das ações sempre esteve voltada para os 
modos motorizados e individuais em detrimento dos não motorizados. Esse modelo promove a perpetuação de um ciclo vicioso, onde a oferta inadequada de transporte coletivo, além de prejudicar a parcela mais pobre da população, estimula o uso do transporte individual, que aumenta os níveis de poluição e congestionamentos, além de demandarem mais recursos para a ampliação e construção de vias. Além disso, os custos dos investimentos e da manutenção da infraestrutura urbana, incluído o sistema viário para atender ao crescimento da demanda, crescem de forma exponencial, devido à incorporação de usuários aos sistemas de transportes, em um contexto de acelerada expansão urbana.

Outro fator que acentua a problemática dos transportes urbanos consiste no aumento das necessidades de deslocamentos, em função do crescimento horizontal das cidades. Essa característica também eleva os custos do transporte em decorrência do aumento da distância percorrida e da baixa renovação de passageiros ao longo do trajeto. Essas questões se tornam mais críticas ao esbarrarem na situação de escassez de recursos orçamentários, e na falta de políticas contínuas de financiamento e investimento, gerando um contexto de subfinanciamento dos investimentos.

Com a criação do Ministério das Cidades, a maior parte dos recursos federais para a mobilidade urbana no Brasil passou a financiar os programas e projetos do órgão, por meio de fontes onerosas e não onerosas. As principais fontes de financiamento das ações são: Orçamento Geral da União (OGU), Fundo de Garantia por Tempo de Serviço (FGTS), do Fundo de Amparo ao Trabalhador (FAT), entre outros, sendo executados, em grande parte, pelo Banco Nacional de Desenvolvimento Econômico e Social (BNDES) e da Caixa Econômica Federal.

Conforme a Lei $\mathrm{n}^{\circ}$ 12.587, a política nacional de mobilidade urbana tem sido operacionalizada por meio dos seguintes programas:

1. 2008: Pró-Transporte;

2. 2010: PAC - Mobilidade COPA 2014;

3. 2010: PAC - Pavimentação e Qualificação de Vias Urbanas - $1^{\mathrm{a}}$ etapa;

4. 2011: PAC - Mobilidade Grandes Cidades;

5. 2012: PAC - Mobilidade Médias Cidades;

6. 2012: PAC - Pavimentação e Qualificação de Vias Urbanas - $2^{\mathrm{a}}$ etapa; 


\section{2013: Pacto da Mobilidade.}

Embora o PAC tenha englobado diversas ações orçamentárias no período acima, os eventos internacionais da Copa e das Olimpíadas também influenciaram a atuação do Ministério com relação à política de mobilidade no período recente. Também é preciso destacar a tendência do setor em buscar parcerias com a iniciativa privada, visto que em 2011, o PAC 2, no Programa Mobilidade Grandes Cidades, contemplou propostas de mobilidade urbana que pretendiam utilizar Parcerias Público Privadas (PPPs). Já o Programa Mobilidade Médias Cidades criado em 2012, tinha como foco beneficiar municípios entre 250 mil e 700 mil habitantes. Em seguida, após as manifestações de 2013 foi lançado o Pacto da Mobilidade Urbana, visando beneficiar mais de cinquenta municípios, por meio da execução de obras de infraestrutura de transportes e da elaboração de estudos e projetos.

$\mathrm{Na}$ Figura 48, apresenta-se a execução orçamentária para os programas de mobilidade urbana, segurança e educação de trânsito no período de 2008 a 2014.

A partir da análise dos dados verifica-se que a partir de 2008 o protagonismo do governo federal como principal financiador das ações de mobilidade urbana no Brasil. Em 2008 ocorreu a retomada das obras que estavam em andamento lento ou paralisadas devido à insuficiência de recursos orçamentários, sendo esse aporte de recursos superado apenas em 2014, após um contínuo comportamento crescente.

Nesse período, deu-se perenidade ao financiamento das ações de mobilidade, assim como se observou o crescimento significativo nos investimentos do setor. No período de 2008 a 2014 foram alocados quase R \$ 3 bilhões nas ações de mobilidade urbana e segurança e educação de trânsito, representando o maior aporte de recursos no setor pelo governo federal.

Na Figura 49 apresenta-se a evolução da execução orçamentária dos recursos onerosos (financiamentos) para o setor saneamento no período de 2002 a 2013. 


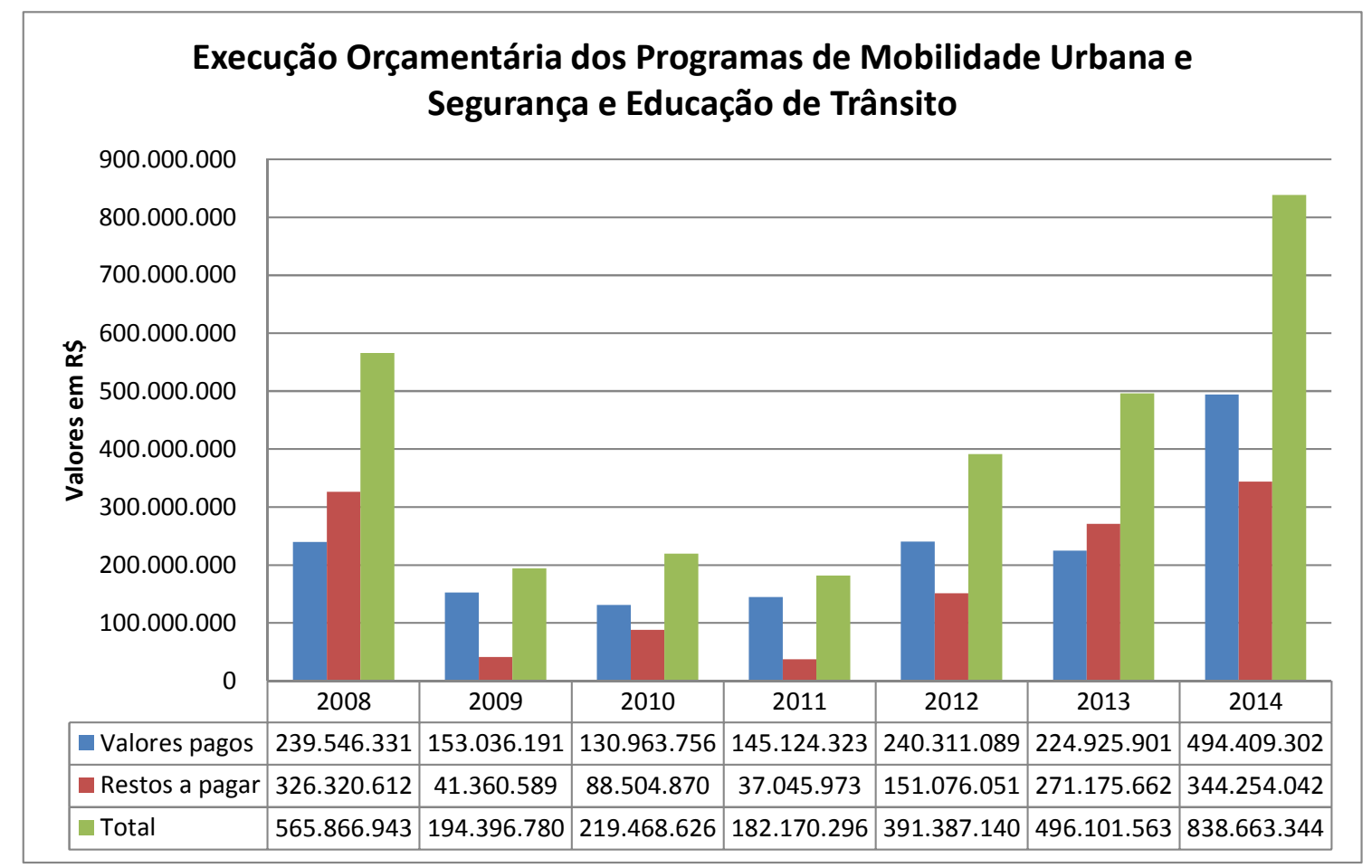

Figura 48 - Execução orçamentária dos programas de mobilidade urbana e segurança e educação de trânsito. Fonte: Siga Brasil.

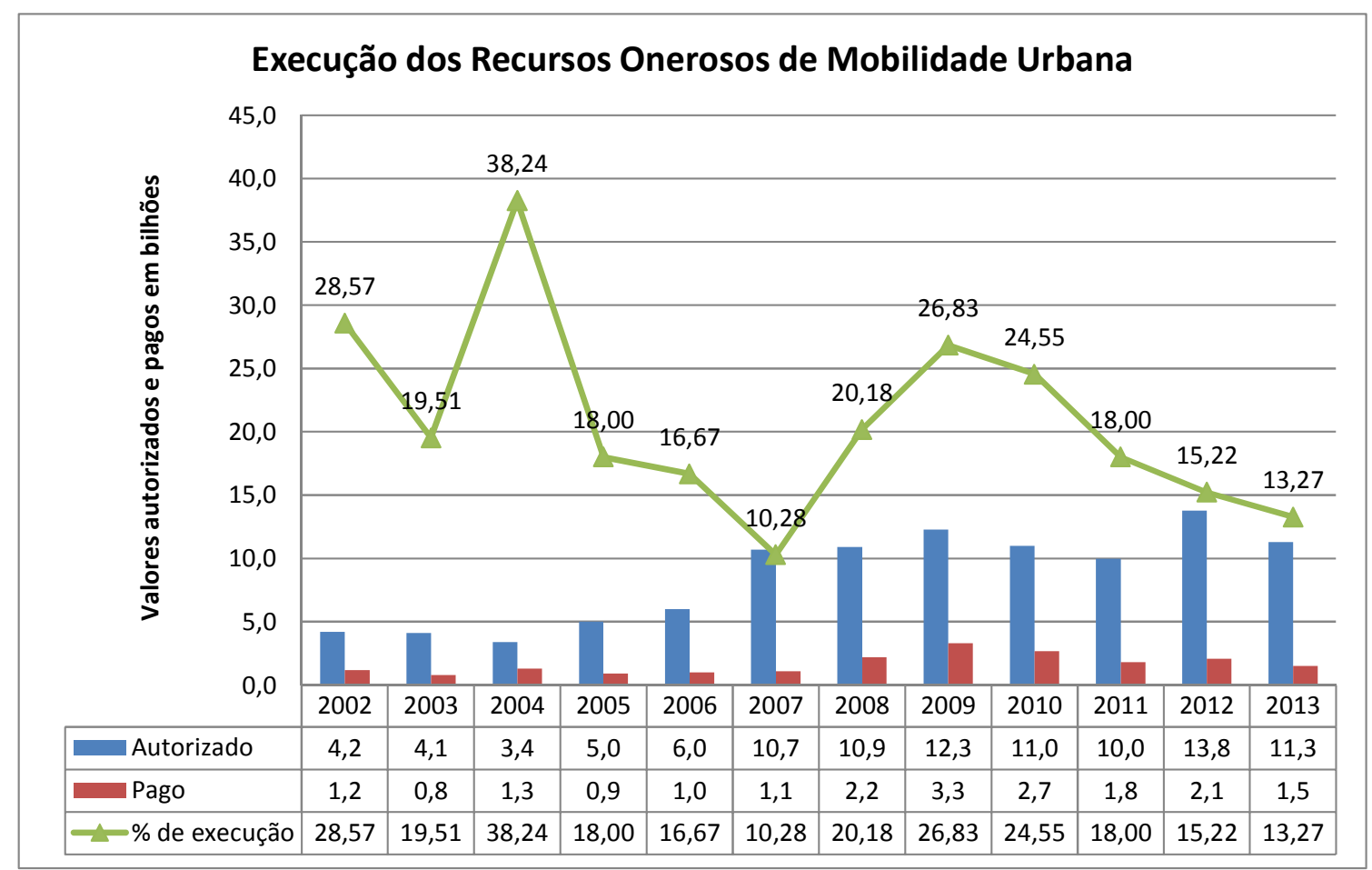

Figura 49 - Execução dos recursos onerosos de mobilidade urbana Fonte: Siga Brasil. 
A partir da análise dos dados percebe-se a confirmação do aumento significativo dos recursos orçamentários disponíveis para financiar as ações de mobilidade a partir de 2007 com o PAC. Comparando-se os anos de 2002 e 2013, houve um aumento de mais de $216 \%$ no aporte de recursos onerosos.

Por outro lado, mesmo que tenha ocorrido o aumento significativo da disponibilização de recursos para o financiamento das ações de mobilidade urbana, é preciso ter atenção com relação à capacidade operacional dos proponentes em executar os recursos orçamentários.

A curva de execução orçamentária mostra a tendência de um percentual de execução médio baixo, sendo pouco maior que $20 \%$. As complexidades técnicas e de remoção de pessoas são apontadas como os principais desafios a serem enfrentados pelos municípios e estados na execução das obras de mobilidade urbana, fazendo com que essas tipologias de obras apresentem o maior tempo de execução quando comparadas com outros setores da política urbana.

$\mathrm{Na}$ Tabela 21, apresenta-se a composição das fontes de recursos onerosos por tipo de fonte, que financiam as ações de mobilidade urbana no MCidades.

Tabela 21 - Recursos onerosos por tipo de fonte

\begin{tabular}{|c|c|c|c|c|}
\hline \multirow{2}{*}{ Ano } & \multicolumn{3}{|c|}{ Fonte R\$ } & \multirow{2}{*}{ Total } \\
\cline { 2 - 5 } & FGTS & BNDES & não determinada & $57.055 .924,14$ \\
\hline 2006 & $57.055 .924,14$ & - & - & $717.120,00$ \\
\hline 2007 & $717.120,00$ & - & - & 0,00 \\
\hline 2008 & - & - & - & $964.350 .269,60$ \\
\hline 2009 & $964.350 .269,60$ & - & - & $9.032 .745 .458,75$ \\
\hline 2010 & $7.842 .745 .458,75$ & $1.190 .000 .000,00$ & - & $5.162 .300,00$ \\
\hline 2011 & $5.162 .300,00$ & - & - & $12.163 .000 .000,00$ \\
\hline 2012 & $9.687 .000 .000,00$ & $2.476 .000 .000,00$ & - & $19.322 .393 .922,77$ \\
\hline 2013 & $19.322 .393 .922,77$ & - & - & $15.036 .060 .609,14$ \\
\hline 2014 & $7.781 .046 .658,05$ & $2.560 .000 .000,00$ & $4.695 .013 .951,09$ & $\mathbf{5 6 . 5 8 1 . 4 8 5 . 6 0 4 , 4 0}$ \\
\hline Total & $\mathbf{4 5 . 6 6 0 . 4 7 1 . 6 5 3 , 3 1}$ & $\mathbf{6 . 2 2 6 . 0 0 0 . 0 0 0 , 0 0}$ & $\mathbf{4 . 6 9 5 . 0 1 3 . 9 5 1 , 0 9}$ & \\
\hline
\end{tabular}

Fonte: Brasil, Câmara dos Deputados, 2015.

A partir da tabela, confirma-se mais uma vez a importância dos recursos do FGTS na implementação da política urbana, visto que durante o período de 2006 a 2014, mais de 
$80 \%$ das ações de mobilidade urbana foram financiadas com essa fonte de recurso, $11 \%$ do BNDES e 8,3\% de fontes não identificadas.

Essas análises reforçam o entendimento de que a criação do Ministério das Cidades também foi um marco importante com relação à política de mobilidade urbana, tanto no sentido conceitual e legal, com a aprovação da Lei 12.587, quanto em relação ao aumento e à continuidade nos investimentos.

As ações desenvolvidas pelo órgão privilegiam a execução de obras de infraestrutura em detrimento das ações de planejamento, indicando mais uma vez a existência de um descolamento entre o discurso e a prática. Verificou-se que quase a totalidade dos programas que viabilizaram a execução da política nacional de mobilidade urbana estava inserida no PAC, seguindo a ótica econômica que este imprimiu a todos os setores onde aportou recursos.

\subsection{Desafios a serem enfrentados para se ter uma política de desenvolvimento} urbano menos setorial

As análises realizadas neste capítulo possibilitaram o aprofundamento acerca de algumas condições de urbanidade que as cidades oferecem e também com relação à execução das ações adotadas em cada uma das políticas setoriais estudadas (habitação, saneamento e mobilidade). Além disso, permitiram perceber algumas evidências que comprovam o fato de a abordagem setorialista ter se consolidado como o "modus operandi" da política urbana e até ter se perpetuado no tempo. Mostraram ainda que, de fato, a soma dessas políticas setoriais tem assumido o lugar da política de desenvolvimento urbano brasileira, que cada vez mais, distancia-se do ideal de política urbana preconizado nas formulações teóricas estudadas no Capítulo 1 da tese, as quais inspiram as lutas de diversos movimentos sociais.

Não se buscou aqui exaurir a análise de todos os dados e indicadores existentes com relação às características das cidades brasileiras, tampouco se objetivou esgotar as possibilidades de análise numérica e conceitual da aplicação dos recursos pelo Ministério das Cidades com relação à política urbana implementada. Tinha-se em mente, principalmente, estudar dados e indicadores usualmente adotados pelos gestores públicos para justificar o discurso das políticas urbanas e para auxiliar o processo de tomada de 
decisão quanto às alternativas de intervenção adotadas (programas e ações), tendo em vista compreender as especificidades dessas práticas.

Além disso, tentou-se verificar se o Ministério das Cidades, em função de toda expectativa que se tinha com relação à sua criação e quanto às respectivas modificações institucionais que o acompanharam, atuou de forma diferente do modelo de desenvolvimento urbano que vinha sendo replicado ao longo de todo o processo de urbanização e ao longo da trajetória das políticas urbanas.

A primeira constatação prática desse capítulo foi com relação à verificação de que a existência de um normativo técnico, ou até de uma lei para nortear a ação pública, não implica, necessariamente, que a prática siga suas recomendações. É possível ter essa conclusão pelo descumprimento de uma série de normativos instituídos: a PNDU definida na criação do Ministério das Cidades (Cadernos MCidades); o Estatuto da Cidade e seus respectivos instrumentos e princípios destinados a orientar o uso do solo; os princípios e os objetivos materializados nas políticas nacionais de habitação, saneamento e mobilidade urbana; os planos diretores e demais planos setoriais desenvolvidos para orientar a ação pública; além de outros normativos menos relevantes que estabeleceram critérios de aplicação de recursos e também deveriam ser considerados no processo de tomada de decisão, mas são ignorados.

Sobre isso, Preteceille (1990) ainda naquela já afirmava que, logo de partida, percebia-se uma contradição na forma como as políticas urbanas são pensadas e conduzidas, visto que aquelas preconizadas não estão em conformidade com as práticas adotadas para sua implementação. De acordo com o autor, essa distorção é ainda maior em função das interferências que o cenário e os processos políticos podem produzir e modificar a tomada de decisões.

Preteceille (1990, p. 54) reforça que as políticas urbanas sofreram, ainda na década de 1990, evoluções importantes que não podem ser analisadas sem se levar em conta suas complexas ligações com as trocas econômicas. O autor considera, desde aquela época, que essas políticas não são simplesmente o reflexo ou o registro dessas relações, mas "traduzem-nas especificando-as e se caracterizam por terem a capacidade de influenciar os processos econômicos". 
Nesse sentido, o estudo das políticas urbanas contribui para a compreensão das questões que surgem em função das relações entre as transformações econômicas e as mudanças sociais. O autor também enfatiza a influência dos interesses relativos aos diferentes atores que interferem na formulação e na implementação das políticas estatais e menciona a diferenciação entre as políticas preconizadas e as praticadas, reforçando a ideia de que muito do que se apresenta nos discursos oficiais em torno das políticas urbanas, são insumos utilizados pelo poder estatal como mecanismo de garantia de uma condição hegemônica, por meio da dominação. Assim, discutir as propostas dessas políticas e difundir um discurso coerente e que aborde pontos centrais da problemática urbana constitui uma das estratégias adotadas para a imposição da ideologia dominante que está imersa nos diferentes níveis da Burocracia e da própria sociedade.

Portanto, além de todos os obstáculos que se apresentam para o enfrentamento da problemática urbana, em termos de sua complexidade intrínseca e da falta de sistemáticas metodológicas que consigam dar respostas e apontar caminhos apropriados para sua solução, é necessário considerar as interferências provenientes das práticas políticas que condicionam a ação estatal.

No caso das políticas setoriais de habitação, saneamento e mobilidade, percebe-se a influência constante dos interesses empresariais do mercado imobiliário, da construção civil e da indústria automobilística, além de outros segmentos, atuantes para a manutenção da forma setorializada de intervir no urbano. O que se percebe é que isso se deve, principalmente, ao fato de essa condição favorecer os ganhos privados e a captura dos agentes públicos.

Dentre os três setores analisados, a política de saneamento parece ser aquela que apresenta a maior evolução na cobertura dos serviços nas regiões mais precárias, tendo o efeito da lógica privada se manifestado de forma menos intensa (este se apresenta como o setor menos lucrativo dos três). Por outro lado, não foi possível realizar análises mais aprofundadas com relação à atuação da antiga Secretaria Nacional de Acessibilidade e Programas Urbanos, atual Secretaria Nacional de Desenvolvimento Urbano (após redação do decreto 8.927/2016), nos mesmos moldes do que foi feito para a SNH, A SNSA e a SEMOB. 
As ações dessa secretaria, antes de 2007, com a institucionalização do PAC, já estavam reduzidas a pequenas intervenções em áreas de situação de risco, as quais fazem parte do escopo de um programa de competência do Ministério da Integração Nacional. Além disso, os indicadores usualmente adotados pelo Ministério das Cidades para descrever e analisar as condições urbanas dos grandes centros se restringem basicamente aos setores de habitação, saneamento e mobilidade, não havendo a ampla divulgação nem a contemplação de indicadores sobre outros temas relevantes para o desenvolvimento urbano.

É fato que no início da implementação da política de desenvolvimento urbano instituída logo após a criação do Ministério existiu uma ação específica do órgão para apoiar os municípios na elaboração de planos diretores. Contudo, com o passar do tempo, essa ação deixou de ser prioridade no órgão, dando espaço para o PAC e, posteriormente, o PMCMV assumirem o papel dos os instrumentos que passaram a "orientar" o "planejamento urbano" das grandes cidades.

Tudo isso reforça a ideia de que os pressupostos apontados no Capítulo 1 da tese com relação ao método para compreender a problemática urbana e o espaço como conceito básico não foram considerados pelas políticas preconizadas pelo Ministério. Isso que já havia sido constatado pela análise dos discursos no Capítulo 2 e foi confirmado pela presente análise da prática.

Também foi possível verificar que os temas levantados nos debates teóricos e conceituais relativos à problemática urbana não são explorados com a mesma importância no momento da prática como o são nos discursos. Uma forma de observar esse fato é contrapor as temáticas que fazem parte dos discursos com aquelas contempladas na ação, bem como observar a cesta de indicadores adotados para monitorar os níveis de qualidade urbana, os quais auxiliam na seleção das ações a serem implementadas pelo poder público. Por meio dessas verificações é possível perceber o deslocamento entre as fundamentações teóricas que justificaram a construção dos discursos políticos e institucionais e as ações orçamentárias e os programas que foram elencados para possibilitar a implementação das políticas urbanas. 
Esse comportamento se estende a todas as políticas setoriais (habitação, saneamento e mobilidade), apresentando-se de maneira menos intensa na habitação, que é o setor que dispõe de maior quantitativo de indicadores e de temas contemplados nos discursos e nas ações, e, de forma mais extrema, na mobilidade que se apresenta como a política menos estruturada das três setoriais analisadas.

A situação é ainda mais problemática com relação às ações da Secretaria de Acessibilidade e Programas Urbanos do Ministério, atual SNDU, que deveria implementar iniciativas para promover a regularização fundiária e os instrumentos do Estatuto da Cidade, por exemplo, mas que não desempenha este papel devido à prioridade política conferida às políticas setoriais. Destaca-se que a implementação dos instrumentos do Estatuto da Cidade e a regularização fundiária, que deveriam estar contemplados nas ações da SNDU, pressupõem o enfrentamento do problema de uso e acesso à terra urbana, que vem sendo ignorado pelo poder público por se contrapor aos interesses dos atores dominantes.

Embora no momento de criação do Ministério das Cidades tenha sido definida uma PNDU provisória alinhada aos princípios do direito à cidade para nortear as políticas de habitação, saneamento, mobilidade e programas urbanos, até que fosse elaborada uma PNDU definitiva por meio de um processo democrático no âmbito do Conselho das Cidades, entre 2007 e 2009 foram instituídas novas regras para orientar a ação do governo federal a partir da criação do PAC e do PMCMV.

Esses dois programas foram adotados pelo governo como políticas anticíclicas, constituindo a principal estratégia de ação estatal, desconsiderando inclusive os instrumentos de planejamento até então já produzidos. Essa mudança na condução da estratégia de desenvolvimento do país resultou na priorização da ótica privada nos investimentos, tornando as políticas ainda mais setorializadas, abandonando a política urbana provisória, os princípios e os instrumentos previstos nas políticas nacionais de cada setor que já haviam sido pactuadas e instituídas.

O PAC e o PMCMV estavam diretamente alinhados com objetivos econômicos que visavam prioritariamente alavancar a economia e gerar empregos, corrompendo a tentativa 
de ação integrada entre as Secretarias que foi sugerida nos Cadernos MCidades publicados em 2004, dando continuidade à construção de um espaço urbano fragmentado e segregado.

A prevalência da lógica setorial favorece o fatiamento dos setores em nichos que seguem a lógica dos interesses vigentes em cada um deles separadamente, desconsiderando os ganhos sociais e espaciais que se poderia alcançar caso as ações fossem planejadas e executadas tomando como referência o espaço em sua totalidade. Essa maneira de atuar sobre o urbano e o território prioriza as estruturas e os ganhos decorrentes de sua implementação de obras e deixa em segundo plano, por exemplo, as pessoas e as reais necessidades sociais.

É preciso salientar que os níveis de precariedade com relação a habitação, saneamento e mobilidade sempre estiveram concentrados nas populações de baixa renda (até $3 \mathrm{SM}$ ), que não têm suas necessidades plenamente atendidas. Atuar sobre o território por meio de ações desarticuladas entre si sem considerar os mecanismos de transformação e organização do espaço fez com que os níveis de precariedade permanecessem e até se acentuassem ao longo do tempo.

Outro ponto que precisa ser enfatizado se refere à importância que o FGTS tem como a principal fonte de recurso que financia as políticas urbanas implementadas pelo Ministério das Cidades. Esse fato, juntamente com a atuação da Caixa Econômica como o agente operador das ações fortalece a lógica setorial e financeira da ação pública, permitindo a priorização da ótica privada. Primeiro, por se tratar de um recurso oneroso (empréstimo) e, segundo, pelo fato de a Caixa ser uma instituição que prioriza a visão financeira dos recursos. Esse mesmo equívoco na forma de operacionalizar a implementação da política urbana foi apontado na época do $\mathrm{BNH}$.

Os desdobramentos disso em cada política setorial podem ser elencados da seguinte forma: (i) o maior volume de recursos alocado na política de habitação está voltado para a população de maior renda (SBPE) fazendo persistir o déficit mesmo com o aumento significativo de recursos pelo poder público; (ii) a política de saneamento está se voltado para o setor privado, buscando parcerias privadas e subvertendo a lógica de direito humano; (iii) a política de mobilidade urbana vem sendo mais solicitada em termos de transportes de uso coletivo mais recentemente, devido à pressão das manifestações sociais 
mais recentes (2013), porém não abandonou a priorização ao uso de automóveis como a principal forma de transporte da população; (iv) as ações de planejamento urbano e a implementação do princípio da função social da cidade não fazem parte das ações governamentais por se situarem na contramão da financeirização da terra e dos ganhos econômicos com as ações que se desenvolvem nas cidades.

Essas constatações apontam a existência de um problema estrutural e conceitual da política urbana que é anterior e maior que os entraves de ordem operacional normalmente apontados (repartição de competências do pacto federativo, capacidade operacional dos entes de elaborar projetos, contratar e executar obras, definição de alternativas técnicas, além de outros aspectos). Tudo isso reforça a percepção de que o espaço não é pensado como um todo.

Essa questão é observada desde as primeiras ações do Estado visando minimizar ou atenuar diferentes faces da problemática urbana, a partir de um modelo de desenvolvimento perverso que segue os interesses do mercado em detrimento das necessidades sociais e também por atuar de forma fragmentada segundo temas ou setores. No meio urbano, os desdobramentos desse modelo de desenvolvimento, tem invertido a lógica de planejamento e de uso e ocupação do solo, preconizados no Estatuto da Cidade e acentua o estado de segregação sócio-espacial.

Essa lógica setorial de agir também reflete na estrutura organizacional dos órgãos e das pastas existentes na Administração Pública, fazendo com que persista um estado de fragmentação institucional entre as secretarias e entre os setores que elas atendem. Além disso, o desequilíbrio entre a capacidade operacional e a importância política e institucional conferida à política de habitação ainda persiste, deixando em segundo plano as políticas de saneamento e mobilidade e as demais ações de desenvolvimento urbano.

Essa fragmentação também é percebida com relação a outras políticas que têm interfaces com a política urbana (ambiental, de ordenamento territorial, regional, rural, além de outras). É necessário compreender que cada uma dessas políticas impacta de forma diferente o espaço, assim como sua implementação desarticulada tende a acentuar as dificuldades que se busca vencer. 
A literatura aponta que a lógica setorial e fragmentada de tratar a problemática urbana deveria ser substituída por uma abordagem espacial / territorial para possibilitar a produção do espaço geográfico de forma a considerar as especificidades de suas estruturas e de sua parte imaterial. Essa abordagem também possibilita o entendimento sobre as diversas atuações dos atores envolvidos nos diferentes usos do território, possibilitando que as diversas temáticas que interagem com a política urbana e que foram mencionadas nos discursos, pudessem ser contempladas nas ações estatais conjuntamente. $\mathrm{O}$ espaço que se busca construir deveria ser o referencial de planejamento para a implementação das ações / políticas, superando a visão do território como receptáculo das intervenções públicas de forma desconectada.

Atualmente, os instrumentos disponíveis para a implantação da política urbana são muito limitados por esta não dispor do instrumento básico de atuação, que é a capacidade de atuar sobre a reorientação na localização das atividades econômicas, ou seja, na espacialização dos usos do território. Embora a capacidade real de realocar atividades econômicas faça parte do discurso oficial, encontra-se fora do seu campo de ação e abrangência (SCHMIDT e FARRET, 1986, p. 84). Dessa forma, para os autores (p. 85), a política urbana não pode continuar a ser marginal e periférica em relação à política geral de desenvolvimento do país.

Sobre isso Steinberger (2006, p. 21) destaca que é preciso repensar a inserção do território e do ambiente nas políticas públicas espaciais, sendo imprescindível romper com as visões segmentadas do espaço para não comprometer sua totalidade. A autora ressalta que ainda hoje impera uma atuação setorial por parte do Estado e da sociedade, em nome da racionalização que privilegia programas e projetos pontuais. Explica que, ao se criticar esse tipo de visão, sugere-se uma abordagem relacional entre as políticas espaciais e seus respectivos instrumentos.

Segundo a autora, a política urbana, por se materializar no território, tem peculiaridades que a difere de outros grupos de políticas. Faz parte do grupo de políticas conceituadas como espaciais, por serem fundamentadas pelo espaço (política rural, urbana, de ordenamento territorial, de desenvolvimento regional e ambiental) e atreladas a um arcabouço teórico-conceitual complexo onde seu conteúdo é focado na produção do espaço 
mediante o uso do território. Dessa forma, são considerados os aspectos físicos e materiais que constituem o território, bem com a dinâmica inerente às práticas sociais.

Desse modo, Steinberger (2006) se utiliza do conceito de território usado no estudo da prática das políticas espaciais, mostrando que a compreensão dessas políticas requer a substituição do entendimento tradicional de território, como receptáculo das ações, pelo conceito de espaço geográfico, que integra a parte material do território à vida subjetiva oriunda da prática social.

Essas reflexões mostram que embora a criação do Ministério das Cidades tenha representado um marco relevante na trajetória da política urbana brasileira, destaca-se que ainda persiste um problema de ordem conceitual que contribui para que a política urbana continue a ser segmentada e setorializada.

A partir dessas reflexões, verifica-se que o Estatuto da Cidade, representação institucional da tentativa de se instituir o direito à cidade no Brasil, ainda não se consolidou a ponto de modificar a forma como a política urbana é conduzida no país, tampouco ainda não foi possível reverter o quadro de precariedade dos grandes centros urbanos, como se pensava no auge das lutas pela reforma urbana.

Devido a isso, a necessidade de intensificação da articulação e da mobilização popular surge como um dos caminhos a se seguir tendo em vista alterar mais concretamente a correlação de forças vigente na sociedade brasileira, que há tempos se mostra dependente e subordinada aos interesses de setores econômicos que regem os mercados e inclusive, a ação estatal.

Assim, partindo da premissa de que o Ministério das Cidades e os respectivos avanços decorrentes da sua criação proporcionariam o cenário mais favorável para a superação dos entreves históricos do desenvolvimento urbano, surgem questionamentos com relação às razões para que a situação dos grandes centros urbanos ainda seja tão crítica e continue a replicar a segregação social e a desigualdade.

Por que o estabelecimento de um arcabouço legal e normativo consistente não foi suficiente para transcender a ótica setorial de planejamento e de implementação da política urbana? Por que mesmo depois de doze anos de governo sob a gestão do PT, que sempre 
apoiou e defendeu as reivindicações dos movimentos em prol do direito à cidade não foi possível superar os problemas observados nas políticas urbanas implementadas em períodos anteriores? Por que mesmo depois de catorze anos de criação do Ministério das Cidades, diante de um cenário onde prevaleceu a prioridade política e o aumento significativo no aporte de recursos para as políticas urbanas por mais de uma década, ainda se apresentam de forma grandiosa os desafios para a implementação de uma política de desenvolvimento urbano menos setorialista?

É na busca de respostas para esses questionamentos que no Capítulo 4 da tese será estudado o comportamento dos atores, bem como da teia de interesses que se consolidou em torno das políticas setoriais de habitação, saneamento e mobilidade, fazendo com que estas tenham substituído uma PNDU. É preciso ainda compreender quais aspectos da prática da ação governamental, considerando de que forma as peculiaridades da Administração Pública Brasileira e do subsistema da política de desenvolvimento urbano contribuem para que permaneça a lógica setorial de intervir no espaço urbano.

\section{Capítulo 4. A coalizão de interesses na política de desenvolvimento urbano do Ministério das Cidades}

No capítulo anterior, chegou-se à conclusão de que a criação do Ministério das Cidades representou um marco na trajetória da política urbana brasileira, a partir dos avanços obtidos no campo jurídico-legal e institucional estabelecidos. Estava embutida nesse contexto a tentativa de modificar o modelo excludente de urbanização que vem se perpetuando desde as primeiras iniciativas do Estado para combater e minimizar os efeitos da problemática urbana.

Por outro lado, apesar de todos os esforços empreendidos no sentido de compreender os aspectos teórico-conceituais associados à problemática urbana, no aprendizado com as experiências das políticas urbanas e dos planos implementados em períodos anteriores, bem como na construção de um discurso institucional alinhado aos princípios do direito à cidade, ainda não foi possível reverter o quadro de precariedade dos grandes centros urbanos, como se pensava no auge das lutas pela reforma urbana. 
As discussões realizadas neste estudo sugerem que existe uma correlação de forças bastante influente, que há tempos se mostra dependente e subordinada aos interesses de setores econômicos específicos, mostrando-se capaz de extrapolar sua lógica de operação para as práticas do Estado.

Desse modo, no presente capítulo, busca-se compreender o comportamento dos atores que participam ou influenciam o processo de tomada de decisão no ciclo da política urbana, tendo em vista identificar os fatores que possibilitem analisar e explicar as mudanças e as permanências que moldaram a política urbana após a criação do Ministério das Cidades.

No atual contexto político-institucional brasileiro, são vários os atores e interesses a serem coordenados e processados na execução de uma política pública: burocracias de diferentes poderes e níveis de governo, parlamentares de diversos partidos e organizações, além de representantes da sociedade civil (sindicatos de trabalhadores, associações empresariais, movimentos sociais). Desse modo, em torno de cada política é formado um arranjo de organizações (com seus mandatos, recursos, competências e instrumentos legais), são criados mecanismos de coordenação, espaços de negociação e decisão entre atores (do governo, do sistema político e da sociedade), além da existência das obrigações de transparência, prestação de contas e controle (GOMIDE e PIRES, 2014).

A influência de grupos de interesse no cenário político desperta a atenção de diversas áreas do conhecimento em função da capacidade que estes têm de intervir nas decisões políticas. Dessa forma, é preciso compreender a dinâmica desses grupos, bem como do seu processo de formação, para entender sua atuação e o que condiciona os respectivos interesses.

Santos (2002) explica que os grupos de interesse podem ser classificados de diversas maneiras, como, por exemplo, pelo tipo de interesse representado, pela intensidade de organização do grupo e em função do campo de ação prioritário. Por destinatários, entendem-se os possíveis interlocutores de um grupo de interesse.

Um grupo pode tentar ganhar os mais importantes destinatários como interlocutores, como o Congresso, o chefe do Executivo, a Burocracia estatal, os partidos e a opinião pública. Contudo, nem todos os interlocutores têm a mesma importância para um mesmo 
grupo. Vale a pena distinguir que a relevância de um destinatário depende de muitos fatores, tais como o tipo de grupo de interesse, a estrutura e o seu papel em um sistema político determinado, além dos objetivos gerais e específicos perseguidos por ele.

Outra distinção que importa esclarecer é a existente entre grupos de interesse e grupos de pressão. Genericamente é possível dizer que, num dado momento, os grupos de pressão são um subconjunto dos grupos de interesse que visam pressionar uma instância qualquer do poder político a alterar as suas políticas num sentido favorável ao grupo ou a mantê-las, caso elas já sejam favoráveis ao interesse do grupo.

Nesse sentido, as atividades dos grupos de pressão passam sempre pela sua relação com entidades públicas. É importante destacar que qualquer grupo, na medida em que está organizado, tem ao seu alcance a capacidade de exercer pressão política, a depender em parte, do número de membros (efeito dimensão) e do controle que tenha de formas socialmente desestabilizadoras de ação política (efeito ação) (PEREIRA, 1999).

Ressalta-se que os personagens pertencentes aos grupos de pressão, necessariamente, devem atuar dentro de uma faixa própria de interesses de seus associados ou representados. Isso porque, embora os grupos de pressão busquem influenciar a distribuição dos recursos numa sociedade, seja para mantê-la sem alteração, ou para introduzir mudanças em seu favor, estes não participam diretamente do processo eleitoral. Por esse motivo, não estão interessados em gerir o poder político, mas aproximar-se dele com facilidade e frequência, a ponto de influenciar suas opções (ZAMPIERI, 2013).

$\mathrm{Na}$ tentativa de cumprir suas funções da maneira mais eficiente possível, os grupos de interesse procuram transformar seus recursos (finanças, quota de filiação e informações) em poder político, de modo que possam desenvolver relações interpessoais com os diferentes participantes do processo político. Uma questão central para o grupo é saber distinguir em cada momento qual tipo de informação poderá elevar suas possibilidades de acesso aos formuladores (SANTOS, 2002).

Nesse sentido, Bin e Castor (2007) destacam que atores tendem a interferir nas estruturas de poder de organizações por meio de táticas políticas como: (i) formação de coalizões, que são alianças em torno de um ponto de vista ou problema; (ii) cooptação, que consiste na tentativa velada de mudar a posição do tomador de decisão; (iii) uso estratégico 
de informações, que envolve manipulação e controle de canais de informações críticas; (iv) uso de especialistas externos, que é o apoio de consultores para legitimar uma proposição.

Os autores também abordam os fatores políticos que caracterizam o jogo de interesses:

i. Negociação e persuasão: decisões podem derivar de negociações, barganhas e manobras de convencimento;

ii. Poder: habilidade do jogador para influenciar as decisões do outro, que pode originar-se da autoridade formal ou do controle sobre recursos ou informações;

iii. Contingências: são capazes de determinar decisões e ações antecipadas à análise criteriosa;

iv. Conflito: diversidade de considerações, crenças e preferências sobre objetivos e meios;

v. Cooptação: tentativa velada de mudar a posição do tomador de decisão;

vi. Coalizão e cooperação: redes de pessoas independentes que se associam em torno de uma oportunidade, ponto de vista ou problema;

vii. Interesses: interesses paroquiais ou pessoais são capazes de determinar decisões;

viii. Influência externa: aspectos externos à organização e ao processo podem influenciar decisões.

Em função de toda complexidade atrelada ao comportamento dos atores na dinâmica das políticas públicas, Santos (2002) destaca que pesquisas recentes apontam para a tendência de estudo de todo o processo de formulação de políticas. A principal preocupação dessa acepção está na tentativa de oferecer uma visão geral da participação dos diferentes atores ou da investigação das relações entre eles, bem como sua capacidade de interferir nos processos decisórios, visando à consecução de seus interesses.

Assim, o tema decisão tem servido ao debate acerca de quais fatores atuam e interferem no processo, ou mesmo nas escolhas de que participam indivíduos ou grupos. Uma dessas discussões tem sido em torno da racionalidade e sua aplicabilidade na análise 
dos processos decisórios, os quais poderão contemplar aspectos da lógica racional, bem como da política (BIN e CASTOR, 2007).

Em democracias presidencialistas como as dos países latino-americanos, o processo de adoção e implementação de políticas públicas ocorre em sistemas políticos que contam com a participação de uma variedade de atores, desde o presidente até eleitores de pequenas comunidades rurais, passando por congressistas, juízes, formadores de opinião e empresários. A complexa interação entre eles é influenciada pelas instituições e práticas políticas de cada país (BID, 2007).

Esse contexto complexo de interação constante entre diferentes atores e instituições transpassa todo o ciclo de políticas públicas. Mesmo na fase de implementação / execução, em que as negociações e coalizões entre grupos de pressão já ocorreram no sentido de fazer acontecer a política a partir de uma tomada de decisão governamental para dar uma solução possível a um problema identificado, ocorrem pressões de diversas origens com o objetivo de direcionar a execução dos programas segundo interesses próprios.

É visando compreender quanto esses atores conseguem interferir nas práticas das políticas urbanas que será utilizado o Modelo de Coalizões de Defesa como referencial teórico para analisar o formato da política urbana brasileira após a criação do Ministério das Cidades. Busca-se entender as razões que possibilitaram as mudanças institucionais necessárias para a criação do órgão juntamente com a definição de uma PNDU, além de descobrir por quais razões ainda existem permanências relacionadas aos padrões de desenvolvimento urbano praticados em períodos anteriores.

\subsection{O modelo de coalizões de defesa}

Atualmente, existem diferentes modelos disponíveis para a análise de políticas públicas, propostos por diferentes autores, destacando-se:

1. o Ciclo da Política Pública, que de acordo com Howlett et al. (2013) vê a política pública como um processo sociopolítico que envolve estágios sucessivos;

2. a Teoria dos Múltiplos Fluxos, que propõe a combinação de três vertentes (a dos problemas, a das políticas públicas e a da política) num determinado 
contexto sócio-institucional e determina as chances que uma política em específico seja adotada, a partir do que se chama de uma "janela de oportunidade" (KINGDON, 2011);

3. a Teoria do Equilíbrio Pontuado, propondo que os processos de políticas públicas são marcados pelo incrementalismo, mas são pontuados por pequenos períodos de crise que geram mudanças radicais (JONES e BAUMGARTNER, 2012);

4. o Modelo de Coalizões de Defesa que procura analisar o processo político por intermédio da interação entre diferentes "coalizões de defesa" que se formam em torno de temas específicos de acordo com interesses e preferências dos atores (SABATIER e WEIBLE, 2007);

5. o Modelo da Lata de Lixo, que considera que os vários atores, participantes do processo decisório, despejam seus diversos problemas e soluções numa mesma plataforma (lata) e que as escolhas daí decorrentes fogem do controle e das preferências individuais (KINGDON, 2011);

6. a Teoria de Mudança Institucional Gradual, a qual defende que mudanças incrementais ocorridas gradativamente ao longo do tempo são relacionadas a características institucionais que favorecem pequenas transformações, sejam nas estratégias de implementação das regras ou na composição dos atores envolvidos, e também à estratégia adotada pelos atores para conduzir estas mudanças (MAHONEY e THELEN, 2010).

Embora existam várias abordagens para se realizar uma análise de políticas públicas, o modelo a ser adotado na presente pesquisa será o Modelo de Coalizões de Defesas "Advocacy Coalition Framework" (ACF), desenvolvido por Sabatier e Jenkins-Smith em 1988, e aperfeiçoado por Sabatier e Weible em 2007. Essa escolha se justifica pelo fato de a abordagem ter como objeto a análise da política pública com foco na capacidade que os grupos de interesses têm de influenciar o processo decisório e de moldarem o formato das políticas públicas implementadas.

Segundo Araújo (2013), essa abordagem compreende a formulação das políticas públicas como produto da competição entre coalizões que compõem subsistemas formados 
por atores individuais e coletivos, de organizações públicas e privadas, que estão ativamente preocupados com determinada questão de política pública.

O modelo, parte da premissa de que essas coalizões interagem no âmbito de um subsistema de políticas públicas, definido como:

“(...) um subsistema consiste num conjunto de atores de diversas organizações públicas e privadas que estão ativamente envolvidos com um problema ou questão de política pública num determinado espaço geográfico, e que regularmente procuram influenciar as decisões do governo em uma determinada área política" (SABATIER e WEIBLE, 2007, p. 192).

Sabatier (1988, p. 139) define uma coalizão de defesa como um conjunto de atores heterogêneos (representantes eleitos e funcionários públicos, líderes de grupos de interesse, pesquisadores, intelectuais, além de outros), que (i) compartilham determinado sistema de crenças, entendidas como englobando valores, ideias, objetivos políticos, formas de perceber os problemas políticos, preferências políticas, pressupostos casuais e (ii) demonstram um grau não trivial de ações coordenadas ao longo do tempo.

$\mathrm{Na}$ medida em que as coalizões são formadas, estas competem entre si buscando imprimir suas crenças em políticas públicas ou em programas governamentais, a partir da mobilização de recursos e do processo contínuo de aprendizagem política. As coalizões constituem grupamentos informais de atores, cada qual com um conjunto diferenciado de crenças direcionadas à questão de política pública em foco e produzem uma atuação coordenada ao longo do tempo, no sentido de influenciar as decisões governamentais e de defender a transformação de suas crenças em decisões e resultados concretos.

O modelo começou a ser desenvolvido em 1988 e concentrou-se em análises de países anglo-saxões, numa tentativa de compreender "padrões de mudança em que as políticas públicas são cada vez mais multifuncionais, intersetoriais e transversais", num contexto de predominância de "problemas perversos" que envolvem conflitos de objetivos e metas, além de disputas técnicas para consecução dos resultados ou definição das estratégias a serem adotadas a fim de abordar os problemas declarados.

O AFC se apresenta como uma tentativa de superar o modelo de "lata de lixo" e enfatiza questões relacionadas às crenças e aos valores políticos, que estão em jogo nas 
disputas entre os subsistemas, ao mesmo tempo em que realiza críticas aos modelos que enfatizam a racionalidade dos processos e atores (SABATIER, 2011). Os autores partem da premissa de que os atores não agem apenas motivados por interesses econômicos ou materiais, sendo as coalizões de advocacia, manifestações de compartilhamento de ideias, valores e compromissos ideológicos comuns.

Esse modelo foi desenvolvido com foco em três propósitos iniciais: proporcionar uma alternativa para os modelos de análise de políticas públicas segundo estágios, que careceriam de robustez conceitual para a construção de hipóteses causais empiricamente testáveis; formular um modelo para estudar as políticas públicas, com base na teoria de sistemas, que sintetizasse algumas das principais contribuições dos debates sobre a gestão "top-down" e "bottom-up"; e analisar a influência das informações técnicas nas políticas públicas (ARAÚJO, 2013).

As bases do modelo consideram que, embora a formulação das políticas se desenvolva por especialistas, no âmbito dos subsistemas, esse processo dependerá do sistema político e socioeconômico para o seu desenvolvimento e que a melhor maneira de lidar com a multiplicidade de atores em subsistemas é organizá-los por meio de coalizões de defesa. Os autores operam uma substituição do modelo racional pelo modelo de crença, visto que, para eles, as crenças dos atores, a rede de crenças e o embate entre elas, se concretizam e se traduzem em políticas públicas. Dessa forma, é possível compreender que as mudanças radicais exigem choques exógenos para os subsistemas.

Sobre o conceito de coalizões, é importante destacar que elas não se restringem aos partidos. As dimensões partidárias, na maioria dos casos, não são suficientes para explicar as coalizões, que se arranjam em torno de problemas ambíguos, de temas polêmicos, setoriais, regionais, além de outros aspectos. Assim, as coalizões detêm crenças, valores, recursos, autoridades e trajetórias, dentre outros signos e significados, que se alteram no decorrer do jogo, fazendo com que adquiram ou percam forças na trajetória histórica do tema em debate.

Os autores também defendem não ser possível estudar uma "Coalizão de Defesa" a partir de uma única decisão, mas sim considerando uma trajetória superior a 10 anos, sendo a temporalidade um critério importante para ser possível diferenciar as coalizões dos 
grupos de pressão. Num período curto é possível identificar apenas o movimento dos grupos de interesses e não o movimento das coalizões, que também disputam por instituições. Em cada coalizão os participantes compartilham crenças e valores fundamentais; nos grupos de pressão, os interesses mais imediatos possuem maior predominância.

Vicente e Calmon (2011) ressaltam as contribuições do Modelo de Coalizões de Defesa quanto à melhoria da compreensão sobre os padrões de mudança em um mundo em que as políticas públicas são cada vez mais multifuncionais, intersetoriais e transversais. $\mathrm{O}$ modelo foi proposto para estudar a formulação e os processos pelas quais as políticas públicas mudam ao longo do tempo, tendo sua abordagem revista e aprimorada várias vezes desde quando foi desenvolvido em 1988. Segundo os autores, o modelo parte de um conjunto de premissas e aspira explicar a formulação e as mudanças nas políticas públicas, tendo como base múltiplas variáveis.

De acordo com os autores, no AFC considera-se que as coalizões são atores fundamentais na análise das ações governamentais por três razões: (i) porque eles constituem um arco de alianças que é capaz de sustentar politicamente os programas e as políticas públicas tanto no nível partidário e parlamentar, quanto na sociedade e entre os atores burocráticos; (ii) porque as coalizões têm o conceito de mobilização como uma característica intrínseca a elas, dado que buscam constantemente apoiadores para a sua causa, a fim de aumentar a sua solidez; (iii) as coalizões são importantes por estabelecerem relevantes espaços de debate e aprendizado em relação às políticas públicas, possibilitando antecipar mudanças e corrigir erros.

Ao se analisar a trajetória da política de desenvolvimento urbano, percebe-se que a influência dos grupos de interesses, agrupados por meio de coalizões, tem influenciado significativamente o formato das ações governamentais. Assim, acredita-se que a adoção do AFC possibilitará a identificação dos atores que compõem as coalizões relevantes ao subsistema de política pública em questão; a identificação das crenças e dos recursos que os une; o conhecimento acerca de suas relações e de que forma influenciaram os diferentes arranjos políticos e institucionais que foram formados ao longo da trajetória dessas políticas, considerando as dinâmicas políticas relevantes na trajetória dessas políticas públicas, buscando responder a razão de ser das permanências observadas. 


\section{Pressupostos e descrição do modelo}

Para fundamentar o modelo de Coalizões de Defesa, Sabatier e Jenkins-Smith propuseram cinco pressupostos:

“(i) que a compreensão dos processos de mudança política e o papel da aprendizagem política a ela associada requer uma perspectiva ampliada de tempo (uma década ou mais); (ii) que a unidade de análise mais útil para o estudo dessa mudança é por meio de subsistemas políticos; (iii) que esses subsistemas têm que incluir a dimensão intragovernamental; (iv) que políticas públicas - ou programas podem ser conceituadas da mesma maneira por sistemas de crenças (conjuntos de prioridades e assunções causais sobre como realizá-las); (v) o papel central das informações técnicas e científicas no processo de mudança política, pois facilita o aprendizado político" (SABATIER e JENKINS-SMITH, 1999, p. 118-120).

Dessa forma, as análises sobre a política em estudo são realizadas com relação às coalizões formadas em torno de um subsistema, buscando compreender como estas competem para imprimir suas crenças na ação das políticas públicas ou programas governamentais, por meio da mobilização de recursos políticos e do processo contínuo de aprendizagem política.

A presente pesquisa levará em conta todas as atualizações do modelo já publicadas pelos autores, considerando a versão mais recente acerca do processo de como políticas públicas são formatadas e modificadas em função da atuação de diferentes coalizões de defesa. Nesse sentido, apresenta-se na Figura 50 um diagrama visando representar os principais componentes do modelo.

No lado direito da figura está representado o subsistema de política pública e sua dinâmica interna, onde geralmente ocorre o processo de aprendizado político. As mudanças observadas na política pública ocorrem em função da coordenação e da competição no interior do subsistema, bem como devido à influência dos eventos exógenos, representados na parte esquerda da figura.

Sabatier e Jenkins-Smith (1993) apontam que existem diferentes instrumentos disponíveis para a atuação das coalizões que podem influenciar as decisões das agências governamentais de forma direta ou indireta, junto aos tomadores de decisão no Legislativo, no Executivo, no Judiciário ou no plano intergovernamental. 
Dentre as formas diretas de influenciar a tomada de decisão, os autores destacam: (i) influenciar no modo como os órgãos definem os investimentos em determinada área ou projeto; (ii) participar ou influenciar os debates e as audiências no âmbito do Legislativo; (iii) propor ao Executivo mudanças nas atribuições e jurisdições de determinados órgãos com o objetivo de influenciar a atuação do governo em áreas específicas; (iv) indicar técnicos ou analistas alinhados a suas ideias para exercer cargos influentes no setor público; (v) elaborar ou apoiar estudos ou pesquisas cujos resultados possam contribuir para dar suporte técnico ou político às propostas relativas a seus interesses; (vi) utilizar a imprensa e demais meios de comunicação para divulgar suas propostas e atacar seus oponentes.

Quanto às formas indiretas de atuação das coalizões, os autores (p. 227) destacam as seguintes: (i) proposição de novas leis ou regras; (ii) mudanças nas dotações orçamentárias de projetos ou programas; (iii) alterações nas formas de financiamento ou nos critérios de contratação de projetos ou programas; (iv) alterações nos processos de seleção ou indicação de pessoas para cargos de direção; (v) modificação nos processos decisórios, alterando quantidade de pontos de veto para uma determinada decisão. 


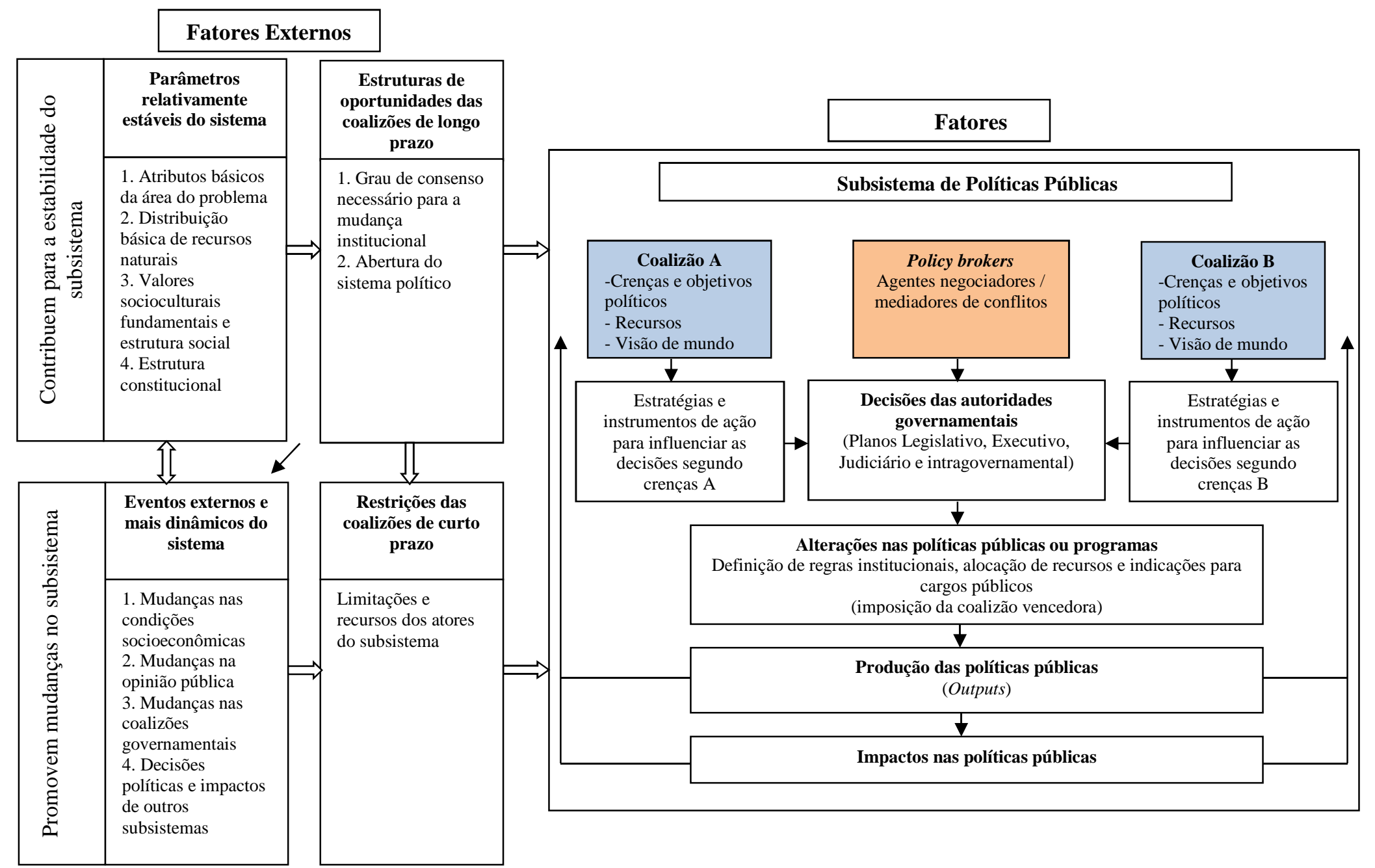

Figura 50 - Diagrama de representação dos componentes do Modelo de Coalizões de Defesa

Fonte: adaptado de Weible; Sabatier e McQueen (2009, p. 123) 
O diagrama apresentado representa os principais aspectos do modelo a partir da seguinte composição:

\section{Eventos externos que contribuem para a estabilidade do subsistema:}

- Atributos básicos da área do problema, objeto de uma determinada área de política pública (características-chave do problema e necessidades de intervenção estatal);

- Distribuição básica de recursos naturais, considerando que a abundância ou carência de recursos disponíveis em uma sociedade condicionam suas possibilidades de desenvolver diferentes setores econômicos e determinam a viabilidade das opções de políticas;

- Valores socioculturais fundamentais e estrutura social: significativas mudanças no poder, na influência e nos recursos financeiros de vários grupos sociais requerem diversas décadas;

- A estrutura constitucional que determina o regime e o sistema político adotado (democracia, presidencialismo, federalismo, e outros) e as regras legislativas básicas;

2. Eventos externos que promovem mudanças no subsistema: apresentam natureza mais dinâmica, podendo afetar substancialmente o subsistema a ponto de enfraquecer os pressupostos causais que justificam a atual política pública; as mudanças nas coalizões governamentais visto que padrões político-partidários são fundamentais no desenho das coalizões; decisões políticas e os impactos de outros subsistemas; eventos políticos ou econômicos;

3. Eventos internos ao subsistema: é no âmbito do subsistema que são gerados os programas ou políticas públicas devido à interação das coalizões. Os produtos desse processo decorrem de mudanças nas regras institucionais e de alocação de recursos impostas pela coalizão vencedora, que opta por estratégias específicas para influenciar o subsistema e atingir seus objetivos políticos.

Sabatier e Jenkins-Smith (1999) ressaltam que a implementação das estratégias de ação de cada coalizão visando à alteração de programas ou de políticas públicas é 
permeada de conflitos, visto que os atores envolvidos percebem o mundo por diferentes perspectivas. Em função disso ocorrem diferentes interpretações das instituições e das práticas governamentais.

Os autores também identificaram a categoria dos "policy brokers" (mediadores) no interior do subsistema, com a função de atuar para chegar a acordos que possam reduzir a intensidade dos conflitos existentes. Fazem parte desse grupo de atores burocratas, parlamentares, juízes de cortes, promotores de justiça, cidadãos no exercício do voto. Geralmente, esses atores pertencem às coalizões e detêm algum poder para fazer valer os compromissos acordados entre as coalizões.

\section{Sistemas de crenças e hipóteses}

Relatos de Vicente (2012, p. 20) mostram que o sistema de crenças orienta os membros de uma coalizão de defesa com relação aos problemas que devem ser considerados prioritários, bem como quanto às relações causais que necessitam ser examinadas de forma mais atenta. Busca mostrar quais instituições governamentais serão mais favoráveis aos pontos de vista defendidos pela coalizão, as quais serão alteradas.

Dessa forma, os sistemas de crenças têm a dupla função de moldar uma perspectiva normativa para fundamentar a interpretação e de promover o diagnóstico com relação aos fenômenos percebidos. Sabatier e Jenkins-Smith (1999, p. 133) apresentam o sistema de crenças de uma coalizão a partir de uma estrutura hierárquica tripartite, em formato piramidal, onde a base apresenta o menor grau de resistência a mudanças, e o topo, o maior. Esse sistema segue uma hierarquia, sendo dividido em três categorias: (i) núcleo duro; (ii) núcleo das políticas públicas; (iii) aspectos instrumentais.

O núcleo duro (deep core) apresenta as crenças com maior resistência a mudanças, uma vez que são semelhantes a um compromisso ideológico profundo ou a um conjunto de doutrinas religiosas fundamentais (JENKINS-SMITH e SABATIER, 1994, p. 181). Essas crenças constituem os compromissos ontológicos e epistemológicos da coalizão.

Os autores apresentam os seguintes exemplos de crenças integrantes do núcleo duro: as concepções sobre a natureza humana, as prioridades relativas a valores fundamentais como direito à vida, dignidade da pessoa humana, liberdade, segurança, poder, 
conhecimento, saúde, amor, beleza, critérios básicos de justiça distributiva, identidade sociocultural, além de outros aspectos (SABATIER e JENKINS-SMITH, 1993, p. 252).

O núcleo das políticas públicas (policy core) constitui o principal objeto de análise do modelo, visto que as preferências políticas se manifestam no seu interior, além de constituírem o principal elo entre as coalizões. Também moldam a projeção ideal de um subsistema de políticas públicas e oferecem os referenciais necessários para o comportamento estratégico das coalizões, além de unirem aliados e dividirem os oponentes. Por ser difícil empreender alterações nesse núcleo de crenças, as mudanças nas coalizões resultam, geralmente, da ação de fatores externos ao subsistema, tais como aqueles inerentes a crises macroeconômicas ou a mudanças governamentais.

Os autores destacam as seguintes crenças do núcleo das políticas públicas: orientação sobre prioridades valorativas básicas, identificação de grupos sociais ou outras entidades cujo bem-estar é objeto de maior consideração; preceitos com componentes empíricos substanciais, como os referentes a causas básicas do problema, distribuição adequada de autoridade entre o governo e o mercado e entre os diferentes níveis de governo, prioridades entre os diferentes instrumentos de política pública e preferências políticas de destaque.

Finalmente, os aspectos instrumentais "secundary aspects" envolvem a parte dos componentes concretos e operacionais que fazem parte de uma política pública. Constituem os aspectos mais suscetíveis a mudanças que ocorrem mediante um processo de aprendizado decorrente da interação entre as coalizões. Esse processo, segundo os autores, é considerado o vetor fundamental para a análise das mudanças nas políticas e nas instituições.

Os autores apresentam os seguintes exemplos de crenças no nível dos aspectos instrumentais: preferências políticas de menor destaque; crenças referentes à importância dos problemas em locais específicos ou à importância relativa de fatores causais em diferentes momentos e locais; decisões sobre alocação de recursos orçamentários; interpretação de normas; informações sobre o desempenho de programas ou instituições específicas, além de outros.

Na Figura 51 apresenta-se uma representação do sistema de crenças das coalizões. 


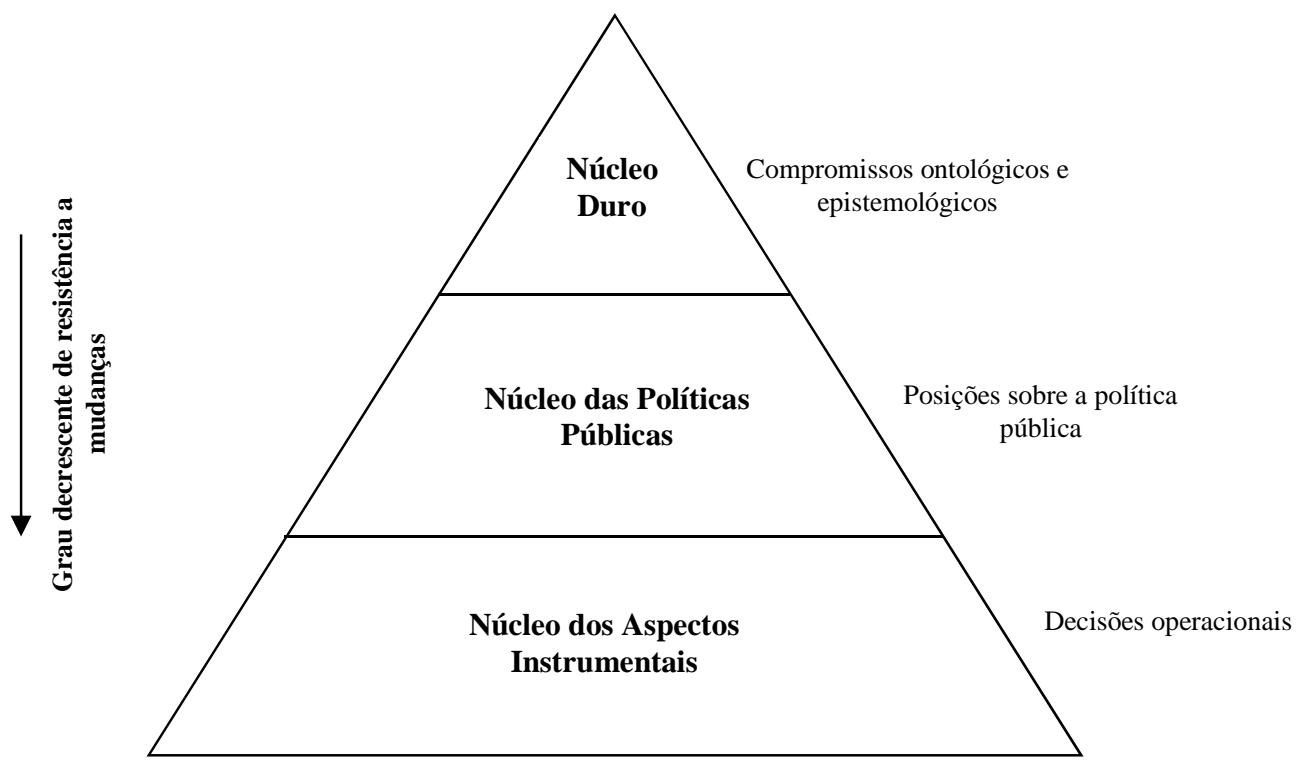

Figura 51 - Representação dos sistemas de crenças

Sabatier e Jenkins-Smith partem da premissa de que é possível identificar um conjunto de evidências empíricas em torno do sistema de crenças, que confirma ou não os elementos presentes em cada um dos três níveis de crenças. Assim, o acúmulo de evidências contrárias a uma crença existente poderá gerar questionamentos, revisões ou até a sua modificação e eventual substituição.

É nessa situação em que as análises técnicas e os estudos científicos que confirmam ou refutam as crenças existentes podem influenciar o processo de mudança institucional, podendo acelerar ou dificultar a realização de mudanças. Essa passa a ser uma das alternativas da coalizão para sustentar suas crenças ou atacar as crenças de seus oponentes.

Para Sabatier (2007) os embates políticos e as defesas de posições acontecem, na maioria dos casos e com maior intensidade, nas áreas de conflitos das duas coalizões, principalmente no núcleo de políticas públicas e nos aspectos instrumentais das crenças. É nessas duas áreas onde geralmente existem as maiores chances de concessões e de alterações no subsistema de política pública.

Desde a concepção da primeira versão do modelo foram definidas doze hipóteses para auxiliar a análise da atuação das coalizões, buscando gerar evidências empíricas sobre o processo de mudança institucional, sendo agrupadas em três categorias: (i) hipóteses de 
coalizão: propõem que o principal aglutinador das coalizões é a concordância sobre as crenças que compõem o núcleo político fazendo as coalizões permaneçam estáveis durante períodos de até dez anos; (ii) hipóteses de mudança política: postulam que uma política tende a permanecer por tanto tempo quanto permanecer no poder da coalizão que a criou, tida como dominante. A única maneira de mudar o núcleo das políticas públicas dá-se por meio de algum evento originado fora do subsistema, alterando a distribuição dos recursos e dos pontos de vista das coalizões; (iii) hipóteses de aprendizado: as coalizões resistem a mudanças em seu núcleo de políticas públicas ou, mesmo, em aspectos instrumentais importantes de seus sistemas de crenças, onde apenas evidências empíricas bastante sólidas podem conduzi-las a rever pontos de vista.

Neste estudo, serão apresentadas as hipóteses já revisadas pelos autores:

"Hipótese 1 de coalizão (revisada): no âmbito de um subsistema de política maduro, o alinhamento de aliados e oponentes em relação às controvérsias que envolvem "core beliefs" tende a ser consideravelmente estável ao longo de uma década ou mais (SABATIER e JENKINS-SMITH, 1999, p. 129);

Hipótese 2 de mudança (revisada): perturbações significativas externas ao sistema (por exemplo, mudanças nas condições socioeconômicas, opinião pública, coalizões governantes, ou decisões políticas de outros subsistemas) constituem causa necessária, mas não suficiente, de mudança nos atributos fundamentai de um programa governamental (SABATIER e JENKINS-SMITH, 1999, p. 147);

Hipótese 3 de coalizão: um ator (ou coalizão) desistiria de aspectos instrumentais de seu sistema de crenças antes de assumir fraquezas no núcleo de políticas públicas ("policy core”) (SABATIER e JENKINS-SMITH, 1993, p. 27);

Hipótese 4 de mudança (revisada): os atributos fundamentais de um programa governamental não serão significativamente revisados enquanto a coalizão que instituiu o programa permanecer no poder, exceto quando a mudança for imposta por uma hierarquicamente superior (SABATIER e JENKINS-SMITH, 1993, p. 217);

Hipótese 5 de mudança (revisada): mudar os atributos fundamentais de um programa de ação governamental requer ao mesmo tempo: (a) perturbações significativas externas ao subsistema (por exemplo, mudanças nas condições socioeconômicas, opinião pública, coalizões governantes, ou decisões políticas de outros subsistemas); (b) aproveitamento inteligente dessas oportunidades pela coalizão até então minoritária no âmbito do subsistema (SABATIER e JENKINSSMITH, 1993, p. 221-222);

Hipótese 6 de coalizão (revisada): atores que compartilham crenças do núcleo político ("policy core") são mais propensos a se submeter à coordenação de curto prazo quando veem seus oponentes como: (a) muito poderosos e (b) muito capazes de impor custos substanciais sobre eles, se vitoriosos (SABATIER e JENKINS-SMITH, 1999, p. 140);

Hipótese 7 de aprendizado: problemas em relação aos quais existem teorias e dados quantitativos aceitáveis são mais conducentes a aprendizado político entre sistemas de crenças do que aqueles em que a teoria e os dados são em geral 
qualitativos, muito subjetivos e ausentes (SABATIER e JENKINS-SMITH, 1993, p. 40-54);

Hipótese 8 de aprendizado: problemas que envolvem sistemas naturais são mais conducentes ao aprendizado político entre sistemas de crenças do que aqueles que envolvem sistemas puramente políticos ou sociais, porque nos primeiros muitas das variáveis críticas não são estrategistas ativas e experiências controladas são mais factiveis (SABATIER e JENKINS-SMITH, 1993, p. 40-54);

Hipótese 9 de aprendizado: aprendizado político entre sistemas de crenças é mais provável quando existe um fórum que é (a): prestigiado o suficiente para forçar profissionais de diferentes coalizões a participar; $e$ (b) dominado por normas profissionais (SABATIER e JENKINS-SMITH, 1993, p. 40-54);

Hipótese 10 de coalizão: elites de grupos de interesses ideológicos (grupos propositores) são mais limitados em sua expressão de crenças e posições sobre políticas do que elites de grupos de interesses materiais (SABATIER e JENKINSSMITH, 1993, p. 152);

Hipótese 11 de coalizão: no âmbito de uma coalizão, as agências governamentais geralmente propugnarão posições mais moderadas do que seus aliados em grupos de interesse (SABATIER e JENKINS-SMITH, 1993, p. 213);

Hipótese 12 de aprendizado: mesmo quando a acumulação de informação técnica não altera a visão da coalizão oposta, ela pode ter importantes impactos na política - ao menos no curto parzo - pela alteração das visões dos mediadores ("policy brokers") ou outros importantes agentes governamentais (SABATIER e JENKINS-SMITH, 1993, p. 219)”.

Embora o modelo proponha doze hipóteses, para a presente pesquisa buscou-se aplicar aquelas que possam proporcionar uma melhor compreensão da conformação e da dinâmica do subsistema de política pública em estudo, bem como do papel desempenhado pelas coalizões de defesa no processo de formulação e implementação da política urbana. Assim, foram escolhidas as hipóteses 1, 2, 4, 5 e 10.

Segundo os autores (1993, p. 55) apenas evidências empíricas podem levar a mudanças, sendo mais provável que essas evidências sejam desenvolvidas e aceitas nas seguintes situações: (i) em áreas do conhecimento onde haja a disponibilidade de dados quantitativos e consensos quanto às teorias; (ii) mais no domínio das ciências naturais do que nas ciências sociais; (iii) em subsistemas onde um fórum profissional prestigiado e respeitado; (iv) em situações envolvendo um nível intermediário de conflito, sem envolver conflito normativo direto, mas complexo o bastante para justificar o empenho de recursos analíticos. 
A partir dessas considerações, na etapa de aplicação do modelo, serão identificadas as evidências empíricas que possibilitam a compreensão do processo de mudança institucional ocorrido no subsistema da política urbana no período de análise (2003 a 2017). Para isso, serão considerados os discursos construídos no momento de criação do Ministério das Cidades, as leis de criação do PAC e do PMCMV, além da análise da influência dos eventos externos de natureza macroeconômica e de mudança governamental.

4.2 Aplicação do modelo no subsistema da política urbana: atores, coalizões crenças e recursos para influenciar o processo decisório

De acordo com Sabatier e Jenkins-Smith (1999, p. 118) a unidade de análise mais útil para entender o processo de mudança que ocorre nas políticas públicas são os componentes intrínsecos a um subsistema de política pública, entendido como o conjunto de atores individuais e coletivos dos vários níveis de governo, bem como de organizações privadas e da sociedade civil organizada, que estão ativamente preocupados com determinada questão de política pública e que regularmente tentam influenciar a tomada de decisão nesse domínio.

Assim, a presente pesquisa tem como objeto os processos de mudança ou de permanência institucional no âmbito do subsistema da política urbana brasileira, desde a criação do Ministério das Cidades em 2003, e seus desdobramentos. Será analisado como diferentes coalizões de defesa influenciam as políticas púbicas de um subsistema, partindo da premissa de que estas coalizões são estabelecidas por um conjunto de atores que compartilham um sistema de crenças, ideias e valores comuns.

Também será priorizada a análise com relação ao núcleo de crenças de políticas públicas por concentrar as posições e decisões mais importantes sobre a política pública e também pelo fato de ser quase impossível modificar as crenças do núcleo duro. Os aspectos instrumentais não serão trabalhados por se tratarem apenas dos procedimentos operacionais da ação, visto que as decisões já foram tomadas no núcleo de políticas públicas. Os autores também sugerem que a análise detalhada e exaustiva de todos os componentes do sistema de crenças implica um número elevado de elementos, dificultando o processo de análise e trazendo poucos acréscimos ao estudo. 
De forma similar ao estudo realizado por Vicente (2012, pp. 36-41), serão adotados nesta tese os procedimentos a seguir:

1. Procedimento 1: identificação da estrutura de crenças que constituem o núcleo das políticas públicas;

2. Procedimento 2: identificação dos principais atores que integram as coalizões e suas respectivas posições e prioridades;

3. Procedimento 3: identificação e caracterização das principais decisões que marcaram a política urbana no período de análise;

4. Procedimento 4: identificação dos conflitos entre as diferentes coalizões nos processos de tomada de decisão;

5. Procedimento 5: análise dos recursos utilizados pelas coalizões no âmbito do subsistema para transformação de crenças e ideias em ações governamentais;

6. Procedimento 6: análise do processo de mudança institucional, identificando os efeitos das decisões decorrentes da interação entre as diferentes coalizões.

A realização desses procedimentos requer a definição prévia dos elementos do núcleo de políticas públicas que irão orientar a análise das coalizões, bem como a definição das categorias que irão viabilizar a identificação e caracterização das coalizões de defesa, além da sua dinâmica de atuação.

Os elementos chave que deverão ser observados com relação à composição do núcleo de políticas públicas são os seguintes:

- crenças e posições políticas de cada ator relevante no subsistema;

- as coalizões e os recursos empregados por elas;

- formas de atuação, prioridades, valores e principais decisões tomadas no interior do subsistema;

- as visões diferentes sobre os principais aspectos da problemática urbana;

- o principais embates e conflitos entre as coalizões.

No Quadro 7, apresentam-se as categorias a serem adotadas para caracterização das coalizões e de sua dinâmica que foram selecionadas considerando os pressupostos e premissas identificados na revisão bibliográfica relativa aos aspectos teórico-conceituais e à trajetória da política urbana, discutidos nos capítulos 1,2 e 3. 
Desse modo, os pressupostos identificados nas contribuições teóricas se somaram aos aspectos observados quanto à problemática e à política urbana com relação à análise dos discursos das políticas e dos planos, bem como com relação à política praticada pelo Ministério das Cidades.

O processo de formulação e implementação da política urbana após a criação do Ministério das Cidades e as respectivas modificações ao longo do tempo, é fruto das interações conflituosas entre grupos de atores unidos por meio de crenças, práticas e interesses. Assim, os atores que fazem parte de cada coalizão foram identificados a partir de seus posicionamentos e quanto à sua capacidade de influenciar na tomada de decisão.

A partir da análise dos discursos, foi possível identificar que os atores individuais e coletivos que influenciaram na dinâmica do subsistema da política urbana no âmbito do Ministério das Cidades desde a sua criação podem ser agrupados, em pelo menos, cinco coalizões de defesa: (i) Coalizão dos Movimentos Sociais Urbanos; (ii) Coalizão dos Especialistas; (iii) Coalizão dos Tecnocratas Desenvolvimentistas; (iv) Coalizão dos Políticos; e (v) Coalizão do Mercado.

A seguir serão descritas as principais crenças que condicionam o pensamento das coalizões identificadas, as quais integram os grupos de atores, bem como será apresentado o papel desempenhado por eles no sentido de condicionar a implementação da política urbana.

Ressalta-se que a análise das crenças compartilhadas pelos atores foi realizada tomando como referência o Quadro 7. 
Quadro 7 - Categorias de análise para caracterizar as crenças das coalizões

\begin{tabular}{|c|c|}
\hline Categorias de Análise & Posições e crenças que delimitam a investigação \\
\hline $\begin{array}{l}\text { A problemática urbana e suas } \\
\text { causas }\end{array}$ & $\begin{array}{l}\text { - o problema é impedimento ao crescimento econômico } \\
\text { - é resultado do modelo de desenvolvimento que acentua a segregação } \\
\text { socioespacial } \\
\text { - deve ser resolvida com protagonismo do Estado } \\
\text { - a solução requer a participação da iniciativa privada } \\
\text { - há limites à organização racional do planejamento urbano } \\
\text { - ênfase na concentração populacional e no processo de urbanização } \\
\text { acelerado e desordenado } \\
\text { - ênfase na ineficiência das políticas públicas } \\
\text { - ênfase na lógica de mercado como elemento dominante de } \\
\text { organização espacial que limita o acesso à terra } \\
\text { - visão integradora (causas múltiplas) }\end{array}$ \\
\hline A política urbana & $\begin{array}{l}\text { - a sociedade civil deve opinar nas decisões } \\
\text { - deve ofertar a infraestrutura necessária para a implantação das } \\
\text { empresas (seletividade de investimentos) } \\
\text { - é um dos braços da política anticíclica para movimentar a economia e } \\
\text { gerar empregos } \\
\text { - não atua nas causas da problemática sendo setorial e fragmentada } \\
\text { - deve ser orientada para as necessidades sociais (priorizar população } \\
\text { de baixa renda) } \\
\text { - é moeda de barganha política }\end{array}$ \\
\hline $\begin{array}{l}\text { O papel do Estado na política } \\
\text { urbana }\end{array}$ & $\begin{array}{l}\text { - é um dos agentes que influenciam na organização do espaço } \\
\text { - representação do poder político institucional } \\
\text { - deve implementar o princípio da função social da propriedade } \\
\text { - deve realizar políticas para ofertar equipamentos, serviços e } \\
\text { infraestrutura urbana para garantir direitos sociais } \\
\text { - deve realizar políticas para ofertar equipamentos, serviços e } \\
\text { infraestrutura urbana para promover o desenvolvimento e o } \\
\text { crescimento econômico }\end{array}$ \\
\hline O uso do solo & $\begin{array}{l}\text {-uso do solo como recurso político eleitoral } \\
\text { - uso do solo como recurso de barganha política } \\
\text { - uso do solo como recurso econômico, reserva de mercado ou de valor } \\
\text { - uso do solo como elemento de redução das desigualdades } \\
\text { socioespaciais } \\
\text { - uso do solo em conformidade com os instrumentos de planejamento e } \\
\text { ordenamento territorial }\end{array}$ \\
\hline A questão habitacional & $\begin{array}{l}\text { - ênfase na segregação social associada ao poder de aquisição da } \\
\text { moradia (limitação da qualidade de vida) } \\
\text { - ênfase na moradia como direito social a ser assegurada pelo Estado } \\
\text { - ênfase na moradia como mercadoria a ser negociada pela iniciativa } \\
\text { privada } \\
\text { - ênfase no Estado e na iniciativa privada como agentes garantidores } \\
\text { das necessidades mínimas de moradia } \\
\text { - visão integradora (causas múltiplas) }\end{array}$ \\
\hline A função social da propriedade & $\begin{array}{l}\text { - apoio incondicional } \\
\text { - apoio parcial com algumas demandas e ressalvas } \\
\text { - oposição total }\end{array}$ \\
\hline
\end{tabular}

Fonte: elaboração da autora. 


\section{Coalizão dos Movimentos Sociais Urbanos}

Os atores da Coalizão dos Movimentos Sociais Urbanos compartilham crenças que defendem o direito à cidade com o objetivo de reverter as desigualdades sociais a partir de uma nova ética social e pela democratização do espaço urbano. Fazem parte desse grupo de atores representantes dos movimentos sociais relacionados à problemática urbana, bem como membros do Conselho das Cidades, que é o canal institucionalizado para promover a participação social no âmbito da política urbana.

Os pleitos dessa coalizão, quanto à luta pelo direito à cidade estão focados principalmente em torno de três eixos: (i) o direito à cidade e à cidadania; (ii) a gestão democrática da cidade; e (iii) a função social da cidade e da propriedade.

Foi em torno desse objetivo que movimentos sociais originaram novas formas de luta política tendo em vista assegurar melhores condições de cidadania e viabilizar maior justiça social visando construir novas relações com o Estado. Buscou-se com essa abordagem imprimir um novo formato de planejamento que fosse capaz de gerar intervenções governamentais que efetivamente promovessem o desenvolvimento urbano, direcionando as ações governamentais segundo as reais necessidades das populações que estão à margem da cidade urbanizada.

Esses movimentos partem da premissa de que os conflitos de interesses na produção e apropriação do espaço construído precisam ser reconhecidos e enfrentados considerando que o solo urbano representa outros recursos, por poder oferecer um conjunto de equipamentos e serviços que deveriam ser ofertados a todos os agentes sociais de forma igualitária.

Por isso, fazem parte desta coalizão todos os movimentos que se situam em torno da problemática urbana, com relação ao uso, a distribuição e a apropriação do espaço urbano. $\mathrm{Na}$ prática, surgem novas lutas pelo acesso à terra e por sua posse, pela moradia; movimentos reivindicando melhores condições dos transportes; o surgimento de organizações relacionadas a associações de moradores; movimentos de favelados ou novos movimentos de desempregados; movimentos pela saúde, além de outros. 
Evers et. al. (1982, p. 133) mostra a relação entre os movimentos sociais, nos primórdios da década de 1980 e a luta por melhores condições de vida nas cidades em função do modelo de desenvolvimento tradicionalmente implementado:

\begin{abstract}
"Visto que as reivindicações por condições adequadas de vida para a maioria da população dos países latino-americanos são incompatíveis com a forma atual de desenvolvimento capitalista do continente, tais reivindicações estão, em última instância, dirigidas contra o capital como relação social de dominação. Ainda assim, $o$ destinatário principal destas demandas inseridas na esfera da reprodução é o Estado" (EVERS et al., 1982, p. 133).
\end{abstract}

Percebe-se que, tradicionalmente, o Estado é reconhecido por esses atores como o ator que deverá receber suas reivindicações para assimilar essas questões e direcionar suas políticas segundo as necessidades dessas populações, que representam os anseios daqueles mais vulneráveis socialmente. Uma forte característica dessas lutas se refere aos questionamentos quanto à ação estatal na distribuição de benfeitorias urbanas e dos equipamentos de consumo coletivo, que usualmente estão voltados para interesses econômicos e empresariais.

De acordo com Jacobi (1980, p. 120) essas benfeitorias realizadas pelo Estado assumem, por um lado, um caráter econômico, incidindo sobre a qualidade de vida urbana, e, por outro, um caráter basicamente político, que se configuram como eixos significativos que permitem a compreensão da dinâmica da realidade urbana a partir das suas contradições.

O autor especifica que esses movimentos estão inseridos em um marco de contradições extremamente complexo que caracteriza a formação dos grandes centros urbanos brasileiros, no contexto do seu desenvolvimento e funcionamento como grandes aglomerados que viabilizam a reprodução das condições necessárias à continuidade do sistema capitalista. Além disso, referem-se à problemática urbana como algo que deriva das contradições geradas pelo desenvolvimento do capitalismo ante as novas e sempre crescentes necessidades postas à reprodução da força de trabalho gerando uma crescente intervenção do Estado. Para Jacobi:

“Os movimentos sociais urbanos constituem uma nova questão na análise das relações de classes e, principalmente, no que diz respeito à tradição das classes populares. Trata-se de problemas sociais novos que, expressando contradições próprias das sociedades capitalistas, não se explicam somente pelo ângulo da 
oposição entre capital e trabalho. Representam antes de tudo, efeitos das distorções e das desigualdades decorrentes de uma aplicação desigual dos recursos públicos empregados no desenvolvimento e manutenção dos aglomerados urbanos" (JACOBI, 1980, p. 221).

É a partir dessa base de carências comuns que emerge uma identidade construída coletivamente sobre a noção de direitos e necessidade com relação à cidadania. Assim, surge da vivência de igualdade na comunidade militante e, ao mesmo tempo, do não atendimento às necessidades coletivas, a noção de direito que define o conteúdo das reivindicações (JACOBI, 1987).

Rolnik (2009, p. 40) destaca que grande parte dos investimentos em urbanização ocorre quando os bairros já estão ocupados, e que esta demanda tem grandes dificuldades de ser atendida, visto que a disputa pelo acesso ao investimento é acirrada e tem grande importância político-eleitoral. Em função da prevalência de um processo de urbanização da pobreza juntamente com a inserção precária destes moradores à cidade, uma das mais importantes demandas populares são bens e serviços públicos que melhoram sua condição de urbanidade. Desse modo, emergiram mobilizações locais com reivindicações organizadas em relação a moradia, transporte, saúde, saneamento, além de outras demandas.

De acordo com Goulart (2011, p. 54) os que foram chamados de "novos" movimentos sociais no Brasil consistiam nos movimentos populares urbanos, que se organizavam em torno de demandas de caráter econômico, da esfera da reprodução da força de trabalho como: água, esgoto, asfalto, moradia, além de outras demandas. Esses equipamentos públicos eram negados aos trabalhadores empregados nas indústrias das grandes e médias cidades, que concentravam enorme contingente operário nas plantas fabris fordistas, como era o caso do ABC paulista e Grande São Paulo. Um movimento que se destaca neste período é o Movimento dos Trabalhadores Sem-Teto (MTST).

A autora também complementa que a atuação desses movimentos se fortalecia por se perceber que a política institucional estava fechada para a ação popular pela via de partidos progressistas ou revolucionários. Também era verdade que a classe trabalhadora, no período de fim da ditadura, não via com bons olhos a política como um espaço de 
conquistas e da viabilização das lutas sociais, tanto pelo clientelismo amplamente utilizado, quanto pela restrição do voto direto, limitando a representação.

Desse modo, por se sentirem negligenciados pelo próprio Estado, a atuação desses movimentos passou a adotar a ocupação como a principal via de luta pela moradia. Vale ressaltar que a luta pela moradia no Brasil tem uma longa história de ocupações de imóveis, sejam eles terrenos ou prédios e casas, efetuadas tanto no centro como nas periferias, sendo a continuidade do processo de periferização como elemento de valorização do capital imobiliário pela via da especulação, o principal fator que levou o MTST para o centro do embate com a ocupação de terrenos nas cidades da Grande São Paulo.

Inicialmente, os movimentos sociais urbanos tinham uma base social onde predominavam trabalhadores que estavam de alguma forma sendo absorvidos pela necessidade de força de trabalho das indústrias em expansão, sobretudo na Grande São Paulo, mais especificamente nas periferias, onde havia, ausência de investimento estatal e privado para a construção de infraestrutura. Contudo, no final da década de 1990, a base social do MTST se apresentava diferente, devido às transformações sofridas pela classe trabalhadora, que passou a trabalhar mais horas, a receber menos, a sofrer maior instabilidade em termos de garantia de emprego, além de ter maiores dificuldades para garantir a reprodução de sua força de trabalho. Assim, a moradia passou a ser um dos itens da "cesta de consumo", que mais onera o salário do sem-teto (Goulart, 2011, p. 190).

Embora a questão habitacional constitua um elemento mobilizador, verifica-se que existem outras demandas emergenciais reconhecidas como essenciais nessas lutas. Nas palavras do MTST este movimento não é ligado à moradia especificamente, mas trata-se de um movimento que, a partir da luta pela moradia, se organiza para o enfrentamento das dificuldades que afetam as massas excluídas:

"O direito à moradia digna é uma bandeira central do nosso movimento. Mas não é única: o trabalhador que não tem acesso ao direito de morar dignamente - o sem teto - também não tem o direito à educação, ao atendimento de saúde, ao transporte coletivo, à infraestrutura básica em seu bairro e a muitas outras necessidades. É aqui que entra nossa proposta de uma Reforma Urbana. Defendemos uma transformação profunda no modo como as cidades estão organizadas. Hoje as cidades servem para dar lucro e são gerenciadas como uma empresa pelos governantes” (MTST, 2015, p. 243-244). 
Também é forte nesse movimento a busca e o fortalecimento do poder popular e a participação da população na deliberação das soluções para os problemas sociais. Nas palavras do MTST:

"Criar poder popular é mais do que um grito de ordem, é nosso grande objetivo. Somos a maioria, mas o poder não está com a gente e sim com os capitalistas. Construir o poder popular, que é o nosso poder, é a forma de transformar isso" (MTST, 2005, p. 4).

Para os representantes do MTST, o poder popular, além de uma forma de organização e de decisões dentro do movimento, seria, principalmente, uma maneira de enfrentar a política institucional do Estado, a partir das áreas ocupadas e da população de seu entorno. Em documento de 2008, fica claro o entendimento do Movimento com relação à captura do Estado pelos interesses do capital, sugerindo que o poder popular é um caminho para romper com essa situação.

O relato a seguir, retirado do Manifesto Popular, mostra que há um debate interno ao movimento sobre a dinâmica do capital, as relações de classe e o Estado. E que se faz ouvir em suas reivindicações pela reforma urbana e transformação social:

"O modelo neoliberal nos sufoca. O dinheiro que vai para o bolso de banqueiros e especuladores como pagamento de uma dívida impagável seria mais que suficiente para resolver os problemas de habitação, infraestrutura urbana e serviços no país (MTST, 2008, s/p).

A partir dessas lutas, é fortalecida a ideia de que é possível a sociedade se organizar politicamente por meio dos movimentos sociais, de modo que os indivíduos participantes desses movimentos sejam veículos dos interesses da coletividade, e não apenas dos seus próprios.

Assim, considerando o processo de democratização vivenciado no Brasil com a especificação da criação de conselhos na $\mathrm{CF} / 88$ como canais institucionais para viabilizar a participação social na gestão das políticas públicas, destaca-se a criação do Conselho das Cidades na tentativa de viabilizar a atuação de representantes sociais na interlocução com o Estado no que diz respeito à política urbana. Pressupõe-se que os integrantes do 
ConCidades, como legítimos representantes da sociedade civil, assumem as particularidades da identidade social dos seus grupos.

Segundo Rodrigues (2012, p. 187), anteriormente à criação do Conselho das Cidades, existiu um processo de articulação entre movimentos sociais que contribuiu para a criação do Ministério das Cidades, no início do governo Lula (2003). Esse processo representou uma inovação, configurando a base para a construção de um novo modelo de gestão participativa, baseada na mobilização de conferências e na institucionalização de conselhos de políticas setoriais, visto que, nas gestões anteriores, a política urbana era pensada de forma dissociada e sem a interlocução com representantes da sociedade civil. A partir dessa mudança institucional, foram inseridos na agenda governamental a própria política urbana e demais temáticas, tais como reforma urbana, sendo articuladas à política habitacional e à política de desenvolvimento urbano.

O processo de criação do Ministério teve participação crucial dos atores (movimentos e entidades) que compuseram o Fórum Nacional de Reforma Urbana. A proposta incluía a criação de um Conselho para influenciar a política urbana, sendo este um exemplo de movimento surgido da criação de direitos, representando uma mudança com relação ao padrão populista. Acreditava-se que esse tipo de participação poderia mudar a cultura política ao romper com as características de fragmentação, desarticulação e exclusão que persistiam propostas anteriores (Rodrigues, 2012, p. 188).

E foi em busca de uma mudança de paradigmas quanto à participação da sociedade na formulação da política urbana que o ConCidades foi criado, sendo responsável pela formulação, implementação e acompanhamento da execução da Política Nacional de Desenvolvimento Urbano (PNDU), como define o Art $1^{\circ}$ do Decreto ${ }^{\circ} 5790$, de 2006:

“(...)órgão colegiado de natureza deliberativa e consultiva, integrante da estrutura do Ministério das Cidades, tem por finalidade estudar e propor as diretrizes para a formulação e implementação da Política Nacional de Desenvolvimento Urbano, bem como acompanhar e avaliar a sua execução” (BRASIL, 2006).

Segundo Rolnik (2009, p. 35) o projeto inicial de construção do ConCidades o concebeu como um campo de interações políticas, arena aberta na qual a trama de interesses em torno da política urbana tivesse a possibilidade de expressão e negociação e 
na qual estivessem representados, com grande peso, os principais demandatários destas políticas - sem-teto, sem-casa, moradores de assentamentos precários no país - além dos setores empresariais e sindicais envolvidos, gestores públicos de municípios, estados e governo federal, ONGs, profissionais e pesquisadores do urbano.

Até o momento, foram realizadas 5 Conferências Nacionais das Cidades com o objetivo de instituir uma política urbana de forma participativa e contemplando efetivar o Estatuto da Cidade, como listado a seguir:

- $\quad 1^{\text {a }}$ Conferência Nacional das Cidades (2003): Cidade para Todos;

- $\quad 2^{a}$ Conferência Nacional das Cidades (2005): Reforma urbana: cidade para todos construindo uma política nacional de desenvolvimento urbano;

- $\quad 3^{\mathrm{a}}$ Conferência Nacional das Cidades (2007): Desenvolvimento urbano com participação popular avançando na gestão democrática das cidades;

- $\quad 4^{\mathrm{a}}$ Conferência Nacional das Cidades (2009): Cidade para todos e todas com gestão democrática, participativa e controle social. Avanços, dificuldades e desafios na implementação da política de desenvolvimento urbano;

- $5^{\mathrm{a}}$ Conferência Nacional das Cidades (2013): Quem muda a cidade somos nós: Reforma Urbana já;

- $\quad 6^{\mathrm{a}}$ Conferência Nacional das Cidades (2017): A Função Social da Cidade e da Propriedade: Cidades inclusivas, participativas e socialmente justas (ainda não há confirmação da sua execução).

$\mathrm{Na} 1^{\text {a }}$ Conferência Nacional das Cidades foram aprovadas as atribuições do Conselho das Cidades (ConCidades), assim como foi estabelecida sua composição. Os principais pontos deliberados na $1^{\text {a }}$ Conferência deveriam funcionar como referências para as Políticas Nacionais na área do desenvolvimento urbano, bem como, deveriam produzir o redirecionamento das ações e programas do Ministério das Cidades. Nesse período, iniciou-se o processo de construção democrática da PNDU, quando foram definidos seus princípios e diretrizes e criado o Conselho das Cidades.

Já a $2^{\text {a }}$ Conferência Nacional das Cidades teve como responsabilidade definir, de forma democrática, a Política Nacional de Desenvolvimento Urbano (PNDU). Buscava-se com a criação da PNDU, instituir o instrumento que deveria nortear as ações dos poderes 
públicos, de forma coordenada e com efetiva participação popular, para reduzir as desigualdades sociais e regionais e garantir uma "cidade para todos".

De acordo com o texto base da $2^{\mathrm{a}}$ Conferência, a pactuação democrática foi $\mathrm{o}$ caminho adotado para a construção da PNDU por se entender que este seria o único meio para a construção de uma política urbana sustentável e duradoura. No evento foram tratados quatro temas considerados pelo ConCidades os grandes desafios para a implantação da PNDU no país: participação e controle social; questão federativa; política urbana regional e regiões metropolitanas e Financiamento do desenvolvimento urbano, nos âmbitos federal, estadual e municipal.

A partir de todas as discussões realizadas no âmbito do ConCidades no sentido de construir democraticamente uma PNDU, chegou-se ao entendimento de que o grande desafio que se apresentou para a realização da $3^{\mathrm{a}}$ Conferência foi a composição de um Sistema Nacional de Desenvolvimento Urbano, objetivando a articulação, integração e cooperação dos entes federados com controle social, através das Conferências e Conselhos, base legal fundamentalmente assentada no Estatuto da Cidade e nos Planos Diretores Participativos, com suporte financeiro dos programas de investimentos no urbano.

Esse Sistema deveria ser regido por uma Política Nacional de Desenvolvimento Urbano que obrigatoriamente deveria estar pautada nas ideias e resoluções da sociedade, fundamentadas nas Conferências, e em particular as que resultaram dessa terceira. A despeito do mérito de o SNDU ser a alternativa mais adequada para a condução de uma PNDU, destaca-se aqui o comprometimento do ConCidaes na elaboração de uma política urbana por meio de um processo democrático, conforme definido desde o momento de sua criação.

Os debates da $3^{\text {a }}$ Conferência Nacional das Cidades foram estruturados em torno das seguintes temáticas:

- compreender se as políticas e os investimentos nos três níveis de governo estavam contribuindo, ou não, para reverter a lógica da desigualdade e da exclusão social, a fragmentação e a desarticulação das intervenções setoriais e intergovernamentais, visando otimizar custos sociais e a qualidade de vida nas cidades (p. 6); 
- verificar em que medida o poder público, em especial o Municipal, estava estruturado para enfrentar os desafios de seu próprio desenvolvimento, bem como verificar se as políticas e os investimentos nos três níveis de governo estavam contribuindo, ou não, para reverter a fragilidade do poder público na ação de planejar as intervenções nas cidades de forma integrada e com participação social (p. 11).

A partir das discussões realizadas até o momento, verificou-se que seria necessário refletir sobre os avanços e as dificuldades para a efetiva implementação da Política Nacional de Desenvolvimento Urbano (PNDU) durante a $4^{\text {a }}$ Conferência Nacional das Cidades, quando foram apontados quatro eixos temáticos que refletiam os principais desafios para implantação desta política: (i) criação e implementação de conselhos das cidades, planos, fundos e seus conselhos gestores nos níveis federal, estadual, municipal e no Distrito Federal; (ii) aplicação do Estatuto da Cidade, dos planos diretores e a efetivação da função social da propriedade do solo urbano; (iii) a integração da política urbana no território: política fundiária, mobilidade e acessibilidade urbana, habitação e saneamento; e (iv) a relação entre os programas governamentais - como PAC e Minha Casa, Minha Vida - e a política de desenvolvimento urbano.

Finalmente, na $5^{\text {a }}$ Conferência Nacional das Cidades foi apresentado um breve balanço quanto à construção do sistema nacional de desenvolvimento urbano, destacandose as seguintes questões:

(i) no âmbito federal não ocorreram muitos avanços na implementação das deliberações da Segunda Conferência das Cidades, que aprovou a sua criação: o SNDU não foi efetivamente criado;

(ii) em relação aos conselhos estaduais das cidades, nos estados onde estes foram instituídos, constatou-se que essas instâncias ainda não estavam funcionando efetivamente ou apresentavam baixa capacidade deliberativa;

(iii)nos municípios, apesar da ausência de indicadores oficiais, as informações disponíveis permitem inferir que também é pequeno o número de conselhos das cidades existentes. 
A estrutura do Conselho das Cidades foi formatada visando privilegiar o debate da elaboração, execução, acompanhamento e avaliação da política de forma continuada. Considerando a natureza do ConCidades, - deliberativa e consultiva - suas principais atribuições estão relacionadas à proposição de normas gerais de direito urbanístico; emissão de orientações sobre a aplicação do Estatuto das Cidades; proposição de diretrizes para distribuição regional e setorial do orçamento do Ministério das Cidades; definição de critérios para a implementação de programas e projetos. Entretanto, o processo de implementação da política urbana aponta que o Conselho das Cidades apresenta restrições quanto à sua força política para deliberar sobre ações e políticas estratégicas para a estruturação das cidades, bem como sobre o financiamento das ações.

Também é preciso destacar que o ConCidades não constitui a simples expressão da Coalizão dos Movimentos Sociais Urbanos, ainda que de fato tenha sido capturado por esta. Mesmo que existam diferentes segmentos da sociedade representados no Conselho e essa é a visão das demais gestões que assumiram o Ministério. isso ocorre, principalmente pelo fato de o ConCidades ter passado a representar o principal canal de interlocução dos movimentos com o governo.

Embora as cinco Conferências Nacionais das Cidades já realizadas tenham promovido a discussão de temáticas essenciais para a superação das questões associadas à política urbana, a atuação do Conselho das Cidades tem esbarrado na sua impossibilidade de deliberar sobre decisões estratégicas acerca das políticas implementadas pelo Ministério, reforçando a ideia de sua natureza predominantemente consultiva, embora a legislação vigente preveja seu caráter deliberativo. As temáticas que nortearam essas discussões no âmbito do ConCidades têm interferido na estrutura da política urbana em termos de legislação, dos programas e, até certo ponto, no orçamento. Contudo, as decisões não interferem sobre questões prioritárias da política, e suas indicações não são, necessariamente, respeitadas nem implementadas.

Destaca-se o fato de o ConCidades discutir as políticas setoriais e demais temáticas articuladas sem avançar na discussão sobre os critérios que condicionam a aplicação de recursos destinados a cada secretaria nacional para a execução dos programas e ações. A ausência desse debate amplia a fragilidade do controle social sobre a ação governamental, e mostra que as resoluções que impactam de forma mais significativa a aplicação de 
recursos são tomadas em esferas burocráticas superiores, assim como foram formulados os principais programas que direcionam a ação pública no âmbito da política urbana: o PAC e o PMCMV.

No Quadro 8 apresentam-se as principais crenças compartilhadas pela Coalizão dos Movimentos Sociais Urbanos.

Quadro 8 - Principais crenças compartilhadas pelos atores da Coalizão dos Movimentos Sociais Urbanos

\begin{tabular}{|l|l|}
\hline \multicolumn{1}{|c|}{ Categorias de Análise } & \multicolumn{1}{c|}{ Posições e crenças que delimitam a investigação } \\
\hline $\begin{array}{l}\text { A problemática urbana e suas } \\
\text { causas }\end{array}$ & $\begin{array}{l}\text { - é resultado do modelo de desenvolvimento que acentua a segregação } \\
\text { socioespacial } \\
\text { - deve ser resolvida com protagonismo do Estado } \\
\text { - ênfase na lógica de mercado como elemento dominante de } \\
\text { organização espacial que limita o acesso à terra } \\
\text { - ênfase na ineficiência das políticas públicas }\end{array}$ \\
\hline A política urbana & $\begin{array}{l}\text { - a sociedade civil deve opinar nas decisões } \\
\text { - deve ser orientada para as necessidades sociais (priorizar população } \\
\text { de baixa renda) }\end{array}$ \\
\hline $\begin{array}{l}\text { O papel do Estado na política } \\
\text { urbana }\end{array}$ & $\begin{array}{l}\text { - deve implementar o princípio da função social da propriedade } \\
\text { - deve realizar políticas para ofertar equipamentos, serviços e } \\
\text { infraestrutura urbana para garantir direitos sociais }\end{array}$ \\
\hline O uso do solo & $\begin{array}{l}\text { - uso do solo como elemento de redução das desigualdades } \\
\text { socioespaciais }\end{array}$ \\
\hline A questão habitacional & $\begin{array}{l}\text { - ênfase na segregação social associada ao poder de aquisição da } \\
\text { moradia (limitação da qualidade de vida) } \\
\text { - ênfase na moradia como direito social a ser assegurada pelo Estado }\end{array}$ \\
\hline A função social da propriedade & - apoio incondicional \\
\hline
\end{tabular}

Fonte: elaboração da autora.

Apesar de todas as ressalvas apresentadas, o ConCidades tem funcionado como uma arena de conflito e pressão dos segmentos que representam a sociedade civil organizada (movimentos sociais, trabalhadores e representantes de entidades acadêmicas e organizações não governamentais) sobre o governo tendo em vista assegurar os interesses da sociedade no processo de tomada de decisão. Também é reconhecido o avanço nos debates sobre a política urbana em um ambiente institucional, visto que em períodos anteriores, esse canal institucionalizado para a participação social nem existia.

Na prática, observa-se que todo aprendizado produzido no processo de participação, quer seja por meio da incorporação de demandas específicas dos grupos populares na lógica e na ação do poder público, ou a partir dos conflitos experimentados com os outros grupos de interesse na definição da política urbana, têm fortalecido a atuação dos atores, a 
partir do alargamento da compreensão do fenômeno urbano e da discussão de novos projetos e estratégias de intervenção sobre as cidades (ROLNIK, 2009, p. 34 e 35).

Os atores que integram esta coalizão apresentam recursos diferenciados para tentar influenciar no processo decisório relativo à política urbana. Enquanto os movimentos sociais articulam suas bases em torno de ocupações, os representantes do Conselho das Cidades apelam para os debates acerca de temas de natureza técnica inerente às políticas setoriais, bem como quanto à modificação de normativos.

\section{Coalizão dos Especialistas}

Os atores da Coalizão dos Especialistas compartilham crenças similares à Coalizão dos Movimentos Sociais Urbanos buscando o direito à cidade com o objetivo de reverter as desigualdades sociais a partir de uma nova ética social e pela democratização do espaço urbano. Além disso, defendem o reconhecimento da complexidade técnica associada à problemática urbana. Fazem parte desse grupo de atores professores, pesquisadores técnicos de notório saber, tecnocratas engajados na defesa do direito à cidade, além de outros que estejam em conformidade com as crenças apresentadas.

Assim, os atores desta coalizão detêm um profundo conhecimento técnico e filosófico acerca dos problemas urbanos, que defendem a adoção de abordagens multidisciplinares para possibilitar o melhor entendimento dos problemas e da proposição de soluções mais adequadas para a problemática urbana, estando também empenhados com a democratização do processo de gestão inerente à política urbana.

Em função dessas características, serão destacados neste grupo de atores os tecnocratas que fizeram parte da primeira gestão do Ministério das Cidades no período da sua criação, quando o órgão ainda era gerido pelo PT. Serão tomados como referências os textos publicados na série dos Cadernos MCidades em 2004, além de outros documentos técnicos e entrevistas produzidos por especialistas na área urbana para tentar captar o discurso desses especialistas.

Ressaltou-se esse momento tendo em vista dar ênfase aos critérios técnicos adotados para a seleção desses atores, uma vez que, tradicionalmente, o alto escalão da Administração Pública selecionado para assumir os altos cargos de gestão é selecionado prioritariamente por critérios políticos e em função de apadrinhamentos. Desse modo, os 
atores nomeados para os cargos de direção e secretária da SNAPU e da SecretariaExecutiva do órgão logo no momento de sua criação poderiam ser enquadrados como tecnocratas desenvolvimentistas, entretanto, foi preferível enfatizar que naquele momento, predominavam as crenças na capacidade destes em contribuir de forma mais técnica e menos política.

Também é preciso pontuar que, mais adiante, quando esses especialistas são destituídos dos cargos, e a gestão do órgão passar a ter orientação predominantemente desenvolvimentista, os técnicos do Ministério que defendem as crenças dos especialistas tentam dar continuidade às ações iniciadas neste período. Contudo, as gestões seguintes voltam a adotar critérios predominantemente políticos para a nomeação dos cargos de alto escalão fazendo com que as crenças dos Especialistas percam força para as crenças dos Tecnocratas Desenvolvimentistas (próxima coalizão a ser analizada).

Para esse grupo de atores, a criação do Ministério das Cidades representa o reconhecimento do Governo do presidente Luiz Inácio Lula da Silva de que os imensos desafios urbanos do país precisam ser encarados como política de Estado. Na época de criação do Ministério, cerca de $80 \%$ da população do país viviam em área urbana e, em escala variável, as cidades brasileiras apresentam problemas comuns que foram agravados ao longo dos anos devido à falta de planejamento, reforma fundiária, controle sobre o uso e a ocupação do solo (MCidades 2004a, p. 7).

Desse modo, foram criadas as publicações dos Cadernos MCidades tendo em vista promover uma reflexão sobre as questões associadas à política urbana de forma democrática e participativa. Buscava-se definir os novos rumos das políticas públicas sobre a responsabilidade do órgão por meio de critérios da justiça social, para propiciar a transformação da vida dos brasileiros pela melhoria das condições que favorecem o exercício da cidadania.

Então de acordo com registros desse conjunto de publicações, fez-se a opção de adotar um novo caminho para a definição da PNDU, por meio da pactuação democrática, mesmo sabendo que essa estratégia iria consumir mais tempo em função de suas especificidades (debate ampliado, pactuação de consensos, esclarecimentos técnicos). Quanto ao aprendizado sobre às questões do urbano, Maricato (2011) ressalta que "o Brasil 
ainda não tem a cultura de uma política urbana. A sociedade ainda conhece pouco e, por isso exige pouco deste assunto". Desse modo, o novo caminho escolhido para formatar a PNDU do MCidades também se deu tendo em vista o aprendizado com as experiências anteriores, no período do Regime Militar, em que as políticas foram definidas por consultores em seus gabinetes. Para os especialistas:

"Não se trata apenas de amor à democracia, mas de entender que não há outra alternativa para formular uma política urbana sustentável e duradoura. A via da concertação nacional constitui, além de condição política, uma condição técnica para formular políticas públicas num país pouco acostumado a planejar investimentos e com uma sociedade pouco informada sobre tais assuntos. Um grande movimento pedagógico é a forma de assegurar a consciência sobre os problemas urbanos atuais e construir alguns consensos que orientem as ações da sociedade e dos diversos níveis de governo" (MCidades 2004a, p. 7).

Para os autores, a Política Nacional de Desenvolvimento Urbano que deveria ser seguida pelo MCidades adotava uma tese central de que se vivia uma crise urbana que necessitava de uma política nacional orientadora e coordenadora de esforços, planos, ações e investimentos dos vários níveis de governo e, também, dos legislativos, do judiciário, do setor privado e da sociedade civil.

Buscava-se com esse caminho a equidade social, maior eficiência administrativa, ampliação da cidadania, sustentabilidade ambiental e resposta aos direitos das populações vulneráveis (crianças e adolescentes, idosos, pessoas com deficiência, mulheres, negros e índios). Nesse sentido, a definição de desenvolvimento urbano proposta para a época tentava conciliar um viés social, voltado para equidade com o viés quantitativo, associado à melhoria da infraestrutura e dos serviços, como pode ser visto a seguir:

"Podemos definir o desenvolvimento urbano como a melhoria das condições materiais e subjetivas de vida nas cidades, com diminuição da desigualdade social e garantia de sustentabilidade ambiental, social e econômica. Ao lado da dimensão quantitativa da infraestrutura, dos serviços e dos equipamentos urbanos, o desenvolvimento urbano envolve também uma ampliação da expressão social, cultural e política do indivíduo e da coletividade, em contraponto aos preconceitos, a segregação, a discriminação, ao clientelismo e a cooptação" (MCidades, 2004a, p. $8)$.

A proposta de política urbana sugerida pelos especialistas ressaltava a importância de se enfrentar o desafio da inclusão territorial. Acreditava-se que um projeto de 
desenvolvimento do país pautado pela inclusão social e ampliação da cidadania não poderia prescindir da tarefa de questionar fortemente o modelo que se perpetuava ao longo do tempo, em todas as escalas territoriais. Deveriam ser propostas alternativas que considerassem a inserção, no centro da agenda do planejamento, da questão do "lugar" dos mais pobres na cidade, que implicava necessariamente o enfrentamento da gestão fundiária urbana (MCidades, 2004c, p. 8).

Para os especialistas responsáveis pela gestão do Ministério das Cidades na época de sua criação, o eixo central da política e, consequentemente, dos programas e ações propostos era um projeto de "inclusão territorial" das maiorias, que garantisse não apenas a melhoria imediata das condições urbanas de vida dos mais pobres, mas também a construção de um modelo mais includente e democrático de cidade. Essa alternativa também envolvia o aproveitamento mais intenso das infraestruturas instaladas, bem como a reabilitação e democratização de áreas consolidadas, degradadas ou subutilizadas.

Desse modo, o Caderno 3 propunha a "Política Nacional de Apoio à Regularização Fundiária Sustentável: princípios, bases e desafios". Tratava-se da política que apresentava propostas para o enfrentamento do tema da irregularidade urbana, que estava cada vez mais presente nas cidades brasileiras, sendo marcadas por vastas áreas ilegais, informais e precárias. Essa política tinha como pressuposto que a solução da questão fundiária seria a condição essencial para qualquer perspectiva de sustentabilidade urbana. $\mathrm{O}$ texto do documento fazia referência ao Programa "Papel Passado", que foi criado em 2003 para dar apoio às ações de regularização fundiária de assentamentos precários em áreas urbanas ocupadas por população de baixa renda.

O Caderno 3 também destacava o processo de construção de um novo marco jurídico para a questão fundiária urbana, buscando conferir uma nova relação com a Câmara Federal (CDUI) e adotar novas práticas cartorárias com a ANOREG e a IRIB, além da construção de uma política nacional para a utilização do patrimônio imobiliário federal nas cidades, envolvendo imóveis da União, INSS, RFFSA, terrenos de Marinha, além de outros. 
O tema da regularização fundiária é amplamente apontado como um desafio para a superação das questões urbanas. Maricato (2011) ressalta a dificuldade de implementar o Estatuto da Cidade, principalmente no que diz respeito à função social da cidade:

"O texto da lei é brilhante, mas temos ainda o desafio de implementá-lo. Temos uma lei bastante inovadora e avançada mas de difícil aplicação. Vivemos num país de ambiguidades e arbitrariedades, o que impede a efetivação do Estatuto. (...) Vivemos uma sociedade patrimonialista, com privatização do aparelho do Estado, onde ainda reina o individualismo. O Estatuto vai na contra mão deste pensamento" (MARICATO, 2011, s/p).

A necessidade de enfrentamento da questão fundiária foi justificada pelos idealizadores da PNDU a ser seguida pelo MCidades no momento da sua criação em função dos resultados maléficos oriundo do modelo de desenvolvimento sócio-econômico que comandou a urbanização acelerada no Brasil nos anos anteriores e produziu cidades fortemente marcadas pela presença das chamadas "periferias".

Destacou-se no Caderno 3 que dezenas de milhões de brasileiros apenas têm tido acesso ao solo urbano e à moradia a partir de processos e mecanismos informais, os quais, frequentemente são ilegais. Essas alternativas para a moradia envolvem a auto-construção de um habitat precário, vulnerável e inseguro localizado em favelas, loteamentos e conjuntos habitacionais irregulares, loteamentos clandestinos, cortiços, casas de frente e fundo, bem como nas ocupações de áreas públicas, encostas, áreas de preservação, beiras de reservatórios e rios.

De acordo com Rolnik (2006, p. 199) a ilegalidade é uma das marcas da cidade brasileira em função de uma parte significativa da população viver em assentamentos precários, apontando que estão nessa condição aproximadamente 40,5\% do total de domicílios urbanos brasileiros, ou 16 milhões de famílias, das quais 12 milhões são famílias de baixa renda, com renda familiar mensal abaixo de cinco salários mínimos. Segundo a autora:

"A presença desse vasto contingente de assentamentos inseridos de forma ambígua na cidade é uma das mais poderosas engrenagens da máquina de exclusão territorial que bloqueia o acesso dos mais pobres às oportunidades econômicas e de desenvolvimento humano que as cidades oferecem. Essa situação de exclusão é muito mais do que a expressão das desigualdades sociais e de renda: ela é agente de reprodução dessa desigualdade. Em uma cidade dividida entre a porção legal, rica e com infraestrutura, e a ilegal, pobre e precária, a população que está em situação 
desfavorável acaba tendo muito pouco acesso a oportunidades de trabalho, cultura e lazer. (...) Além disso, esse modelo alimenta de forma permanente relações políticas marcadas pela troca de favores e manutenção de clientelas, limitando o pleno desenvolvimento de uma democracia verdadeiramente includente" (ROLNIK, 2006, p. 200).

Para os autores do Caderno 3, todo esse processo foi o resultado de séculos de dominação e apropriação privada das terras e das áreas públicas, o que fez surgir um aparato jurídico-institucional, econômico, social e ideológico que elevou a propriedade da terra como um valor fundamental de controle das classes dominantes (MCidades, 2004c, p 39). Desse modo, acreditava-se que a realidade fundiária apresentava características extremamente preocupantes, as quais exigiam ações integradas e que contemplassem iniciativas de natureza jurídica, institucional, legislativa. Além disso, era essencial a elaboração de programas integrados que promovessem com agilidade o acesso à terra das populações de baixa renda, prevalecendo a preocupação com a regularização das áreas ocupadas, bem como com a oferta de áreas livres urbanizadas (MCidades, 2004c, p 40).

O Governo Federal partia do entendimento de que programas de regularização não poderiam ser formulados em um nível governamental único por correr o risco de assumir uma natureza intrinsecamente curativa, remedial. Portanto, era preciso desenvolver uma estratégia que atuasse em todas as esferas governamentais para ter sentido, ser sustentáveis e ser implementadas em um contexto amplo de políticas públicas, urbanas e habitacionais. Acreditava-se que só assim seria possível intervir no mercado imobiliário para realizar o controle efetivo dos processos de acesso ao solo urbano, visando assim quebrar o ciclo perverso que historicamente tinha produzido a informalidade urbana, visando prevenir a continuada produção ilegal das cidades (MCidades, 2004c, p 45).

Para Rolnik (2006, p. 203) as iniciativas importantes na área do desenvolvimento urbano ocorreram, fundamentalmente, no plano institucional, sendo asseguradas pelo direito constitucional à moradia, aprovado pela Emenda Constitucional no 26, de 02/2000, e pelo Estatuto da Cidade, instituído pela Lei no 10.257, de 10 de julho de 2001.

A autora ressalta que a disponibilização do acesso à terra em condições adequadas não ganhou destaque nas práticas de planejamento e gestão do solo urbano, indicando que a agenda do planejamento urbano e regulação urbanística na maior parte das grandes 
cidades brasileiras esteve primordialmente voltada para a cidade formal, das classes médias e dos médios e grandes empreendedores. Segundo Rolnik:

"O quadro acima descrito revela a magnitude do desafio a enfrentar: trata-se de um desafio que requer a mobilização de quantidades consideráveis de recursos para investimentos dirigidos à melhoria de qualidade do habitat de uma população com baixíssima capacidade de retorno. Por outro lado, o desafio está longe de resumir-se a uma equação financeira: a máquina de exclusão territorial tem, como vimos, enorme correlação com a concentração de renda e poder em nossa sociedade. Dessa forma, a construção de cidades mais equilibradas, eficientes e justas requer a implementação de políticas urbanas que, além de mobilizar recursos financeiros, introduzam mecanismos permanentes de acesso à terra legal e formal por parte dos mais pobres, redesenhando a natureza e instrumentos até agora em vigor no campo do planejamento e gestão do solo urbano em nossas cidades" (ROLNIK, 2006, p. 201).

Outros aspectos abordados nos Cadernos MCidades faziam referência ao desafio de governar o Brasil e democratizar a gestão de um país que imerso na tradição patrimonialista, repleto de imensas desigualdades sociais e detentor de uma rica diversidade cultural e geográfica. Em função desses aspectos, buscava-se de forma democrática e participativa, dar espaço para que todos pudessem definir os rumos das políticas públicas por meio de critérios de justiça social que atendessem especialmente àqueles que fossem mais necessitados. O contexto daquela época se mostrava favorável a essa nova forma de governar por ter sido marcado pela gestão do Presidente Luiz Inácio Lula da Silva, que foi eleito pelo desejo de mudança, justiça social e desenvolvimento (MCidades, 2004d, p. 7)

Santos (2011, p. 33) ressalta a importância da aprovação do Estatuto da Cidade, que regulamentou o capítulo da Constituição referente à política urbana, visto que nesta lei, as diretrizes de participação ganham objetividade, principalmente pela inscrição de diversos mecanismos e instrumentos, que deveriam ser ainda detalhados e complementados por outros canais de participação. A partir dos instrumentos apresentados, buscava-se constituir um sistema municipal de gestão e participação democrática, considerando-se as realidades locais.

O Estatuto reforça a participação da sociedade na gestão da política urbana ao estabelecer que a gestão democrática "deve se realizar por meio da participação da população e das associações representativas dos vários segmentos da comunidade na 
formulação, execução e acompanhamento de planos, programas e projetos de desenvolvimento urbano". Além disso, no capítulo IV, Art. 43 (BRASIL, 2001), são detalhados os instrumentos básicos para efetivação da gestão democrática da cidade:

(i) órgãos colegiados de política urbana;

(ii) debates, audiências e consultas públicas;

(iii) conferências sobre assuntos de interesse urbano;

(iv) iniciativa popular de projeto de lei e de planos, programas e projetos de desenvolvimento Urbano.

Desse modo, no Caderno 2 (MCIDADES, 2004d, p. 15) destacou-se o fato de que, com a aprovação dessa lei, as prefeituras poderiam contar, com um novo instrumental para a regulação do uso do solo, tendo em vista enfrentar o desrespeito aos direitos urbanos:

- aplicar a função social da propriedade e da cidade;

- legalizar e urbanizar a parte da cidade ilegal;

- possibilitar uma gestão democrática;

- recuperar para a coletividade a valorização imobiliária;

- fortalecer o planejamento com participação social.

O objetivo expresso no discurso institucional na época de criação do Ministério das Cidades tinha como argumento central a construção de uma PNDU por meio de um processo democrático, como pode ser visto a seguir:

“A base de uma política urbana com participação popular, visando desmontar o modelo, ainda ativo, de um Estado generoso para com as elites e perverso para com milhões de pessoas, está no reconhecimento de que a participação nas políticas públicas é um direito dos cidadãos e de que o caminho para o enfrentamento dos mesmos está diretamente vinculado à articulação e integração de esforços e recursos nos três níveis de governo - federal, estadual e municipal” (MCIDADES, 2004d, p. $17)$.

Nesse período, o trabalho desenvolvido pelo ConCidades foi realizado em total alinhamento com a equipe de especialistas que foram nomeados para gerir o Ministério nos principais cargos de direção e na Secretaria-Executiva, tendo como um dos produtos relevante a definição dos princípios da política nacional de desenvolvimento urbano, bem 
como as respectivas diretrizes. Ressalta-se que ambas as coalizões compartilham das mesmas crenças com relação à política urbana.

Logo com a criação do MCidades, além da publicação dos Cadernos 1 a 8, foram realizados muitos esforços institucionais para colocar de pé o modelo de gestão participativa no âmbito da política urbana. Um esforço empreendido foi com relação ao trabalho desenvolvido em parceria com o Conselho das Cidades, que recebeu a responsabilidade de construir a PNDU democraticamente. Nesse período, foi aprovada por Resolução na $1^{\text {a }}$ Conferência Nacional das Cidades a missão do Ministério:

"Garantir o direito à cidade a todos os seus habitantes, promovendo a universalização do acesso à terra urbanizada e à moradia digna, ao saneamento ambiental, à água potável, ao trânsito e à mobilidade com segurança, e ao ambiente saudável, por meio da gestão democrática. $O$ direito à cidade implica na formulação e implementação de uma política de desenvolvimento urbano e regional, com a garantia de respeito aos direitos humanos relacionados à vida urbana, de forma sustentável para as gerações presentes e futuras" (MCIDADES, 2003, p.1).

Parte-se da premissa de que grande parte dos atores que integram esta coalizão são os mesmos que se apropriaram acerca das construções teóricas sobre a problemática urbana apresentadas pelos autores discutidos no Capítulo 1 desta tese (Castells, Lefebvre, Lojkine, Harvey, Santos), na tentativa de aplicar esses conhecimentos à realidade brasileira. Esses atores também se destacam por terem elaborado diferentes produções técnicas tecendo críticas ao modelo de desenvolvimento que vinha sendo implementado no Brasil, acentuando as desigualdades sociais e privilegiando o mercado por fazer parte da estratégia macro do Estado para alavancar o desenvolvimento. Também foram esses atores que se mobilizaram em conjunto com os movimentos sociais com o objetivo de fortalecer a luta pela reforma urbana, tendo em vista construir uma política de desenvolvimento urbano de forma democrática e que possibilitasse o direito à cidade. Também é por essa razão que estes atores foram enquadrados como Especialistas e não como Tecnocratas Desenvolvimentistas. Em função das suas crenças, diretamente alinhadas à busca pelo "direito à cidade" que seu papel foi ressaltado.

Desse modo, a Coalizão dos Especialistas abordada aqui teve seu ponto máximo de atuação quando esteve presente na direção do MCidades de janeiro de 2003 até junho de 2005 (2 anos e meio), sob a gestão do Ministro Olívio Dutra do PT. A partir de julho de 
2005, houve a substituição desse ministro por Márcio Fortes do PP, que foi o ministro a passar mais tempo à frente da direção do órgão. Essa primeira troca de ministro mostrou-se prejudicial aos objetivos de construção de uma PNDU segundo os princípios e diretrizes preconizados na época de criação do MCidades, visto que representou um rompimento com os anseios das bases que compuseram o Movimento pela Reforma Urbana, já que o PP compartilhava de uma visão diferenciada sobre a política urbana.

No Quadro 9 apresentam-se as principais crenças compartilhadas pela Coalizão dos Especialistas.

Quadro 9 - Principais crenças compartilhadas pelos atores da Coalizão dos Especialistas

\begin{tabular}{|c|c|}
\hline Categorias de Análise & Posições e crenças que delimitam a investigação \\
\hline $\begin{array}{l}\text { A problemática urbana e suas } \\
\text { causas }\end{array}$ & $\begin{array}{l}\text { - é resultado do modelo de desenvolvimento que acentua a segregação } \\
\text { socioespacial } \\
\text { - deve ser resolvida com protagonismo do Estado } \\
\text { - há limites à organização racional do planejamento urbano } \\
\text { - Visão integradora (causas múltiplas) }\end{array}$ \\
\hline A política urbana & $\begin{array}{l}\text { - a sociedade civil deve opinar nas decisões } \\
\text { - deve ser orientada para as necessidades sociais (priorizar população } \\
\text { de baixa renda) } \\
\text { - não atua nas causas do problema sendo setorial e fragmentada }\end{array}$ \\
\hline $\begin{array}{l}\text { O papel do Estado na política } \\
\text { urbana }\end{array}$ & $\begin{array}{l}\text { - deve implementar o princípio da função social da propriedade } \\
\text { - deve realizar políticas para ofertar equipamentos, serviços e } \\
\text { infraestrutura urbana para garantir direitos sociais } \\
\text { - é um dos agentes que influenciam na organização do espaço }\end{array}$ \\
\hline O uso do solo & $\begin{array}{l}\text { - uso do solo como elemento de redução das desigualdades } \\
\text { socioespaciais } \\
\text { - uso do solo em conformidade com os instrumentos de planejamento e } \\
\text { ordenamento territorial }\end{array}$ \\
\hline A questão habitacional & - visão integradora (causas múltiplas) \\
\hline A função social da propriedade & - apoio incondicional \\
\hline
\end{tabular}

Fonte: elaboração da autora.

No período atual, aponta-se o "Impeachment" da presidente Dilma e a gestão do MCidades sob a coordenação do PSDB como os principais marcos nas sucessões de ministros, reforçando o distanciamento dos objetivos no momento de criação do Ministério, visto que a orientação política atual está fundamentada no neoliberalismo e na centralização da gestão e do processo decisório. Um dos resultados dessa mudança rebatem diretamente na atuação do Conselho das Cidades que teve praticamente a interrupção de 
suas atividades devido à decisão de não realização da $6^{\mathrm{a}}$ Conferência Nacional das Cidades que já deveria ter acontecido no ano de 2016.

Assim, com as sucessivas trocas de gestão no órgão, associadas com as mudanças no formato da política urbana ao longo dos anos, que inicialmente, assumiu o caráter das setoriais (habitação, saneamento e mobilidade) e depois foi substituída pela lógica dos grandes programas do governo (PAC e PMCMV), verifica-se o enfraquecimento significativo da Coalizão dos Especialistas abrindo espaço para o fortalecimento dos Tecnocratas Desenvolvimentistas.

Atualmente, essa coalizão se apresenta fragmentada e é representada, principalmente, por acadêmicos que defendem o direito à cidade, profissionais de orientação extremamente técnica e social que ainda integram o quadro burocrático do Ministério das Cidades, e estudiosos sobre a problemática urbana que criticam a perpetuação do modelo de desenvolvimento que produz cidades fragmentadas e acentua as desigualdades sociais. Os questionamentos realizados por esses atores normalmente são fruto de reflexões sobre a complexidade da temática urbana e sobre as questões políticas que contribuem para a continuidade do modelo que tradicionalmente vem moldando as cidades e reforçando a situação crítica da pobreza.

\section{Coalizão dos Tecnocratas Desenvolvimentistas}

Fazem parte desta coalizão os atores ocupantes dos altos cargos de gestão do governo federal como um todo, durante os governos sob gestão do PT (Lula e Dilma) que viabilizaram a criação do MCidades e fizeram parte do processo decisório acerca dos principais programas do Governo Federal no período de 2007 a 2015: PAC e PMCMV. São considerados aqui os tecnocratas que compuseram a grande coalizão política mobilizada durante as gestões coordenadas pelo PT (2 governos lula e Dilma) que tinham poder de deliberação e optaram pela retomada dos investimentos na política urbana. Esses atores traçaram as macro estratégias de desenvolvimento para o país e deliberaram sobre as principais mudanças institucionais que fizeram com que o governo federal passasse a se nortear por crenças desenvolvimentistas.

Da mesma maneira que a coalizão desses atores proporcionou a definição de um novo contexto institucional e mais favorável para a política urbana (Criação do Ministério 
e do Conselho das Cidades, definição de uma PNDU e de estratégias para a efetivação do Estatuto da Cidade), as decisões tomadas por esse grupo de atores foram tomando novos rumos ao longo do tempo, fazendo com que os objetivos iniciais fossem progressivamente substituídos pelos objetivos e critérios de implementação adotados pelo PAC e pelo PMCMV.

Para que essas novas crenças sobre a política urbana pudessem prevalecer, foi ocorrendo, progressivamente, a substituição de atores relevantes que, anteriormente, assumiam o papel de "Especialistas" por outros assumidamente "Tecnocratas Desenvolvimentistas". Tiveram papel de destaque nesta coalizão Dilma Rousseff, Guido Mantega e Miriam Belchior.

Ressalta-se que o PAC e o PMCMV foram delineados na Presidência da República e, posteriormente, contaram com instâncias interministeriais para a tomada de decisão, coordenação e acompanhamento das ações. Com isso, no que diz respeito à política urbana, o centro decisório migrou do Ministério das Cidades, passando a ter voz preponderante a Presidência da República e as respectivas instâncias gestoras que contaram com a participação do Ministério da Fazenda e do Planejamento.

Optou-se por este recorte por tentar analisar o comportamento dos atores no período desde a criação do Ministério das Cidades até o tempo que durou o segundo mandato da Presidente Dilma, período em que foram determinadas as diretrizes da PNDU, as políticas setoriais e os critérios do PAC e do PMCMV. Também se optou por esse recorte tendo em vista que embora alguns atores tenham sido substituídos nos altos escalões, acredita-se que a coalizão se manteve estável. Desse modo, a saída do PT do Governo Federal representou a ruptura com a Coalizão dos Tecnocratas Desenvolvimentistas e a formação de uma nova coalizão que tem crenças e orientações políticas muito distintas daquela preconizada pela coalizão inicialmente mobilizada pelo PT.

O Programa de Aceleração do Crescimento (PAC) é um programa do Governo Federal anunciado em janeiro de 2007, com a previsão inicial de investimento de R\$ 503 bilhões para o período 2007-2010. Tinha como foco o aumento do investimento em infraestrutura nas áreas nas áreas de logística (rodovias, ferrovias, hidrovias, portos e aeroportos), transporte, energia (geração e transmissão de energia elétrica, petróleo, gás 
natural e combustíveis renováveis), saneamento, habitação e recursos hídricos (BRASIL, 2007). Já no final de 2008 foi anunciada a suplementação de investimentos para o Programa que passou a totalizar R \$ 656,5 bilhões.

Os objetivos do Programa declarados no momento do seu lançamento foram: o incentivo ao investimento privado, o aumento do investimento público em infraestrutura e a remoção de obstáculos (burocráticos, administrativos, normativos, jurídicos e legislativos) ao crescimento (BRASIL, 2007). Buscava-se com o PAC a promoção do crescimento de maneira mais célere e sustentada, com distribuição de renda, tanto no âmbito social como no regional. A estratégia adotada envolvia o incentivo ao investimento privado, a partir de um conjunto de projetos de investimento público e diversas formas de Parcerias Público-Privadas (PPPs).

As medidas adotadas para a efetivação do PAC foram organizadas em cinco eixos: a) investimento em infraestrutura; b) medidas institucionais e econômicas de estímulo ao crédito e ao financiamento; c) desoneração e administração tributária; d) melhoria do ambiente de investimento e; e) medidas fiscais de longo prazo (BRASIL, 2007). Considerando que o setor privado deveria responder pela maior parcela do investimento, foram contempladas medidas de aperfeiçoamento do sistema tributário, bem como medidas de desoneração do investimento, sobretudo em infraestrutura e construção civil, para aumentar o investimento privado.

De acordo com Romagnoli (2012, p. 2) em fins de 2008, a crise econômica que assolava no cenário internacional adquiriu novos contornos que preocuparam o Governo Federal. Assim, foram expedidas medidas de incentivo à liquidez na economia doméstica (mudança nas regras do recolhimento sobre depósitos compulsórios) e outras voltadas para as políticas de estabilização cambial (leilões de parte das reservas cambiais, com o objetivo de estabilizar a cotação do dólar), tentando criar estímulos diretos à atividade econômica. Parte desses estímulos esteve concentrada no setor da construção civil e de infraestrutura, em função de estes setores apresentarem papel relevante na geração de emprego e influenciarem diretamente no comportamento do PIB.

Desse modo, a crise internacional passou a influenciar a conjuntura econômica do país fazendo com que o Governo tomasse a decisão de combatê-la, privilegiando o setor da 
construção civil (dentre outros), impulsionando a criação do Programa Minha Casa, Minha Vida (PMCMV) que se tratava principalmente de uma ação anticíclica para conter os efeitos da crise. O PMCMV foi aprovado pela Medida Provisória $\mathrm{n}^{\circ} 459$, em março de 2009, com investimentos da ordem de $\mathrm{R} \$ 34$ bilhões (sendo $\mathrm{R}$ \$ 25,5 bilhões do Orçamento Geral da União, R\$ 7,5 bilhões do FGTS e R\$ 1 bilhão do BNDES). Tinha como meta a construção de um milhão de moradias no prazo de dois anos, além da promessa de geração de emprego, renda e sustentação econômica para um país temeroso da crise (ROMAGNOLI, 2012, p. 3).

A segunda edição do PAC, denominada PAC 2, foi lançada em 2010 com previsão de investimentos da ordem de $\mathrm{R} \$ 1,59$ trilhão, sendo $\mathrm{R} \$ 955$ bilhões para o período de 2011-2014 e R \$ 631,4 bilhões para o período pós 2014. O PAC 2 foi estruturado em torno de seis eixos: (1) PAC Cidade Melhor; (2) PAC Comunidade Cidadã; (3) PAC Minha Casa, Minha Vida; (4) PAC Água e Luz para Todos; (5) PAC Transportes e PAC Energia (BRASIL, 2010). Nesta edição do PAC também foi prevista a construção de Unidades Básicas de Saúde, creches, pré-escolas e postos de polícia comunitária.

A adoção dessas estratégias pelo Governo Federal corrobora o entendimento de Schmidt e Farret (1989, p. 77) ao apontar que os planos e implantação de estruturas urbanas obedeceram sempre às diretivas emanadas do governo central e de sua camada gerencial. Para os autores, a tecno-burocracia tem imperado com poucas restrições a partir da sua associação com os interesses privados. Desse modo, contestar as políticas vigentes implica a contestação do esquema de administração do poder que está embutido nelas. Em função disso, "a política urbana sempre esteve a reboque de uma concepção concentradora do capital instalado no Brasil".

Segundo Rodrigues e Salvador (2011, p. 152) a implementação de políticas e programas públicos é feita em função das opções realizadas pelo governo para a condução do Estado, uma vez que suas ações são estratégias pensadas, planejadas e avaliadas, considerando as preferências econômicas e políticas estabelecidas em cada momento histórico. Desse modo, para a compreensão de uma política ou um programa adotado é preciso analisar, além de suas características intrínsecas, os determinantes econômicos que condicionam a conjuntura política em que se encontra com destaque para os atores sociais e os interesses envolvidos, bem como a abrangência de suas ações. Por isso, os autores 
ressaltam que o PAC surgiu como uma promessa de retorno do Estado como indutor da economia e do crescimento econômico de forma planejada, sendo defendido por meio de um discurso desenvolvimentista e intervencionista.

Para Sicsú et al. (2007, p. 508) o novo-desenvolvimentismo constitui uma alternativa de política de desenvolvimento que busca compatibilizar crescimento econômico com equidade social, visando estimular o debate em torno da constituição de um programa alternativo ao projeto neoliberal. Essa ideia é compartilhada por Mauricio (2013, p.183) ao enfatizar que a configuração do neo-desenvolvimentismo no Brasil passa a ganhar relevo no contexto da política e da economia dos consecutivos governos federais assumidos pelo Partido dos Trabalhadores (2003-2015) em função das estratégias de desenvolvimento adotadas.

Outra nomenclatura adotada para definir a estratégia de desenvolvimento adotada pelos governos sob gestão do PT foi mencionada por Mantega, em entrevista em 2007, que tentava conceituar o social-desenvolvimentismo, como apresentado a seguir:

\footnotetext{
"O social-desenvolvimentismo é isso, é uma nova modalidade de crescimento econômico. É para distinguir do desenvolvimentismo, porque nós já tivemos no Brasil o desenvolvimentismo. O que era o desenvolvimentismo? Era um crescimento conduzido pelo Estado - que não é o caso agora - um crescimento mais vigoroso da economia, mais rápido. Nós chegamos a crescer 10, 12, 14\%, porém, sem a inclusão dos trabalhadores. Os salários diminuíam, o salário mínimo era menor. Você não tinha distribuição de renda naquela ocasião. E agora o que você tem é um crescimento mais harmônico, com inclusão social por causa dos programas sociais $e$ do tipo de crescimento. Mas, eu queria destacar uma outra diferença do crescimento do passado. No passado, quando a economia crescia, ela crescia criando desequilíbrios, criava mais inflação, na base do endividamento externo ou interno, com dívida pública, com déficit público. E agora a diferença é que nós estamos crescendo mais e com a inflação sob controle, com a dívida pública diminuindo, com $o$ endividamento externo diminuindo, com a vulnerabilidade externa menor. Então, essa é a novidade no país. Nós nunca tivemos isso no Brasil antes. [Podem chamar de] social-democracia. Eu chamo de social-desenvolvimentismo porque o desenvolvimento é uma palavra forte” (MANTEGA, 2007).
}

Assim, a corrente social-desenvolvimentista unifica-se na "ênfase no mercado interno e no papel do Estado para influenciar a distribuição de renda e a alocação de investimentos" (BASTOS, 2012). Moreira (2015, p. 17) defende que, a estratégia do social-desenvolvimentismo busca um dinamismo econômico que seja capaz de permitir o aprofundamento do processo de distribuição de renda e de expansão da infraestrutura. Para 
o autor, no social-desenvolvimentismo, o aspecto social é o elemento novo, sendo capaz de induzir o crescimento econômico por meio do processo de distribuição de renda que tem o potencial de dinamizar o mercado de consumo doméstico, como foi observado na história recente brasileira.

Um elemento que deve ser destacado no retorno do desenvolvimentismo no momento atual é que ele se realiza em condições históricas diferentes das que propiciaram o debate original durante o século XX. Assim, o terreno social, político e econômico de onde emerge o neo desenvolvimentismo no século XXI, guarda características próprias que dialogam com as recentes mudanças experimentadas nas duas primeiras décadas deste século, mas que também carrega o peso das tradições políticas e econômicas anteriores, como variados graus de populismo e nacionalismo presentes nas relações entre o processo político brasileiro e o desenvolvimento do capitalismo (BOITO, 2012, p. 1).

Mauricio (2013, p. 183) ressalta que o retorno ideológico do desenvolvimentismo ocorreu devido à crise do mercado e do neoliberalismo associada à crise econômica iniciada em 2008, e os impasses da esquerda na viabilização de uma alternativa socialista. Para o autor, esses desafios levaram ambos, mercado e esquerda, de volta ao arcabouço teórico desenvolvimentista, em suas diversas nuances, revisitando a discussão acerca do papel do Estado na indução de desenvolvimento.

O autor complementa essa discussão mostrando que o neo desenvolvimentismo se mostra como uma terceira via entre a ortodoxia e o populismo, apontando, em certos momentos, para o fortalecimento do Estado e, em outros, para o fortalecimento do mercado; a centralização e a descentralização; a concorrência e os campeões nacionais; o público e o privado; política industrial e abertura; política fiscal e monetária ativa e austera (MAURICIO, 2013, p. 184).

Daí surge a crítica tecida ao PAC por Rodrigues e Salvador (2011). Para os autores o Programa se apresenta de forma pontual sem estar associado com a ampliação, universalização e garantia dos direitos sociais. A estratégia do PAC, na verdade, privilegia a manutenção das altas taxas de juros que estimulam os investimentos privados e o aquecimento da economia. Além disso, apresenta uma baixa execução orçamentária e 
baixa efetividade como multiplicador de investimentos privados na economia, que era uma das suas promessas no anúncio de seu lançamento.

"Além disso, as medidas institucionais propostas contribuem para a manutenção da política estagnacionista que é a causa precípua da limitação de gastos com as políticas sociais: a supremacia da política econômica, que privilegia o pagamento dos serviços da dívida (juros e amortização da dívida) em detrimento dos demais gastos. Além da fragilização dos direitos sociais, caso se confirme as propostas originais de reforma tributária e de implantação do fundo de pensão dos servidores públicos federais" (RODRIGUES e SALVADOR, 2011, pp. 152-153).

Mesmo que as iniciativas do governo federal estivessem circunscritas em torno de uma estratégia macro de desenvolvimento, Cople et al. (2009, p. 5) discute que o PAC foi lançado visando criar condições macrossetoriais para o crescimento do país no período de 2007 a 2010. O Programa buscava promover a aceleração do crescimento econômico, o aumento do emprego e a melhoria das condições de vida da população.

Contudo, segundo os autores, a intenção de "remoção dos obstáculos ao crescimento" acrescido do incentivo ao investimento privado constituem uma maneira de promover mudanças nas leis a fim de favorecer o capital em detrimento das condições de vida das classes trabalhadoras. Nessas condições, o PAC estaria reforçando o papel do Estado como garantidor de condições externas (infraestrutura) à produção capitalista, atuando diretamente na sua viabilização ou, indiretamente, como seu principal financiador, favorecendo os objetivos do capital industrial e do capital bancário e especulativo.

Na prática, a ênfase concedida à conformação de um mercado consumidor de massas e à adoção de medidas anticíclicas para o combate aos efeitos da crise internacional permitiu que o governo Lula recebesse, progressivamente, maior apoio da coalizão neo desenvolvimentista. No entanto, a adoção de políticas em conformidade com o social desenvolvimentismo, como especificado por Mantega, não impediu a preponderância dos interesses da coalizão neoliberal (SILVA, 2013, p. 12).

Isso se justifica pelo fato de existirem limites inerentes ao presidencialismo de coalizão, que levaram à formação de uma base de apoio parlamentar da qual faziam parte setores políticos conservadores, bem como em função da existência de atores com poder de veto com fortes interesses no mercado financeiro. Segundo a autora: 
"A ocorrência de conjunturas críticas - o descontentamento com os baixos índices de crescimento econômico (2006) e a crise internacional (2008) - foi essencial para que a coalizão novo-desenvolvimentista passasse a ocupar um papel central na condução da agenda pública. A moeda de troca (implícita), entretanto, era a manutenção dos interesses da coalizão neoliberal” (SILVA, 2013, p. 12).

De forma similar ao PAC, o PMCMV consistiu em uma política anticíclica adotada pelo Governo Federal como uma alternativa para alavancar a economia em resposta à crise econômica internacional de 2008. De acordo com Jardim (2015, p. 175-176) “o PMCMV teve como inspiração modelos chileno e mexicano, os quais, na ocasião, foram avaliados pelos órgãos representativos do setor empresarial como aqueles mais adequados para dinamizar a produção habitacional, resguardando um papel protagonista para o setor empresarial".

A autora ressalta que o setor privado assumiu um nível de protagonismo tão elevado na execução do Programa, sugerindo que o PMCMV teria surgido como iniciativa setor da construção em função de pressões do mercado sobre o governo. Para alavancar seu projeto de desenvolvimento, o Estado teria se conciliado com os interesses do mercado, visando ao aumento da geração de empregos na construção civil bem como ao crescimento de investimentos privados no setor de infraestrutura. Esses dois aspectos faziam parte da estratégia adotada pelo governo para alavancar a economia.

A parceria entre o Governo Federal e o setor da construção civil se tornou ainda mais estrita durante o período do PAC 1 e 2 e também do PMCMV, quando o ministro Guido Mantega, em 2012, ao anunciar a continuidade do Programa Minha Casa, Minha Vida durante o governo Dilma, destacou novas medidas para estimular o setor da construção civil. Constituíram-se, portanto, alianças entre mercado (empreiteiras, bancos privados, empresas de construção, fundos de pensão) e Estado (prefeitos, governadores e executivo federal).

Segundo o ministro, a indústria da construção civil tem grande importância para a economia brasileira, devido à sua capacidade de gerar empregos e por realizar o sonho dos brasileiros de adquirir a casa própria, como pode ser visto no seu discurso:

"Além disso, o setor é responsável por quase metade do investimento que nós fazemos no país. Assim, estimular esse setor significa estimular o investimento no país” (MANTEGA, 2012). 
Em pronunciamento, a presidente Dilma Rousseff ressalta esse entendimento e também destaca a importância da parceria com o setor da construção no sentido de viabilizar a estratégia para alavancar o desenvolvimento:

"O setor da construção civil vem reivindicando essas medidas [...]. É um reconhecimento da importância do setor para geração de empregos e estímulo a várias cadeias produtivas" (ROUSSEFF, 2012).

Segundo Moreira (2015, p. 14) a proposta por trás do PAC e PMCMV, associada a outras políticas, consiste em uma estratégia para implantar um padrão de desenvolvimento para o país, caracterizando um desenvolvimentismo visto que este padrão apresenta a combinação peculiar de incentivos para o investimento privado, o aumento da produtividade e da renda (setores, agentes, financiamento, regulação, composição e organização dos mercados, distribuição da renda).

O autor salienta que no desenvolvimentismo há uma política pró-ativa com o objetivo de desenvolver o país por meio de um projeto com um objetivo deliberado, que visa atingir determinados fins a partir do aumento da produção e da produtividade. Portanto, em função das medidas adotadas no PAC e no PMCMV, somadas a outras, leva o autor a sustentar que o Governo Federal buscou um novo modelo de desenvolvimento chamado de social-desenvolvimentismo, caracterizado pela estabilidade econômica, a consolidação da democracia, a manutenção do crescimento do emprego e da renda com elevação da inclusão social.

Embora a estratégia desenvolvimentista proposta pelos governos sob gestão do PT tenha sua importância, por representar a retomada dos investimentos federais em políticas estratégicas para a melhoria da qualidade de vida da população, a combinação das medidas econômicas para alavancar a economia resultou na acentuação de alguns problemas que incidem sobre as cidades. Um dos pilares desse projeto de desenvolvimento para o país constitui em incentivos para a indústria automobilística, que exacerbou ainda mais a situação crítica dos transportes nas cidades brasileiras devido ao crescimento exorbitante da frota de veículos nos últimos anos. 
Esse aspecto foi ressaltado pelo professor Leonardo Herszon Meira, em apresentação realizada na Comissão de Desenvolvimento Urbano da Câmara dos Deputados no Seminário sobre Mobilidade Urbana, como apresentado a seguir:

"Quais são os principais problemas da maioria das cidades? O primeiro é o que já falamos: um crescimento exorbitante da frota nos últimos anos, e nada leva a crer que isso vai mudar a curto prazo. A indústria automobilística é um dos pilares da economia brasileira. É difícil tentar adotar algum tipo de medida que freie a venda de veículos novos, porque a economia brasileira está muito montada também na indústria automobilística, e não há como aumentar a malha viária a cada 4, 5 ou 10 anos, não há como dobrar o número de vias. Esse crescimento desordenado é impossivel, não se consegue fechar essa conta” (BRASIL, 2011a, pp.7-8).

A fala do professor foi reforçada pelo Sr. Otávio Cunha, executivo da Confederação Nacional dos Transportes que também teve palavra sobre o assunto no mesmo evento:

"Na verdade, tudo isso remonta ao problema da política do automóvel, introduzida no Brasil sem que as cidades brasileiras tenham sido preparadas para o uso do automóvel. Não há lugar para estacionar, não há avenidas largas; então, há toda essa dificuldade, de maneira que a política do automóvel aplicada pelo Governo Federal, incentivando o transporte individual em detrimento do transporte coletivo, levou efetivamente a essa crise, é a maior razão dessa crise que estamos vivendo hoje, aliada a outros problemas já citados pelo Prof. Leonardo” (BRASIL, 2011a, p. 43).

Além do incentivo à política automobilística, a estratégia desenvolvimentista adotada pelo governo federal envolveu outros tipos de facilidades ao mercado, sendo um deles a desoneração de impostos, tendo em vista a ampliação dos investimentos. A iniciativa envolve a diminuição da carga tributária arrecadada pelos empresários de alguns setores da economia, de forma a facilitar os investimentos privados. Essa prática foi instituída pelo Governo Federal, sendo amplamente defendida pelos representantes empresariais.

É possível identificar essa fala no discurso do Sr. Leonardo Maia Moll, Diretor de Relações Institucionais da Associação Brasileira de Baterias Automotivas e Industriais na abertura da XII Conferência das Cidades, realizada na Comissão de Desenvolvimento Urbano da Câmara dos Deputados, como apresentado a seguir:

"A contrapartida do Estado - e na verdade entendo que não é bem uma contrapartida, pois penso que será um benefício que o Estado vai ter - seria a redução dos tributos que incidem sobre a cadeia, quando vinculamos esses tributos ao atingimento de metas. Por exemplo, hoje há informalidade no setor (não adianta querer tampar o sol com a peneira: há, sim, sonegação fiscal), e pode ser uma 
oportunidade de reduzir essa sonegação fiscal o estabelecimento de metas ou incentivos fiscais. A receita tributária poderá inclusive aumentar” (BRASIL, 2011b, p. 73).

Foi a partir dessa escolha por incentivo ao setor privado que, paralelamente às medidas de incentivo à economia, também foi desenvolvido um "lobby" pesado na defesa do setor privado como um dos principais parceiros do governo no alcance de resultados na implementação das políticas públicas de infraestrutura. Em diferentes períodos da história houve a discussão sobre a concessão e privatização de diferentes setores de serviços, como no caso do saneamento, durante a década de 1990. Ressalta-se que, nesse período, como relatado no Capítulo 2 desta tese, a política de saneamento vivenciou sua fase crítica até o período atual.

Com a retomada do viés desenvolvimentista na política recende, o debate acerca das parcerias privadas com relação à prestação de serviços públicos foi fortalecido, como pode ser visto na fala do Sr. Paulo Roberto Oliveira, Presidente da Associação Brasileira das Concessionárias Privadas dos Serviços Públicos de Água e Esgoto - ABCON, em audiência pública realizada na Comissão de Desenvolvimento Urbano da Câmara dos Deputados, sobrea versão preliminar do Plano Nacional de Saneamento Básico (PLANSAB). Na ocasião surgiu a discussão sobre o papel do setor privado para o alcance das metas do PLANSAB:

\footnotetext{
"O setor privado não é um problema, como diziam no início: "O setor privado só quer cobrar, só quer ter lucro”. O setor privado se apresenta hoje como uma das soluções na universalização de saneamento. Somos um parceiro facilitador dessas soluções; somos uma opção à disposição dos gestores públicos. Cabe ao gestor público, seja municipal ou estadual, definir a forma como vai ser prestado o serviço. E também nos consideramos uma alternativa para acelerar a universalização, que é o objetivo do PLANSAB. E também divulgar que a participação do setor privado é uma possibilidade, uma alternativa para poder cumprir as metas do PLANSAB, seja através de concessões ou de qualquer tipo” (BRASIL, 2011c, pp. 42-43).
}

Com relação à política urbana, muitas críticas foram feitas quanto à conciliação dos interesses do Estado ao mercado, visto que essa prática já foi intensamente apontada como uma das principais razões do insucesso das diversas tentativas de empreender uma política urbana em períodos anteriores. Maricato (2017) destaca que a alternativa do desenvolvimentismo incorre no mesmo erro por fortalecer o mercado e enfraquecer a 
política urbana. Para a autora, as ações realizadas no âmbito da política urbana são determinadas em função dos interesses de um grupo de atores que representam o mercado. Isso pode ser constatado quando a autora se refere à iniciativa desenvolvimentista empreendida pela presidente Dilma:

“A Dilma Rousseff tem uma cabeça muito desenvolvimentista. Esse pessoal dificilmente enxerga uma cidade. Os metrôs em construção no País, por exemplo. Todos eles seguem uma lógica ditada pelo mercado imobiliário. Quase todos vão para aeroportos. Tem mulher que deixa criança sozinha e passa 4 horas por dia nos transportes. Foi por aí que se traçou o desenho desses metrôs? Não. Foi pelos interesses do mercado imobiliário. (...) A cabeça dos desenvolvimentistas é assim: precisamos investir para o País crescer e criar emprego. É menos pior que o ultraliberalismo do governo Temer, porque pelo menos se investe. Mas eles não percebem que o desenho da linha que essa grande obra vai criar marca a cidade, as relações sociais na cidade, acrescenta renda e valorização às terras que ela está atravessando" (MARICATO, 2017).

Outras críticas tecidas ao PAC e ao PMCMV se referem às "facilidades e flexibilizações normativas" empreendidas pelas competências gestoras dos programas, no sentido de melhorar a execução das obras e agilizar alguns procedimentos considerados entraves ao andamento das ações, tais como, licenciamento ambiental, análise técnica da qualidade dos projetos, critérios de elegibilidade para a distribuição de recursos regionalmente, metas e diretrizes preconizados em lei e em outros planos de orientação das políticas setoriais. Sobre isso, Rolnik (2009) ressalta que:

"De fato, mesmo que o Estatuto da Cidade estabeleça a obrigatoriedade de vincular os ciclos orçamentários subsequentes à aprovação de planos diretores às suas definições e propostas, na área de desenvolvimento urbano, pouca autonomia real têm as arenas decisórias locais sobre estes investimentos - sejam elas participativas ou não -, uma vez que a área de desenvolvimento urbano do Estado brasileiro permanece estruturada em burocracias altamente setorializadas $e$ centralizadas que funcionam através de processos decisórios bastante penetrados pelos interesses de atores econômicos e políticos que deles dependem para sobreviver" (ROLNIK 2009, p. 46).

As flexibilizações de normativos técnicos e de procedimentos tradicionalmente adotados para garantir a qualidade dos projetos e das obras também é uma preocupação expressa pelo Deputado Flaviano Melo, ao discursar na Comissão de Desenvolvimento Urbano da Câmara dos Deputados, em audiência pública sobre o Programa Minha Casa, Minha Vida, com a presença do então Ministro das Cidades Agnaldo Ribeiro. O 
parlamentar lamentou o fato de a imprensa ter divulgado notícias relatando a baixa qualidade e a localização inadequada das construções do PMCMV, além de sugerir que alguém está tendo algum lucro com essa situação:

"A situação é preocupante, e eu acho que a Caixa Econômica e o Ministério das Cidades tinham que olhar isso com todo o carinho, para evitarem o desperdicio. Por quê? Porque o beneficiário do programa, a pessoa que adquire essas casas, é aquela que não tinha a mínima condição de ter um imóvel. Normalmente, morava em um lugar inapropriado. Então, não é justo que ela saia de um lugar inapropriado para outro. Hoje nós estamos vendo as manifestações populares, que estão assustando todo mundo. Uma pessoa dessas tem todo o direito e o desejo de protestar, porque sabe que o dinheiro público foi mal usado. E, se foi mal usado, alguém foi beneficiado. Sr. Ministro, eu gostaria de perguntar o seguinte: quem é o responsável por isso? A Caixa libera dinheiro para o construtor, para o Estado, para o Município. Como se libera uma obra desse tipo? Como se constrói uma obra em lugar alagado, que não é apropriado para a construção de um conjunto habitacional?” (BRASIL, 2013, p. 13).

Segundo Rolnik (2009) as discussões apresentadas permitem a compreensão acerca de algumas características da política urbana, que impedem as tentativas de implementação de uma agenda que possibilite uma reforma "na direção de cidades pactuadas e planejadas democraticamente em uma esfera pública". Isso se explica em função da existência de uma complexa rede de corretagem política que contempla atores dos altos escalões da burocracia e dos espaços locais, que intermedia a transferência de recursos para os municípios, a partir das diferentes formas de acesso ao crédito, além dos interesses privados embutidos nos diferentes setores que integram a política urbana.

Maricato (2011) ressalta essa tendência ao criticar o formato do PAC e do PMCMV ao afirmar que a retomada dos investimentos viabilizada por uma estratégia desenvolvimentista fortaleceu a associação entre burocracia e mercado na busca de atendimento de seus interesses de forma conjunta. Acontece que, tradicionalmente, os interesses privados, como verificado em períodos anteriores da história, sempre prevaleceram e deturparam a estratégia macro de desenvolvimento traçada pelo Governo Central.

Para a autora, no momento em que o Estado se une ao mercado para colocar em prática o seu plano de desenvolvimento, acaba se sujeitando a suas leis de operação, e aos seus interesses respectivamente. De acordo com Maricato (2017) isso ocorreu no primeiro governo do presidente Lula, visto que: 
"Quando Lula entrou a gente criou o Ministério das Cidades e houve um declínio da condição de vida urbana. A minha tese é a de que, com o Lula, voltou o investimento federal nas cidades. E na hora em que o dinheiro apareceu, os movimentos sociais perderam espaço. $O$ dinheiro apareceu e os capitais tomaram comando sobre a cidade. Enquanto não tinha dinheiro, a gente tinha democracia urbana e experiências avançadas, como urbanização de favelas, os Céus. (...)Todo o orçamento foi feito drenado para algumas políticas orientadas pelo interesse de capitais. Isso foi muito notável nos megaeventos, nas obras urbanas do PAC 2. O PAC 1 ainda conservava uma virtuosidade desse ciclo que eu estou falando. (...) o Minha Casa, Minha Vida desandou mesmo. Não que não seja importante você pegar um recurso e investir para a construção massiva de moradia. Mas essa produção, com exceção de $2 \%$ do orçamento, foi orientada pelo mercado. E ela não enfrentou no que é o nó do problema habitacional, que é a função social da propriedade. $O$ Minha Casa, Minha Vida jogou o conjunto dos pobres para fora da cidade. A mesma coisa que a ditadura fazia” (MARICATO, 2017).

No Quadro 10 são apresentadas as crenças dos atores que integram a Coalizão dos Tecnocratas Desenvolvimentistas. Ressalta-se que alguns atores integrantes da Coalizão dos Tecnocratas Desenvolvimentistas também passam a atuar na Coalizão dos Políticos a ser discutida no próximo item. Esses atores, além de delimitarem a estratégia macro de desenvolvimento para o país também compõem a base aliada do governo.

Quadro 10 - Principais crenças compartilhadas pelos atores da Coalizão dos Tecnocratas

Desenvolvimentistas

\begin{tabular}{|l|l|}
\hline \multicolumn{1}{|c|}{ Categorias de Análise } & \multicolumn{1}{|c|}{ Posições e crenças que delimitam a investigação } \\
\hline $\begin{array}{l}\text { A problemática urbana e suas } \\
\text { causas }\end{array}$ & $\begin{array}{l}\text { - a solução requer a participação da iniciativa privada } \\
\text { - o problema é impedimento ao crescimento econômico } \\
\text { - ênfase na concentração populacional e no processo de } \\
\text { urbanização acelerado e desordenado }\end{array}$ \\
\hline A política urbana & $\begin{array}{l}\text { - deve ofertar a infraestrutura necessária para a implantação das } \\
\text { empresas (seletividade de investimentos) } \\
\text { - é um dos braços da política anticíclica para movimentar a } \\
\text { economia e gerar empregos }\end{array}$ \\
\hline $\begin{array}{l}\text { O papel do Estado na política } \\
\text { urbana }\end{array}$ & $\begin{array}{l}\text { - deve realizar políticas para ofertar equipamentos, serviços e } \\
\text { infraestrutura urbana para promover o desenvolvimento e o } \\
\text { crescimento econômico }\end{array}$ \\
\hline O uso do solo & $\begin{array}{l}\text { - uso do solo como recurso econômico, reserva de mercado ou } \\
\text { de valor }\end{array}$ \\
\hline A questão habitacional & $\begin{array}{l}\text { - ênfase no Estado e na iniciativa privada como agentes } \\
\text { garantidores das necessidades mínimas de moradia }\end{array}$ \\
\hline A função social da propriedade & - apoio parcial com algumas demandas e ressalvas \\
\hline
\end{tabular}

Fonte: elaboração da autora. 


\section{Coalizão dos Políticos}

Fazem parte desta coalizão os parlamentares dos partidos políticos, assessores e integrantes do poder público de carreira ou de cargos de livre nomeação que atuam na Administração Pública segundo os interesses políticos de um determinado grupo de interesses.

Para melhor compreender as crenças e o comportamento dos atores que fazem parte desta coalizão é preciso refletir acerca do modelo político existente no Brasil: o presidencialismo de coalizão, uma vez que são os parlamentares que integram o poder Legislativo os protagonistas deste processo.

A expressão "presidencialismo de coalizão" foi abordada de forma pioneira no artigo escrito pelo cientista político Sérgio Abranches (1988), que buscou sintetizar a especificidade do sistema político brasileiro, considerando a combinação entre a representação proporcional, o multipartidarismo e o "presidencialismo imperial", juntamente com a organização do Executivo por meio de grandes coalizões políticopartidárias e regionais. Para o autor é essa combinação que caracteriza o regime políticoinstitucional brasileiro como um "presidencialismo de coalizão", possibilitando inferir que, no Brasil, um governo não se faz capaz de viabilizar suas iniciativas no processo de implementação da política estatal se não dispor de base de apoio político no Congresso Nacional.

Assim, o governo de coalizão é uma estratégia recorrente dos presidentes brasileiros, onde a cooperação entre Executivo e Legislativo, na forma de coalizões multipartidárias, assegura patamares elevados de sucesso do Executivo na aprovação de sua agenda. Os movimentos dos partidos da coalizão na arena legislativa assumem importância estratégica, pois buscam calibrar as propostas do Executivo de acordo com as suas posições políticas em relação a cada "policy".

Para Mendes (2016) o presidencialismo de coalizão, retrata uma relação de poder do Executivo que detém um maior controle sobre mecanismos de orçamento e burocratização, definindo o Legislativo como ponto único de negociações para aprovação de projetos de lei. $\mathrm{O}$ autor destaca que o sistema não permite governabilidade, que a política funciona com base em trocas e pela descaracterização dos Poderes Executivo e Legislativo. Esse 
tipo de sistema foi introduzido no Brasil com a Constituição de 1988, visando compatibilizar o Presidencialismo com o multipartidarismo.

A coalizão consiste numa medida adotada em democracias multipartidárias onde o Executivo não controla majoritariamente as cadeiras do Congresso, recorrendo a essa ferramenta por uma questão de sobrevivência em termos de governabilidade. Por possuírem vontades divergentes, os Poderes Executivo e Legislativo são vistos como atores separados que vivenciam embates profundos em função de o sistema presidencialista brasileiro, da maneira como foi estruturado, apresentar uma forma híbrida de governo e misturar características específicas na produção legislativa, fazendo com que se aproxime dos regimes parlamentaristas (MENDES, 2016).

Essa forma de governar se impõe em formações de maior heterogeneidade e conflito onde a solução mais provável é a grande coalizão, que inclui maior número de parceiros e admite maior diversidade ideológica. Para Abranches (1988):

"Evidentemente, a probabilidade de instabilidade e a complexidade das negociações são muito maiores. Estes contextos, de mais elevada divisão econômica, social e política, caracterizam-se pela presença de forças centrífugas persistentes $e$ vigorosas, que estimulam a fragmentação e a polarização. Requerem, portanto, para resolução de conflitos e formação de "consensos parciais", mecanismos $e$ procedimentos institucionais complementares ao arcabouço representativo da liberal democracia” (ABRANCHES, 1988, p. 27).

O autor complementa mostrando que a formação de coalizões envolve três momentos típicos, sendo o primeiro, a constituição da aliança eleitoral, que requer negociação em torno de diretivas programáticas mínimas, na maioria das vezes amplas, e de princípios que deverão ser obedecidos na formação do governo, caso se concretize a vitória eleitoral. $\mathrm{O}$ segundo momento ocorre com a constituição do governo, onde predomina a disputa por cargos e compromissos relativos ao programa mínimo de governo inicialmente definido, mas que ainda é bastante genérico. Por fim, no terceiro momento, o autor defende que a transformação da aliança em coalizão efetivamente governante representa o problema da formulação da agenda real de políticas e das condições de sua implementação.

Dessa maneira, numa estrutura multipartidária fracionada, o sucesso das negociações para a construção de um acordo que compatibilize as divergências e potencialize os pontos de consenso, é fator decisivo para possibilitar que o sistema político possa atender ou 
conter legitimamente demandas políticas, sociais e econômicas competitivas. A observância desses compromissos, mesmo que de maneira efêmera, constitui um dos requisitos essenciais para a legitimidade e continuidade da coalizão.

A política de coalizão envolve o processo permanente de negociação dos conflitos, além do enfrentamento dos partidos por meio de manobras calculadas para a obtenção de cargos e de influência decisória visando influenciar os outros partidos, mas principalmente persuadir suas próprias bases acerca dos benefícios da coalizão.

De acordo com Boarin (2015) com a Constituição de 1988, o Poder Legislativo recuperou prerrogativas que lhe haviam sido subtraídas durante o regime militar, a despeito da manutenção de algumas tutelas do Executivo ou, ainda, do Presidente da República. Também é importante destacar que o sistema de separação de poderes vigente no Brasil atribui ao Presidente da República um conjunto de competências e prerrogativas institucionais, que lhe confere recursos e vantagens estratégicas na definição da agenda legislativa e uma forte influência sobre a produção legal. A partir disso, o processo decisório no âmbito do Congresso Nacional tem sido marcado pela presença do Legislativo e do Executivo, compondo o presidencialismo de coalizão.

E foi a partir de 1988, quando se viabilizou o presidencialismo de coalizão que os grupos de interesse passaram a atuar na busca por influência no processo decisório, por meio da comunicação com o governo e da obtenção de informações relevantes para o planejamento da estratégia referente à consecução de seus interesses. Portanto, a análise do padrão de relacionamento entre os atores que participam de um processo de formação de políticas revela os diferentes interesses existentes e os diversos projetos que articulam esses interesses.

Boarin (2015) esclarece que, na Ciência Política, os grupos de interesse são abordados como canais de articulação entre Estado e sociedade, bem como o são os partidos políticos e os movimentos sociais como mostrado a seguir:

“(i) grupos de pressão são grupos organizados em torno de uma issue, ou um conjunto delas, visando interesses particulares ou para a sociedade como um todo, mas que não tem interesse em chegar ao poder a ponto de assumir o controle da máquina governamental"; (ii) já os movimentos socais "tentam emplacar visões mais amplas e gerar mudanças sociais mais profundas (usualmente em favor de grandes segmentos desfavorecidos da população) elou, defende questões específicas (como o movimento negro, os ambientalistas e as feministas); (iii) por último, os partidos 
políticos devem ser vistos como "uma coleção de grupos de interesses que se alimenta da energia desses grupos e movimentos, com o objetivo de ganhar as eleições $e$ assumir o controle do Governo" (BOARIN, 2015, p. 3).

Para Santos (2002, p. 197) "pressão" é empregada quando os canais de acesso para um grupo de interesses estiverem obstruídos ou quando for ínfima a possibilidade do grupo ter seus interesses levados em consideração pelos tomadores de decisão. Assim surge o termo "lobby" que se refere a uma atividade particular dos grupos de interesse na tentativa de influenciar a deliberação de novas leis. Desse modo, o autor explica que "pressão" e "lobby" constituem técnicas de influência que podem ser empregadas pelos grupos de interesse na busca de seus objetivos.

Tendo em vista maximizar suas funções e tornar sua atuação o mais eficiente possível, os grupos de interesse procuram transformar seus recursos em poder político, de modo que possam desenvolver relações interpessoais com os diferentes participantes do processo político. Uma questão central para o grupo é saber distinguir em cada momento qual tipo de informação poderá elevar suas possibilidades de acesso aos formuladores. A partir daí o grupo articula seus recursos de maneira a otimizar sua ação, tanto para os seus membros quanto para os formuladores de políticas (SANTOS, 2002, p. 199).

Segundo Boarin (2015) o lobby pode ser definido como defesa de interesses junto aos tomadores de decisão política, de forma lícita ou ilícita, a partir de uma estratégia que envolve o uso de informação por parte dos grupos e dos políticos. Sua mobilização se dá em diferentes momentos do processo decisório, iniciando-se com a definição da agenda e se estendendo até a regulamentação das decisões tomadas e suas respectivas avaliações. Os lobistas utilizam diferentes procedimentos, tais como o contato direto com o tomador de decisões e seus assessores, obtenção, por meio da mídia, do apoio da opinião pública, além de outros.

Para a autora, o argumento central da literatura sobre a influência de grupos de pressão no comportamento dos parlamentares está na relação de troca onde os políticos, para se manterem no poder, precisam de apoio. Dessa forma, são duas as principais variáveis explicativas para acesso e influência dos grupos de interesse: a primeira procura estimar, com base no financiamento de campanha, em que medida as contribuições 
financeiras determinam o comportamento dos deputados; enquanto a segunda foca especificamente nas atividades de "lobby".

Além do "lobby" e do financiamento de campanha, a relação entre política e burocracia é um aspecto central no funcionamento dos governos, uma vez que é na esfera política que ocorrem as principais disputas para definir o escopo e os arranjos institucionais das políticas públicas. As burocracias são responsáveis por gerir as políticas, constituem o principal canal de entrega de bens e serviços aos cidadãos e promovem, por meio dos cargos de confiança, a conexão intrínseca com a política.

Em função das características observadas na Administração Pública Brasileira, partese da premissa de que existe uma conexão negativa entre nomeações baseadas em escolhas discricionárias (cargos de livre nomeação) e sua conexão com a esfera político-partidária em decorrência da histórica patrimonialização do Estado observada no processo de desenvolvimento político brasileiro, que apresentou diferentes formas de clientelismo e patronagem. E foi em função dessa conexão entre nomeações de cargos e patrimonialismo que houve a diminuição da legitimidade da esfera política como instância de controle e definição dos rumos das políticas públicas.

Assim, uma das posições no debate sobre a relação entre burocracia de nomeação discricionária e política no Brasil, considera o espaço destinado ao "livre provimento de cargos" excessivamente amplo e indevidamente politizado, produzindo efeitos negativos sobre a capacidade de planejar e implementar boas políticas.

Sobre esse aspecto, Lopez (2015, p. 14) defende que limitar de modo radical o espaço disponível para nomeações de membros externos às carreiras de Estado seria imperativo para ampliar a eficiência da gestão, por reduzir a influência de decisões particularistas dos políticos. $\mathrm{O}$ autor também ressalta que a alta rotatividade dos cargos decorrente das trocas políticas a cada nova gestão, devido aos rearranjos inerentes às coalizões de governo reduz a capacidade governamental de planejar o ciclo de execução das políticas. Para o autor:

"O loteamento de cargos e sua utilização como moeda de troca sugere precisamente essa fusão entre particularismo $e$ ineficiência decorrentes da politização ou partidarização da burocracia de confiança. Um exemplo empírico dessas implicações é apresentado por Borges e Coelho que, no capítulo 2 deste livro, indicam como a partidarização da burocracia, além de possíveis custos associados à 
seleção de pessoal pouco qualificado para os cargos, envolve a criação de estruturas desconexas e fragmentadas, que acabam por impossibilitar aos ministros e seus partidos controlar e coordenar de forma efetiva o processo de produção de políticas" (LOPEZ, 2015, p. 14).

As peculiaridades inerentes ao modelo político brasileiro, o presidencialismo multipartidário, fazem com que o presidente promova uma negociação bem-sucedida com os atores para conseguir formar e manter coalizões partidárias majoritárias tendo em vista a sua governabilidade. Desse modo, a divisão de cargos, a alocação de verbas do orçamento (emendas parlamentares, alocação discricionária de recursos orçamentários sob a jurisdição dos ministérios para estados e municípios), e o acordo sobre algumas políticas públicas são os recursos centrais para alcançar esse objetivo. Segundo Lopez (2015), em busca de sua sobrevivência política:

“O presidente é um ator central na política das nomeações. Os cargos são, por um lado, instrumentos dos partidos para levar adiante os interesses e acordos com grupos de pressão, e também um recurso da Presidência para controlar as ações dos parceiros da coalizão e as agências burocráticas. (...) todas essas dimensões do processo de preenchimento dos quadros da burocracia de livre provimento sugerem um cenário complexo do processo de divisão de poder. Este cenário se acentua devido à política executiva de nosso presidencialismo ter ministros duplamente responsivos ao presidente e ao seu partido/ facção/bases eleitorais, e também devido à estrutura burocrática ser definida, na prática, ora pelo presidente, ora pelos diversos parceiros da coalizão. Combinam-se influências e preferências do próprio presidente, dos partidos da coalizão, dos interesses corporativos, das redes político-pessoais, da própria burocracia ministerial de carreira e dos ministros. A orientação programática turva dos partidos torna ainda mais difícil compreender as lógicas de nomeação, sua relação com o processo de governo e suas implicações sobre a gestão das políticas" (LOPEZ, 2015, p. 19).

Como efeitos dessa prática de partidarização ou politização da burocracia de livre nomeação e também como resultado da crença dos atores que fazem parte dessa coalizão de que a máquina estatal é utiliza para o atendimento de seus interesses, estabeleceu-se o vínculo frequentemente entre nomeações para a máquina pública e desvio de recursos e outras práticas ilícitas. Lopez (2015) ressalta essa relação afirmando que:

“Corrupção e nomeações de confiança naturalmente se associam porque a prática corrupta é, em um dos lados, gestada por nomeados que ocupam posições de poder no aparato estatal. O controle sobre as nomeações é, nesse sentido, aspecto fundamental na relação com a corrupção, seja para coibi-la, seja para praticá-la. Em nosso sistema, há importantes incentivos institucionais para que os cargos funcionem como mecanismo de extração de recursos públicos ou privados, via doação de empresas, para partidos. É recorrente observar que a origem de alguns dos maiores 
escândalos de corrupção reside nas nomeações partidárias para posições-chave na estrutura estatal ou de estatais. Os principais "escândalos" de corrupção denunciados nos últimos anos foram orquestrados a partir do controle partidário de cargos de confiança em empresas estatais" (LOPEZ, 2015, p. 24).

O autor enfatiza que a luta por cargos em alguns setores do governo foi, gradualmente, assumindo conotação mais econômica entre os partidos. Com isso, o controle de cargos de ordenação de despesa e realização de contratos governamentais passou a ser mais disputado na Esplanada. Contudo, enfatiza que é no âmbito das empresas estatais, por este setor ser menos sujeito à transparência pública e à ação dos órgãos de controle, que a conexão entre política, extração de recursos públicos e partidos é mais intensa.

Um exemplo prático de fundamental importância para a compreensão das relações de interesses e poder que se constituem no âmbito da política urbana é apresentado por Rolnik (2009, p. 35) ao tratar da mudança de gestão do Partido dos Trabalhadores (PT), representada pelo Ministro Olívio Dutra e seu gabinete, por Márcio Fortes, do Partido Progressista (PP) que ocorreu no Ministério das Cidades em 2005, em plena preparação da Segunda Conferência Nacional e campanha dos Planos Diretores Participativos. A nomeação de Fortes para o órgão atendia à demanda do presidente da Câmara dos Deputados, do mesmo partido, em plena crise político-institucional que o governo Lula atravessava, em razão de denúncias de corrupção e compra de votos no Parlamento.

A autora ressalta que predominava naquele período uma política de coalizão para constituir maioria no Congresso (já que o PT havia elegido apenas 91 dos 513 deputados e 14 dos 81 senadores) a qual pressionava para a mobilização dos recursos tradicionalmente utilizados na política brasileira para esta finalidade: a repartição de cargos no governo entre os participantes da coalizão; o atendimento de demandas de investimentos na base dos deputados; além da compra de votos. Também foi destacado o fato de a entrada de novas representações no Legislativo, comprometidas com interesses populares e políticas includentes e redistributivas, conviverem com elites poderosas que continuavam amplamente representadas no Congresso e defendiam objetivos opostos, tais como proprietários de terra, setores empresariais e oligarquias familiares. 
Esse episódio mostra de forma mais explícita a existência de limites e contradições entre uma proposta de Reforma do Estado brasileiro na área de desenvolvimento urbano e o forte conservadorismo de sua estrutura, apesar da importante mudança de direção política representada pela presença do PT. Para Rolnik (2009):

“(...) não é por acaso que justamente esta, entre as várias áreas do Estado brasileiro, é profundamente afetada pela lógica política tradicional, fortemente estruturada no clientelismo, patronagem e controle por coalizões de interesses empresariais, reinventados no contexto urbano e metropolitano brasileiros. Para entendê-la é necessário analisar onde e como se dão os processos decisórios reais sobre os investimentos urbanos e sua relação com o sistema político e modelo federativo no país (ROLNIK, 2009, p. 35).

É fato que a ação estatal, tanto pelo investimento em urbanização, quanto pela regulação do território é determinante para os segmentos que representam os interesses empresariais e para os interesses dos representantes sociais. Dessa forma, os atores que representavam esses diferentes grupos teriam que competir pelo voto popular, fazendo com que os investimentos nas áreas urbanas tenham se constituído em um forte dispositivo eleitoral. Tem-se, a partir desses investimentos, grandes possibilidades de retorno político para seus promotores, sob a forma do voto, bem como pelo acesso aos meios para o financiamento de campanhas. Rolnik (2009) discorre que:

"Considerando as regras atuais de organização partidária e de competição eleitoral e os custos crescentes das campanhas eleitorais, para garantir sua sobrevivência política, os parlamentares necessitam não apenas de mecanismos de acesso à distribuição de recursos públicos como também de alternativas de financiamento de suas campanhas. O controle de postos-chave na máquina estatal, em condições de interferir nas regras de contratação de serviços e obras, assim como a garantia de um fluxo de recursos para alimentar esta máquina podem responder a esta dupla função - de provocar possíveis retornos eleitorais positivos por parte dos beneficiários diretos das obras e serviços, e também de recepção de possíveis prêmios por parte dos contratistas sob a forma de contribuições para custear campanhas (ROLNIK, 2009, p. 43).

Portanto, a lógica que rege o jogo político-eleitoral interfere significativamente no processo decisório sobre a política urbana, especialmente no que diz respeito aos investimentos em obras e ampliação de serviços. Do mesmo modo, o acesso a recursos financeiros representados pelas emendas parlamentares ou pelos convênios ligados aos programas do Ministério das Cidades, dependem essencialmente das relações que os 
governantes locais estabelecem com o governo federal, parlamentares e relações pessoais. Assim, os recursos materiais do Estado desempenham um papel fundamental na operação do sistema de política de coalizão, onde os partidos políticos que apoiam ou participam da coalizão do governo, passam a dispor de inúmeros privilégios ao acessarem o aparelho do Estado.

As políticas de desenvolvimento urbano são suscetíveis a essas práticas patrimonialistas uma vez que os recursos são geograficamente determinados, e os microinvestimentos realizados nas periferias contribuem para sustentar mandatos em eleições sucessivas. De um lado, esses pequenos valores orçamentários são insuficientes para garantir condições de urbanidade básica, mas de outro, apresentam resultados visíveis no curto prazo que podem possibilitar a retribuição por parte do eleitor. Desse modo, os atores políticos envolvidos no jogo político-partidário, estão geralmente mais interessados nas consequências de suas ações em curto prazo em razão da temporalidade da política eleitoral (ROLNIK, 2009, p. 46).

Para a autora, a distribuição seletiva e individual de benefícios, bem como a realização de investimentos em obras juntamente com a regulação urbanística voltada para a criação de novas frentes de expansão imobiliária, dá a este modelo a sustentação política das coalizões de governo junto às elites e ao poder econômico, bem como garante o apoio pelo voto popular. Esse modelo de Estado e de sistema político continuou em vigor no âmbito da política urbana, mesmo sob o comando de um governo de origem operária e popular, uma vez que o rompimento dessa lógica requer grandes reformas institucionais. Mas isso envolve uma agenda complexa, com efeitos de longo prazo, que apenas irá mobilizar apoio desses atores se ganharem grande relevância política ou quando estes não se virem ameaçados, no curto prazo quanto à retribuição do eleitor.

Sobre esse aspecto, faz-se importante replicar a fala do deputado estadual licenciado Carlos Marun, durante debate sobre o andamento do PMCMV na modalidade Sub 50 (política habitacional em municípios com até 50 mil habitantes), realizado na Câmara dos Deputados em 11/04/2012. Nesse evento o parlamentar se manifesta insatisfeito com as mudanças de regras propostas pelo Ministério das Cidades que julgou ser mais relevante realizar uma nova seleção de municípios para receberem os recursos do órgão priorizando 
o critério da pobreza. A fala do deputado deixa claro o interesse desses atores políticos no retorno dos investimentos realizados para a construção de casas, como mostrado a seguir:

"Erraram os que tomaram a decisão de cancelar esse leilão. Por que eu digo isso? Primeiro, porque mudaram a regra do jogo depois que ele tinha começado. (...) segundo, porque essa mudança vai gerar atraso na implantação. É obvio que muitos prefeitos investiram na aquisição de terrenos pensando em fazer essas construções, iniciá-las antes das eleições, sim, porque neste Brasil há eleições, felizmente; (...) é claro que o administrador público está também de olhos nas eleições. Esse atraso condena esse projeto a ser executado somente depois das eleições. (...) trago ao debate também a questão do novo critério da miséria. Eu também defendo o combate à miséria. É justa, é correta a luta para que vivamos em um país onde não existam miseráveis. Mas o critério da miséria como preponderante para um programa habitacional tem que ser melhor avaliado. Ele deixa fora, digamos, desconsidera a capacidade de produção de Estados e Municípios, a capacidade de fazer contrapartida, a expertise em fazer. (...) nós lutamos pela meritocracia” (BRASIL, 2012, p. 4-5).

Em seu discurso, o parlamentar assegura que o critério de alocação de recursos na política habitacional segundo a situação de miséria não deve ser considerado como o fator preponderante. Também tenta argumentar que o prefeito da cidade poderá ter perdas políticas em função de a diminuição nos investimentos em habitação poder comprometer os resultados eleitorais.

Historicamente, escuta-se falar sobre as relações escusas entre o Estado e os grupos de interesse empresariais, tendo como repercussão a politização das políticas públicas e da burocracia, além da acentuação da percepção negativa com relação à atuação dos atores políticos na ação governamental. Essa relação é minuciosamente explicada nos autos do processo instaurado pelo Ministério Público Federal (2016a) a respeito da Operação Lava Jato, deflagrada em 17 de março de 2014. É preciso deixar claro que a menção feita a esta operação não se dá no sentido de apoiar politicamente sua atuação. Embora a corrupção seja um tema que demanda investigação e punição dos agentes responsáveis por sua efetivação, a Lava Jato faz parte da estratégia de outra coalizão política que também defende seus interesses próprios. Busca-se aqui, então, relatar as estratégias da coalizão dos políticos de forma didática, tendo em vista detalhar como os acordos são realizados e propagados ao longo do tempo, a partir dos depoimentos coletados em delação premiada, documentados nos processos iniciados pelo Ministério Público Federal. 
A Lava Jato consiste em uma investigação da Polícia Federal e do Ministério Público Federal com relação a uma organização criminosa formada por políticos, servidores públicos, executivos de empreiteiras e doleiros. Inicialmente, descobriu-se que um grupo de 16 empreiteiras rateavam entre si contratos na PETROBRAS, mediante o pagamento de propina e desvio de dinheiro público, que era repassado a partidos políticos. A partir das informações coletadas em grampos telefônicos, documentos apreendidos e nos depoimentos e acordos de delação, a PF e o MPF vêm mapeado todo o esquema de corrupção. Com o avanço das investigações, novas fases da operação estão sendo realizadas mostrando que outras estatais fizeram parte do esquema, bem como o envolvimento de mais parlamentares e agentes públicos.

As investigações apontam que grandes empreiteiras, por meio de seus executivos, constituíram um cartel para fraudar procedimentos licitatórios, mediante ajustes recíprocos e corrupção de funcionários públicos de alto escalão e de agentes políticos. Com isso, era imposto um cenário artificial de "não concorrência", permitindo-lhes elevar ao máximo o preço que receberiam em decorrência da execução das respectivas obras. Para que obtivessem a colaboração de agentes públicos, as empresas cartelizadas comprometiam-se a repassar, após o início da execução das obras, percentuais dos valores totais dos contratos que lhes fossem adjudicados. Parte desses valores foi entregue diretamente aos agentes públicos corrompidos por meio dos chamados operadores financeiros. Por fim, uma terceira parte foi direcionada aos partidos mediante doações ou por meio de outras operações de lavagem de dinheiro.

De acordo com os autos do processo (MPF, 2016a, p. 6-7) existia um cenário de macrocorrupção que extrapolava a PETROBRAS, onde a distribuição dos altos cargos na Administração Pública Federal, incluindo as Diretorias da PETROBRAS, representava um instrumento para a arrecadação de propinas, em benefício do enriquecimento de agentes públicos, da perpetuação criminosa no poder e da compra de apoio político dos partidos para garantir a fidelidade ao governo.

Além do reconhecimento das práticas ilícitas que já vinham sendo investigadas no âmbito da PETROBRAS, também foram identificados relatos associados à ELETRONUCLEAR, chegando inclusive a temas que ainda não eram objeto de 
investigação criminal tais como a cartelização das empreiteiras para a construção ou reforma dos estádios que sediariam as partidas da Copa do Mundo de 2014.

Nesse esquema, foram englobadas praticamente todas as grandes obras públicas de construção civil realizadas pelo ente público (como exemplo do estado do Rio de Janeiro), algumas delas custeadas com recursos federais, inclusive provenientes do Programa de Aceleração do Crescimento. Dentre elas, cita-se a construção do Arco Metropolitano e a urbanização de grandes assentamentos precários na cidade do Rio de Janeiro, ação vulgarmente denominada por "PAC Favelas" (MPF, 2016b, p. 4).

Assim, o Ministério Público Federal (2016b, p. 4) verificou que as organizações criminosas investigadas pela Operação Lava Jato apresentavam uma mesma estruturação e divisão de tarefas, constituída em cinco núcleos básicos: (i) o núcleo econômico, formado por executivos das empreiteiras cartelizadas contratadas para execução de obras, as quais ofereceram vantagens indevidas a mandatários políticos e gestores públicos; (ii) o núcleo administrativo, composto por gestores públicos do governo, os quais solicitaram e administraram o recebimento das vantagens indevidas pagas pelas empreiteiras; (iii) o núcleo financeiro operacional, formado por responsáveis pelo repasse das vantagens indevidas e pela ocultação da origem dos recursos, inclusive por meio de empresas constituídas exclusivamente com tal finalidade; (iv) o núcleo político, formado pelo líder da organização criminosa, havendo evidências, dependentes do maior aprofundamento das investigações, de que recursos ilícitos alimentaram financeiramente diversos políticos e campanhas eleitorais vinculadas aos partidos da coalizão.

Essa engrenagem servia a projetos pessoais de enriquecimento ilícito de detentores de cargos, funcionários públicos e políticos, e, sobretudo, a projetos de poder de partidos políticos. O então Presidente da República (Lula) foi apontado como grande interessado e beneficiário dessa forma de garantir governabilidade (compra de apoio de terceiros partidos) e da perpetuação no poder pelo recebimento de propinas que seriam usadas para financiar campanhas eleitorais nos mais diversos níveis. Nesse contexto, várias empresas próximas ao governo foram beneficiadas pela corrupção que fraudou licitações da Administração Pública Federal. Segundo as informações do Ministério Público Federal:

“A motivação da distribuição de altos cargos na Administração Pública Federal excedeu a simples disposição de cargos estratégicos a agremiações políticas 
alinhadas ao plano de governo. Ela passou a visar à geração e à arrecadação de propina em contratos públicos. Restou comprovado que determinados agentes políticos, guiados por interesses escusos, fecharam os olhos para projetos de governo, em troca do direito de fazer indicações de pessoas de sua confiança para cargos públicos. Nesse esquema, os apadrinhados que assumiram altos cargos da Administração Pública serviam aos interesses escusos de seus padrinhos políticos, inclusive arrecadando propinas. Assim, dentro de um sistema criminoso bastante conhecido nas sombras do poder, objetivava-se, na realidade, permitir que os agentes políticos responsáveis pelas indicações colocassem nos cargos pessoas comprometidas com a arrecadação de propina” (MPFa, 2016, p. 11).

Desse modo, houve a "distribuição de centenas de cargos de direção em Ministérios, Secretarias, Empresas Públicas e Sociedades de Economia Mista, assim como dos 18.374 cargos de confiança já previstos desde o governo anterior" (MPF, 2016a, p. 24). Destaca-se que a distribuição de cargos para arrecadar propina não teve por propósito único garantir a governabilidade, mas também objetivou a perpetuação no poder do próprio partido do então Presidente da República (com a majoritária distribuição de cargos), e o enriquecimento ilícito. A arrecadação de propinas, assentada na distribuição de cargos públicos, permitiu o direcionamento de vantagens indevidas a agentes e partidos políticos, servidores públicos, operadores financeiros e empresários.

Os indicados para ocupar os altos cargos do Governo cumpriam com o compromisso assumido com seus padrinhos, políticos e partidos, de "prestar favores" a particulares no exercício de suas funções públicas obtendo dos "favorecidos", em contrapartida, o repasse de centenas de milhões de reais em vantagens indevidas. A partir desse esquema, recursos ilícitos foram utilizados para proporcionar o enriquecimento ilícito de agentes públicos e políticos, empresários e operadores financeiros, bem como para financiar campanhas eleitorais milionárias dos partidos aliados. As informações do Ministério Público Federal mostram que:

"Essa articulação, iniciada logo no começo de 2003, mostrou-se eficiente na obtenção do apoio dentro da Câmara dos Deputados e do Senado Federal. Com a distribuição de cargos realizada pela Casa Civil, comandada por JOSÉ DIRCEU, em maio daquele ano, já se registrava que o número de Deputados Federais dos partidos da base de apoio ao Governo de LULA chegava a 526, um número muito maior aos 254 que originalmente tinham lhe conferido apoio. No final de 2003, dos 15 partidos representados na Câmara dos Deputados, 11 apoiavam LULA. Esse grupo reunia 376 Deputados Federais, ou cerca de $73 \%$ da Casa. Em relação à base parlamentar no início da legislatura, o Governo incorporou o apoio, dentre outros, do PMDB e do PP, que reuniam mais de 120 Deputados Federais. (...) Dessa maneira, a atuação do Congresso Nacional esteve alinhada às prioridades e projetos definidos pelo então Presidente da República: entre fevereiro de 2003 e abril de 2004, as casas 
legislativas tornaram lei 82 propostas, sendo 68 delas $(82,9 \%)$ de iniciativa do Poder Executivo e somente $14(17,1 \%)$ de autoria do Poder Legislativo" (MPF, 2016a, p.1213).

Desse modo, a atuação de integrantes do Governo Federal para garantir apoio de parlamentares no primeiro mandato presidencial do PT foi, em parte, desvelada na Ação Penal n 470. Além do loteamento político dos cargos públicos, foi apontada a distribuição de uma "mesada" a agentes políticos ("mensalão") em troca de apoio às propostas do Governo submetidas ao Congresso Nacional.

Os autos do processo também mostram que o esquema vinha se perpetuando ao longo do tempo ao mencionar parte do ocorrido durante a indicação do Brasil para sediar a Copa do mundo em 2014, como relatado a seguir:

“(...) quando o Brasil foi escolhido para sediar a Copa do Mundo de 2014, várias empresas interessadas nas obras necessárias reuniram-se previamente para averiguar quais seriam os interesses de cada uma na tentativa de fazer um conluio. $O$ acerto prévio deu-se de maneira mais consistente entre ODEBRECHT e ANDRADE GUTIERREZ, sendo que ambas deram cobertura à outra para fraudar as licitações. Em decorrência do acerto, a ANDRADE GUTIERREZ venceu as licitações para a construção de estádios em Brasília e Manaus. Em relação à reforma do Estádio do Maracanã no Rio de Janeiro, CLÓVIS PRIMO informou que já havia um acerto antecedente com o governador SÉRGIO CABRAL para que um consórcio formado pela ODEBRECHT e pela DELTA executasse as obras. Como a ANDRADE GUTIERREZ tinha interesse em participar do consórcio, ROGÉRIO NORA procurou SÉRGIO CABRAL para fazer tal pedido. O governador orientou então que ROGÉRIO NORA deveria se entender com a ODEBRECHT, mantendo-se a cota de participação acertada para a DELTA” (MPF, 2016a, p.9).

Com o avanço das investigações da Lava Jato, verificou-se uma situação de corrupção generalizada na esfera política, indicando que todos os partidos que faziam parte da grande coalizão do governo federal estavam envolvidos nos crimes de corrupção ativa e passiva, lavagem de dinheiro e falsidade ideológica, além de citações a formação de cartel e fraude a licitações.

De acordo com notícia de 11/04/2017 (Barbosa e Maia, 2017), o ministro do Supremo Tribunal federal (STF) Edson Fachin, relator da Operação Lava Jato na Corte, determinou a abertura de inquéritos contra oito ministros do governo do presidente Michel Temer, além de 24 senadores e 39 deputados federais. Esse grupo faz parte do total de 108 
alvos dos 83 inquéritos que a Procuradoria-Geral da República (PGR) encaminhou ao STF com base nas delações dos 78 executivos do Grupo Odebrecht, sendo todos com foro privilegiado nesta Corte.

Segundo a notícia, o presidente da República Michel temer é citado nos pedidos de abertura de dois inquéritos, entretanto, ele não é incluído na lista de investigados pela PGR devido à "imunidade temporária" que o cargo de Presidente lhe confere. Segundo as normas vigentes, o Presidente não pode ser investigado por crimes que não decorreram do exercício do mandato.

Esses relatos mostram, de forma detalhada, como a Coalizão dos Políticos costuma agir para alcançar seus objetivos de acordo com seus interesses, lançando mão dos seguintes recursos: o uso acentuado do "lobby", o loteamento de cargos de livre nomeação para fins políticos, o estreitamento de relações com atores do mercado, a seleção de obras específicas e a liberação de pagamento dos empreendimentos para fins eleitorais, a corrupção.

Assim, depois de compreender a forma de atuação dessa são apresentadas no Quadro 11 as principais crenças compartilhadas por esses atores.

Quadro 11 - Principais crenças compartilhadas pelos atores da Coalizão dos Políticos

\begin{tabular}{|l|l|}
\hline \multicolumn{1}{|c|}{ Categorias de Análise } & \multicolumn{1}{c|}{ Posições e crenças que delimitam a investigação } \\
\hline $\begin{array}{l}\text { A problemática urbana e suas } \\
\text { causas }\end{array}$ & $\begin{array}{l}\text { - o problema é impedimento ao crescimento econômico } \\
\text { - a solução requer a participação da iniciativa privada } \\
\text { - ênfase na concentração populacional e no processo de urbanização } \\
\text { acelerado e desordenado }\end{array}$ \\
\hline A política urbana & $\begin{array}{l}\text { - deve ofertar a infraestrutura necessária para a implantação das } \\
\text { empresas (seletividade de investimentos) } \\
\text { - é moeda de barganha política }\end{array}$ \\
\hline $\begin{array}{l}\text { O papel do Estado na política } \\
\text { urbana }\end{array}$ & $\begin{array}{l}\text { - representação do poder político institucional } \\
\text { - deve realizar políticas para ofertar equipamentos, serviços e } \\
\text { infraestrutura urbana para promover o desenvolvimento e } \\
\text { crescimento econômico }\end{array}$ \\
\hline O uso do solo & $\begin{array}{l}\text {-uso do solo como recurso político eleitoral } \\
\text { - uso do solo como recurso econômico, reserva de mercado ou de valor }\end{array}$ \\
\hline A questão habitacional & $\begin{array}{l}\text { - ênfase no Estado e na iniciativa privada como agentes garantidores } \\
\text { das necessidades mínimas de moradia } \\
\text { - ênfase na moradia como recurso de barganha política }\end{array}$ \\
\hline A função social da propriedade & \begin{tabular}{l} 
apoio parcial com algumas demandas e ressalvas \\
\hline
\end{tabular} \\
\hline
\end{tabular}

Fonte: elaboração da autora. 


\section{Coalizão do Mercado}

O cerne do conflito inerente à problemática urbana parte do entendimento apresentado por Santos Junior (2011, p. 67), que aponta a moradia e o solo urbano como bens necessários para a existência das pessoas na cidade, por serem bens fundamentais para a reprodução social na cidade. O problema fundamental na economia capitalista apontado pelo autor se refere ao fato de que a moradia e o solo urbano são tratados como mercadorias e, nessa condição, são bens comercializáveis, podendo ser vendidos e comprados.

Por essa razão, o acesso à moradia e ao solo urbano é mediado pelas regras que definem o acesso e o uso da propriedade privada, segundo as leis de mercado. Assim o autor destaca os seguintes atores que controlam o acesso ao solo nas cidades:

"Os corretores de imóveis buscam lucros através da compra e venda de moradias e escritórios. Portanto, eles operam no mercado de moradia buscando obter valor de troca. Os proprietários de terras urbanas também buscam obter valor de troca como seu objetivo e, para tanto, procuram alcançar o máximo de valorização das suas propriedades. Os incorporadores da indústria da construção de moradias precisam criar valores de uso para outros agentes (os moradores) com o objetivo de criar valores de troca para si mesmos. Eles têm interesse em comprar terrenos pelo menor preço possível para realizar o máximo de lucro na construção e venda dos imóveis. Os agentes incorporadores constroem o parque imobiliário da cidade visando à venda de moradias no mercado para as diferentes classes sociais. Portanto, eles vão procurar diferenciar o seu produto e se beneficiar da localização de cada imóvel construído na cidade. Os construtores de infraestrutura (transporte $\boldsymbol{e}$ comunicação) têm interesse na permanente construção e reforma da cidade e sua intervenção pode desvalorizar ou valorizar as diferentes áreas da cidade. Eles também estão permanentemente criando valores de uso para outros agentes (setores empresariais, moradores, agentes incorporadores) com o objetivo de criar valores de troca para eles mesmos. Os agentes financeiros, como já vimos, desempenham um papel fundamental no mercado de moradia, disponibilizando recursos (créditos) para os construtores e compradores de imóveis, devido aos altos custos envolvidos na produção habitacional. Os agentes governamentais têm como obrigação garantir o acesso à moradia por parte da população, ou seja, como governo, eles deveriam estar preocupados em garantir o acesso da população à moradia como valor de uso. Eles podem produzir diretamente valores de uso (habitação) para a população ou interferir indiretamente, através da regulação do mercado imobiliário (definindo onde e como podem ser construídas as moradias)" (SANTOS JUNIOR, 2011, p. 70).

Nesse sentido, fazem parte desta coalizão atores privados, empresários dos setores produtivos que têm interface no meio urbano, que se mobilizam para interferir nos processos políticos em favor de seus interesses, os quais estão voltados para a acumulação de capital. Apresentam uma relação estrita com atores estatais, principalmente com 
integrantes da Coalizão dos Políticos, fazendo com que suas crenças e recursos para direcionar o processo de tomada de decisão sejam preponderantes e até se sobreponham em grande parte das situações.

Marques e Bichir (2002, p. 3) apontam que o Estado brasileiro teria como uma de suas principais características sua interpenetração com atores privados, tendo como consequências a formação de "anéis burocráticos", que englobariam grupos do Estado e do setor privado, a privatização e a segmentação do Estado, além da privatização de políticas como as sociais. Os autores defendem que a origem disso estaria nas próprias relações entre Estado e classes dominantes no Brasil que são mediadas por círculos de interessados ou então no desenho equivocado das instituições brasileiras, que dão margem para o personalismo, o clientelismo e a corrupção.

As empresas privadas de construção civil representam um dos setores de maior destaque das empresas nacionais que movimentam a economia brasileira. Em função disso, constituem um dos principais sustentáculos da tríplice aliança entre o capital nacional, o multinacional e o Estado, que constitui o tripé que instaura e desenvolve o capitalismo brasileiro. Sua importância vem crescendo progressivamente, desde o início do processo de contratação, pelo Estado, de empresas privadas para a construção de obras e serviços de engenharia, ainda na década de 1940 (MARQUES e BICHIR, 2002, p. 9).

Conforme Matela (2014, p. 155), a partir de meados do século XX até os anos 1980, estabeleceu-se no Brasil um padrão de regulação da acumulação capitalista classificado como fordismo periférico que norteou o período nacional-desenvolvimentista. Nesse período, prevaleceu uma política industrial com forte incentivo à substituição de importações associado à presença de filiais de indústrias de capital estrangeiro no espaço econômico nacional. As características macroestruturais que regularam esse período favoreceram o estabelecimento de alianças de classe no Brasil.

O autor (2014, p. 156) afirma que uma das condições do desenvolvimento do capitalismo no Brasil, nesse período, foi a formação de aliança entre os capitais estrangeiros e os nacionais, pautada em duas regras básicas: (i) destinar esferas de acumulação específicas (industrial, bancária, agrária e outras) para cada tipo de capital, reservando ao capital nacional a acumulação urbana (setores imobiliário, obras e serviços 
públicos); (ii) garantir ao capital nacional níveis de rentabilidade compatíveis com o capital industrial estrangeiro por meio de privilégios.

Dessa forma, as relações patrimonialistas entre capitais mercantis e o Estado passaram a orientar decisivamente as políticas e os investimentos públicos, mostrando que a aliança de classes em escala nacional está associada às coalizões políticas, bem como com as formas de relação entre o Estado e os capitais que realizam sua acumulação. A estratégia adotada tinha um caráter protetivo tendo em vista defender suas posições e a reserva de mercados.

Assim, as empresas que integraram as alianças desse período constituíram um grupo de interesses que visava manter e fortalecer a sua posição na economia brasileira. Para isso, contaram com medidas e iniciativas do Estado que favoreceram sua atuação, destacandose: a disposição do governo para investir em obras públicas, as normas relativas à licitação de obras públicas, a preferência nas compras e licitações públicas, financiamentos realizados a juros subsidiados, isenções fiscais e taxa de câmbio favorável.

Marques e Bichir (2002, p. 10) reforçam esse entendimento ao afirmarem que:

(...) "o mercado de obras públicas se estrutura de forma hierárquica em escalas distintas, cada qual integrando redes de relações pessoais e institucionais diferentes, parcelas distintas da classe política, circuitos de corrupção específicos $e$ tipos de obras e empresas diferentes” (MARQUES e BICHIR, 2002, p. 10).

Para Marques (2016, p. 27) a formação histórica do Estado no caso brasileiro e a constituição dos atores políticos e econômicos forneceram recursos de poder às empresas privadas, no mesmo tempo em que o Estado e suas instituições se tornaram o ator mais importante na produção de políticas. Assim, de forma contraditória, as empresas assumiram papel de grande importância e, ao mesmo tempo, tornaram-se dependentes do protagonismo do Estado que concentrava recursos e a capacidade decisória, mas dependia do setor privado.

Para o autor, essa condição estabelecida entre Estado e o setor privado reservou um papel econômico de destaque para os capitais da construção e da produção da cidade. Esse legado foi intensificado com a decisão política de expansão de infraestrutura nacional a partir dos anos 1950 (estradas, hidrelétricas, portos, aeroportos), quando foi criado um 
forte mercado para empresas de construção pesada. Nesse sentido, entende-se que o Estado foi o grande produtor desses setores econômicos, os quais viabilizaram uma grande parte da estratégia de desenvolvimento, em uma relação quase simbiótica.

Essa relação próxima entre Estado e setor privado teve como um desdobramento as práticas de corrupção. Apesar do crescente destaque que vem tendo na mídia atualmente, devido aos inquéritos e delações que envolvem a operação Lava Jato da Polícia Federal, a temática corrupção não é um fenômeno recente. Para Hernandes (2011, p. 37), a corrupção associada ao setor da construção civil, como forma organizada, surge durante o governo de Juscelino Kubitschek, com o Plano de Metas, no qual a execução de uma série de obras eivadas de diversos vícios, aliada à falta de transparência, abriu espaço para a disseminação da prática sistematizada de superfaturamento no país, propiciando lucros exagerados às empreiteiras. Posteriormente, durante o período militar, a falta de transparência nas ações do governo e a censura criaram um ambiente de aparente ausência de corrupção. Entretanto, a intensa intervenção estatal e o grande número de obras públicas realizadas no período constituíram um terreno propício para essa prática.

Segundo as notícias de 13 de março de 2017 relativas ao depoimento de delação premiada de Emílio Odebrecht, no âmbito da Operação Lava Jato, os pagamentos não contabilizados (caixa dois) existem e reinaram desde seu antepassado no Brasil. O empresário afirma que:

"Isso sempre foi modelo reinante no país e que veio até recentemente. Porque houve o impedimento e foi a partir de 2014 e 2015. Mas até então, sempre existiu, desde a minha época, da época do meu pai, da minha época e também de Marcelo, de todos aqueles que foram executivos do grupo" (ODEBRECHT, 2017, s/p).

De acordo com os delatores, a década de 1940 foi o marco para o início do esquema de repasse ilegal de dinheiro de empreiteiras a políticos no Brasil. Essa afirmação foi confirmada por Emílio Odebrecht e por Sérgio Machado, ex-deputado federal (1991-1994), ex-senador (1995-2003) e ex-presidente da Transpetro (2003-2014), uma subsidiária da Petrobrás, que afirma:

"O esquema ilícito de financiamento de campanha e de enriquecimento ilícito desvendado pela Lava Jato ocorre desde 1946” (MACHADO, 2017, s/p). 
Segundo o especialista em economia do Centro de Política das Políticas Públicas da FGV, Marcos Fernandes Gonçalves (2017), o período representativo para o início do financiamento por parte das empreiteiras é o Pós-Guerra Mundial (1945). A partir desse marco, observou-se o aumento significativo do investimento em infraestrutura no Brasil, o que impulsionou o surgimento daquelas que viriam a ser as grandes construtoras brasileiras.

O autor afirma que o movimento se acentuou com o Plano de Metas, de Juscelino Kubitschek, principalmente com a construção de Brasília. Depois teve o primeiro Plano Nacional de Desenvolvimento, no governo do general Castelo Branco e o segundo Plano Nacional de Desenvolvimento com Ernesto Geisel, ambos com investimentos pesados em infraestrutura. Nessa época as grandes construtoras passaram a se destacar e a crescer devido ao "boom" das empreiteiras.

Em função dessas relações, pautadas por interesses escusos, no que diz respeito às políticas públicas, a patronagem e o clientelismo, assim como o corporativismo, apresentam-se, como um fenômeno político e social que se faz presente em diversos tipos de relações entre o Estado e a sociedade, como já detalhado no item referente à Coalizão dos Políticos. Sobre isso, Romano (2007) aponta que:

(...) "a patronagem e o clientelismo podem ser considerados como uma forma hierarquizada de representação de interesses e de apresentação de demandas, centrada no intercâmbio entre clientes demandantes e patrões com poder e influência nas agências que administram o acesso a recursos públicos" (ROMANO, 2007, p. 101).

Jora e Franceschi (2015, p. 3) argumentam que mudanças no âmbito da competição eleitoral ocorreram mais intensamente com o retorno do multipartidarismo e com a redemocratização em 1982, quando se passou a ter a necessidade de recursos para o financiamento das campanhas eleitorais, devido à insuficiência de recursos dos próprios candidatos, pessoas físicas e partidos. A partir dessa época, as contribuições empresariais se fizeram imprescindíveis. E foi em função dessa mudança no contexto eleitoral que as alianças entre as grandes empresas da construção se fizeram ainda mais fortalecidas, abrindo espaço para o estabelecimento de novos acordos entre empresários e políticos no 
sentido de alcançar seus objetivos pessoais. Souza (2013) reforça esse aspecto apontando que:

\footnotetext{
“(...) aumentou as chances de troca de favores entre os candidatos eleitos e as empresas ou os indivíduos interessados nas decisões políticas. Dessa forma, a dinâmica na qual financiadores oferecem doações com a expectativa de obter em troca vantagem direta (...), passou a predominar, no lugar das doações coordenadas em busca de políticas específicas" (SOUZA, 2013, p. 4).
}

Os aspectos discutidos no item anterior, relacionado à Coalizão dos Políticos permite o entendimento de que o financiamento de campanha constitui um dos meios que possuem os partidos políticos para adquirem recursos que serão destinados a campanhas eleitorais, servindo como moeda de troca para a articulação com os interesses de empresários. O financiamento privado tem origem em doações financeiras tanto de pessoa física, quanto de pessoa jurídica, além da utilização de recursos dos próprios candidatos.

Recentemente, constatou-se que o Brasil arrecada, nos tempos de eleições presidenciais, cerca de dois bilhões de reais provenientes de financiamentos privados, sendo que a maior parte desses recursos é caracterizado como doação de grandes empresas. Desse modo, acredita-se que as grandes somas de recursos doadas estão atreladas a interesses. Assim, entende-se que, parte da representação política potencialmente captável pelos grandes financiadores gera, em curto prazo, a proteção de interesses especiais (LIMA e SOUZA, 2013, p.8).

As autoras sugerem, portanto, a existência no Brasil, da compra de influência política de forma legalizada, visto que, frequentemente, grandes empresas fazem a captura de políticos por meio de vultosos financiamentos. Destacam ainda que o cerne do problema está na influência desproporcional exercida por alguns poucos financiadores (de expressivo poder econômico) sobre os políticos que conseguem ser eleitos. Como as doações são concentradas, aqueles que investiram nas campanhas políticas cobram benesses dos que foram eleitos, gerando trocas de favores que costumam refletir nos processos decisórios e nos rumos da ação estatal.

Desse modo, a corrupção tornou-se uma prática recorrente no cenário político brasileiro, funcionando como o caminho mais usual a ser percorrido por aqueles que estão no poder e aspiram nunca perdê-lo. Nesse contexto são realizadas diversas tentativas 
obstinadas de manter, a qualquer custo, as garantias até então obtidas, fazendo com que muitos partidos lancem mão de financiamentos robustos, com o objetivo de vencer as eleições sucessivamente. Ribeiro (2006) descreve a situação atual afirmando que:

(...) "em nossos dias cresce uma corrupção pós-moderna. Esta não é um furto aos cofres públicos efetuado por indivíduos ou classes gananciosos. É, em seu cerne, uma corrupção fruto da busca do poder pelo poder, que portanto se auto-alimenta, porque a praticam grupos que têm por finalidade principal reeleger-se, assim necessitam de recursos pingues para serem competitivos no próximo pleito" (RIBEIRO, 2006, p. 79).

A corrupção ocorre tanto por meio do superfaturamento de grandes obras, como em função de pequenos procedimentos que envolvem propinas. Os protagonistas dessa prática geralmente são agentes políticos e/ou agentes administrativos. Pode ocorrer em quaisquer dos três poderes, contudo, ressalta-se o Poder Executivo, em razão da sua prerrogativa de arrecadar e implementar política por meio da realização de gastos dos recursos políticos. Do outro lado dessa relação estão os agentes privados, sobretudo empresários fornecedores de bens e serviços ao Estado (SANCHEZ, 2001, p. 56).

Marques (2016) salienta essa prática junto aos capitais relacionados às temáticas do urbano:

\begin{abstract}
"Adicionalmente, os capitais do urbano tendem a acumular muito poder político devido a suas conexões com a classe política, considerando o seu destaque econômico. Isso ocorre através de corrupção associada a obras e outros contratos públicos, como já vastamente demonstrado em inúmeros escândalos políticos, mas também de forma oficial pelo financiamento de campanhas políticas. A escala dos capitais do urbano e as suas conexões os tornam centrais no financiamento de campanhas eleitorais locais e nacionais, o que lhes compra acesso e aumenta a capacidade de influência. Por outro lado, é razoável argumentar que o financiamento eleitoral e as múltiplas associações entre elites políticas locais e produtores do urbano amalgamam interesses em coalizões políticas e econômicas orientadas à realização de políticas. Os resultados destas, entretanto, são diferentes dos gerados pela armadilha fiscal da "growth machine". Enquanto nesta a promoção de renovação urbana e o nexo com os capitais incorporadores estão no centro, no modelo brasileiro a obtenção de contratos públicos para obras e serviços parece ser o interesse principal” (MARQUES, 2016, p. 29).
\end{abstract}

De maneira mais precisa, as trocas de favores entre os agentes públicos e os agentes privados, tendo em vista beneficiar as grandes empresas da construção, geralmente ocorrem da seguinte maneira: 
1. venda de informações privilegiadas sobre decisões governamentais em troca de recursos financeiros e/ou apoio político;

2. mudança de regras para benefício de uma empresa de engenharia pelo favorecimento, a partir de atos administrativos, possibilitando o aditamento de contratos, a elevação do teto contratual e até mesmo a mudança do objeto estabelecido;

3. facilitação de contratos decorrente do pagamento de uma comissão ou "taxa" de intermediação para obter contratos junto ao Estado. A facilitação é perceptível quando grande parte dos contratos são tratados como emergenciais de modo a evitar o procedimento licitatório;

4. fraudação de licitações públicas ignorando critérios técnicos e de custos na seleção de empreiteiras para executar projetos de obras públicas. Buscando burlar a concorrência, as empresas poderão entrar em acordo antes da entrega da proposta, atuando na forma de rodízio para ganhar as licitações e permutando as obras após a obtenção do contrato. As licitações forjadas ou combinadas são identificadas pela existência dos mesmos licitantes e contratados e a propriedade de várias empresas pelos mesmos sócios;

5. sobrepreço ou superfaturamento por meio do aumento dos preços de serviços vendidos para propiciar lucros adicionais às empresas em troca de propinas;

6. agilização de pagamentos pela antecipação de liberações orçamentárias e pagamentos de obras executadas e medidas pelo agente público às empresas de engenharia em troca de propinas;

7. alteração de quantidades e especificações técnicas por meio do não cumprimento do projeto de engenharia em função de acordos que permitam o uso de materiais em quantidade e qualidade inferiores ao pré-estabelecido. A alteração é possível por falhas na fiscalização e pela falta de tradição no setor público de um maior controle da qualidade da obra contratada. Essa situação é mais frequente quando ocorre o conluio entre o fiscal e o executor da obra.

Para Abranches (2016, p. 1), tem sido comum considerar clientelismo e corrupção como fenômenos idênticos, embora não sejam. "A troca de favores por votos ou apoio político, a distribuição e uso de cargos públicos, embora sempre corram o risco de serem operadas em território moralmente difuso, podem não envolver o fluxo ilegal de recursos 
financeiros para benefício partidário ou pessoal". O autor sugere que há corrupção, mas não necessariamente clientelismo, no caso de pagamento de propina para obtenção de uma licença, ou para a solução de uma pendência burocrática. Por outro lado, o uso de propina para financiar favores para os eleitores e para a base do partido ou do político é mais frequente nos ambientes clientelistas, visto que o dinheiro pago nunca se trata de uma doação filantrópica ou ideológica. É sempre um investimento com expectativa de obter vantagem lucrativa futura devido a vantagens lucrativas já obtidas.

Desse modo, o presidencialismo de coalizão é, intrinsecamente, um modelo que se assenta na fragmentação que impossibilita maiorias unipartidárias e, consequentemente, requer a formação da maioria por meio de coalizão. Mas não é um modelo político intrinsecamente clientelista. O clientelismo não está no presidencialismo nem na coalizão, contudo, faz parte do modo de formação das coalizões, envolvendo os apetites, atitudes e objetivos dos partidos e dos políticos e caracteriza o modelo político quando ele é o modo dominante de formação de maiorias.

A cultura clientelista é uma unanimidade na estrutura partidária brasileira, sendo fortalecida pela preferência por grandes coalizões em lugar de coalizões simples $(50 \%+1)$ ou quando a grande coalizão é uma condição necessária à governabilidade. Outras práticas institucionais induzem à impunidade e a uma cultura social de leniência, que formam o cenário político-institucional favorável para a conexão clientelismo-corrupção. Abranches (2016) relata que, em função dessas práticas clientelísticas, os objetivos das políticas implementadas pelo Estado ficam em segundo plano e passam a ser regidos de acordo com as estratégias desses esquemas (2016):

“Essa modalidade de relacionamento político caracteriza-se pela ausência de compromissos programáticos e agendas claras e factíveis de políticas públicas, que são substituídos pelo vínculo direto entre o partido no poder e suas bases. Por meio dessas ligações diretas, o governo e o aparato estatal transferem benefícios, privilégios e prerrogativas para as bases, no território eleitoral do partido, e para as elites, no espaço de financiamento de campanhas. (...) A dificuldade e os riscos na busca de "parceiros" para expandir a rede de corrupção promovem a "cartelização" dos fornecedores e a divisão negociada e proporcional das parcelas desviadas para o financiamento do esquema entre os membros do cartel e entre os partidos da coalizão. Essa cartelização, o volume, extensão e complexidade desses fluxos, a necessidade de operações sofisticadas de lavagem de dinheiro induzem à formação de organizações criminosas. O que era um esquema direto de corrupção, se transforma em uma organização criminosa e se cria, então, o terceiro elo dessa conexão, o do crime organizado. $O$ que as pesquisas mostram é que o grau de consolidação e abrangência desses esquemas de clientelismo-corrupção-crime organizado, em ambientes institucionais propícios, termina por operar como um poderoso incentivo à 
sua disseminação e reduzir dramaticamente as alternativas de relacionamento político. (...) Na ausência de uma barreira moral e dada a baixa probabilidade de punição, os partidos e os políticos, as empresas e os empresários acabam aderindo ao esquema dominante" (ABRANCHES, 2016, p.2).

É nesse ambiente permissivo e de baixa transparência nas transações públicas que se fortalece a promiscuidade entre agentes públicos e privados onde o "lobbying" se mostra como uma estratégia buscada pelos grupos de pressão para participar do processo estatal de tomada de decisões. De acordo com Oliveira (2004):

\begin{abstract}
“Os grupos de pressão são grupos de interesse que exercem pressão. A pressão é a atividade de um conjunto de indivíduos que, unidos por motivações comuns, buscam através do uso de sanções ou da ameaça do uso delas, influenciar sobre decisões que são tomadas pelo poder político, seja a fim de mudar a distribuição prevalente de bens, serviços, honra e oportunidades, seja a fim de conservá-la frente às ameaças de intervenção de outros grupos ou do próprio poder político" (OLIVEIRA, 2004, p. 3).
\end{abstract}

No caso da Coalizão do Mercado, o "lobby" está voltado aos centros de decisão, buscando influenciar burocratas e/ou políticos para a tomada de decisões que beneficiem um grupo social ou empresarial, um programa econômico ou uma linha de atuação de determinado segmento sócio-econômico, mediante uma legislação específica ou por meio de medidas especiais. O "lobbying" passa a ser então, o mecanismo operacional de persuasão adotado pelos grupos de pressão para instrumentar a melhor decisão em conformidade com suas aspirações.

Embora o "lobbying" sempre tenha sido visto como um instrumento com atuação comumente dirigida ao poder Legislativo, o sistema político brasileiro apresenta peculiaridades que se refletem na maneira como essa estratégia é empreendida, sendo mais fortemente dirigido ao poder Executivo. Um dos aspectos que levam os grupos de pressão a dirigirem sua atuação ao poder Executivo, é que este centraliza o processo de tomada de decisões. Com isso, o Executivo tem prerrogativas que permitem o controle da agenda do Legislativo, além da importância das ações governamentais que dependem de aprovação de recursos orçamentários. 
Assim, o Executivo dispõe de recursos importantes que lhe permitem garantir não só a prioridade às leis por ele introduzidas, como também boas chances de aprovação das suas propostas. Para Oliveira (2004):

"A centralização do processo de tomada de decisões no poder Executivo, iniciada durante a ditadura militar e em prática até os dias de hoje, aliada ao forte poder de legislar do presidente, que lhe dá o poder de editar e reeditar Medidas Provisórias, controlar sua tramitação através do pedido de urgência e lhe possibilita ter iniciativa exclusiva sobre matérias orçamentárias e tributárias, além de seu poder de barganhar verbas e atribuições de maneira pouco democrática, utilizando-se do Colégio de Líderes, são os fatores que garantem a preponderância do poder Executivo sobre o poder Legislativo. Dessa forma, seria impossivel que os grupos de pressão desprezassem o poder Executivo enquanto foco de atuação" (OLIVEIRA, 2004, p. 36).

Os desdobramentos das relações clientelísticas entre agentes públicos e privados são materializados nas cidades, gerando um espaço fragmentado e desigual, conforme a dinâmica da acumulação de capital e dos conflitos que dela emergem. Nesse sentido, a cidade capitalista se configura a partir da disputa entre os agentes com relação ao controle do uso do solo urbano. Oliveira (2013, p. 59) destaca que a organização socioespacial no sistema capitalista ocorre, geralmente, segundo os interesses da classe dominante. Isso pode ser comprovado ao se analisar o acesso aos serviços públicos de qualidade, que são diferenciados a depender da renda do cidadão. Trata-se de um espaço de jogo de interesses, numa dinâmica que envolve tempo, força do trabalho e conflitos entre as classes sociais.

Para o mercado formal de produção da cidade, a relação com o aparelho estatal se dá a partir da produção e do fornecimento de bens cujo demandante é o próprio Estado. Também são relevantes as regras que balizam as transações econômicas realizadas neste mercado, as leis e normas estabelecidas nos diferentes níveis de governo que afetam a competitividade e rentabilidade de seus produtos, a política de tributação sobre os imóveis, as normas de uso e ocupação do solo, as políticas de crédito imobiliário, além de outros aspectos relacionados aos vários setores que constituem a política urbana (ROLNIK, 2009, p. 38). A autora destaca que:

"Setores empresariais envolvidos na produção da cidade formal estabelecem conexões privilegiadas com segmentos burocráticos de agências públicas que detêm o controle sobre o encaminhamento dos processos decisórios na implementação de projetos e programas, assim como de controle urbanístico, garantindo a destinação de áreas da cidade para seus mercados e protegendo a rentabilidade de seus investimentos. Na área de desenvolvimento urbano, estes processos decisórios se dão 
no interior da burocracia de gestão do território, altamente permeada por redes de influência que articulam de setores empresariais a mandatos parlamentares $e$ partidos políticos, já que empreiteiras de obras públicas, concessionários de serviços $e$ incorporadoras e construtoras são os maiores financiadores de campanhas eleitorais locais" (ROLNIK, 2009, p. 38).

Ainda na década de 1980, Bernardes (1986) já ressaltava o protecionismo do Estado com relação a interesses privados no âmbito da política urbana ao destacar que:

“Com efeito, o Estado ao privilegiar determinadas políticas públicas - como a própria política habitacional -, o fez em resposta à pressão de interesses específicos $e$, se nenhuma ênfase foi conferida à definição e implementação de uma política urbana abrangente, isto se deve ao fato de que, a par do não reconhecimento, em certos setores do aparelho estatal, das implicações do fenômeno de interesses para decidir quanto à forma de ação a adotar. Como a habitação, o saneamento básico, os transportes urbanos e, em pequena escala, até mesmo o planejamento urbano, suscitariam o interesse de grupos empresariais capazes de exercer pressão sobre o sistema, mas outros aspectos do desenvolvimento urbano eram evitados, pois se revelavam capazes de provocar conflitos, seja em nível do próprio aparelho estatal, seja com as classes dominantes interessadas na manutenção do "status quo" (BERNARDES, 1986, p. 88).

Marques (2016, p. 16-17) parte da premissa de que os capitais representam um ator potencialmente muito importante para as políticas urbanas em função da sua influência na produção de políticas por meio do uso de recursos de poder e pela adoção de estratégias políticas em conexão com vários atores que interagem com instituições que produzem as políticas urbanas. Segundo o autor, em economias de mercado, a maior parte dos capitais opera em cidades, sendo interessante para os capitais que têm seus circuitos de valorização associados diretamente à cidade, influenciar as políticas urbanas.

Desse modo, as relações e interações entre esses capitais com o Estado e o espaço urbano, bem como suas atividades e estratégias de valorização, são fundamentais para a compreensão das economias políticas do urbano. Isso explica o fato de os instrumentos de controle e coordenação do uso do solo não serem implementados, assim como consolida o pensamento tradicional de abordar a política urbana setorializada. Assim, cada setor tem uma lógica própria de funcionamento, de atores protagonistas e de interesses, como mostra Rolnik (2009):

"No Brasil, a gestão governamental do território se estrutura em "setores" (tais como habitação, saneamento, transporte, meio ambiente, urbanismo, patrimônio 
histórico, patrimônio público etc.) com seus respectivos marcos regulatórios e burocracias verticalizadas situadas em agências, empresas públicas, autarquias e órgãos de administração direta vinculados às esferas municipal, estadual e federal. A fragmentação institucional, constantemente abordada como responsável pela ineficiência e baixa capacidade gerencial, burocratização excessiva e desordem nas cidades, constitui, na verdade, parte de uma estratégia de maximização de interesses particulares de burocratas, parlamentares e empresários fornecedores e provedores $e$ bens e serviços reproduzindo uma privatização cartorializada das políticas públicas (...) Neste processo de redes de influência é necessário acrescentar ainda a interferência das forças políticas de apoio à coalizão governante, que controlam a nomeação de pessoas para ocuparem os cargos considerados chave para o funcionamento operacional dos programas" (ROLNIK, 2009, p. 36-39).

Um exemplo clássico ocorrido no âmbito da política urbana com relação à força dos atores políticos e privados consiste no momento de criação da Fundação Casa Popular (FCP), cujo processo de formação originou-se de uma iniciativa da burocracia executiva, na qual foi vetada por uma coalizão de interesses. Segundo Mello (1991) os grupos de interesses afetados pela criação da FCP eram compostos por proprietários, compradores, corretores, construtores, empreiteiros (macroempresariado da construção civil) e segmentos da burocracia estatal. A coalizão fez resistência à criação da FCP alegando a possibilidade de falência de construtoras, a quebra de empresas fornecedoras, a falência de estabelecimentos bancários, o desemprego de operários, tendo como resultado uma crise social.

Segundo o autor, na época, o Estado estava fragmentado e tinha sua capacidade de implementar decisões enfraquecida, ficando mais visível a interdependência entre os custos e os benefícios da política. Desse modo, a coalizão orientada pelos interesses do macroempresariado da construção civil e das clientelas da máquina dos Institutos de Aposentadoria e Pensão (IAPs), que representavam os burocratas, fez oposição à criação da FCP porque esta canalizaria grande quantidade de fundos sociais para a construção de habitações em massa com foco na população de baixa renda.

Marques (2016, p. 26) considera que a interdependência de atores públicos e privados na produção de políticas passaria por redes sociais construídas ao longo da formação histórica dos setores de políticas e de suas comunidades profissionais, formando um "tecido relacional do Estado" e gerando uma teia ampla e heterogênea de atores, organizações e indivíduos do/no publico e do/no privado. Segundo o autor, os atores privados teriam papel potencial de destaque por seus recursos de poder, mas sua ação 
dependeria de suas estratégias/ações (coletivas ou individuais) e das posições que ocupam em tal tecido relacional, e não apenas de suas posições de riqueza, status e em organizações.

Desse modo, os setores empresariais sustentam a política e a política sustenta a acumulação capitalista, fazendo com que o ciclo das políticas se mostre como uma verdadeira arena do poder em detrimentos das orientações técnicas necessárias para a implementações de ações governamentais que promovam de fato o desenvolvimento urbano. Bernardes ressalta que:

"Tudo isso vem a confirmar um dos mais graves problemas do planejamento e dos planejadores, que dissociados da ação executiva e distanciados da cúpula do poder, pouco ou nada influíam nas decisões dos órgãos executores, essencialmente setoriais, nem eram considerados pelos escalões superiores, dos quais emanam as políticas públicas” (BERNARDES, 1986, 90).

A partir de todas as discussões, são apresentadas no Quadro 12 as crenças dos atores que fazem parte da Coalizão do Mercado.

Quadro 12 - Principais crenças compartilhadas pelos atores da Coalizão do Mercado

\begin{tabular}{|l|l|}
\hline \multicolumn{1}{|c|}{ Categorias de Análise } & \multicolumn{1}{|c|}{ Posições e crenças que delimitam a investigação } \\
\hline $\begin{array}{l}\text { A problemática urbana e suas } \\
\text { causas }\end{array}$ & $\begin{array}{l}\text { - a solução requer a participação da iniciativa privada } \\
\text { - o problema é impedimento ao crescimento econômico } \\
\text { - ênfase na concentração populacional e no processo de urbanização } \\
\text { acelerado e desordenado }\end{array}$ \\
\hline A política urbana & $\begin{array}{l}\text { - deve ofertar a infraestrutura necessária para a implantação das } \\
\text { empresas (seletividade de investimentos) } \\
\text { - é moeda de barganha política }\end{array}$ \\
\hline $\begin{array}{l}\text { O papel do Estado na política } \\
\text { urbana }\end{array}$ & $\begin{array}{l}\text { - deve realizar políticas para ofertar equipamentos, serviços e } \\
\text { infraestrutura urbana para promover o desenvolvimento e } \\
\text { crescimento econômico } \\
\text { - representação do poder político institucional }\end{array}$ \\
\hline O uso do solo & $\begin{array}{l}\text {-uso do solo como recurso de barganha política } \\
\text { - uso do solo como recurso econômico, reserva de mercado ou de valor }\end{array}$ \\
\hline A questão habitacional & $\begin{array}{l}\text { - ênfase na moradia como mercadoria a ser negociada pela iniciativa } \\
\text { privada } \\
\text { - ênfase na moradia como recurso de barganha política }\end{array}$ \\
\hline A função social da propriedade & \begin{tabular}{l} 
- oposição total \\
\hline
\end{tabular} \\
\hline
\end{tabular}

Fonte: elaboração da autora.

O comportamento dos atores que integram esta coalizão vem sendo o mesmo desde os primórdios, quando foram estabelecidas as primeiras relações entre o Estado e representantes do empresariado inerente aos mercados existentes no meio urbano 
(corretoras de imóveis, proprietários de terras urbanas, incorporadores da indústria da construção de moradias, agentes incorporadores, construtores de infraestrutura, além de outros).

\subsection{Atuação das coalizões e influências dos eventos externos e mudanças}

\section{institucionais}

A análise das crenças das coalizões estudadas, juntamente com a verificação das interferências promovidas por eventos externos e mudanças institucionais observados durante o período de mobilização da coalizão política que se manteve no poder entre 2003 e 2015, permite o entendimento acerca das crenças que de fato orientaram as decisões e as práticas adotadas no âmbito da política urbana.

Para isso, é preciso visualizar o período de atuação da coalizão de acordo com a linha do tempo apresentada na Figura 48, onde é representado o movimento das coalizões e de suas respectivas crenças. Parte-se do reconhecimento de que as decisões sobre essa política foram prioritariamente influenciadas por atores que compunham a estrutura interna do Ministério das Cidades, por atores externos que fizeram parte do alto escalão do Governo Federal, por atores do Legislativo, bem como por agentes externos ao governo que advogavam segundo os interesses da iniciativa privada.

Vale destacar que as cinco coalizões estudadas fizeram parte de uma macro coalizão do Governo Federal mobilizada pelo PT para a garantia de governabilidade e de sua permanência e sobrevivência no poder durante o período apontado. Desse modo, todas as coalizões continham integrantes que faziam parte da mesma coalizão de aliados, que, além dos aspectos relacionados à política urbana, também lidavam com os acordos voltados para acertos políticos.

Para fins didáticos, considera-se que essa macro coalizão teve início em 2003 (criação do Ministério das Cidades) e perdurou até o final de 2015 com a aceitação da denúncia de crime de responsabilidade cometido pela presidente Dilma Rousseff e seu afastamento do cargo. Embora o processo de "impeachment" tenha sido concluído em 2016, já em 2015 houve o desfazimento da coalizão encabeçada pelo PT e a formação de uma nova coalizão no Governo Federal coordenada pelo PMDB, PSDB e demais partidos aliados. 
No Quadro 13 apresenta-se a consolidação das crenças relativas às coalizões estudadas neste estudo. A partir dessa Tabela é possível verificar que a Coalizão dos Movimentos Sociais Urbanos apresenta similaridades de crenças com relação à Coalizão dos Especialistas, enquanto a Coalizão dos Políticos apresenta semelhanças com a Coalizão do Mercado.

Assim, é possível verificar que os principais conflitos entre as cinco coalizões estudadas se situam com relação às crenças identificadas que transitam entre dois pontos extremos, dividindo aqueles que acreditam e buscam uma política urbana mais voltada às necessidades sociais e espaciais e aqueles que visualizam o urbano prioritariamente em função dos ganhos econômicos e financeiros que os diferentes mercados viabilizados pelas cidades podem oferecer.

O período de duração da grande coalizão do Governo Federal está representado na Figura 52 por meio da representação de três fases, com o objetivo de visualizar os momentos em que as diferentes crenças orientaram o processo decisório, impactando no formato da política urbana implementada. Ressalta-se que essas crenças sempre estiveram presentes no contexto político que rege as políticas urbanas. Entretanto, é necessário identificar os períodos em que cada uma delas assumiu protagonismo em função dos eventos externos e das mudanças institucionais ocorridas durante o período de observação.

Como pode ser visto no Quadro 13, as Coalizões da Sociedade Civil e dos Especialistas comungam de crenças direcionadas a aspectos técnicos, sociais e essenciais para o devido enfrentamento dos problemas das cidades. Entretanto, essas duas coalizões são as que dispõem de menor capacidade de influenciar no processo decisório por não disporem de recursos políticos que são usualmente adotados para estabelecer barganhas e consensos entre os partidos da base aliada do governo.

Por outro lado, as Coalizões dos Políticos e do Mercado comungam crenças que privilegiam a lógica liberal em detrimento das reais necessidades sociais. Embora a Coalizão dos Tecnocratas Desenvolvimentistas não esteja completamente voltada para as crenças liberais, essas três coalizões, juntas, dispõem de todos os recursos políticos necessários para a pactuação de acordos entre os aliados. 
Quadro 13 - Similaridades e diferenças nas crenças das coalizões

\begin{tabular}{|c|c|c|c|c|c|}
\hline \multirow{2}{*}{$\begin{array}{l}\text { Categorias de } \\
\text { Análise }\end{array}$} & \multicolumn{5}{|c|}{ Posições e crenças que delimitam a investigação } \\
\hline & $\begin{array}{l}\text { 1. Coalizão dos Movimentos Sociais } \\
\text { Urbanos }\end{array}$ & 2. Coalizão dos Especialistas & $\begin{array}{l}\text { 3. Coalizão dos Tecnocratas } \\
\text { Desenvolvimentistas }\end{array}$ & 4. Coalizão dos Políticos & 5. Coalizão do Mercado \\
\hline $\begin{array}{l}\text { A problemática } \\
\text { urbana e suas causas }\end{array}$ & $\begin{array}{l}\text { - é resultado do modelo de } \\
\text { desenvolvimento que acentua a } \\
\text { segregação socioespacial } \\
\text { - deve ser resolvida com } \\
\text { protagonismo do Estado } \\
\text { - ênfase na lógica de mercado como } \\
\text { elemento dominante de organização } \\
\text { espacial que limita o acesso à terra } \\
\text { - ênfase na ineficiência das políticas } \\
\text { públicas }\end{array}$ & $\begin{array}{l}\text { - é resultado do modelo de } \\
\text { desenvolvimento que acentua a } \\
\text { segregação socioespacial } \\
\text { - deve ser resolvida com } \\
\text { protagonismo do Estado } \\
\text { - há limites à organização racional do } \\
\text { planejamento urbano } \\
\text { - visão integradora (causas múltiplas) }\end{array}$ & $\begin{array}{l}\text { - a solução requer a participação da } \\
\text { iniciativa privada } \\
\text { - o problema é impedimento ao } \\
\text { crescimento econômico } \\
\text { - ênfase na concentração } \\
\text { populacional e no processo de } \\
\text { urbanização } \\
\text { desordenado acelerado }\end{array}$ & $\begin{array}{l}\text { - a solução requer a participação da } \\
\text { iniciativa privada } \\
\text { - o problema é impedimento ao } \\
\text { crescimento econômico } \\
\text { - ênfase na concentração populacional } \\
\text { e no processo de urbanização } \\
\text { acelerado e desordenado }\end{array}$ & $\begin{array}{l}\text { - a solução requer a participação } \\
\text { da iniciativa privada } \\
\text { - o problema é impedimento ao } \\
\text { crescimento econômico } \\
\text { - ênfase na concentração } \\
\text { populacional e no processo de } \\
\text { urbanização acelerado e } \\
\text { desordenado }\end{array}$ \\
\hline A política urbana & $\begin{array}{l}\text { - a sociedade civil deve opinar nas } \\
\text { decisões } \\
- \text { deve ser orientada para as } \\
\text { necessidades sociais } \\
\text { população de baixa renda) }\end{array}$ & $\begin{array}{l}\text { - a sociedade civil deve opinar nas } \\
\text { decisões } \\
\text { - deve ser orientada para as } \\
\text { necessidades sociais (priorizar } \\
\text { população de baixa renda) } \\
\text { - não atua nas causas do problema } \\
\text { sendo setorial e fragmentada }\end{array}$ & $\begin{array}{l}\text { - deve ofertar a infraestrutura } \\
\text { necessária para a implantação das } \\
\text { empresas (seletividade de } \\
\text { investimentos) } \\
\text { - é um dos braços da política } \\
\text { anticíclica para movimentar a } \\
\text { economia e gerar empregos }\end{array}$ & $\begin{array}{l}\text { - deve ofertar a infraestrutura } \\
\text { necessária para a implantação das } \\
\text { empresas (seletividade } \\
\text { investimentos) } \\
\text { - é moeda de barganha política }\end{array}$ & $\begin{array}{l}\text { - deve ofertar a infraestrutura } \\
\text { necessária para a implantação das } \\
\text { empresas (seletividade de } \\
\text { investimentos) } \\
\text { - é moeda de barganha política }\end{array}$ \\
\hline O uso do solo & $\begin{array}{l}\text { - uso do solo como elemento de } \\
\text { redução das desigualdades } \\
\text { socioespaciais }\end{array}$ & $\begin{array}{l}\text { - uso do solo como elemento de } \\
\text { redução das desigualdades } \\
\text { socioespaciais } \\
\text { - uso do solo em conformidade com } \\
\text { os instrumentos de planejamento e } \\
\text { ordenamento territorial }\end{array}$ & $\begin{array}{l}\text { - uso do solo como recurso } \\
\text { econômico, reserva de mercado ou } \\
\text { de valor }\end{array}$ & $\begin{array}{l}\text {-uso do solo como recurso político } \\
\text { eleitoral } \\
-\quad \text { uso do solo como recurso } \\
\text { econômico, reserva de mercado ou de } \\
\text { valor }\end{array}$ & $\begin{array}{l}\text {-uso do solo como recurso de } \\
\text { barganha política } \\
\text { - uso do solo como recurso } \\
\text { econômico, reserva de mercado ou } \\
\text { de valor }\end{array}$ \\
\hline $\begin{array}{l}\text { O papel do Estado na } \\
\text { política urbana }\end{array}$ & $\begin{array}{l}\text { - deve implementar o princípio da } \\
\text { função social da propriedade } \\
\text { - deve realizar políticas para ofertar } \\
\text { equipamentos, serviços } \mathrm{e} \\
\text { infraestrutura urbana para garantir } \\
\text { direitos sociais }\end{array}$ & $\begin{array}{l}\text { - deve implementar o princípio da } \\
\text { função social da propriedade } \\
\text { - deve realizar políticas para ofertar } \\
\text { equipamentos, serviços e } \\
\text { infraestrutura urbana para garantir } \\
\text { direitos sociais } \\
\text { - é um dos agentes que influenciam na } \\
\text { organização do espaço }\end{array}$ & $\begin{array}{l}\text { - deve realizar políticas para ofertar } \\
\text { equipamentos, serviços e } \\
\text { infraestrutura urbana para promover } \\
\text { o desenvolvimento e o crescimento } \\
\text { econômico }\end{array}$ & $\begin{array}{l}\text { - deve realizar políticas para ofertar } \\
\text { equipamentos, serviços es e } \\
\text { infraestrutura urbana para promover o } \\
\text { desenvolvimento e o crescimento } \\
\text { econômico } \\
\text { - representação do poder político } \\
\text { institucional }\end{array}$ & $\begin{array}{l}\text { - deve realizar políticas para } \\
\text { ofertar equipamentos, serviços e } \\
\text { infraestrutura urbana para } \\
\text { promover o desenvolvimento e o } \\
\text { crescimento econômico } \\
\text { - representação do poder político } \\
\text { institucional }\end{array}$ \\
\hline $\begin{array}{l}\text { A } \\
\text { habitacional }\end{array}$ & $\begin{array}{l}\text { - ênfase na segregação social } \\
\text { associada ao poder de aquisição da } \\
\text { moradia (limitação da qualidade de } \\
\text { vida) } \\
\text { - ênfase na moradia como direito } \\
\text { social a ser assegurada pelo Estado }\end{array}$ & - visão integradora (causas múltiplas) & $\begin{array}{l}\text { - ênfase no Estado e na iniciativa } \\
\text { privada como agentes garantidores } \\
\text { das necessidades mínimas de } \\
\text { moradia }\end{array}$ & $\begin{array}{l}\text { - ênfase no Estado e na iniciativa } \\
\text { privada como agentes garantidores } \\
\text { das necessidades mínimas de moradia } \\
\text { - ênfase na moradia como recurso de } \\
\text { barganha política }\end{array}$ & $\begin{array}{l}\text { - ênfase na moradia como } \\
\text { mercadoria a ser negociada pela } \\
\text { iniciativa privada } \\
\text { - ênfase na moradia como recurso } \\
\text { de barganha política }\end{array}$ \\
\hline $\begin{array}{l}\text { A função social da } \\
\text { propriedade }\end{array}$ & - apoio incondicional & - apoio incondicional & $\begin{array}{l}\text { - apoio parcial com algumas } \\
\text { demandas e ressalvas }\end{array}$ & $\begin{array}{l}\text { apoio parcial com algumas } \\
\text { demandas e ressalvas }\end{array}$ & - oposição total \\
\hline
\end{tabular}




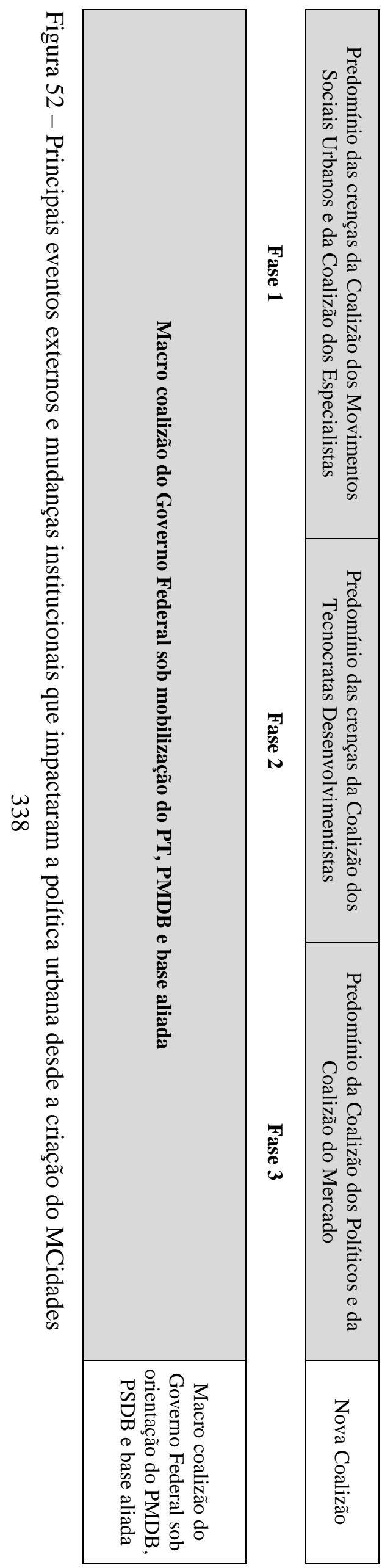

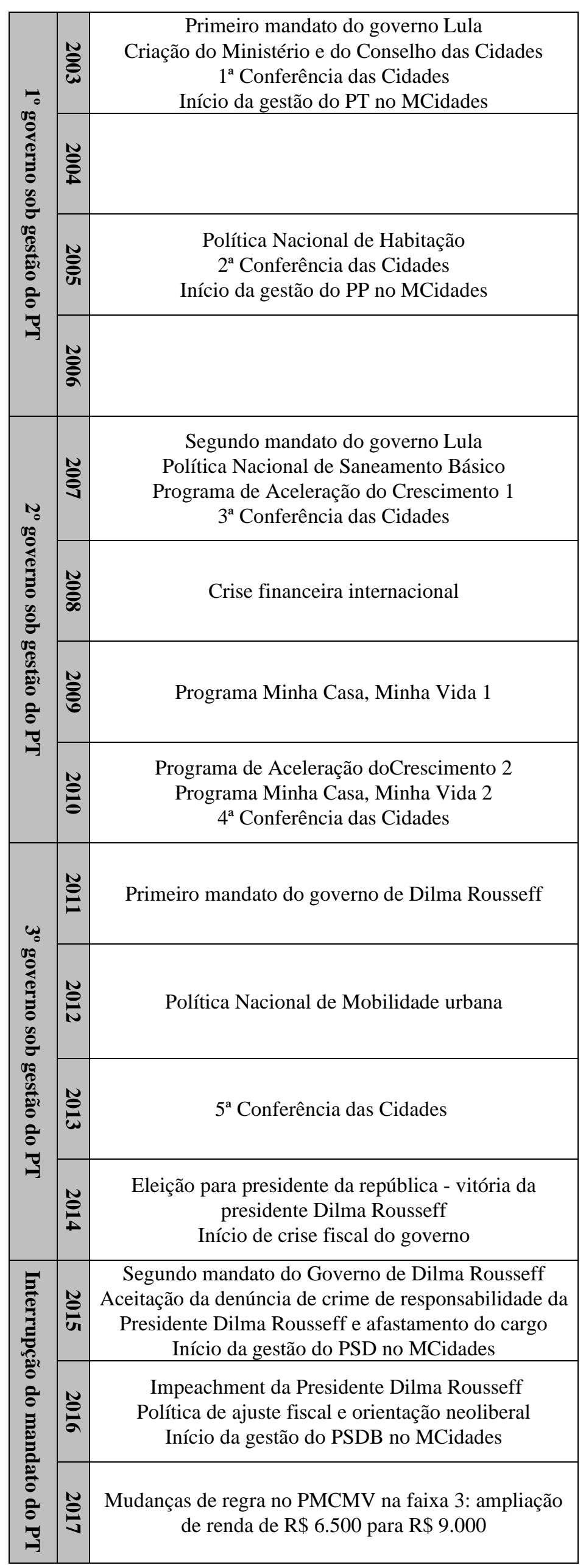


Em determinado momento do período analisado, verifica-se que a aliança entre a Coalizão dos Tecnocratas Desenvolvimentistas com a dos Políticos e a do Mercado foi crucial para que as crenças e os interesses políticos e econômicos superassem os esforços empreendidos pelas coalizões da Sociedade Civil e dos Especialistas no sentido de transformar as práticas ancestrais adotadas no âmbito da política urbana.

O início da fase 1 da coalizão macro do Governo Federal foi marcado por um período de baixo investimento na política urbana, dando continuidade ao comportamento observado em períodos anteriores. Por outro lado, era o momento em que se tinha a vontade de colocar em prática um novo modelo de gestão, mais participativo e inclusivo, em contraposição ao modelo vivenciado na época da ditadura. Também existia uma forte preocupação com os efeitos nefastos da desigualdade instalada nos grandes centros brasileiros em função do processo de urbanização desordenado vivenciado nas décadas anteriores.

No início da grande coalizão viabilizada pelo PT, as iniciativas governamentais estavam voltadas primordialmente para a construção e estruturação de um conjunto de políticas públicas focadas na implementação do projeto de Estado implícito na Constituição Federal de 1988, que priorizava direitos fundamentais para os cidadãos. Essa realidade era o reflexo das vitórias alcançadas pelo exercício da participação social materializado pelo movimento da reforma urbana.

A primeira vitória desse movimento foi a publicação do Estatuto da Cidade em 2001, que se tratava de uma lei de iniciativa popular, sendo consolidada, em seguida, pela criação do Ministério e do Conselho das Cidades. Também fez parte desse conjunto de vitórias e iniciativas a proposição de uma PNDU após a criação do MCidades com ações prioritárias para populações de baixa renda e tentativa de implementação dos instrumentos previstos no Estatuto da Cidade.

Os princípios que regiam os objetivos dessas ações eram a gestão participativa e a função social da propriedade. Desse modo, o início do governo coordenado pelo PT trazia consigo a esperança de combate aos modelos anteriores de desenvolvimento os quais priorizavam o crescimento econômico e exacerbavam a segregação urbana, além de concentrarem o processo decisório e de concepção das ações em um grupo seleto da alta 
cúpula do Governo Federal. Buscava-se, naquela época, encontrar meios para promover o desenvolvimento com equidade e acreditava-se que, pela primeira vez na história da política urbana do país, existia a estrutura institucional para o alcance desse objetivo.

Nesse período, prevaleciam as crenças da Coalizão dos Movimentos Sociais Urbanos juntamente com a Coalizão dos Especialistas. Destaca-se inclusive, o fato de alguns atores dessa coalizão terem feito parte primeira gestão do Ministério das Cidades, juntamente com o ministro Olívio Dutra. Foram nomeados os seguintes técnicos para ocupar os respectivos cargos:

- Ermínia Terezinha Menon Maricato para a Secretaria-Executiva;

- Raquel Rolnik para a Secretaria de Programas Urbanos;

- Benny Schvarsberg para o cargo de Diretor de Planejamento Urbano;

- Otilie Macedo Pinheiro como Diretora de Apoio à Gestão Municipal e Territorial.

Esse grupo de especialistas, empenhados na efetiva transformação da política urbana vigente, estava à frente da Secretaria Nacional do Ministério que buscava estabelecer uma nova cultura urbana para o país, cujas bases estavam referenciadas na Constituição Federal e no Estatuto da Cidade. A secretaria tinha como desafios estratégicos iniciais a implementação dos planos diretores e a ampliação das ações de regularização fundiária.

Entretanto, em 2005 um evento mostrou como as alianças políticas em torno de um modelo de coalizão de interesses pôde afetar significativamente o andamento da política de desenvolvimento urbano em curso. Em julho de 2005, a gestão do Ministério das Cidades saiu da gestão do PT e passou a ser liderada pelo PP, que era um partido aliado da base do governo, mas que não comungava do ideário alavancado pela gestão petista.

Desse modo, essa primeira mudança de gestão, devido à necessidade de rearranjar os cargos politicamente, abriu espaço para o enfraquecimento de algumas proposições que haviam sido determinadas logo no momento da criação do órgão. Embora o Conselho das Cidades estivesse com sua atuação em curso, por meio da realização de três Conferências das Cidades (2003, 2005 e 2007), focado na construção de uma PNDU de forma democrática, gradativamente, foi sendo retomado o foco nas políticas setoriais de forma fragmentada. 
Paralelamente ao processo técnico de discussão das políticas e das diretrizes que o Ministério das Cidades deveria seguir para a implementação da política urbana preconizada na sua criação, existia o movimento político de ajustes na grande coalizão do Governo Federal que vivencia um processo permanente de negociação de conflitos.

Destaca-se que a governabilidade do Presidente da República e sua sobrevivência política dependem, necessariamente, dos acordos firmados com a base aliada do governo. Assim, faz-se uso dos principais recursos disponíveis para garantir a estabilidade da coalizão: divisão de cargos, alocação de verbas do orçamento, acordos sobre determinados assuntos que envolvem as políticas públicas, além de outros aspectos de menor impacto no processo decisório, mas não menos importantes.

O fim da primeira fase da coalizão do Governo Federal foi marcado com o lançamento do PAC 1 pelo presidente Lula que estava ancorado em uma estratégia macro de desenvolvimento do Governo Federal, a qual envolvia diversos Ministérios que conduziam as políticas de infraestrutura do país. Em função da orientação desenvolvimentista que estava embutida no PAC 1 , houve o enfraquecimento das crenças da Coalizão dos Movimentos Sociais Urbanos e da Coalizão dos Especialistas que até então fundamentavam a estratégia das políticas em curso, e a ascensão das crenças da Coalizão dos Tecnocratas Desenvolvimentistas.

Ressalta-se que a Coalizão dos Movimentos Sociais Urbanos e a Coalizão dos Especialistas eram as que se apresentavam mais frágeis em termos de recursos, tanto para colocarem seus planos em prática quanto para realizarem as barganhas e o convencimento no processo de tomada de decisão, por não disporem de cargos nem do controle sobre recursos financeiros e orçamentários.

A segunda fase da grande coalizão do Governo Federal representou o auge da gestão do PT com relação à política urbana, em função da retomada dos investimentos nas áreas de competência do MCidades de forma nunca exercida. Com o PAC e o PMCMV, nas suas duas fases, houve o maior aporte de recursos para as ações implementadas pelo órgão central de implementação da política urbana, viabilizando o atendimento a demandas sociais que estavam sendo reprimidas há décadas (habitação, saneamento, urbanização de favelas, mobilidade urbana, contenção de áreas de risco). 
Nesse período, foi vivenciado o auge da Coalizão dos Tecnocratas Desenvolvimentistas, que adotaram esses programas e demais estratégias econômicas, visando ao desenvolvimento do país, tendo como um dos pilares articular a movimentação da economia com a equidade.

Durante a segunda fase da coalizão do Governo Federal ocorreu a consolidação da fragmentação e setorialização da política urbana, bem como o fortalecimento da Coalizão dos Políticos e da Coalizão do Mercado, devido ao grande aporte de recursos e investimentos proporcionados pelo Governo Federal. A disponibilidade de recursos para o financiamento das diversas ações de infraestrutura promovidas pelo governo viabilizada pelo PAC e pelo PMCMV passou a ser a principal moeda de troca para a garantia de apoio e mobilização da base aliada do governo.

Também se percebeu nesse período a diminuição do papel do Conselho das Cidades, tanto em função do número de conferências realizadas, já que só houve uma (2010), quanto em função da necessidade de construção de uma PNDU de acordo com os princípios e diretrizes preconizados no período de criação do órgão. As decisões deliberadas pelo ConCidades passaram a ser ignoradas pelo ministro e demais dirigentes que não tinham mais a necessidade de construção de uma PNDU democraticamente. Aqui, o PAC e o PMCMV já funcionavam como as "políticas" prioritárias.

Desde a implementação do presidencialismo de coalizão, este foi o período em que houve a maior taxa de investimentos do Governo Federal, juntamente com a recomposição e o fortalecimento do funcionalismo público em função da ampliação de cargos e de salários, fortalecendo a nomeação de cargos na máquina pública como recurso para barganha política e intermediação de interesses. Essas práticas clientelísticas já existiam na esfera pública brasileira como já apresentado neste Capítulo, contudo, o contexto de investimentos e valorização do setor público promovidos pelo PT abriu novos espaços para as negociações das coalizões que influenciavam a tomada de decisão em âmbito governamental e que tinham a ânsia de ocupar e aparelhar a máquina estatal.

A segunda fase da coalizão se encerra com o enfraquecimento das crenças desenvolvimentistas e o fortalecimento das crenças da Coalizão dos Políticos e da Coalizão do Mercado, justamente pela importância desses recursos. Essas crenças perduraram 
durante toda a terceira fase da grande coalizão do Governo Federal e ficaram até mais acentuadas com a formação da nova coalizão coordenada pelo PMDB e PSDB que se consolidou com a saída do PT. Desse modo, a terceira fase da grande coalizão do Governo Federal praticamente abandonou as crenças da Sociedade Civil e dos Especialistas em função das pressões dos políticos e do mercado pela barganha dos recursos.

A necessidade de financiamento das campanhas eleitorais que garantiam a sobrevivência política da base aliada do governo também existia como uma demanda que precisava ser administrada e atendida. Assim, a grande coalizão do Governo Federal, para se manter mobilizada, requeria, cada vez mais, a disponibilidade de recursos para a barganha política. Em função disso, a Coalizão dos Políticos tinha como um forte aliado a Coalizão do Mercado que poderia fornecer os recursos necessários para custear as campanhas.

Assim, foi sendo consolidada ao longo do tempo uma tríplice aliança entre Estado, mercado e políticos. O mercado precisava do apoio do Estado para se instalar e alavancar seus interesses, o Estado precisava do mercado para executar sua estratégia de desenvolvimento, assim como os políticos dependiam da máquina estatal e do retorno do mercado para o financiamento de campanhas e sua consequente perpetuação no poder.

Essa aliança foi feita em torno do controle de cargos estratégicos na máquina estatal tendo em vista interferir nas regras de contratação de serviços e obras, bem como viabilizar a concessão de outros benefícios. Desse modo, a nomeação de cargos garantia tanto o retorno eleitoral por parte dos beneficiários das ações públicas (obras e serviços) quanto por parte daqueles que executavam as obras e os serviços sob a forma de contribuições para custear as campanhas eleitorais.

Essa é uma questão nevrálgica para entender a razão de a política urbana ser cada vez mais tratada de forma fragmentada e setorializada, uma vez que essa forma de abordar a política favorece o reconhecimento e o beneficiamento de cada mercado que atua neste subsistema de política pública (setor imobiliário, de obras e serviços, proprietários de terras urbanas e de imóveis, agentes financeiros). Quanto mais o mercado alcança os seus ganhos em termos de maximização de lucros, maior será o retorno em forma de contribuições para o financiamento das campanhas políticas. Desse modo, é interessante para a grande 
coalizão do governo que pretende alcançar níveis satisfatórios de governabilidade e de sobrevivência política, deixar prevalecer as crenças da Coalizão dos Políticos e a Coalizão do Mercado.

Naturalmente, em função de suas peculiaridades, o mercado se apropria do espaço urbano como se estivesse diante de uma mercadoria ou de um "locus" que deve estar prioritariamente voltado para a maximização de ganhos financeiros. Esta é a lógica que deve orientar o processo de uso e ocupação do solo, de forma que as funções precípuas que deveriam ser desempenhadas pela cidade ficam em último plano. Quando o mercado está aliado ao Estado e aos atores políticos, o que acontece na maioria das vezes, a sua forma de atuação predatória diante do território fica ainda mais acentuada, visto que, além dos ganhos de capitais que normalmente busca, deverá gerar ganhos ainda maiores para bancar os interesses dos atores políticos.

Em função da intermediação de interesses necessária para a sobrevivência política, a Coalizão dos Tecnocratas Desenvolvimentistas teve sua estratégia aliada às coalizões dos Políticos e do Mercado. Por outro lado, é preciso ressaltar que a coalizão mobilizada pelo PT buscou, de certo modo, satisfazer os anseios das coalizões da Sociedade Civil e dos Especialistas que também faziam parte do grupo de aliados ao governo. Contudo, com o passar do tempo e, devido a mudanças institucionais ocorridas, surgiram condições e oportunidades necessárias para que as demais coalizões passassem a dispor de todos os recursos necessários para viabilizar as barganhas políticas. As instâncias de participação social e o diálogo com os movimentos permaneceram abertos, os programas implementados pelo MCidades mantiveram ações específicas para as populações de baixa renda, a cobertura de saneamento cresceu significativamente no período, além de outras tentativas de atender aos anseios dos Movimentos Sociais Urbanos e dos Especialistas.

Ao se retomar as hipóteses 1, 2, 4, 5 e 10, que foram priorizadas neste estudo, é possível verificar que todas elas foram confirmadas. Observou-se, com relação à hipótese 1 que o alinhamento de aliados e oponentes relativos a crenças tendeu a ser estável ao longo do período (maior que uma década). O que se modificou ao longo do tempo foi o protagonismo das coalizões que foram se sucedendo ao longo do tempo. 
Quanto às hipótese 2, 4 e 5 observou-se que de fato perturbações externas não foram suficientes para produzir mudanças nos atributos fundamentais de um programa governamental enquanto a coalizão que o instituiu permaneceu no poder. Apesar de todas as críticas e mudanças no contexto econômico já em 2014, não existiram intercorrências capazes de impedir o curso do PAC nem do PMCMV que eram as principais estratégias de desenvolvimento adotadas pelo governo. O desenho desses programas e o aporte de recursos apenas foi modificado com a formação da nova coalizão viabilizada pelo PMDB, PSDB e demais aliados.

A hipótese 10 já se comprova no momento de análise da segunda fase da macro coalizão do Governo Federal, ao se verificar que as coalizões dos Movimentos Sociais Urbanos e dos Especialistas perderam força e deram espaço para a ascensão da Coalizão dos Tecnocratas Desenvolvimentistas. Como visto anteriormente, as primeiras coalizões, embora dispusessem de um forte entrosamento ideológico, eram as que dispunham de menos recursos para incorporar suas crenças nas políticas.

A partir de tudo que foi relatado quanto ao movimento das coalizões em busca de seus objetivos, é possível inferir que a política urbana, mesmo em um contexto institucional favorável para sua transformação, como mostra a grandeza do discurso institucional construído ao longo dos anos, viu-se mais uma vez negligenciada pelo fato de o jogo político vigente prevalecer a qualquer tentativa de mudança. Não se pode esquecer que os burocratas que determinam as estratégias macro de desenvolvimento para o país (neste caso a Coalizão dos Tecnocratas Desenvolvimentistas) também fazem parte da Coalizão dos Políticos, precisando de apoio dos aliados para garantir governabilidade e sobrevivência política.

Esse processo político perdura ao longo de muitos anos, sendo este o maior impedimento à profunda transformação da política urbana brasileira. Acreditava-se que um governo constituído por representantes das bases dos movimentos sociais fosse condição necessária e suficiente para a implantação de uma política urbana que preconizasse a equidade e de fato transformasse a realidade das cidades. Contudo, a história mostra que a realidade política brasileira é o gargalo mais desafiador a ser enfrentado. Um desafio ainda maior que a universalização da moradia digna, da melhoria das condições de infraestrutura 
e dos serviços urbanos, devido às instituições explícitas e tácitas que condicionam o jogo político.

Também é importante apontar que muitos atores da classe política e outros que integram o Estado fazem parte de uma elite que costuma comungar de privilégios no âmbito da sociedade, os quais são mantidos pelo controle que estes desempenham no meio social. Inclusive, alguns atores políticos também integram o grupo de agentes que ganham com os mercados disseminados pelo espaço urbano, por possuírem empreendimentos privados em diferentes setores econômicos.

Essa mesma elite não costuma olhar para as necessidades das classes oprimidas pela estrutura social vigente, assim como disseminam a crença de que os problemas das cidades são primordialmente oriundos do crescimento populacional e de uma urbanização desordenada. Assim, não se enxergam como devedores àqueles que foram oprimidos por um modelo de desenvolvimento que promoveu a acentuação das desigualdades sociais e da segregação urbana. Não conseguem enxergar o tamanho da dívida que se tem em relação à população de baixa renda que, desde os primórdios da formação social brasileira, fica à margem dos benefícios que a cidade pode oferecer, devendo ser eles os principais beneficiários da política urbana implementada pelo Estado.

A partir dessas ponderações surgem questionamentos acerca do que se deve esperar dos tempos atuais e futuros com relação às condições a vida urbana no Brasil. O que esperar de uma nova coalizão política que se formou em torno do ideário neoliberal, onde as políticas urbanas vão abandonando os recortes estabelecidos para as populações de baixa renda e se voltando novamente para as populações da classe média que precisam de menos subsídios do governo e podem trazer maiores retornos aos financiamento da casa própria, por exemplo? O que esperar de um Estado que ao invés de ter suas políticas orientadas segundo as demandas sociais relativas às temáticas tratadas por suas pastas tem seu cotidiano voltado para as alianças e negociações inerentes a uma eterna política de coalizão de interesses? O que esperar de uma política urbana cada vez mais setorializada e fragmentada, favorecendo o fatiamento da cidade em nichos de potenciais ganhos econômicos? 
A única resposta que se tem para o momento é que o critério absoluto que rege o estágio atual da política urbana é a sua capacidade de continuar a viabilizar a mobilização das coalizões de interesses e a maximização de lucros que se pode obter a partir do uso do território. Desse modo, fica cada vez mais distante uma PNDU que promova de fato a transformação das cidades brasileiras baseada na gestão democrática e no direito à cidade para todos. Fica mais distante acreditar que um dia vai ser possível sobrepor o interesse público ao privado.

\section{CONCLUSÕES}

No âmbito de diferentes organizações governamentais ainda persiste uma desconfiança velada acerca de pessoas que se dispõem a buscar no meio acadêmico e científico esclarecimentos e respostas sobre a razão de ser dos problemas que prejudicam ou até comprometem o ciclo das políticas públicas empreendidas pelo Estado. Em algumas áreas, existe a crença de que as proposições de abordagens teóricas não são capazes de apontar soluções práticas para os problemas diagnosticados.

Esse pensamento ultrapassado revela uma característica ainda presente em alguns órgãos da Administração Pública brasileira: a cultura de que o aprimoramento técnico e científico não consegue apontar caminhos que sejam capazes de transformar as ações governamentais de forma prática e aplicável. Salienta-se que se trata de um ambiente político, onde a racionalidade a dinâmica de interações entre atores e interesses constitui a orientação maior.

Por essa razão, esta tese nasceu de uma vontade incansável de transpor essas barreiras com o objetivo de realizar uma análise crítica sobre a problemática e as políticas urbanas combinada com um modelo de análise de políticas públicas, tendo em vista entender as razões de o setorialismo ter se consolidado como a forma primordial de se abordar esses assuntos. A ideia de um modelo de desenvolvimento urbano "inadequado" surgiu de forma intuitiva, porém, ao longo do estudo, foram encontradas diversas evidências que comprovaram esta desconfiança, bem como esclareceram algumas das questões estruturais que acentuaram os problemas urbanos ao longo do tempo. 
Embora em cada capítulo da pesquisa tenha sido possível identificar diferentes aspectos essenciais para o enfrentamento da problemática urbana por parte do aparelho estatal e da sociedade, a percepção de que as estratégias econômicas são a principal inspiração para as iniciativas empreendidas pelo Estado para a promoção do desenvolvimento, mostrou-se como um fator de grande relevância que precisa ser considerado. Atribui-se a isso, principalmente, o fato de se ter constatado que a política de desenvolvimento urbano não alcançou a integração à política global de desenvolvimento que seria necessária à sua efetiva implementação.

Para compreender a natureza da problemática urbana e seus respectivos determinantes, buscou-se, no Capítulo 1, conhecer o que a teoria diz a respeito do tema, a partir da leitura de autores marxistas que abordaram o tema com muita propriedade.

A leitura desses autores possibilitou o entendimento de que o estudo dessa temática requer a compreensão de aspectos implícitos, das crises, das tensões e contradições que existem no meio urbano. Os autores acionados na revisão teórica partem da premissa de que as abordagens convencionais (não críticas) apresentam limitações para responder a respeito desses aspectos em função da sua incapacidade de olhar além da lógica que privilegia o crescimento econômico, sendo também inadequadas quanto à abordagem do espaço. Ressaltam a necessidade de adotar uma teoria capaz de integrar as análises do espaço com a das lutas sociais e os processos políticos.

Desse modo, a abordagem crítica teve como desafio desvendar a cidade e a urbanização na busca de uma resposta política apropriada que explicasse os conflitos relativos à reprodução e sobrevivência da força de trabalho no meio urbano. Segundo essa abordagem, a cidade deveria ser compreendida como espaço socialmente produzido, assumindo diferentes configurações, de acordo com os vários modos de organização socioeconômica e de controle político.

Nas obras estudadas, foi apontado pelos autores (Henri Lefebvre, Manuel Castells, David Harvey, Jean Lojkine, Milton Santos) que a concentração de recursos em determinadas classes da sociedade, a dificuldade de acesso ao solo urbano, a segregação sócio-espacial e a questão habitacional constituem consequências de um processo de industrialização/urbanização orientado primordialmente para os ganhos do capital. 
Esses autores apresentaram formulações teóricas que se mostram atuais até o presente momento, ressaltando a complexidade do tema e a necessidade de adotar um método adequado e mais abrangente para analisar as questões urbanas sob diferentes perspectivas, inclusive destacando a abordagem crítica como aquela mais apropriada para esse propósito. As principais discussões contidas nas suas formulações teóricas transitaram em torno de cinco pressupostos centrais: (i) o espaço como conceito básico da problemática urbana; (ii) o método adotado para compreender a problemática urbana; (iii) aspectos políticos da problemática urbana; (iv) o Estado como principal interventor na problemática urbana; (v) temas relevantes para entender a problemática urbana.

Em suas explanações, os autores destacam o espaço urbano como o local onde as relações sociais se reproduzem, sendo repleto de tensões, contradições e conflitos. Santos inova ao afirmar que o uso do espaço é o principal aspecto a definir o território, sendo importante entender que a divisão do trabalho constitui o motor da vida social e da diferenciação espacial.

Segundo os autores, o processo de industrialização / urbanização apresentava mecanismos ocultos de distribuição de renda com um efeito concentrador, que acabou provocando uma situação de segregação urbana. Ressaltam ainda que as disposições diferenciais desses recursos são fonte básica de desigualdade por representarem a capacidade que os indivíduos têm de reagir às mudanças no espaço.

Tinha-se, portanto, o entendimento de que o modelo de desenvolvimento estava baseado na economia de mercado, favorecendo a remuneração do capital e dos que detentores dos meios de produção, tendo como resultado a concentração desses ganhos e a acentuação das desigualdades sociais.

O Estado aparece como um dos atores que interferem na organização do espaço, e, por estar capturado por esses interesses capitalistas, realiza seus investimentos de forma seletiva, tendendo a privilegiar o capital. Assim, atua de forma relevante na difusão da segregação urbana, tornando o quadro ainda mais crítico, e oferece as condições necessárias para a consolidação do sistema de produção capitalista.

A habitação é apontada pelos autores como o centro da dialética conflitual da problemática urbana, configurando o nível mais forte de segregação social. Também foi 
destacada a incapacidade da economia privada em garantir as necessidades mínimas de moradia para as populações de baixa renda por não constituir uma atividade lucrativa para o mercado.

Em função das diversas consequências negativas sobre as cidades, decorrentes do processo de urbanização, surgiu a necessidade da interferência do Estado para implementar ações no sentido de resolver ou minimizar os problemas que passaram a existir no meio urbano. Desse modo, a primeira política urbana foi direcionada ao problema habitacional, por ter sido o primeiro tema a protagonizar uma crise social e ascender à agenda governamental.

Como constatado no Capítulo 2, ao longo do tempo, novas temáticas foram somadas ao discurso institucional na medida em que o Estado passou ater a compreensão das causas, dos efeitos e de algumas interfaces entre a problemática urbana com outros temas, tais como: efeitos deletérios do modelo de desenvolvimento pautado pela lógica econômica, as desigualdades inter e intra-regionais, interfaces com as temáticas ambiental, rural e de ordenamento territorial, relação entre as condições críticas de urbanidade dos grandes centros com os elevados níveis de pobreza, a questão do acesso e do uso do solo, saneamento, transportes, além de outros.

A análise dos discursos das políticas urbanas já produzidas mostrou que a ação estatal é fragmentada e setorializada e prevalecendo ao longo do tempo. A atuação concentrada em três setores: habitação, saneamento e transportes. Muitos são os fatores contribuem para essa situação: historicamente, a percepção dos problemas urbanos se deu em torno de temas isolados, na medida em que iam se manifestando no espaço; prevalência de um padrão de pensamento departamentalizado e fragmentado na execução da ação pública; atuação dos atores que priorizam os interesses dos setores (habitação, saneamento, transportes).

Além dessa percepção, verificou-se que nenhum dos discursos das políticas já preconizadas, nem os planos concebidos, desde seus antecedentes, consideraram o espaço como conceito básico da problemática urbana. Em todos os documentos analisados prevaleceu a ótica setorial que prioriza as ações em torno das políticas setoriais de habitação, saneamento e transportes, posteriormente denominada de mobilidade urbana. 
As análises realizadas no Capítulo 3 possibilitaram o aprofundamento acerca das condições de urbanidade que os grandes centros urbanos apresentam e também com relação à execução das ações implementadas pelo MCidades em cada uma das políticas setoriais estudadas (habitação, saneamento e mobilidade). Além disso, apontaram algumas evidências que comprovam a consolidação da abordagem setorialista como o "modus operandi" da política urbana e sua perpetuação no tempo. Fazendo com que, de fato, a soma dessas políticas setoriais tenha assumido o lugar de uma política de desenvolvimento urbano brasileira.

O panorama da habitação no Brasil relativo à década mais recente foi analisado a partir diferentes indicadores, tais como: a evolução do déficit absoluto para o Brasil e regiões, no período de 2004 a 2014; a composição do déficit habitacional para o Brasil e regiões no período de 2004 a 2014, segundo as quatro variáveis que o compõem; a inadequação dos domicílios para Brasil e regiões no período de 2004 a 2014; a comparação entre o déficit total absoluto e o número de domicílios vagos no Brasil no período de 2004 a 2014; o percentual do déficit urbano por faixa de renda no Brasil no período de 2004 a 2014; a população em aglomerados subnormais no Brasil em 2000 e 2010.

As referidas análises mostram que a situação desse setor no Brasil ainda é um grande desafio a ser enfrentado, apesar de todos os esforços já empreendidos. O déficit habitacional voltou a crescer em 2013, após vivenciar um período de queda desde 2004, tendo como principais componentes a coabitação familiar e o ônus excessivo com aluguel. Também se destaca que a pior situação se encontra nas metrópoles da região Sudeste e no Nordeste, que é assolado pelos mais altos índices de pobreza do país. Com relação à inadequação dos domicílios que não fazem parte do universo daqueles que são computados no cálculo do déficit habitacional, verifica-se que a principal justificativa para a situação ocorre em função da carência de infraestrutura.

O estudo também mostra que a relação entre o déficit habitacional total absoluto e o quantitativo de domicílios vagos, a partir de 2008, vem piorando, mostrando que os esforços para a construção de novas unidades habitacionais têm sido concentrados na produção de habitações voltadas para um público alvo que não integra o déficit. Ressaltase que desde os primórdios da série histórica de apuração do déficit habitacional, verificase sua concentração prioritariamente na faixa de renda de até três salários mínimos. 
O panorama do saneamento básico no Brasil apresentou uma situação menos crítica do que a de habitação, mostrando que a cobertura de abastecimento de água, esgotamento sanitário e coleta de resíduos sólidos aumentaram no Brasil e em todas as regiões. Por outro lado, alguns gargalos ainda permanecem, uma vez que a região Norte continua a apresentar os piores indicadores de saneamento do Brasil, seguida do Nordeste, assim como a cobertura de esgotamento sanitário ainda é em torno de $61 \%$.

Com relação à mobilidade urbana, o panorama apresentado mostra que os incentivos ao uso de automotores ainda constitui a principal estratégia governamental para a solução do transporte no Brasil, como mostra o crescimento constante da produção da frota de veículos automotores e da taxa de motorização no país.

Pelas análises realizadas, foi possível constatar que o problema do transporte público no Brasil ainda se apresenta muito precário e requer mais investimentos, além da adoção de novas alternativas técnicas para sua solução. A partir das informações acerca da divisão modal de algumas capitais do país e também em função da análise dos indicadores sobre a extensão de BRTs e de metrôs, verifica-se que as opções para o transporte público coletivo de qualidade ainda são muito escassas. Em função disso, uma das consequências negativas que incidem na sociedade é o fato de o tempo gasto no deslocamento casa / trabalho ainda ser um grande desafio a ser superado.

Com relação ao panorama recente dos investimentos realizados na implantação das políticas setoriais de habitação, saneamento e mobilidade urbana, percebe-se que ocorre o crescimento significativo a partir de 2007, com o PAC. Embora o aporte de recursos para financiar as ações do Ministério tenha crescido de forma impactante, ainda prevalece a supremacia institucional e a priorização dos interesses da $\mathrm{SNH}$ com relação às demais secretarias, sendo ínfimos os investimentos implementados pela SNAPU, que é a unidade responsável pela implementação das ações relativas aos instrumentos propostos no Estatuto da Cidade.

A análise da ação desenvolvida pelo Ministério das cidades também possibilitou verificar que os temas levantados nos debates teóricos e conceituais relativos à problemática urbana não são explorados com a mesma importância no momento da prática como o são nos discursos, já que as temáticas que fazem parte dos discursos não estão 
contempladas na íntegra no momento da ação. Outro aspecto relevante com relação ao formato da política urbana brasileira é o deslocamento entre as fundamentações teóricas que justificaram a construção dos discursos políticos e institucionais e as ações orçamentárias e os programas elencados para viabilizar as políticas urbanas.

Também é importante enfatizar a relevância do FGTS como a principal fonte de recurso que financia as políticas urbanas implementadas pelo Ministério das Cidades. Esse fato, juntamente com a atuação da Caixa Econômica como o agente financeiro e operador das ações fortalece a lógica setorial e financeira da ação pública, permitindo a priorização da ótica privada. Primeiro, por se tratar de um recurso oneroso (empréstimo) e, segundo, pelo fato de a Caixa ser uma instituição que prioriza a visão financeira dos recursos. É sabido que esse mesmo equívoco na forma de operacionalizar a implementação da política urbana foi apontado na época do BNH.

Os desdobramentos disso em cada política setorial podem ser elencados da seguinte forma: (i) o maior volume de recursos alocado na política de habitação está voltado para a população de maior renda (SBPE) fazendo persistir o déficit mesmo com o aumento significativo de recursos pelo poder público; (ii) a política de saneamento está se voltado para o setor privado, buscando parcerias privadas e subvertendo a lógica de direito humano; (iii) a política de mobilidade urbana vem sendo mais solicitada em termos de transportes de uso coletivo mais recentemente, devido à pressão das manifestações sociais mais recentes (2013), porém não abandonou a priorização ao uso de automóveis como a principal forma de transporte da população; (iv) as ações de planejamento urbano e a implementação do princípio da função social da cidade não fazem parte das ações governamentais por se situarem na contramão da financeirização da terra e dos ganhos econômicos com as ações que se desenvolvem nas cidades.

Assim, no caso das políticas setoriais de habitação, saneamento e mobilidade, percebe-se a influência constante dos interesses empresariais do mercado imobiliário, da construção civil e da indústria automobilística, além de outros segmentos, atuantes para a manutenção da forma setorializada de intervir no urbano. E isso se deve, principalmente, ao fato de essa condição favorecer os ganhos privados e a captura dos agentes públicos. 
Desse modo, verifica-se que a política de desenvolvimento urbano padece de dois problemas centrais, sendo o primeiro, a prevalência da visão setorial e fragmentada acerca da problemática e da política urbana sem considerar o espaço como conceito básico da problemática urbana, e o segundo, relativo à atuação dos atores que se beneficiam com a manutenção da ação setorializada.

Para entender o comportamento dos atores que participam ou influenciam o processo de tomada de decisão no ciclo da política urbana, aplicou-se no Capítulo 4 o Modelo de Coalizões de Defesa no subsistema desta política, considerando o período de ação do MCidades, compreendido entre o ano de sua criação, 2003 até 2016. Buscou-se com isso, identificar, analisar e explicar as mudanças e as permanências que moldaram a política urbana após a criação do órgão, levando em conta que no atual contexto políticoinstitucional brasileiro são vários os atores e interesses a serem coordenados e processados na execução de uma política pública.

A análise desse processo possibilitou a identificação de pelo menos cinco coalizões, de defesa que se configuraram segundo suas crenças e recursos: (i) Coalizão dos Movimentos Urbanos, (ii) Coalizão dos Especialistas, (iii) Coalizão dos Tecnocratas Desenvolvimentistas, (iv) Coalizão dos Políticos e (v) Coalizão do Mercado. A análise das crenças dessas coalizões, juntamente com a verificação das interferências promovidas por eventos externos e mudanças institucionais observados durante o período de mobilização da macro coalizão política que se manteve no poder entre 2003 e 2015, permite o entendimento acerca das crenças que de fato orientaram as decisões e as práticas adotadas no âmbito da política urbana.

Percebeu-se ainda, que, ao longo do período estudado, as crenças da Coalizão dos Movimento Sociais Urbanos e dos Especialistas prevaleceu logo após a criação do Ministério das Cidades, sendo substituídas, posteriormente, pelas crenças da Coalizão dos Tecnocratas Desenvolvimentistas. Destaca-se que a adoção do PAC e do PMCMV como políticas anticíclicas do governo e configuradas como as estratégias prioritárias do Governo Federal voltadas para o desenvolvimento, foi o principal fator que abriu espaço para o fortalecimento das crenças desenvolvimentistas. 
É preciso ressaltar que, paralelamente ao processo técnico de discussão das políticas públicas e das diretrizes que o Ministério das Cidades deveria seguir para a implementação da política urbana preconizada na sua criação, existia o movimento político de ajustes na grande coalizão do Governo Federal que vivenciava um constante processo de negociação de conflitos. Esse aspecto é relevante visto que a governabilidade do Presidente da República e sua sobrevivência política dependem, necessariamente, dos acordos firmados com a base aliada do governo.

Nesse caso, para manter-se no poder, os agentes políticos fazem uso dos principais recursos disponíveis para garantir a estabilidade da coalizão: divisão de cargos, alocação de verbas do orçamento, acordos sobre determinados assuntos que envolvem as políticas públicas, além de outros aspectos de menor impacto no processo decisório, mas não menos importantes.

As análises apontaram que a necessidade de financiamento das campanhas eleitorais que garantiam a sobrevivência política da base aliada do governo também existia como uma demanda que precisava ser administrada e atendida, o que se apresentou como o principal fator a favorecer a ascensão das crenças dos políticos e do mercado em detrimento das crenças desenvolvimentistas. Constata-se que, a grande coalizão do Governo Federal, para manter-se mobilizada, requereu, cada vez mais, a disponibilidade de recursos para efetuar barganhas políticas e negociações com a base aliada para se manter no poder.

Nesse contexto, a Coalizão dos Políticos juntamente com a Coalizão do Mercado eram as que dispunham de mais recursos para viabilizar as barganhas, o que as conferia certa superioridade de forças com relação à Coalizão dos Movimentos Sociais Urbanos e a Coalizão dos Especialistas.

Os fatos mostraram que ao longo do tempo foi consolidada uma tríplice aliança entre Estado, mercado e políticos. O mercado precisava do apoio do Estado para se instalar e alavancar seus interesses, o Estado precisava do mercado para executar sua estratégia de desenvolvimento, assim como os políticos dependiam da máquina estatal e do retorno do mercado para o financiamento de campanhas e sua consequente perpetuação no poder. 
Essa aliança foi feita em torno do controle de cargos estratégicos na máquina estatal tendo em vista interferir nas regras de contratação de serviços e obras, bem como viabilizar a concessão de outros benefícios. Desse modo, a nomeação de cargos garantia tanto o retorno eleitoral por parte dos beneficiários das ações públicas (obras e serviços) quanto por parte daqueles que executavam as obras e os serviços sob a forma de contribuições para custear as campanhas eleitorais.

Essa é uma questão nevrálgica para entender a razão de a política urbana ser cada vez mais tratada de forma fragmentada e setorializada, uma vez que essa forma de abordar a política favorece o reconhecimento e o beneficiamento de cada mercado que atua neste subsistema de política pública (setor imobiliário, de obras e serviços, proprietários de terras urbanas e de imóveis, agentes financeiros). Quanto mais o mercado alcança os seus ganhos em termos de maximização de lucros, maior será o retorno em forma de contribuições para o financiamento das campanhas políticas. Desse modo, é interessante para a grande coalizão do governo que pretende alcançar níveis satisfatórios de governabilidade e de sobrevivência política, deixar prevalecer as crenças da Coalizão dos Políticos e a Coalizão do Mercado.

A partir de tudo que foi relatado quanto ao movimento das coalizões em busca de seus objetivos, é possível inferir que a política urbana, mesmo em um contexto institucional favorável para sua transformação, como mostra a grandeza do discurso institucional construído ao longo dos anos, viu-se mais uma vez negligenciada pelo fato de o jogo político vigente prevalecer a qualquer tentativa de mudança. Não se pode esquecer que os burocratas que determinam as estratégias macro de desenvolvimento para o país (neste caso a Coalizão dos Tecnocratas Desenvolvimentistas) também fazem parte da Coalizão dos Políticos, precisando de apoio dos aliados para garantir governabilidade e sobrevivência política.

Esse processo político perdura ao longo de muitos anos, sendo este o maior impedimento à profunda transformação da política urbana brasileira. Acreditava-se que um governo constituído por representantes das bases dos movimentos sociais fosse condição necessária e suficiente para a implantação de uma política urbana que preconizasse a equidade e de fato transformasse a realidade das cidades. Contudo, a história mostra que a realidade política brasileira é o gargalo mais desafiador a ser enfrentado. Um desafio ainda 
maior que a universalização da moradia digna, da melhoria das condições de infraestrutura e dos serviços urbanos, devido às instituições explícitas e tácitas que condicionam o jogo político.

Depois de percorrer o caminho desta tese consigo compreender mais profundamente o porquê de a crise habitacional ter se destacado como o problema mais urgente a ser enfrentado nos primórdios da política urbana. Trata-se da face mais perversa da problemática urbana, na medida em que revela, logo de partida, que a cidade é segregada e não está disponível para todos. O acesso ao solo urbano condicionado ao poder de compra de uma pessoa é apenas uma das evidências de que existir nos grandes centros urbanos custa muito caro, sendo remota a possibilidade de que a infinidade de indivíduos que vivem nessas áreas tenham assegurados os fatores básicos e essenciais à manutenção da vida humana.

Nesse contexto, não é apenas a ausência de moradia digna que se deixa de usufruir. $\mathrm{O}$ acesso limitado à terra urbana também pressupõe que uma gama de outros direitos e oportunidades são inviabilizados, visto que a localização onde uma pessoa reside pode dizer muito sobre suas potenciais oportunidades na sociedade. A exposição a doenças de veiculação e origem hídrica, a dificuldade em transitar livremente e até de realizar a atividade corriqueira de se deslocar de casa para o trabalho, a exposição aos perigos de se habitar áreas de risco e de altos índices de violência, são apenas alguns dos desafios do cotidiano das populações que vivem em áreas precárias, na tentativa de se fixar em algum lugar e sobreviver à vida urbana. Essas populações estão sempre à margem dos ganhos de desenvolvimento inerentes à cultura de modernidade e de vida promissora que está associada à vida na cidade.

Desse modo, o papel da política de desenvolvimento urbano não se restringe apenas a dotar as cidades de infraestrutura, equipamentos e serviços que possam prover espaços públicos de melhor qualidade. Deveria, acima de tudo, promover transformações mais profundas na inadequação do meio urbano, visando à construção de espaços mais democráticos e voltados para os aspectos mais humanos da sociedade. As cidades não podem ser vistas apenas como receptáculos de coisas e pessoas, tampouco como um campo fértil de diferentes mercados. No fundo, a cidade alimenta a alma da vida urbana e sustenta 
a essência da própria sociedade, assim como também pode ser ponto de partida para uma humanidade menos superficial e materialista.

E mesmo que a lógica de "políticas anticíclicas" instituídas para reestabelecer o capital em tempos de crise, juntamente com a defesa da propriedade privada continuem a fazer parte da estratégia estatal no conduzir das políticas urbanas, assim como a subordinação do interesse público ao privado e o não enfrentamento da questão fundiária se apresentem como entraves à função social da propriedade, não há como pensar em cidades "urbanizadas" sem se modificar as bases da ordem social dominante.

Essa situação se torna ainda mais trágica frente às evidências de um sistema político corrompido, impregnado de interesses escusos e voltado primordialmente para os ganhos econômicos que a cidade pode produzir, associado a uma atuação estatal superficial e "curativa". A manutenção desse "modus operandi" do Estado aponta que os resultados a serem alcançados pela política de desenvolvimento urbano brasileira tenderão a se manifestar de forma limitada, continuando a produzir um espaço segregado e muito distante do ideário associado à proposta de desenvolvimento e modernidade que se consolidou em torno do urbano.

Assim, os questionamentos, as análises, as proposições e os diferentes olhares apresentados nesta tese são apenas uma singela tentativa de ampliar o debate em torno da problemática e da política de desenvolvimento urbano, bem como contribuir para a construção do conhecimento técnico e científico sobre o tema. 


\section{Referências Bibliográficas}

ABRANCHES, S. H. H. (2016). Clientelismo, petróleo e corrupção no presidencialismo de coalizão. Ecopolítica,11 março, 2016.

ABRANCHES, S. H. H. (1988). Presidencialismo de coalizão: o dilema institucional brasileiro. Revista de Ciências Sociais, Rio de Janeiro, vol. 31, nº 1, 1988.

ARAÚJO, S. M. V. G. (2013). Política ambiental no Brasil no período 1992-2012: um estudo comparado das agendas verde e marrom. Tese de doutorado - Instituto de Ciência Política, Universidade de Brasília. 2013.

AZEVEDO, S. (1996). A crise da política habitacional: dilemas e perspectivas para o final dos anos 90. In. AZEVEDO, Sérgio de; ANDRADE, Luis Aureliano G. de (orgs.). A crise da moradia nas grandes cidades - da questão da habitação à reforma urbana. Rio de Janeiro: Editora UFRJ, 1996.

AZEVEDO, S. (1988). Vinte anos de política de habitação popular (1964-86): criação, trajetória e extinção do BNH. Revista de Administração Pública, Rio de Janeiro, 22(4):107-119, out/dez, 1988.

BACEN (2011). Banco Central do Brasil. Estatísticas Básicas do BACEN (SFH - SBPE). Banco de dados.

BARBOSA, B. e MAIA, G. (2017). Lava Jato: Fachin abre inquérito contra ministros e parlamentares. Notícia divulgada no portal uol.com.br em 12/04/2017. Em: <http://noticias.uol.com.br/politica/ultimas-noticias/2017/04/11/lava-jato-fachin-abreinquerito-contra-ministros-senadores-e-deputados-diz-jornal.htm

BASSUL, J. R. (2010). Estatuto da cidade: a construção de uma lei. In: CARVALHO, C. S.; ROSSBACH, A. (orgs.). O estatuto da cidade: comentado. São Paulo: Ministério das Cidades/ Aliança das Cidades, 2010, pp.71-90.

BASTOS, P. P. Z. (2012). A economia política do novo-desenvolvimentismo e do social desenvolvimentismo. Economia e Sociedade (UNICAMP. Impresso), v. 21, p. 779-810, 2012.

BERNARDES, L. (1986). Política urbana: uma análise da experiência brasileira. Análise e Conjuntura, Belo Horizonte, 1(1): 83-119, jan/abr. 1986.

BID (2007). A política das políticas públicas: progresso econômico e social na América Latina: relatório 2006 / Banco Interamericano de Desenvolvimento e David Rockefeller Center for Latin America Studies, Harvard University; tradução Banco Interamericano de Desenvolvimento. - Rio de Janeiro: Elsevier; Washington, DC: BID, 2007.

BIN, D. e Castor, B. V. J. (2007). Racionalidade e política no processo decisório: estudo sobre orçamento em uma organização estatal. RAC, v. 11, n. 3, Jul/Set 2007: 35-5. 
BOARIN, P. V. (2015). O lobby dos grupos de interesse e a política comercial internacional no Brasil: estratégias de influência diferentes para uma política diferente? In: I Seminário Internacional de Ciência Política Universidade Federal do Rio Grande do Sul Estado e Democracia em Mudança no Século XXI, Porto Alegre, 9 a 11 de setembro de 2015.

BOITO, A. (2012). As bases políticas do neodesenvolvimentismo. Trabalho apresentado na edição de 2012 do Fórum Econômico da FGV, São Paulo. Disponível em <http://eesp.fgv.br/sites/eesp.fgv.br/files/file/Painel\%203\%20\%20Novo\%20Desenv\%20B R\%20-\%20Boito\%20-\%20Bases\%20Pol\%20Neodesenv\%20-\%20PAPER.pdf >. Acesso em 15 jan 2017.

BONDUKI, N. G. (2009a). Do Projeto Moradia ao Minha Casa, Minha Vida. Teoria e Debate, São Paulo, n. 82, p. 8-14, mai./ jun. 2009.

BONDUKI, N. (2009b). Política Habitacional e inclusão social no Brasil: revisão histórica e novas perspectivas no governo Lula. Estado, Planejamento e Políticas Públicas. Brasília, IPEA. 2009.

BONDUKI, N. G. (1994). Origens da habitação social no Brasil. In: Análise Social, vol. XXIX (127), 1994, (3º, pp. 711-732.

BOTEGA, L. R. (2008). A política habitacional no Brasil (1930-1990). In: Periódico de divulgação científica da FALS, ano I, nº 2, março / 2008. 14 p.

BRANDÃO, Arnaldo Barbosa. Problemas de teoria e metodologia na questão da habitação. Projeto: arquitetura, planejamento, desenho industrial, construção. São Paulo, no 66, p. 102-108, ago. 1984.

BRASIL (2016) O desafio da Mobilidade urbana. Câmara dos Deputados, Centro de Estudos e Debates Estratégicos Consultoria Legislativa. Estudos Estratégicos 7. Brasília, 2016. 348 p.

BRASIL (2016). Decreto $\mathrm{n}^{\circ}$. 8.927, de 8 de dezembro de 2016. Aprova a Estrutura Regimental e o Quadro Demonstrativo dos Cargos em Comissão e das Funções de Confiança do Ministério das Cidades, remaneja cargos em comissão e substitui cargos em comissão do Grupo-Direção e Assessoramento Superiores - DAS por Funções Comissionadas do Poder Executivo - FCPE.

BRASIL (2013). Câmara dos deputados, Comissão de Desenvolvimento Urbano, transcrição da audiência pública: construção de conjuntos habitacionais pelo Programa Minha Casa, Minha Vida em áreas inadequadas, documento $n^{\circ}$ 0799/13. Brasília, 19 de junho de 2013.

BRASIL (2012). Lei Federal $n^{\circ}$. 12.587, de 3 de janeiro de 2012. Institui as diretrizes da Política Nacional de Mobilidade Urbana e dá outras providências.

BRASIL (2012). Câmara dos Deputados, Comissão de Desenvolvimento Urbano, transcrição da audiência pública: debate sobre o andamento do Programa Minha Casa, Minha Vida, documento no 0304/12. Brasília, 11 de abril de 2012. 
BRASIL (2011a). Câmara dos Deputados, Comissão de Desenvolvimento Urbano, transcrição de Seminário sobre o tema Mobilidade Urbana, documento $n^{\circ}$ 2098/11. Brasília, 07 de dezembro de 2011.

BRASIL (2011b). Câmara dos Deputados, Comissão de Desenvolvimento Urbano, transcrição da conferência de abertura da XII Conferência das Cidades, documento $\mathrm{n}^{\circ}$ 2018/11. Brasília, 30 de novembro de 2011.

BRASIL (2011c). Câmara dos Deputados, Comissão de Desenvolvimento Urbano, transcrição da audiência pública: debate sobre a versão preliminar do Plano Nacional de Saneamento Básico, documento nº 0529/11. Brasília, 18 de maio de 2011.

BRASIL (2010). Ministério do Planejamento, Orçamento e Gestão (2010). Programa de Aceleração do Crescimento: balanço do PAC 2007-2010. Brasília, 2010, 232 p.

BRASIL (2009). Lei $n^{\circ} 11.977$, de 7 de julho de 2009. Dispõe sobre o Programa Minha Casa, Minha Vida - PMCMV e a regularização fundiária de assentamentos localizados em áreas urbanas.

BRASIL (2008). Manual de BRT Bus Rapid Transit - Guia de Planejamento. Tradução de Arthur Szász, a partir da $3^{\mathrm{a}}$ edição (junho de 2007) do BRT Planning Guide. Publicado por Institute for Transportation \& Development Policy. Brasília, dezembro 2008. 898 p.

BRASIL (2007). Lei Federal $n^{\circ}$. 11.445, de 5 de janeiro de 2007. Estabelece diretrizes nacionais para o saneamento básico e dá outras providências.

BRASIL, (2007). Decreto $\mathrm{n}^{\circ}$ 6.025, de 22 de janeiro de 2007, que institui o Programa de Aceleração do Crescimento (PAC). Presidência da República, Casa Civil.

BRASIL (2007). Ministério do Planejamento, Orçamento e Gestão (2007). Programa de Aceleração do Crescimento: Medidas Institucionais. Brasília, 22 de janeiro de 2007. 82 slides. Apresentação em Power Point.

BRASIL (2006). Decreto $\mathrm{n}^{\circ} 5.790$ de 25 de maio de 2006. Dispõe sobre a composição, estruturação, competências e funcionamento do Conselho das Cidades - ConCidades, e dá outras providências.

BRASIL (2005). Lei Federal no n $^{\text {11.124, de } 16}$ de junho de 2005. Dispõe sobre o Sistema Nacional de Habitação de Interesse Social - SNHIS, cria o Fundo Nacional de Habitação de Interesse Social - FNHIS e institui o Conselho Gestor do FNHIS.

BRASIL (2003). Decreto $\mathrm{n}^{\circ}$. 4.665, de 3 de abril de 2003. Aprova a estrutura Regimental e o Quadro Demonstrativo de Cargos em Comissão do Ministério das Cidades e dá outras providências.

BRASIL (2001). Lei Federal n ${ }^{\circ} 10.257$ de 10 de julho de 2001. Regulamenta os artigos. 182 e 183 da Constituição Federal, estabelece diretrizes gerais da política urbana e dá outras providências. 
BRASIL (1999). Plano de Ação para o Desenvolvimento Urbano 1999-2003. Secretaria de Estado de Desenvolvimento Urbano. Presidência da República. Brasília, DF, 1999. 48 p.

BRASIL (1991). Brasil: Um Projeto de Reconstrução Nacional 1990-1995. Brasília, DF, 1991. $138 \mathrm{p}$.

BRASIL (1987). Programa de Ação Governamental 1987-1991. Secretaria de Planejamento e Coordenação. Brasília, DF, 1987. 304 p.

BRASIL (1986). Lei $\mathrm{n}^{\circ}$ 7.486, de 06 de junho de 1986. I Plano Nacional de Desenvolvimento da Nova República (1986-1989).

BRASIL (1979). Resolução no ${ }^{\text {1, de }} 05$ de dezembro de 1979, Aprovações do Congresso nacional. III Plano Nacional de Desenvolvimento (1980-1985).

BRASIL (1974). Lei $\mathrm{n}^{\circ}$ 6.151, de 04 de dezembro de 1974. II Plano Nacional de Desenvolvimento (1975-1979).

BRITO, M. F. (2012). A visão contábil da sociedade ou os limites da Política Nacional de Desenvolvimento Urbano. Universidade de Brasília, Faculdade de Arquitetura e Urbanismo, Programa de Pós-Graduação em Arquitetura e Urbanismo, 2012. 170 p.

CALANDRO, M. (2000). A indústria automobilística brasileira: integração produtiva no Mercosul, regimes automotivos e perspectivas. Revista Eletrônica FEE, Porto Alegre, v. 28, n. 1, p. 116-136, 2000.

CALDAS, M. F. (2015). Política urbana, ação governamental e a utopia da reforma urbana no Brasil. Tese de doutorado, Universidade Federal de Minas Gerais, Escola de Arquitetura, 2015. $271 \mathrm{p}$.

CARDOSO, F. H. (1994). Mãos à Obra Brasil: proposta de governo. Brasília: [s. n.], 1994. $131 \mathrm{p}$.

CARDOSO, F. H. (1998). Avança Brasil: proposta de governo. Brasília: [s. n.], 1994. 172 p.

CARVALHO, C. H. R (2016). Desafios da mobilidade urbana no Brasil. Texto para discussão 2198 - Instituto de Pesquisa Econômica - Brasília: Rio de Janeiro: IPEA, maio de 2016.

CASTELLS, M. (2014). A questão urbana. Tradução Arlene Caetano, 6 ${ }^{a}$ edição, São Paulo: Paz e Terra, 2014.

CEF (2009). Caixa Econômica Federal. Relatório executivo - Demandas de habitação no Brasil. Brasília: CEF, 2009.

CINTRA, A. O. (1978). Planejando a cidade: política ou não política. In: CINTRA, A. O. e HADDAD, P. R. (org.). Dilemas do Planejamento Urbano e Regional no Brasil. Rio de Janeiro: Zahar Editores, 1978. 
Conselho Curador do FGTS (2016). Contratações com recursos do FGTS. Caixa Econômica Federal. Elaboração de banco de dados - CBIC. Conselho Curador do FGTS, Brasília, 2016.

COPLE, A. C.; SANTOS, C.; COUTINHO, L. R. S.; QUELES, P., FREITAS, C. (2009). O PAC de 1,15 Trilhões de reais: um modelo desenvolvimentista? - notas para debate. In: IV Jornada Nacional de Políticas Públicas. Neoliberalismo e lutas sociais: perspectivas para as políticas públicas, 25 a 28 de agosto de 2009, São Luís / MA.

COSTA, A. M.; PONTES, C. A. A.; MELO, C. H.; LUCENA, R. C. B.; GONÇALVES, F. R.; GALINDO, E. F. (2002). "Classificação de doenças relacionadas a um saneamento ambiental inadequado (DRSAI) e os sistemas de informações em saúde no Brasil: possibilidades e limitações de análise epidemiológica em saúde ambiental." In: XXVIII Congreso Interamericano de Ingenieria Sanitaria y Ambiental, Cancún, Mexico, 27 al 31 de outubro, 2002.

DUARATE, M. P. L. (2013). O governo Vargas e as primeiras tentativas do Estado na provisão de habitação popular. In: XXIII Simpósio Nacional de História - Conhecimento Histórico e Diálogo Social. Natal/RN, 22 a 26 de julho 2013. ANPUH Brasil.

EVERS, T. et al. (1982). Movimentos de bairro e Estado: lutas na esfera da reprodução na América Latina. In: VARIOS. Cidade, povo e poder. Rio de Janeiro, CEDEC/Paz e Terra, n. 5, 1982.

FERREIRA, F. C. F. (2011). A reforma urbana, o Estatuto das Cidades e os planos diretores. In: Políticas públicas e direito à cidade: programa interdisciplinar de formação de agentes sociais e conselheiros municipais / Orlando Alves dos Santos Junior, Ana Carolina Christovão, Patrícia Ramos Novaes, organizadores.- Rio de Janeiro: Letra Capital: Observatório das Metrópoles: IPPUR/UFRJ, 2011.

FRANCISCONI, J. G. e SOUZA, M. A. A. de (1976). Política Nacional de Desenvolvimento Urbano: Estudos e Proposições Alternativas. Série Estudos para o planejamento, n. 15, Brasília, 1976.

FRANCO NETTO, G.; FREITAS, C. M.; Andahur, J. P.; Pedroso, M. de M.; Rohlfs, D. B. (2009). "Impactos socioambientais na situação de saúde da população brasileira: Estudo de indicadores relacionados ao saneamento ambiental inadequado". In: Tempus. Actas em Saúde Coletiva, vol. 4, n. 4, p. 53-71. 2009.

FREITAS, C. M. e PORTO, M. F. S. (2006). Saúde, ambiente e sustentabilidade. Rio de Janeiro: Editora FIOCRUZ, 2006.

GALVÃO JUNIOR, A. C. (2009). "Desafios para a universalização dos serviços de água e esgoto no Brasil.” Rev Panam Salud Publica. 2009; 25(6):548-56.

GOMIDE, A. de A. e PIRES, R. R. C. (2015). Análise Comparativa: arranjos de implementação e resultados de políticas públicas. In: Capacidades estatais e democracia: arranjos institucionais de políticas públicas. Brasília: Ipea, 2014. Disponível em: http://repositorio.ipea.gov.br/bitstream/11058/3098/1/Livro_Capacidades\%20estatais\%20e 
$\% 20 \mathrm{democracia} \_$arranjos\%20institucionais\%20de $\% 20$ pol\%C3\%ADticas $\% 20 \mathrm{p} \% \mathrm{C} 3 \% \mathrm{BAb}$ licas.pdf. Acesso em: 25 jun. 2015.

GONÇALVES, M. F. (2017). Delatores citam esquema de empreiteiras com governo desde os anos 1940. Por que a década é referência. Notícia divulgada no portal expresso.com.br em 14/03/2017. Em: <https://www.nexojornal.com.br/expresso/2017/03/14/Delatores-citam-esquema-deempreiteiras-com-governo-desde-os-anos-1940.-Por-que-a-d\%C3\%A9cada-\%C3\%A9refer\%C3\%AAncia

GOULART, D. C. (2011). O anticapitalismo do Movimento dos Trabalhadores Sem-Teto - MTST. Tese apresentada ao Programa de Pós-Graduação em Ciências Sociais da Faculdade de Filosofia e Ciências da Universidade Estadual Paulista - Campus Marília como requisito para obtenção do título de doutor. Marília / SP, 2011.

GUIMARÃES, M. C. R. (2013). A questão urbana na dinâmica de reprodução capitalista. In: Argumentum, Vitória (ES), v. 5, n. 1, p. 180-196, jan/jun 2013.

HARVEY, D. (1996). In: Do gerenciamento ao empresariamento: a transformação da administração urbana no capitalismo tardio. Espaço \& Debates, no 39, p. 48-64, 1996.

HARVEY, D. (1980). A justiça social e a cidade. Prefácio e tradução de Armando Corrêa da Silva.São Paulo, editora Hucitec, 1980. 291 p.

HELLER, L. (1998). "Relação entre saúde e saneamento na perspectiva do desenvolvimento.” In: Ciência \& Saúde Coletiva, 3(2):73-84, 1998.

HELLER, L. e CASTRO, J. E. (2007). "Política pública de saneamento: apontamentos teóricoconceituais.” In: Engenharia Sanitária e Ambiental Vol.12 - No 3 - jul/set 2007, 284295.

HERNANDES, P. P. (2011). Combate à corrupção no Brasil: análise sob a ótica da economia da corrupção. Prevenção e combate à corrupção no Brasil: $6^{\circ}$ Concurso de monografias: trabalhos premiados / Presidência da República, Controladoria-Geral da União. Brasília: CGU, 2011.

HOWLETT, M. e Ramesh, M.; P., A. (2013). Política pública: seus ciclos e subsistemas: uma abordagem integradora / Michael Howlett, M. Ramesh, Anthony Perl; tradução técnica Francisco G. Heidemann. Rio de Janeiro: Elsevier, 2013.

JACOBI P. R. (1987). Movimentos sociais urbanos numa época de transição. In: SADER, E. (org). Movimentos sociais na transição democrática. São Paulo: Cortez, 1987.

JACOBI, P. R. (1980). Movimentos sociais urbanos no Brasil. Boletim Informativo e Bibliográfico de Ciências Sociais, BIB. Rio de Janeiro, nº 9,1980, p. 221-236.

JARDIM, M. C. (2015). A construção social do mercado de trabalho no setor de construção civil nas obras do Programa de Aceleração do Crescimento (PAC): consensos e conflitos. In: Revista Sociedade e Estado, Volume 30, Número 1, Janeiro/Abril 2015. 
JENKINS-SMITH, H.C. e SABATIER. P.A. (1994). Evaluating the advocacy coalition framework. Journal of Public Policy. v. 14, n. 2, 1994.

JOÃO PINHEIRO, F. (2016). Centro de Estatística e Informações. Déficit habitacional no Brasil 2005 / Fundação João Pinheiro, Centro de Estatística e Informações. - Belo Horizonte, 2006. 94p.

JOÃO PINHEIRO, F. (2015). Centro de Estatística e Informações. Déficit habitacional no Brasil 2005 / Fundação João Pinheiro, Centro de Estatística e Informações. - Belo Horizonte, 2006. 128p.

JOÃO PINHEIRO, F. (2013). Centro de Estatística e Informações. Déficit habitacional no Brasil 2005 / Fundação João Pinheiro, Centro de Estatística e Informações. - Belo Horizonte, 2006. 78p.

JOÃO PINHEIRO, F. (2009). Centro de Estatística e Informações. Déficit habitacional no Brasil 2005 / Fundação João Pinheiro, Centro de Estatística e Informações. - Belo Horizonte, 2006. 129p.

JOÃO PINHEIRO, F. (2005). Centro de Estatística e Informações. Déficit habitacional no Brasil 2005 / Fundação João Pinheiro, Centro de Estatística e Informações. - Belo Horizonte, 2006. 120p.

JONES, B. D. e BAUMGARTNER, F. R. (2012) From There to Here: Punctuated Equilibrium to the General Punctuation Thesis to a Theory of Government Information Processing. The Policy Studies Journal, v. 40, n. 1, 2012.

JORA, E. C. e FRANCESCHI, L. L. (2015). O financiamento de pessoas jurídicas em campanhas políticas como circunstância geradora de corrupção eleitoral. In: XI Seminário Nacional Demandas Sociais e Políticas Públicas na Sociedade Contemporânea. I Mostra Nacional de Trabalhos Científicos, 2015.

KINGDON, J. W. (2011). Agendas, Alternatives and Public Policies. Boston: Longman, 2011.

LEFEBVRE, H. (2004). A revolução urbana. Tradução Sérgio Martins, 2a reimpressão. Belo Horizonte: Editora UFMG, 2004.

LEFEBVRE, H. (1991). O direito à cidade. Tradução Rubens Eduardo Frias, 1a edição. São Paulo: Editora Moraes, 1991.

LIMA, A. C. da C. e SIMÕES, R. F. (2009). Teorias do desenvolvimento regional e suas implicações de política econômica no pós-guerra: o caso do Brasil. Texto para discussão $\mathrm{n}^{\circ}$ 358. Belo Horizonte: UFMG/Cedeplar, 2009.

LIMA, H. M. C. e SOUZA, A. M. S. (2013). Reforma política e democracia: a implementação do financiamento público das campanhas eleitorais como garantia do princípio constitucional da isonomia. In: XXII Encontro Nacional do CONPEDI / UNICURITIBA. Tema: 25 anos da Constituição Cidadã: Os Atores Sociais e a 
Concretização Sustentável dos Objetivos da República. Centro Universitário Curitiba / Curitiba - PR, 29 de maio a 01 de junho de 2013.

LIMONAD, E. (1999). Reflexões sobre o espaço, o urbano e a urbanização. GEOgraphia Ano $1-\mathrm{N}^{\circ}$ 1, 1999, p. 71-91.

LOPEZ, F G. (2015). Cargos de confiança no presidencialismo de coalizão brasileiro / organizador: Felix Garcia Lopez. - Brasília: IPEA, 2015.

LOJKINE, J. (1981). O Estado capitalista e a questão urbana. Tradução estela dos Santos Abreu. São Paulo: Martins Fontes, 1981.

MACHADO, S. (2017). Delatores citam esquema de empreiteiras com governo desde os anos 1940. Por que a década é referência. Notícia divulgada no portal expresso.com.br em 14/03/2017. Em:

<https://www.nexojornal.com.br/expresso/2017/03/14/Delatores-citam-esquema-deempreiteiras-com-governo-desde-os-anos-1940.-Por-que-a-d\%C3\%A9cada-\%C3\%A9refer\%C3\%AAncia

MADEIRA, R. F (2010). O setor de saneamento básico no Brasil e as implicações do marco regulatório para a universalização do acesso. Revista do BNDES n. 33. Jun/2010.

MAHONEY, J. e KATHLEEN, T. (2010). Theory of Gradual Institutional Change. In Explaining Institutional Change. Ambiguity, Agency and Power. Cambridge University Press, 2010.

MANTEGA, G. (2012). Disponível em: <http://www.fazenda.gov.br/audio/2012/dezembro/a041212.asp>.

MANTEGA, G. Entrevista Roda Viva. 03.12.2007. Disponível em http://www.rodaviva.fapesp.br/materia/451/entrevistados/guido_mantega_2007.htm. 2007.

MARICATO, E. (2017). Direito à moradia é absoluto na Constituição, o à propriedade não. Entrevista concedida ao portal Brasileiros.com.br em 18/01/2017.

MARICATO, E. (2011). O Estatuto da Cidade é uma conquista popular. Entrevista concedida ao portal Vermelho.org.br em 05/07/2011.

MARQUES, E. C. (2016). De volta aos capitais para melhor entender as políticas urbanas. Novos Estudos, CEBRAP São Paulo, V. 35,02, 15-33, julho de 2016.

MARQUES, E. C. e BICHIR, R. M. (2002). Estado e empreiteiras: Permeabilidade e políticas urbanas em São Paulo (1978-98). In: III Encontro da ABCP, Niterói, julho de 2002.

MARQUES, C. e FREY, H. (2015). As mudanças habitacionais em regiões metropolitanas brasileiras. URBE Revista Brasileira de Gestão Urbana (Brazilian Journal of Urban Management), 2015, maio/ago, 7(2), 250-567. 
MATELA, I. P. (2014). Reestruturação urbana neoliberal e as empresas de ônibus na cidade do Rio de Janeiro. Cad. Metrop., São Paulo, V. 16, no 31, pp. 151-169, junho de 2014.

MAURICIO, F. R. C. (2013). Do velho ao novo desenvolvimentismo: elementos para um debate teórico crítico. In: IV Seminário CETROS Neodesenvolvimentismo, Trabalho e Questão Social 29 a 31 de maio de 2013 - Fortaleza - CE - UECE - Itaperi.

MENDONZA, E. S. G. (2005). Donald Pierson e a escola sociológica de Chicago no Brasil: os estudos urbanos na cidade de São Paulo (1935-1950). Sociologias, Porto Alegre, ano $7, \mathrm{n}^{\mathrm{o}} 14$, jun/dez 2005, p. 440-470.

MCIDADES (2016). Ministério das Cidades. Secretaria Nacional de Saneamento Ambiental. Panorama do saneamento básico no Brasil. Apresentação, Brasília, março de 2016.

MCIDADES (2015a). Ministério das Cidades. Secretaria Executiva. Relatório de Gestão, Brasília, março de 2015.

MCIDADES (2015b). Ministério das Cidades. Secretaria Nacional de Habitação. Relatório de Gestão, Brasília, março de 2015.

MCIDADES (2013). PLANSAB: Plano Nacional de Saneamento Básico. Mais saúde com qualidade de vida e cidadania. Ministério das Cidades, Secretaria Nacional de Saneamento Ambiental. Brasília, 2013.

MCIDADES (2010a). Avanços e desafios: Política Nacional de Habitação - Ministério das Cidades, Secretaria Nacional de Habitação. Brasília, 2010. 96 p.

MCIDADES (2010b). Ministério das Cidades. Secretaria Nacional de Habitação. Relatório de Gestão, Brasília, março de 2010.

MCIDADES (2005). Déficit habitacional no Brasil. Ministério das Cidades. Secretaria Nacional de Habitação. Brasília, 2005.

MCIDADES (2004a). Ministério das Cidades. Política Nacional de Desenvolvimento Urbano. Novembro de 2004, 85 p.

MCIDADES (2004b). Ministério das Cidades. Política Nacional de Habitação. Novembro de 2004, 104 p.

MCIDADES (2004c). Ministério das Cidades. Planejamento Territorial Urbano e Política Fundiária. Novembro de 2004, 88 p.

MCIDADES (2004d). Ministério das Cidades. Participação e Controle Social. Novembro de 2004, 128 p.

MCIDADES (2003). Ministério das Cidades. $1^{\text {a }}$ Conferência Nacional das Cidades, Resoluções. Brasília, 23 a 26 de outubro de 2003. 
MELLO, M. A. B. C. (1991). Interesses, atores e ação estratégica na formação de políticas sociais: a não-política da Casa Popular. Revista Brasileira de Ciências Sociais, $\mathrm{n}^{\circ}$ 15, ano 6, fev de 1991.

MENDES, M. A. S. (2016). Anatomia do presidencialismo de coalizão: uma perspectiva históricoeconômica financiada pelo processo orçamentário federal. Alethes: Per. Cien. Grad. Dir. UFJF, v. 06, n. 11, pp. 240-267, mai/ago, 2016.

MOBILIZE BRASIL (2016). Portal de Mobilidade Urbana Sustentável. Página oficial na internet: http://www.mobilize.org.br. Acesso em: agosto de 2016.

MONTE-MÓR, R. L. (2006). As teorias urbanas e o planejamento urbano no Brasil. In: Economia regional e urbana: contribuições teóricas recentes / Célio Campolina Diniz, Marco Aurélio Crocco. Organizadores. Belo Horizonte: editora UFMG, 2006.

MOREIRA, V. L. B. e PINA, S. M. G. (2012). Mais do mesmo? A trajetória da Habitação Social no Brasil. In: Congresso PLURIS 2012, Reabilitar o Urbano Paranoá6, Brasília, 2012.

MPF (2016a). Ministério Público Federal, Procuradoria da República no Paraná ForçaTarefa Lava Jato. Distribuição por dependência aos autos $\mathrm{n}^{\mathbf{o}}$ 500661729.2016.4.04.7000/PR e 5035204-61.2016.4.04.7000/PR. Curitiba, 14 de setembro de 2016.

MPF (2016b). Ministério Público Federal, Procuradoria da República no Estado do Rio de Janeiro. Núcleo de Combate à Corrupção - Força Tarefa Lava Jato. Documento $\mathrm{n}^{\mathrm{o}}$ : 76031223-2-0-3-231-392759 - consulta à autenticidade do documento através do site http://www.jfrj.jus.br/autenticidade.

MOREIRA, C. S. (2015). Do Nacional-Desenvolvimentismo ao social desenvolvimentismo: a retomada do projeto trabalhista. In: XVIII Encontro de Economia da Região Sul, 10 a 12 de junho de 2015 Área 2 Desenvolvimento Econômico. Porto Alegre, RS.

MTST (2015). As linhas políticas do MTST: Resolução final do I Encontro Nacional (2011). Revista InSURgência, Brasília, ano 1, vº 1, n.1, jan./jun de 2015.

MTST (2008). Manifesto Popular de 28 de março. Disponível em: http://www.mtst.org.br. Acesso em: 17 jul. 2016.

MTST (2005). Cartilha de princípios. Disponível em: http://www.mtst.org/linhaspoliticaseorganizativas.pdf. Acesso em: 24 dez. 2016.

NADALIN, V. G.; KRAUSE, C. e NETO, V. C. L. (2014). Distribuição de aglomerados subnormais na rede urbana e nas grandes regiões brasileiras. Texto para discussão 2012 Instituto de Pesquisa Econômica - Brasília: Rio de Janeiro: IPEA, dezembro de 2014.

ODEBRECHT, E. (2017). Emílio diz a Moro que Odebrecht paga caixa 2 desde a época de seu pai. Notícia divulgada no portal estadao.com.br em 13/03/2017. Em: < 
http://politica.estadao.com.br/blogs/fausto-macedo/emilio-diz-a-moro-que-odebrecht-pagacaixa-2-desde-a-epoca-de-seu-pai/

OLIVEIRA, A. C. DE J. (2004). Lobby e Representação de Interesses: lobistas e seu impacto sobre a representação de interesses no Brasil. Tese de doutorado em Ciências Sociais apresentada ao Departamento de Ciência Política do Instituto de Filosofia e Ciências Humanas da Universidade Estadual de Campinas, 20/02/2004.

OLIVEIRA, V. (2013). A produção capitalista do solo urbano e a ação do Estado na questão da habitação no Brasil. Revista Eletrônica Geoaraguaia. Barra do Garças-MT. V 3, n.2, p 56 - 82. Agosto/dezembro. 2013.

PEREIRA, T. D. (2012). Questão habitacional no território: sobre soluções para a acumulação na racionalidade burguesa. In: Textos \& Contextos (Porto Alegre), v 11, n. 2, p. 376-389, ago/dez 2012.

PEREIRA, C. (1999). Sistemas eleitorais. Rio de Janeiro, Ed. da Fundação Getúlio Vargas.

PINTO, M. B. (2005). Questão habitacional como expressão da questão social na sociedade brasileira. In: Libertas, Juiz de Fora, v.4 e 5, especial, p. 92-117, jan/dez/2005, ISSN 1980-8518.

PIROLA, E. N. (2009). Economia urbano regional: uma resenha para contextualizar o debate. In: XI Colóquio Internacional sobre poder local, Bahia, 14 a 16 de dezembro de 2009

PRETECEILLE, E. (1990). Paradigmas e problemas das políticas urbanas. In: Espaço \& Debates nº 29, 1990, (p. 54-67).

RIBEIRO, R. J. Financiamento de Campanha. In: AVRITZER, Leonardo; ANASTASIA, Fátima (Org.). Reforma Política no Brasil. Belo Horizonte: UFMG, 2006, p 79.

RODRIGUES, A. M. (2012). A política urbana do governo Lula (2003-2010): permanências e mudanças. Revista Continentes (UFRRJ) ano 1, nº 1, 2012.

RODRIGUES, C. M. L. (2012). Os movimentos populares e o fetiche da participação no governo Lula. Revista Mundos do Trabalho, vol. 4, n. 7, janeiro-junho de 2012, p. 178197.

RODRIGUES, T. A. e SALVADOR, E. (2011). As implicações do Programa de Aceleração do Crescimento (PAC) nas Políticas Sociais. SER Social, Brasília, v. 13, n. 28, p. 129-156, jan./jun. 2011

ROEHE, N. S. (2011). A indústria automobilística e a política econômica do governo Geise: tensão em uma parceria histórica (1974 - 1978). Tese apresentada como requisito para obtenção do grau de Doutor pelo Programa de Pós-Graduação da Faculdade de Filosofia e Ciências Humanas da Pontifícia Universidade Católica do Rio Grande do Sul. Porto Alegre, 2011. 
ROLNIK, R. (2009). Democracia no fio da navalha limites e possibilidades para a implementação de uma agenda de reforma urbana no Brasil. R. B. Estudos Urbanos e Regionais V. 11, nº 2, novembro de 2009.

ROLNIK, R. (2006). A construção de uma política fundiária e de planejamento urbano para o país - Avanços e desafios. Políticas Sociais - Acompanhamento e Análise, 12, fevereiro de 2006, IPEA.

ROLNIK, R. e KLINK, J. (2011). Por que nossas cidades continuam tão precárias? Novos Estudos, 89, março de 2011, pp. 89-109.

ROMAGNOLI, A. J. (2012). O programa "minha casa, minha vida": continuidades, inovações e retrocessos. Temas de Administração Pública, edição especial, $V^{\circ} 4, n^{\circ} 7$ (2012).

ROMANO, J. O. (2007). Política nas políticas: um olhar sobre os estudos na agricultura brasileira. Tese de doutorado, Curso de Pós-Graduação em Ciências Sociais em Desenvolvimento, Agricultura e Sociedade. Seropédica, RJ Março de 2007.

ROUSSEFF (2012).

Disponível

em:

<http://www.fazenda.gov.br/audio/2012/dezembro/a041212.asp>.

SABATIER, P. A. (1988). An advocacy coalition framework of policy change and the role of policy-oriented learning therein. Policy Sciences, v. 21, p. 129-168, 1988.

SABATIER, P. A. e JENKINS-SMITH, H. C. (1999). The Advocacy Coalition Framework: an Assessment. In: SABATIER, Paul A. (Ed.). Theories of the Policy Process. Boulder: Westview Press, 1999. p. 117-166.

SABATIER, P. A. e JENKINS-SMITH H. C. (1993). The Advocacy Coalition Framework: Assessment, Revisions, and Implications for Scholars and Practioners. In: SABATIER, Paul A.; JENKINS-SMITH, Hank C. (Ed.). Policy Change and Learning: an Advocacy Coalition Approach. Boulder: Westview Press, 1993. p. 211-235.

SABATIER, P. A. e WEIBLE, C. M. (2007). The advocacy coalition framework: innovations and clarifications. In: SABATIER, P. A. (Ed.) Theories of the policy process. Boulder, CO Westview Press, 2007. p. 189-220.

SANCHEZ, F. F. (2001). Controle da corrupção e reforma do Estado (Ogoverno Covas 1995-2000). Lua Nova, nº 52, 2001.

SANT' ANNA, M. J. G. (2003). A concepção de cidade em diferentes matrizes teóricas das Ciências Sociais.

SANTOS, M. (2012a). Por uma geografia nova. 6a edição, 2a reimpressão. São Paulo: Editora da Universidade de São Paulo, 2012.

SANTOS, M. (2012b). A natureza do espaço: Técnica e tempo, razão e emoção. 4a edição, 7a reimpressão. São Paulo: Editora da Universidade de São Paulo, 2012. 
SANTOS, H. (2002). Grupos de interesse e redes de políticas públicas Uma análise da formulação de política industrial. Civitas - Revista de Ciências Sociais Ano 2, no 1, junho 2002.

SANTOS, M. R. M. (2011). Apontamentos para uma agenda de democratização da política municipal de desenvolvimento urbano. In: Políticas públicas e direito à cidade: programa interdisciplinar de formação de agentes sociais e conselheiros municipais / Orlando Alves dos Santos Junior, Ana Carolina Christovão, Patrícia Ramos Novaes, organizadores. Rio de Janeiro: Letra Capital: Observatório das Metrópoles: IPPUR/UFRJ, 2011.

SANTOS JUNIOR, O. A. (2011). A Produção Capitalista do Espaço, os Conflitos Urbanos e o Direito à Cidade. In: Políticas públicas e direito à cidade: programa interdisciplinar de formação de agentes sociais e conselheiros municipais / Orlando Alves dos Santos Junior, Ana Carolina Christovão, Patrícia Ramos Novaes, organizadores. Rio de Janeiro: Letra Capital: Observatório das Metrópoles: IPPUR/UFRJ, 2011.

SANTOS JÚNIOR, O. A. (2009). Políticas públicas, arenas e atores sociais: o fórum nacional de reforma urbana e a agenda pelo direito à cidade. In: XIII Encontro da Associação Nacional de Pós-Graduação e Pesquisa em Planejamento Urbano e Regional. Florianópolis - Santa Catarina, 25 a 29 de maio de 2009.

SAULE JÚNIOR, N. e ROLNIK, R. (2001). Estatuto da Cidade: novos horizontes para a reforma urbana. São Paulo, Pólis, 2001. xxp. (Cadernos Pólis, 4).

SCHMIDT, B. e FARRET, R. (1986). A questão urbana. Rio de Janeiro, editora: Jorge Zahar.

SHIMBO, L. Z. (2010). Habitação social, habitação de mercado: a confluência entre Estado, empresas construtoras e capital financeiro. Tese de doutorado, Programa de PósGraduação em Arquitetura e Urbanismo, Escola de Engenharia de São Carlos, Universidade de São Paulo. Junho / 2010.

SILVA, R. R. M. (2013). A construção política do novo desenvolvimentismo no Brasil e na Argentina. In: VII Congreso Latinoamericano de Ciencia Política, organizado por la Asociación Latinoamericana de Ciencia Política (ALACIP). Bogotá, 25 al 27 de septiembre de 2013.

SILVA, M. C. da; SOUZA, V. C. L. de; TRINDADE, J. R. e MARQUES, G. S. (2014). A dinâmica capitalista e a questão urbana: uma aproximação a partir de diferentes abordagens neomarxistas. In: Cadernos CEPEC, Vol. $\mathrm{N}^{\circ}$ 2, fevereiro de 2014. Centro de Pesquisas Econômicas da Amazônia, Universidade federal do Pará, p. 1-28.

SISCÚ, J.; PAULA, L. F.; MICHEL, R. (2007). Por que novo desenvolvimentismo? Revista de Economia Política, vol. 27, n. 4, 2007.

SOUZA, M. A. A. (2015). O II PND e a política urbana brasileira: uma contradição evidente. In: DEÁK, C. e SCHIFFER, S. R. (organizadores). O Processo de Urbanização no Brasil. 2 ed., reimpressão - São Paulo: Editora da Universidade de São Paulo, 2015. pp. 111-143. 
SOUZA, C. P. R. (2013). A evolução da regulação do financiamento de campanha no Brasil (1945-2006). Resenha eleitoral, Florianópolis, jan/jun 2013. Disponível em: <https://www.tre-sc.jus.br/site/resenha-eleitoral/n-3-janjun- 2013/integra/artigos/aevolucao-da-regulacao-do-financiamento-de-campanha-no-brasil-1945-

2006/index9a6b.html?no_cache=1\&cHash=aada090d0f45baa87c5c1b22c7951d69>.

Acesso em: 20 jan. 2017.

SOUZA, N. de J. (2005a). Teoria dos polos, regiões inteligentes e sistemas regionais de inovação. Análise, Porto Alegre, v. 16, n. 1, p. 87-112, jan./jul. 2005.

SOUZA, N. de J. (1993). Desenvolvimento polarizado e desequilíbrios regionais no Brasil. Análise Econômica. Porto Alegre: UFRGS, ano 11, n. 19, p. 29-59, mar.1993.

SOUZA, P. C. de (2005b). Uma crítica francesa acerca do espaço urbano. Ser Social, Brasília, nº 17, p. 59-112, jul/dez 2005.

SOUZA, Í. G. S. de e AGUIAR, D. R. D. (2015). Mudança estrutural no mercado brasileiro de automóveis. Teoria e Evidência Econômica - Ano 21, n. 45, p. 282-303, jul./dez. 2015.

STEINBERGER, M. (2006). Território, ambiente e políticas públicas espaciais. Marília Steinberger et alii (organizadora) - Brasília: Paralelo 15 e LGE Editora, 2006. 408 p.

STEINBERGER, M. (1998). Por uma política urbana-regional. Sociedade e Estado, Vol XIII, n. 1, jan-jul 1998, p. 19-54, CDU 301:321(05).

TRINDADE, T. A. (2012). Direitos e cidadania: reflexões sobre o direito à cidade. Lua Nova, São Paulo, 87: 139-165, 2012.

VICENTE, V. M. B. (2012). Análise de mudanças institucionais na política de ordenamento territorial urbano no Distrito Federal (1991-2009). Tese de doutorado submetida ao Programa de Pós-Graduação em Administração da Universidade de Brasília. Brasília, 2012.

VICENTE, V. M. B. e CALMON, C.D. P. (2011). A análise de políticas na perspectiva do modelo de coalizões de defesa. In: XXXV Encontro da ANPAD, Rio de Janeiro/RJ - 04 a 07 de setembro de 2011. Anais de Congresso.

WEIBLE, Christopher M.; SABATIER, Paul A.; MCQUEEN, Kelly (2009). Themes and Variations: Taking Stock of the Advocacy Coalition Framework. Policy Studies Journal, v. 37, n. 1, p. 121-140, 2009.

ZAMPIERE, E (2013). Ação dos grupos de pressão no processo decisório das comissões permanentes do Congresso Nacional. E-legis, n. 12, p. 122-136, set/dez 2013. 